\author{
UNIVERSIDADE DE SÃO PAULO \\ FACULDADE DE FILOSOFIA, LETRAS E CIÊNCIAS HUMANAS \\ DEPARTAMENTO DE HISTÓRIA \\ PROGRAMA DE PÓS-GRADUAÇÃO EM HISTÓRIA SOCIAL
}

A Alexandria dos antigos: entre a polêmica e o encantamento

Joana Campos Clímaco

(VERSÃO CORRIGIDA)

São Paulo 


\author{
UNIVERSIDADE DE SÃO PAULO \\ FACULDADE DE FILOSOFIA, LETRAS E CIÊNCIAS HUMANAS \\ DEPARTAMENTO DE HISTÓRIA \\ PROGRAMA DE PÓS-GRADUAÇÃO EM HISTÓRIA SOCIAL
}

\title{
A Alexandria dos antigos: entre a polêmica e o encantamento
}

\section{(VERSÃO CORRIGIDA)}

Joana Campos Clímaco

\begin{abstract}
Tese apresentada ao Programa de Pós-
Graduação em História Social do Departamento de História da Faculdade de Filosofia, Letras e Ciências Humanas da Universidade de São Paulo, para obtenção do título de Doutor em História.
\end{abstract}

Orientador: Prof. Dr. Norberto Luiz Guarinello

São Paulo 
Para Glauber.

Para meus pais. 


\section{Agradecimentos}

Agradeço inicialmente à FAPESP pela bolsa concedida entre 2010 e 2012, que viabilizou a realização desta pesquisa de doutorado.

Aos funcionários da Biblioteca da FFLCH e do departamento de História.

Ao meu estimado orientador, Professor Norberto Luiz Guarinello, pela dedicação, paciência e generosidade.

Agradeço aos Professores Maria Isabel D’Agostino Fleming e Carlos Augusto Ribeiro Machado pelas leituras atentas da qualificação e sugestões que foram cruciais para o desenvolvimento do trabalho. Agradeço também à Professora Maria Luiza Corassin, pela oportunidade de cursar sua disciplina e desfrutar de sua experiência.

Aos Professores Alan Bowman, Judith Mckenzie e Bryan Ward-Perkins, que foram muito gentis em me receber em Oxford e colaboraram para o desenvolvimento da pesquisa.

Ao Professor Mohamed Kenawi pela receptividade em Alexandria e viabilização de uma importante conferência na Bibliotheca Alexandrina.

Agradeço às Faculdades Integradas Maria Imaculada (FIMI) pela oportunidade de ministrar os cursos de História Antiga I e II entre 2007 e 2009, aos colegas de trabalho Rogério Carvalho, Samantha Lodi, Luis Marcos Ferreira, Renata Tamaso, Rodrigo de Almeida e todos os alunos e funcionários.

Agradeço aos amigos de longa data de Brasília e colegas de graduação da Universidade de Brasília (UnB), que mesmo a distância se fazem sempre presentes.

Agradeço a toda a minha família de Goiânia e de São Carlos e à vovó Nini, pelo carinho, pela torcida e por entenderem a minha ausência em vários momentos importantes durante esses anos de trabalho intenso.

Aos amigos queridos que tive a imensa sorte de encontrar em São Paulo os agradecimentos são infinitos: Adriano Damas, Alex Degan, Bruna Capannacci, Cássio Duarte, Eduardo Dimitrov, Fábio Joly, Fernanda Guimarães, Isabel Schwartzman, 
Kerlley Pozzi, Kleber Valadares, Lígia Feichas, Luiz Vailati, Maria Adriana da Silva, Maíra Volpe, Miguel Palmeira, Paula Argôlo, Priscila Dorella, Vânia Feichas, Rafael Benthien, Rafaela Deiab, Regina Rezende, Tatiana Bina, Sinara Cotrim, Waleska Barbosa e Wellington Mello. Rafaela e Miguel leram partes da tese e ajudaram na fase final de revisão, a eles sou especialmente grata.

Aos novos amigos feitos nas viagens para Oxford e Alexandria e aos felizes reencontros: Abu Mulumba, Amy Mulumba, Audrey Balay, Chris Rodriguez, Érica da Silva, Lyvia Vasconcelos, Mark Kyriakos, Mario Paganini, Michelle Clark, Patricia Olofsen, Reham Galal, Rowan Innes, Vasiliki Lagari e Yvonne Naughton.

Aos meus amigos do Laboratório de Estudos sobre o Império Romano (LEIR): Bruno dos Santos, Camila Côndilo, Camila Zanon, Fábio Faversani, Fábio Morales, Gilberto Francisco, Gustavo Oliveira, Ivana Lopes, Juliana Bastos, Rafael da Costa Campos e Uiran Gebara.

Agradeço aos meus queridos sogros Célia e Ângelo pelo carinho e acolhida.

Aos meus irmãos Júlia, Léo, ao meu cunhado Alexandre e à minha sobrinha Aninha, que chegou ao mundo no ano de 2011 trazendo uma enorme alegria para todos nós.

Aos meus pais Rosana e João Carlos não tenho palavras para expressar o quanto sou grata por todo o apoio, amparo, incentivo e enorme carinho em todas as fases da minha vida.

E ao Glauber, por debater comigo todas as etapas deste trabalho e revisar grande parte da tese, além do companheirismo, compreensão e amor em todos os momentos. 
Você estava distraído. Eu the falava justamente dessa cidade quando fui interrompido.

Você a conhece? Onde fica? Como se chama?

Não tem nome nem lugar. Repito a razão pela qual quis descrevê -la: das inúmeras cidades imagináveis, devem se excluir aquelas em que os elementos se juntam sem um fio condutor, sem um código interno, uma perspectiva, um discurso. É uma cidade igual a um sonho: tudo o que pode ser imaginado pode ser sonhado, mas mesmo o mais inesperado dos sonhos é um quebra cabeça que esconde um desejo, ou então o seu oposto, um medo. As cidades, como os sonhos, são construídas por desejos e medos, ainda que o fio condutor de seu discurso seja secreto, que as suas regras sejam absurdas, as suas perspectivas enganosas, e que todas as coisas escondam uma outra coisa.

Eu não tenho desejos nem medos - declarou o Khan , e meus sonhos são compostos pela mente ou pelo acaso.

As cidades também acreditam ser obra da mente ou do acaso, mas nem um nem outro bastam para sustentar as suas muralhas. De uma cidade, não aproveitamos as suas sete ou setenta e sete maravilhas, mas a resposta que dá às nossas perguntas.

- Ou as perguntas que nos colocamos para nos obrigar a responder, como Tebas na boca da Esfinge. 


\section{Resumo}

Além de Roma, nenhuma cidade no Alto Império Romano foi mais analisada, caracterizada e criticada a partir de perspectivas externas do que Alexandria no Egito. As imagens produzidas pela literatura ajudaram a elaborar a representação da cidade que a historiografia contemporânea perpetuou: uma cidade enorme, linda, rica, turbulenta e polêmica. O objetivo desta tese de doutorado é discutir as diversas representações sobre Alexandria, reforçadas e divulgadas por autores antigos entre o século I a.C. e III d.C.. Acreditamos que tais representações, associadas à grandeza e prosperidade de Alexandria que a assemelhavam à capital do Império, ilustram uma percepção da cidade como um espelho de Roma e, também, uma ameaça à sua hegemonia. Todas as ênfases nas qualidades e realizações de Alexandria por um lado, e nos seus problemas e tendência à rebelião, por outro, não eram inocentes e são indicativas de uma mentalidade que vislumbrava a cidade como um local que demandava a atenção contínua por parte dos representantes do poder romano. A intenção desta pesquisa é analisar os motivos que geraram essa dualidade nas narrativas, por meio do mapeamento das temáticas e contextos mais tratados pela tradição clássica.

Palavras-chave: Alexandria Romana, Egito Greco-Romano, Ptolomeus, Tradição Clássica. 


\section{Abstract}

Apart from Rome, no city in the early Roman Empire was more analyzed, characterized and criticized by external perspectives than Alexandria in Egypt. The images produced by the literature helped create the representation of the city that the contemporary historiography has perpetuated: an enormous, beautiful, rich, turbulent and polemic city. The aim of this doctorate thesis is to discuss the several representations about Alexandria reinforced and divulged by ancient authors between the first century $\mathrm{BC}$ and third century $\mathrm{AD}$. We believe that theses representations associated to Alexandria's greatness and prosperity that made it similar to the capital of the Empire illustrate a perception of the city as a mirror to Rome and a threat to its hegemony. All the emphasis on Alexandria's qualities and achievements on the one hand, and on its problems and rebellious tendency on the other, were not innocent, and indicate a mentality that understood the city as a place that demanded continuous attention by the representatives of Roman power. The objective of this research is to analyze the reasons that led to this duality in the narratives by means of listing the themes and contexts mostly dealt with by the classical tradition.

Keywords: Roman Alexandria, Graeco-Roman Egypt, Ptolemies, Classical Tradition. 


\section{Sumário}

Introdução 1

Capítulo 1: Alexandria se impõe no Mediterrâneo- situando o debate...........................10

1.1 Breve apresentação e delimitação do objeto..................................................10

1.2. Grandiosidade e planejamento de Alexandria.............................................19

1.3. Capital do Egito frente ao mundo grego...................................................27

1.4. Novo centro de estudos e de referência para eruditos.................................32

1.5. Posição comercial estratégica e intercâmbio cultural...................................40

1.6. Crise na dinastia ptolomaica e a conquista do Egito...................................46

Capítulo 2: Adjetivações de uma polis helenística no Império Romano........................57

2.1. Estabelecimento de um forte vínculo com o mito de Alexandre..................57

2.2. Desenvolvimento inicial da cidade: embelezamento e sofisticação..............80

2.3. Biblioteca e Museu: Alexandria como centro cultural................................90

2.4. Festivais e culto à Serápis: formas de legitimação da realeza ...................102

Capítulo 3: Alexandria torna-se uma ameaça política..............................................113

3.1. Alexandria e Roma: aproximação e interdependência................................113

3.2. O governo de Ptolomeu XII Aulete: aumento da presença romana...........126

3.3. Assassinato de Pompeu em Alexandria: abalo nas relações harmônicas...140

3.4. Cleópatra e Marco Antônio: hegemonia romana em risco.........................152

3.5. Vitória de Otávio sobre o Oriente: A conquista do Egito...........................165

Capítulo 4: A Alexandria conflituosa e rebelde.......................................................180

4.1 A intensificação de uma má fama: estabelecimento de um topos...............180

4.2. Augusto e Tibério: retomada da ordem e predomínio da paz.....................190

4.3. De Calígula a Nero: tempo de conflitos sociais..........................................194

4.4. Vespasiano, Tito e o Oriente: um novo rumo para o Império? ...................218

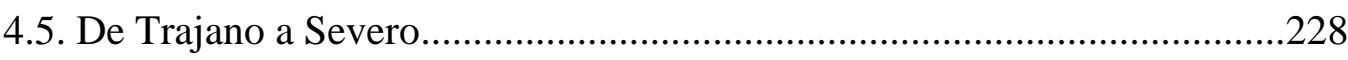

4.6. Massacre dos alexandrinos por Caracala.................................................238 
Capítulo 5: Centro comercial e festivo.

5.1. Centralidade comercial e prosperidade agrícola.......................................247

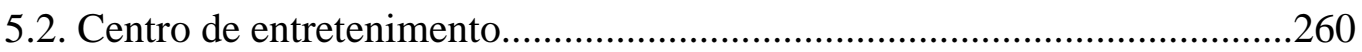

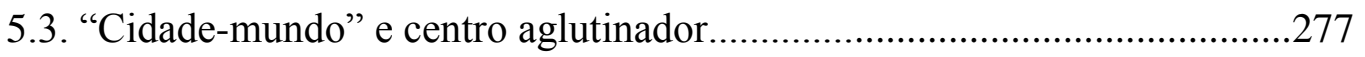

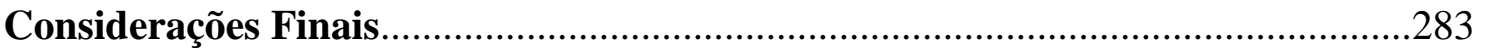

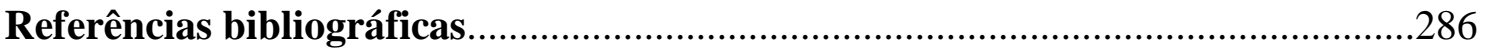

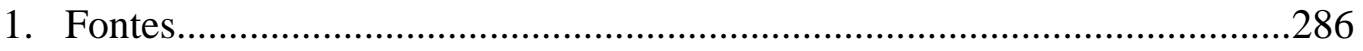

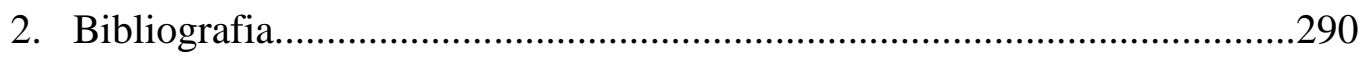




\section{Introdução}

Duas grandes metrópoles. Dois formigueiros humanos que englobavam variadas culturas e etnias. Roma e Alexandria. Uma no Ocidente, outra no Oriente. Uma era a capital de um enorme império em ascensão. Outra era a sede do reino milenar do Egito e segunda maior cidade do mundo greco-romano. Não há como entender Alexandria sem refletir sobre Roma e vice-versa. Porém para acessar Roma há uma infinidade de fontes de diversas naturezas e uma riqueza ainda maior de percepções e pontos de vista. Enquanto que para compreender Alexandria os vestígios são mais escassos e nebulosos e quase não falam do ponto de vista de seus habitantes. O que faz com que inevitavelmente se tenha que partir de Roma e da pluralidade de domínios do Império Romano para se pensar Alexandria. Que Alexandria é essa que a tradição clássica nos apresenta? Ou melhor, quais representações de Alexandria a literatura construiu?

Alexandria tornara-se a mais importante fundação de Alexandre no Mediterrâneo (fundada em 331 a.C.) e a cidade já tinha trezentos anos de existência quando foi incorporada por Otávio e transformada na capital da província romana do Egito em 31 a.C.. No tempo que precedeu a conquista, tornou-se a segunda metrópole do Império Romano em população e tamanho, além de adquirir destaque como o mais renomado centro cultural e comercial da região. Alexandria era também a capital do antigo reino do Egito, um território rico e intrigante para os gregos e romanos há muitos séculos, pela peculiaridade e sofisticação de sua cultura milenar. Além disso, o Egito era um dos principais fornecedores de trigo para Roma ao lado da Sicília e África, distribuído através do porto de Alexandria, que era também o mais dinâmico ponto de acesso e escoamento aos artigos de luxo do Oriente.

Além de Roma, nenhuma outra cidade no Império Romano dispõe de tantos testemunhos a partir de perspectivas externas quanto Alexandria. Em contrapartida, a escassez de narrativas dos próprios habitantes, que a caracterizam e a explicam para o público de fora, é também notória. Entre os autores do período romano que tratam de Alexandria, apenas Fílon, Apiano e Aquiles Tacio são alexandrinos. Por que esse desequilíbrio de depoimentos entre os relatos internos e externos? A intenção da presente tese de doutorado é analisar os motivos que resultaram na produção de tantas perspectivas predominantemente externas sobre a cidade. A partir dessa multiplicidade 
de narrativas, o objetivo é discutir os vários eixos escolhidos pelos autores para explicar Alexandria, resultando em uma ampla gama de identidades construídas para a cidade. Pretende-se investigar os vários contextos alexandrinos legados pela tradição clássica entre o séc. I a.C. e III d.C. e analisar as imagens perpetuadas sobre a cidade em um universo dominado por Roma. Essas balizas temporais foram estabelecidas, pois foi a partir do século I a.C. que as relações entre Alexandria e Roma se estreitaram, resultando no seu papel crescente na política romana e na conquista por Otávio em 31 a.C.. Após o século III, com a cristianização de Alexandria, a cidade passa por grandes transformações e as questões a serem investigadas mudam de foco.

Uma das hipóteses da tese é que Alexandria foi expressivamente abordada a partir de perspectivas externas e por autores envolvidos com o poder romano, justamente pela cidade servir em muitos momentos como um espelho para Roma, por ser semelhante a ela em muitos aspectos. A importância da metrópole e sua especificidade naquele contexto influenciaram no modo como a tradição de escritos romanos antigos percebia a imponência da cidade e nas imagens que divulgava sobre ela. Esses retratos da cidade mudaram no decorrer dos três séculos analisados? Foram alterados conforme as tradições que a descrevem?

Os relatos sobre a Alexandria grandiosa, mas também ameaçadora, começaram a ser veiculados como uma forma de se aumentar a conscientização a respeito do "perigo que estava ao lado". Ou seja, não bastava espalhar escritos difamando a sua imagem, era preciso também demonstrar sua importância e imponência concedidas pelo fundador Alexandre, para informar que a cidade tinha condições de rivalizar com Roma caso tivesse organização para isso. Portanto, muitos dos textos visavam reportar, de diferentes formas, o fato de que Alexandria era similar a Roma. Chamar a atenção para essa semelhança tinha o objetivo de aconselhar os cidadãos do Império para a necessidade de se ter cautela com a cidade? Assinalar para a grandeza e beleza de Alexandria não indicariam uma necessidade de valorizar ainda mais a enormidade romana, pois outras cidades poderiam se tornar majestosas?

Crítica e hostilidade excessivas podiam ter a intenção de elogiar o inimigo da vítima ou aumentar a própria glória (através da crítica do outro). Em uma sociedade onde o renome era conquistado à custa de outros, era necessário trazer o oponente para baixo (MARINCOLA, 1998, p. 163-164). Ou seja, criticar Alexandria chamaria a atenção para as melhores qualidades de Roma, enquanto que elogiá-la ilustraria os 
pontos em que a capital precisava aumentar a sua proeminência. Assim, é provável que Alexandria fosse tão caracterizada pela tradição clássica por ser tão análoga a Roma. Tal percepção foi se manifestando de diferentes formas ao longo dos primeiros séculos de imperialismo romano, conforme a capital adquiriu importância e se sobressaiu no Ocidente, após a conquista de Cartago. Inicialmente, Roma se relacionou com Alexandria através de acordos diplomáticos (com os Ptolomeus) e por meio da intromissão "amigável” nos assuntos da realeza (no tempo do rei Ptolomeu Aulete, por exemplo). Em seguida, através da anexação, pois o fortalecimento das duas cidades as transformaram em oponentes no contexto de disputa entre Otávio e Marco Antônio, daí a necessidade de incorporar Alexandria ao Império Romano. E, finalmente, através da vigília contínua (três tropas romanas no Egito) e de diferentes estratégias para manter o cerco sobre a cidade, depois que o território foi conquistado por Otávio. Além da presença do exército fixo no Egito, pode-se destacar a proibição do imperador em relação à posse da Boule pela cidade, um contraste em relação às outras antigas poleis do Império que mantiveram a sua. Otávio destinou o cargo de prefeito do Egito especificamente à ordem equestre e proibiu os senadores de entrarem no território sem a sua autorização. Todas essas medidas tinham a intenção de diminuir a autonomia de Alexandria e mantinham-na vigiada por Roma.

Alexandria era necessária para Roma, pois a cidade facilitava o acesso à produção egípcia (trigo e papiro) que eram vitais para o Império e a uma rota comercial muito rica e variada em produtos de origens diversas. Uma vigília mais constante sobre a cidade era necessária também para mantê-la pacífica, pois em virtude de sua grandeza populacional e de ter se tornado um ponto de integração de vários povos, poderia provocar mobilizações de grande dispersão e amplitude, já que sua posição como ponto de integração entre culturas diversas facilitava o acúmulo de multidões. É possível que os escritos do período funcionassem como uma forma de alertar para o seu potencial, o que a aproximava de Roma. Embora fosse importante ressaltar a similaridade, era igualmente essencial assinalar sua complexidade e tendência à polêmica, que se expressavam na natureza revoltosa dos cidadãos alexandrinos, aspectos que as fontes fizeram questão de avivar, polemizar e rememorar.

É importante sublinhar, contudo, que a maioria dos autores não estava preocupada em descrever e situar Alexandria, porém o faziam principalmente quando o destino do Egito repercutia em questões imperiais. Nesse sentido, produziram imagens 
de Alexandria em momentos específicos, que agradam, desagradam, fascinam ou ameaçam Roma. Em muitos casos encantam e preocupam simultaneamente. Construíram assim uma variedade de identidades imperiais para Alexandria a partir de diferentes posições externas. Essas percepções e entendimentos díspares sobre a cidade serão aqui discutidos e o único elemento que os agrupa é o contexto dos primeiros quatro séculos de Império Romano e toda a dinâmica da época. Ou seja, a tentativa de reunir os textos e entendê-los conjuntamente é um recurso metodológico que auxiliou a tessitura da pesquisa.

O foco principal do trabalho foi analisar as diversas representações de Alexandria construídas pelas elites imperiais, definindo e divulgando várias identidades alexandrinas produzidas pelo outro para o mundo antigo. Os autores foram analisados como parte do imaginário da época, que dizem algo a respeito das ideias que circulavam em determinados meios, com a intenção de reforçar certas tendências, propagar algumas polêmicas e silenciar outras. Portanto, as motivações para a escrita não podem ser deixadas de lado ao se analisar os relatos, pois a maioria dos autores era defensora da ordem romana. Nesse sentido, produziam identidades alexandrinas a partir de diferentes posições de poder e conforme os seus interesses. Assim, o foco da nossa discussão será principalmente as identidades alexandrinas atribuídas por outros.

Segundo Denys Cuche (1999, p. 197) a identidade é resultante do que o indivíduo ou grupo afirma para si mesmo, mas é também resultando da identificação imposta pelos outros. No entanto, a de dentro e de fora são identidades produzidas segundo diferentes preceitos, pois se as identidades de dentro privilegiam as sutilezas e particularidades internas, e reinventadas cotidianamente, a produção e a divulgação de identidades externas são mais estratégicas e têm menor fluidez, pois, em grande parte, são determinadas por motivações externas. Assim, o poder de definir a identidade e de marcar a diferença não pode ser separado das relações mais amplas de poder. Portanto, identidade e a diferença não são, nunca, inocentes. A identidade romana era a identidade normativa a partir da qual as outras identidades seriam definidas, o que seria uma forma sutil de manifestar o poder (SILVA, 2000, p. 81-83). Deste modo, as identidades alexandrinas articuladas pelos autores seriam definidas a partir de Roma e dos interesses imperiais. Nesse sentido, a literatura projetava para Alexandria os contrastes das identidades que os romanos queriam construir de si mesmos, principalmente de suas 
fragilidades. Portanto, as representações sobre Alexandria também dizem muito sobre as identidades romanas nesse "jogo de espelhos".

Além de debater a formação das diversas identidades alexandrinas produzidas pela tradição clássica, o objetivo principal da tese é investigar como Alexandria era representada por essa mesma tradição, pois a representação marca e "fixa" uma ou outra identidade e a partir daí a difunde através do discurso. Segundo Tomaz Tadeu da Silva, (2000, p. 91) é por meio da representação que a identidade e a diferença passam a existir, pois representar significa dizer: "essa é a identidade", "a identidade é isso". Ou seja, a partir da representação as identidades são delimitadas como uma coisa e não outra, e por meio delas são atribuídas certas características a determinados grupos. É também por meio da representação que a identidade e a diferença se aliam a sistemas de poder, pois quem tem o poder de representar tem o poder de circunscrever a identidade, uma vez sendo por meio dos discursos que as identidades se fortalecem, melhor, "dizer" colabora para definir e reforçar a identidade que se está descrevendo (SILVA, 2000, p. 93). Portanto, a representação estabelece, fixa e propaga determinadas identidades, fazendo-as ser muitas vezes "essencializadas" e cristalizadas a partir de uma posição de poder (WOODWARD, 2000, p. 17-18). Em sendo assim, suas nuances e fissuras são muitas vezes ignoradas, pois as pessoas e grupos recriam suas identidades de forma contínua dentro dos parâmetros estabelecidos para defini-los. Enquanto que a representação nem sempre apreende essa dinâmica, por ser mais superficial, acabando por divulgar com frequência preconceitos e lugares-comuns, principalmente quando são representações articuladas a partir de perspectivas das elites e dos jogos de poder. Dessa forma, a tradição clássica representa os alexandrinos a partir de lugares de fala e de interesses próprios, portanto, não capta toda a complexidade das identidades dos próprios alexandrinos, apesar de também interferir nessa construção identitária. Assim, essa pesquisa se concentrará nessas diversas representações e em como elas mudam no tempo respondendo aos interesses do poder e às identidades criadas pelos próprios alexandrinos. Tais identidades internas, com toda a sua multiplicidade e diversidade podiam até provocar fissuras nas representações, embora não seja esse o foco da tese.

No mestrado, o meu objeto de pesquisa foi um conjunto de documentos denominado Acta Alexandrinorum, um gênero literário nebuloso e pouco conhecido, proveniente de Alexandria (CLÍMACO, 2007). Em linhas gerais, são panfletos políticos da elite grega da metrópole de reação ao comando romano e teor anti-judaico, 
encontrados em vários lugares do Egito, o que indica a sua relativa circulação. Os fragmentos de papiro recuperados narram o julgamento de importantes líderes alexandrinos diante de autoridades romanas, normalmente o próprio imperador. Alguns são claramente fictícios, enquanto outros apresentam uma base documental mais sólida. Embora a natureza da documentação, sua origem e propósito de escrita, e mesmo seu agrupamento seja repleto de contradições e discordâncias, seu ideal de exaltar Alexandria e questionar algumas práticas romanas é nítido.

Devido ao estado lacunar dos textos dos Acta, foi necessário buscar na tradição clássica alguns escritos que abordassem Alexandria, para ajudar no entendimento do contexto. Nessa análise, foi observado o quanto a cidade era criticada e ao mesmo tempo elogiada por alguns autores. Daí surgiu a ideia para a tese de doutorado: mapear as narrativas sobre Alexandria nesses três séculos e questionar a origem e os motivos desse retrato ambíguo da cidade. Então, de certa forma, a tese de doutorado serviria de contraponto à dissertação, pois se naquela documentação tivemos acesso ao modo como a elite alexandrina estabelecia sua defesa sobre Alexandria, nesse momento o olhar para a cidade é direcionado de fora.

Desse modo, o corpus documental da pesquisa foi formado buscando nos escritos greco-romanos (entre os séculos I a.C. e III d.C) os relatos sobre Alexandria e as menções passageiras tratando de assuntos da cidade, ou de eventos lá ocorridos. No primeiro mapeamento, foram excluídas as menções muito pontuais, que apenas citassem a cidade. Entretanto, algumas passagens expressivas, mesmo que breves, foram incorporadas. Em seguida, os conteúdos mais mencionados e as temáticas mais significativas tratadas pelos autores foram elencadas. Assim, foi se delineando o objeto de pesquisa da tese e montada uma estrutura para o trabalho com base nas temáticas frequentes e nas hipóteses iniciais do estudo. Trata-se de uma proposta desafiadora, já que foram agrupados autores de gêneros, contextos, públicos e propostas de escrita muito variadas, e não há condições de um grande aprofundamento na obra de cada um deles, pois o ideal é discutir o tratamento fornecido a respeito de Alexandria. No entanto, não devem ser esquecidas as peculiaridades de cada narrativa, seu contexto de produção e seus objetivos de comunicar algo específico (mesmo que façam parte de um gênero).

Apesar de o período ptolomaico não ser o objeto da pesquisa, é importante destacar como autores do Império Romano avaliavam o passado alexandrino, pois a 
compreensão de seu período de formação e de sua história anterior é primordial na produção das identidades alexandrinas pela literatura imperial. A visão divulgada do passado ptolomaico é também essencial para compreender o contraste estabelecido com o presente romano nos escritos. Ou seja, o intuito é demonstrar que o período anterior é normalmente descrito em contraponto a uma nova era, assim, é normalmente trazido à tona para demonstrar os ganhos obtidos a partir de Roma. Os escritos também remetem mais ao Egito e Alexandria na medida em que seus destinos começam a se cruzar com Roma, ou conforme reportam algo sobre a metrópole oriental que ajudasse no entendimento de alguma questão imperial. São, portanto, narrativas que recorrem à época dos Ptolomeus normalmente para demonstrar o papel decisivo de Roma na política externa do reino. Assim, praticamente não temos descrições contínuas sobre o período helenístico. Nesse sentido, dificilmente se pode falar de relatos "descomprometidos", que pretendem entender o passado alexandrino por ele mesmo. Dessa forma, o que está aqui incluído da era anterior, tem o objetivo principal de demonstrar como a Alexandria ptolomaica era concebida na tradição literária imperial.

Em virtude da opção por uma perspectiva temática, entendida como a mais viável para a organização das fontes, devido à quantidade e repetição de contextos e assuntos abordados, algumas passagens da documentação são tratadas em mais de uma ocasião. Nesse sentido, os autores aparecem e reaparecem em diferentes momentos, dependendo da quantidade de temas discutidos e do tratamento mais resumido ou minucioso a respeito de Alexandria nos escritos. Assim, algumas passagens serão repetidas, por fornecerem elementos para compreensão de um e outro tema. Cada capítulo está dividido em subitens, e cada um destes foi organizado cronologicamente (por período de escrita) e, quando possível, separado também por tradição (grega ou latina). A organização de um arsenal documental tão extenso foi realmente desafiadora, e alguns problemas inevitavelmente apareceram, pela surpresa com relação à quantidade de fontes encontradas, imensamente maior do que estipulado inicialmente, resultando por vezes em rearranjos dos capítulos para incorporar toda a variedade.

O primeiro capítulo está dividido em duas partes. Na primeira a intenção foi mapear brevemente o objeto de pesquisa em uma linha cronológica, agrupando os autores por período, tradição e gênero e observando as temáticas levantadas no tratamento da cidade. O objetivo foi refletir também sobre como o contexto de escrita afetou esses autores, e, ao mesmo tempo, como os escritores produziram essa atmosfera. 
$\mathrm{Na}$ segunda parte do capítulo elaboramos uma contextualização sucinta sobre Alexandria a partir da bibliografia principal, elencando os temas mais debatidos e os aspectos mais notórios e questionados sobre sua história, que foram depois abordados no decorrer da tese a partir das fontes.

No segundo capítulo, tentou-se formar um quadro da Alexandria ptolomaica em sua fase inicial a partir das fontes posteriores. Ou seja, o objetivo foi questionar como a literatura apreendia o passado alexandrino e principalmente o contexto de fundação da cidade por Alexandre, o qual gerou tantas versões no período romano. A fase de construção e rápido desenvolvimento da cidade, o estabelecimento de seus sofisticados edifícios e todo o investimento da realeza para tornar a cidade notória nas redondezas são os aspectos muito destacados, principalmente pelos autores gregos da segunda sofística. Em suma, a história inicial de Alexandria foi muito usada para explicar a Alexandria do período subsequente. Em linhas gerias, o capítulo destaca as temáticas mais citadas a respeito do princípio de sua história, discute o impacto do passado ptolomaico nas representações da cidade no período romano, e demonstra a notoriedade conquistada pela cidade helenística na documentação posterior.

O terceiro capítulo foi dedicado a analisar a percepção das fontes sobre a fase final do período ptolomaico, momento em que as relações políticas e diplomáticas entre Egito e Roma foram intensificadas. Como os autores avaliam essa aproximação entre os territórios e o percurso político do Egito até ser incorporado no Império? Portanto, esse capítulo é sobre o passado ptolomaico mais recente, em sua fase de decadência, até o processo da conquista do reino, seus antecedentes e desdobramentos. Qual o retrato divulgado sobre a dinastia ptolomaica em sua fase de crise? Pretende-se ilustrar também as mudanças na percepção em relação ao Egito ocorridas na época, a partir do contexto de disputa entre Otávio e a parceria estabelecida entre Marco Antônio e Cleópatra. Nesse sentido, discutiremos como na visão dos autores a conquista era vista como necessária, pois foi essencial para promover uma era de paz e ordem sem precedentes no Egito.

No quarto capítulo o objetivo foi analisar como os primeiros três séculos de Império são descritos nas fontes. Ou seja, se antes discutíamos a representação do passado helenístico, o objetivo aqui foi debater a configuração das imagens da Alexandria romana. A literatura enfoca principalmente a postura de alguns imperadores diante da cidade e os problemas sociais da época. Há um nítido predomínio de questões 
polêmicas nas narrativas, envolvendo disputas e embates entre os habitantes (principalmente gregos e judeus), ou entre os alexandrinos e imperadores. Assim, intensificou-se a divulgação de um topos a respeito dos habitantes de Alexandria como um povo turbulento e conflituoso, em uma época que o governo na cidade era harmônico. Dessa forma, a intenção foi examinar a representação da cidade como um local problemático no império.

No quinto e último capítulo, foram examinados os relatos de Alexandria como um pólo comercial e de intercâmbio no período romano, posição reforçada pelos escritos, por ser de importância vital para Roma. Investigamos também os registros em tom de censura que descrevem a cidade como um centro de entretenimentos e prazeres, algo visto como maléfico para a sua imagem. Tanto a expressividade comercial, quanto a tradição festiva de Alexandria eram aspectos que tornavam a cidade mais dinâmica e aglomerada, daí também ser objeto de crítica. 


\section{Capítulo 1: Alexandria se impõe no Mediterrâneo - situando o debate}

\subsection{Breve apresentação e delimitação do objeto}

A tradição clássica legou para a humanidade uma variedade imensa de gêneros literários, produzidos ao longo de quase um milênio, fundamentais para o pensamento e para a intelectualidade contemporânea. O objetivo dessa etapa inicial do trabalho é apontar que a riqueza de escritos do período (entre o século I a.C. e III d.C.) gerou uma diversidade de perspectivas sobre Alexandria. Além da profusão de gêneros, deve-se sublinhar também o variado background dos autores, desde a origem, nível educacional, status familiar, motivação para a escrita, o público destinado, além do modo como se relacionavam com o poder romano e com a herança literária grega mais antiga. Nesse sentido, algumas aproximações costuradas entre os autores foram elaboradas apenas e exclusivamente para fins didático-metodológicos.

O enfoque da pesquisa é o conteúdo presente nas obras de cada autor sobre a cidade de Alexandria. A multiplicidade de fontes aponta a construção de identidades plurais sobre a cidade produzidas prioritariamente por perspectivas externas (com a exceção dos autores alexandrinos Fílon, Apiano e Aquiles Tacio). A despeito de toda a diversidade, são perceptíveis alguns eixos comuns para explicar a cidade em meio aos vários gêneros, como também à divulgação de imagens cristalizadas e de lugarescomuns sobre o local. Tais elementos semelhantes produzem algumas visões mais gerais sobre Alexandria, que circulavam nas elites imperiais. Ou seja, para além da disparidade de pontos de vista, examinaremos principalmente as concordâncias, entendendo que elas nos fornecem pistas a respeito do imaginário da época e posicionamentos frequentes diante da cidade.

Sabe-se que o letramento na Antiguidade era restrito, portanto eram normalmente membros das elites e/ou pessoas influentes politicamente em suas comunidades locais que tinham condições de atingir os maiores níveis de instrução e divulgar seus escritos. Nesse sentido, mesmo a posição social não sendo determinante nos relatos, por serem muitas vezes críticos do projeto político de que faziam parte, ao 
pertencerem às classes mais altas e bem instruídas do império é algo que, grosso modo, pode agrupá-los, pessoas normalmente partidárias e comprometidas com o poder romano. No que se refere à audiência pretendida pelos escritores, John Marincola (1997, p. 23) argumenta, que pela taxa de letramento ser baixa, não se deve acreditar em uma divulgação em enorme escala, contudo apenas de diferentes distinções dentro das elites. Assim, por mais tentador que pareça, não é conveniente postular categorias muito variadas de leitores, cada um desejoso de um tipo de história específico. Em linhas gerais, tratava-se de uma elite escrevendo para a elite, que foi se tornando mais vasta e heterogênea conforme o Império foi se ampliando.

Entre os autores gregos do período helenístico a busca maior era por erudição, fazendo com que muitos saíssem de suas terras nativas para aprofundar os estudos em algum centro de ensino de prestígio, principalmente Atenas e Alexandria. Essa possibilidade era restrita aos que tinham recursos, consequentemente, era privilégio de membros das elites locais. Nesse sentido, muitos desses eruditos podiam não atuar politicamente em suas cidades, mas era natural que alcançassem algum tipo de destaque social. A abertura do mundo promovida pelas conquistas de Alexandre resultou em inovações na escrita da história, pois seus feitos forneceram material para a composição literária em uma escala jamais vista. Tais novidades na história e em outros gêneros aparecem como reações às mudanças no mundo político do quarto século a.C., onde o predomínio da Macedônia destruiu as barreiras de participação política definidas para os gregos até aquele momento (MARINCOLA, 1997, p. 22-24). No período helenístico a escrita da história passou a focar também em outros povos com os quais os gregos entraram em contato após a expansão territorial de Alexandre. No século I a.C. historiadores gregos como Diodoro de Sicília e Estrabão ainda se concentraram nessa diversidade, embora o interesse maior fosse no estabelecimento do contato dessas outras culturas com Roma.

Posteriormente, a historiografia romana tornou-se domínio por excelência dos escritores mais envolvidos na vida pública de Roma. Preferencialmente, tratava-se de homens com feitos militares e políticos que, por sua vez, enfatizavam tais temas. Dessa forma, a nobreza romana controlou o retrato do passado de uma forma inimaginável para os gregos (MARINCOLA, 1997, p. 26). Sob o império, a escrita perdeu grande parte de sua "liberdade criativa", pois serviria em última instância para agradar ao soberano e referir todas as coisas a um único indivíduo. Além disso, as fronteiras 
estendidas do império impossibilitaram que qualquer autor fosse especialista em todas as localidades importantes (MARINCOLA, 1997, p. 88). Assim, a autoridade para a escrita da história, que para os gregos se justificava com base na experiência intelectual e no trabalho investigativo, passou a ser associada ao tempo de serviço em cargos públicos. Nesse sentido, o sinal de status era atrelado ao número de postos ocupados. Os historiadores gregos do império também mencionavam a posição social com frequência, seguindo a tendência da época (MARINCOLA, 1997, p. 141-144). Mesmo quando historiadores de menor status começaram a escrever, seguiam o modelo dos "mais elevados" e, então, escreviam uma história patriótica e voltada para os feitos de eminentes romanos (KRAUS, 2007, p. 241). Houve também uma tendência à biografia a partir do Império Romano, pois como a quantidade de líderes políticos e militares foi reduzida com relação ao período da República a uma só pessoa (imperador) e aqueles em sua volta. Portanto, os assuntos tendiam a se concentrar nos grandes líderes do passado romano (KRAUS, 2007, p. 250).

$\mathrm{Na}$ virada do séc. I e II d.C. o movimento da segunda sofística influenciou a historiografia antiga. Assim, foram os escritos gregos que nesse momento dominaram tanto o cenário historiográfico, quanto o de outros gêneros. Esses autores pregavam um retorno aos clássicos gregos, pelo predomínio da latinização da escrita. Segundo Simon Swain, (1996, p. 60) tais autores são representativos de uma elite detentora de paideia, "à moda antiga". Trata-se do movimento de retomada da escrita grega tradicional. A maioria dos autores da segunda sofistica encorajava uma volta ao aticismo, talvez como uma reação a Roma e à latinização. O conhecimento do grego ático era importante para ligar essa elite e reforçar a identidade grega sob Roma. Em alguns autores a obsessão pelo passado era de certa forma uma resistência contra Roma. Nesse sentido, a segunda sofística não deve ser tratada como um mero movimento cultural, pois o controle romano obrigou esses gregos a redefinirem suas identidades em várias esferas (SWAIN, 1996, p. 87-89). Assim, tais escritores se voltam para um passado mais distante e glorioso (SWAIN, 1996, p. 31). Porém, para se destacarem em seu ofício e serem ouvidos, os autores tinham que seguir as regras e os preceitos de sua época, e para isso, deveriam ter certa influência política. Portanto, além de serem homens versados na paideia, tinham ainda que se destacar na vida cívica e/ou política de suas cidades.

Foi organizada uma breve apresentação dos principais autores aqui trabalhados seguindo uma ordem cronológica e as tradições a que se afiliavam (grega ou latina) para 
ilustrar um pouco a diversidade de percepções e posicionamentos diante de Alexandria. É importante esclarecer que nessa exposição, são mencionados os autores com narrativas mais expressivas e extensas a respeito de Alexandria, por se tratarem dos textos mais importantes que compõem o presente objeto de pesquisa. Aqueles escritos que fazem referências pontuais e passageiras serão citados ao longo da tese conforme estiverem sendo tratados temas onde suas referências se encaixam.

Diodoro de Sicília escreveu quando o Egito ainda era independente e faz importantes referências à Alexandria ptolomaica. Pretendia escrever uma história universal, talvez pelo contexto mais amplo que as conquistas helenísticas, e, nesse momento Roma, estavam promovendo. Posteriormente, entre o final do século I a.C. e início do I d.C., o geógrafo Estrabão elaborou um relato minucioso sobre o Egito e Alexandria. $\mathrm{O}$ autor vivenciou o contexto de conquista, mas seu cenário de escrita é posterior, embora trate do período anterior da história alexandrina e de sua contemporaneidade. Os dois autores se interessavam por questões "etnográficas" e provavelmente escreveram em grego para alcançar um público mais amplo no Império,

Entre os séculos I a.C. e I d.C há um predomínio de textos de autores latinos envolvidos com o poder, portanto, não é de se surpreender que fossem eles também os que mais falaram de Alexandria. Antes da conquista, os primeiros comentários sobre a cidade estão nas Guerras Civis de Júlio César, e na Guerra de Alexandria, também atribuída a ele, mas de autoria desconhecida. Cícero menciona a cidade em diferentes ocasiões de sua vasta obra. Percebe-se nesse momento a crescente importância da cidade, pois se tornou alvo de debate entre alguns dos homens mais célebres e influentes de Roma. A contribuição de Cícero é importante para investigar a percepção da elite governamental sobre Alexandria no contexto de crescente intromissão romana na política egípcia, anos antes de sua conquista.

Sob Augusto, o arquiteto Vitrúvio e o historiador Tito Lívio fizeram algumas menções à cidade referentes ao contexto ptolomaico, como posteriormente fizeram Sêneca, o poeta Lucano e Plínio, o velho, ainda focados nessa era. Apesar de Plínio elaborar uma obra enciclopédica e etnográfica, sua percepao era que outros povos só começaram a fazer parte da história quando entraram na esfera de existência romana. Nesse sentido, não se nota um grande esforço para tentar apreender as discrepâncias de outras culturas em relação aos valores romanos (GEARY, 2005, p. 67). Quinto Cúrcio Rufo é a única biografia preservada em latim sobre Alexandre e foi escrita entre os 
reinados de Tibério e Cláudio. Chama atenção a concentração dos escritos no passado helenístico de Alexandria, em uma época que a cidade já estava absorvida no Império.

Os judeus helenizados, Fílon de Alexandria e Josefo da Judéia escreveram no século I d.C. e são as mais importantes fontes para analisar as disputas entre os habitantes gregos de Alexandria e judeus ocorridas na época. Ambos discorreram a partir de um ponto de vista completamente favorável aos judeus e de condenação aos seus oponentes. O trabalho de Fílon foi uma das fontes usadas por Josefo para falar dos problemas de Alexandria no tempo de Calígula, mas Josefo também se remete a outros eventos posteriores.

Em contraste aos autores gregos anteriores, os gregos da segunda sofística tinham a intenção de reforçar os valores da cultura grega clássica, antes de ser "contaminada" por outros povos. Plutarco, que viveu até a época de Adriano, foi o primeiro autor a seguir essa "tendência", com a diversidade de assuntos que abordou. Segundo Marincola, Plutarco foi talvez o autor mais importante da segunda sofística, no entanto, seu orgulho grego era conciliável como um sentimento genuíno de admiração por Roma, por ter restaurado a liberdade aos gregos (1997, p. 86). O orador Dion Crisóstomo era mais ativo politicamente do que Plutarco (MARINCOLA, 1997, p. 187). Porém, ambos apresentam semelhanças, tratam de Alexandria em pormenores e escreveram no início do século II d.C.

Até o final do século II d.C., outros gregos da segunda sofística ainda teciam comentários sobre a cidade em sua fase inicial. Arriano, que foi governante da Capadócia sob Adriano, escreveu uma biografia sobre Alexandre na perspectiva de um especialista em questões militares. O historiador Apiano apesar de ser nativo de Alexandria, elaborou uma História Romana e fala muito pouco de sua própria terra, além de se centrar na era helenística. Como Apiano, o geógrafo Pausânias aborda alguns momentos do passado alexandrino sob os Ptolomeus, enquanto o sofista Filostrato trata da presença de Vespasiano na cidade. O nativo de Alexandria, Aquiles Tacio fornece um relato pessoal e afetivo sobre a cidade em seu romance As Aventuras de Leucippe e Clitophon. Este autor exalta o centro urbano mais que os outros alexandrinos citados até agora (Fílon e Apiano). Ateneu, nativo da colônia grega de Náucratis no Egito, que escreveu entre o final do século II e início do III, descreve detalhadamente a vida cultural do período ptolomaico. 
Percebe-se que no século II d.C. houve um predomínio de autores da segunda sofística, e de gêneros mais romanceados nos comentários sobre a cidade, daí refletirem sobre uma Alexandria cronologicamente mais distante, seu contexto de fundação, o período ptolomaico e as guerras civis. Apenas Dion Crisóstomo e Filostrato remetem à conjuntura imperial e mais recente de Alexandria.

No século II é notável o predomínio de escritos em grego que tratam de Alexandria. Entre os latinos, as fontes mais importantes são Plínio o jovem, Tácito e Suetônio. Tácito é mais um exemplo de latino que exerceu também uma carreira política notável em Roma, pois alcançou o posto de cônsul. Suetônio, por sua vez, não era um homem político, apesar de ter adquirido prestígio na corte de Trajano; observa-se que os comentários dos latinos são pontuais e breves, e tendem a usar mais lugares-comuns para tratar de Alexandria. A noção de transformação histórica e das mudanças era mais aplicada para a história de Roma do que para o entendimento de outros povos. Nesse sentido, era comum que certas imagens do passado fossem ainda usadas para descrever povos em constante mudança (GEARY, 2005, p. 66).

Entre os séculos II e III d.C., Dion Cássio e Herodiano retomam o gênero historiográfico em grego de uma perspectiva mais favorável a Roma e interessada em questões contemporâneas (em contraste com os gregos da segunda sofística). Dion Cássio alude à Alexandria no relato detalhado de sua época e de períodos anteriores. $\mathrm{O}$ historiador foi pró-consul da África e governante da Panônia e Dalmácia, além de ter entrado para o Senado muito cedo. Ou seja, apesar de escrever em grego, era um autor profundamente envolvido na política romana. Herodiano escreveu outra História Romana por volta de 250 d.C. e tratou de questões mais contemporâneas. Sabe-se que tivera algum cargo oficial, embora de menor status que Dion Cássio (talvez procurador de ordem equestre ou liberto imperial), em quem grande parte de sua obra se baseou.

Segundo Marincola (1997, p. 30-32), um aspecto peculiar dos escritos dos sécs. II e III é a tentativa de se reconciliar com as ordens de um só homem, ao mesmo tempo em que se percebe um interesse em uma história antiquária, preocupada com um passado distante e glorioso. Alguns dos autores têm um foco mais restrito, e expunham com mais detalhes os eventos de que participavam e eram conhecedores, como Dion Cássio e Herodiano. No entanto, a tradição grega de história contínua não viu sinais de término, pois também se manteve expressiva ao lado das narrativas de questões contemporâneas. 
O contexto imperial e as particularidades do seu cenário político influenciaram a escrita dos autores clássicos e, portanto, o modo como caracterizavam Alexandria. Contudo, é preciso evitar análises deterministas que ignorem as mudanças empreendidas e impossibilitem observar mudanças e nuances nas avaliações dos autores.

Alguns escritos são mais "engajados" e outros menos comprometidos com o poder romano, apesar de a maioria dos autores serem ou membros diretos do governo, ou funcionários imperiais de menor escalão. Ou ainda eruditos das elites provinciais, que tinham estudado em Atenas e tiveram a oportunidade de viajar por variados lugares do Império. Assim, eram homens que enalteciam os valores culturais gregos, embora entendessem que o comando romano era necessário para estabelecer a ordem e a paz naquele mundo. Portanto, para além de toda a diversidade dos escritos em inúmeros pontos, deve-se atentar para o peso da tradição e suas amarras como um elemento de aproximação da literatura.

Nota-se o predomínio das fontes aqui trabalhadas entre os séculos I e II d.C., no entanto, algumas se remetem a séculos anteriores, embora possam também descrever sua contemporaneidade. A partir desse breve percurso cronológico situando os autores no tempo e conforme as tradições (grega e latina) é possível elencar algumas hipóteses importantes. Entre a segunda metade do séc. I a.C. e primeira metade do séc. I d.C. percebe-se a preponderância de escritos latinos nas referências à Alexandria, pois entre os gregos apenas Diodoro e Estrabão mencionaram o centro urbano. Todavia, o peso da cidade na obra dos dois gregos é considerável. Ambos tinham visitado o Egito e testemunhado a importância da cidade, talvez daí o destaque dado à metrópole em seus trabalhos, que serviram de fonte de informação para autores posteriores. Com relação aos latinos do mesmo período, todos os autores foram homens públicos de enorme importância nas decisões romanas (Cícero, César e Sêneca). Mesmo Lívio, que não se interessava por cargos políticos, era amigo próximo de Augusto, e Vitrúvio participou do projeto de reconstrução de Roma ao lado do imperador.

É possível que depois de Diodoro ter sugerido o potencial de Alexandria para rivalizar com Roma, caso tivesse condições (o elemento mais marcante na narrativa do autor sobre a cidade), foram os latinos que incorporaram a ideia e começaram a lhe dedicar atenção em seus relatos. A partir de tal verificação, a necessidade de vigilância em relação a Alexandria foi surgindo primeiramente nas mentes romanas e mais 
inseridas nos núcleos de poder. Depois de o ideal se fortalecer nessa tradição, os autores gregos, também, passaram a se dedicar ao assunto, e uma espécie de topos foi se configurando nos registros sobre a cidade. Assim, Diodoro, Cícero e César forneceram indícios para os círculos imperiais a respeito da grandeza e preparo de Alexandria, algo que aos poucos repercutiu em escritos de outros domínios do Império. Além disso, é provável que os acontecimentos do século I (em que Alexandria apareceu como "protagonista") ${ }^{1}$ tenham também ressoado na mentalidade das elites imperiais, o que se refletiu no aumento de escritos em grego sobre a cidade, a partir do séc. I d.C..

Através do mapeamento inicial, nota-se a difusão de conteúdos a respeito de Alexandria em um núcleo predominantemente latino, o que sugere uma audiência mais restrita, ou seja, para aqueles mais próximos aos setores do poder. Nesse sentido, a noção a princípio localizada, difundiu-se para escritos de intelectuais de vários domínios do Império, pressupondo uma maior publicização dos textos e a consolidação de imagens alexandrinas divulgadas para além das elites mais próximas ao comando. Tratar-se-ia, em um primeiro momento, de uma preocupação circunscrita aos centros de poder que se propagou para outros meios? É importante ressalvar que esses outros grupos também começaram a fazer parte das elites influentes em Roma e se integrar às classes dirigentes, à medida que o império se orientalizou e que o centro foi se deslocando para fora de Roma. Ou seja, como o poder não estava mais localizado, e sim fragmentado e disperso, a audiência pretendida pelos escritos também se ampliou substancialmente, daí talvez a necessidade de se escrever em grego.

Percebe-se nessa breve apresentação, a variedade de gêneros, propósitos e afiliações dos autores aqui trabalhados. O orador Cícero, o ditador Júlio César e o retórico Sêneca foram os primeiros latinos a narrar embates de Roma com Alexandria, e elaboraram escritos ilustrando a importância crescente do Egito para o Império. Diodoro de Sicília foi pioneiro de um tipo de história universal, e escreveu no contexto de engrandecimento de poder romano em meio aos reinos helenísticos. Tito Lívio, Tácito, Apiano, Dion Cássio e Herodiano propuseram histórias no sentido mais "tradicional", embora Apiano fosse alexandrino e falasse de uma perspectiva provincial, enquanto os outros eram mais influentes nos círculos imperiais. O geógrafo Estrabão e o arquiteto romano Vitrúvio foram testemunhas do novo tempo inaugurado por Augusto, e das

\footnotetext{
${ }^{1}$ Referimos-nos à morte de Pompeu em Alexandria, à Guerra de César com os alexandrinos e ao conflito civil entre Otávio e Marco Antônio.
} 
transformações implantadas pelo primeiro imperador, o primeiro mapeando o seu império e o segundo revelando suas maravilhas arquitetônicas. Plutarco e Suetônio dedicaram-se ao gênero biográfico, Plutarco estabelecendo comparações entre romanos e gregos ilustres e Suetônio abordando a vida dos primeiros doze imperadores. Quinto Cúrcio Rufo e Arriano elaboraram biografias de Alexandre séculos depois de sua morte, embora o primeiro tenha escrito em latim e o segundo em grego. Ateneu e Dion Crisóstomo preocuparam-se em memorizar os feitos helenísticos e encorajar a retomada dos valores gregos no mundo romano, Ateneu propagando a cultura helenística e Dion aconselhando mudanças para as cidades. Fílon e Josefo escreveram em grego sobre os judeus, para explicar o judaísmo ao Império e também fortalecer a crença desse grupo que começava a se dispersar. Ao lado dos alexandrinos Fílon e Apiano, o romancista Aquiles Tacio também era nativo da cidade, e demonstra mais "patriotismo" que os anteriores, pois o primeiro estava mais preocupado em descrever o judaísmo, enquanto o segundo tratou das guerras romanas.

Em uma perspectiva de análise semelhante a da presente tese, o artigo do autor M.B. Trapp "Images of Alexandria in the writings of the Second Sophistic" na coletânea de Anthony Hirst e Michael Silk, Alexandria: Real and Imagined examina as imagens de Alexandria divulgadas pela segunda sofística. $\mathrm{O}$ agrupamento proposto pelo autor ajuda no entendimento dos autores como membros de uma elite integrada sob Roma, que tinham interesses comuns com relação à metrópole oriental, para além da diversidade de visões:

Entre eles, portanto, Filostrato, Dion, Plutarco e Aquiles nos ofereceram de forma interessante um variado conjunto de visões de Alexandria e seus habitantes, enfocando por vezes na riqueza e magnificência física da cidade, e em seu status no império, por vezes na vivacidade e perspicácia de seus habitantes, e por vezes no potencial de essa vivacidade e perspicácia revelarem um lado mais sombrio, mais negro e mais destrutivo. Os moralistas Dion, Plutarco e Filostrato analisaram mais o caráter do povo e enfatizaram os tons mais escuros e as tendências; o novelista Aquiles Tacio, compondo um tipo menos moralmente desafiador de entretenimento, olhou ao invés disso para o lugar, e pintou um retrato mais abertamente elogioso. (2004, p. 124) ${ }^{2}$

\footnotetext{
2 "Between them, therefore, Philostratus, Dio, Plutarch and Achilles have offered us an interestingly varied set of views of Alexandria and its inhabitants, focusing now on the wealth and physical magnificence of the city, and its status in the empire, now on the liveliness and wit of its inhabitants, now on the potential of that liveliness and wit to show a darker, more dangerous and destructive side. The moralists, Dio, Plutarch and Philostratus, have looked more to the character of the people and emphasized
} 
Para além da diversidade de tonalidades empregadas para retratar Alexandria, e das motivações e preocupações específicas de cada autor para descrevê-la, é igualmente essencial pensar nesses intelectuais como articuladores de pensamentos comuns, por terem tido um background educacional semelhante, além de serem defensores de uma ordem que muito os privilegiava. Nesse sentido, pretende-se refletir sobre o objeto como uma "elite integrada" que circulava, dialogava e ponderava conjuntamente a respeito de pontos importantes do mundo em que viviam e das concepções que defendiam.

\subsection{Grandiosidade e planejamento de Alexandria}

Desde que foi fundada por Alexandre em 331 a.C. e desenvolvida pela dinastia macedônia dos Ptolomeus, Alexandria se sobressaiu no Mediterrâneo, tendo se tornado a maior cidade do mundo helenístico no decorrer dos trezentos anos seguintes. Foi também a sede da realeza ptolomaica durante quase toda a sua duração, rapidamente ocupando o lugar de Mênfis, a antiga capital faraônica. Os Ptolomeus dominaram o equilíbrio de poder entre os reinos sucessores de Alexandre durante praticamente todo o período entre a sua morte e a decadência das monarquias helenísticas, provocada pela ascensão de Roma. Portanto, Alexandria se desenvolveu como a representante desse reino hegemônico, vitorioso e rico e incorporou muitos de seus valores e ideais.

Com uma rapidez surpreendente Alexandria se tornou a maior metrópole do mundo, maior até do que as enormes cidades do passado como Atenas, Corinto e Siracusa e tão grande quanto às novas fundações dos Selêucidas como Antioquia no Orontes e Selêucida no Tigre (ROSTOVTZEFF, 1941, p. 415). No entanto, rapidamente ultrapassou as outras sedes helenísticas, reflexo da competição entre os reis por grandeza e esplendor através de seus centros urbanos e do predomínio de Ptolomeu nessa "corrida".

A velocidade do seu crescimento fora impressionante. Estima-se que no começo do séc. III sua população já ultrapassava os cem mil habitantes (GODDIO; CLAUSS, 
2006, p. 54). As sondagens sugerem que até o final do período ptolomaico um total de 400 mil imigrantes gregos alcançou o Egito (embora não se saiba a origem exata desses helenos), dos quais trezentos mil se estabeleceram em Alexandria, e o resto se dividiu entre Mênfis e Ptolemais (BOWMAN, 2011, p. 327). No início do período romano, quando a população de Alexandria atingiu o auge, esse número alcançou a média de quinhentos mil habitantes, transformando-a na metrópole mais populosa do Mediterrâneo oriental, só ficando atrás de Roma em termos populacionais, que tinha por volta de um milhão de habitantes (DELIA, 1988). Dominic Rathbone (1993, p. 54) calcula que as outras metrópoles do Egito juntas somavam em torno de quinhentos mil habitantes, e que um terço dos egípcios vivia em cidades. O Egito como um todo teria entre quatro e cinco milhões de habitantes, sendo o reino de maior densidade populacional do mundo romano. Tais dados, mesmo que sejam meras aproximações e sugestões, permitem vislumbrar a grandeza alcançada por Alexandria naquele cenário.

Alexandria foi estabelecida entre o Mediterrâneo e o lago Mareótis, em uma estreita faixa de terra de frente para a ilha de Faros, e com acesso a um dos afluentes do Nilo. Quando Alexandre e seus auxiliares chegaram ao Egito, teriam logo percebido aquela localização privilegiada, talvez entendendo a necessidade de se fundar uma polis no local. Influenciado pelos escritos antigos, na historiografia contemporânea um dos pontos mais debatidos na história alexandrina se refere justamente às motivações de Alexandre ao eleger o local para a construção da metrópole. André Bernand (1966, p. 49) especula que o conquistador talvez fora atraído pelo fato de o local ser suficientemente perto do Egito, para que pudesse aproveitar suas riquezas, mas ao mesmo tempo, localizado nas suas extremidades, o que ajudaria a preservar suficientemente sua personalidade grega e escapar das incursões de outros povos. JeanYves Empereur (1998, p. 37) acredita que o instinto de um grego ao conquistar um reino fechado como o Egito, teria sido o de abri-lo e tirá-lo de sua "concha", buscando uma forma de estabelecer contato entre o novo domínio e a região de fora, o Mediterrâneo, estimulando também o tráfego marítimo com o mundo grego. Para justificar o seu argumento, o autor incorpora as lendas de fundação com relação ao potencial do local para desenvolver uma grande cidade, de dimensões ainda inalcançadas entre outras cidades gregas (1988, p. 46).

É provável que Alexandre tivera acesso a muitas informações sobre o Egito e sua prosperidade. Estava ele convencido das vantagens de se construir um centro urbano 
acessível a esse território milenar, embora, também, aberto ao mundo comercial e marítimo dos gregos, de que era herdeiro. Ou seja, é plausível que tenha havido alguma ponderação e meditação sobre o assunto, não se tratando de uma mera descoberta repentina quando Alexandre viu o local pela primeira vez.

A vantagem do terreno como um ponto de acesso ao Egito e ao mundo grego atualmente parece evidente, porém acreditar que Alexandre pensara tão estrategicamente na enormidade que uma cidade construída ali poderia atingir se trata de pura especulação moderna. Entende-se a escolha do local como uma grande astúcia do fundador, contudo alguns historiadores contemporâneos consideram que fundar um porto em um local de difícil acesso não era uma decisão muito inteligente. Empereur (1998, p. 36) questiona as motivações de Alexandre em construir um centro urbano em um local aparentemente limitado, em virtude da dificuldade imposta pelo litoral no momento de ancorar os navios. Bernand (1966, p. 13) atribui sua decisão às lições que tivera com seu mestre Aristóteles. O autor argumenta que ao ler A Política, tem-se a nítida impressão de que o filósofo foi o urbanista e arquiteto inspirador de Alexandre, pois as características da cidade tinham muito em comum com alguns preceitos de Aristóteles a respeito do que ele considerava uma estrutura urbana ideal. Além disso, Alexandre tinha um bom conhecimento de geografia, e como aluno de Aristóteles estaria ciente da prosperidade do local, algo já mencionado por Homero. Dessa forma e com tudo isso em mente, o macedônio chegou ao Egito com uma equipe bem treinada (WILLIAMS, 2004, p. 2).

Nesse novo mundo helenizado, demandava-se uma capital grega para o Egito, que não podia mais figurar como uma monarquia egípcia. Por mais internacional que a população de Mênfis fosse, tal cidade não podia servir a esse propósito, nem poderia ser Tebas, consequentemente Alexandria era o local ideal (ROSTOVTZEFF, 1941, p. 264). Segundo Peter Fraser (1972, p. 3), certamente ainda a maior autoridade nos estudos da Alexandria ptolomaica, Alexandre já teria pensado na prosperidade comercial daquele terreno. Sua intenção seria principalmente abrir mais o Egito para o comércio com os gregos (MAEHLER, 2004, p. 2).

A posição intermediária de Alexandria no litoral do Egito e, ao mesmo tempo, de frente para o mundo grego a tornou um ponto atrativo para muitos povos desde sua fundação, resultando em um crescimento vertiginoso da cidade já nos quarenta anos de reino do primeiro Ptolomeu. No entanto, é essencial sublinhar o fato de se tratar de uma 
cidade planejada nos moldes helenísticos, e que nesse sentido, apesar de seu caráter híbrido greco-egípcio, a metrópole teve um desenvolvimento artificial diferenciado das antigas poleis. Artificial, pois instituições gregas foram para lá "transplantadas", mas também se situavam em uma nova dinâmica geométrica de ruas paralelas e grandes avenidas (o que se tornou típico das cidades helenísticas e era uma diferença marcante com relação às poleis clássicas). Portanto, o desenvolvimento planejado era por si só um elemento que a distinguia substancialmente de cidades como Atenas e Roma (HAAS, 1997, p. 24). Em outras palavras, qualquer comparação com essas grandes cidades deve levar esse fato em consideração. A nova metrópole tentou racionalizar o espaço no Egito, nesse sentido era uma criação muito diferente dos outros espaços urbanos característicos do local (FINNERAN, 2005).

Segundo Bernand (2001, p. 65), o plano hipodâmico de Alexandria, com avenidas perpendiculares, foi algo que estimulou a movimentação de seu cotidiano, pela possibilidade de organizar grandes manifestações cívicas e religiosas, além de facilitar o transporte de mercadorias do porto para o lago, intensificando ainda mais o movimento perpétuo na cidade. As avenidas eram importantes também para transferir carregamentos pesados para as vias aquáticas (ERDKAMP, 2005, p. 201). Para além de sua existência greco-egípcia, não há como pensar a cidade sem considerar também sua faceta planejada, assim entramos em outro tema que tanto intriga a historiografia moderna, qual a identidade preponderante de Alexandria? Talvez por ter sobrevivido tão pouco da cidade antiga, essa seja uma discussão que desafia ainda mais os acadêmicos.

Qual era a feição predominante de Alexandria? Enquanto alguns autores enfatizam sua fachada essencialmente grega e seu isolamento do resto do Egito $^{3}$, outros a entendem como uma representante do contexto helenístico refletindo toda sua miscigenação e cosmopolitismo ${ }^{4}$. E uma terceira vertente mais atual, ressalta sua natureza egípcia com base nas descobertas arqueológicas recentes ${ }^{5}$. Essa última vertente enfatiza também a originalidade de um estilo alexandrino, que seria mais do que a síntese da cultura egípcia e grega.

\footnotetext{
${ }^{3}$ Cf. LEWIS, 2001, p. 4; ERSKINE, 1995, p. 42 e 48; JONES, 1926, p. 28; DELIA, 1991, p. 5; FRASER, 1971, p. 93 e 94 ; p. 111 e 112.

${ }^{4}$ Cf. BELL, 1941. P. 1; DAVIS, 1951, p. 103; BAGNALL, 1993, p. 230.

${ }^{5}$ Cf. EMPEREUR, 1998; 2002, GREENBERG; HAMMA; GILMAN; MOORE (eds.), 1996; STEEN, (ed.), 1993/ HARRIS; RUFFINI (eds.), 2004.
} 
Fraser (1972, p. 36) ressalta sabermos muito pouco do desenvolvimento inicial da cidade, das diversas etapas de seu crescimento como um todo, e a respeito de que construções podem ser atribuídas a que reis. O autor acredita que a partir de Filopator o "elemento puramente grego" da cidade entrou em declínio, com o enfraquecimento dos vínculos dos helenos com a terra mãe, permitindo mais mistura (1972, p. 78). Com relação às leis, Fraser considera que o código civil alexandrino fora desde o começo um complexo de elementos derivados de diferentes códigos civis de todo o mundo grego, porém com nítida predominância do ateniense (1972, p. 112).

A opinião de Fraser é construída com base em vestígios literários, contudo o que a arqueologia subaquática revelou nos últimos vinte anos não pode ser desconsiderado, com relação à intensidade de sinais da presença da cultura egípcia em Alexandria. Tais evidências devem ser consideradas, mesmo que os elementos tenham sido introduzidos aos poucos e conforme as necessidades de agradar a parcela da população egípcia lá presente (EMPEREUR, 1998; 2002). Os arqueólogos Frank Goddio e André Bernand, (2004, p. 80) que juntamente com Empereur são responsáveis por grande parte dessas descobertas, tendem a negar o impacto egípcio na cidade. Eles acreditam que a presença de tantos objetos egípcios teria inicialmente uma explicação ornamental, e posteriormente sucumbiram à prática religiosa. O "Egito antigo" nessa nova cidade essencialmente grega fora possivelmente absorvido pelo seu exotismo. $\mathrm{O}$ maior consenso historiográfico é que como supremo comandante dos gregos e de seus aliados, Alexandre só podia ter fundado uma cidade grega. Desde os arquitetos que a planejaram, o nome do local e seus habitantes eram gregos, os templos principais eram dedicados a divindades gregas, o grego era lá falado, e Alexandria não era nem considerada parte do Egito, mas se localizava na "beirada do Egito" (Alexandria ad Aegyptum) (2004, p. 78).

Pela quantidade de vestígios arqueológicos faraônicos encontrados em Alexandria, Empereur acredita que a metrópole tinha uma aparência egípcia considerável (1998, p. 75). Outras evidências sugerem que as divindades egípcias não familiares para os imigrantes do Mediterrâneo foram logo traduzidas com equivalentes do panteão grego, o que promoveu desde cedo uma espécie de sincretismo. Nial Finneran (2005) define Alexandre como "multi-culturalista" e, portanto, ao fundar a cidade sua prioridade teria sido o contato entre gregos e egípcios. Por ter sido responsável pelo projeto do porto, provavelmente Alexandre teria pensado em estimular 
sua heterogeneidade populacional (VASUNIA, 2001, p. 269). Pascale Ballet (1999, p. 158) chama a atenção para o fato de que muitos vestígios faraônicos foram encontrados perto de monumentos de prestígio dos Ptolomeus, o que não seria mera coincidência, mas traduziam uma vontade política dos reis de introduzir um pouco do mundo egípcio na capital.

O francês Jean Bingen (2007, p. 54) é um grande defensor da política essencialmente grega dos Ptolomeus. Ressalta que uma das peculiaridades do sistema real de Alexandria era o isolamento das diferentes funções do monarca, que não se misturavam: ele era ao mesmo tempo o basileus para os gregos do mundo rural, o faraó do alto e baixo Egito para os egípcios e seus sacerdotes, e soberano de Alexandria, uma capital com a qual o palácio mantinha relações ambíguas. O rei tinha que lidar com a expansão e administração do império, e ao mesmo tempo com as pressões vindas de fora. Bingen (2007, p. 254) justifica que foi apenas no período romano que o Egito teve acesso às correntes de mistura vindas do Oriente e iniciadas em outros locais anteriormente, e segundo a sua concepção, no período helenístico ainda se podia falar de um Egito fechado para o mundo externo. Para o autor, Alexandria não era parte do Egito, pois para os egípcios da chora, a cidade representava um modelo e uma fonte de autoridade, já que se localizava na sombra do rei e era um centro de administração de poder externo (2007, p. 283).

Deve haver uma distinção entre o ideal por trás da fundação da cidade e sua realidade configurada em trezentos anos, que tornaram esse "ideal original" inviável, devido à força cultural do território em que a cidade foi instalada, e da presença de uma parcela significativa da população nativa, exigindo a atenção contínua dos reis. Claro que tudo depende muito de para onde direcionamos o olhar, e uma Alexandria mais grega ou mais egípcia pode ser encontrada dependendo das evidências acessíveis.

Sally-Ann Ashton (2004, p. 28) considera a presença de representações em estilo egípcio encontrados na cidade como um sinal de que os Ptolomeus teriam escolhido algumas regiões específicas da metrópole na qual se representavam como faraós, confirmando os indícios do impacto da cultura nativa na fase do seu desenvolvimento. No entanto, muitos objetos egípcios encontrados em Alexandria foram trazidos de fora da cidade durante o período romano (ASHTON, 2004, p. 33). A vitalidade dos objetos ainda no período romano sugere que não tinham sido descartados no tempo anterior, pois ainda eram alimentados e cultivados pelos reis de alguma forma, mesmo que 
tivessem uma origem externa e tenham sido transferidos para lá tardiamente, a mando de imperadores mais atraídos pelo Egito.

Na visão de Joseph M. Modrezejewski (1993, p. 263), a situação dos egípcios como sujeitos dos Ptolomeus era sempre enfatizada, mesmo que os reis tenham promovido uma revitalização da cultura faraônica após os persas, para a realeza conquistar legitimidade entre os nativos. Além disso, os gregos jamais foram colocados num estado de submissão em relação à realeza no estatuto jurídico, apesar de também estarem a serviço do rei. Dessa forma, mesmo nascidos no Egito, gregos fariam de tudo para preservar sua origem cívica para se diferenciar dos "bárbaros autóctones" (MODREZEJEWSKI, 1993, p. 253). A análise do papirólogo é voltada para a legislação do Egito greco-romano, e demonstra que nesse setor as fronteiras entre gregos e egípcios foi bem demarcada. No entanto, não se pode esquecer de que houve uma extensão do status de helênico ou novos-gregos no período ptolomaico, pois muitos que não eram conhecidos como gregos no período clássico passaram a ser, como era o caso dos macedônios, trácios, sírios e até judeus ${ }^{6}$. A comunidade dos helenos passou a englobar todos os imigrantes helenófonos e não distinguia de forma precisa “atenienses" e "trácios", por exemplo. O essencial era se diferenciar dos nativos (MODREZEJEWSKI, 1993, p. 264-266).

Bernard Legras (2004, p. 20) estabelece uma diferenciação entre identidade política e religiosa dos Ptolomeus, considerada "dupla", enquanto a identidade cultural permanecia grega. Com relação ao fato de gregos terem começado a adorar deuses egípcios, Alan Samuel (1983, p. 76) diz que mesmo essa adoração era feita "à moda" grega, e não egípcia. $\mathrm{O}$ autor não estaria negando as evidências? Pois o fato de gregos estarem idolatrando divindades egípcias no Egito e até mesmo em outras regiões (Ísis, por exemplo) denota um momento original, em que havia espaço para tais inovações e adições, mesmo que executadas de forma própria e atreladas à cultura de origem, e de maneira familiar de acordo com as próprias tradições.

A historiadora inglesa Judith Mckenzie oferece uma contribuição riquíssima para essa discussão em sua obra The Architecture of Alexandria and Egypt (2008). Apesar de o trabalho ser sobre a arquitetura alexandrina, a autora analisa conjuntamente todos os tipos de evidências para formar o seu "retrato arquitetônico" sobre Alexandria,

\footnotetext{
${ }^{6}$ A situação dos judeus é um caso diferenciado pela expressividade da comunidade em Alexandria, e será abordado mais adiante no capítulo 4.
} 
uma análise completa na qual ela é precursora. Não há como entender a metrópole sem atentar para essa combinação de diferentes resquícios, justamente pela infeliz situação da preservação de seus vestígios e pela escassez de relatos como os existentes para outros locais, permitindo "pintar" um quadro mais completo e detalhado. Mckenzie ressalta que até o final do séc. III a.C. a cidade tinha todas as facilidades e os edifícios de uma cidade grega (2008, p. 37). O seu traçado, o plano de defesa, sua vida intelectual, foi quase toda estabelecida pelos primeiros dois Ptolomeus, enquanto o terceiro se encarregou da construção de santuários aos deuses locais (2008, p. 3). Segundo a autora, a maior parte dos monumentos de Alexandria era clássica, porém mesmo nesses, seu estudo minucioso identificou algumas influências egípcias. Nesse sentido, a autora se coloca contra a linha historiográfica predominante que entende Alexandria como um "corpo estranho" no Egito. Mckenzie analisou o contexto egípcio em seu conjunto para compreender Alexandria, e percebeu que mesmo a arquitetura clássica da nova cidade era muito semelhante a do resto do Egito. Ou seja, devemos sim olhar para o Egito como um todo para entender a nova entidade helenística.

Nesse sentido, por mais que os testemunhos escritos descrevam Alexandria como uma cidade de organização basicamente grega, principalmente pelas instituições lá estabelecidas, a influência egípcia era nítida em muitos detalhes (2008, p. 74). Essas minúcias podem ser um sinal da receptividade dos arquitetos gregos de Alexandria às influências egípcias (2008, p. 3). Mckenzie também identifica traços de um estilo originalmente alexandrino, nem grego, nem egípcio, mas com características próprias, que foram usadas também em outros lugares do Egito até o séc. VI d.C. e encontrados em regiões distintas do mundo romano até o séc. II d.C.. Esses aspectos específicos da arquitetura alexandrina foram encontrados principalmente fora do Egito, em locais que estavam sob o controle ou influência política dos Ptolomeus (em Cirenaica na Líbia e Chipre, por exemplo) (2008, p. 94-95). Até mesmo os materiais de templos egípcios fora de Alexandria foram influenciados por técnicas clássicas. Portanto, a autora sugere que talvez o uso de tais técnicas na metrópole fizera os egípcios apreciarem suas vantagens e, assim, se tornaram padronizadas por todo o país (2008, p. 136). É justamente essa habilidade de trocar de identidades o que torna Alexandria uma cidade tão intrigante como fenômeno urbano e cultural (FINNERAN, 2005).

Entender Alexandria isoladamente não é uma alternativa, por mais que grande parte de sua construção inspirada nas poleis gregas antigas a apartasse do Egito em 
alguns aspectos. Contudo, sua localização central em uma dinâmica de intercruzamento de povos e em um ponto importante no Egito esvaziou seu potencial políade, ao mesmo tempo em que sua composição social na qual predominaram egípcios na formação original a "devolviam ao Egito", apesar da resistência da política helenizante. Ou seja, mesmo considerando a diferente trajetória histórica da cidade em relação aos outros centros do Egito, concebê-la deslocada de suas redondezas não é apropriado. Tratava-se da sede de um novo reino, estabelecido em um território milenar, e por mais que a dinastia greco-macedônia estivesse ciente de sua superioridade cultural, tinha informações sobre a antiguidade do Egito, algo que lhes impunha respeito e admiração, mesmo que discordassem do modo como viviam e fossem avessos a aglumas de suas crenças distintas.

Além do planejamento das ruas da cidade, a presença de símbolos egípcios é muito instigante. Alguns foram construídos pelos Ptolomeus em homenagem aos antigos faraós, embora já apresentassem traços originais. Outros foram levados para Alexandria de variadas partes do Egito em tempos diferenciados, porém ambos tinham a finalidade de simbolizar a antiguidade e imponência do território sobre o qual se assentava aquela nova entidade. Nesse sentido, entendemos a criação de Alexandria como algo artificial e atípico. Seu desenvolvimento planejado teve muito em comum com outras cidades helenísticas fundadas na mesma época. No entanto, além da construção ordenada, seu papel como a nova capital "grega" do Egito, mas ao mesmo tempo em contato com o mundo faraônico a dotou de características ímpares.

\subsection{Capital do Egito frente ao mundo grego}

Além das vantagens daquele local específico para a construção de Alexandria, o Egito fazia parte do imaginário grego há séculos. O território os fascinava e intrigava pela antiguidade de sua história e longa duração de seu reino faraônico e pelas práticas religiosas consideradas exóticas e "bizarras". A partir de Heródoto começa a haver especulação sobre aquele país de "hábitos estranhos" (MATTHEWS; ROEMER, 2003, p. 11). Desde cedo os gregos sinalizaram uma estima pela cultura egípcia que nunca demonstraram pelas outras culturas orientais, em virtude de sua sabedoria antiga 
(VASUNIA, 2001, p. 4). Também causava admiração o ecossistema e identidade unificada do Egito, adaptada e mantida por milênios, contrastante com a história e cultura fragmentada dos helenos (STEPHENS, 2003, p. 241). E mais: comparado à tradição comercial dos gregos, um povo acostumado ao comércio e atividades marítimas, o Egito era "fechado e introspectivo". Mesmo se as mudanças processadas na mentalidade dos egípcios desde os últimos faraós forem consideradas, o país ainda era visto como um povo absorto sobre si mesmo, que enxergava o deserto e o mar como suas fronteiras.

Empereur (1998, p. 42) enfatiza a antiga familiaridade dos gregos com o norte do Egito por meio da mitologia, e que a importância do Delta também já fora reforçada por autores gregos. Além disso, marinheiros e comerciantes gregos conheciam a fama dos egípcios como hostis a estrangeiros. Mesmo a colônia portuária grega de Náucratis fundada no séc. VII não ficava no mar, mas a quilômetros de distância e havia um isolamento claro em relação ao Egito do vale (EMPEREUR, 1998, p. 37). Nesse sentido, o afastamento de Náucratis a contrastava com Alexandria, que foi povoada com egípcios desde suas etapas iniciais de desenvolvimento (MCKENZIE, 2008, p. 40). A localização da cidade no litoral sugere então uma influência grega, pois os faraós sempre tinham sido relutantes em encorajar desenvolvimentos litorâneos (VASUNIA, 2001, p. 270).

Susan Stephens (2003, p. 22) percebe na fundação da colônia de Náucratis o início de uma transformação e de abertura do Egito, pois seu estabelecimento foi o resultado dos contatos entre gregos com a região do Delta, constituídos desde a idade do bronze (tiveram origem pela participação de gregos no exército de Psamético I). De qualquer maneira, fica claro que a intensificação de contatos entre o Egito e o mundo mediterrâneo aumentou ainda mais com a fundação de Alexandria e ajudou a desenvolver uma cultura grega comum, denominada de "helenística", pois mesmo com Náucratis a separação entre as culturas ainda era preponderante (BAGNALL; RATHBONE, 2004, p. 37).

Os arqueólogos Frank Goddio e Manfred Clauss (2006, p. 43-45) também insistem que a abertura do Egito começara há um tempo considerável. No último milênio do período faraônico a região do Delta se tornara o centro de poder egípcio e o local foi se configurando como um ponto de encontro entre os povos do Mediterrâneo, 
da Líbia até a Palestina. Nesse processo, os autores avaliam que a fundação de Náucratis foi o primeiro passo para o amálgama entre as culturas grega e egípcia.

A importante obra de Susan Stephens, Seeing Double: Intercultural Poetics in Ptolemaic Alexandria, situa a poesia alexandrina no contexto intermediário entre Egito e Grécia. A autora demonstra como mesmo antes da fundação de Alexandria, já havia entre os gregos um conhecimento considerável a respeito do território egípcio, o que ela nomeia de "Egito imaginado". Stephens argumenta que desde cedo o Egito era abordado por autores gregos como Heródoto, Platão e Isócrates (2003, p. 20-22). As evidências sugerem que a situação de contatos e conhecimentos recíprocos já estava sendo alterada há algum tempo, mas por não ser uma situação formalizada, ainda haviam muitos impasses para as trocas. Nesse sentido, a fundação de Alexandria ajudou a intensificar esse quadro.

A partir de Alexandre e principalmente com a sua nova fundação no Egito, através de uma migração massiva de gregos para esse território, a cultura grega e egípcia passou por um novo momento de estabelecimento de contatos e julgamentos recíprocos com relação ao modo de viver do outro. A fundação de Alexandria de certa forma tornou o Egito antigo mais acessível, mas ao mesmo tempo deu maior visibilidade às suas "estranhezas", estabelecendo um contraste em relação à cultura dos novos moradores. Alexandria abriu o Egito para os gregos, lhes transformando nos protagonistas das relações sociais, e como novos governantes do país, relegaram os egípcios a um estatuto inferior. Entretanto, mesmo sendo conquistada, a cultura egípcia ainda era a maioria, e a mais antiga do local. Era imperativo entender a sua tradição, ou torná-la inteligível aos gregos dali, daí uma maior ponderação sobre os elementos discrepantes com relação aos novos habitantes.

Autores gregos da corte de Ptolomeu tinham a preocupação de informar os habitantes helenos instalados em seu novo lar sobre o Egito mais antigo. Assim, surgiu uma nova literatura, dedicada a divulgar as antiguidades egípcias para uma audiência grega. Hecateu de Abdera, que sobreviveu através de Diodoro de Sicília, foi o maior expoente dessa tendência. Segundo Stephens (2003, p. 33), a obra de Hecateu apresenta uma importante inovação por ser "egitocêntrica", pois até então o Egito era colocado à margem na dinâmica da história mundial. Trata-se do primeiro relato com uma perspectiva favorável ao Egito elaborada por gregos. A autora enfatiza que os comentários sobre o Egito de autores como Heródoto e Hecateu de Abdera são 
essenciais para entender como os gregos do séc. III, residentes no Egito, absorveram do novo ambiente. Além da literatura, a historiadora realça a popularidade dos monumentos egípcios entre os visitantes gregos da época e o fato de estarem acessíveis ao público. Dessa forma, gregos também vivenciavam os festivais religiosos que aconteciam no espaço público (2003, p. 44-45). Assim, Stephens se posiciona contra a tendência historiográfica predominante que defende que mesmo ao entrarem em contato no norte do Egito, os mundos de gregos e egípcios se misturaram pouco, pois apesar de permanecerem lado a lado, não dialogavam em quase nada por não se compreenderem. Acreditamos que essa visão subestima a força do cotidiano e das relações configuradas nos contatos diários. Não considera também a capacidade dos nativos e dos imigrantes de olhar para o ambiente em que se instalaram tentando compreendê-lo. Por mais forte que fosse a herança grega trazida para a nova terra, tratava-se de um novo meio e de uma realidade inédita. Nesse sentido, os imigrantes se esforçariam para compreender e dialogar com esse ambiente, mesmo que fossem presos e conservadores com relação à cultura de origem, que passara por muitas transformações em relação à Grécia Clássica.

A construção de Alexandria permitiu um maior acesso às riquezas do Egito e fez com que gregos e romanos fizessem concessões com relação às "estranhezas" daquele país. No entanto, não deixavam de mencionar e avaliar tais hábitos. Os comentários e avaliações tornaram-se ainda mais constantes e polêmicos, conforme o Egito passou a fazer parte da esfera de influência romana e se tornou primordial para o seu abastecimento.

Há de se fazer uma diferenciação entre gregos e romanos com relação ao modo de caracterizar os egípcios, pois enquanto para os gregos o Egito era em alguns aspectos um desafio para sua auto-imagem, para os romanos era além de tudo, um território a ser conquistado (MATTHEWS; ROEMER, 2003, p. 12). Para os conquistadores, o aspecto negativo da imagem grega que produziu os egípcios como bárbaros prevaleceu, pois era um retrato conveniente aos governantes da época. A rejeição aos deuses era ainda o mais discrepante na avaliação da cultura egípcia. No entanto, a partir do séc. II a.C a religião egípcia se disseminou pelo Mediterrâneo (através de Ísis e Serápis). Contudo, eram divindades que apareciam em forma humana, o que era mais aceitável aos gregos. A difusão desses cultos transformou o discurso egípcio entre as pessoas da região. Assim, nesse momento começaram a aparecer textos que lidavam com a religião egípcia 
de forma "sofisticada", para além dos aspectos contrastantes (Plutarco e Apuleio, por exemplo) (MATTHEWS; ROEMER, 2003, p. 17).

Para os gregos, havia um diálogo maior entre suas culturas, e uma maior admiração pela sofisticação da cultura egípcia. Um exemplo é que nos sécs. I e II d.C., ao tratar de gêneros romanceados da segunda sofística, Simon Swain (1996, p.118) observa a concentração das cenas não urbanas em cenários egípcios, o que se explicava pela sua posição na história grega, pois era o povo mais familiar entre todos os estrangeiros. Ao passo que Roma nunca é mencionada nessas novelas, sugerindo uma maior idealização do passado grego (SWAIN, 1996, p. 113). É provável que aludir ao Egito nesses romances significava remeter aos seus aspectos idílicos e paradisíacos. Assim, a qualidade e as benesses da terra eram a contrapartida para os hábitos estranhos.

Todas as impressões manifestadas sobre os egípcios se mantinham na "superfície" de sua cultura. Ou seja, os autores ficavam presos aos estereótipos conhecidos e não lhes interessava buscar um entendimento mais completo sobre a tradição milenar. Os discursos gregos sobre o Egito poupavam descrever a realidade presente e se prendiam ao Egito antigo, evitavam assim, falar sobre o seu desenvolvimento os descrevendo em contextos a-históricos (VASUNIA, 2001, p. 7). Michel Chauveau (2000, p. 171) reflete que os egípcios ficaram em desvantagem em relação ao conhecimento sobre os gregos, pois estes já chegaram ao Egito com opiniões pré-concebidas em relação aos habitantes, enquanto os nativos sabiam pouco dos imigrantes. Assim, quase não se sabe a opinião dos egípcios sobre o helenismo.

A percepção dos gregos sobre o Egito é um tema amplo e muito estudado, desde Heródoto, passando pelos poetas helenísticos, até autores posteriores, como Diodoro, Estrabão e Plutarco. A historiografia contemporânea tende a fazer uma separação rígida entre Alexandria e Egito, principalmente a partir da nomeação da cidade de acordo com algumas fontes (Alexandria ad Aegyptum) e devido ao fato de a maioria dos autores separar as duas entidades nos seus relatos. $\mathrm{O}$ tratamento da realeza ptolomaica e depois dos imperadores destinados a um e outro também era muito diferente, como também o percurso histórico da cidade e toda a vivência lá criada em relação ao resto do Egito. No entanto, os limites não são assim tão claros, e percebe-se no objeto da pesquisa, que em alguns momentos não é possível fazer demarcações. Para citar só dois exemplos: alguns autores se referem a "egípcios", mas incluem alexandrinos entre eles; outros abordam as transformações no Egito ptolomaico e romano (muitas delas causadas pelas 
repercussões criadas pela fundação de Alexandria), mas garantem não estar tratando da cidade.

\subsection{Novo centro de estudos e de referência para eruditos}

Durante os trezentos anos de governo ptolomaico, a história de Alexandria se caracterizou pela negociação constante dos reis macedônios com os nativos, pois a dinastia teve que incorporar elementos da cultura faraônica e aceitar a autoridade dos templos para ser aceita e legitimada no Egito. Porém ao mesmo tempo, os reis nunca hesitaram em reforçar a percepção da superioridade da cultura grega, algo manifestado claramente na criação de instituições que preservariam e afirmariam incessantemente a força da herança clássica promovida pela dinastia. Assim, o Museu e a Biblioteca foram os lugares por excelência onde a cultura grega foi perpetuada, reproduzida e estimulada. Através das duas instituições, a Grécia Clássica pôde se manter viva e pulsante. Esses centros de perpetuação do conhecimento grego e da produção de novos saberes foram fundamentais para tornar Alexandria cada vez mais notória naquele mundo. Por meio dos estabelecimentos, o ideal de promover a imagem de uma Alexandria essencialmente grega era nítido, já que a base dos conhecimentos estava nos autores clássicos, mesmo que servissem apenas de inspiração para novos escritos.

As duas instituições não eram estáticas e muito se transformaram no decorrer da história alexandrina, embora no contexto de implantação e desenvolvimento pelos primeiros Ptolomeus, o ideal era reforçar ali o conhecimento de um cânone grego básico para helenos de origens diversas e com pouco em comum. No contexto da decadência de Atenas como a principal metrópole intelectual do Egeu, o enfraquecimento cultural foi percebido pelos reis do Egito. Assim, em certo sentido, Alexandria foi desenvolvida para preencher esse vazio e se tornar a "nova Atenas". Atenas não perdeu o seu espaço como centro educacional, mas deixou de ser a única opção entre os eruditos quando passou a competir com Alexandria. Aproveitando-se de sua preponderância política nas terras conquistadas por Alexandre, os reis investiram grandes somas para atrair para a sede real "especialistas" das mais variadas regiões. Dessa forma, era reunido um grupo de estudiosos itinerantes, que aperfeiçoavam seus conhecimentos no Museu e 
produziam saberes inovadores, por meio da troca de informações e da experimentação em novos setores.

Através do patrocínio real, a corte helenística atraiu para a metrópole, pensadores de todo o mundo grego, muitos dos quais já tinham perdido o forte vínculo com suas terras de origem (FRASER, 1972, p. 306). Assim, essa "intelligentsia" do Museu e da Biblioteca estabeleceu uma ligação forte com os reis (FRASER, 1972, p. 310). Em seu período de formação não há como dissociar as instituições de um ideal de legitimar a nova realeza instalada em território egípcio, tanto que, quando a dinastia entrou em crise e interrompeu esse patrocínio, houve um grande afluxo de eruditos da cidade, que começaram a migrar para outros centros. Assim, a efervescência intelectual de Alexandria começou a diminuir ainda no período helenístico. Segundo Fraser (1972, p. 79), a situação insegura da cidade não era mais atrativa para a elite cultural. $O$ historiador ressalta que o patrocínio real foi um fenômeno predominante do séc. III e aumentou novamente com Cleópatra e Aulete (1972, p. 312). O fim do patrocínio para as artes causou aos poucos uma "alienação" em Alexandria, pois sua elite intelectual e crítica começou a emigrar da cidade, e Roma absorveu essa saída de estudiosos alexandrinos (FRASER, 1972, p. 809). Apesar de perder força no século II e diminuir o ritmo da produção de conhecimentos com o fim do patrocínio real, a interrupção pode também ter sido um fenômeno importante para dar vida própria às instituições até então completamente atreladas à realeza.

Para a formação da Biblioteca foi adquirido e copiado a maioria dos clássicos da literatura grega e de outros povos. Através da formação desse notável acervo, reuniu-se pela primeira vez e em enorme escala a cultura literária de diversas partes do mundo. Dessa forma, outros povos puderam pela primeira vez, explicar em grego suas tradições para os gregos (MOMIGLIANO, 1991, p. 14). Um intercâmbio intelectual e uma produção de saber ímpar foram sendo desenvolvidos entre os eruditos das duas instituições, e muitos desses estudiosos depois saíam de Alexandria para ensinar em outros lugares do Mediterrâneo. Ou seja, formou-se uma cultura de pensadores itinerantes e um acúmulo de conhecimentos, novos e antigos, compartilhado por essa “elite intelectual". Dessa forma, Alexandria conquistou enorme atratividade, reunindo estudiosos de muitos lugares e levando seus sábios para outros locais, provocando assim, uma "integração das elites" e um saber comum e inovador. O conhecimento dos clássicos servia como um elemento forte de ligação e identificação entre os que o 
possuíam. Nesse sentido, em um contexto de maior mistura entre povos a paideia era um eixo de unificação.

Edward Watts apresenta uma boa definição dessa rede intelectual que estava plenamente formada no Império Romano:

O mundo romano era uma vasta coleção de cidades e vilas espalhadas
como ilhas por todo um mar de zona rural. Dentro dos limites dessa
cidade estavam homens cultos, mas a conexão entre esses homens e
seus compatriotas culturais era raramente sustentada por contatos cara
a cara. Todavia, a administração do império se apoiava nesses
homens, e qualquer um que esperasse ter seus interesses protegidos
precisava desenvolver uma rede de conexões dentre a classe culta.
A formação cultural e educacional compartilhada por todos se apoia
no coração dessas redes. $(2006, \text { p. } 7)^{7}$

A tendência de muitos estudiosos de saírem de suas terras nativas para aprender com um professor renomado ou em um centro intelectual específico ajudou a reforçar a conexão entre a elite intelectual (WATTS, 2006, p. 9). Toda essa "rede intelectual" foi se configurando desde o início do período ptolomaico e teve Alexandria como o maior centro.

Fala-se muito da decadência das instituições na era imperial, no entanto, por mais que sua efervescência tenha diminuído, continuaram exercendo prestígio entre os intelectuais do império. Além disso, a simbologia atrelada aos estabelecimentos não se perderia tão facilmente. Watts (2006, p. 152) sugere que por proporcionar um conhecimento compartilhado e acessível a todos que circulavam na Biblioteca, a instituição pode ser vista como um fator de integração das elites acadêmicas do Mediterrâneo, pois os intelectuais posteriormente levavam o saber adquirido para outros locais, fazendo a sabedoria circular por várias regiões. Desde a fundação, o Museu e a Biblioteca começaram a produzir um alto nível de cultura intelectual em Alexandria, tornando a cidade atrativa para uma grande multiplicidade de estudantes (WATTS, 2006, p. 147).

Apesar da redução de patrocínio à imigração de intelectuais para a Biblioteca no Império, o patrocínio ao Museu continuou e aumentava ainda mais conforme alguns

\footnotetext{
7 "The Roman world was a vast collection of cities and towns scattered like islands throughout a sea of countryside. Within this city were cultivated men, but the connection of these men to their cultural compatriots were rarely sustained by face-to-face contact. Nevertheless, the administration of the empire rested upon these men, and anyone who hoped to have his interests protected needed to develop a network of connections among the cultured class. The common cultural and educational background that they all shared lay at the heart of these networks."
} 
imperadores se interessassem pela instituição. Era comum também que esses eruditos se destacassem na vida pública de suas cidades, pois muitas trocas intelectuais aconteciam através da política. Autores importantes de outros centros gostavam de visitar Alexandria, mesmo que não se fixassem na cidade, talvez para divulgar seus trabalhos e obter reconhecimento (WATTS, 2006, p. 153-154).

Alan Bowman (2010, p. 105) destaca que sob o império há evidências para atividades mercantis realizadas dentro da elite intelectual alexandrina. Assim, não eram grupos tão separados como se supunha. Tais vestígios sugerem que não se tratava de uma elite isolada e alheia à dinâmica da metrópole, mas envolvida e consciente do ritmo vertiginoso de comercialização da região, na qual Alexandria tinha um papel preponderante.

Devido à circulação de saberes e de ideias proporcionada por essas instituições, elas tiveram um importante papel em reunir homens com interesses intelectuais comuns, mesmo que fossem de etnias e religiões diferentes, e tais eruditos viajavam com frequência para Roma (CAPPONI, 1975, p. 9). A presença desses homens na capital do Império talvez ajudasse a anunciar a importância de Alexandria, dos saberes lá produzidos e das contendas vivenciadas pelos seus habitantes, o que chamou a atenção para a sua efervescência cultural e social. Ou seja, trata-se de um momento de intercâmbio intenso e de diálogos profundos entre culturas diversas, e Alexandria foi colocada no centro desse processo.

A Biblioteca de Alexandria teve um papel crucial na disseminação dos clássicos gregos e na sua preservação para a posteridade. Dessa forma, o Egito foi a fonte através da qual grande parte dessa literatura chegou a Roma. Sem a Biblioteca e os escritores do círculo de Calímaco, a literatura da Roma de Augusto seria de uma natureza muito diferente, embora os escritores romanos dificilmente atribuíssem sua ancestralidade literária ao Egito (DALBY, 2000, p. 172).

Alan Samuel (1983, p. 67-74) enfatiza o conservadorismo dos gregos nessas instituições, justificando que seus membros aceitavam pouquíssima literatura de outros povos em seu cânone, e que mesmo a literatura contemporânea grega tivera pouca aceitação nos círculos literários. Ou seja, dever-se-ia preservar não apenas os escritos gregos, mas principalmente autores tradicionais como Homero. $\mathrm{O}$ autor afirma que dentre os novos textos produzidos em Alexandria, se tornaram mais populares àqueles inspirados nos modelos gregos anteriores, e criados no ambiente de edição e 
reinterpretação dos clássicos. Samuel realça ainda que, mesmo quando algum escrito egípcio alcançava a Biblioteca para ser retrabalhado, seu conteúdo era relativamente helenizado e esvaziado de sua base egípcia. Tal situação se explicava não apenas pelo conservadorismo dos gregos com relação ao seu cânone, mas também pela ausência de uma produção literária mais sistemática dos egípcios. Uma prova disso é que o interesse dos gregos por questões egípcias era maior que o dos próprios nativos, e mesmo dos alexandrinos, por temáticas nativas. Samuel constrói o seu argumento com base na realização de um levantamento quantitativo de papiros encontrados no período. A maior parte desses escritos são cópias de escritores do séc. V a.C. e anteriores, tendo permanecido pouco de escritos alexandrinos contemporâneos, e ainda menos de referências cruzadas à literatura egípcia (1983, p. 71-72). Seu raciocínio é convincente, porém ao querer reforçá-lo em todas as esferas, tende a ignorar os exemplos contrários à sua tese, ou seja, aqueles de originalidade e inovação do ambiente alexandrino. Quando o autor se depara com tais situações, as desconsidera e as entende como exceções.

Stephens (2003, p. 251-254) destaca a importância da Biblioteca para reforçar a noção de coletividade grega. No entanto, a autora argumenta que mesmo os clássicos gregos sendo a base de quase todos os poetas e eruditos da Biblioteca, estes eram muitas vezes usados para adaptar mitos gregos a uma nova realidade. De qualquer maneira, sabe-se muito pouco sobre o funcionamento das instituições e dos conteúdos trabalhados no local. Com relação à Biblioteca, a maioria dos escritos preservados refere-se a versões de reedição e reinterpretação de Homero. Tais gramáticos e editores alexandrinos foram cruciais ara a preservação dos textos homéricos.

Como já foi dito, os problemas dinásticos e a crise na realeza resultaram na interrupção de patrocínio aos estudiosos, que, consequentemente, começaram a sair de Alexandria em busca de outros locais de trabalho. Assim, ocorreu uma diáspora da intelectualidade alexandrina, que começou a levar o conhecimento lá adquirido para outros núcleos, resultando em um fortalecimento, expansão e integração dos conhecimentos da elite intelectual do Mediterrâneo.

Infelizmente as poucas fontes disponíveis a respeito das instituições são tardias (do período romano) e remetem mais ao prestígio que legaram, do que ao seu funcionamento e história no tempo de maior efervescência. Ou seja, sobreviveram na documentação mais como um mito a ser desvendado pelos historiadores contemporâneos. 
Mesmo que no período romano os dois estabelecimentos já não tivessem mais o esplendor e fervor da época dos Ptolomeus, ainda dispunham de prestígio, renome e impunham respeito pelo trabalho realizado no passado. Nesse sentido, muito ainda se falava das instituições, e o fato de a maior disponibilidade de relatos ser da época imperial, indica que o fascínio e o respeito pelos órgãos permaneceram, mesmo depois do enfraquecimento como centros de difusão de saberes.

A despeito da intensa produção literária realizada na Biblioteca, e dos trabalhos de reedição e revisão de clássicos gregos, é intrigante o fato de não ter sobrevivido nenhum relato minucioso a respeito da história de Alexandria, na perspectiva dos nativos e intelectuais que trabalhavam nos acervos. Por que uma cidade com tamanha cultura literária legou tão pouco de sua própria história? Como as duas instituições priorizavam os conhecimentos clássicos e novas interpretações da literatura grega talvez interessasse pouco mapear uma nova história de Alexandria, pois a memória reforçada pelos autores era justamente a ligação da cidade com o passado grego. Como Alexandria era uma cidade nova, planejada e sem uma tradição consolidada, era necessário fabricar sua memória e associá-la ao passado grego de mais prestígio, criando assim uma identidade alexandrina ligada à experiência grega. Até mesmo os "nacionalistas" da cidade, os gregos do Ginásio, estavam mais interessados em criticar o império e exaltar a cidade de forma indireta, do que em elaborar uma memória própria de Alexandria ${ }^{8}$. Criticar Roma talvez tivesse efeitos mais imediatos do que produzir uma literatura mais focada nas antiguidades alexandrinas.

A obra de Robert Smith The Art of Rhetoric in Alexandria: Its Theory and Practice in the Ancient World (1974) é o único trabalho conhecido voltado para os usos da retórica em Alexandria. Portanto, trata-se de uma inestimável contribuição para entender a vida intelectual da cidade. $O$ autor analisa a abrangência da prática da retórica na metrópole, e conclui que principalmente no período romano, conforme Atenas minguava como autoridade no assunto, o treinamento retórico ensinado desde o período ptolomaico se intensificou em Alexandria, com a chegada de imigrantes treinados no tema. No entanto, é perturbador o fato de terem sido preservados apenas os exercícios de retórica influenciados pelos antigos oradores gregos, enquanto em Roma estava se desenvolvendo uma tradição mais voltada para as cortes. Apesar da popularidade de oradores latinos como Cícero no império, não há evidências da

\footnotetext{
${ }^{8}$ Estamos nos refirindo à tradição dos Acta Alexandrinorum, como os escritos críticos a Roma.
} 
popularidade de nenhum deles em Alexandria (1974, p. 111-113). Os exemplos trabalhados pelos alunos eram situações da antiga história grega, e não foram encontrados modelos de conjunturas mais contemporâneas debatidas pelos estudantes (1974, p. 119). Smith enfatiza o fato de não ter se desenvolvido em Alexandria uma escola que abordasse as questões cívicas e polêmicas ocorridas da cidade. Ao invés disso, os ensinamentos continuavam presos nos exemplos gregos do passado, enquanto a própria Alexandria com todos os seus problemas entre as comunidades cívicas teria sido o contexto ideal pra isso (1974, p. 137).

É intrigante que justamente os alexandrinos, famosos naquele contexto por testarem a lei até os seus limites, não deixaram testemunhos de seus debates nesses treinamentos em retórica (SMITH, 1974, p. 120). A situação não poderia ser uma consequência da vigilância cerrada imposta por Roma? A vigília teria resultado em uma espécie de "censura" nesse meio letrado, promovendo uma ênfase maior nos divertimentos e na preservação da memória helênica antiga para reforçar continuamente a identidade grega da cidade. Bowman (2007, p. 177) ressalta a frequência de viagens dos intelectuais alexandrinos no período de Augusto, sugerindo que a circulação dessas elites intelectuais ainda era constante e que a cidade continuava preponderante no seu papel como centro de estudos. Mesmo que a educação pós-elementar estivesse disponível também em outras grandes metrópoles, a reputação de Alexandria como um núcleo de estudos renomado atraía aqueles pais ansiosos para providenciar aos filhos uma educação grega completa (ROWLANDSON; HARKER, 2004, p. 145).

Ballet (1999, p. 145) questiona sobre podermos ou não chamar Alexandria de a "nova Atenas" e argumenta que a metrópole nunca substituiu totalmente a capital intelectual do mundo grego com relação ao saber global e conceitual, voltado para novos conceitos de ciências, linguagem e nutrido de projetos filosóficos. O saber acumulado em Alexandria não suscitava reflexões originais sobre o homem e o cosmos, pois preservava principalmente os conhecimentos antigos. Os gêneros popularizados em Alexandria como a mímica e as novelas eram inspirados nas antigas tragédias e comédias gregas e mais voltados para os divertimentos e para a descontração, do que para temas filosóficos (BALLET, 1999, p. 173). Comparada à Atenas, faltava a Alexandria uma tradição literária própria. Assim, tratava-se de outro tipo de helenismo, que para se difundir teve que adotar a tradição literária da Grécia Clássica. Nesse sentido, é provável que a "modernidade" de Alexandria fosse vista pelos gregos como 
um fator de diferenciação, inferiorizando a nova metrópole. Trapp (2004, p. 127-128) argumenta que até mesmo Náucratis tinha mais prestigio entre alguns gregos pela sua antiguidade em relação a Alexandria, por sua tradição mais "sólida" e por ter sido formada por colonos fechados para o ambiente externo e novas influências.

Sob o Império Romano, Alexandria não era mais o centro cultural imponente que fora sob os Ptolomeus, mas sua população continuava sofisticada e amava os “prazeres da vida". Jones (1978, p. 37) ressalta sua adoração por diversão, piadas e brincadeiras e seu repúdio por autoridades. Dessa forma, além dos aspectos culturais, Alexandria também se tornou atrativa como um centro de entretenimentos. No período romano, os alexandrinos ficaram conhecidos por sua devoção ao teatro, a espetáculos públicos e divertimentos, o que lhes rendeu uma fama de debochados, engraçados e pouco concentrados em assuntos que demandavam seriedade. Haas (1997, p. 84) observa que procissões e espetáculos públicos de homenagem ou demonstração de hostilidade a indivíduos eram comuns em Alexandria.

Os locais para entretenimento e festivais foram todos construídos sob os Ptolomeus, que não economizaram em festas para exaltarem a si mesmos e se popularizarem (MCKENZIE, 2008, p. 48). Alguns espaços foram inovados ou transformados no período romano, como o hipódromo que se transformou em circo para a corrida de cavalos, embora ainda fosse usado como estádio pelos atletas (MCKENZIE, 2008, p. 220). Apesar da fama dos alexandrinos como "baderneiros" ter se difundido principalmente no Império, confusões decorrentes de corridas de cavalos já são mencionadas pelo poeta do período ptolomaico Teócrito (STEPHENS, 2003, p. 248). Mckenzie (2008, p. 112) identificou a influência da pintura alexandrina em Roma, introduzida por artistas alexandrinos moradores da metrópole, ainda no período ptolomaico. O número de egípcios em Roma aumentou consideravelmente as relações comerciais e os contatos culturais, dentre esses egípcios havia escravos, músicos e atores.

O objetivo até aqui foi ressaltar a notoriedade e importância de Alexandria em variadas esferas e demarcar os elementos que a destacavam e a tornavam objeto de admiração e atenção diante de Roma. Já foi realçada a centralidade cultural da metrópole e sua posição como ponto de encontro de muitos povos, mas toda essa agitação da cidade não teria sido alcançada sem a sua dinâmica comercial. 


\subsection{Posição comercial estratégica e intercâmbio cultural}

A localização de Alexandria, situada em um ponto de cruzamento de muitos povos do mundo grego, mas que também facilitava o acesso às profundezes do Egito foi um fator que estimulou a rápida aglomeração de pessoas no local. $\mathrm{O}$ crescimento da cidade foi ainda mais intensificado pela efervescência comercial do local, cujo porto logo se tornou importante. O movimento constante de ir e vir estimulava a intensidade das mudanças e as intensas trocas culturais, além da rápida circulação não só de artigos, mas principalmente de informações, saberes, técnicas, ideias e rumores.

Antes da chegada de Alexandre, as vantagens e desvantagens do terreno escolhido para a futura cidade já eram conhecidas pelos gregos viajantes e marinheiros que comercializavam em Náucratis e por soldados que chegavam como militares colonos. Em oposição à maioria dos autores que enfatiza as conveniências visíveis do local como motivadores de Alexandre, Goddio e Bernand realçam as condições desfavoráveis do porto. Os arqueólogos (GODDIO; BERNAND, 2004, p. 114-115) consideram que os egípcios não tinham feito nada para tornar esse litoral menos inóspito para estrangeiros anteriormente. A costa era inconveniente para mercadores gregos e fenícios, enquanto para os egípcios representava um sistema eficiente de defesa, pois além do mar, só era possível entrar no território através dos principais afluentes do Nilo. Além disso, durante o período faraônico, os governantes do Egito exerciam um rígido controle em relação às fronteiras. Apesar do difícil acesso, a prosperidade comercial do local era notória para os gregos, com considerável experiência nos mares, e assim, não se sentiam desafiados a desbravar esse litoral.

Platão e Aristóteles tinham visões opostas quanto à construção de uma cidade no litoral. Platão considerava o risco de o local se tornar muito exposto ao comércio internacional, podendo corromper a metrópole, e o fácil ingresso de estrangeiros poderia inflar a população a promover a anarquia, pois mercadores e navegantes não eram bem vistos. Contudo, Aristóteles acreditava que uma cidade aberta ao comércio internacional teria mais facilidade de se defender por terra e mar. A facilidade de transporte e comunicação dentro do próprio território também seriam vantajosas. Como Alexandre foi pupilo de Aristóteles é provável que essa visão o tenha influenciado (GODDIO; BERNAND, 2004, p. 148). 
Alexandre teria considerado essas circunstâncias ao fundar Alexandria, por ter adquirido um grande conhecimento dos mares e litorais e estar informado sobre a importância do Egito. Assim, a cidade se situou bem nessa comunidade global em expansão e no sistema de mercado mundial que emergia (WILLIAMS, 2004, p. 21). Em virtude das circunstâncias, a fundação de Alexandria rapidamente impulsionou a continuidade dessa tendência "internacionalizante". O mar estava associado a ser "cosmopolita" e aberto a todas as influências, promovendo uma riqueza econômica, de povos e idéias. Alexandria é indissociável desse princípio, ou seja, a permeabilidade da metrópole foi determinante para o seu desenvolvimento (FINNERAN, 2005). Outro fator que facilitou a integração das culturas na visão de Williams é que por ser uma cidade nova, Alexandria não tinha uma elite tradicional dominada por poucas famílias. Pelo contrário, com o seu alargamento, seus grupos de destaque foram sendo formados por comerciantes de fronteira, ao invés de laços de família (2004, p. 46).

No séc. II Alexandria já era a maior metrópole do mundo conhecido e o posto comercial mais dinâmico (GODDIO; CLAUSS, 2006, p. 54). Conforme crescia, precisava do Egito inteiro para alimentá-la. A cidade não necessitava de um território próprio (de uma chora que a abastecesse), pois além de todo o Egito lhe enviar produtos, ela recebia tudo que chegava dos outros países (BERNAND, 2001, p. 53-54). Dessa forma, tornou-se praticamente auto-suficiente. A diferença em relação ao período de comercialização anterior, é que Alexandria, nomeada por Rostovtzeff de "o maravilhoso novo portão", promoveu a abertura do Egito, o que não teria sido realizado sem a cooperação de estrangeiros acostumados com uma economia monetária e experientes em relação ao sistema comercial do mundo mediterrâneo (1941, p. 364). A novidade não foi apenas a entrada de estrangeiros, o que já ocorrera antes, mas o fato de torná-los bem-vindos e necessários, além de lhes garantir um papel de protagonista nas negociações.

Os Ptolomeus e os gregos comerciantes que chegaram com eles introduziram uma economia monetária no Egito (conforme já existia em outras regiões gregas). Fizeram isso provavelmente por se sentirem desafiados diante da necessidade de organizar a conquista macedônia e as terras enormes e férteis que a conquista do Egito abriu para eles (BINGEN, 2007, p. 187). Os reis adotaram um sistema monetário exclusivo. Ou seja, o dinheiro estrangeiro que entrava no território deveria ser convertido em moeda ptolomaica. Assim, a cunhagem de moedas em Alexandria era 
usada em um circuito fechado, pois as que eram confeccionadas na cidade permaneciam restritas ao Egito, e moedas produzidas em outros lugares do Mediterrâneo não entravam no país. O sistema teve origem com o primeiro Ptolomeu, que fechou as fronteiras para moedas estrangeiras em 305 (GODDIO; BERNAND, 2004, p. 143). Confiantes na sua riqueza e poder, Rostovtzeff (1941, p. 401) argumenta que os Ptolomeus provavelmente fizeram isso para se isolarem do resto do mundo helenístico. Os reis queriam que seu império fosse uma unidade fechada, com uma estrutura e uma cunhagem uniforme, o que os tornaria auto-suficientes. Nesse sentido, foram diferentes dos Selêucidas, mais "adaptáveis" ao meio. Rostovtzeff está aparentemente equivocado em falar de isolamento, pois toda a realidade criada para a cidade caminhava no sentido contrário. Acreditamos que isso foi feito para os reis serem os condutores das negociações e terem maior controle sobre seus lucros.

Conforme a comercialização crescia, o controle dos Ptolomeus sobre a região também se fortaleceu, permitindo que Ptolomeu I Soter construísse uma marinha forte, através do estímulo à imigração, que introduziu novas técnicas de construção naval (WILLIAMS, 2004, p. 54). A predominância nos mares e as conquistas fora do Egito possibilitaram aos reis o acúmulo de grandes fortunas para a construção de sofisticados monumentos que embelezaram Alexandria rapidamente (WILLIAMS, 2004, p. 38).

O sucesso econômico de Alexandria estava diretamente relacionado à sua posição como potência naval, e o controle dos mares estava atrelado à riqueza antiga e duradoura do Egito. Ou seja, conquistas militares e sucessos econômicos estavam interligados (WILLIAMS, 2004, p. 32). Alexandria se desenvolveu então como um importante centro para a construção naval, ao mesmo tempo em que se tornou uma cidade sofisticada e exuberante.

Com relação à produção egípcia, o território era o principal produtor de papiro do Mediterrâneo, que era comercializado através de Alexandria. É provável que no período faraônico os reis tivessem monopólio sobre o papiro. No entanto, foi sob os Ptolomeus que sua produção se expandiu a ponto de exportar para toda a região (BAGNALL; RATHBONE, 2004, p. 23). A produção e difusão do papiro passaram a ser ainda mais controladas pelo governo depois da conquista romana (CAPPONI, 1975, p. 146).

Antes da transformação em província, o trigo egípcio já era importante para o Mediterrâneo e o crescimento de Roma no período republicano exigiu maiores safras. 
Assim, Roma tornou-se cada vez mais dependente do seu fornecimento. Durante o Principado, África e Egito ocuparam o lugar da Sicília como os maiores fornecedores de Roma, em virtude do aumento de necessidades da cidade, e a Sicília simplesmente não era grande o suficiente para abastecer o crescente mercado romano (ERDKAMP, 2005, p. 219). A maior parte do trigo egípcio chegava à capital do império através de impostos. Assim, não se deve colocar tanta ênfase na sua comercialização (ERDKAMP, 2005, p. 208). A própria cidade de Roma era o seu maior destino, apenas em anos muito produtivos o suprimento era direcionado para as cidades do Oriente (ERDKAMP, 2005, p. 226). Com base em dados fornecidos por Flávio Josefo, a historiografia é praticamente consensual com relação à importância do Egito como o fornecedor de um terço do trigo necessário à Roma, sendo os outros dois terços supridos pela África ${ }^{9}$. No entanto, Erdkamp duvida da afirmação de Josefo com base em outras informações e defende a predominância do Egito em relação à África (2005, p. 226). Os acadêmicos (CASSON, 1984, p. 82; ERDKAMP, 2005, p. 233) discordam também com relação ao momento que o suprimento egípcio se tornou vital para Roma, se ainda na República (perspectiva defendida por Casson) ou apenas no império (visão de Erdkamp). Erdkamp diz que há poucas menções nas fontes para defender a visão de Casson, no entanto, ele nem menciona as importantes passagens de Cícero com relação à questão, como veremos mais adiante.

Aparentemente a riqueza do país era motivo suficiente para os romanos intervirem nas questões internas do Egito, e pode ter sido essa abundância que o salvou da conquista direta pelo império por tanto tempo. Em outras palavras, não foi uma coincidência que a batalha final pelo trono imperial tenha sido disputada nos portões de Alexandria (GODDIO; CLAUSS, 2006, p. 56).

O transporte em larga escala de grãos do vale era essencial para o suprimento de comida na própria Alexandria, assim como em Roma, e o Nilo a ligava também, à costa do Mar Vermelho, através do entreposto de Copto. Alexandria também se tornou o mais importante ponto de acesso e condutor dos artigos da Índia, Arábia e de outros lugares do Oriente. Itens de luxo como incensos, pimentas, temperos, perfumes e pedras preciosas chegavam ao Egito via Alexandria e de lá eram mandados para outros lugares. Muitos desses produtos eram ainda manufaturados, processados e difundidos na cidade, juntamente com produtos artesanais baseados em produtos nativos, como papiro, vidro e

\footnotetext{
${ }^{9}$ BAGNALL; RATHBONE, 2004, p. 22; CASSON, 1984, p. 83.
} 
têxteis. Alexandria era também conhecida no Mediterrâneo oriental pelo seu trabalho de artes: jóias, vidros, mosaicos e esculturas eram particularmente proeminentes (BAGNALL, 2004, p. 52-53).

A disseminação desse comércio de luxo, se já era importante sob os Ptolomeus, em virtude de uma cultura de ostentação estimulada pelos reis, se intensificou no final da República e atingiu o seu ápice no Império. Em decorrência das conquistas, dos triunfos e butins realizados por generais vitoriosos, a entrada de artigos orientais em Roma começou a criar "modas" e estimular o comércio de artigos de luxo. Roma passou a consumir uma grande quantidade de artigos de luxo a partir de sua disponibilidade em Alexandria (WILLIAMS, 2004, p. 91). Grande parte ficava restrita no mercado egípcio e alexandrino, mas o resto ia para a Itália e outras regiões. Andrew Wallace-Hadrill (2008, p. 328) defende que o aumento do luxo foi possibilitado pelo aumento do comércio, mas também trouxe prosperidade a mercadores e artesão, possibilitando uma maior mobilidade social. Como Alexandria era a maior fornecedora de trigo, além de fonte de abastecimento para artigos de luxo, não resta dúvida de que tais bens viajavam nas mesmas embarcações, sendo até um incentivo a mais para os mercadores fazerem a viagem (2008, p. 332). Segundo Wallace-Hadrill, (2008, p. 360) tratava-se de um processo com três estágios: iniciava-se com a importação de artigos exóticos do Oriente, através de conquistas e butins que estimulavam "modas". Tais modas criavam um apetite maior por esses produtos, o que aumentava a produção e comercialização com o Oriente. E o último estágio era o da imitação de tais modas em Roma, ao ponto de divulgar os mesmos produtos para o Ocidente.

Dessa forma, Alexandria servia como ponto de contato entre todos os portos do Oriente e tinha uma posição importante para suprir a si mesma com a quantidade de produção egípcia exigida pela sua população. O porto de Alexandria se destacava pela comercialização lá realizada, mas principalmente por servir de condutor para produtos de que boa parte do Mediterrâneo dependia. No final do período ptolomaico, através desse vínculo com o Oriente, a presença alexandrina no Mediterrâneo tinha diminuído e se deslocado para o Mar Vermelho, de onde exportava itens de luxo trazidos pelo Nilo dos portos (WILLIAMS, 2004, p. 101). Fraser (1972, p. 133) considera que apesar da "decadência cultural" do final do período ptolomaico, Alexandria ainda era o maior centro de "comércio mundial". A posição fraca do Egito no Mediterrâneo apresentou-se como uma boa oportunidade para Cleópatra, que fez Alexandria reconquistar sua 
autoridade em questões mundiais. Assim, para a rainha, restaurar a glória dos seus antepassados significava retomar o Mediterrâneo. Portanto, deu pouca importância para o comércio com o Oriente através do Mar Vermelho (WILLIAMS, 2004, p. 110).

Sob Roma, Alexandria era a segunda cidade do império, e o mais importante núcleo comercial do Mediterrâneo Oriental, pelo qual passava produtos de todo o mundo. No entanto, deixou de ser a capital marítima, perdendo seu predomínio como potência naval (WILLIAMS, 2004, p. 114). Como já foi dito, a estrutura urbana de Alexandria facilitava a movimentação e a rápida circulação de produtos através da comunicação entre os dois portos. O sistema hipodâmico da cidade, com grandes avenidas, foi outro fator que facilitou o transporte e a circulação de produtos, pois os artigos podiam ser levados através de uma rota direta (GODDIO; BERNAND, 2004, p. 148). O porto de fora era usado principalmente para essa comercialização internacional, mas o porto interno do lago Mareótis era também importante, pois era aonde chegavam às embarcações vindas de dentro do Egito. Ballet (1999, p. 33) considera que o lago era um verdadeiro "mar interior", pois unia Alexandria ao Nilo, e mais a oeste, ao Mar Vermelho. Era esse lago que concedia a Alexandria sua reputação de primeiro empório da região. O lago era ligado por canais ao Nilo, mas também ao mar, por isso ficava repleto de viajantes e comerciantes (EMPEREUR, 1998, p. 215).

O Egito não era importante para o império apenas pelo trigo, mas pela quantidade de riquezas que afluía para Roma através de impostos, por ser a província mais populosa e rica do império (CAPPONI, 1975, p. 168). A incorporação do Egito trouxe até mesmo inflação nos preços de Roma, pela quantidade de riqueza absorvida dos Ptolomeus (CAPPONI, 1975, p. 157). Tais impostos em trigo geravam excedentes, pois o montante era superior às necessidades da população. O excedente era revendido pelo Estado de volta à Alexandria, que tinha então o suficiente para se nutrir e alimentar muitas grandes cidades do baixo Mediterrâneo (CLARYSSE, 2000, p. 60).

Com a intensificação do comércio com o Oriente e o aumento no fornecimento de trigo para a capital, havia um fluxo praticamente contínuo de carregamentos de Alexandria para Roma a partir do século I a.C., com o envio de manufaturados da própria cidade, além do trigo e itens de luxo (CASSON, 1984, p. 83). Dessa forma, o porto de Alexandria tornou-se o mais importante do Mediterrâneo para a circulação de produtos mundiais e artigos de luxo e se sobressaiu também como ponto de escoamento da produção egípcia de trigo e papiro. O porto interno era vital para escoar os artigos 
mundiais para dentro do Egito, e levar toda a produção do vale à Alexandria, que encaminharia esses produtos por variadas regiões do Mediterrâneo. Sob Roma, o porto se manteve ativo e fervilhante, mas foi reordenado pela potência, pois a maior parte era destinada à cidade e ditada pelas necessidades do Império.

\subsection{Crise na dinastia ptolomaica e a conquista do Egito}

Como já foi dito, todas as vantagens de Alexandria a tornaram um centro visado, e os reis investiram todos os seus recursos para tornar a cidade ainda mais atraente. Esse embelezamento da metrópole, que os romanos consideravam esbanjamento excessivo, só foi possível pela posição hegemônica dos Ptolomeus nos reinos helenísticos, possibilitando a entrada de muitas riquezas no local. A efervescência cultural, dinâmica comercial e imponência das edificações de Alexandria a transformaram na cidade mais importante do mundo helenístico e não passaram despercebidas por Roma.

Os Ptolomeus dominaram o equilíbrio de poder entre os reinos helenísticos fundados pelos generais de Alexandre durante a maior parte desses trezentos anos de governo. Como os romanos estavam fixando suas conquistas e ambicionando ainda mais territórios, logo perceberam a importância de tecer boas relações e alianças com a dinastia. Dessa forma, durante os três séculos de era ptolomaica, as relações com Roma se estreitaram, começando de maneira sutil através de tratados e alianças diplomáticas, e se intensificaram no século I devido aos problemas na realeza, que demandaram o auxílio romano em muitas ocasiões. Portanto, as brigas entre os reis foram bem aproveitadas por Roma para aumentar o cerco sobre o Egito e finalmente conquistá-lo em 31 a.C..

No reino de Ptolomeu IV Filopator (221-204), apareceram os primeiros sinais de declínio da dinastia, por constantes disputas entre seus membros. A partir do séc. II, guarnições militares eram cada vez mais numerosas no reino, pois diminuída a autoridade da realeza, muitas rebeliões de nativos eclodiram. A região de Tebas tornouse a mais instável. No entanto, sabe-se pouco das rebeliões, praticamente ininterruptas nesse período, pois a literatura que remete à época narra apenas a história dinástica, as querelas na família ptolomaica e o estabelecimento de relações com Roma 
(ROSTOVTZEFF, 1941, p. 69). Bernand (2001, p. 29) acredita que esses conflitos familiares dos reis alimentaram as subversões da população alexandrina e os problemas sociais, já que os monarcas não serviam de "bons exemplos" para o povo. A população culturalmente heterogênea da cidade talvez tenha sido mais uma "faísca" para a eclosão de conflitos e um estímulo ainda maior para o "caráter revolucionário dos alexandrinos" (BERNAND, 2001, p. 29).

O séc. I foi de crescente dependência egípcia de Roma, pois nas incessantes desavenças dinásticas, a classe dirigente romana interviu várias vezes para apoiar uma ou outra facção. Mas os "favores" romanos começaram a sair caros para os reis, e a "amizade" constituída entre os dois territórios foi lentamente se transformando em dependência financeira do Egito.

Foi provavelmente o endividamento diante de Roma que tornou o rei Ptolomeu XII Aulete extremamente impopular entre os alexandrinos, resultando na sua expulsão do reino entre 59 e 58. Ptolomeu buscou refúgio na capital e foi reinstalado no trono com ajuda militar e financeira romana. Fraser ressalta que a subserviência à Roma foi $o$ principal fator que uniu a população contra o rei (1972, p. 795). O autor chama a atenção para a força do povo na resolução de conflitos dinásticos, quando a dinastia estava enfraquecida, apoiando uma ou outra facção real. Na visão de Fraser, essa instabilidade política foi o motivo principal que promoveu a emigração de intelectuais da cidade (1972, p. 120-121).

Os episódios de resistência cultural aos dirigentes gregos foram raros, mas não podem ser desconsiderados, embora o mais comum fosse a eclosão de problemas por questões sociais e econômicas. Dentre as situações de resistência pelos nativos (aos governantes gregos), o mais sugestivo e impactante foi a divulgação do Oráculo do Oleiro, escritos que pregava a destruição de Alexandria e que circulou por quase quinhentos anos na região de Tebas (BOWMAN, 2007, p. 168).

No processo de maior controle por Roma e enfraquecimento do poder real, somado à fragilidade da dinastia provocada pelas incessantes disputas, brigas e assassinatos, aparentemente os Ptolomeus foram perdendo legitimidade diante da população alexandrina. Além disso, muitos territórios com os quais o Egito comercializava começaram a ser incorporados pelo império, além da anexação de regiões de antigo domínio dos Ptolomeus, como a ilha de Chipre (HUZAR, 1988, p. 347). Aproveitando-se desse cenário instável, os alexandrinos começaram a se mobilizar 
de formas mais autônomas e dissociadas do poder, sinalizando para Roma que a maior metrópole oriental tinha muitas formas de reunir multidões e se manifestar a partir de tais aglomerações.

Os momentos em que a população começou a se manifestar contra seus reis demonstraram a capacidade de se autogovernar dos alexandrinos e foram vistos com cautela pelos romanos? A possibilidade de essas multidões abalarem a ordem estabelecida passou a ser motivo de preocupação? Acreditamos que o potencial revoltoso dos alexandrinos começou a criar alarde, como também a sua capacidade de agregar multidões e dispersar povos, devido à localização da cidade, sua grandeza e mistura populacional. Não seria Alexandria a única cidade a ter essa posição tão semelhante à da capital do império? Empereur (1998, p. 48) destaca que a grandiosidade de Alexandria era comparável apenas a Roma, portanto era inevitável que algum dia as suas cidades se tornassem rivais. Segundo Runia (2000, p. 363), o maior diferencial entre os dois centros era apenas que Alexandria não era a sede do poder.

As palavras de Trapp resumem bem o potencial representado pela cidade aos olhos de Roma:

Se a perspectiva na qual eu apresentei esses textos e autores do período imperial romano for justa, Alexandria, conforme representada na imaginação das elites educadas da época, emerge como um caso bastante singular entre as grandes cidades do mundo. Para a ambivalência familiar atribuída a toda e qualquer grande cidade (que pode ser visto tanto como paradigmas da riqueza e dos produtos da ingenuidade humana, ou como armadilhas e fontes de corrupção) Alexandria adicionava a dimensão extra da bem sucedida, porém suspeita arrivista. Fundada pelo último dos grandes helenos livres, mas somente atingindo seu apogeu como centro econômico e cultural em uma era na qual a perspectiva histórica do período imperial tendia a ignorar (ou ao menos subestimar em comparação com os centros do quinto e quarto séculos do helenismo), Alexandria emitia convites contrários, para celebrar e para depreciar. $\left(2004\right.$, p. 130) ${ }^{10}$

\footnotetext{
10 "If the light in which I have presented these texts and authors of the Roman imperial period is a fair one, Alexandria, as represented in and to the imaginations of the educated élite of the day, emerges as a rather singular case among the great cities of the world. To the familiar ambivalence attributable to any and all great cities (which can be seen either as paradigms of wealth and the products of human ingenuity, or as snares and sources of corruption) Alexandria added the extra dimension of the successful but suspect parvenu. Founded by the last of the great free Hellenes, but only attaining its acme as economic and cultural centre in an era which the historical perspective of the imperial period tended to ignore (or at least to undervalue in comparison to the centres of the fifth and fourth century Hellenism), Alexandria issued contradictor invitations, to celebrate and to disparage."
} 
O primeiro momento de conflito direto com Roma e que comprometera a convivência pacífica estabelecida até então entre as duas metrópoles ocorreu após o assassinato de Pompeu em Alexandria em 48 a.C.. No contexto do final da guerra civil, o romano foi buscar refúgio na cidade, confiante nos "favores" devidos pelos reis e ao invés de proteção, ele foi assassinado a mando de Ptolomeu. Sua morte foi interpretada pelos romanos e pelo seu inimigo Júlio César como uma afronta, e como uma intromissão indevida em assuntos de Estado. Segundo Bowman (2007, p. 169), a morte de Pompeu em Alexandria demonstra a importância da cidade naquele contexto préconquista. O episódio foi um dos desencadeadores da guerra de Alexandria com César (entre 48 e 47), e durante os combates, em que Ptolomeu foi rapidamente derrotado, é notável a persistência dos alexandrinos em prosseguirem no conflito de forma independente da realeza. Assim, apesar da derrota, o povo conseguiu demonstrar sua capacidade de resistência a Roma. Teria sido mais fácil para Ptolomeu mobilizar um exército muito maior que o de César, pelas suas condições improvisadas no início da guerra. Assim, o fato de não ter feito isso é, na visão de Williams, prova da falta de legitimidade dos reis entre os egípcios, da separação de Alexandria de todo o Egito e da reticência dos Ptolomeus em armarem egípcios tão conhecidos por sua fama turbulenta (2004, p. 100).

O estopim dos problemas entre Roma e Alexandria ocorreu no reino de Cleópatra VII, a última rainha da dinastia ptolomaica. O governo de Cleópatra pode ser caracterizado como o "último suspiro" na tentativa de manter a autonomia alexandrina e restabelecer o prestígio perdido dos Ptolomeus. Ou seja, a rainha se esforçou para mudar o quadro desfavorável para a realeza naquele contexto. No entanto, sua aliança com Marco Antonio, um romano respeitável que na aliança com a rainha se posicionou contra a própria pátria, foi interpretada como uma tentativa de rivalizar com Roma. Antônio teve três filhos com a rainha, mudou-se para Alexandria, mesmo casado com Otávia (irmã de Otávio) e devolveu ao Egito terras já sob domínio imperial. Otávio venceu Marco Antônio em 31 a.C., e assim, entendia-se que Roma havia vencido Alexandria, através da anexação do Egito como província. É notável a proliferação de narrativas sobre Alexandria a partir desse momento, mesmo os relatos que remetem a períodos anteriores, como à fundação e à era ptolomaica.

Rostovtzeff (1941, p. 69) observa a ironia de o mais passivo dos reinos helenísticos e mais obedientes às ordens romanas, ter produzido a mulher mais forte, 
capaz e ambiciosa, que tinha o objetivo de revitalizar o mundo helenístico e dar a ele uma nova forma com o Egito em seu centro. Tratava-se de um sonho digno das gloriosas tradições que tinham se formado no mundo helenístico. $\mathrm{O}$ autor chama de passividade as alianças promovidas com Roma até então, e que eram convenientes para os dois lados. No entanto, as manifestações dos alexandrinos contra seus reis já haviam demonstrado que seus habitantes tinham força para agir autonomamente caso precisassem.

Após a conquista de Otávio, Alexandria foi controlada politicamente, contudo, manteve sua expressividade em outros setores. Portanto, por mais que Otávio enfatizasse sua vitória e comemorasse Actium, o romano não esqueceria facilmente o que se passara. Dessa forma, estabeleceu medidas para manter um controle mais rígido sobre o Egito, que seus sucessores mantiveram em funcionamento. As celebrações da conquista de Alexandria denotam que parte do problema estava resolvida, e comemorála era importante para convencer a população da importância da tomada do Egito e da necessidade de controlar sua capital.

A partir da incorporação de Alexandria, o Egito tornou-se uma província romana. Até que ponto as medidas implantadas por Augusto foram inovações em relação ao período ptolomaico? Os acadêmicos debatem a respeito do predomínio da continuidade ou da ruptura no processo de transferência de poder político. A continuidade foi defendida com base na predominância de cargos e instituições ptolomaicas, das quais os imperadores a partir de Augusto fizeram grande uso (MILNE, 1924, p. 121). No entanto, Martin Goodman (1997, p. 265) e Maurice Sarte (1994, p. 456) demonstram como sob a superfície da permanência (pois os nomes de certos postos e estabelecimentos não tinham mudado) foram realizadas mudanças burocráticas profundas, por meio da infiltração de funcionários romanos em postos de comando antes reais e egípcios.

Em um célebre artigo sobre o tema, Naphtali Lewis (1970, p. 5-6) defende que a reorganização de todo o maquinário administrativo tornaram as mudanças no Egito mais visíveis até do que as transformações trazidas pelo helenismo. As alterações eram mais perceptíveis nas grandes cidades do Egito, principalmente em Alexandria onde se situava a base do novo comando. Na chora, parte da antiga estrutura foi mantida e a presença da potência romana foi aparentemente menos concreta. 
Alexandria não era mais a metrópole preponderante de um reino, mas apenas a capital de uma província. No entanto, pela vitalidade do Egito para Roma, manteve-se a vigília constante sobre a cidade. Apesar da presença fixa do exército, que provavelmente tivera um impacto considerável, Capponi ressalta que o Egito já era controlado militarmente por Roma mesmo antes da conquista $(1975$, p. 9).

Ao invés do rei, estabeleceu-se em Alexandria um prefeito romano. Eram nomeados para o cargo os principais homens de ordem equestre (senadores não eram permitidos) que tinham relações próximas com o imperador. Os prefeitos deveriam lhe prestar contas com enorme frequência, e questões cívicas mais graves eram encaminhadas ao príncipe. Além de não poderem assumir a prefeitura, senadores não podiam entrar no Egito sem a autorização imperial. Assim, o Egito era praticamente a propriedade pessoal do imperador.

A transferência de poderes foi feita em etapas e muito foi aproveitado da estrutura administrativa anterior, no entanto, a população alexandrina notara que nesse momento o controle emergia de fora, o que nos faz discordar da visão de Legras. Segundo o autor (2004, p. 27), imperador e prefeito eram de certa forma, continuadores dos faraós, pois no plano político foram os aspectos faraônicos da monarquia ptolomaica que prevaleceram.

Outro ponto que resulta em grandes debates na historiografia sobre Alexandria se refere à ausência da Boule. Todas as metrópoles de fundação helenística e as cidades e colônias gregas mais antigas receberam um conselho em sua época de fundação e a mantiveram sob Roma. À Alexandria não foi permitida a posse da Boule e a grande questão que intriga os acadêmicos se refere ao momento de sua perda, se ocorreu no final do período ptolomaico, quando os reis podiam ter suprimido a instituição como castigo aos protestos da população ${ }^{11}$. Ou foi mais uma inovação imposta por Augusto e uma forma de driblar as pretensões imperiais da elite alexandrina (MILNE, 1924, p. 133; FRASER, 1972, p. 93-94)? Atualmente, a primeira visão é a mais consensual entre os acadêmicos. Segundo Bowman e Rathbone (1992, p. 115), a ausência da Boule foi de certa forma preenchida com a atuação política dos gregos do Ginásio, que atuou em muitos momentos como o grupo representativo de Alexandria diante de Roma. Esse foi o grupo que promoveu maiores resistências à potência, reclamando sobre a autonomia perdida sob o novo comando.

\footnotetext{
${ }^{11}$ Cf. BOWMAN, 1986, p. 211; MILNE, 1924, p. 282; BELL, 1932, p. 184.
} 
A despeito de utilizarem grande parte da burocracia ptolomaica para introduzir a administração imperial, os romanos realizaram uma série de modificações nas funções, nos cargos e também no status cívico dos habitantes. A carga fiscal imposta aos residentes era inversamente proporcional ao seu grau de helenização. Porém, essa delimitação foi feita de forma artificial e com base em categorias definidas pelos próprios romanos. Nesse processo, foram transferidos para o grupo dos egípcios muitos gregos dos ginásios de grandes cidades do Egito. Modrezejewski (1990) discute tais definições de status a partir da legislação. A categoria de helenos passou por novas significações, e foi reforçada pelos romanos. Logo após a conquista romana, realizou-se uma seleção dos mais privilegiados entre os grupos, e se a intenção foi recuperar o elemento grego, isso não foi alcançado, pois muitos egípcios helenizados e próximos aos círculos alexandrinos foram integrados à gente do Ginásio. $\mathrm{O}$ aumento da nomenclatura grega foi visível, no entanto, isso não indicava o pertencimento étnico do indivíduo, mas uma disseminação indiscriminada de traços culturais gregos. Se a comunidade helenística estava desagregada, esse momento sugeriu um novo modo de valorizá-la, mas em um esquema jurídico e fiscal original, não mais relacionado com as origens étnicas de cada heleno (1990, p. 278). Nesse sentido, o pertencimento à Alexandria e os vínculos antigos com a cidade foram o aspecto mais valorizado, algo que foi feito provavelmente para controlar e satisfazer as elites mais poderosas da cidade, pois os romanos acreditavam que ao se aliarem a elas, teriam mais facilidade e legitimidade para governar.

Para definir o status da população, realizavam-se sofisticados censos a cada quatorze anos. Assim, a manutenção dos cadastros era central para tais delimitações, para fins de taxação e controle da população (BAGNALL; FRIER, 1994, p. 29). Capponi (1975, p. 96) ressalta a impopularidade dos censos no Egito, justamente por terem sido acompanhados da introdução de novas categorias aplicadas ao povo.

Apesar das atitudes negativas dos romanos diante da cultura egípcia e de uma tentativa de reforçar o helenismo, eles sabiam que a valorização dos templos era fundamental para manter o controle no país. Assim, os imperadores adotaram também uma titulatura egípcia e se apresentavam como faraós nesses templos em muitas ocasiões (CLARYSSE; WILLEMS, 2000, p. 33).

Alguns imperadores tinham uma postura de maior valorização e admiração dos egípcios (como Nero e Calígula), porém esse não foi o caso de Augusto. Os 
monumentos egípcios levados a Roma por ocasião da conquista foram transferidos como prêmios de guerra e símbolos de sua vitória, e não como sinal de admiração pela cultura faraônica (CLARYSSE; WILLEMS, 2000, p. 30). A transferência do obelisco para Roma, e as posteriores visitas dos imperadores a Alexandria resultaram em um interesse na arquitetura egípcia em Roma. Mesmo que essa não fosse a intenção de Augusto, se refletiu na construção de estruturas na cidade com características egípcias, como obeliscos, pirâmides, pinturas de parede e o templo a Ísis e Serápis. Segundo Wallace-Hadrill (2008, p. 358), houve uma significativa popularidade de motivos faraônicos nos círculos da corte, diante de cenário de repressão à disseminação do culto de Ísis em Roma, pouco depois do triunfo em 28, novamente em 21 e depois sob Tibério. Além disso, Augusto e depois Tibério investiram em antigos templos egípcios. O principal indicativo do fascínio de um imperador pela cultura egípcia ocorreu no reinado de Adriano, com a construção da vila egípcia (alusão a Canopo) em Tivoli (MCKENZIE, 2008, p. 185).

Com relação às inovações urbanas realizadas em Alexandria por ocasião da conquista, alguns edifícios romanos foram construídos para denunciar a presença imperial na metrópole. Além disso, Alexandria foi embelezada com recintos semelhantes à de outras cidades do Oriente (MCKENZIE, 2008, p. 4). As principais facilidades para a vida cívica grega continuaram em uso, mas instituições tipicamente romanas foram adicionadas, como um anfiteatro e banhos, além da construção de edifícios em honra aos imperadores (MCKENZIE, 2008, p. 149). Ou seja, estava claro para os alexandrinos que uma alteração de poder estava sendo efetuada na cidade.

A obra de Lívia Capponi Augustan Egypt: The Creation of a Roman Province analisa a fase de transição entre os Ptolomeus e Augusto. As comemorações da tomada de Alexandria indicavam a ênfase no início de uma nova era (1975, p. 28). No entanto, Augusto parece ter sido cauteloso nesse processo de transferência de poderes, talvez pelo medo de ressurgirem oposições por parte dos antigos partidários de Antônio. Assim, aparentemente não desarmou o Egito logo após a conquista, mas aproveitou muito do exército ptolomaico no exército romano (CAPPONI, 1975, p. 23). O imperador também rapidamente se apropriou de terras antes pertencentes a Antônio e Cleópatra (CAPPONI, 1975, p. 106). A política de isentar os alexandrinos dos impostos, provavelmente tinha a intenção de conquistar seu apoio (CAPPONI, 1975, p. 87). Para isso, Augusto provavelmente empregou sua própria rede de libertos e escravos na coleta 
de impostos e outros postos compulsórios, com o intuito de manter um maior controle sobre a arrecadação (CAPPONI, 1975, p. 75).

Apesar das inovações, o primeiro século de império foi relativamente tranqüilo em Alexandria, apesar da vigília constante sobre a cidade. Sob Augusto e Tibério a situação da metrópole foi pacífica e seu enriquecimento e desenvolvimentos foram visíveis. Mas a partir de Calígula conflitos irromperam entre os dois setores socialmente mais expressivos da população: a elite grega do Ginásio e a comunidade judaica, a maior da Diáspora. A Alexandria romana se faz notar pela eclosão de tumultos constantes. Após Calígula, os problemas se repetiram com gravidade nos principados de Cláudio, Nero e Trajano, quando ocorreu o conflito que abalou drasticamente o judaísmo na cidade (entre 115 e 117). Se durante o período ptolomaico já existia alguma insatisfação mútua entre os grupos, os conflitos só se manifestaram de forma mais severa nesse novo contexto, talvez como uma resposta dos grupos às medidas introduzidas de fora e que interferiam na maneira de conviver da sociedade alexandrina. $\mathrm{Na}$ demarcação de status, os judeus foram rebaixados para a mesma categoria dos egípcios, que pagavam os maiores impostos a Roma. Ou seja, tratava-se do grupo de menor status social. Assim, os judeus começaram a protestar diante das autoridades romanas, conquistando algumas concessões, o que começou a enfurecer os alexandrinos, conscientes de sua superioridade e supremacia na cidade.

Os problemas entre judeus e alexandrinos são os mais discutidos pela historiografia contemporânea que estuda a Alexandria romana ${ }^{12}$, principalmente pela riqueza dos relatos de Fílon e Josefo e pela descoberta de uma documentação lacunar, embora muito reveladora, que fornece a perspectiva dos alexandrinos do Ginásio nos embates, os Acta Alexandrinorum ${ }^{13}$. A descrição das revoltas por esses autores são também as principais fontes que atribuem aos alexandrinos à fama de conflituosos e embasam os acadêmicos modernos ao abordarem os problemas na cidade.

A gravidade dos conflitos entre judeus e alexandrinos exigiu a presença e interferência romana em inúmeras ocasiões. Os problemas serviram para confirmar a

\footnotetext{
${ }^{12}$ Cf: BARCLAY, 1996; BARRACLOUGH, 1984; COLLINS, 2000; MELEZE-MODRZEJEWSKI, 1987.

${ }^{13}$ A mais consagrada edição e análise dos textos são de Musurillo, cf. MUSURILLO, 1954. Em 2008, Andrew Harker propos uma nova edição, contestando muitas das posições de Musurillo e acrescentando textos ainda não editados, cf. HARKER, 2008. Em 2010 um estudioso francês da l'Ecole Pratique des Hautes Etudes Chris Rodriguez publicou uma edição em francês dos textos, com alguns que Harker ainda não havia incluído em seu trabalho. Cf. RODRIGUEZ, 2010.
} 
tendência revoltosa dos alexandrinos e fortalecer sua má fama nos escritos daquele contexto? Ou as narrativas sobre os conflitos são carregadas retoricamente e exageram a respeito dos conflitos, justamente para firmar ainda mais essa perspectiva a respeito da população? O quanto dessa má fama pode ser tratado como topos ou retórica? Os relatos que apresentam o lugar-comum da Alexandria polêmica em contraste com a encantadora começaram a ser veiculados nesse período ou já eram recorrentes? Pela pesquisa se centrar nessa época de transição de poderes, interessa saber justamente o momento em que a má fama começou a se fortalecer na tradição escrita clássica.

A tese de doutorado de William Barry Faces of the crowd: Popular society and Politics of Roman Alexandria, 30 BC-AD 215 (1988) tenta desconstruir a imagem de Alexandria como uma cidade turbulenta, na sua visão o maior consenso historiográfico entre os acadêmicos modernos. Com a intenção de derrubar essa visão convencional ele mapeia todos os episódios de turbulência narrados pelas fontes, e todas as situações que envolvem algum comportamento da multidão em oposição à elite governamental. Como turbulência, Barry entende também momentos de aglomerações pacificas, que eram igualmente fundamentais para reunir grandes agrupamentos na cidade, o que ele nomeia de "turbulências não-violentas" (1988, p. 24). O autor acredita que temos de ser cautelosos em confiar na imagem que os antigos nos fornecem de Alexandria, pois eles normalmente fazem generalizações a partir de episódios isolados (1988, p. 9). Tais generalizações a respeito dos conflitos da cidade são pouco precisas e, às vezes, mais alimentadas por retórica do que pelos acontecimentos de Alexandria. Barry (1988, p. 54-57; p. 61) acredita que a possibilidade da formação de multidões na cidade era o que transmitia a sua imagem de turbulência, algo que as fontes descrevem pouco, apesar de realçarem sua presença com frequência. Não só as multidões em conflito deviam assustar, mas principalmente os grupos reunidos para espetáculos, que eram os maiores. Essas aglomerações eram as mais heterogêneas, étnica e socialmente.

A partir do seu levantamento, Barry considera que de forma geral os alexandrinos eram respeitosos com as autoridades. Assim, opõe-se a visão tradicional, que considera uma simplificação das fontes (1988, p. 85). Ou seja, na visão de Barry, Alexandria teve problemas como todas as outras grandes cidades do Império, inclusive numericamente a cidade presenciou menos conflitos do que Roma, o que não poderia lhe render a fama de instabilidade. A grandeza das multidões e o potencial para 
problemas que a cidade podia apresentar é que estariam por trás dos relatos sobre a Alexandria turbulenta.

Concordamos com Barry de que há um exagero no tratamento dos alexandrinos como propensos a rebelião, e que muitos autores de fato usam esse topos sem o menor embasamento. No entanto, as fontes nos dão exemplos concretos dos problemas e se elas exageram, seria justamente por Alexandria ter algum valor diferenciado para Roma, daí tanta atenção concedida à sua tendência turbulenta.

A intenção desse capítulo foi ressaltar as especificidades de Alexandria no contexto mediterrânico, e demonstrar as diferentes vertentes pelas quais a cidade ganhou destaque. O objetivo foi também pontuar brevemente os tópicos mais mencionados pela historiografia ao destacar a importância adquirida pela metrópole, para na sequência discutirmos como as fontes se posicionam frente a tais temas. Os diferentes posicionamentos ajudaram a formar, consolidar e divulgar várias representações de Alexandria no contexto imperial, e o intuito aqui será vislumbrá-las em sua diversidade. 


\section{Capítulo 2: Adjetivações de uma polis helenística no Império Romano}

\subsection{Estabelecimento de um forte vínculo com o mito de Alexandre}

O presente capítulo discute as imagens da Alexandria ptolomaica divulgadas pela literatura clássica posterior, começando com autores gregos helenísticos do século I a.C como Diodoro de Sicília e Estrabão e se estendendo até o grego da segunda sofística, Ateneu, do séc. III d.C.. A intenção é ilustrar como a Alexandria helenística ainda era abordada no período romano, principalmente por autores gregos, mas também por latinos, embora com menor detalhamento e interesse. Pretende-se entender até que ponto a sua fundação por Alexandre e o desenvolvimento rápido promovido pela dinastia ptolomaica eram elementos importantes na formação e divulgação de suas representações produzidas pelo Império Romano.

Nenhuma cidade do Império, além de Roma, foi tão falada e analisada quanto Alexandria. Nesse sentido, é primordial analisar como o passado alexandrino era imaginado nos retratos da cidade promovidos por perspectivas externas e como a literatura faz diferentes usos desse passado para articular identidades alexandrinas divergentes ou semelhantes. Em uma cidade multicultural como Alexandria, de fundação recente e sem tradições consolidadas, como os autores representavam essas identidades tão fluídas, fragmentadas e com imensas contradições internas?

A cidade ganhou relevo na literatura do período, e os escritos se dedicam a explicar o seu crescimento e importância, ora remetendo ao contexto de fundação, ora enfocando em todo o investimento dos reis Ptolomeus, resultando na formação de uma multiplicidade de representações da cidade. Qual era o valor do passado helenístico nesses relatos? Esse passado era caracterizado de diferentes formas de acordo com as complexas identidades alexandrinas explicitadas seguindo categorias divergentes? Vários são os eixos escolhidos pelos autores para explicar a sua imponência e "destino afortunado", ajustados de acordo com o contexto, as expectativas do momento de escrita e conforme o que pretendiam reportar. A intenção é apresentar os temas mais narrados por cada fonte e ressaltar os aspectos que tornavam a cidade notável em seu meio, causando um misto de admiração e apreensão, diante de todo o potencial que 
desenvolvera. A partir daí, pretende-se formar um quadro da Alexandria helenística caracterizado diferentemente conforme as tradições (grega e latina), embora com aspectos comuns, articulando então diversas representações da cidade ptolomaica no Império. Quais são as temáticas privilegiadas e ignoradas para explicá-las? A escolha dos temas sobre a cidade helenística refletia as diferentes percepções da cidade imperial e do que se pretendia divulgar sobre ela?

Um dos assuntos mais abordados pela tradição ao caracterizar Alexandria é a sua fundação por Alexandre. A enormidade e prosperidade do novo estabelecimento situado na "entrada" do Egito, já conhecido dos gregos por suas riquezas e hábitos exóticos, tornaram-se um lugar-comum na representação dos alexandrinos, que depois será contraposto por outro, referente à sua tendência a instabilidade e conflitos. Sua história inicial era valorizada talvez com o intuito de ressaltar seu "início iluminado". Era necessário recorrer à Alexandria de outrora, para entender a cidade do presente. Assim, retrocediam à sua origem promissora para justificar o desenvolvimento posterior. Os antigos com frequência faziam uso de mitos de origem para explicar eventos contemporâneos. Dessa forma, a cidade que no presente adquiriu importância tal, não seria compreendida sem a possibilidade de olhar para as suas origens, justamente porque sua procedência estava associada ao maior mito e herói daquele momento: Alexandre. $\mathrm{O}$ uso de mitos de origens era também uma forma de lidar com a fragmentação do presente. Ou seja, uma cidade que tinha identidades tão diversas e mutantes se apegaria ao seu passado perdido, como uma forma de contestar questões contemporâneas e justificar a criação de novas identidades (WOODWARD, 2000, p. 23).

$\mathrm{Na}$ antiguidade era comum que um "líder carismático" fosse usado para explicar e legitimar a origem de um novo povo, para que posteriormente seus descendentes tivessem uma tradição mais antiga com quem se identificar e se vincular (GEARY, 2005, p. 96.). A comunidade dos alexandrinos era recente e culturalmente muito diversificada, deste modo, precisava ser inventada e idealizada. Era necessário criar "laços imaginários" entre pessoas com pouco em comum, portanto, os mitos fundadores tinham esse intuito. Pouco importava se eram verdadeiros ou não, eles serviam para conceder à identidade "nacional" sua liga "sentimental e afetiva" (SILVA, 2000, p. 85). Assim, o vínculo com Alexandre teria sido algo divulgado pelos próprios alexandrinos desde sua história inicial, ajudando a fortalecer a identificação entre os novos moradores 
da cidade. Se era um elemento interno da identidade alexandrina, com os séculos passou a fazer parte da representação da cidade, e foi publicado diferentemente de acordo com o momento de escrita e propósito de cada autor. Ou seja, tornou-se um eixo comum na representação alexandrina, todavia foi apropriado de formas distintas. Essas diferentes "tonalidades" nas lendas de fundação demonstram a diversidade das imagens alexandrinas propagadas.

$\mathrm{Na}$ mentalidade greco-romana, Alexandre era um personagem chave, que mudara o rumo da história do mundo habitado ao derrotar o império persa, iniciando então um período de expansão da cultura grega. Para entender o retrato divulgado sobre Alexandria a partir do século I a.C., é primordial analisar como os antigos caracterizavam a cidade em sua longa-duração. Nesse sentido, remeter às origens era fundamental, para entender o que viria depois. Ou seja, é atribuído, ao momento de fundação, grande parte do potencial e desenvolvimento futuro da cidade, provavelmente pelos autores terem em mente a Alexandria de seu tempo (já próspera), e não dissociarem essa imagem de sua fundação. Alexandre era um visionário, por ter escolhido um terreno pré-destinado para a fundação do sítio que levaria o seu nome. Consequentemente, parte considerável da prosperidade futura de Alexandria foi estabelecida pelo fundador quando decidiu construí-la naquele exato local.

Diodoro de Sicília é o primeiro autor em ordem cronológica que trata especificamente de Alexandria no contexto em que Roma se torna preponderante no mundo mediterrâneo, ao absorver antigos reinos helenísticos no seu comando. $\mathrm{O}$ autor garante ter visitado muitas das localidades que descreve, embora só existam evidências de sua visita ao Egito, realizada entre 60 e 57 (BURTON, 1973, p. 39). Percebe-se o impacto da viagem para o autor, que começou a Biblioteca Histórica com um livro sobre o Egito antigo. Diodoro é a fonte mais importante para o período imediatamente pós-Alexandre, apesar de não ter sido contemporâneo dos primeiros reis, como Políbio foi para os eventos do período helenístico tardio.

Antes de tratar da sua narrativa sobre a fundação, deve-se destacar que na primeira menção que Diodoro faz a Alexandria, ele associa o nome da cidade a Alexandre. Ou seja, faz isso de forma a introduzi-la aos seus leitores. Tal referência está presente no livro I sobre o Egito, o relato mais detalhado do país desde Heródoto, em que trata dos costumes "estranhos" de seus habitantes. A primeira citação é feita para estabelecer um marco temporal, pois contabiliza a longa duração do reino egípcio, desde 
Ísis e Osíris, até a conquista egípcia de Alexandre, momento em que "Alexandre fundou

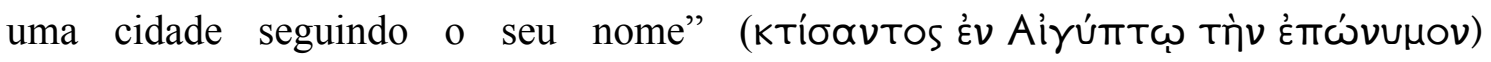
${ }^{14}$ (Bibliotheca Historica 1.23.1). Assim, Alexandria entra na sua narrativa como um novo momento da história egípcia. Tratava-se do fim de uma era, e da origem de um novo tempo, um tempo em que o Egito foi "tocado" por um grego memorável, que deixaria a sua marca naquele reino milenar. Sua passagem pelo local alteraria o rumo do território, que não seria mais o mesmo após a fundação.

Ainda no livro sobre o Egito, Diodoro estabelece uma cronologia das grandes

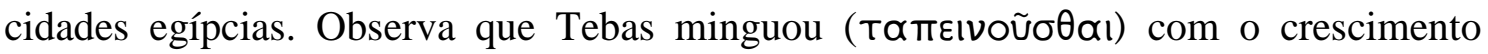

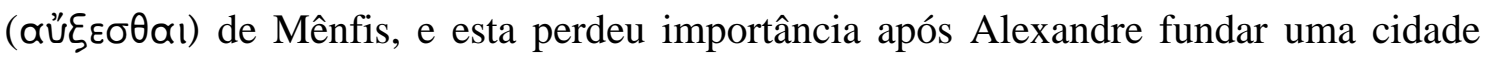

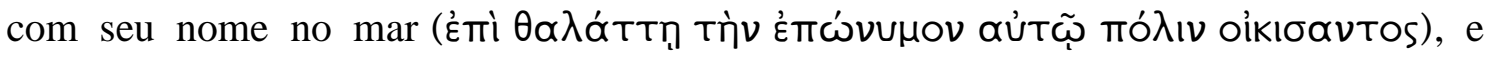

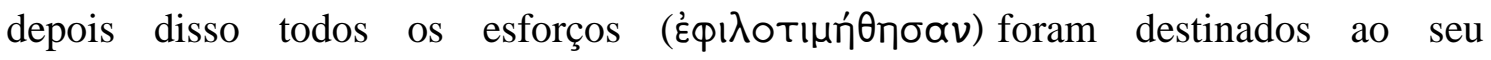
desenvolvimento ( $\propto \cup ̌ \xi \eta \sigma ı v)$ (Bibliotheca Historica 1.50.6). Neste contexto, Alexandria se tornou o foco de atenção dos reis, por ser uma fundação do herói. O Egito tornou-se então digno de menção, pois ao ser conquistado, Alexandre concedeu uma polis grega a esse reino. O foco volta para o Egito, embora em uma perspectiva diferenciada. A ênfase não era mais no Egito exótico e diferente, mas no novo estabelecimento grego, que agrega ao Egito uma outra identidade, uma identidade helênica, que se tornou predominante. Não fora justamente a fundação grega no território que encorajou Diodoro a refletir sobre o Egito?

A partir de Alexandria, mesmo as antiguidades egípcias foram analisadas sob outra perspectiva. Ou seja, se antes o Egito era visto como um local distante e misterioso, nesse momento, sua cultura é revista e explicada para os gregos, por se tornar mais acessível. O Egito tornou-se relativamente helenizado com a fundação de Alexandria e passou a ser alvo de atenção dos gregos. Portanto, a cidade concedeu algo de inovador para o Egito, mas também levou muito do Egito para si. Diodoro enquadra Alexandria em uma sucessão de importantes cidades egípcias, mas ao mesmo tempo, destina suas explicações para a cidade em um momento separado de seu trabalho, demonstrando que a fundação era parte do Egito, mas exigia uma atenção específica. $O$ autor volta a tratar do Egito em outros momentos de sua obra, cita Alexandria de forma

${ }^{14}$ Todas as traduções foram feitas a partir do inglês da Loeb Classical Library em conferência com o original grego, e quando necessário, algumas alterações foram feitas com base nos termos em grego. 
pontual também em repetidas ocasiões e concentra suas atenções para a fundação no livro XVII. Deixemos as palavras com Diodoro:

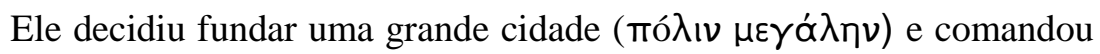
os encarregados que ficaram para trás a estabelecer a cidade entre o pântano e o mar. Ele delimitou o sítio (Tótrov) e o traçado das ruas com habilidade e ordenou que a cidade se chamasse Alexandria seguindo o seu nome. Foi convenientemente situada perto do porto de Faros, e ao estabelecer o ângulo certo para as ruas, ele possibilitou que a cidade respirasse com os ventos etésios, pois quando esses sopram por uma grande extensão ( $\mu \varepsilon$ ýotov) do mar, eles esfriariam o ar da cidade, então proporcionou aos muitos habitantes um clima moderado

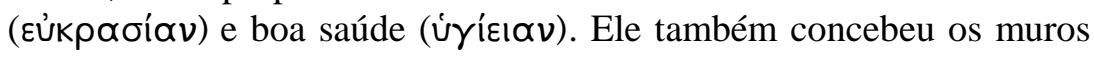
para que fossem ao mesmo tempo extremamente largos

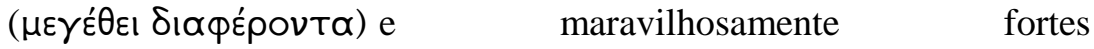

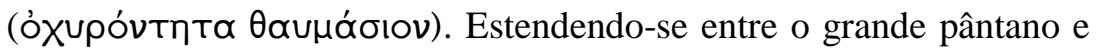
o mar, permite por terra apenas dois acessos, ambos estreitos e

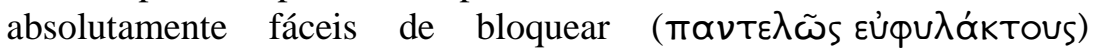
(Bibliotheca Historica 17.52).

Pode-se observar no trecho citado como a descrição da instalação da cidade remete inicialmente à decisão de Alexandre. Ele é retratado como o sujeito principal de todo o processo, pois todas as decisões são baseadas nas suas ordens e determinações. Ou seja, Diodoro não trata apenas da história da fundação, mas da resolução de Alexandre de fundar uma grande cidade, situada em um lugar privilegiado pela natureza. Foi essa escolha que concedeu àquele local sua existência memorável. Percebe-se a racionalidade atribuída ao projeto, pois tudo foi pensado para tornar o local acessível, mas ao mesmo tempo protegido, além de agradável para a habitação. Dessa forma, o autor enfatiza a genialidade e racionalidade do ato de Alexandre e seu talento como arquiteto. Percebe-se o quanto Diodoro associa a evolução posterior de Alexandria à decisão de Alexandre de fundá-la ali e não em outro local.

Os aspectos mais realçados por Diodoro nesse trecho são a grandeza territorial e a boa posição defensiva do novo centro urbano, além da escolha do local adequado. Diodoro escreveu em um contexto de guerra civil, de crise da República e ao mesmo tempo, de engrandecimento de Roma, que passou de uma cidade-estado para uma cidade imperial. Não se sabe exatamente quando morreu (entre 36 e 30), mas provavelmente não viu o Egito ser incorporado à província. A ênfase na grandeza de Alexandria não era também uma referência ao crescimento de Roma, que diferentemente de Alexandria, foi realizado de forma desordenada? Na concepção de 
Diodoro, Alexandria era principalmente uma cidade greco-macedônia, pois sua grecidade foi concedida pelo rei macedônio Alexandre, que através de sua fundação, mudou a dinâmica cívica do Egito.

Estrabão remete à fundação de forma passageira, e após mencionar a cidade em outros contextos. Ele não conhecera a obra de Diodoro, mas os dois fornecem testemunhos do mesmo período da cultura helenística e ambos visitaram Alexandria e o Egito (entre 25 e 24 a.C.), com um intervalo de aproximadamente 30 anos (YOYOTTE, 1997, p. 28). Sua caracterização sobre Alexandria é uma das mais detalhadas de que se tem notícia, e cobre a fundação até a conquista de Otávio. O autor vivenciou o contexto de incorporação do Egito ao Império Romano, embora seu cenário de escrita fosse posterior.

Estrabão estabelece uma ordenação menos cronológica para falar da cidade, pois, diferente de Diodoro que pretendia elaborar um relato enciclopédico, Estrabão estava mais interessado em sua contemporaneidade, e remetia ao passado apenas para contextualizar certos temas atuais. Assim, deve-se ressaltar a "modernidade" de Estrabão em relação ao seu contexto de escrita e por ter vivenciado Alexandria intensamente, pois tinha passado mais de cinco anos na cidade (YOYOTTE, 1997, p. 17). A intenção do autor era que sua obra servisse aos homens do estado, portanto tinha uma finalidade prática e didática.

Apenas no livro 17, em que elabora uma caracterização minuciosa do Egito, é que sua narrativa é mais focada na construção e desenvolvimento de Alexandria, após fazer uma detalhada descrição do Delta. Em momentos anteriores de sua obra ele chama a atenção para a importância comercial e cultural da região, além de mencionar, em mais de uma ocasião, que morou na cidade (Geographica 1.3.17; 2.3.5). Seu envolvimento pessoal torna o testemunho sobre o Egito o mais vivo e detalhado de seus escritos, pois foi também a província em que acompanhou mais de perto a incorporação ao Império (YOYOTTE, 1997, p. 26).

Estrabão começa o relato de Alexandria citando o seu desenvolvimento pelos reis, em seguida aborda o processo de construção, e depois faz uma detalhada descrição da cidade do seu tempo. Como Diodoro, Estrabão retrocede ao episódio de fundação, para ressaltar o bom posicionamento da cidade e a escolha do terreno adequado. Observa que quando Alexandre visitou o Egito, e viu a posição vantajosa

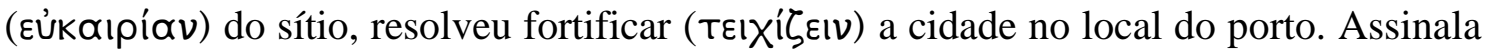


ainda o sinal de boa sorte e prosperidade futura (associada à abundância e produtividade), o que foi logo revelado na demarcação do terreno:

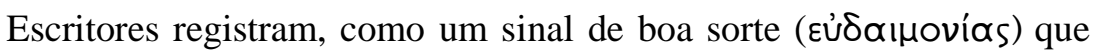
desde então acompanha a cidade, um incidente que ocorreu no momento de traçar as linhas de fundação: Quando os arquitetos estavam marcando as linhas do cercado com giz, o suprimento de giz acabou; e quando o rei chegou, os guardiões pegaram um pouco da refeição de cevada destinada aos trabalhadores, e dessa forma as ruas, agora em número maior do que antes, foram demarcadas. Então essa ocorrência, eles dizem que foi interpretada como um bom presságio

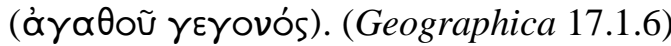

O autor assinala a autoria de Alexandre no início do processo, mas realça também a presença de arquitetos na demarcação do terreno. Ou seja, em relação à Diodoro o processo está menos centrado em Alexandre, embora sua perspicácia na escolha do terreno fora realçada logo no início. Estrabão agrega mais um elemento além da posição adequada, defensiva e da qualidade do terreno já assinaladas anteriormente por Diodoro: os presságios indicando a prosperidade, atribuindo certa predestinação ao contexto de fundação. Percebe-se aqui o estabelecimento de um mito, que ronda os relatos sobre a construção, pois várias circunstâncias colaborariam para a sua futura sorte. Além da decisão certeira de Alexandre ao visualizar o local, a boa sorte foi logo confirmada na demarcação do terreno, reafirmando a genialidade da decisão do fundador.

Estrabão enumera as várias vantagens (Eưkaıpía) do local, o fato de a cidade estar situada entre dois mares, o Mediterrâneo, que ele chama de mar egípcio, e o lago Mareótis, que pela grandeza, o autor define como outro mar. O seu bom posicionamento foi importante para garantir a qualidade do ar e sua salubridade (que Diodoro também havia ressaltado) (Geographica 17.1.7). Na sequência, o autor realça o formato $(\sigma \times \tilde{\eta} \mu \alpha)$ da cidade, o intercruzamento de duas grandes avenidas e suas edificações, estabelecidas pelos reis (Geographica 17.1.8). Enfoca assim, no planejamento e racionalidade do projeto, e na importância dos reis na sua execução.

Estrabão provavelmente frequentou a Biblioteca e o Museu durante os anos em que morou na cidade, dessa forma, tivera acesso aos seus arquivos e convivera com os intelectuais do lugar. Provavelmente chegara ao Egito com um bom conhecimento sobre o local, e lera Políbio, onde estavam expressas opiniões gregas e romanas a respeito dos 
Ptolomeus e sua sede real (YOYOTTE, 1997, p. 19). Apesar de sua pretensão de elaborar um registro mais técnico e pragmático da cidade, com a intenção de informar os homens do governo sobre cada localidade do Império, percebe-se a influência da carga lendária para legitimar a importância de Alexandria. $\mathrm{O}$ autor garante ter viajado muito para buscar seus conhecimentos, no entanto, foi principalmente através de livros que colheu suas informações. Sobre o Egito, por exemplo, além de sua experiência no local, usou como uma de suas fontes principais Timagenes de Alexandria, seu contemporâneo, cujo relato infelizmente se perdeu (KNOX, 1985, p. 642).

O judeu-alexandrino Fílon não fala explicitamente sobre a fundação de sua cidade. Contudo, fica claro no seguinte trecho, onde o filósofo analisa a profundidade da criação de Moisés, que Fílon está fazendo uma referência à própria terra, embora exista um consenso historiográfico que entende o relato como uma alusão à cidade ideal de Platão (RUNIA, 1989, p. 398). David Runia (1989, p. 405) observa o quão revelador seria se no único momento em que Fílon chama uma cidade terrena de megalópole ele estivesse se referindo a Alexandria, principalmente por estar descrevendo o contexto de criação do cosmos. O judeu definia a existência de Alexandria como uma cidade planejada, comparável ao universo em sua racionalidade (RUNIA, 1989, p. 407). Nesse sentido, sua concepção não era tão diferente à de Diodoro e Estrabão. O comentário faz uma clara alusão às lendas sobre Alexandre, denotando que Fílon estava falando de Alexandria nessa passagem (SLY, 1996, p. 32). Porém, o fato de não nomear o fundador na narrativa infere que por ser judeu, o autor não tinha interesse de reforçar o vínculo da cidade com Alexandre, um contraste claro em relação aos seus predecessores. Fílon relata o seguinte:

Quando uma cidade está sendo fundada para satisfazer as ambições elevadas (

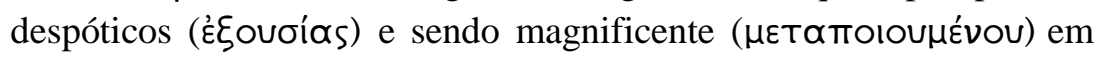
suas ideias, que de bom grado adicionaria um novo brilho

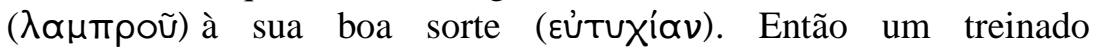

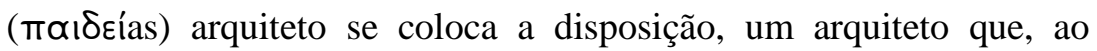
observar o clima favorável e a posição conveniente (Eưkaıpíav) do terreno, primeiramente faz um rascunho em sua cabeça de quase todas as partes ( $\mu$ ḱpך) da cidade que devem ser criadas, templos, ginásios, a

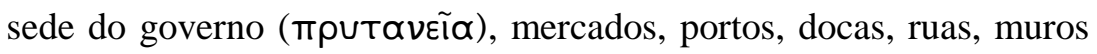

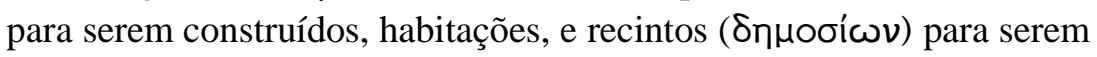
edificados. Então, depois de ter recebido em sua própria alma, como se fosse em argila, as figurações desses objetos, ele realiza a imagem

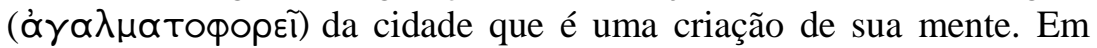


seguida, pelo poder inato de sua memória, ele relembra a imagem das várias partes dessa cidade, e marca as suas características de modo mais distintivo: e como um bom artesão, ele começa a construir a cidade de pedras e madeira, mantendo-se atento sobre o padrão e fazendo os objetos visíveis e tangíveis corresponder à ideia incorpórea (De Opificio Mundi 17-18).

Fílon era antes de tudo um filósofo, daí talvez o objetivo de não concentrar o seu escrito na história de Alexandria e não citar o nome de Alexandre, pois isso desviaria o foco do seu relato que estava voltado para uma questão maior: a criação do cosmos. Ou seja, suas preocupações eram filosóficas e voltadas para o judaísmo, mas como tivera uma educação grega, sua herança helênica também influenciava na escolha de suas temáticas. Portanto, de uma forma indireta, sugere que o planejamento de Alexandria a aproximara da perfeição e reflete que deus criou o mundo da mesma forma, primeiro concebeu o todo, e depois realizou as partes integradas. Assim, poderia estar usando Alexandria como uma metáfora do mundo, em busca de sua completude, por ter sido inicialmente inspirada e depois racionalizada. Dessa forma, mesmo sem atribuir nome à cidade, nem aos seus arquitetos e governantes, a passagem se assemelha em muitos aspectos às narrativas de fundação de Alexandria, e por ser nativo, é plausível que Fílon estivesse falando de sua própria cidade.

O historiador judeu Flávio Josefo menciona a fundação de Alexandria com o intuito principal de provar o pertencimento da comunidade judaica na cidade desde Alexandre. Nas Antiguidades Judaicas, Josefo afirma que Alexandre deu aos judeus de Alexandria direitos iguais aos macedônios e que muitos judeus foram ao Egito por

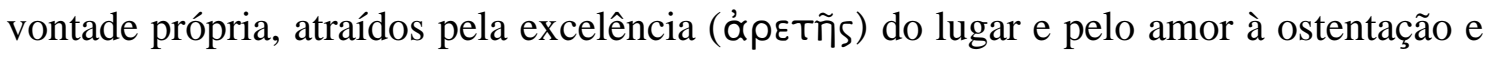

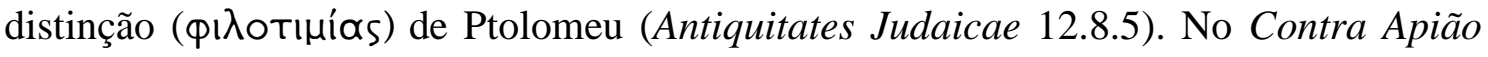
novamente Josefo garante que o local lhes foi dado como residência por Alexandre e adverte que não foi por falta de gente para povoar a cidade que o rei concedeu a cidadania aos judeus de Alexandria, mas por reconhecer a lealdade demonstrada pelo povo (Contra Apionem 2.36-43).

Fílon nada menciona de Alexandre e da herança grega de Alexandria, e Josefo cita o fundador apenas para comprovar a consideração demonstrada diante dos judeus. Ou seja, aos autores não interessava ressaltar a identidade helênica de Alexandria, pois isso reforçaria os direitos dos gregos de seu tempo (séc. I d.C.), que faziam oposição à vivência dos judeus na cidade. A intenção de Josefo é enfatizar a porção judaica da 
identidade alexandrina, que fora garantida e legitimada por Alexandre. Nesse sentido, essa identidade não podia ser contestada, principalmente pelo fundador reconhecer nos judeus habitantes da cidade um status semelhante ao dos residentes macedônios. Portanto, o autor concebe a identidade original de Alexandria como grega, por ter sido fundada por um greco-macedônio. Porém, tal grecidade foi diminuída a partir do momento que outras comunidades receberam o direito do fundador de habitá-la. Dessa forma, o próprio fundador concede à cidade uma composição multicultural, na qual os judeus tiveram um papel preponderante.

Devemos apartar os relatos dos judeus nessas discussões sobre a fundação, por terem intenções diferenciadas de seus contemporâneos, embora sua tradição de escrita e as fontes usadas fossem semelhantes. Alexandria tinha valor para Fílon por ser sua terra natal, portanto, não é de se estranhar que com seu depoimento o autor quisesse enfatizar a importância, enormidade e racionalidade de sua pátria. Mas suas pretensões são claramente filosóficas e alegóricas. Já Josefo tinha uma consideração por Alexandria por ser o maior centro da Diáspora judaica. Porém, mais do que defender a cidade, o autor ambicionara reforçar que a habitação dos judeus no local era legítima e antiga. A antiguidade garantiria o pertencimento e a parcela judaica da identidade alexandrina.

Percebe-se como as identidades são mutantes e fluídas, conforme os interesses diferenciados em fixá-la. Principalmente para grupos minoritários vítimas de alguma discriminação ou injustiça coletiva, o maior vínculo e identificação seriam estabelecidos com sua própria coletividade em um contexto mais amplo (CUCHE, 1999, p. 191). Portanto, a pretensão dos autores judeus em explicar Alexandria para o público externo tinha antes de tudo o ideal de reforçar os direitos da própria comunidade. Assim, a identidade alexandrina fora definida prioritariamente seguindo esse intuito. Grupos perseguidos também usam a identidade como fator de mobilização política, talvez daí o interesse de Josefo em reforçar o vínculo entre Alexandre e a comunidade judaica (WOODWARD, 2000, p. 34).

No decorrer do século I d.C. os únicos autores gregos que abordaram o contexto de fundação são Estrabão e os judeus Fílon e Josefo, citados acima. No entanto, os autores gregos de fato rarearam nesse período em relação à produção de escrita latina, portanto, era natural que menos autores gregos tratassem de Alexandria. Como reação à latinização da tradição escrita, a literatura da segunda sofistica surgiu visando ao retorno 
das narrativas em grego. Consequentemente, Alexandria ganhou um espaço considerável nessa literatura.

Nessa categoria de escritos, dois biógrafos de Alexandre, Plutarco e Arriano, descrevem a fundação da cidade. A fundação é descrita em contexto de extrema exaltação à figura de Alexandre. Consequentemente, as circunstâncias da sua chegada ao Egito e às origens da cidade são vistas como provas da sua genialidade. Mesmo que carregadas de mito, os registros são fundamentais para entender Alexandria como um locus privilegiado do período helenístico, que se manteve fervilhante nos séculos subsequentes. Daí o contínuo detalhamento dos relatos produzidos em um contexto cronologicamente mais distante dos eventos tratados. $\mathrm{O}$ fato de os relatos terem circulado nos séculos I e II d.C. sugere que os papéis de Alexandre e dos Ptolomeus não tiveram um impacto negativo no período romano, considerando a ininterrupta validade dos escritos para a história inicial de Alexandria (KRASILNIKOFF, 2009, p. 25).

Plutarco narra os pormenores da fundação no livro sobre Alexandre. Como Diodoro e Estrabão, ele também conhecia Alexandria, daí talvez o interesse de detalhar a sua importância. Para o autor, a decisão de Alexandre ao escolher o terreno foi de certa forma inspirada por Homero, pois pouco antes de falar sobre a fundação, o autor

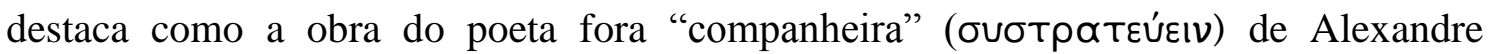
durante suas viagens. Plutarco reporta que após conquistar o Egito (Aijútrtou kpaotńoas) e decidir fundar uma cidade grega, grande e populosa seguindo o seu nome

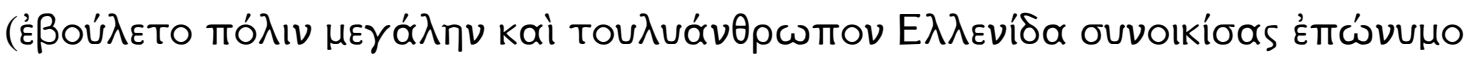

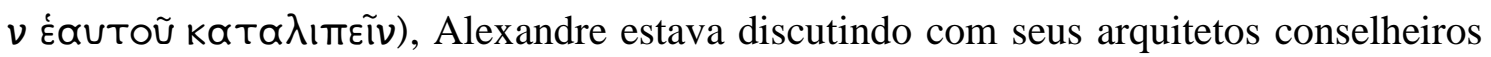
sobre o melhor terreno (ToTrov) para a construção. Foi então que teve uma maravilhosa visão durante o sono, determinando a sua escolha. Segundo Plutarco, um homem com aspecto venerável falou para ele que existia uma ilha na frente do Egito, chamada de Faros (remete a um trecho da Odisséia). No mesmo momento, Alexandre se levantou e foi para o local (Vita Alexandri 26.1). Plutarco expõe o seguinte:

E quando ele viu um terreno de vantagens naturais incomparáveis

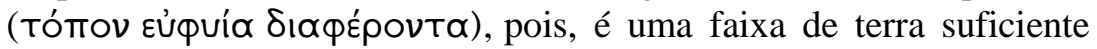
para um largo istmo, se estendendo entre um grande lago

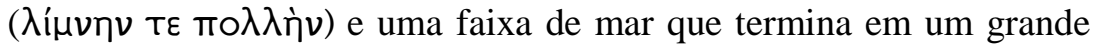
( $\mu \varepsilon \gamma \alpha \dot{\alpha} \lambda \omega)$ porto, ele disse que percebeu no momento que Homero 


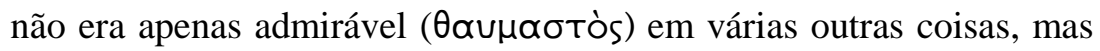

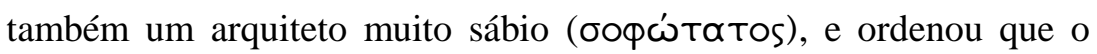
plano da cidade fosse desenhado de acordo com esse terreno. Não havia giz a disposição, então eles pegaram a cevada e com isso marcaram na terra escura uma área redonda, para dentro da qual ficavam linhas retas para produzir a figura de um capacete

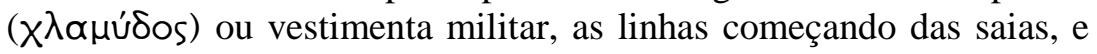
estreitando a largura da área uniformemente. $\mathrm{O}$ rei estava encantado com o projeto; mas de repente pássaros do rio e da lagoa, infinitos em número e de todos os tipos e tamanhos, se assentaram no local como nuvens e devoraram toda a refeição de cevada, de modo que até mesmo Alexandre tenha ficado perturbado com o presságio.

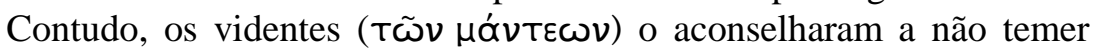
( $\theta \propto \rho \rho \varepsilon \tilde{v})$ pois, a cidade fundada por ele teria recursos abundantes e

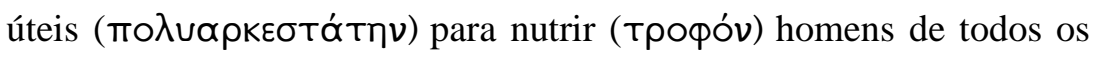
lugares ( $\pi \alpha v \tau \circ \delta \alpha \pi \tilde{\omega} v)$, e então ele ordenou àqueles encarregados do trabalho de prosseguirem, enquanto ele se dirigiu ao templo de Amon. (Vita Alexandri 26.4-6)

Percebe-se o quanto Plutarco entende Alexandria como um estabelecimento grego. A inspiração por Homero seria uma forma de legitimar a herança helênica e reafirmar a sua importância naquele mundo atrelada à sua identidade grega. Alexandre era um grande conhecedor do poeta, que já mencionava a prosperidade do Egito em sua obra. Assim, é plausível que tivesse em mente tais passagens quando resolveu fundar a cidade (VASUNIA, 2001, p. 255). Tivera acesso também a muitos relatos sobre o Egito, que certamente lhe deixaram um grande impacto (VASUNIA, 2001, p. 265).

É possível que Alexandre estivesse mesmo preparado e munido com uma grande quantidade de informações quando chegou ao Egito. No entanto, a referência à Homero como sábio pretendia, além de ressaltar a sabedoria de Alexandre, reforçar a descendência e identidade grega de Alexandria. Mas diferente dos autores helenísticos anteriores (Diodoro e Estrabão) que atribuíram essa herança grega à Alexandre, um greco-macedônio, Plutarco remeteu à Homero, um símbolo ainda mais antigo e atrelado à Grécia Clássica. Ou seja, o autor concedeu à Alexandria uma identidade grega mais legítima e pura, e a presença de Homero no texto teria esse intuito. $\mathrm{O}$ fato de Homero aparecer na estória de maneira inspiradora para Alexandre em um sonho fortaleceria ainda mais a identidade grega, através da legitimação divina.

O relato de Plutarco é mais adjetivado e lendário que o de Estrabão, pois este, mesmo ao mencionar os presságios de fundação, demonstra que não pretendia se aprofundar com relação à versão lendária da construção da cidade. Em seguida, Plutarco 
descreve o famoso episódio da visita de Alexandre ao oráculo de Amon, confirmando

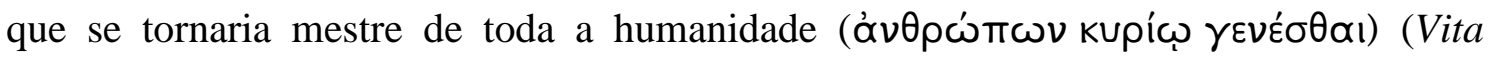
Alexandri 27.4). Nesse sentido, se Alexandre era hegemônico entre os homens e Alexandria era a sua fundação inspirada por Homero, o autor poderia inferir aqui a primazia de Alexandria como capital helenística ainda no seu tempo.

Em Estrabão observa-se uma ênfase maior na racionalidade da decisão de Alexandre, que teve a sua idéia depois de visualizar o terreno, enquanto em Plutarco a predestinação do local é reforçada. Pois apesar de Alexandre já ter tomado a sua decisão com relação ao estabelecimento de uma grande cidade no Egito, foi um sonho que lhe anunciou o melhor local. Além disso, os sinais de fortuna da região foram definitivamente confirmados pelo episódio da demarcação do terreno com a cevada. A presença de Homero como a inspiradora sinaliza que era para os gregos que a glória e o sucesso referentes à fundação deveriam ser atribuídos. $O$ trecho vincula Homero a Alexandre, e ambos, à origem de Alexandria e dessa forma legitima a identidade incontestavelmente grega da metrópole. O ideal de Plutarco talvez fosse demonstrar a continuidade e vivacidade da cultura helênica clássica através das novas instalações helenísticas, inspiradas e "abençoadas" por Homero, o grego "antigo", ao lado de Alexandre, o grego "macedônio".

A onda de aticismo começou na época de Plutarco, talvez pela enorme quantidade de literatura grega a que teve acesso durante sua temporada em Atenas (SWAIN, 1996, p. 62). O detalhamento de seu relato demonstra como a história local das recentes instalações helenísticas era importante para a segunda sofística (SWAIN, 1996, p. 77). Indica também o valor simbólico de Alexandria como representante desse helenismo. Toda a carga mitológica e as lendas de predestinação da cidade serviam para legitimar sua identidade grega, pois seu destino afortunado fora confirmado por sinais divinos. Os mitos concederiam tradição e antiguidade a uma cidade de fundação recente, que ansiava por amadurecer sua própria cultura. Portanto, as lendas de origem e o conhecimento de sua ancestralidade eram essenciais no estabelecimento dessa herança e para reforçar a identidade grega da cidade.

Deve-se ressaltar também, que diferente de Estrabão que visava a uma audiência mais erudita e atuante politicamente, com a finalidade principal de instruir e moralizar, Plutarco tinha um estilo mais voltado para o homem comum. Nesse sentido, aumentar a carga lendária resultaria em uma divulgação mais ampla. Além disso, o gênero 
biográfico, popularizado no Império podia contar com uma documentação mais vasta, e, portanto, se basear mais em mitos e anedotas (KRAUS, 2005, p. 253). Marincola explica que em toda história mais antiga, na qual os autores se distanciavam cronologicamente do contexto narrado, a tendência a usar mitos e improbabilidades era maior do que na história contemporânea (1997, p. 235). Além disso, os mitos eram importantes para conferir ideologia cívica e fortalecer os vínculos de pertencimento a uma cidade (FEENEY, 1998, p. 53). Principalmente uma entidade nova, que ansiava por sua identidade própria para unificar gregos de regiões tão distintas precisava de mitos para solidificar seu valor histórico. Assim, estabelecer e fortalecer o vínculo com Alexandre, ele mesmo um mito e um grande marco do passado, era ainda mais atraente. Ressaltar o elo entre Alexandre e Alexandria foi uma forma de reforçar a importância da cidade e conceder a ela uma antiguidade e um passado mítico, mesmo que recente. Dessa forma, Plutarco ajudava a fabricar uma identidade grega para Alexandria, e naturalizar essa identidade através da associação com Alexandre, estabelecendo assim uma separação entre o novo estabelecimento e o Egito antigo.

Na Morália, Plutarco faz uma observação que ilustra ainda mais a sua concepção do quanto Alexandre foi fundamental para marcar uma nova era no Egito, e do período helenístico como uma entrada de "civilização" no Oriente. Relata que os novos sujeitos

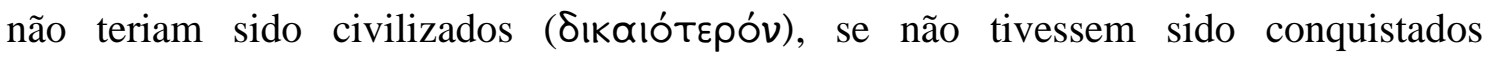
( $\dot{\alpha} \lambda o ́ \omega t \omega \nu)$ por Alexandre. E mais: o Egito não teria a sua Alexandria e nem a Mesopotâmia a sua Selêucida se não fosse por ele. Plutarco observa que foi pela

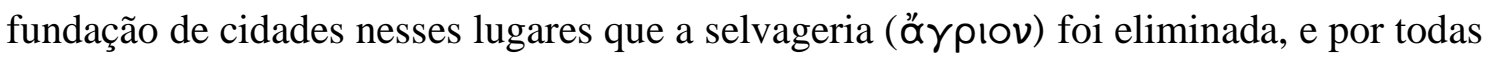
essas realizações Alexandre podia ser considerado um grande filósofo (Moralia. De Fortuna Alexandri 328.F.5). Assim, o autor estabeleceu uma hierarquia entre Alexandria e o "resto" do Egito, onde predominaria a "selvageria", embora as instalações gregas ajudassem a espalhar civilidade. Nesse sentido, Alexandria era um corpo diferenciado instalado em um Egito de tradições "bárbaras". Na sua concepção esse Egito "de fora" pouco tinha se alterado no tempo de Alexandria, ou seja, a dinâmica das transformações históricas ainda não alcançara todo o Egito.

Arriano, outro biógrafo de Alexandre e representante da segunda sofística, elaborou um registro que é um exemplo de combinação de literatura grega com o exercício de poder romano (SWAIN, 1996, p. 242). O autor teve cargos imperiais e era muito próximo do imperador Adriano, um grande entusiasta do resgate da cultura grega. 
O relato é posterior ao de Plutarco e menos lendário e partidário da herança grega de Alexandria, embora também mencionasse a sua posição ideal, beleza e prosperidade

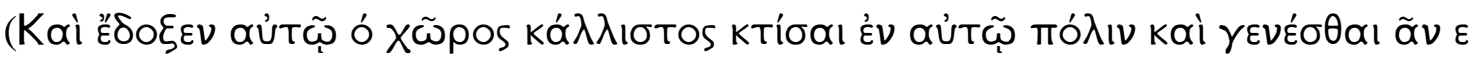

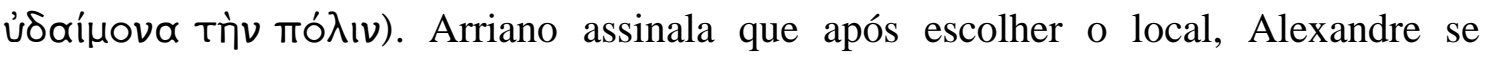
encheu de ansiedade para começar o trabalho, e ele mesmo marcou onde seria a praça central, quantos templos seriam construídos, em honra a quais deuses, alguns gregos, e Ísis, a egípcia, e onde o muro deveria cercar. Em virtude de tudo isso, ofereceu sacrifícios, que se provaram favoráveis (Anabasis Alexandri 3.1.5.2).

Em seguida, conta a estória da marcação e explica não ter motivos para duvidar de sua veracidade (Anabasis Alexandri 3.2.1). Por mais que tente evitar, incorpora a lenda e justifica a sua carga de verdade. Como Plutarco, Arriano ressalta que após a fundação, Alexandre seguiu ao oráculo de Amon para saber sobre o seu destino (Anabasis Alexandri 3.3.1). Mencionar a homenagem a deuses gregos e egípcios poderia defender a conciliação entre as duas culturas promovidas por Alexandre. $\mathrm{O}$ comentário de Arriano sugere também um momento do Império Romano em que a cultura egípcia já era mais aceita e vista de modo favorável, ao menos com relação à adoção da divindade Ísis no panteão greco-romano. Diferentemente de Plutarco, no entanto, ele indica o relativo pertencimento de Alexandria ao Egito como um todo e atribui uma identidade helenística para a cidade, através da conciliação entre suas duas culturas predominantes. Na sequência, Arriano narra o seguinte:

Dizem que ele dividiu o governo do Egito entre muitos, pois estava admirado com a natureza e força do país

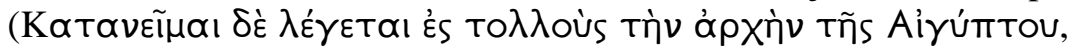

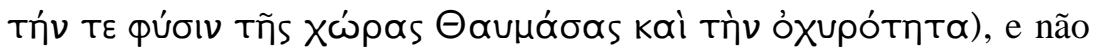
achou seguro confiar o comando de todo o Egito a um só. Os romanos, me parece, aprenderam com Alexandre a manter a vigília ( $\varphi \cup \lambda \propto \kappa \tilde{n})$ sobre o Egito, e a nunca mandar ninguém do Senado como pró-cônsul, mas apenas aqueles que classificam como cavaleiros. (Anabasis Alexandri 3.5.7)

A originalidade do relato de Arriano, é que ele verbaliza abertamente a percepção do Egito de sua época, e transfere tal preocupação a Alexandre, que com sua sapiência já estaria ciente da força daquele local. Fica implícito que o autor estava falando da Alexandria do seu tempo, mesmo ao citar o fundador (SWAIN, 1996, p. 245). Em relação a Plutarco a representação grega de Alexandria é enfraquecida pela 
presença de elementos egípcios e pelo menor destaque concedido a Alexandre. $\mathrm{O}$ registro sugere também uma mudança temporal, uma época em que Alexandria perdera o seu brilho como cidade autônoma, conforme foi cerceada por políticas romanas e se tornou uma cidade do Império. Assim, o foco do autor é na vigília promovida por Roma, atribuindo uma identidade romana para Alexandria ao lado da identidade helenística. Percebe-se que com o tempo, os autores agregaram novas identidades à Alexandria e que por Arriano ser um autor mais inserido na elite romana (mesmo que escrevesse em grego) contestaria a pureza de sua identidade grega como forma de frear suas pretensões.

No mesmo contexto de Arriano, Pausânias também tratou da fundação, porém cita os rumores que diziam antes haver no local uma pequena cidade egípcia chamada Rakhotis (Graeciae descriptio. Elis 1.5.21.9.11). Assim, chama atenção para uma antiguidade egípcia anterior na região. No entanto, em outro trecho, quando menciona exemplos de cidades que foram reduzidas a nada, apesar de um dia terem sido imponentes (como Tebas e Babilônia), cita a fundação de Alexandre no Egito, e de Seleuco em Orontes, como cidades de fundações recentes e que alcançaram seu

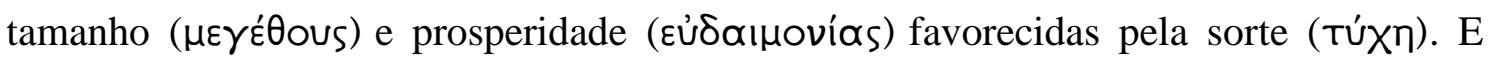
depois alude a um exemplo e reflete que "a força da sorte era maior e mais maravilhosa do que os desastres e a prosperidade das cidades"

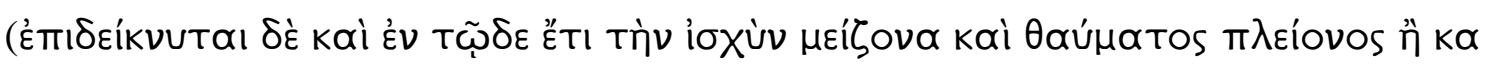

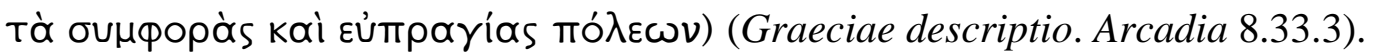

O apelo a precedentes históricos é uma forma de reivindicar identidades (WOODWARD, 2000, p.11). Portanto, o fato de Pausânias começar sua narrativa sobre a fundação assinalando a antiguidade egípcia anterior no local sublinharia os antecedentes egípcios no terreno de Alexandria. A antiguidade concedia tradição e reforçaria uma identidade cívica, nesse sentido, o autor deixa claro que antes de tornarse grego o sítio era egípcio. Porém, logo na sequência, Pausânias sugere que a antiguidade não legitimava tudo e que a sorte às vezes tinha um papel determinante. Estava provavelmente se referindo à "sorte" das fundações gregas em terrenos "bárbaros", por eminentes gregos, levando a civilização para o local. Dessa forma, o autor entende que a partir de Alexandre se poderia considerar tais localidades como legitimamente gregas. Ou seja, enfatiza a identidade grega de Alexandria, embora a cidade estivesse instalada em um terreno egípcio mais antigo, teria, portanto, uma 
identidade menos "pura" e que já pressupunha mais miscigenação do que àquela assinalada por Plutarco. Pausânias atribui a prosperidade e grandeza de Alexandria à sorte. Assim, em relação aos relatos anteriores o autor concede menos racionalidade e planejamento ao projeto.

Apiano, autor originário de Alexandria e que escreveu no tempo de Antonino Pio não descreve a fundação, apenas relata no prefácio que trataria de todas as terras governadas pelos romanos. No seu mapeamento das regiões cita "a grande cidade fundada por Alexandre na borda do Egito, e o próprio Egito"

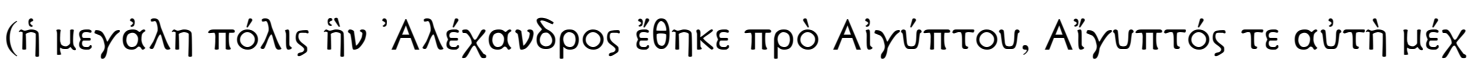
рı) (Bellum Civile. Praefatio 1). Percebe-se que, como alexandrino, Apiano estabelece uma demarcação clara entre Alexandria e todo o Egito, ao observar que a cidade não ficava dentro do território, mas nas suas fronteiras. No entanto, o autor fala pouco sobre a sua cidade, embora trate dos problemas da realeza ptolomaica, como será visto no capítulo seguinte. Swain (1996, p. 251) sugere que no livro perdido sobre o Egito, Apiano poderia ter ressaltado mais claramente seu "patriotismo".

Como representantes da segunda sofística, Plutarco, Arriano e Pausânias valorizavam os feitos dos gregos, consequentemente, Alexandria não era simplesmente uma importante polis do Egito, mas uma primorosa realização de Alexandre e dos gregos. Além disso, os autores estavam escrevendo em um "contexto seguro", pois a cidade já estava inserida no Império. Ou seja, já conquistada por Roma, o foco sobre a sua "fundação iluminada" podia ser valorizado sem representar algum risco para os remanescentes partidários de Antônio. No entanto, apesar de absorvida no comando imperial e relativamente pacificada, o local continuava sendo digno de muitas atenções, portanto era necessário justificar de forma mítica a sua proeminência, talvez para legitimar a sua importância no presente. Os autores reforçam então, que Alexandre concedeu valor àquele local e que após ser "tocado" por um grego lendário, o Egito e essa localidade em especial, mereciam atenção. Ou seja, quanto mais forte a veiculação de sua fundação mítica, maior também a sua identidade e evolução indissociáveis de Alexandre. Aumentar a carga lendária tinha também o propósito de conceder valor aos sinais divinos que assinalavam a prosperidade e sucesso da cidade.

O cenário de fundação foi também comentado pelos autores latinos Vitrúvio, Plínio e Quinto Cúrcio. Vitrúvio, que escreveu em um contexto da recém-incorporação do Egito à província (provavelmente antes de 27), mencionou o planejamento de 
Alexandria no prefácio de sua obra. Antes de falar de sua construção, Vitrúvio realça a importância que Alexandre dava às fontes de abastecimento, e em seguida cita Alexandria como um exemplo (De Architectura. Praefatio 2.3). Explica que enquanto Alexandre realizava suas conquistas, o arquiteto Deinocrates foi da Macedônia até o exército, se apresentou ao rei, e o seguiu até o Egito. Chegando lá, depois que Alexandre observou um porto naturalmente protegido (portum naturaliter tutum), um excelente mercado (emporium egregium), campos de trigo por todo lado, e as vantagens do Nilo (inmanis fluminis Nili magnas utilitates) ordenou que Deinocrates construísse uma cidade (civitatem) que deveria se chamar Alexandria, seguindo o seu nome (De Architectura. Praefatio 2.4).

Vitrúvio destaca a perspicácia da decisão de Alexandre. No entanto, observa que sua sábia escolha deveria ser compartilhada com o arquiteto Deinocrates na execução do projeto. A descrição é breve, mas realça em poucas linhas o nome da cidade associado a Alexandre e a prosperidade do local (De Architectura. Praefatio 2.4). A ênfase de Vitrúvio é na abundância de trigo e posição da cidade como empório do Império, possibilitada pela construção do porto. Em relação aos relatos dos autores gregos, é nítido o seu maior realce no papel comercial da Alexandria de sua época. O planejamento da cidade é também mais marcado, pela menção à presença decisiva do arquiteto ao lado do rei.

Fazendo uso do trecho de Vitrúvio, Bernand (1966, p. 58-59) considera que a grandiosidade e monumentalidade característica de Alexandria foi estabelecida por Deinócrates, pois foi quem convenceu Alexandre do projeto. No entanto, o arqueólogo não descarta a possibilidade de o arquiteto ter se inspirado em motivos egípcios. Essa influência seria visível na valorização do colossal, na amplitude das avenidas, e na busca por simetria, todos os elementos presentes nas cidades dos mortos do Egito antigo. Ou seja, se as instituições eram heranças gregas, grande parte da fachada era composta de motivos egípcios. Assim, deve-se ter cautela em desvincular Alexandria totalmente de suas redondezas, embora esteja claro que a intenção dos autores não era realçar essa influência, que reforçaria sua identidade egípcia.

Tito Lívio, autor praticamente contemporâneo de Augusto, não aborda o contexto de fundação, no entanto, remete ao cenário de mistura populacional criada pela chegada de Alexandre e dos gregos no Egito. O autor deixa transparecer uma relativa 
admiração pela antiguidade da civilização egípcia, ao se referir várias vezes ao reino ancestral (regnum patrium) dos egípcios (Ab Urbe Condita 45.13.5.1). Porém, observa a decadência dos gregos ao se misturarem, quando menciona que os macedônios, ao controlarem Alexandria no Egito (Alexandriam in Aegypto), Selêucia e Babilônia e outras colônias espalhadas pelo mundo, se degeneraram (degenerarunt) em sírios, partos e egípcios (Ab Urbe Condita 38.17.11.1). Com tal comentário o autor infere certo desprezo pelas fundações helenísticas, pois sua miscigenação teria "contaminado" a pureza da cultura grega, e a permissividade de aceitar elementos egípcios na realeza teria resultado no declínio do esplendor da cultura helênica. Assim, o autor destitui Alexandria de sua herança grega e reforça a sua identidade helenística, macedônica e mista, carregada de influências egípcias.

Plínio, o Velho, ressalta que além de gabar-se das antigas glórias (gloriam), o Egito podia se orgulhar de ter tido, no reino do rei Amasis, 20 mil cidades (urbium), e mesmo na sua época ainda havia um grande número, apesar de pouco importantes (dentre elas, Tebas, Copto e Mênfis). No entanto, afirma ser justo que os elogios (laudetur) ficassem com Alexandria, construída por Alexandre na costa do mar egípcio (litore Aegyptii). Plínio observa as circunstâncias de sua construção, enfatizando a antiguidade do sítio, chamado de Rakhotis em tempos antigos. Nota ainda a delimitação do terreno pelo arquiteto Deinócrates, famoso pelo talento em muitos setores. Plínio menciona a grande área ocupada pela cidade e que um quinto do terreno foi dedicado aos palácios reais (parte regiae dicata) (Naturalis Historiae 5.11.60-63).

No livro 7, Plínio novamente destaca o talento de Deinócrates ao falar de vários artistas que foram homenageados por suas invenções e feitos. Sua grande realização foi estabelecer as medições (metatus) para o plano de Alexandre. É sugestiva sua comparação entre o planejamento de Alexandria e outras importantes invenções, nos setores da astronomia, geometria e medicina, por exemplo (Naturalis Historiae 7.37.125). O autor demonstra uma atitude respeitosa em relação ao Egito antigo, embora deixe evidente a sua percepção da superioridade da cultura grega, pois Alexandria era a maior realização no Egito. No entanto, a nova entidade fora instalada em um terreno antigo, onde já havia uma sucessão de cidades imponentes. Assim, Alexandria foi inserida em uma dinâmica de cidades antigas e estabelecida em um terreno também ancestral. 
Como Vitrúvio, Plínio sugere que o fundador deveria dividir as honras de seu feito com o arquiteto. No entanto, o plano foi elaborado apenas após o comando virtuoso do fundador. Mencionar a importância do arquiteto na execução do projeto era uma forma de reforçar o planejamento da cidade, e Alexandria deveria ser louvada pelo sucesso de um plano bem executado. Os dois relatos são também nitidamente menos carregados de mitologia, e elogiam Alexandre mais pela racionalidade do que pelo caráter de visionário. Como Pausânias, a ênfase de Plínio na antiguidade de Rakhotis, e o fato de situar Alexandria em uma dinâmica de importantes cidades egípcias, chamam a atenção para a sua história egípcia anterior. Além disso, o autor assinala a importância da cidade como sede real, pois parte considerável do território era destinada aos palácios. Através da menção à herança egípcia de Alexandria e sua ênfase no caráter real da cidade, Plínio sublinha a sua identidade oriental.

O relato de Quinto Cúrcio Rufo é a única biografia preservada em latim sobre Alexandre e foi escrita antes que as de Plutarco e Arriano citadas anteriormente, entre os reinos de Tibério e Cláudio. A sua narrativa sobre a fundação aparece depois de uma sequência de crítica ao Egito. Cúrcio aponta que quando Alexandre decidiu ir para o local já estava informado sobre a situação complexa, e convenceu suas tropas dizendo que os egípcios sempre tinham problemas com seus governantes, portanto, os considerariam aliados e não inimigos (Aegyptios semper praetoribus eorum infestos pro sociis ipsos, non pro hostibus aestimaturos). Cúrcio afirma que ao saberem da entrada do macedônio no território, os egípcios se apressaram em ajudar na destruição das tropas persas, pois eram "um povo volúvel, instável, e mais inclinado a começar uma revolução do que conquistar grandezas" (ad cuius famam Aegyptii, vana gens et novandis quam gerendis aptior rebus, ex suis quique vicis urbibusque huc [ipsum] ${ }^{\circ}$ concurrunt ad delenda praesidia Persarum) (Historiae Alexandri Magni 4.1.28-30).

De Mênfis, Alexandre partiu para o interior do Egito, e depois de resolver as questões de forma a não mexer nos costumes nativos dos egípcios (ut nihil ex patrio Aegyptiorum more mutaret), decidiu visitar o Oráculo de Júpiter-Amon, que confirmava sua futura liderança sobre todas as terras (terrarum omnium rectorem fore ostendit) (Historiae Alexandri Magni 4.7.1-28). Depois de voltar de Amon, Alexandre seguiu para o lago Mareótis. Ao contemplar a natureza do local, decidiu primeiramente construir uma cidade na ilha, mas como esta não parecia suficientemente ampla para um 
grande estabelecimento, escolheu o terreno de Alexandria (inde ut adparuit magnae sedis insulam haud capacem esse, elegit urbi locum, ubi nunc est Alexandrea, appellationem trahens ex nomine auctoris). Tomando toda a região entre o lago e o mar, planejou um circuito de oito estádios para os muros e deixou homens encarregados de sua construção (Historiae Alexandri Magni 4.8.1.1).

Cúrcio ressalta que Alexandre colocou dois homens em comando do Egito e deu a eles quatro mil soldados para defender a região. Deixou Cleômenes de Náucratis encarregado da coleta de impostos da África e do Egito. Em seguida, ordenou que habitantes das cidades vizinhas fossem para Alexandria e, dessa forma, a preencheu com uma grande população (Ex finitimis urbibus commigrare Alexandream iussis novam urbem magna multitudine inplevit). Na sequência menciona o episódio da demarcação como um bom presságio (omen), pois a região forneceria suprimentos para muitas terras (magnam illam urbem advenarum frequentiam culturam, multisque eam terris alimenta praebituram) (Historiae Alexandri Magni 4.8.6.1).

Apesar do detalhamento, percebe-se que o relato de Cúrcio não é tão entusiasta com relação à excelência e predestinação do local. No entanto, não deixou de ressaltar a prosperidade e grandeza de Alexandria, além do planejamento dedicado ao projeto de construção. Contudo, antes de qualquer elogio, o primeiro aspecto enfatizado por Cúrcio foi a tendência dos egípcios à rebelião e em seguida, a riqueza agrícola da cidade. Ou seja, aqui deixa transparecer os dois motivos pelos quais se deveriam prestar especial atenção à metrópole egípcia na mentalidade romana: produtividade e turbulência, deixando evidente a referência à sua Alexandria contemporânea. É possível que o fato de ser um autor latino e mais próximo do tempo de Augusto sejam elementos que interferiram na menor exaltação à cidade e na maior ênfase na polêmica, por ainda estar "contaminado" pela propaganda de Otávio. Assim, o autor podia usar a versão mais lugar-comum que tinha a respeito do Egito da sua época e transferir toda essa carga para o momento de fundação. Outro aspecto que difere Cúrcio das outras biografias é o fato de não definir Alexandria em nenhum momento como uma cidade grega, embora observe que o fundador a preencheu com habitantes das cidades vizinhas, sugerindo a predominância de egípcios na sua composição social inicial. Provavelmente, o autor estaria aproximando a cidade do Egito para afastá-la de Alexandre e de sua herança grega, reforçando assim a identidade egípcia. 
Com a fundação, Alexandria teve o seu nome vinculado a um dos homens de mais prestígio da época, algo ponderado pelos antigos ao estabelecer julgamentos sobre a cidade. Bernand (1966, p. 1) faz uma analogia, dizendo que (coincidentemente ou seguindo o seu destino) a metrópole viveria perigosamente como o seu fundador. Runia (1989, p. 402-403) discute que a escolha do lugar adequado, juntamente com a menção à antiguidade do local de fundação era uma espécie de topos nos relatos de fundação de cidades. As cidades helenísticas tentavam conciliar sua origem bárbara com lendas de fundação, que as ligassem ou às grandes cidades da Grécia Clássica ou aos heróis do ciclo épico. Algumas cidades tinham ainda mais sorte de já figurarem em lendas gregas, e tinham apenas que divulgar seus antecedentes homéricos (JONES, 1966, p. 49). Principalmente em uma nova fundação, onde os imigrantes continuavam ligados aos centros de origem. Talvez por isso, fosse importante colocar ênfase na fundação da cidade por Alexandre, que seria o denominador comum de todos os novos moradores (KNOX, 1985, p.25).

Se séculos depois de sua fundação os autores reforçam o vínculo da cidade com Alexandre, é possível que tal traço fora um elemento forte em toda a história anterior de Alexandria, enfatizado desde os Ptolomeus e que sobrevivera ao período imperial. Precisaria, no entanto, ser resgatado pelos gregos da segunda sofística, em virtude de tantos relatos de condenação a Alexandria com base nos topos negativos divulgados por autores latinos logo após Augusto.

Segundo Susan Stephens (2002, p. 187), a proeminência de histórias de fundação ilustra a dimensão colonizadora do governo ptolomaico, pois precisavam de novos territórios, mas deveriam também reconfigurar o imaginário com relação ao que era ser grego naquele novo tempo. Uma forma de fazer isso era legitimando a importância dos lugares em que se estabeleciam, através do destaque na antiguidade dos terrenos. Stephens (2002, p. 173) sugere ainda a especificidade de Alexandria, que diferente das outras cidades gregas não tinha um passado mítico e um referencial de heróis, daí a decisão de Apolônio de escrever sua epopéia, "fabricando" um passado lendário que servisse de referência aos Ptolomeus. Os poetas helenísticos tiveram um papel fundamental nesse processo de legitimação da realeza junto ao local de instalação. Os autores do império, e principalmente os representantes da segunda sofística, ajudaram a retomar os mitos cívicos e de fundação de cidades para fortalecer a herança grega das novas fundações (SWAIN, 1996, p. 73). Os reis helenísticos tiveram a 
iniciativa de vincular a nova história alexandrina à memória de seu herói fundador como uma forma de reforçar a identificação entre os novos habitantes do local. Ou seja, foi uma identidade forjada internamente que depois seria reforçada por outsiders.

O livro de Diana Spencer, The Roman Alexander: reading a cultural myth discute a criação e recriação do mito e da história de Alexandre, durante o período romano. O argumento principal é que o Alexandre que deixou a marca na história moderna é uma criação romana, criada e desenvolvida durante o seu domínio no Mediterrâneo (2002, p. xiv). No entanto, a autora demonstra como a preocupação referente à própria imagem e sua divulgação já era uma apreensão do próprio Alexandre. Por exemplo, Calístenes, o sobrinho de Aristóteles, acompanhou o rei nas campanhas exclusivamente para registrar seus feitos. Assim, toda uma política "midiática" de propaganda foi organizada (2002, p. 6). Alexandre sabia da importância da celebração visual de si mesmo, controlando a identidade dos que fabricavam a sua imagem. Sabia também do poder da representação como parte das funções de um grande líder. Tinha consciência ainda, do valor de manipular a própria imagem como uma reflexão calculada com base nas realizações de seus predecessores.

Não bastava realizar grandezas, deveria haver algum investimento literário para que o retrato da grandeza se tornasse mais durável e permanente. Assim, a autora acredita que por trás de mística de um governante como Alexandre, existiria até mais manipulação do que ação (SPENCER, 2002, p. 128). Ao serem pronunciadas e divulgadas as proposições se efetivavam e se tornavam mais concretas e Alexandre, como seus sucessores Ptolomeus tinham consciência da importância do discurso.

O fortalecimento de Alexandre como mito no período romano colocou em evidência seus grandes feitos, aumentando ainda mais o foco sobre eles, principalmente aqueles que ainda "rendiam frutos" a Roma, como era o caso de Alexandria. Grande parte de suas realizações foram divulgadas posteriormente, após os seus resultados duradouros em longo prazo, por mais que um elaborado background ideológico moldara a sua conquista no Egito, em virtude de todos os conhecimentos a que teve acesso e que precederam os seus feitos no local (VASUNIA, 2001, p. 249). Suas ações foram resgatadas e rememoradas sob Roma, pois serviam até mesmo de exemplo para o Império Romano, colaborando para fortalecer ainda mais o papel de Alexandre como mito e ajudando a reforçar seu vínculo com Alexandria, pois em um contexto de miscigenação, a identificação com Alexandre podia estar sendo enfraquecida. 


\subsection{Desenvolvimento inicial da cidade: embelezamento e sofisticação}

A documentação analisada atribui grande parte do sucesso de Alexandria à decisão do fundador de estruturar a cidade naquele local, no entanto, sua passagem por lá foi muito breve. Após a morte de Alexandre e toda a disputa entre seus sucessores pelo território conquistado, ocorre um relativo equilíbrio de poder, e Ptolomeu cedo insistiu na sua opção pelo Egito, talvez por ser uma região que estava ainda relativamente fora dos circuitos comerciais gregos mais importantes. Mas seus motivos principais, segundo Bingen (2007, p. 19-20), eram os mesmos que levariam os romanos a ambicionarem a sua incorporação posteriormente: as riquezas e principalmente, a abundância de trigo. Ptolomeu percebeu também que através de Alexandria, seria mais fácil vincular a sua imagem à memória do conquistador.

Com a morte de Alexandre, os sucessores empreenderiam esforços no sentido de provarem a participação ao seu lado nas batalhas, a começar por Ptolomeu, que transferiu o corpo do herói para ser enterrado em Alexandria e associou a fundação de Alexandre com a sede de seu novo poder estabelecido no Egito (SPENCER, 2002, p. 8). Os sucessores criaram um mundo onde legitimação divina se associaria a sucessos militares, e esses determinariam o governo monárquico e a identidade do rei (SPENCER, 2002, p. 32). O contexto instável e incerto do séc. IV a.C. gerou uma audiência ansiosa por explicações sobre o passado (2002, p. 36). Nesse sentido, o vínculo da realeza com Alexandre seria uma forma de confortar uma população fragmentada e insegura.

O estabelecimento da realeza e a transferência de sua sede de Mênfis para Alexandria foi um processo que levou alguns anos desde a fundação, e não cabe descrevê-lo aqui, principalmente em virtude do silêncio das fontes a esse respeito. $\mathrm{O}$ silêncio da documentação é um indício que não lhes interessava falar sobre uma realeza instalada em território egípcio. $\mathrm{O}$ foco voltaria para o reino a partir do momento em que a sede foi transferida e instalada para a nova fundação grega. Nesse sentido, os escritos priorizam uma representação grega da dinastia macedônia estabelecida em uma terra oriental.

A intenção nesta etapa é observar como os autores narram o desenvolvimento inicial do novo estabelecimento e a importância dos primeiros reis em garantir o 
esplendor e a sofisticação de sua fachada. Pretende-se refletir sobre os comentários principais do início do governo ptolomaico, para compreender o quanto o desenvolvimento de Alexandria e sua dinâmica cultural eram atribuídos aos primeiros reis. Ou seja, nas representações da Alexandria imperial que espaço era reservado aos reis helenísticos e como os relatos exploram o vínculo dos reis com Alexandre e os entendem como seus herdeiros? Assim, refletiremos sobre o quanto os primeiros reis eram responsabilizados pelo sucesso da cidade e/ou por suas falhas.

A documentação é consideravelmente mais escassa do que para o contexto de fundação. Pouco se sabe a respeito do desenvolvimento inicial de Alexandria, principalmente do período referente ao reinado de Ptolomeu I (FRASER, 1972, p. 6). Assim, sobre a época de formação e a respeito da política administrativa implementada pelos primeiros reis há poucas informações. Há mais dados para o tempo imediatamente após a morte de Alexandre. As fontes do período romano enfocam mais em episódios isolados da história dinástica, que denotam o esbanjamento da corte, as festas, suntuosidade dos edifícios, e depois se deslocam para os primeiros conflitos entre Ptolomeus e Selêucidas, e em seguida para a progressiva presença de Roma na resolução dos impasses. Portanto, o foco sobre os Ptolomeus aumenta conforme eles começaram a se relacionar com Roma (tema que será tratado no capítulo seguinte). A escolha das temáticas tratadas já sugere um pouco do que as fontes queriam divulgar e do que pretendiam ignorar e talvez até esquecer. As seleções são por si só importantes indicativos do modo como concebiam o passado ptolomaico de Alexandria.

Dando sequência ao relato de fundação sobre a cidade (citado acima), Diodoro menciona o seu rápido desenvolvimento:

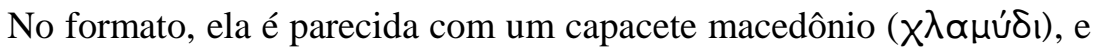
é dividida por uma avenida admirável em extensão e beleza

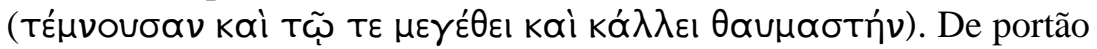
a portão percorre uma distância de quarenta furlongs; tem um plethron de largura, e está adornada em toda sua extensão com ricas fachadas de casas e templos

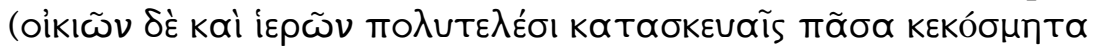
ı). Alexandre ordenou que se construísse um palácio admirável pelo tamanho e solidez do trabalho

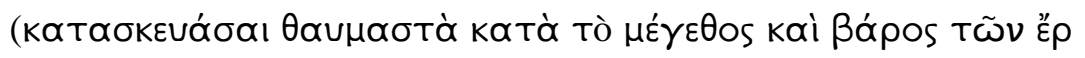
$\gamma \omega \nu)$. E não apenas Alexandre, mas aqueles que depois dele governaram o Egito até a nossa época, com poucas exceções engrandeceram o palácio ainda mais com adições extravagantes 


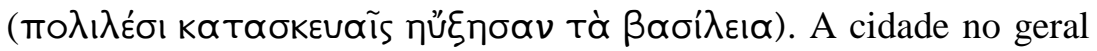
tem crescido tanto nos últimos tempos que muitos a tomam como a primeira cidade do mundo habitado

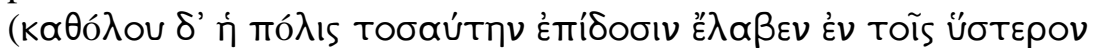

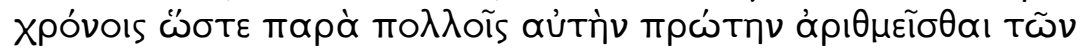

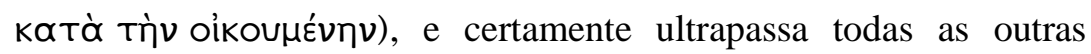
cidades em beleza, extensão, abundância e luxo

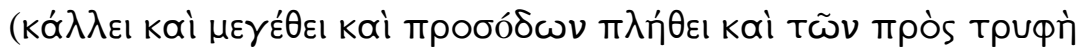

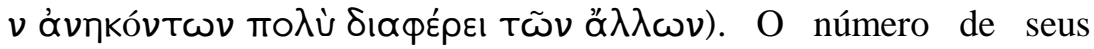
habitantes supera o de outras cidades. Na época em que estávamos no Egito, aqueles que mantinham os registros de censos da população diziam que sua população livre ultrapassava os trezentos mil, e que o rei recebia dos rendimentos do Egito, mais do que seis mil talentos (Bibliotheca Historica 17.52.3-6).

Percebe-se a quantidade de adjetivos usados por Diodoro para descrever a cidade, todos associados à grandiosidade e riqueza. $\mathrm{O}$ autor ficara tão impressionado com o local, que chega a colocá-lo a frente de Roma em termos de beleza e sofisticação, justificando que muitos assim o percebiam no seu tempo. Diodoro fornece uma dica do tipo de rumor em circulação no seu meio (nas províncias e talvez até em Roma), sobre a monumentalidade de Alexandria, que já tinha trezentos anos de existência em sua época. Ele nota o crescimento contínuo da cidade, talvez por isso a classificara como primeira, ou seja, mantendo tal ritmo de desenvolvimento o potencial da cidade seria enorme. Mckenzie (2008, p. 75) interpreta o comentário de Diodoro como uma evidência do crescimento contínuo da metrópole durante todo o período ptolomaico, por isso sua motivação a especular sobre o local na década antes de Cleópatra subir ao trono, por volta de 60-56 a.C. O autor enfoca aqui na importância de Alexandre e dos reis no desenvolvimento inicial da cidade. Juntos eles concederam à cidade uma exuberância sem precedentes, através da sofisticação dos edifícios e no luxo generalizado. A ênfase é também na identidade real de Alexandria, já que grande parte dos investimentos fora destinada aos palácios. Destaca também sua grandeza populacional, indicando que ainda no seu tempo havia um grande movimento migratório para a cidade.

Diodoro menciona que um grande feito dos reis de Alexandria

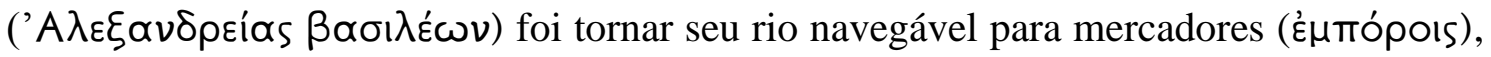
ajudando também na luta contra os navios piratas (Bibliotheca Historica 3.43.5). O trecho indica a "abertura do mundo" promovida pelo helenismo e as boas condições comerciais destinadas pelos reis à região. $\mathrm{O}$ fato de Diodoro sempre nomear os 
monarcas de "reis de Alexandria" ilustra a sua relativa separação do Egito e a instauração de uma identidade original naquele local, que seria mais do que o amálgama das tradições grega e egípcia.

Outro destaque dado pelos autores referente às realizações dos primeiros reis se refere à concretização da transferência do corpo de Alexandre da Babilônia para o Egito. Segundo Diodoro, o feito foi ordenado pelo primeiro Ptolomeu e alcançado depois de dois anos de preparo (Bibliotheca Historica 18.28.3). Relata que o rei foi com seu exército até a Síria, para receber o corpo, e em seguida, o considerou digno das

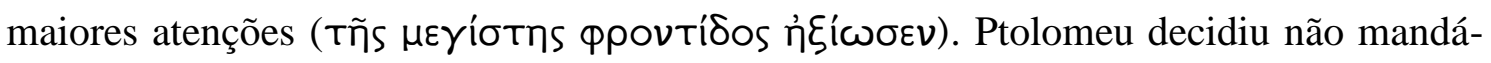
lo a Amon, pois preferiu construir a tumba na cidade fundada pelo próprio Alexandre

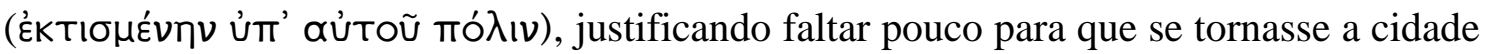
mais renomada do mundo habitado

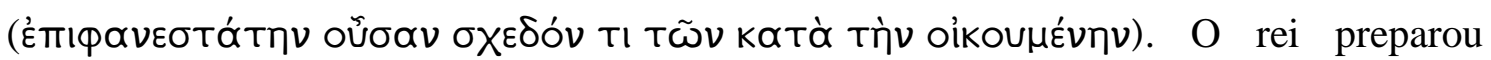
então um recinto condizente com as glórias de Alexandre. Em seguida, Diodoro descreve as homenagens prestadas ao herói e afirma que homens de origens diversas

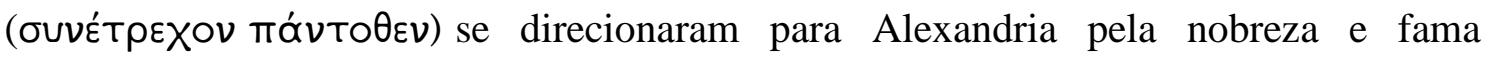

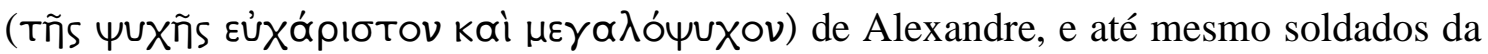
Síria se alistaram nas campanhas de Ptolomeu, mesmo sabendo que seu rei estava prestes a guerrear com eles (Bibliotheca Historica 18.28.5.3).

Com a transferência do corpo, percebe-se como Diodoro está mais uma vez, ligando Alexandre a Alexandria, mencionando a negação de Ptolomeu a levar o seu corpo para Amon. Ou seja, dever-se-ia deixar o rei repousar em sua fundação grega, e não associá-lo a símbolos egípcios. Tal decisão tem um grande valor simbólico, denotando a formação de uma nova identidade no Egito, da qual Alexandre e a nova realeza lá instalada eram representantes. Diodoro fornece um argumento adicional justificando que Alexandria era merecedora do corpo, pois era a mais renomada cidade do mundo habitado. Aqui o autor se posiciona com mais ênfase do que na passagem anterior com relação à colocação de Alexandria em uma espécie de "ranking" de cidades. Diodoro sugere também a fama consensual de Alexandre, venerado em todos os lugares por onde passava, realçando que ele era celebrado não apenas entre os gregos, mas entre homens de origens diversas, o que demonstra a sua vertente conciliadora reunindo culturas diferentes sob sua égide. Diodoro concede então, uma 
identidade helenística para Alexandria ao atrair variadas culturas, sendo a cidade um reflexo de Alexandre. Ou seja, na sua concepção Alexandre era o símbolo de um novo tempo em que diferentes culturas podiam estabelecer maiores diálogos e contatos através de Alexandria, sua representante. Seu corpo na cidade legitimaria essa realidade ímpar.

Estrabão relata que Ptolomeu conseguiu evitar que Pérdicas levasse o corpo com ele da Babilônia para o Egito, em um ato de ganância e desejo de tomar o Egito. Quando Ptolomeu foi ao seu ataque, e Pérdicas foi morto pelos seus soldados, seus companheiros partiram para a Macedônia, e permitiram que o corpo fosse levado para receber uma sepultura em Alexandria. $\mathrm{O}$ autor observa que o túmulo ainda estava lá no seu tempo, mas em um sarcófago diferente, pois na época dos reis era de ouro, e nesse contexto era de vidro (Geographica 17.1.8). Estrabão sugere que Ptolomeu conseguiu o corpo em um ato de defesa e sua transferência para Alexandria foi um resultado do acaso, e não um ato premeditado que exigiu enormes preparações, como defende Diodoro. Essa eventualidade legitimaria ainda mais o seu pertencimento a Alexandria, que tinha adquirido o direito de guardar o corpo do rei. O autor reforça assim, o vínculo entre Ptolomeu e Alexandre e de ambos com Alexandria.

Estrabão segue a mesma tendência de Diodoro na descrição da cidade, talvez por também ter vivenciado Alexandria de maneira pessoal; primeiro a descreve e depois enumera algumas impressões. O autor começa destacando seu formato e dimensões, e ressalta o seu planejamento, sua divisão em duas avenidas largas e perpendiculares, algo que a tornaria um local ideal para a prática de corrida de cavalos e para passeios de charrete (Geographica 17.1.8). A via Canópica era, portanto, um importante elemento de integração social na cidade (HAAS, 1997, p. 85). Assim, Estrabão observa a inclinação da cidade para desenvolver-se como um centro de entretenimentos.

O autor destaca também que no Sema (outra parte do palácio real) repousavam os túmulos de Alexandre e dos reis (aqui é que descreve o processo de transferência de seu corpo para Alexandria, mencionado acima). Com esse comentário observando que a memória de Alexandre e dos Ptolomeus fazia parte do mesmo complexo mortuário nos palácios reais, Estrabão estabelece a forte ligação entre Alexandre e os reis helenísticos (ERSKINE, 2002, p. 164). Estrabão encerra com a narrativa sobre os portos, ressaltando a existência do porto privado dos reis, a distribuição de templos e do teatro 
(Geographica 17.1.8). Com toda essa estruturação, o autor sublinha a importância da cidade ao mesmo tempo como centro real, espiritual e comercial.

O enfoque principal da descrição de Estrabão é na suntuosidade dos palácios, como em Diodoro:

E a cidade contém os mais lindos ( ó́ $\lambda ı$ Io) recintos públicos e palácios reais, que constituem entre um quarto e um terço de todo o circuito da cidade; pois cada rei adicionou por amor ao esplendor ( públicos e, além disso, investiria com seus próprios custos com uma residência, em adição aquelas já existentes, para que então, citando as palavras do poeta (se referindo a Homero, Odisséia 17.266), "ficasse

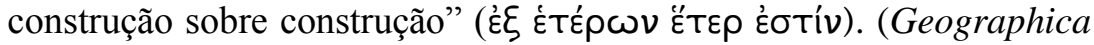
17.1.8)

Estrabão foi o primeiro a relatar que um setor significativo da cidade era específico de palácios e edifícios públicos (MCKENZIE, 2008, p.174). Porém, o autor não detalha a respeito das funções administrativas dos prédios destinados ao governo que ficariam no centro da cidade, talvez pela perda de importância dessas instituições no período em que escreve (FRASER, 1972, p. 30). Estrabão destacou então, as identidades: real e administrativa de Alexandria ainda nos seus dias, com sua riqueza de monumentos e edifícios públicos. $\mathrm{O}$ autor sugere que a estrutura da cidade e sua fachada pouco tinham se alterado na sua época, mantendo grande parte do antigo esplendor real.

No livro sobre o Egito, Estrabão menciona várias das "curiosidades” egípcias, e principalmente os animais adorados em cada cidade, algo que particularmente o impressionava. O culto a animais é o aspecto cultural mais destacado nos textos sobre as vilas egípcias, talvez por ser justamente o que mais contrastava o território historicamente em relação a outros povos. O autor explica que alguns animais eram adorados em todo o Egito, enquanto outros em nomos específicos (Geographica 17.1.40). Descreve Mênfis como a residência real dos egípcios, que continha templos como o do deus Ápis e Osíris, onde o touro ficava em uma espécie de santuário.

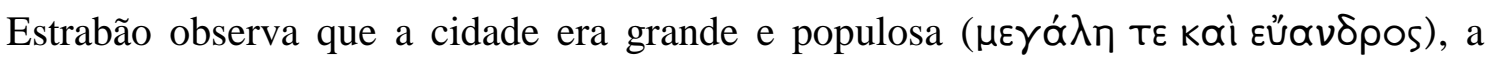
segunda depois de Alexandria e também formada por uma mistura de homens

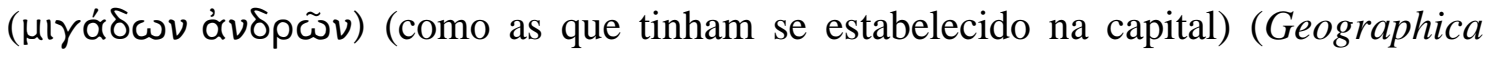
17.1.31). Estrabão cita Tebas também como a grande metrópole do Egito

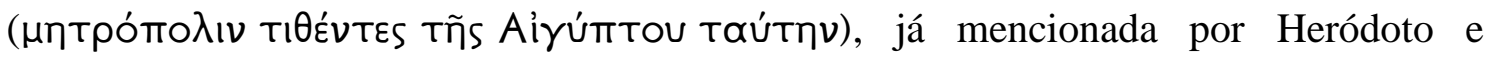


outros com relação à riqueza. E garante que mesmo no seu tempo ainda havia sinais de sua magnitude, pois conservava muitos templos, apesar da grande destruição por Cambises. Ressalta que ainda havia no local aproximadamente quarenta tumbas reais sofisticadas (Geographica 17.1.46). Apesar de citar Heródoto e "outros" como referências para entender o Egito antigo, destaca que tais autores falam "muitas coisas

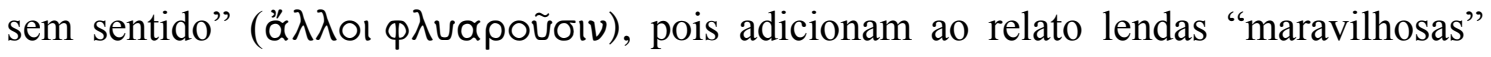

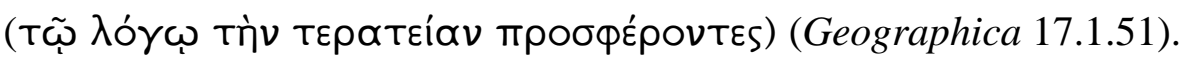

O fato de Estrabão se referir a Mênfis como a segunda cidade do Egito na época da conquista indica a continuidade do seu desenvolvimento no período ptolomaico (MCKENZIE, 2008, p.152). Mesmo que o local não tivesse mais o mesmo magnetismo como capital e centro religioso, ainda se desenvolvia por sua importância comercial. Lá se localizava o porto principal do interior, a partir do qual o trigo era trazido pelos afluentes do Nilo, de lá saía a leste em direção a Alexandria e a oeste em direção ao Pelusium (BALLET, 1999, p. 109).

É importante ilustrar brevemente a visão de Estrabão sobre o Egito como um todo, para entender como ele vislumbrava Alexandria como parte integrada ou distanciada do reino milenar. $\mathrm{O}$ autor demonstra o impacto da construção da nova cidade, ao mencionar a diminuição da importância de Tebas e Mênfis. No entanto, chama a atenção para o relativo "cosmopolitismo" de Mênfis, que a assemelhava a Alexandria. Ou seja, ao falar da antiga capital, reforça a composição multicultural de Alexandria, assinalando a sua identidade helenística. Destaca também a continuidade de Mênfis e Tebas como locais de culto principais dos egípcios. Assim, ocorre uma “divisão de funções” entre as principais cidades do Egito. Alexandria tornou-se a capital helenística e real, e Tebas e Mênfis continuaram sendo as sedes da religiosidade egípcia. Por mais que Estrabão defina Alexandria como um novo corpo instalado no Egito, ele a insere em uma dinâmica própria do país, pois sua fundação resultara no remanejamento de outros pólos. Dessa forma, o autor não dissocia Alexandria de seus arredores, demonstrando o impacto de sua construção no Egito como um todo, embora a fundação helenística se destacasse de suas redondezas em termos culturais.

Pausânias, que escreveu quase dois séculos depois de Estrabão, fez importantes considerações sobre o primeiro Ptolomeu. Ou seja, mesmo sendo um grego da segunda sofistica, o autor demonstra um apreço pela realeza helenística. Assinala que Ptolomeu se tornou o principal responsável pela divisão das conquistas de Alexandre em reinos 
após a sua morte, por ter lhe sido sempre fiel (Graeciae descriptio. Áttica 1.6.2). O autor reclama que aqueles que acompanharam os reis com o propósito de registrarem

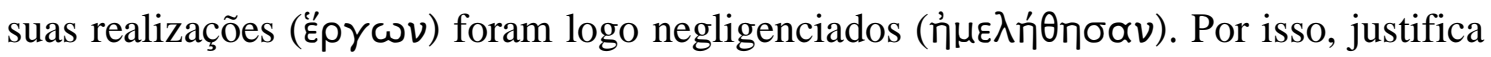

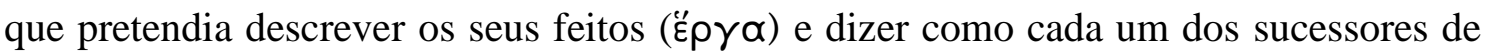
Alexandre conquistou seus reinos (Graeciae descriptio. Áttica 1.6.1). Pausânias atribui à Ptolomeu a primazia das conquistas, nesse sentido ele seria o principal e legítimo herdeiro de Alexandre.

Com relação ao corpo de Alexandre, Pausânias observa que Ptolomeu I o enterrou em Mênfis, mas que foi Ptolomeu II o responsável por sua transferência para Alexandria. Ptolomeu I foi pessoalmente para o Egito, matou Cleômenes, que

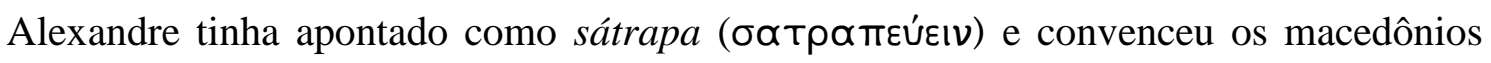
encarregados de levar o corpo para o Egeu a entregá-lo para ele. Dessa forma, o rei providenciou o seu enterro em Mênfis, de acordo com os ritos macedônicos, e sabendo que Pérdicas promoveria guerra, manteve o Egito vigiado ( $\varphi \cup \lambda \propto \kappa \tilde{n})$ (Graeciae descriptio. Áttica 1.6.3).

Pausânias narra as primeiras disputas de território após a morte de Alexandre, e novamente ressalta a precedência de Ptolomeu nessa divisão, que teve seu poder ameaçado em inúmeros momentos, mas conseguiu defender o Egito e assegurar a sua soberania (Graeciae descriptio. Áttica 1.6.2-1.7.3). Esse Ptolomeu casou-se com sua irmã, contrariando os costumes macedônios e seguindo a tradição egípcia

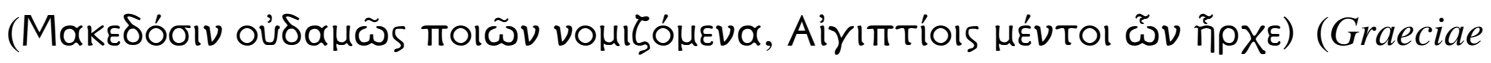
descriptio. Áttica 1.7.1). Seu testemunho indica a parcela egípcia da realeza, quando menciona a passagem do corpo de Alexandre por Mênfis, mesmo que tenha sido enterrado de acordo com ritos macedônios. Assinala também a "infiltração" de hábitos egípcios no cotidiano da monarquia. Ou seja, apesar de assegurar o vínculo macedônio de Ptolomeu através de Alexandre, concebe os Ptolomeus como reis helenísticos, que faziam importantes concessões aos egípcios. Ao mesmo tempo, Pausânias enfatiza a integridade do caráter de Ptolomeu, e a sua força na defesa do Egito, pois sofrera várias tentativas de conspiração ao assumir o controle da região. Assim, o autor confirma o seu comando no Egito e chama a atenção também para o início de uma fragmentação territorial logo após a morte de Alexandre, sugerindo a fragilidade dos reinos helenísticos. 
Cúrcio foi o único latino que mencionou a transferência do corpo de Alexandre. Observa que Ptolomeu o transportou para Mênfis e de lá, depois de alguns anos, para Alexandria onde toda a honra foi prestada em sua memória e seu nome (Historiae Alexandri Magni 10.10.20.3). Como Pausânias, o autor não cita a transferência da Babilônia, mas indica a sua passagem por Mênfis. É perceptível como os relatos referentes ao destino do corpo de Alexandre são contraditórios, refletindo os diferentes interesses em disputa (ERSKINE, 2002, p. 170). Diodoro e Estrabão não mencionam a sua passagem pela cidade egípcia de Mênfis, ressaltando que o corpo foi trazido da Babilônia (onde morreu), diretamente para Alexandria. A ênfase de Cúrcio e Pausânias na passagem do corpo pelo Egito ressaltaria a porção egípcia e helenística da identidade de Alexandre, que os textos anteriores de Diodoro e Estrabão não vislumbram? Nesse sentido, a passagem prévia pela antiga capital faraônica para depois se estabelecer em Alexandria seria uma forma de promover uma conciliação entre as culturas através de Alexandre e conceder uma identidade também egípcia para Alexandria.

O empenho de Ptolomeu I para transferir o corpo para Alexandria sugere o esforço dos reis para se alinharem à imagem do mito heróico. O corpo de Alexandre na cidade seria também um importante vínculo entre a nova localidade e o mundo grego (FINNERAN, 2005, p. 52). Reforçaria, portanto, o valor de Alexandria naquele universo, e passa a ser mais um motivo para respeitar e venerar a cidade. Mesmo que os autores tenham discordâncias quanto à identidade de Alexandre, o vínculo do herói com a cidade é consensual, e a presença de seu corpo na cidade fortalecia ainda mais essa ligação.

Foi visto em Diodoro e Estrabão o realce na grandeza das edificações e dos palácios reais de Alexandria, algo menos notado pelas fontes latinas, com exceção do farol de Faros, edifício que se sobressaía e impressionava ainda mais pela imponência. César ressalta a sua enormidade no relato da guerra de Roma com os alexandrinos, em que foi protagonista (entre 49 e 48 a.C.). O autor aproveita a oportunidade para expor sua experiência militar na região e justificar aos romanos suas ações políticas. Primeiramente, fala da existência na ilha de uma torre de grande altura e da maravilha de sua construção (Pharus est in insula turris magna altitudine, mirificis operibus exstructae; quae nomen ab insula accepit). A ilha, localizada na frente de Alexandria, na sua época estava conectada a terra por uma espécie de ponte de 900 metros de comprimento. César observa que lá havia residências de egípcios e uma habitação do 
tamanho de uma cidade (In hac sunt insula domicilia Aegyptiorum et vicus oppidi magnitudine; ) e que qualquer navio fora de seu curso, os habitantes tinham o hábito de saquear como piratas. Devido à estreiteza da entrada de Faros, nenhum navio podia entrar no porto sem o consentimento dos ocupantes (Bello Civili 3.112.2.1). O autor denota aqui certa selvageria na cidade atribuída à presença de egípcios, embora sublinhe também a importância comercial do local.

Plínio ressalta a responsabilidade do rei na construção do Farol e seu custo de 800 talentos. Adverte que Ptolomeu Filadelfo deveria ser louvado pela obra e por sua generosidade, pois deixou o nome do arquiteto, Sostrato de Cnidos inscrito no edifício, ao invés de vincular a obra a si mesmo (magno animo, ne quid omittamus, Ptolemaei regis, quo in ea permiserit Sostrati Cnidi architecti structura ipsa nomen inscribi) (Naturalis Historiae 36.18.83.2). Plínio aqui infere o esbanjamento (pelo custo do projeto) atrelado à humildade, pela qual o rei deveria ser louvado. Como na passagem citada anteriormente, em que Plínio notava a presença do arquiteto na construção de Alexandria, a sua intenção era novamente apontar o planejamento e a racionalidade do projeto. Assim, a monumentalidade do farol era obra humana e fruto de grande elaboração e sua imagem não deveria ser exclusivamente vinculada a um ato heróico e impulsivo de Alexandre.

Em contraste com a opinião de Plínio, Arriano atribui a primazia pela construção do Farol à orientação do Oráculo, e não a uma decisão real. Assim, Alexandre encarregou Cleômenes de sua construção, ressaltando que o Farol deveria ser "enorme e

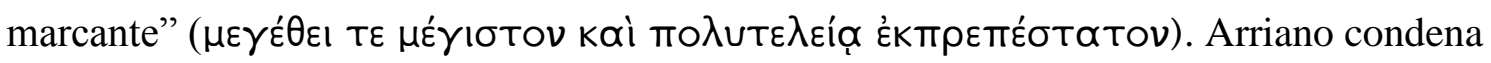
esse ato com o argumento de que um bom rei não podia dar um comando importante como esse a um homem com a má reputação de Cleômenes, responsável por um grande

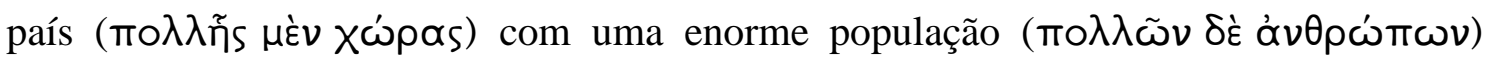
(Anabasis Alexandri 7.23.7-8). Por ser centrado em Alexandre, o relato de Arriano pretendia associar toda a magnificência de Alexandria ao fundador e não à realeza posterior. A intenção era também enfatizar que uma obra com imponência tal deveria ser considerada um feito essencialmente grego, e ao mesmo tempo divino, por ter sido ordenado pelo oráculo.

Nessa fase do desenvolvimento inicial da cidade a ênfase dos autores é na motivação dos reis em transformar Alexandria na sede legítima de uma realeza herdeira de Alexandre. Portanto, todos os investimentos foram feitos para divulgar a sua riqueza 
e poder. Mas os retratos sobre o significado dos primeiros reis para a história alexandrina são divulgados diferentemente segundo os autores. As representações de Diodoro e Estrabão são de reis ambiciosos e de Alexandria como a manifestação suprema do monumental, do grandioso e do excessivo. Suas narrativas são mais entusiastas com relação à dedicação dos reis na sofisticação da cidade e em Alexandre como um conciliador que atraiu uma grande população para a cidade. Os latinos e gregos posteriores mencionam menos a importância dos reis no desenvolvimento da cidade. Os latinos ressaltam a funcionalidade e o planejamento da cidade, como fica aparente nos comentários de César e Plínio sobre Faros. Arriano direciona novamente o foco para Alexandre, que presenteou a cidade com um imponente farol.

Se a fundação de Alexandria era um eixo comum nas representações da cidade segundo autorias diversas, o cenário já se tornou mais diversificado no período imediatamente subsequente. As representações do início do período helenístico são mais complexas, pois as identidades criadas para a cidade eram múltiplas, inferindo a complexidade populacional e a dinâmica de seu desenvolvimento. Mesmo os gregos anteriores (Diodoro e Estrabão) que no contexto de fundação eram mais enfáticos em relação ao vínculo entre Alexandre e Alexandria, já sugerem mais a mistura populacional da cidade e as influências egípcias.

\subsection{Biblioteca e Museu: Alexandria como centro cultural}

A Biblioteca e o Museu de Alexandria são as instituições que fizeram a fama da cidade na posteridade, e embora sejam muito investigadas pela historiografia contemporânea, foram pouco descritas pela tradição clássica. O mais intrigante é que não sobreviveram significativos testemunhos das instituições nem para o período contemporâneo aos Ptolomeus, a época de maior esplendor, entretanto as principais evidências são do período romano. Entre os gregos, Estrabão é novamente a fonte principal, e Ateneu apresenta a sua versão séculos depois, que dialoga em alguns pontos com a de Estrabão. Vitrúvio e Sêneca fornecem julgamentos claramente avessos ao sucesso da Biblioteca, enquanto o relato de Josefo enfoca na tradução da Bíblia para o grego, realizada na instituição. Apesar de o seu relato ter o objetivo principal de 
promover uma apologia ao judaísmo na cidade, apresenta alguns elementos importantes para a divulgação do retrato da instituição e da realeza. Como os estabelecimentos são retratados pela literatura e em que medida são partes importantes das representações alexandrinas?

Estrabão enuncia sobre a importância da Biblioteca antes de falar da cidade propriamente dita, talvez por ter sido a instituição que tornou Alexandria renomada. $\mathrm{O}$ autor explica que Aristóteles foi o primeiro a começar uma coleção de livros, deixando o exemplo de como organizar uma biblioteca para os reis do Egito

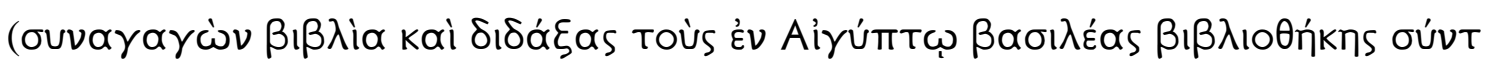
$\alpha \xi i v)$. Estrabão conta como a biblioteca de Aristóteles foi sendo passada de mão em

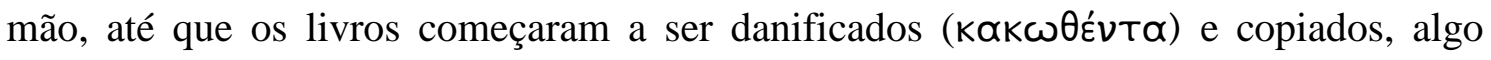
ainda feito na Alexandria de seu tempo. Segundo o autor, Neleu, o discípulo de Aristóteles e Teofrasto, herdou a biblioteca de Teofrasto (que já continha a de Aristóteles). Neleu deixou os livros em Scépis armazenados para seus herdeiros. Porém, quando os cidadãos ouviram que os reis Atálidas (a quem a cidade estava submetida), estavam buscando livros para construírem a sua biblioteca em Pérgamo, os esconderam no subterrâneo, em uma espécie de vala (Geographica 13.1.54). A observação de Aristóteles ter ensinado Ptolomeu sobre a Biblioteca sugere que na visão de Estrabão foi uma invenção peripatética, que chegou a Ptolomeu através do ateniense Demétrio de Falareu (BAGNALL, 2002, p. 351). O autor estaria assim tirando dos Ptolomeus à glória de serem os precursores daquele enorme projeto?

Muito tempo depois, quando os livros tinham sido danificados por umidade e traças, seus descendentes venderam tanto os livros de Aristóteles, quanto os de Teofrasto para Apelicon de Teos por um preço alto. No entanto, Apelicon, que era mais um bibliófilo do que um filósofo; buscando uma forma de restaurar as partes corroídas, fez novas cópias dos textos, preenchendo as lacunas incorretamente, e publicou os livros

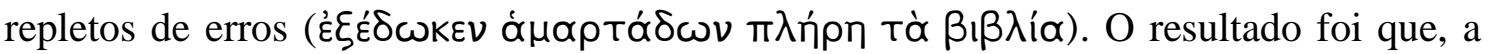
geração dos Peripatéticos que estudou após essa aquisição de livros, apesar de ter mais material de estudo à disposição em relação a gerações anteriores, não podia afirmar nada com certeza, pois estava se baseando em probabilidades, devido a grande quantidade de erros das cópias. Sila conseguiu levar a biblioteca para Roma após capturar Atenas, então o gramático Tirânio, fã de Aristóteles, a tomou para si, através de 
um suborno ao bibliotecário. Estrabão lamenta ser então comum o fato de vendedores

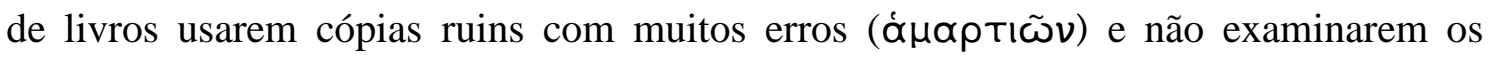
textos ( acontecia com os livros copiados à venda em Roma e Alexandria (Geographica 13.1.54).

O comentário de Estrabão pode ser entendido como uma reclamação sobre a negligência dos copistas comerciais em Roma e Alexandria (KNOX, 1985, p. 20). Apesar de Estrabão não fazer nenhum julgamento explícito acerca do trabalho realizado na Biblioteca, sua menção ao amontoado de cópias indica que apesar da quantidade, tratar-se-ia de um material pouco confiável para a pesquisa. Porém, ressalta a intensa atividade de pesquisa na Instituição sob Roma, denotando a continuidade de seu importante papel como centro de estudos. O fato de enfocar na produção de cópias sugere que a Biblioteca não podia ser louvada pelos trabalhos originais realizados no local. Entretanto, indica a intensidade de pesquisa no local e a grandeza de seu acervo, ainda em pleno vigor na sua época.

Com o estabelecimento da escola filosófica de Aristóteles no Liceu, foi organizada a primeira biblioteca institucional, "uma ferramenta para pesquisa". Talvez por isso seja que Estrabão fale de Aristóteles como o primeiro colecionador de livros (KNOX, 1985, p. 10). Barbara Gold (1987, p. 34) justifica que o apetite de Ptolomeu por livros era tanto, que pode sim, ter levado a falsificações, como produto de rivalidades. Sem a ampla gama de textos encontrados na Biblioteca, que serviam de base para diversas atividades "acadêmicas", muitos trabalhos não teriam sido possíveis (como a obra de Eratostenes, por exemplo) (BAGNALL, 2002, p. 360). Mesmo Estrabão deve ter aproveitado a Biblioteca para suas pesquisas nos anos em que ficou em Alexandria.

Além da Biblioteca, Estrabão alude à importância de Alexandria como um centro de conhecimentos. No livro XIV ele faz um paralelo com o povo de Tarso, tão

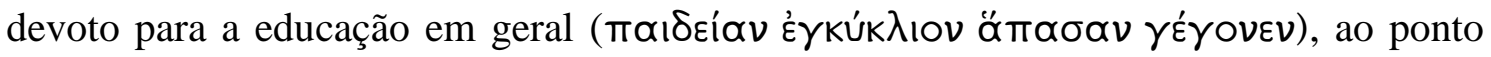
de superar Atenas, Alexandria ou qualquer outro lugar que tivera lições com os filósofos. A diferença de Tarso para as outras cidades é que os homens interessados em

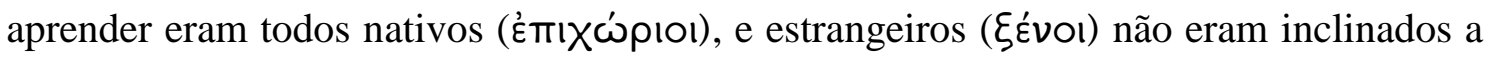
ficar lá; nem os nativos, pois mesmo após completarem sua educação no exterior, 
poucos voltavam para casa (Geographica 14.5.13). Ao colocar Alexandria ao lado de Atenas, Estrabão demonstra entender ambas como centros de educação de referência, mas sugere que de modo diferente de Tarso, as duas eram mais habitadas por estrangeiros. $O$ autor infere que muitos que iam para Alexandria se fixavam definitivamente, por amor à educação, mas também pelos atrativos oferecidos pela cidade. Em contraste com essas outras cidades, Alexandria admitia estrangeiros e também mandava muito de seus cidadãos para fora. $O$ trecho é sugestivo por indicar que Alexandria não atraia apenas pela intelectualidade, mas também por seus entretenimentos (Geographica 14.5.13.12-15). Segundo Cribiore (2001, p. 120), os prazeres de Alexandria facilmente desviavam os alunos dos seus estudos.

Mais adiante, Estrabão ressalta a presença de eruditos ( alexandrinos em Roma (Geographica 14.5.15.10). O autor indica a circularidade e mobilidade dos estudiosos desse mundo. Entende Alexandria como um centro cosmopolita e itinerante e de importância comparável a Atenas, com relação aos seus ensinamentos e produção de conhecimentos. Ele sugere que a capital tinha acesso a muitos conhecimentos através do que era produzido em centros gregos. Ou seja, a presença de eruditos em Roma ajudava a assinalar o valor intelectual de Alexandria. Estrabão situa Alexandria ao lado das poleis gregas, Atenas e Tarso. Ou seja, culturalmente Alexandria era vista como continuadora dos gregos.

Estrabão menciona rapidamente o Museu e indica o seu pertencimento aos palácios reais. Afirma que o lugar tinha um caminho público (uma Exedra) com cadeiras e uma "grande casa", o local comum dos eruditos que dividiam o recinto. Esse grupo de homens não apenas tinha propriedades compartilhadas, como também um sacerdote encarregado, antes indicado pelo rei e no seu tempo apontado pelo imperador (Geographica 17.1.8). Não há relatos sobre o Museu no período ptolomaico, assim o extrato de Estrabão ajuda a investigar o seu funcionamento no tempo anterior. Infelizmente sobre o seu papel como instituição se sabe muito pouco (FRASER, 1972, p. 315-320). A passagem é breve, mas ilustra certo isolamento dos intelectuais do Museu, que tinham uma vivência voltada para a instituição, assistida por um sacerdote e patrocinada pelos reis. Assim, os experimentos e descobertas eram proporcionados pela realeza e os bons resultados ajudavam no fortalecimento de sua imagem, por trazerem importantes avanços para a humanidade. 
Dois séculos depois de Estrabão, Ateneu apresentou outra versão a respeito do destino da biblioteca de Neleu. Afirma que o rei Ptolomeu Filadelfo havia comprado todos os livros de sua grande biblioteca, e os transferiu para "sua linda cidade de Alexandria”, juntamente com os obtidos em Atenas e Rodes,

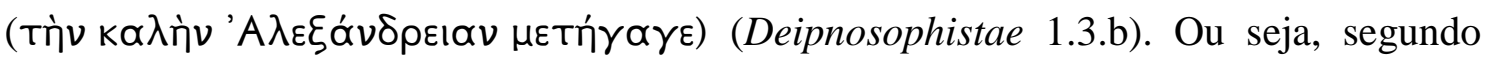
Ateneu, a biblioteca herdada por Atenas foi para Alexandria, e não para Roma, como conta a estória de Estrabão. Portanto, a Biblioteca de Alexandria seria anterior a qualquer esforço nesse sentido por parte de Roma. $\mathrm{O}$ fato de o autor ser procedente de Náucratis pode ter interferido na sua defesa em favor de Alexandria. Barnes argumenta que a versão de Estrabão é a mais aceita, por ser anterior (BARNES, 2000, p.66).

A respeito do número de livros e da coleção no salão das musas, Ateneu diz que não precisava nem falar, pois era algo que estava na memória de todos

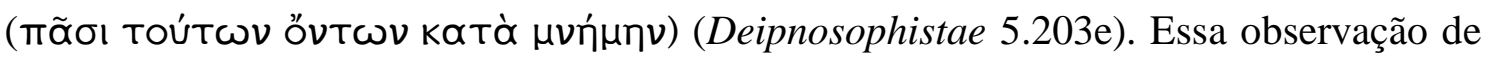
Ateneu é importante para ressaltar a euforia que rondava as estórias da instituição, mesmo séculos depois do seu estabelecimento inicial, pois ainda estava presente no imaginário de todos, mesmo os que não conheciam Alexandria.

Com relação ao Museu, Ateneu não descreve a sua organização, talvez pelos mesmos motivos que achava não ser necessário descrever a Biblioteca por estar na memória de todos. Ateneu cita um sátiro que comparava os homens do Museu aos "pássaros numa gaiola", como uma forma de ironizar os filósofos que ficavam discutindo no local, pois eram alimentados como os mais requintados pássaros (Deipnosophistae. 1.22d). A alimentação é provavelmente uma metáfora em relação aos investimentos reais para as atividades do Museu, e ao gerenciamento promovido pelos monarcas (BARNES, 2000, p. 62). Como Estrabão, Ateneu ilustra o isolamento dos eruditos do recinto e o investimento e encorajamento ofertados pelos reis. Dessa forma, enfatiza a subordinação e dependência do Museu à realeza. Em relação à Estrabão, Ateneu vincula ainda mais às instituições aos reis.

Flávio Josefo remete à Biblioteca para ressaltar a boa disposição dos Ptolomeus em relação à comunidade judaica e provar o pertencimento do grupo a Alexandria. Trata da tradução da Septuaginta pelo segundo Ptolomeu, um rei profundamente interessado no aprendizado e um grande colecionador de livros

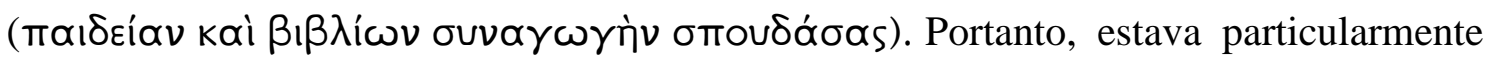


ansioso para traduzir a lei e a constituição política dos judeus para o grego, apesar da resistência do sacerdote Eleazar (Antiquitates Judaicae 1.10-13).

No livro 12, Josefo relata novamente sobre a paixão de Ptolomeu Filadelfo por livros, ao permitir a tradução da lei judaica, e libertar milhares de judeus escravizados no Egito. Josefo faz uma paráfrase da Carta de Aristeas, um documento apologético do judaísmo (do séc. II a.C.) e a primeira fonte a falar dos investimentos de Ptolomeu na Biblioteca. Josefo narra o seguinte:

Demétrio de Falareu, que estava encarregado da biblioteca do rei, estava ansioso para reunir, se conseguisse, todos os livros do mundo

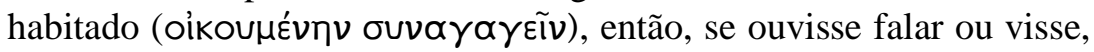
qualquer livro que compensasse o estudo, ele o compraria; e então ele se esforçou para realizar os desejos do rei, pois era um grande devoto

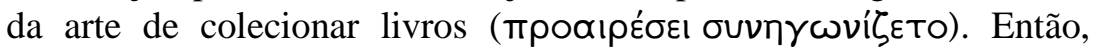
quando Ptolomeu the perguntou quantas dezenas de milhares de livros ele já tinha reunido, ele respondeu que o número atual estava por volta de duzentos mil, mas que em um curto período ele juntaria em torno de quinhentos mil. Ele mencionou que tinha sido informado que entre os judeus também havia muitos trabalhos sobre a lei, que valiam o estudo e mereciam um lugar na biblioteca do rei, mas tendo sido escrita na caligrafia e no seu dialeto, não seria pouco trabalhoso realizar a sua tradução para a língua grega. Pois, apesar da caligrafia ser semelhante à escrita peculiar siríaca (aramaico), e da língua parecer com a outra, era de um tipo distinto. Não havia nada, contudo, ele disse, que os impedia de ter esses livros traduzidos e ter os escritos em sua biblioteca, pois ele tinha recursos abundantes para realizar esse

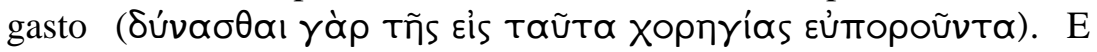
então o rei, convencido de que Demétrio tinha lhe dado um excelente

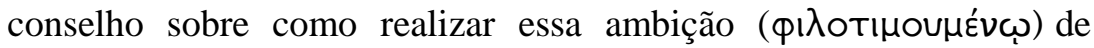
obter uma grande quantidade de livros, escreveu para o sacerdote supremo dos judeus que isso deveria ser feito. (Antiquitates Judaicae 12.12-25)

O relato de Josefo sobre o processo de tradução é longo e detalhado, portanto, estão destacados aqui apenas alguns pontos principais. Josefo conta que o sacerdote Eleazar exigiu do rei a liberação dos judeus, em troca da realização da tradução, o que Ptolomeu concedeu. Comprometeu-se ainda, a pagar uma recompensa a cada um dos presos, uma quantia significativa para o reino. Dessa forma, Josefo deixa explícita a generosidade do rei. O rei solicitou que o sacerdote mandasse seis anciãos de cada tribo versados nas leis, para debaterem até o ponto de surgir uma tradução apurada. Junto à carta, foram enviadas também oferendas riquíssimas ao

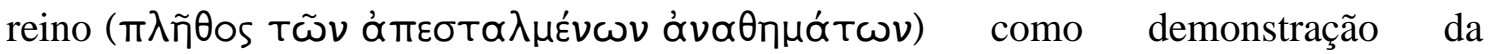


generosidade do rei e honra ao deus dos judeus. Então, o sacerdote enviou ao Egito setenta anciãos em companhia da lei. Os setenta chegaram e foram recebidos com enorme pompa e emoção pelo rei, que afirmou que celebraria a chegada deles todos os dias de sua vida. Em seguida, foi preparada uma grande recepção e um banquete de acordo com os hábitos alimentícios específicos de cada tribo (Antiquitates Judaicae 12.17-96).

Josefo conta que Ptolomeu endereçou várias perguntas filosóficas aos anciãos, dessa forma, o banquete durou doze dias. Aristeas conta os detalhes das questões filosóficas, mas Josefo decidiu não abordar o assunto. Em seguida, foram levados a um local especialmente preparado para o trabalho, e ficaram lá por setenta e dois dias. Os anciãos trabalhavam ininterruptamente durante nove horas por dia, e iam ao palácio prestar honras ao rei diariamente. Depois que terminaram a tradução, Demétrio reuniu os judeus e leu a versão finalizada. O povo aprovou e agradeceu aos anciãos e à Demétrio pela iniciativa. Quando este leu a tradução para Ptolomeu, o rei ficou impressionado com a profundidade das leis, e ambos se perguntaram por que historiadores ou poetas anteriores nunca às haviam mencionado. $\mathrm{O}$ rei ordenou que os livros fossem guardados com muito cuidado, para permanecerem intactos. E depois de presentear cada um dos anciãos pelo maravilhoso feito (enumera novamente todos os generosos presentes), lhes mandou de volta, prometendo lealdade sempre que precisassem (Antiquitates Judaicae 12.25-118).

Josefo ressalva a generosidade de Ptolomeu diante dos judeus, mas também toda a pompa, riqueza e exuberância da realeza. Assinala a ambição e grandiosidade do projeto universal pretendido pelos reis, de reunir todos os livros do mundo habitado. Elogia também a devoção de Ptolomeu por conhecimento e estudos, denotando que sua apreciação por livros era autêntica, e não um mero luxo. O autor apresenta uma visão favorável à realeza ptolomaica e à Biblioteca. Contudo, fica claro que seu julgamento é parcial, por ser grato aos reis pela boa vontade diante do judaísmo, um contraste em relação a alguns imperadores de seu tempo. Como na passagem citada anteriormente referente ao contexto de fundação, novamente a intenção de Josefo é reforçar a aceitação e legitimidade da comunidade judaica em Alexandria.

Em outra parte das Antiguidades, Josefo argumenta que a postura de Alexandre sobre os judeus de Alexandria foi compartilhada pelos primeiros dois Ptolomeus. Filadelfo liberou os prisioneiros judeus e tentou aprender um pouco da lei judaica 
(Antiquitates Judaicae 2.44.2). E praticamente todos os outros reis tiveram a mesma atitude de bondade diante dos judeus (Antiquitates Judaicae 2.49.5). No Contra Apião, ao se defender de uma acusação de Apião, um grego que condenava os judeus por não adorarem os mesmos deuses dos alexandrinos, Josefo responde que os próprios egípcios brigavam entre si com relação à religião. Apesar de legitimar o pertencimento dos judeus no Egito, Josefo também condena os egípcios pela adoração a animais (Contra Apionem 2.66-67).

Josefo divulga uma imagem do período ptolomaico como um tempo harmônico e de grandes concessões e benfeitorias para a comunidade judaica e de Ptolomeu Filadelfo como um rei generoso, sábio e um completo devoto da aprendizagem. Contudo, seu retrato vai ao encontro do que era severamente criticado entre outros autores com relação ao luxo e esbanjamento excessivos da realeza. O autor destaca a grandiosidade do projeto da Biblioteca que pretendia reunir os livros de todo o mundo habitado. Ou seja, tratava-se de um projeto universal no qual Alexandria seria o grande centro. Josefo exagera o interesse e obstinação do rei pelas leis objetivando principalmente suscitar a curiosidade e o interesse generalizados em relação aos preceitos judaicos.

Entre os autores gregos citados nota-se uma relativa admiração com relação ao conhecimento elaborado na Biblioteca, contudo os latinos Vitrúvio e Sêneca expressam claramente sua opinião negativa sobre o saber veiculado na instituição. Vitrúvio se volta exclusivamente para a fundação da Biblioteca nas suas considerações sobre os Ptolomeus. O autor tece um julgamento da importância de livros, de se ter ampliado o acesso a eles e de legarem o conhecimento humano para a posteridade. Observa que agradecimentos deviam ser estendidos aos que realizaram tal feito. Em contrapartida, aqueles que aproveitaram ideias dos outros como se fossem suas deviam ser julgados, algo muito praticado na sua época.

Em seguida, Vitrúvio narra sobre a fundação das duas bibliotecas, advertindo que os Atálidas mereciam elogios, enquanto os Ptolomeus deveriam ser censurados, pois os primeiros fundaram uma biblioteca em Pérgamo impulsionados pela paixão à literatura e a instituição foi estabelecida para a consulta geral. Porém, Ptolomeu Filadelfo fundou a Biblioteca em Alexandria seguindo o mesmo modelo, motivado unicamente pela inveja e avareza (tunc item Ptolomaeus infinito zelo cupiditatisque incitatus studio non minoribus industriis ad eundem modum contenderat Alexandriae 
comparare). Após completar a tarefa, o rei dedicou jogos em honra às Musas e à Apolo, e estabeleceu prêmios e homenagens para os autores bem sucedidos daqueles dias (De Architectura 7 Praefatio 4.6). Vitrúvio menciona também uma competição de poetas organizada no recinto. O rei escolhera seis juízes experientes pra examinar os competidores e não conseguiu achar um sétimo jurado adequado para a tarefa, então consultou os diretores da Biblioteca para saber se conheciam alguém. Eles sugeriram Aristófanes ${ }^{15}$, que havia lido cada livro da Biblioteca sistematicamente (De Architectura 7 Praefatio 5.1).

O autor enfatiza à falta de originalidade da produção da Biblioteca na descrição do evento. Relata que quando os poemas começaram a ser recitados, toda a multidão (populus) manifestou aos juízes sobre o que aprovar. Então os seis concordaram que dariam o primeiro prêmio ao poeta que mais agradara a audiência (multitudini). Porém Aristófanes considerava que o primeiro prêmio deveria ser entregue ao que menos satisfizera o público (De Architectura 7 Praefatio 6.1). Quando o rei (provavelmente Ptolomeu III Euergetes) e companhia demonstraram grande indignação por não entenderem a sua colocação, Aristófanes levantou e pediu permissão para falar. Informou que apenas um deles era um verdadeiro poeta, pois os outros tinham recitado trabalhos emprestados, e os juízes deveriam avaliar composições originais. Aristófanes citou um grande número de papiros que havia memorizado, exatamente iguais aos recitados, e insistiu para que os autores confessassem ser ladrões. O rei então ordenou que fossem condenados, enquanto Aristófanes conquistou um alto posto e se tornou bibliotecário (195 b.C) (De Architectura 7 Praefatio 7.1).

Vitrúvio talvez conte essa estória com o intuito de ressaltar a falta de originalidade da produção da Biblioteca, da mesma forma que anteriormente censurara a abundância de livros. $\mathrm{O}$ autor explicita a sua opinião sobre a instituição, e na sequência narra esse episódio, sugerindo que sua intenção era ilustrar um exemplo do argumento anterior, inferindo que quantidade e qualidade não eram sinônimas. A passagem retrata o acesso do povo aos conhecimentos produzidos na Biblioteca. Assim, em contraste com o Museu que gerava saberes em relativo isolamento, os habitantes de Alexandria de alguma forma participavam e se envolviam com o que era desenvolvido no recinto. Seu

\footnotetext{
${ }^{15} \mathrm{O}$ crítico, que viveu entre 257-180, no governo de Euergetes, provavelmente trabalhava na biblioteca, antes de suceder Eratóstenes como diretor.
} 
comentário indica que esse tipo de competição se tornara uma forma de entretenimento em Alexandria.

Vitrúvio descreve mais um episódio ocorrido em Alexandria sobre um poeta macedônio que foi para a cidade e citou suas composições de crítica à Ilíada e Odisséia diante do rei. Quando Ptolomeu percebeu que o pai da poesia e da filologia, cujos trabalhos eram estimados em todos os lugares, estava sendo caluniado sem poder responder, ficou coberto de raiva (Ptolomaeus vero cum animadvertisset poetarum parentem philologiaeque omnis ducem absentem vexari et cuius ab cunctis gentibus scripta suspicerentur ab eo vituperari, indignans nullum ei dedit responsum). $\mathrm{O}$ autor observa que este homem teve um destino trágico, dizendo que a pena foi merecida, por ousar falar mal de Homero (De Architectura 7 Praefatio 8.3).

Na primeira menção feita por Vitrúvio com relação à origem da Biblioteca, percebe-se claramente a sua visão negativa sobre os Ptolomeus, percepção que reafirma ao descrever uma situação que demonstra o predomínio do plágio no estabelecimento. Com relação ao segundo episódio, é provável que estivesse fazendo uma referência aos trabalhos de revisão, crítica e interpretação de Homero, realizados na Biblioteca. Ou seja, eram trabalhos ultrajantes para a memória do poeta, pois a maior herança dos gregos não deveria ser questionada e nem retrabalhada. É plausível que tivesse também a intenção de rebaixar a produção da Biblioteca, exaltando apenas os clássicos gregos como originais e dignos de valor eterno. A condenação se estende principalmente à realeza por ter perdido o controle do que era realizado no local, em virtude do excesso de investimentos na instituição. $O$ trecho sugere ainda que Homero foi a maior autoridade literária em meio à nova realeza instalada no Egito. Vitrúvio esboça certo preconceito com relação à cultura helenística, concebendo apenas os conhecimentos da Grécia Clássica como digna de apreço universal. Ou seja, entende que a identidade helenística de Alexandria colaborou para enfraquecer os valores helênicos. Fica claro, tanto em Estrabão (como foi visto anteriormente), quanto em Vitrúvio, o grau do vínculo das duas instituições com a corte, pois ressaltam a centralidade do rei no seu funcionamento e na divulgação dos saberes produzidos no local.

Como Vitrúvio, Sêneca indica claramente sua aversão à instituição, por considerá-la um exemplo de luxo e esbanjamento. Argumenta que até para os estudos, gastos só eram justificáveis se existissem limites. Questiona sobre o sentido de ter infinitos livros e bibliotecas, cujos títulos seus donos dificilmente leriam no decorrer de 
uma vida inteira. Sêneca justifica que o aprendiz não absorve uma massa enorme de livros e que era mais enriquecedor se render a uma pequena quantidade de autores do que a uma enormidade deles. Cita que 40 mil livros foram queimados em Alexandria, mas que não se daria ao trabalho de elogiar (laudaverit) essa Biblioteca, como havia feito Tito Lívio, que a considerava como a maior realização e sinal de bom gosto e solicitude do rei (qui elegantiae regum curaeque egregium id opus ait fuisse) e o mais bonito memorial da riqueza real (pulcherrimum regiae opulentiae monimentum).

Sêneca considera que através de tal projeto só instruíam o luxo (luxuria), colecionando livros unicamente para a exibição (spectaculum) e como decoração de suas salas. $\mathrm{O}$ autor justifica que o problema não era reunir a maior quantidade de livros desejada, contanto que não fossem destinados à exibição, pois o problema era o excesso (nimium). Questiona ainda o sentido de colecionar livros de autores desconhecidos e sem renome (ignotorum auctorum) apenas pela sua beleza exterior (Seneca. Ad Serenum. De tranquillitate animi, 9.5 e Tito Lívio. Periochae 112.42).

Além do seu comentário citado por Sêneca, Lívio não faz outras menções à Biblioteca, apenas realça em alguns momentos a riqueza e esbanjamento dos Ptolomeus. Como exemplo, menciona a exposição (viseretur exposita) da coleção dos saques dos macedônios, com estátuas, pinturas, ouro, prata, manufaturados com muito trabalho no palácio de Pela para uso contínuo. Não ficavam no palácio apenas para a exibição imediata (praesentem modo speciem), como era feito no palácio de Alexandria, que ficava abarrotado de objetos (referta) (Ab Urbe Condita 45.33.7.3). O autor adverte que expor relíquias sem nenhuma utilidade, apenas para a exposição, era um exemplo de ostentação. A coleção não tinha finalidade prática e estava exposta apenas para o desfrute, da mesma forma como os livros mencionados por Sêneca eram usados essencialmente como adornos e decoração.

É curioso que tanto Vitruvio, quanto Sêneca, ambos latinos e profundamente inseridos na elite governamental romana, apresentam uma visão negativa da Biblioteca. Seria uma espécie de "despeito" por Roma nunca ter fundado uma instituição à altura? Ou era já fruto da recente onda de propaganda de Augusto contra os Ptolomeus e seus excessos?

Suetônio menciona um projeto de César de começar a construir bibliotecas públicas em Roma com uma grande quantidade de livros gregos e latinos (Divus Julius 44). Knox acredita que a menção de Suetônio foi resultado da influência da biblioteca 
alexandrina, depois do retorno do Egito. No entanto, César não teve tempo de implementar seu projeto (1985, p. 184). A referência de Suetônio à Biblioteca, apesar de indireta, indica certo grau de admiração de um romano influente em relação à instituição, algo ausente em outros escritos latinos e sugere que o exemplo alexandrino poderia ser usado por Roma.

Aulo Gélio também narra a respeito de quem teve a primazia no estabelecimento de uma biblioteca pública (publicae). Porém em contraste com a versão de Estrabão, afirma ter sido o tirano Pisístrato o primeiro a instituir uma em Atenas. No entanto, quando Xerxes tomou posse da cidade, transferiu toda a coleção para a Pérsia. Até que muito tempo depois, o rei Seleuco Nicanor, levou todos os livros de volta a Atenas. Em um momento posterior, uma enorme quantidade de livros, quase 700 mil volumes, foram adquiridos ou copiados de manuscritos no Egito sob os reis Ptolomeus. Contudo, quase todos foram queimados não intencionalmente (non sponte neque opera consulta) pelos soldados auxiliares durante a primeira guerra romana com Alexandria (por César, em 48 b.C) (Noctes Atticae 7.17.3.4). Talvez o autor esteja indicando a precedência de Atenas nesse processo. Ou seja, Alexandria não deveria levar todos os créditos pelo sucesso do estabelecimento. Sugere também o esvaziamento da instituição, e talvez a perda de sua importância e influência, após o "acidente" de César.

Apesar da escassez de documentação contemporânea sobre o funcionamento do Museu e da Biblioteca, há muitas referências a pessoas envolvidas nas instituições. Mesmo posteriormente, muitos autores citam com frequência sábios e importantes “intelectuais" (filósofos, retóricos, médicos) que viveram na cidade, mesmo que não falem sobre Alexandria ${ }^{16}$. Talvez não fosse necessário explicar o funcionamento dos órgãos, pois como Ateneu ressaltara, tratava-se especificamente de algo presente na memória de todos, portanto, fazia parte do imaginário da época.

Percebe-se que apenas com Ateneu, autor do século III, maiores atenções se voltam para as instituições. Foi no contexto da segunda sofística que o foco é direcionado para esses pólos do conhecimento fundados pelos reis? Era necessário exaltar a riqueza dos reis, herdeiros de Alexandre, e seus investimentos culturais? Percebe-se que os latinos celebram menos ainda o desenvolvimento dos

\footnotetext{
${ }^{16}$ Existem algumas referencias em Fronto, Diogenes Laertio, Celso, Plutarco e Plínio, o Velho.
} 
estabelecimentos, e quando o fazem, deixam claro que se tratava de mero esbanjamento, e não de um projeto intelectual e cultural em grande escala.

O distanciamento cronológico dos relatos, que descrevem mais a Biblioteca e o Museu do período dos reis do que a de sua época é mais um indicativo da consolidação de alguns aspectos da história alexandrina como mito no império. As narrativas são tão cercadas de mistério e não parecem ter a intenção de informar sobre a história da cidade. As descobertas na área da matemática, astronomia, geometria, medicina e anatomia são relatadas pelos seus eruditos (para citar só os exemplos mais conhecidos dos estudiosos que frequentariam as instituições: Euclides, Eratóstenes, Arquimedes, Ptolomeu, Galeno). Graças a esses comentários é que se sabe sobre as instituições, pois a tradição posterior falou pouco dos avanços conquistados.

O silêncio a respeito do conhecimento produzido na Biblioteca e no Museu e com relação ao potencial intelectual de Alexandria é sugestivo, principalmente se analisado paralelamente aos mesmos relatos que descreviam a grandeza e a riqueza da metrópole. Evitavam tecer testemunhos sobre a Biblioteca, pois era um assunto não conveniente para os romanos reforçarem? Ou seja, a centralidade e a força cultural de Alexandria não deveriam ser exaltadas e estimuladas, pois a cidade superaria Roma caso se desenvolvesse ainda mais nesse setor. Diferentemente da riqueza do Egito, que era aproveitada e necessária ao Império Romano, portanto, havia todo o interesse em sua continuidade, assim, rememorá-la com frequência poderia ajudar na manutenção. Evitava-se vincular as instituições às representações de Alexandria. Além disso, nos poucos momentos em que os estabelecimentos foram descritos, são associados à realeza, porém de maneira a exemplificar seus excessos. Ou seja, era mais interessante entender e divulgar a imagem das instituições como meros caprichos dos reis, do que como setores na qual Alexandria inovou e adquiriu destaque naquele mundo.

\subsection{Festivais e culto à Serápis: formas de legitimação da realeza}

Outro aspecto da representação ptolomaica de Alexandria reforçada pelo Império é a sua cultura de entretenimentos e festivais. A tradição festiva da cidade remete aos primeiros Ptolomeus, que não pouparam investimentos em promover 
celebrações com a intenção de exibir o poder e a riqueza da realeza, além de comemorar as conquistas. Sob Roma a rotina de entretenimentos e espetáculos se manteve e foi intensificada em alguns setores, embora fosse extremamente mau vista por autoridades de fora, como será visto no capítulo $\mathrm{V}$.

Alexandria é também responsável pela introdução e fortalecimento de um novo culto no Mediterrâneo: a adoração a Serápis. Sua veneração se tornou forte na própria cidade já no governo do primeiro Ptolomeu, difundiu-se por todo o Egito e alcançou inúmeras regiões do Império Romano, principalmente no tempo de Trajano e Adriano. Serápis tinha uma composição híbrida (um misto de elementos gregos e egípcios), e seu culto era destinado às duas culturas, apesar de ter se tornado mais popular entre os gregos. O fato de ter sido uma divindade "inventada" por um rei estimulou a busca de suas origens, para a qual Tácito e Plutarco apresentam algumas versões.

Mesmo não fazendo parte do corpos dessa pesquisa, por ser um poeta do período helenístico e contemporâneo aos reis, Teócrito tem uma passagem muito ilustrativa com relação à rotina dinâmica da cidade promovida por suas festas, que é conveniente citar aqui. No Idílio 15 o autor descreve o espanto de duas imigrantes da Sicília, Gorgo e Praxinoa, com a horda alexandrina ao chegarem para a festa de Adonis, instituída pela

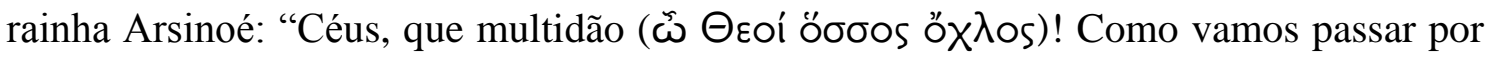
essa terrível lotação (óvó́pı $\theta \mu \mathrm{ol})$ e quanto tempo vai nos levar, eu não posso imaginar" (Idílio $15,38-55)$.

As moças ainda observam a variedade de "sotaques" gregos que ouviam no meio da aglomeração, quando um estrangeiro chama atenção para o jeito específico que elas

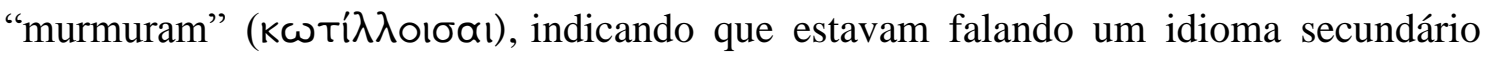
(Idílio 15, 80-98). Assim, ao entrar na multidão, mudaram sua identidade abandonando o sotaque dórico e adotaram a koine, algo "exigido" pelo meio multi-étnico alexandrino. Essa integração simboliza a aquisição de uma nova identidade urbana sob os auspícios de Ptolomeu (HINGE, 2009, p. 74). Teócrito fala também da desordem em Alexandria com suas corridas de cavalo rivais, caos que era transformado em ordem e harmonia no palácio real. Ou seja, na sua visão eram os Ptolomeus que estabeleciam e mantinham o funcionamento das coisas, o que marcava o seu papel como continuadores dos faraós (STEPHENS, 2003, p. 167).

O mais famoso festival ptolomaico era a Ptolemaia, a festa instituída por Ptolomeu II Filadelfo por volta de 280 a.C em homenagem ao pai, Ptolomeu Soter. A 
magnificência e imponência da festa foram preservadas pelo relato de Callixenius de Rodes, e transmitida por Ateneu quase cinco séculos depois da realização. Se no início do séc. III d.C. ainda havia alguma preocupação de descrever a imponência de festivais realizados vários séculos antes, pode-se inferir que a sua grandiosidade na época foi de alguma forma memorável.

O texto de Ateneu se concentra na procissão dionisíaca da festa, pois o deus era considerado o ancestral da dinastia e a festa celebrava a entrada de Ptolomeu no Olimpo, junto a Alexandre (KAHIL, 1993, p. 79). Visava também exaltar as origens divinas e heróicas da dinastia ptolomaica (associada aos macedônios) e difundir a ideologia real para a população, simbolizando o seu poder. Pretendia divulgar também o "triunfo do helenismo" através de elementos predominantemente gregos (THIERS, 2003, p. 24). As festividades refletiam a riqueza dos Ptolomeus e a vontade de transformar Alexandria numa "cidade museu" principalmente para a população grecomacedônia (GOUKOWSKY, 2000, p. 146). Era também o momento em que delegações vinham de diversas regiões para participar, portanto, Alexandria exercia ainda mais a sua função de capital da realeza (DUNAND, 1981, p. 13). No entanto, não era uma festa voltada para toda a população, o acesso restrito e seu público selecionado entre os gregos, o povo egípcio no geral era excluído da festa. Segundo Dunand (1981, p. 3132), a festa era direcionada principalmente aos alexandrinos e representantes das cidades e da realeza. Tinha, portanto, uma função propagandística, porém restrita ao público greco-macedônio, pois na primeira etapa da conquista, o mais importante era conquistar a adesão dos gregos. No decorrer dos séculos é que a dinastia começou a se direcionar mais para os egípcios.

Como Teócrito, o relato de Callixenius tinha a intenção de servir de propaganda da dinastia. Curiosamente, nenhum autor antes de Ateneu abordou a festa ao tratar do período helenístico. Ateneu é a narrativa mais detalhada sobre a vida cultural de Alexandria nessa época. Ele escreve em um contexto de revitalização do aticismo, e apresenta uma visão romantizada sobre a monarquia ptolomaica e Alexandria. Mas seu espírito grego está voltado para o período helenístico e especificamente para a realeza, pois na sua concepção, a história do Egito ptolomaico era essencialmente a história de seus reis. Para Ateneu a história do Egito começava com a chegada dos gregos sob Psamético, porém foi sob os Ptolomeus que o Egito ganhou vida, principalmente os primeiros, pois os reis mais tardios aparecem pouco (THOMPSON, 2000, p. 78-79). 
Ateneu descreve longamente e com minúcias as comemorações instituídas na cidade pelos reis, e concede atenção especial a Ptolemaia, procissão organizada pelo “mais excelente” rei Ptolomeu Filadelfo (áaíotou) (Deipnosophistae 5.196a). Salta aos olhos a grandiosidade e magnificência da festa, repleta de ouro, de animais exóticos, de estátuas homenageando vários deuses (principalmente gregos) e os reis, sem falar da enorme quantidade de pessoas envolvidas (todas numeradas no relato, para cada setor). Além da grandeza do espetáculo, o autor destaca a riqueza do material usado na procissão; abusavam do ouro, prata, ébano, mármore, e tapetes persas para a confecção das carruagens, estátuas e fantasias, deixando claro que era primordial para a realeza divulgar a imagem de sua riqueza. Segundo Dunand (1981, p. 15-19), a exibição de toda essa abastança visava demonstrar as conquistas dos reis e exibir os frutos do comércio ptolomaico com a Arábia, Índia e África. Portanto, era também uma festa da vitória destinada a exaltar a presença militar da dinastia por todas as regiões conquistadas. Nesse sentido, a procissão tinha também um valor pedagógico.

No final Ateneu cita o total de 2239 talentos gastos no espetáculo (Deipnosophistae 5.203c) e observa que nenhuma monarquia fora tão rica quanto o

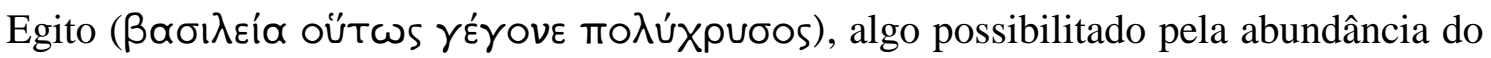
Nilo por suprir todos os homens suficientemente de grãos (Deipnosophistae 5.203c). O comentário de Ateneu sublinha a missão do Egito de alimentar a humanidade (DUNAND, 1981, p. 14). Pretendia também assinalar a generosidade do rei (DUNAND, 1981, p. 25-26).

Depois de descrever detalhadamente a Ptolemaia, cada setor da procissão, a quantidade de pessoas, animais e o luxo dos materiais usados, o autor detalha, ainda de acordo com Callixenius, os barcos sofisticados de Filadelfo. Ateneu observa que este Ptolomeu superava muitos reis em riqueza ( $\left.\pi \lambda \circ \operatorname{ú}_{\tau} \omega\right)$, e se devotava com enorme zelo ( navios. Ateneu delineia a enormidade dos navios ( $\left.\mu \varepsilon^{\prime} \gamma ı \tau \alpha \tau \tilde{\omega} \nu \pi \lambda \circ i ́ \omega \nu\right)$ em posse do rei, ressaltando que havia em torno de quatro mil, entre os despachados para as ilhas e outros territórios governados por ele (incluindo a Líbia). Em seguida, delineia as partes do enorme navio que Filopator mandou construir para banquetes, com salões de festa, quartos para hospedagem com elementos gregos e ainda um salão com "motivações

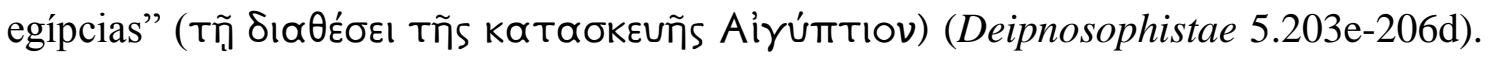


Mckenzie (2008, p. 49) ressalta que esse tipo de celebração era típico do Oriente, e não de gregos e macedônios, sugerindo a presença egípcia na vida cultural da realeza.

Ateneu menciona ainda outro festival, em que destaca a presença de multidões junto à realeza. Ele relata que Plutarco, um dos participantes do banquete contou que em

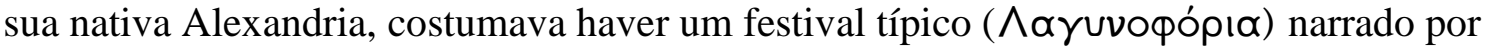
Eratóstenes no tratado sobre Arsinoé. Novamente observa que Ptolomeu Filadelfo

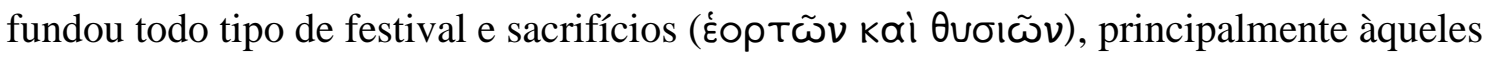
relacionados a Dionísio. Explicaram a Arsinoé que os celebrantes comiam o que lhes era trazido, enquanto ficavam deitados em camas de junco e cada homem bebia de um jarro especial trazido de sua casa. Arsinoé respondeu que deveria se tratar de uma grande sujeira, pois a multidão era uma mistura ( $\pi \propto \mu \mu$ ı 7.276a).

Muito é debatido na historiografia com relação às intenções dos reis em investirem tanto em festas. Na visão de Ateneu, Filadelfo foi extremamente importante para a vida cultural de Alexandria, para além de seus excessos (THOMPSON, 2000, p. 78). Stephens enfatiza a importância dos espetáculos públicos para criar a imagem de uma realeza que casaria duas tradições, grega e egípcia (2002, p. 248). O texto de Ateneu assinala esse "casamento" apenas na descrição do navio do rei, por apontar a presença de aspectos dos dois cultos. Na Ptolemaia a predominância de elementos gregos é nítida, e esse apelo visual substancialmente helênico deveria ter um grande impacto para o povo. Dever-se-ia ressaltar o poder e a riqueza da realeza, e também a sua faceta divina, que se tornaria mais palpável através das procissões e da presença das divindades para o povo (CHAUVEAU, 1997, p. 43).

Ateneu menciona ainda os animais exóticos e raros mantidos no palácio real de Alexandria, a partir dos Comentários de Ptolomeu Euergetes II (Deipnosophistae 14.654c), algo que Diodoro também já ressaltara como uma espécie de fixação dos Ptolomeus, pois lutaram para trazer para a cidade todo tipo de serpentes (Bibliotheca

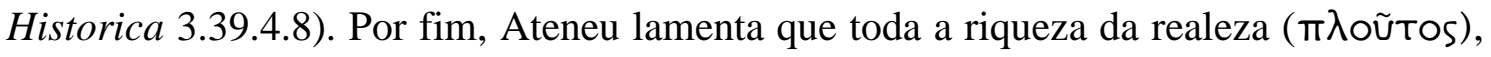
depois de ser mantida por um período tão longo, foi perdida pelo último Ptolomeu, um mero jogador e tocador de flautas (Deipnosophistae 5.206d).

Apesar do provável exagero da narrativa, não resta dúvida de que os Ptolomeus eram considerados por seus contemporâneos como os reis mais ricos da época 
(ROSTOVTZEFF, 1941, p. 407). Para Trapp (2004, p. 129), a ênfase na sofisticação talvez tivesse a intenção de realçar os excessos da realeza. Nesse sentido, o relato de Ateneu também tinha um ideal moralizante. No entanto, mais do que moralizar, o autor celebra as realizações dos Ptolomeus. Não parece ser o seu intuito condenar ou julgar a realeza ao expor os gastos para o festival, pelo contrário, justifica que no Egito a fecundidade do Nilo permitia maiores gastos, pois o rio compensaria. O retrato geral de Ateneu sobre o Egito era de uma terra já fértil e próspera (fruto do Nilo), e que foi ainda mais enriquecida em virtude de toda a dedicação da realeza. Assim, a abundância maior era proveniente de seus reis e estava representada em Alexandria. O escrito expõe a opulência e ostentação da dinastia e ilustra ao mesmo tempo, a generosidade de Ptolomeu Filadelfo ao compartilhar sua riqueza e conquistas com o povo.

Apesar de ser egípcio de Náucratis, a visão de Ateneu sobre o Egito é repleta de clichês, embora não fosse o elemento fabuloso que o fascinasse (o Egito "maravilhoso" de Heródoto) (MCKENZIE, 2008, p. 79). O autor sinaliza um conhecimento limitado sobre o Egito para além de sua realeza (MCKENZIE, 2008, p. 84). Além disso, não demonstra interesse, simpatia e nem conhecimento pela religião egípcia, pelo contrário, compartilha do repúdio romano pelo culto aos animais (THOMPSON, 2000, p. 80). Talvez por ser nativo de uma antiga colônia grega no Egito Ateneu exaltasse a época de maior florescimento do helenismo no território, algo que não vivenciava mais, já que no seu tempo o território era governado por Roma. É intrigante que um autor do séc. III d.C. seja o que forneça dados mais detalhados sobre os Ptolomeus, suas festividades e luxos. Seria uma tentativa de resgatar a era perdida, em que o Egito tinha autonomia? Ou ainda, era uma forma de reagir ao poder externo, retomando os valores helenísticos?

Tácito não se manifesta em relação a fundação lendária de Alexandria e sobre os reis, mas faz uma longa descrição a respeito do estabelecimento do culto a Serápis, a quem o autor parece atribuir à prosperidade de Alexandria. Tratando do contexto da viagem de Vespasiano a Alexandria, Tácito narra as várias versões sobre a origem da divindade:

A origem dessa divindade ainda não foi tratada de modo geral pelos autores: os sacerdotes egípcios contam a seguinte história: quando o rei Ptolomeu, o primeiro dos macedônios que colocou o poder do Egito em uma base firme (Ptolemaeo regi, qui Macedonum primus Aegypti opes firmavit) estava concedendo à nova cidade de Alexandria muros, templos e ritos religiosos, apareceu a ele em seu sono a visão de um jovem homem de extraordinária beleza e com estatura sobrehumana, que o advertiu a mandar seus amigos mais leais a Ponto e 
trazer a estátua em sua direção; a visão dizia que esse ato seria um ato feliz para o reino e que o lugar que recebesse o deus seria grande e famoso (laetum id regno magnamque et inclutam sedem fore quae excepisset): depois dessas palavras, o jovem pareceu ter sido levado aos céus em uma chama de fogo. Ptolomeu, movido por esse presságio milagroso, revelou sua visão noturna aos sacerdotes egípcios, cuja função é interpretar tais coisas. Quando eles demonstraram saber pouco de Ponto e de países estrangeiros (Atque illis Ponti et externorum parum gnaris), ele questionou Timóteo, um ateniense do clã de Eumolpidae, que ele tinha chamado de Elêusis para presidir sobre os ritos sagrados, e lhe perguntou o que era essa religião e o que a divindade significava. Timóteo descobriu, ao questionar homens que tinham viajado a Ponto, que lá havia uma cidade (urbem) chamada Sinope, e que não longe dela havia um templo a Júpiter Dis, famoso a muito entre os nativos: e que ao seu lado se sentava uma figura feminina chamada Proserpina. Mas Ptolomeu, apesar de propenso a acreditar em superstições sobre a natureza dos reis, quando se sentiu seguro novamente, estando mais apto a prazeres do que a ritos religiosos (voluptatum quam religionum adpetens), começou gradualmente a negligenciar a questão e voltar sua atenção para outras coisas, até que a mesma visão, agora mais terrível e insistente, apareceu para ele, ameaçando ruína sobre o rei e seu reino se suas ordens não fossem cumpridas. Então Ptolomeu ordenou que enviados e presentes fossem dirigidos ao rei Scydrothemis- que governava o povo de Sinope na época- e quando a embaixada estava prestes a ir ele os instruiu a visitar o Apolo de Pythias. Os enviados encontraram os mares favoráveis; e a resposta do oráculo foi certeira: Apolo os mandou seguir e trazer de volta a imagem de seu pai, mas deixar a de sua irmã. (Historiae 4.83.3)

Essa passagem conta que em meio aos investimentos do primeiro Ptolomeu para estabelecer a sua realeza, o rei recebeu um chamado dos céus sugerindo que precisava de uma divindade para proteger a dinastia em Alexandria. A narrativa indica que Serápis "escolheu" Ptolomeu, desse modo, forças divinas estariam legitimando e abençoando o seu reinado e sua sede real.

Na sequência, Tácito relata que o processo para estabelecer o culto estava demorando, apesar do esforço do rei e seus enviados, até que uma visão aterrorizadora apareceu a Scydrothemis, o avisando a não demorar em atender ao pedido do deus. Mas como ele ainda hesitou, vários desastres foram enviados pela ira divina. Ele chamou uma assembleia do povo e tornou públicas as ordens do deus, as visões que tinham aparecido para ele e para Ptolomeu, e os infortúnios que o estavam castigando. O povo ficou contra o rei, pois era hostil ao Egito (vulgus aversari regem, invidere Aegypto). Tácito diz que nesse ponto, a lenda se tornara nebulosa, e cita as várias diferentes versões a que teve acesso. Segundo a tradição, o próprio deus voluntariamente embarcou na frota que estava na costa, milagrosamente cruzou uma grande extensão do 
mar e alcançou Alexandria em dois dias (tertio die tantum maris emensi Alexandriam adpelluntur). Foi construído um templo apropriado para o tamanho da cidade (Templum pro magnitudine urbis) no quarteirão chamado Rakhotis, onde antes havia um santuário dedicado a Ísis. Tácito afirma ser essa a versão mais conhecida sobre a origem e chegada do deus, embora relate estar ciente de outras que diziam que o mesmo deus foi trazido da Síria no reino de Ptolomeu III. Outros diziam que Ptolomeu I introduziu o deus, mas que veio de Mênfis, "uma famosa cidade e o símbolo do antigo Egito" (inclutam olim et veteris Aegypti columen) (Historiae 4.84.15).

Marincola (1997, p. 125) afirma que Tácito tentava evitar o uso de fábulas. No entanto, a extensão da estória de Serápis na sua narrativa indica que a origem lendária do deus de algum modo lhe impressionara. Sugere também que na sua visão, Alexandria devia o seu desenvolvimento à força de tal divindade que se impôs na cidade de maneira abrupta. A lenda assinala o poder do deus, que não pôde ser ignorado por Ptolomeu, o obrigando a deixar de lado a dedicação aos projetos da cidade para enfocar no estabelecimento do culto. Tácito podia estar usando Serápis como uma metáfora de Alexandria. Assim, uma divindade tão poderosa e famosa justificaria a fama da cidade onde se centrava o seu culto e explicaria toda a prosperidade e imponência do centro urbano em muitos setores.

Plutarco descreve rapidamente o estabelecimento do culto a Serápis em Sobre

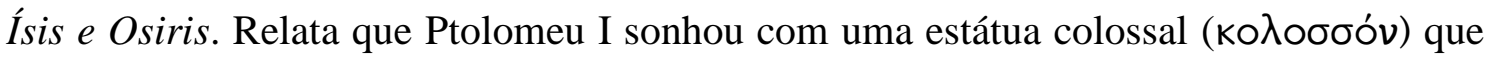
nunca havia visto. No sonho, ele foi instruído a transportá-la com toda a velocidade para Alexandria. Como ele não sabia onde estava localizada a estátua, pesquisou entre seus amigos, e descobriu um homem muito viajado chamado Sosibo, que garantiu que ele mesmo havia visto essa imagem, e que se tratava da estátua de Pluto, localizada em Sinope. Seus enviados conseguiram buscar a estátua depois de grande dificuldade. Quando ela foi exposta em Alexandria, Timóteo, Manetho e outros associados especialistas nas leis sagradas, disseram que era realmente a estátua de Pluto, e que seu nome em egípcio era Serápis. Plutarco menciona que depois a divindade mudou de natureza, e começou a ser associada a Osíris. Por esse motivo Serápis era o deus de

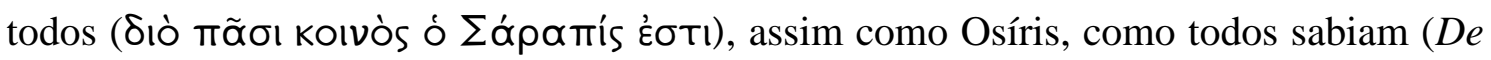
Iside et Osiride 361.F - 362.A).

Através desse relato, Plutarco constrói a natureza grega e egípcia da divindade, e enfatiza a sua adoração por todos. Como Tácito, Plutarco ilustra o poder e chegada de 
Serápis em Alexandria graças à sensibilidade de Ptolomeu. Além disso, ela foi logo aceita e legitimada por todos, o que ressaltava ainda mais a atitude certeira do rei. Serápis tornou-se a divindade padroeira de Alexandria, mas seu culto se popularizou por todo o Egito e difundiu-se para além do Oriente romano. A divindade pode ser entendida como uma metáfora de Alexandria: tratava-se de um deus híbrido, composto por identidades diversas, e a importância do seu culto ultrapassou as fronteiras inicialmente estipuladas, pois conquistou uma ampla aceitação por todo o Império. Além de grandeza e imponência do culto, que não puderam ser ignoradas pelos outros reinos após o aparecimento.

O objetivo desse capítulo foi construir um retrato da fase inicial da Alexandria ptolomaica divulgada por textos do período romano. Como autores da era imperial explicavam o passado de Alexandria e o caminho percorrido pela metrópole até se tornar a segunda potência do Mediterrâneo? A sua fundação, construção, o estabelecimento de seus edifícios e instituições são indiscutivelmente os aspectos predominantes das narrativas. Quanto mais vinculados a Alexandre, mais detalhados são os escritos. A ele é atribuída à prosperidade, grandeza, beleza, planejamento e racionalidade da cidade. Enquanto os autores gregos ilustram Alexandre como um visionário, os latinos enfocam na racionalidade, planejamento e perspicácia do fundador.

As narrativas sobre a cidade e a quantidade de adjetivações promovidas tornaram-se mais escassas conforme se afastaram do tempo de Alexandre. Diodoro e Estrabão são mais elogiosos e divulgam a imagem de uma fundação essencialmente helênica, enquanto os latinos (Vitrúvio, Quinto Cúrcio e Sêneca) fazem mais uso de lugares-comuns e julgamentos negativos ao caracterizá-la. Assim, as representações gregas de Alexandria são reforçadas por autores gregos (Diodoro, Estrabão e Plutarco), que em alguns casos consideram também a identidade helenística (Pausânias, Arriano e Ateneu), aludindo sutilmente à mistura de seu povo.

Entre os latinos, interessava menos fortalecer a herança grega de Alexandria. Menciona-se mais a sua faceta helenística que a aproximaria do Oriente, através da presença de egípcios e a força despótica da realeza. $\mathrm{O}$ foco principal é na magnificência da dinastia que abusou da ostentação para desenvolver a cidade. Assim, a representação monárquica de Alexandria na sua história inicial foi muito propagada pelos autores citados. 
Com relação aos primeiros reis, o enfoque é principalmente nos investimentos em edificações, no embelezamento da cidade e nos festivais. Tantos gastos visavam tornar Alexandria a herdeira legítima de Alexandre e a representante da dinastia ptolomaica. No entanto, a preocupação com a exuberância era tanta, que fez os reis perderem o foco, pois a cidade se tornou um exemplo de ostentação e excessos. Sobre o estabelecimento da Biblioteca e Museu, curiosamente pouco foi falado. Observa-se até uma tendência a evitar tecer comentários sobre as realizações das instituições e uma propensão a destituir a cidade e a realeza do mérito pela criação dos estabelecimentos.

A intenção foi demonstrar que os escritos sobre a Alexandria ptolomaica ganharam relevo na documentação a partir do século I a.C. e foram abundantes até a época de Adriano, depois disso apenas Ateneu abordou a época dos primeiros reis com mais fôlego. Não são poupados adjetivos para descrever a notoriedade que a cidade adquiriu, indicando que sua proeminência chamava a atenção naquele contexto. Mas o que causava mais alarde era que a crescente importância adquirida pela cidade começou a aproximá-la de Roma em muitos aspectos, às vezes até superando a capital do Império.

Os relatos dos gregos são mais detalhados, elogiosos e associam o desenvolvimento da cidade a Alexandre. Já os escritos latinos são mais pontuais, breves e enfocam em questões específicas que interessava divulgar no Império. Ou seja, era mais importante apontar a prosperidade e os deslizes dos reis do que descrever a herança helênica da cidade e sua imponência em vários setores. Censurar os reis era uma forma de louvar a superioridade da era romana. Nesse sentido, Alexandria é retratada como uma cidade imperial, e definida a partir de uma perspectiva do poder e conforme convinha às suas elites retratá-la. Ou seja, tais autores se permitiam ser mais críticos.

Alguns eixos comuns para explicar a cidade são observáveis, como a importância de Alexandre, a prosperidade, localização privilegiada, grandeza, beleza, e exuberância, e ilustram alguns aspectos da representação alexandrina. Contudo, explicações diferenciadas são atribuídas a esses eixos comuns, indicando que as representações da cidade não eram tão consensuais e estáticas. Conforme os relatos avançam no tempo (tanto no contexto de escrita, quanto na história alexandrina) é perceptível que Alexandria é retratada de forma mais plural e complexa. Mesmo que as imagens recebidas privilegiassem um ou outro tema, elas eram retrabalhadas no 
contexto específico de cada autor, enriquecendo o quadro identitário da cidade e sinalizando que o tempo estava trazendo mudanças, por mais que alguns lugarescomuns insistissem em se manter. 


\section{Capítulo 3: Alexandria torna-se uma ameaça política}

\subsection{Alexandria e Roma: aproximação e interdependência}

O objetivo desse capítulo é discutir como a literatura avalia o momento de transição representado pelo final do reinado ptolomaico no Egito, a sua conquista por Otávio e a consequente transformação do último grande reino helenístico em província romana. Para entender as representações de Alexandria sob o principado, é necessário pontuar algumas ocorrências da era anterior, com o intuito de melhor compreender a percepção dos antigos a respeito das relações configuradas entre o Egito e Roma. Apesar de o Egito como um todo não ser o foco aqui, os romanos viam Alexandria como sua representante. Assim, é preciso recorrer a acontecimentos mais amplos ocorridos no reino e que muitas vezes repercutiam em Alexandria, pois era lá que a realeza estava instalada.

A hipótese é que no final do séc. I a.C. ocorreu um deslocamento das preocupações relacionadas à Alexandria em virtude de alterações nas relações políticas entre o Egito e a potência romana. Se até então o Egito era caro a Roma pela importância de seu suprimento de trigo, começou a ser visto também como uma ameaça política. Portanto, o cenário de desafio político é a temática mais frequente para descrever Alexandria no séc. I a.C.. As fontes foram ordenadas cronologicamente, situando as narrativas que tratam dos primeiros momentos em que Roma e Egito começaram a se relacionar diplomaticamente. Como os autores avaliam esse caminho percorrido por Alexandria até se tornar parte do império?

O período desde a morte de Pompeu até a Batalha de Actium, a qual marcou efetivamente a derrota de Cleópatra e Marco Antônio, é descrito como um momento chave na história alexandrina e na consicentização com relação ao valor de Alexandria para o Império Romano. A época assinalou mudanças drásticas nas relações até então configuradas entre Roma e Alexandria. A capital do império estava passando por transformações brutais decorrentes do crescimento provocado pelas conquistas, levando a desavenças e interesses conflitantes na camada dirigente. Assim, grande parte das intervenções nos reinos do Mediterrâneo é resultante dos embates e problemas na ordem 
senatorial, acarretando também a choques entre o reinado egípcio e líderes romanos. Pretende-se investigar como os embates que eclodiram desse cenário complexo, de certa forma, abalaram as esferas máximas da elite romana, no sentido de evidenciarem a necessidade de um cuidado com a metrópole oriental. Além disso, se o final do reinado ptolomaico é marcado por uma crescente dependência para com Roma, o governo de Cleópatra representou uma tentativa de "reviravolta", de retomada da soberania egípcia, e mesmo que a rainha não tenha saído vitoriosa, os diversos capítulos desse processo foram suficientes para intensificar a vigília sobre o Egito pelos séculos seguintes. Como esse momento representou um contexto delicado nas relações estabelecidas entre Roma e o Egito, as narrativas que o abordam indicam uma conscientização de sua singularidade.

Neste contexto, a primeira parte do capítulo, objetiva discutir o cenário anterior à situação de embate entre a última representante da dinastia ptolomaica, Cleópatra e o triunviro romano, Otávio. O intuito é mapear como a documentação caracterizou as primeiras ocasiões de contatos e conhecimentos recíprocos entre os dois territórios (Roma e Egito) e como descreveu o aprofundamento dessa parceria. É importante observar que em relação à conjuntura de fundação e desenvolvimento inicial de Alexandria tratada no capítulo anterior, as narrativas são mais breves e episódicas, fazendo com que tenhamos que costurar autores diferentes de modo a ordenar uma sequência de eventos tratados. Entre os latinos, apenas Tito Lívio tentou apreender algo do mundo helenístico em suas várias etapas, porém com o intuito principal de sinalizar a presença romana nas transações ptolomaicas desde as primeiras fases do reino. Em meio aos autores gregos (Diodoro, Estrabão, Apiano, Dion Cássio), era vital entender esse universo helenístico em que Roma engrandeceu o seu poder, principalmente para explicitar o caos da vivência dinástica dos Ptolomeus, que tornou a intromissão romana essencial em vários momentos críticos.

Os primeiros contatos diplomáticos entre o antigo reino e a potência romana remetem ao reinado de Ptolomeu II Filadelfo, quando foi estabelecida uma aliança entre os territórios, depois de o rei mandar uma embaixada ao Senado. Ptolomeu foi o primeiro monarca helenístico a executar a ação, e Roma retornou o gesto de forma amistosa (273 a.C.) (HEKSTER, 2012, p. 8). Esse estreitamento de laços foi renovado em diferentes momentos, principalmente durante as Guerras Púnicas, nas quais os egípcios resolveram ficar neutros graças a interesses econômicos (218-202/149-146). 
Com a vitória de Roma sobre Aníbal (Cartago) e Felipe (Macedônia), o Senado romano agradeceu os egípcios pela manutenção da neutralidade e ofereceram apoio caso Felipe tentasse algo no território egípcio. Assim, a relação com Roma, nesse momento dominante no Mediterrâneo Ocidental, tornou-se prioridade na política externa dos Ptolomeus (MARLOWE, 1971, p. 139).

Como os autores trabalhados avaliaram a inserção do Egito na esfera de dominação romana e o fim da era helenística? Como se viu no capítulo anterior, a literatura considera que o início do reino helenístico foi marcado pelo governo de reis benfeitores, que não mediram esforços em investir e desenvolver Alexandria e estabelecer a autoridade no Egito. No entanto, o período iniciado no século II é descrito como uma era de caos que clamou pela presença romana. Portanto, foi a falta de governabilidade dos Ptolomeus que exigiu a sua interferência. Políbio, Diodoro de Sicília e Tito Lívio são as principais fontes que detalham eventos do reinado ptolomaico $^{17}$. No entanto, outros autores eventualmente mencionam alguns episódios pontuais, na medida em que se interessam pelas suas repercussões diante de Roma e de sua política externa.

Tito Lívio relata que no contexto após a Segunda Guerra Púnica (202 a.C.), três enviados romanos se dirigiram ao rei para anunciar a derrota de Aníbal e dos cartagineses e para agradecer a Ptolomeu Epifânio por ter permanecido leal em um período crítico, quando até aliados mais próximos dos romanos tinham se revoltado (mansisset). Solicitaram também, caso Roma resolvesse declarar guerra a Filipe, que o Egito preservasse a mesma fidelidade (fide) (Ab Urbe Condita. 31.2.5). O autor demonstra sua concepção de que a aproximação entre os territórios estava beneficiando ambos, romanos e egípcios.

Diodoro de Sicília, remetendo ao cenário da Terceira Guerra Púnica, provavelmente em 138 a.C., faz a seguinte avaliação:

Cipião Africano e seus companheiros embaixadores vieram a Alexandria para pesquisar todo o reino (ő $\lambda \eta \nu ~ \beta \propto \sigma ı \lambda \varepsilon i ́ a v)$. Ptolomeu acolheu os homens com uma grande recepção e muita pompa

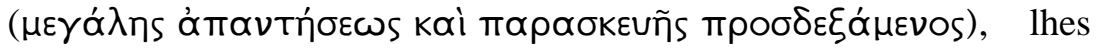
ofereceu banquetes caros, e os conduziu mostrando seu palácio e

\footnotetext{
${ }^{17}$ Apesar de Políbio não fazer parte do corpus documental da pesquisa, pois está fora das nossas balizas temporais, como ele era a principal referência para os seus sucessores na temática aqui tratada, ele será mencionado em alguns momentos com o intuito de ilustrar o impacto de sua visão nas fontes posteriores.
} 
outros tesouros reais. Mas os enviados romanos eram homens de

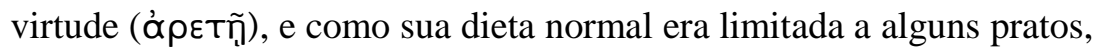
e apenas para aqueles que eram bons para a saúde, eles depreciaram

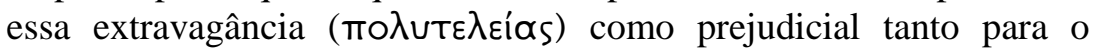
corpo quanto para a mente. $\mathrm{O}$ espetáculo de tudo que o rei considerava maravilhoso $(\theta \alpha \cup \mu \alpha \zeta \circ \mu \varepsilon ́ v \omega \nu)$ eles consideraram como um show a parte sem valor (á $\xi i ́ \omega \nu$ ), mas se ocuparam detalhadamente daquilo que realmente valia: a situação e força da cidade

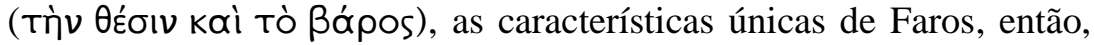
subindo o rio para Mênfis, a qualidade da terra (ápєtrì), e as bênçãos trazidas a ela pelo Nilo, o grande número $(\pi \lambda \tilde{n} \theta$ os) de cidades egípcias e as miríades não contadas de seus habitantes, a forte posição defensiva (óxupótᄁTa) do Egito, e a excelência (úmepoxńv) de todo o país, que era adequada para providenciar a segurança e a grandeza de um império

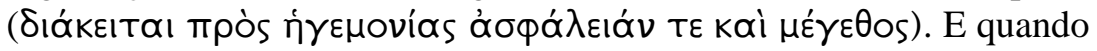

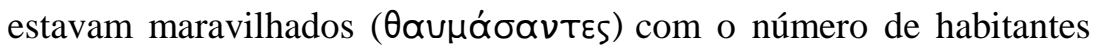

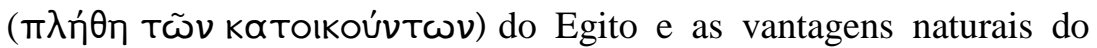

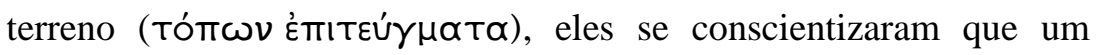

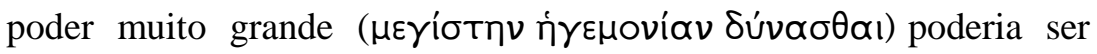
construído ali, se esse reino algum dia achasse um governante digno

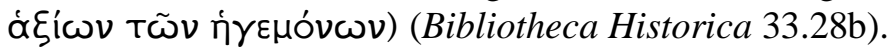

Diodoro enfatiza com clareza a sofisticação exagerada e o esbanjamento dos Ptolomeus em oposição à moderação e virtuosidade dos romanos. O autor escreve precisamente em um momento em que as riquezas e o luxo orientais abarrotavam Roma, e grande parte de suas elites começaram a se deixar levar pela ostentação, fator de incômodo para muitos "moralistas" romanos. Talvez daí o realce de Diodoro nessa questão, estabelecendo um contraste entre Roma e o Egito. O autor ilustra como toda essa riqueza era tentadora, mas ao mesmo tempo repulsiva a Roma. Representar o excessivo em Alexandria era também uma forma de enfatizar a moderação romana.

Diodoro destaca também a grandeza de Alexandria, seu potencial para organizar um poderio digno, embora não estivesse preparada para isso pela falta de seriedade de seus governantes. Como já visto no capítulo anterior, Diodoro entende que a grandeza de Alexandria a colocava em primeiro lugar (a frente de Roma) ou segundo lugar (depois de Roma) entre as cidades mais importantes do mundo "civilizado". Se antes o autor chamava a atenção para a proeminência da metrópole desde Alexandre, reafirma nesse momento a possível realização de seu destino, que poderia ser ainda mais promissor, caso fosse encontrado um poder virtuoso. 
É notável aqui a percepção de Alexandria como um local propenso a se estruturar um grande império, caso fosse estabelecido um governo bem organizado. Fica evidente que o autor está usando como referência um poder que ele vivenciava (Roma), dessa forma sugere que se o comando egípcio tivesse consciência de sua potencialidade, poderia abalar a supremacia romana. As palavras de Diodoro indicam algum tipo de advertência para que Roma não deixasse um poder significativo se consolidar ali. O autor chama a atenção para a falta de preparo dos governantes do seu tempo (Ptolomeus), demonstrando que na sua visão não era esse o poder adequado para um local tão singular. O comentário poderia ser também uma forma de assinalar a superioridade do governo romano e seu preparo para comandar um império. Sinaliza, contudo, que deveria haver consenso para se contruir um bom governo. Ou seja, em um contexto de muitas querelas políticas em Roma, é possível que a passagem aludisse a importância de se alcançar a harmonia.

Além das Guerras Púnicas, os problemas entre os reinos helenísticos, e as pretensões imperiais dos Selêucidas no Egito também foram ocasiões para a mediação romana. À medida que Roma se expandia para o Oriente, encontrando resistência de outros reinos helenísticos, o Egito se mantinha fora das hostilidades. Dessa forma, continuou sendo seu aliado. Aos poucos, aquele que era "protegido" foi se tornando um protetorado, e as relações diplomáticas passaram a ser cada vez mais fundamentais para os dois territórios (LEWIS, 1983, p. 10).

Aproveitando-se de uma briga entre os dois irmãos Ptolomeus (Ptolomeu VI Filometor e Ptolomeu VI Euergetes II) pelo trono, o rei Selêucida Antíoco IV Epífânio (171-168) conquistou grande parte do Egito. No entanto, em 168 a.C., depois dos dois reinos enviarem embaixadas a Roma pedindo auxílio, Políbio observa que a intervenção do Senado impediu que Antíoco estabelecesse um protetorado no Egito, e ajudou Ptolomeu a recuperar seu reino. Políbio considera que nesse momento os romanos salvaram o Egito, como resume no seguinte trecho:

O senado, tendo sido informado que Antíoco tinha se tornado mestre (Kúpıov) do Egito, e de tudo menos Alexandria, pensando que o engrandecimento ( $\alpha u ̋ \xi \eta \sigma ı)$ deste rei dizia respeito a eles mesmos, despacharam Gaius Popilio e outros para irem como enviados ( era a exata situação das negociações (Historiae 29.2.1-3). 
Tito Lívio, um autor que se apoiou substancialmente no relato de Políbio, detalha mais o contexto, e destaca como os Ptolomeus recorreram a Roma em busca de soluções para seus problemas. O autor aponta a importância decisiva dos romanos na resolução do impasse e o oportunismo de Antíoco, que se aproveitava da briga entre os dois irmãos, fingindo tomar partido do mais velho com a intenção de cercar o reino. Sob o pretexto de restaurá-lo ao trono, declarou guerra (bellum) ao mais novo, que estava em posse (tenebat) de Alexandria. Dessa forma, Antíoco "estava quase colocando as mãos em um reino muito rico" (potiretur regno opulentissimo) (Tito Lívio. Ab Urbe Condita 44.19.10). Enviados alexandrinos (Alexandrini legati) foram a Roma pedir ajuda contra o cerco do rei. Lívio diz que os enviados eram sujos, com cabelos e barbas mal-feitas e cumpridas, e entraram no Senado levando galhos de oliva. O autor ressalta a precariedade dos discursos proferidos por eles (et oratio quam habitus fuit miserabilior) (Ab Urbe Condita 44.19.6). Provavelmente se tratava de mais um lembrete que enfatizava a desordem que reinava entre os representantes da cidade, tal qual aquele pronunciado por Diodoro. Em relação ao relato original de Políbio, a versão de Lívio sublinha ainda mais a riqueza do Egito e a fragilidade da liderança ptolomaica, talvez em virtude do seu contexto de escrita posterior. A seguir, Lívio narra alguns problemas que acometiam a dinastia:

Reclamando desse ataque, os enviados imploraram ao Senado para salvar um reino e um casal real que eram aliados do governo romano (opem regno regibusque amicis império Romano). Esses eram os benefícios concedidos para Antíoco pelo povo romano, e tal era sua influência em todos os reis e povos (omnes reges gentesque auctoritatem), tal que, se eles mandassem embaixadas para declarar a Antíoco que o Senado não queria fazer guerra com reis seus aliados, Antíoco imediatamente partiria dos muros de Alexandria (moenibus Alexandreae) e lideraria seu exercito de volta à Síria. Se eles hesitassem em fazer isso, rapidamente Ptolomeu e Cleópatra teriam seu reino roubado (extorres) e chegariam a Roma com vergonha do povo romano, por eles não terem ajudado na fase final da sua crise ( $A b$ Urbe Condita 44.19.8).

Os senadores mandaram então enviados para colocar fim na guerra e ameaçaram no caso de a querela (bello) não terminar, que o causador do problema (referindo-se a Antíoco) não seria mais considerado aliado romano. A embaixada juntamente com os enviados alexandrinos partiu para Alexandria depois de três dias para resolver o conflito (Ab Urbe Condita 44.19.13). O autor demonstra como o destino egípcio estava 
condicionado às decisões romanas e marca a fragilidade dos reinos helenísticos diante da ascensão do poderio romano. Novamente a intenção de retratar a fragilidade da liderança ptolomaica era uma forma de fortalecer a imagem do poder romano.

Lívio reflete que o possível risco de uma guerra civil entre os irmãos seria de o ganhador da disputa sair desgastado, mas ainda não ser páreo para Antíoco, uma vez que este estava muito fortalecido e com a "chave para o Egito" (claustra Aegypti teneri) em suas mãos. Pois Antíoco conquistara quase todo o território ao fingir apoiar o Ptolomeu mais velho. Essa percepção de que a desunião estava fortalecendo Antíoco, foi aceita pelos irmãos. Assim, a paz foi estabelecida por consenso geral, e o Ptolomeu mais velho voltou para Alexandria, sem oposição até por parte da multidão (multitudine), que tinha proclamado como rei o irmão mais novo. A cidade estava esgotada pela escassez de todos os suprimentos (omnium rerum adtenuata inópia erat), não apenas durante o cerco, mas depois que os inimigos deixaram a cidade (Ab Urbe Condita 45.11.7). O autor sugere como a multidão alexandrina estava descrente de seus líderes e preferia acatar as ordens romanas. Dessa forma, enfatiza novamente a fraqueza da autoridade dos reis, sua falta de legitimidade na população e sugere que a crise estava abalando a disponibilidade dos recursos do Egito. Portanto, demandava-se a presença romana não apenas para estabelecer um poder mais firme no reino, mas para regularizar a situação de escassez.

Antíoco decidiu declarar guerra aos dois irmãos mesmo assim, e depois do tempo de trégua terminado, seus oficiais navegaram para Pelusium, foram bem recebidos pelos habitantes (incolebant) de Mênfis e estavam se direcionando a Alexandria, quando os enviados romanos o alcançaram. Ao se aproximarem, Antíoco os cumprimentou e deu a mão para Popílio, que lhe entregou o decreto do Senado ( $A b$ Urbe Condita 45.12.3). Antíoco falou que ia reunir seus amigos e decidir o que fazer. Popilio desenhou um círculo em volta do rei e disse "antes de você sair desse círculo, me dê uma resposta que eu vou devolver ao Senado". Depois de hesitar por um momento, Antíoco respondeu que seguiria a ordem. Após a sua desistência do Egito, os romanos foram para Chipre, onde expulsaram a frota Selêucida. Esse famoso episódio que narra à audácia e força de Popílio foi contado posteriormente por muitos autores. Lívio relata ainda: "Essa embaixada conquistou uma grande reputação (clara) entre os povos (per gentis), pois o Egito tinha sido claramente tirado de Antíoco depois que ele já tinha a sua posse, e seu reino ancestral foi restaurado à casa de Ptolomeu (patrium 
regnum stirpi)" (Ab Urbe Condita 45.12.8). Além da popularidade da embaixada, o autor afirma também que os dois cônsules daquele ano conquistaram grande reputação por essa atitude corajosa (Ab Urbe Condita 45.12.9).

Os enviados de Ptolomeu agradeceram aos romanos em nome dos reis e diziam que deviam mais ao Senado e ao povo romano do que aos seus pais e deuses imortais, pois tinham sido libertados e conseguiram recuperar seu reino ancestral (regnum patrium). Os romanos responderam que estavam satisfeitos e que o Senado se esforçaria para convencê-los que a maior fortaleza (praesidium) de seu reino tinha sido fundada pela boa fé depositada no povo romano (Ab Urbe Condita 45.13.5).

Lívio demonstra claramente a fraqueza dos Ptolomeus diante de Antíoco, e deste diante de Roma. Portanto, se aliar a Roma era a única forma de libertação e uma verdadeira salvação para o reino, pois se não fosse pela autoridade do Senado em resolver a situação, o Egito teria sido absorvido por outro reino. A narrativa demonstra também o alcance das questões egípcias dentro de Roma, pela respeitabilidade conquistada pelos cônsules e pelos envolvidos na trama. Além disso, sugere a pequenez de qualquer reino diante do poderio imperial, a quem Antíoco facilmente se dobrou. $\mathrm{O}$ autor observa que no Egito o fato foi visto como uma prova da bondade romana. Todo o relato de Lívio chama a atenção para a fragilidade das lideranças egípcias, que estava ocasionando a perda dos recursos do território, sugerindo que Roma deveria gerir esses recursos antes que se perdessem definitivamente. Ilustra também o interesse romano na produção egípcia desde cedo.

O historiador judeu Flávio Josefo também aborda o contexto com o objetivo de assinalar a força romana. Ele afirma que Antíoco queria tomar o Egito por ambição e por considerar seu governante do momento muito fraco ( $\alpha \sigma \theta \varepsilon v \tilde{\omega} v)$ para governar um

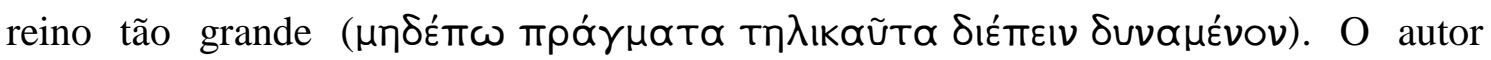
destaca que por ordem romana, Antíoco foi expulso não apenas de Alexandria, mas de

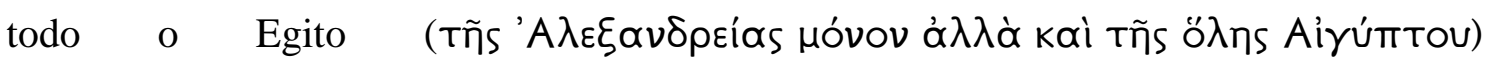
(Antiquitates Judaicae 12.242-245). Ou seja, por obediência à autoridade romana, todo o Egito foi poupado. Josefo sugere a fraqueza dos Ptolomeus em reverterem a situação por conta própria. Portanto, se Antíoco é retratado como ambicioso e prepotente, os Ptolomeus são caracterizados como governantes passivos e com pouco poder de comando. Dessa forma, Josefo contrasta a grandeza do reino com a fragilidade de sua 
liderança. Ao mesmo tempo em que ilustra a ambição desmedida de Antioco, sendo Roma o poder mediador e equilibrado em meio às lideranças inconsequentes.

Após descrever o episódio de Popílio, Dion Cássio diz que mesmo após a resolução romana do problema selêucida, os irmãos prosseguiram com a briga

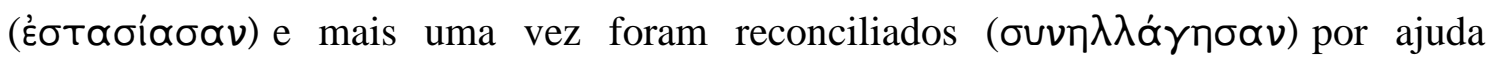
romana (Historiae Romanae 20.25). Ou seja, mesmo escrevendo mais de três séculos após os acontecimentos, Dion demonstra a autoridade romana no destino egípcio naquele momento. Nesse sentido, a intervenção foi importante não apenas para a política externa egípcia e para impedir sua incorporação por outro reino, mas para resolver questões internas dos Ptolomeus e destes com a população.

Observa-se como os autores, tratados até aqui, demonstram que a falta de governabilidade egípcia era completa e em todos os setores. As narrativas discutem pouco as razões do interesse romano de se colocar ao lado dos Ptolomeus e impedir o avanço de Antíoco. Embora seja compreensível que na concepção romana, um rei que estava se fortalecendo de tal maneira, se tomasse um reino rico como o Egito poderia representar um perigo enorme. Dessa forma, interessava mais a eles manter e apoiar uma dinastia frágil, inconstante e em disputa, que para governar precisava recorrer a Roma com frequência, do que apoiar uma realeza mais ousada e em processo de fortalecimento.

No séc. II, o Egito começou a se recolher externamente como consequência de problemas internos causados pela resistência de nativos, mas principalmente por mais disputas dinásticas pelo trono, levando os Ptolomeus a apelarem novamente a Roma em busca de soluções. Devido a tantas querelas dinásticas e problemas familiares, os autores demonstram como os Ptolomeus estavam se tornando extremamente impopulares dentro do Egito e aludem que essa falta de aceitação e legitimidade dos líderes acabou sendo conveniente pra Roma.

Por volta de 165 houve uma revolta (Kívnols) dos egípcios contra os reis em Tebas. Diodoro relata que apesar do desespero (ámóvoı $\mathbf{v}$ ) dos egípcios e da força

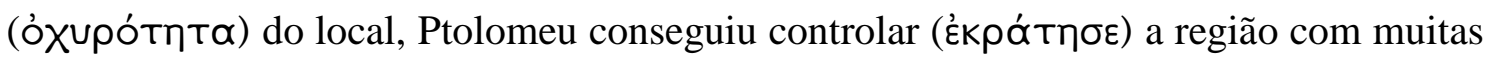
dificuldades (Bibliotheca Historica 31.17b.1). O autor também aborda o momento que a população se revoltara contra Ptolomeu VII Physcon, que matou seus próprios filhos (entre 133 e 131). Diodoro relata a crueldade ('́тó $\lambda \mu \eta \sigma \varepsilon v)$ do ato cometido para se 
vingar da repulsa da mulher por ele. E não contente com o seu feito, o autor afirma que o rei cometeu uma abominação ( $\mu$ úoos) ainda maior; depois de mutilar o corpo de um dos meninos, mandou levá-lo a Alexandria e colocar as partes na frente do palácio, para dar de "presente" para sua esposa, Cleópatra II, em seu aniversário. Quando isso foi feito e o acontecimento ficou conhecido por todos, a rainha declarou luto e a multidão

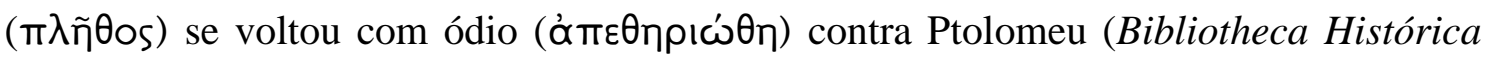
34/35.14.1). Diodoro escreveu no final da era ptolomaica, e sua intenção era aparentemente ressaltar a falta de preparo dos governantes do local, por cometerem atrocidades dentro da própria dinastia. $\mathrm{O}$ autor estaria pensando em Roma como uma alternativa para o governo do local?

Referente a esse cenário de instabilidade interna generalizada e para tratar das inovações administrativas introduzidas pelo Império Romano no Egito, Estrabão reflete: “(...) como os reis estavam realizando um mau governo, a prosperidade estava desaparecendo por prevalecer a anarquia”.

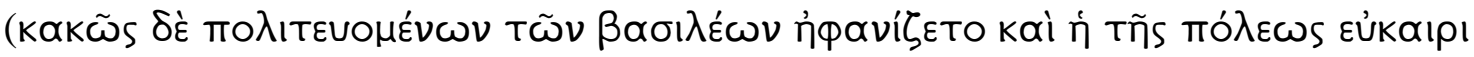
$\propto$ Siò tìv ávouíav) (Geographica 17.1.12). Nesse mesmo contexto, o autor cita o desgosto de uma viagem que Políbio fizera ao Egito. Este autor havia estabelecido uma divisão dos habitantes da cidade, delimitação que foi convenientemente usada por Estrabão para auxiliar no entendimento dos problemas:

De qualquer forma, Políbio, que tinha visitado a cidade, sentiu desgosto ( $\beta \delta \varepsilon \lambda \cup ́ t \tau \varepsilon t \alpha \iota)$ com o estado das coisas em curso; ele dizia que três agrupamentos habitavam a cidade

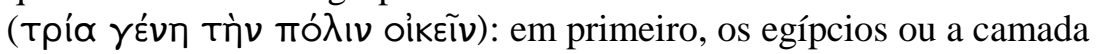

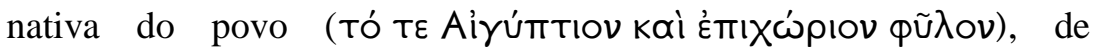
temperamento difícil e não inclinados para a vida cívica

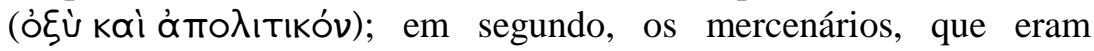
severos, numerosos e incontroláveis

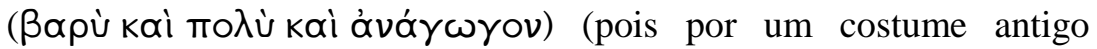
tinham mantido estrangeiros armados, e tinham sido treinados para comandar e não ser comandados, pela inutilidade dos reis); e em terceiro, a categoria dos alexandrinos, que também não eram claramente inclinados para a vida cívica

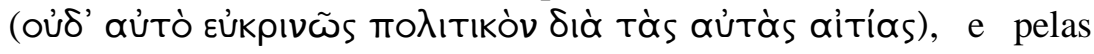
mesmas razoes, mas ainda assim eram melhores que aqueles outros,

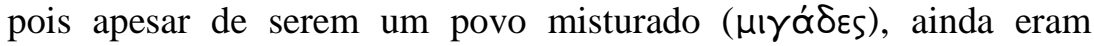
gregos por origem e tinham consciência dos hábitos (हُقous) gregos (Geographica 17.1.12). 
O relato infere que era a população misturada da cidade que causava os problemas e gerava os principais conflitos na cidade, pela diferença de temperamentos entre os povos. Estrabão observa ainda, que Políbio tinha presenciado a disputa de

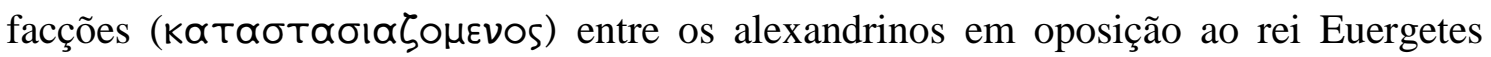

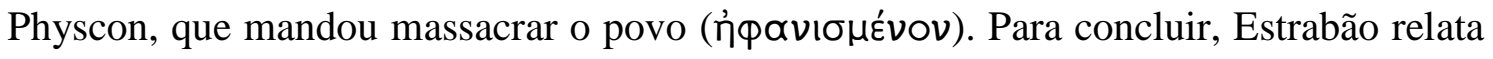
que Políbio havia definido a sua viagem como "longa e dolorosa"

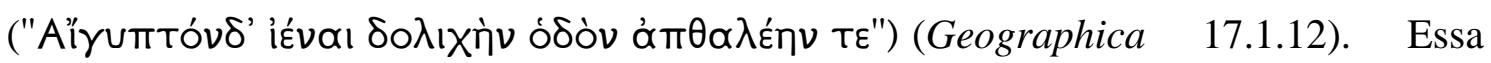
observação de um dos autores mais lidos pela tradição, e veiculada tempos depois por Estrabão, pode ter ajudado na divulgação da imagem do predomínio do caos em Alexandria no tempo dos reis. Colaborou para assinalar também a falta de controle das autoridades diante das manifestações da população, que começava a se dividir em facções para fazer oposição ao poder. Estrabão traz à tona a instabilidade do contexto provavelmente com o intuito de demonstrar a quebra em relação ao novo período que vivenciava, a era de paz instaurada por Roma.

Há poucas menções sobre a realeza do século II e início do I, fora alguns comentários breves dos gregos da segunda sofística em relação aos problemas dinásticos de alguns reis. Ou seja, os relatos privilegiam esses aspectos negativos da realeza. Nos Dizeres dos romanos (Regum et imperatorum apophthegmata 200.F.2), Plutarco conta de um rei (provavelmente Ptolomeu VII) que mal conseguia andar por causa de seu peso. Relata que Cipião, numa visita de inspeção a Alexandria, chegou lá

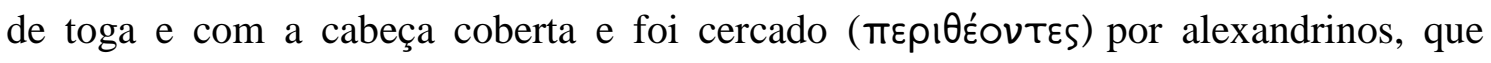
insistiram para ele mostrar o rosto. O rei não conseguia alcançá-los por causa de sua vida sedentária (’ópyíav). Assim, Cipião, cochichou para Panateu, que "os alexandrinos já tinham recebido algum benefício ( $\alpha \pi \circ \lambda \varepsilon \lambda \propto u ̛ ́ k \propto \sigma l)$ de nossa visita, pois foi por nossa causa que eles conseguiram ver seu rei andar." O autor denota a falta de preparo do rei para exercer a sua função, em contraste com a responsabilidade dos romanos, que em sua visita ao reino logo perceberam o absurdo da situação.

Pausânias aborda os problemas do governo de Ptolomeu VI Filometor (que viveu entre 181-145). Começa o relato observando que seu nome "o que ama a mãe"

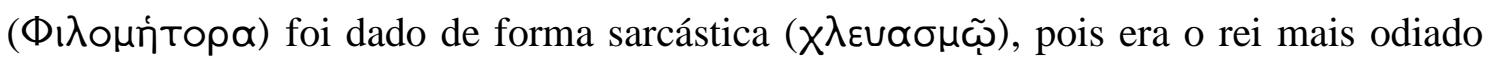
pela mãe. O autor conta sobre as dificuldades do rei para governar em virtude dos problemas com ela. A rainha não o deixava assumir o trono, acreditando que Alexandre, 
o filho caçula seria mais subserviente aos seus comandos. Assim ela induziu o povo a escolherem-no como rei. Mas a população se opôs

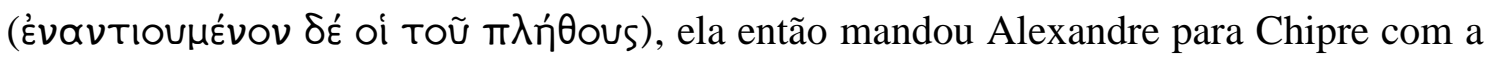
desculpa de torná-lo general. Armou ainda um complô contra o rei, que coagido por ela, tentou provocar a morte de Ptolomeu, mas ele fugiu e escapou a bordo de um navio, e logo os alexandrinos transformaram o seu irmão em rei, após a sua volta de Chipre. Por fim, Alexandre mandou matar a própria mãe, e quando os alexandrinos descobriram, ele fugiu por medo dos cidadãos. Dessa forma, Ptolomeu voltou e assumiu o controle do Egito pela segunda vez. Este rei guerreou contra os Tebanos que tinham revoltado

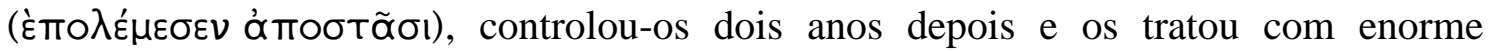
crueldade. Segundo Pausânias, a mãe de Ptolomeu usava o povo como "massa de manobra", promovendo intrigas entre os irmãos, que se refletiam em revoltas da população contra Ptolomeu (Graeciae descriptio. Attica 9.2.8). Pausânias ilustra a falta de harmonia nas relações dinásticas. Aponta, além disso, que quando as dificuldades na realeza estavam finalmente se resolvendo, surgiram problemas sociais graves. Contudo, o rei também não teve talento em controlar os distúrbios. O monarca que só convivera com a "crueldade" da mãe, reproduziu o mesmo tratamento "malévolo" e autoritário no tratamento com seus súditos.

Nas Guerras Civis, o historiador alexandrino Apiano relata sobre o rei (Ptolomeu XI Alexandre II) colocado no reino por Sila, e depois de alguns dias de governo foi condenado à morte no Ginásio (80 a.C.):

Sila declarou que Alexandre (o filho de Alexandre o último soberano do Egito), que tinha sido criado em Cós e entregue a Mitridates pelos habitantes daquela ilha, e tinha fugido para Sila e se tornado seu

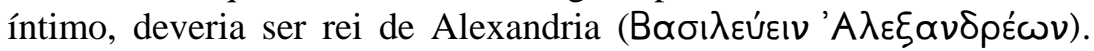
Ele fez isso, pois o governo de Alexandria estava sem um soberano da linha masculina, e as mulheres da casa real queriam um homem da mesma linhagem, por esperar colher uma grande recompensa de um

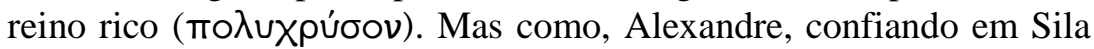
se comportou de maneira muito ofensiva diante deles, os alexandrinos, no décimo nono dia do seu reinado, arrastaram-no do palácio para o ginásio e o condenaram a morte; pois eles também ainda não temiam

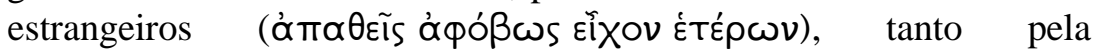

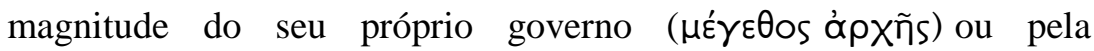
inexperiência com relação a perigos externos (Bellum Civile 1.11.102.25). 
Apiano argumenta que os alexandrinos fizeram isso por atitudes ofensivas cometidas pelo monarca (talvez se referindo à morte de sua esposa). Apesar de o autor não explicar mais sobre o ocorrido, é significativa a atitude dos alexandrinos de assassinarem um rei, mesmo que ainda sem legitimidade pelo pouco tempo de governo e por ser considerado um estrangeiro. $\mathrm{O}$ autor sugere a ousadia dos alexandrinos em relação à falta de atitude de seus governantes. Enfatiza a riqueza e grandeza de seu reino, que trouxe confiança aos alexandrinos para realizarem o ato. No entanto, sublinha também a fragilidade dos governantes em relação à coragem e iniciativa do povo. A percepção de Apiano em relação à realeza vai ao encontro do que os outros autores de fora também apontavam, embora não estabeleça julgamentos sobre a atitude extrema dos alexandrinos.

Percebe-se como a seleção dos autores para falar dos reis privilegia, além da "passividade" com que governavam, elementos que denotem o predomínio da "irresponsabilidade" e da "crueldade" na realeza ptolomaica. Assinalam que a falta de tato da realeza era perceptível tanto no trato familiar e nos cenários de impasses em ocasiões de resolver a sucessão, quanto na relação com a população e no enfrentamento de seus problemas.

André Bernand (2001, p. 28) observa que todas as monarquias conheceram dramas familiares, contudo nenhuma civilização suscitou rivalidades tão sangrentas quanto a dinastia dos Ptolomeus. O autor justifica que o mau comportamento dos alexandrinos surgira como influência do péssimo exemplo dado pelos seus reis, que não se entendiam. Assim, as querelas de família teriam alimentado os problemas sociais e as revoltas da população. Bernand (2001, p. 29) associa então os distúrbios no governo aos problemas sociais que começaram a surgir. Biezunska-Malowist (1988, p. 239) desenvolve um trabalho para denunciar a turbulência do período ptolomaico e realça que essa era de governo no Egito não foi sempre consensual, como a historiografia geralmente coloca. Afirma também que o Egito conheceu todas as formas de resistência ao governo: ativa e passiva. A autora ressalta que as revoltas armadas no tempo de Ptolomeu IV e V são geralmente apresentadas como revoltas dos egípcios a gregos e macedônios. Ela observa que o período romano não teve movimentos indígenas tão perigosos quanto o ptolomaico e que todos os meios eram usados pelo governo para conter as revoluções, mesmo os mais cruéis (1988, p. 241). Infelizmente as fontes para o período ptolomaico são mais escassas do que para a era posterior, principalmente para 
esse contexto de revoltas. Sabe-se mais de assuntos que eram significativos o suficiente para serem narrados por autores interessados na relação entre Egito e Roma. Ou seja, questões internas egípcias não eram tão relevantes a ponto de serem extensivamente relatadas. Além disso, o fato de os autores enfatizarem os problemas ptolomaicos, em contraste à ordem estabelecida por Roma, ajuda a ressaltar ainda mais a tendência instável da era ptolomaica, em todos os setores. Assim, deve-se ter cautela em sempre realçar sua turbulência, como faz Malowist.

Até que ponto deve-se aceitar a visão dos antigos (escrita sob Roma) como reflexo da época ptolomaica? A retórica a favor do Império tendia a engrandecer os problemas sob a era anterior. Apesar de serem apontados alguns episódios de protestos do povo contra o governo, o consenso mais geral dos escritos antigos é que o governo ptolomaico era turbulento, e o povo pacífico. As manifestações populares são até aceitas, em virtude da postura irresponsável dos reis, que resultou na perda de controle da população. Enquanto sob Roma a situação se inverte, o governo é descrito como pacífico e ordenado, e o povo instável, como será visto no capítulo seguinte. Os dois padrões de consenso das fontes devem ser vistos com cautela, devido à tendência dos escritos em marcar a negatividade de todas as esferas sociais alexandrinas, desde o reino que foi lá estruturado, até o povo, que manteve o padrão de comportamento desse reino.

\subsection{O governo de Ptolomeu XII Aulete: aumento da presença romana}

No século I, a aproximação entre Roma e Egito foi intensificada, pois os problemas dinásticos se acentuaram e o governo romano começou a intervir progressivamente no comando egípcio. Quando o rei Ptolomeu IX Lathyrus morreu (80), Sila apoiou seu sobrinho (mencionado acima) que foi proclamado como Ptolomeu XI Alexandre II, mas foi logo linchado pelos alexandrinos. Instalou, então, o filho ilegítimo de Latyrus no trono, Ptolomeu XII Aulete. Sua pretensão ao reino se tornou ainda mais ilegítima quando a declaração de um testamento de Ptolomeu X ou XI foi publicada em Roma, no qual legava o Egito a Roma, talvez como recompensa por todas as ajudas anteriores nos impasses dinásticos (SCHULLARD, 1982, p. 106-107). Livia Capponi (1975, p. 5) argumenta que com a divulgação do testamento a tomada do Egito 
se tornou questão de debate público, tanto em Roma quanto em Alexandria. Para a autora a anexação só não ocorreu nessa época, pois não se chegava a um acordo em Roma a respeito de quem era o candidato mais adequado para o comando egípcio.

O reinado de Ptolomeu XII Aulete é o mais tratado pela documentação. Cícero é a fonte principal, mas Estrabão, Plutarco, Suetônio, Apiano, Dion Cássio e Ateneu também versam sobre o contexto. O rei Aulete foi expulso (ou fugiu) de Alexandria, buscou refúgio em Roma, e depois retornou sob amparo e proteção romanas. A partir do seu governo as intromissões romanas nas crises da realeza se tornaram incisivas, evidenciando o crescimento de seu poder. Tratou-se também de um momento de conscientização em relação ao papel vital do Egito para Roma, pois ao mesmo tempo em que a República ampliava seu poder político, conscientizou-se da vitalidade da riqueza egípcia.

A narrativa de Cícero é a mais ilustrativa da importância da tomada do Egito nesse contexto, algo que em vida ele não viu acontecer efetivamente. Cícero é uma fonte riquíssima para o contexto de problemas diplomáticos e políticos entre a classe dirigente de Roma e a realeza ptolomaica no século I a.C.. Deste modo, o depoimento sobre o reinado de Aulete e seus problemas com os alexandrinos é central em sua narrativa. O relato de Cícero é o mais minucioso para analisar o contexto de saída do rei e para medir a sua repercussão em Roma. Repetidas vezes ele menciona a expulsão do rei, a restituição por Gabínio e a embaixada que foi a Roma protestar contra o retorno e acabou massacrada. Os escritos denunciam que os problemas da dinastia ptolomaica não envolviam apenas o Egito, em virtude da importância da riqueza do território naquele mundo. Justifica, portanto, que interferências mais incisivas por parte do comando romano eram necessárias.

Depois das reformas de Sila em Roma, a facção democrática tentou estabelecer uma série de medidas para favorecer o povo, pois estava ocorrendo uma grande concentração de terra pública nas mãos de poucos. No final de 64 a.C. P. Servilio Rullo ocupou o cargo de tribuno e propôs uma lei agrária em benefício popular, que estabelecia que durante cinco anos dez decúviros teriam o poder para agir em seu nome. Eles deveriam alocar terras, estabelecer colônias, na Itália e nas províncias. Para a compra dessas terras os comissionários podiam usar recursos públicos e butins de guerra. Cícero, cônsul da época, foi ferozmente contra a possibilidade da venda de terras públicas, pois acreditava que o poder sobre a terra na mão de poucos poderia fugir ao 
controle do Estado. Seu discurso foi vencedor, e fez Rullo retirar a proposta. Nesse momento, Cícero faz uma digressão sobre Alexandria, apontando como seria perigoso se poucos homens resolvessem se apoderar de um território tão caro aos romanos (e assim, controlar sua produtividade), tornando privadas, terras públicas do povo romano. O autor deixa claro que a possibilidade da posse de terras egípcias era uma de suas maiores preocupações, que o levou a se posicionar contra a proposta. O seguinte trecho (parte do discurso pronunciado diante da assembléia popular) ilustra suas preocupações:

E a respeito de Alexandria e de todo o Egito (Alexandrea cunctaque Aegyptus), quão secretamente é negociado! Como é mantido fora do caminho! Quão secretamente é entregue totalmente aos decúnviros! Quem de vós ignora que é dito que, por virtude do rei Alexas, vosso reino não se tornou propriedade do povo romano? Aqui eu, cônsul do povo romano, não apenas não pronuncio nenhum julgamento sobre esse ponto, nem digo o que penso; pois a questão me parece não apenas difícil de decidir, como até difícil de discutir! E vejo alguém que alega que o testamento foi feito; Eu estou ciente que existe um decreto do Senado alegando que entrou na herança da época quando, após a morte de Alexas, mandamos comissários a Tyre para recuperar para o nosso povo uma quantia em dinheiro depositado lá por mim. Eu me lembro que Lúcio Philippo frequentemente contava esses fatos no Senado, realçando que quase todos concordam que ele que ocupa o trono hoje nem por nascimento, nem por espírito é como um rei (neque genere neque animo régio esse) ${ }^{18}$. Pelo outro lado, dizem que não existe testamento, que o povo romano não deve se mostrar tão ansioso por cercar todos os reinos; que nossos cidadãos estão propensos a deixar Roma e emigrar para aquele país, atraídos pela fertilidade da terra e pela abundância de todos os tipos de suprimentos (agrorum bonitatem et omnium rerum copiam). Essa questão tão importante pode assim ser decidia por Rullo com seus colegas e decúnviros, e de que forma ele vai se decidir? (De Lege Agraria 2.16.41-43)

Cícero cita o já mencionado testamento, redigido alguns anos antes, em que Ptolomeu decretava o povo romano como herdeiro do Egito. Cícero deixa claro que o rei seguinte não tinha legitimidade, portanto já se podia considerar o Egito propriedade de Roma (mesmo que ainda existisse um rei no comando). Portanto, tornando-se terra pública, ele questiona se poderia um reino assim tão rico ser negociado por decúnviros. Dessa forma, demonstra sua preocupação sobre o que aconteceria se poucos homens se responsabilizassem pelo seu controle, deixando claro que o Egito era um dos objetivos dos decúnviros ao estabelecerem a medida.

$\overline{{ }^{18} \text { Referindo-se ao rei Ptolomeu XII Aulete. }}$ 
O trecho acima demonstra que na sua concepção, a atratividade do Egito também era alvo de preocupação, pois seu "inchaço" poderia torná-lo mais dinâmico. Ou seja, o aumento da multidão era motivo de atenção. Era algo também que podia alterar a distribuição de terra, o que não interessava a Roma. Cícero declara que ele mesmo gostaria de fazer uma viagem ao Egito, algo que não chegou a realizar: "Eu estou há muito tempo ansioso de fazer uma visita a Alexandria e ao resto do Egito (Alexandream reliquamque Aegyptum), e também para fugir daqui, onde as pessoas estão cansadas de me ver, e só voltar quando elas sentirem um pouco a minha falta. (Epistulae ad Atticum 2.5.1.)". Empereur (1998, p. 12-13) acredita que a concepção de Cícero ilustra o surgimento de uma obsessão por parte dos líderes romanos pela ameaça representada por Alexandria.

Cícero faz referência ao testamento talvez com o objetivo de justificar e legitimar a conquista que estava sendo arquitetada. Como homem público e de influência no poder romano, seu relato é ilustrativo como a expressão de uma parcela significativa da elite romana. Em seguida, o autor demonstra novamente a atratividade do Egito aos romanos, e sua produtividade. Aqui deixa claro, que apesar do testamento, o reino ainda não era de Roma, embora isso fosse apenas uma questão de tempo, como o próprio testamento confirmava:

Pois cada alternativa é de tamanha importância que você não deve de forma alguma deixar o caminho para ele ou apoiar sua decisão. Se Rullo desejar ser amigo do povo, ele vai conceder o reino ao povo romano. E também, pela virtude de sua lei, vai vender Alexandria, vai vender o Egito, e nós vamos descobrir que ele é o juiz, o árbitro, o dono de uma cidade riquíssima e da terra mais bonita (urbis copiosissimae pulcherrimorumque agrorum), em resumo, o rei do país mais próspero (opulentissimi regni). Mas ele não vai tomar tudo para si, ele não vai ser avarento: ele vai decidir que Alexandria é do rei, que não é do povo romano. (De Lege Agraria 2.2.16.43)

Cícero considerava a possível tomada de Alexandria e do Egito como um prêmio a todos os romanos e justificava a riqueza como o principal motivo de interesse no Egito. Na sequência, Cícero continua reforçando o argumento, de que os decúnviros não poderiam decidir sobre isso, pois se tratava de um assunto de estado, e caso o Egito fosse incorporado, deveria ser abertamente. Usa o exemplo do consulado de 65, ano em que Crasso tentou tornar o Egito tributário e não conseguiu, mas ao menos fez isso de forma aberta e sob o conhecimento de todos: 
Em primeiro lugar, por que há dez na comissão para decidir sobre a herança do povo romano, quando vocês apontaram cem para decidir disputas sobre heranças de questões privadas? Quem vai apresentar a causa do povo romano? E onde? Quem são os decúnviros que estão propensos a doar o reino de Alexandria a Ptolomeu por nada? Mas se Alexandria fosse o objetivo, por que não seguir o mesmo rumo tomado no consulado de Lúcio Cota e Lúcio Torquato (65 a.C.)? Por que não abertamente como antes? Por que não fazer por aquele país, como então, franco e honrosamente? Ou fizeram aqueles homens, romanos, que foram incapazes de alcançar o reino por um curso direto, agora imagine que eles pudessem chegar a Alexandria através de estratégias mistas e obscuras (nunc caecis tenebris et caligine se Alexandream perventuros arbitrati sunt) (De Lege Agraria Contra Rullum 2.17.1).

Em 65, Crasso encarregou um tribuno de propor a anexação do Egito, provavelmente sua intenção era cercá-lo como uma base militar contra Pompeu. O triúnviro acreditava que abrir os tesouros e o trigo do Egito seria um forte apelo para o povo e para os Equites e assim, ele conquistaria popularidade. Mas os Optimates, liderados por Catulo foram contra a proposta, e Crasso foi derrotado (SCHULLARD, 1982, p. 106).

Sob o governo de Ptolomeu XII Aulete começou a ficar mais evidente que a perda da independência egípcia era apenas uma questão de tempo. O rei foi oficialmente coroado em 76, mas já iniciara seu reino cinco anos antes. As atitudes de Aulete desde o princípio do mandado demonstram que ele estava consciente do papel de Roma na definição dos reinos de seus antecessores imediatos e também do crescente envolvimento romano em questões egípcias. Sabia também da importância de se tomar o partido certo, pois o equilíbrio de poder em Roma estava frágil e passando por constantes mudanças (HEKSTER, 2012, p. 9-10). Provavelmente Pompeu tinha ido ao Egito em 67, e o rei Aulete se associou ao romano, ciente de que se tratava de um dos homens mais poderosos do Mediterrâneo (HEKSTER, 2012, p. 10). O rei ofereceu a Pompeu presentes e um massivo apoio militar, que este aceitou. Desde o início de seu reino Aulete ambicionava uma aliança com Roma, e para isso demonstrou considerável conhecimento da sua política, jogando em grupos diferentes quando necessário (HEKSTER, 2012, p. 11). Até que em 59 comprou o reconhecimento romano do seu trono por seis mil talentos. Para pagar a sua conta, endividou o Egito, pedindo empréstimos a Roma, resultando na elevação dos impostos no reino. Tudo isso o tornou extremamente impopular, até que em 58 foi banido do trono e buscou refúgio em Roma. 
Aulete só foi restaurado ao reino em 55 pelo pró-cônsul da Síria, o general Aulo Gabínio, depois de um empréstimo romano. Enquanto isso, sua filha Berenice IV ficou no seu lugar.

Primeiramente, o Senado decretou que o rei deveria ser reinstalado pelo prócônsul da Cilícia, Lentulo Spinther. No entanto, Pompeu queria fazer parte da empreitada ao lado do governador, o que Cícero foi contra, pois poderia assim estabelecer uma base no Egito. O Senado também se opôs, e oportunamente, Catão divulgou (ou inventou) um oráculo dizendo que a expedição representava um mau presságio, reforçando a oposição de todos.

Nas Cartas a Ático (59 a.C), Cícero menciona a motivação de Pompeu em resolver a situação do rei, independente dos presságios divulgados (Epistularum Ad Atticum II.16.2.7). Contudo, depois de toda a oposição do Senado, Pompeu acatou as ordens e abandonou completamente as negociações. O caso ficou parado em virtude do oráculo (57 a.C). Cícero aconselhou Lentulo a persistir no seu plano de ir substituindo Pompeu, lhe garantindo que quando o rei percebesse que sua restauração por Pompeu seria impraticável, apoiaria Lentulo, pois não teria outra escolha e aprovaria a medida (Epistularum Ad Familiares I.vb.1-2). Nas Cartas a Lentulo Spinther, Cícero aconselha o pró-consul sobre como proceder diante de um Senado ferozmente contra o plano, caso decidisse restaurar o rei ao trono:

Como não existe nenhum decreto do Senado que tenha tirado de suas mãos a restauração do trono do rei de Alexandria, a resolução que foi redigida, e, você sabe que foi vetada, contra a restauração do rei por quem quer que fosse, deve ser considerada como uma ebulição de raiva de alguns homens (magis iratorum hominum studium), mais do que uma posição firme do Senado, e sua autoridade deve ser medida de acordo. Nesse caso você, que tem controle da Cilícia e Chipre, está na posição de julgar o que pode atingir e obter. E se as circunstâncias forem favoráveis de te dar a oportunidade de tomar (tenere possis) Alexandria e o Egito, sua honra e a do império serão preservadas se você proceder a Alexandria com uma força naval e militar, depois de fixar o rei em Ptolemais ou qualquer outro lugar para que quando você tiver pacificado e cercado aquela cidade, Ptolomeu possa retomar o seu reino, para que fique claro que ele foi reinstalado pelo seu apoio, como o Senado originalmente havia decidido, e que ele será reinstalado sem uma multidão ${ }^{19}$ (sine multitudine reducatur) como era a intenção de acordo com o partido religioso da Sibila.

Mas Pompeu e eu aprovamos essa decisão com a justificativa de que percebemos que sua política será julgada de acordo com os resultados. Se tudo sair como desejamos e rezamos, haverá consenso universal de

\footnotetext{
${ }^{19}$ O tradutor traduz como "reinstalado sem um anfitrião".
} 
que julgou bem e com coragem, mas se houver qualquer obstáculo, as mesmas pessoas vão dizer que agiu com avareza e imprudência. Então não é tão fácil para nós julgar como deve agir, pois é você que tem o Egito diante dos seus olhos (cuius prope in conspectu Aegyptus est). $\mathrm{O}$ que nós sentimos é isso, que se achar satisfatório, você pode tomar posse daquele reino e não deve hesitar em fazer isso, mas se há alguma dúvida sobre isso, não deve tentar. Sobre isso eu posso te garantir, que se realizar a empreitada para sua própria satisfação, será aplaudido antes da sua volta por muitos, e depois de sua volta por todos, mas eu posso entender que qualquer acontecimento inesperado vai ser encarado como perigo (periculosam), pela decisão contrária do Senado e da questão religiosa. Mas pela minha parte, enquanto eu te pressiono a realizar o que não pode deixar de te trazer glória (laudem), eu te aviso sobre a possibilidade de resultar em conflito (dimicatione deterreo), e eu volto para o que eu falei no início da carta, que homens vão basear o julgamento de toda a sua empreitada não tanto na sua política, mas no resultado dela.

Mas se essa maneira de proceder te parece arriscada (periculosa), outra possibilidade te é apresentada, que se o rei continuar fiel aos seus amigos que lhe emprestaram dinheiro na sua província e esfera de comando, você deve ampará-lo com tropas e suprimentos, sabendo que a natureza e posição geográfica (naturam et regionem) da província te permitem tanto assegurar o seu retorno lhe prestando assistência, ou impedir por ignorá-lo. Então o cálculo da situação (In hac ratione quid res), em que oportunidade, e que tempo, ninguém vai julgar tão facilmente como você mesmo, mas qual era nossa opinião, eu achei que eu, de todos os homens, era a pessoa adequada para te falar. (Epistularum Ad Familiares. 1.7.4-5)

Para Cícero a questão religiosa era o motivo usado pelo Senado para a proibição da ida ao Egito, o que ele considerava uma tolice. O trecho demonstra o controle romano sobre o reino desde a expulsão do monarca, e a ansiedade representada pela oportunidade de restaurar o rei ao trono sob amparo romano. Cícero enfatiza que mesmo que a monarquia fosse restabelecida, teria que ficar claro que era pela boa ação dos romanos. Suas palavras denotam que a situação em Alexandria não era tranqüila durante a ausência do rei. Ou seja, o autor temia pelo aumento da revolta na cidade caso o exército romano não estivesse lá presente para garantir a ordem no momento de retorno do rei. Assinala assim, certa apreensão diante das multidões, além de apontar a boa posição defensiva do Egito.

Nas Cartas ao seu irmão (56 a.C.), Cícero explica o rumo dos acontecimentos a Quinto Túlio Cícero e demonstra sua indignação pela resolução do caso ter sido tirada de Lentulo, declarando também a sua posição contra a participação de Pompeu. Cícero provavelmente temia que Pompeu pudesse tomar posse do reino caso executasse a ação. Indica assim, a cautela com relação ao poder que seria estruturado no Egito. 
Com relação à questão do rei alexandrino (de Rege Alexandrino), um decreto do Senado foi passado ressaltando o seu perigo para o bem comum, de ele ser restaurado com uma multidão (cum multitudine eum reduci periculosum reipublicae videri). E com relação ao que foi discutido no Senado - sobre se o rei devia ser restaurado por Pompeu ou por Lentulo - parecia que Lentulo estava predominando nessa questão. Nesse momento eu me coloquei tanto a serviço de Lentulo, mas sem desagradar Pompeu, mas seu caso foi enfraquecido pela obstrução dos detratores de Lentulo. Então seguiram dias em que o Senado não pôde se encontrar. $\mathrm{O}$ que vai ser decidido pelos tribunos eu não posso adivinhar, mas suspeito que Canínio vai executar seu plano com violência. Eu não posso atender aos desejos de Pompeu nessa questão; mas todos vêem o que seus amigos querem; e aqueles que estão financiando o rei não fazem segredo da grande quantidade de dinheiro que estão empregando para brigar contra Lentulo. É um grande motivo de ressentimento para mim terem tirado o caso das mãos de Lentulo e não é convincente para mim os motivos pelos quais fizeram isso. (Epistularum Ad Quintum Fratrem 2.2.1-3)

Nota-se em Cícero a expectativa com relação à tomada de Alexandria, algo que segundo ele, todos os romanos queriam. Porém o autor demonstra que as negociações da cidade já eram responsabilidade romana, e teria que ficar claro aos alexandrinos que a monarquia só seria restaurada pela boa ação daqueles.

Na mesma época, a anexação de Chipre pelo Senado também enfureceu os alexandrinos (HUZAR, 1988, p. 347). Ptolomeu Aulete tinha concedido a ilha a Roma, mas o local ainda não havia sido formalmente anexado, e estava sendo governado pelo irmão de Ptolomeu. Enquanto César estava na Gália, deixou Clódio no comando da cidade e este deu ordens a Catão, para tomar Chipre e remover o rei, que cometeu suicídio em sua chegada. Cícero condena Clódio pela atitude que resultou na morte do monarca, pelo ato ter colocado em risco as boas relações até então estabelecidas com o Egito (De Domo Sua 8.20.5). Nesse discurso, Cícero demonstra certo respeito pelo reino e um cuidado para não arruinar as relações amistosas com os Ptolomeus.

No Pro Caelio, Cícero detalha sobre a embaixada de cem alexandrinos que foi a Roma protestar contra o retorno de Aulete e acabou massacrada. Os assassinatos resultantes desse massacre foram extremamente condenados por ele (De Haruspicum Responsis 16.34.11 e Pro Caelio 9.23.10). A situação ocorreu quando Pompeu estava tentando restaurar o rei, mas alguns alexandrinos liderados por Dio, um importante estudioso da cidade, se dirigiram ao Senado para justificar a sua expulsão do reino. Os 
alexandrinos foram derrotados e mortos por ordens de Pompeu, e Caelio ${ }^{20}$ era acusado de envolvimento no massacre. Cícero pronuncia nesse discurso sua defesa a Caelio, visto como uma inocente ferramenta de Ptolomeu e Pompeu (Pro Caelio 10.23-24). Cícero retrata a morte de Dio como uma lástima, por ser um homem tão devoto da educação e dos princípios da conduta humana (qui cum doctrinae studio atque humanitatis) (Pro Caelio 10.24.11). No De Haruspicum Responsis, Cícero fala dos atos brutais cometidos contra os enviados alexandrinos. O autor considerava o ocorrido um erro dos romanos, "um ato vergonhoso aos olhos dos deuses imortais" (quod non minus quam de Alexandrinis indignum dis immortalibus esse visum certo scio) (De Haruspicum Responsis 16.34.11).

O plano da restauração de Aulete só foi executado posteriormente por Gabínio, que recebeu dez mil talentos e o colocou de volta no trono. A maior parte da soma emprestada ao rei foi concedida por C. Rabírio Póstumo, um publicano, usurário e cliente de César. Depois de voltar para Roma, tanto Rabírio, quanto Gabínio foram julgados por estas questões, e Cícero foi coagido por Pompeu a defender ambos. Cícero justifica que o rei tinha sido expulso de seu reino, e por necessidade apelou a Rabírio, que avaliou o empréstimo como sem riscos, pois todos achavam que o rei teria o seu posto devolvido com a ajuda romana. Cícero diz que se Ptolomeu tivesse sido honesto, todos aprovariam a medida de Rabírio e o considerariam astuto, mas como o rei o enganou, por isso ele estava sendo julgado. $\mathrm{O}$ autor ressalta, portanto, que Rabírio era vítima da desonestidade do rei (Pro C. Rabirio Postumo Oratio I). Em seguida:

(Discurso a favor de Gaius Rabírio Póstumo - pronunciado diante da corte em 54)

(...) Seu cliente ${ }^{21}$ era um homem de negócios com muitas transações, que cobria muitas províncias, e se colocava a disposição até de reis. Ele antes tinha emprestado uma grande quantidade de dinheiro a esse mesmo rei de Alexandria; e no meio disso ele nunca deixou de enriquecer seus amigos, lhes enviando comissões, lhes concedendo ações, os ajudando com sua riqueza e os apoiando com seu crédito. Em suma, por essa generosidade e pela sua magnitude ele reproduziu a vida e os hábitos de seu pai.

Nesse meio tempo o rei tinha sido expulso de seu reino e veio a Roma, com objetivos astutos (dolosis) como a Sibila disse, e como Póstumo, aprendeu a duras penas. O rei apelou a ele por necessidade; e meu cliente lhe deu um adiantamento - não o primeiro, pois ele já tinha feito isso sem ver seu creditor, que naquela época ainda ocupava o

\footnotetext{
${ }^{20}$ Caelio um aspirante a carreira pública, foi pupilo de Cícero a partir de 66.

${ }^{21}$ Referindo-se a Rabírio.
} 
trono. Ele achou que o empréstimo não envolvia riscos, pois ninguém duvidava que o rei estava em processo de ser restaurado ao trono pelo Senado e pelo povo de Roma. Mas nos presentes e nos seus empréstimos ele foi muito longe, pois emprestou não apenas o seu dinheiro, mas também 0 de seus amigos (...). (Pro Rabirio Postumo Oratio 2.4).

Cícero justifica que não se podia culpar Rabírio pelo mau uso do dinheiro emprestado, principalmente por ter feito o empréstimo a um rei que tinha boas relações com Roma (Pro Rabirio Postumo Oratio 2). O orador relata que o Senado considerava que Gabínio tinha entrado em Alexandria instigado pelo pagamento de Rabírio. Assim, ele seria ainda culpado pelo ato de Gabínio. No entanto, Cícero justifica que este agira assim pelo bem da República (dicebat rei publicae causa) (Pro Rabirio Postumo Oratio 8.20-21).

O autor retrata Rabírio como vítima de Ptolomeu, pois assim que chegou a Alexandria, foi obrigado a se colocar inteiramente a disposição do rei. Este lhe advertiu que para receber o pagamento, deveria assumir o posto de seu tesoureiro, usando o título do ofício de lá (dioecetes) (Pro Rabirio Postumo Oratio 8.22). Cícero justifica o fato de Rabírio não ter tido escolha, por isso não podia ser julgado, principalmente por estar obedecendo a ordens reais (Pro Rabirio Postumo Oratio 10.28). Nessa parte, Cícero ressalta a autoridade e poder de mando do rei de forma negativa, talvez para contrastar com a liberdade romana. $\mathrm{O}$ autor menciona ainda a ousadia dos enviados alexandrinos presentes no julgamento de Gabínio:

Voltemos àqueles alexandrinos, quanta audácia a deles! Outro dia no julgamento de Gabínio, eles se manifestavam (excitabantur) a cada palavra, eles negavam que dinheiro tivesse sido dado a Gabínio, mesmo a evidência de Pompeu sendo lida repetidamente, que o rei havia lhe escrito que nenhum dinheiro tinha sido dado a Gabínio a não ser para questões militares.

"Não é a testemunha alexandrina que faz o empréstimo" pergunta. "E o que depois? Emprestam quanto agora e para o que?" "Pois agora afirma o que então negavam" "Por que motivo?". Mas se eles falavam a verdade naquela época, quando a verdade estava escrita, agora eles mentiam. Se eles mentiam na época, eles devem nos provar que agora estão falando a verdade. Nós ouvimos falar a muito de Alexandria, agora nós sabemos. Daquele lugar é que vêm todas as trapaças (praestigiae). De lá vem todo o tipo de farsa (fallaciae). É de lá que todas as tramas (argumenta) dos três escritores (mimorum) se 
baseiam. E não há nada que eu deseje mais, juízes, do que olhar esses homens cara a cara. (Pro Rabirio Postumo 12.34-35) $)^{22}$

Cícero justifica que Rabírio era ainda menos culpado, pois tinha dado o dinheiro para Gabínio executar a ação, e não tinha recebido nenhum pagamento de volta do rei (Pro Rabirio Postumo 13.38). Deve-se destacar no trecho acima o julgamento que Cícero pronuncia contra os alexandrinos. Trata-se da maior generalização de sua obra sobre o povo. Nessa etapa, Cícero destaca a fama de Alexandria como um povo traiçoeiro, que na sua visão se confirmou com a presença dos enviados alexandrinos em Roma e no modo como agiram no julgamento.

Esta embaixada, da mesma forma que a mencionada anteriormente que tentou evitar o retorno do rei, podem ter sido vistas dentro de Roma como tentativas de resistência de alexandrinos a intervenções romanas. Foram, portanto, episódios que confirmaram a ousadia do povo. Cícero aparentemente menciona essa ocorrência também com a intenção de reforçar como os próprios alexandrinos estavam insatisfeitos com seus reis e, consequentemente, demandavam a presença romana. Se até então aceitavam passivamente a presença romana, pois seus próprios reis não tinham autoridade para governar, talvez essas tenham sido as primeiras tentativas de resistência pelo povo alexandrino. Ou seja, a multidão alexandrina começou a se dar conta de sua força e desafiar autoridades de forma independente do poder. Demonstrou assim, sua capacidade de se autogovernar. Nesse sentido, talvez esses ocorridos tenham sido desafiadores para a elite imperial e ajudaram na difusão da fama dos alexandrinos como propensos a propagar tumultos.

Suetônio relata que César também tentou ganhar influência sobre o Egito no contexto de saída do rei, algo que outras fontes não relatam. César arriscou se apoderar do Egito através de um decreto dos tribunos, após conquistar a confiança das massas romanas. Aproveitou-se da oportunidade da deposição do rei (Aulete), que era aliado (amicum) do povo romano. $\mathrm{O}$ autor relata que a ação dos alexandrinos era geralmente condenada (resque vulgo improbabatur). A condenação pode se referir tanto à oposição

\footnotetext{
${ }^{22}$ Como o latim desse trecho é confuso, o trecho todo está aqui transcrito: 'non est,' inquit, 'tum Alexandrinis testibus creditum.' quid postea? 'creditur nunc.' quam ob rem? 'quia nunc aiunt quod tum negabant.' quid ergo? [35] Ista condicio est testium ut, quibus creditum non sit negantibus, isdem credatur dicentibus? at, si verum tum severissima fronte dixerunt, nunc mentiuntur; si tum mentiti sunt, doceant nos verum quo voltu soleant dicere. audiebamus Alexandream, nunc cognoscimus. illinc omnes praestigiae, illinc, inquam, omnes fallaciae, omnia denique ab eis mimorum argumenta nata sunt. nec mihi longius quicquam est, iudices, quam videre hominum voltus.
} 
do oráculo ou ao fato dos atos dos alexandrinos terem sido censurados pela ousadia. Contudo, Suetônio observa que César não teve êxito em sua empreitada, pela oposição da facção aristocrática (Divus Julius 11).

Plutarco relata que após se refugiar em Roma, Aulete queria se aconselhar com Catão, e mandou chamá-lo. Mas este exigiu que o rei fosse ao seu encontro, o que em um primeiro momento ofendeu Ptolomeu. Catão censurou o rei por suas atitudes anteriores, mas suas palavras de sabedoria convenceram Ptolomeu a voltar e se reconciliar com seu povo (Toĩs moגítaıs). Plutarco relata que o rei teve a impressão de ter sido avisado por um deus, e não apenas por um bom homem (Cato minor 35.2-5). Aqui, Plutarco sugere que a ajuda romana nessa situação não foi apenas política, mas repleta de inspiração divina, para a qual o rei teve que se dobrar.

Nas Guerras Sírias, Apiano ressalta que apesar de Gabínio ter derrotado os alexandrinos e restaurado Ptolomeu XII ao poder, foi banido pelo Senado por ter entrado em Alexandria sem sua permissão:

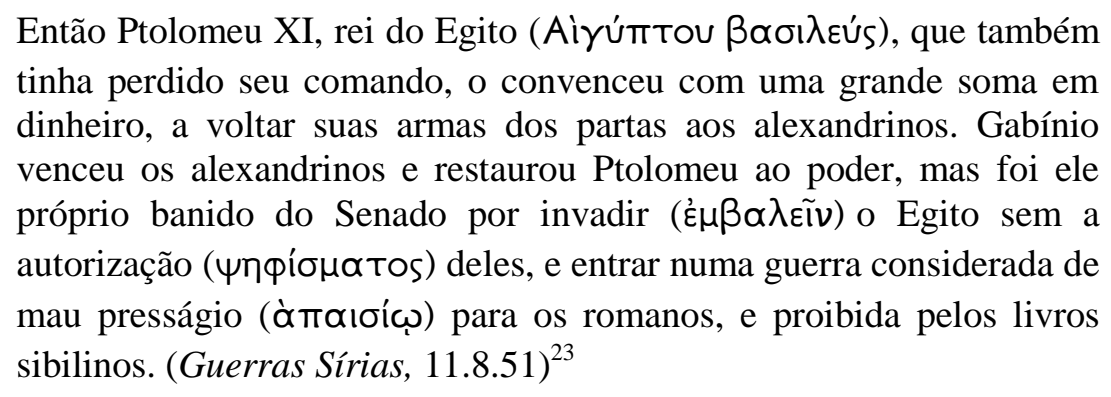

Tanto em Cícero, quanto em Apiano que escreveu mais de dois séculos depois, percebe-se como antes de Otávio, a entrada de autoridades no Egito já era restrita e dependia da aprovação do Senado.

Dion Cássio, que escreveu séculos depois de Cícero, também relata em detalhes a situação de Aulete. $O$ autor afirma que os egípcios estavam furiosos

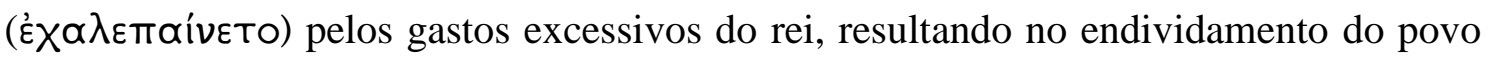
com Roma, a quem pagara grandes somas para garantir o seu reinado. Além disso, o rei

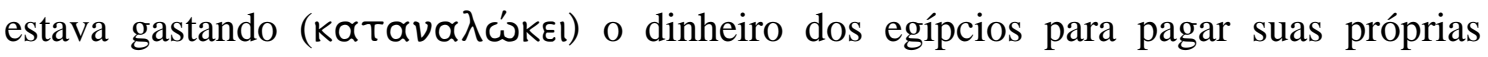
dívidas. Os alexandrinos estavam indignados também por ele não tentar conseguir Chipre de volta. Como não conseguia acalmá-los (i்ouXó̉ $\varepsilon ı v$ ), pois não tinha tropas de

${ }^{23} \mathrm{O}$ autor refere-se a Ptolomeu XI, mas estamos tratando de Ptolomeu XII. 
fora, Aulete foi a Roma, acusando seus compatriotas de expulsarem-no de seu reino (Historiae Romanae 39.12-13). Quando os alexandrinos descobriram a verdade, mandaram uma embaixada de cem homens a Roma para contar tudo que haviam sofrido

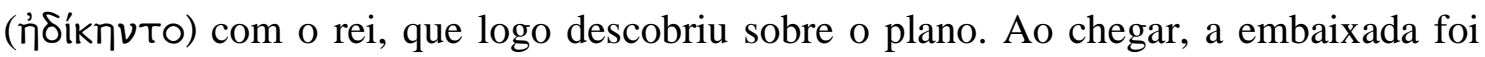
massacrada ( $\varepsilon \varphi \theta \varepsilon ı \rho \varepsilon)$. No entanto, o fato se tornou extremamente conhecido fora de

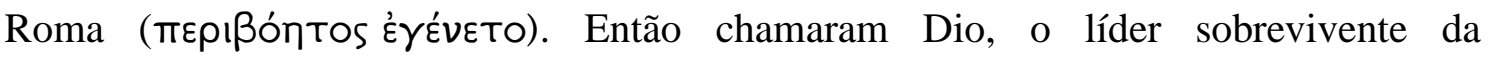
embaixada, para saber a verdade. Contudo, Ptolomeu também conseguiu providenciar a sua morte antes mesmo que entrasse no Senado. Mesmo assim o rei não foi punido, por estar sob a proteção de Pompeu (Historiae Romanae 39.13-15).

Dion comenta ainda o aviso que os romanos tinham recebido dos livros sibilinos,

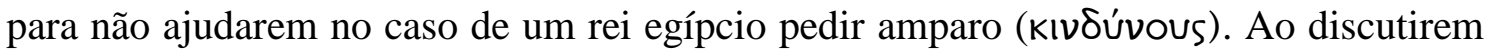
a questão, alguns senadores tinham decidido mandar Ptolomeu de volta sem um exército, ou escoltado ( $\kappa \varepsilon \lambda \varepsilon v o ́ v \tau \omega \nu)$ por Pompeu, mas o Senado foi contra o plano, temendo que o romano conquistasse ainda mais poder fazendo isso, usando o suprimento de trigo (oítou) como desculpa (Historiae Romanae 39.16).

Gabínio conquistou (vikńoas) os egípcios no mesmo dia e restaurou Ptolomeu ao trono. Esta vitória rápida surpreende o autor, que se aproveita desse contexto para censurar a postura dos alexandrinos de sempre protestarem por tudo e assumirem uma postura corajosa em qualquer situação (

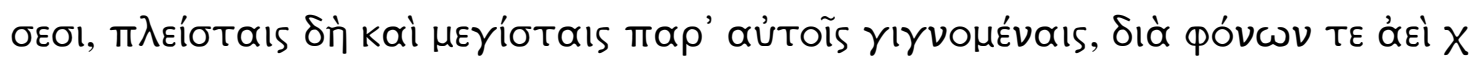

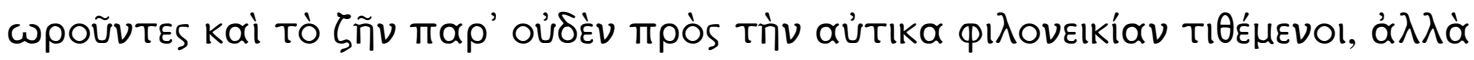

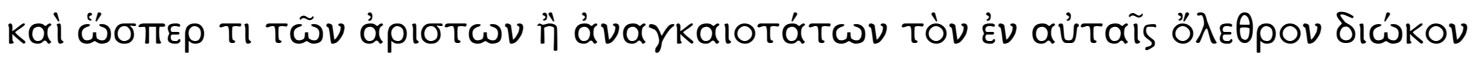
TES). Por ter contrariado o aviso das leis sibilinas, Gabínio não alertou o Senado, mas

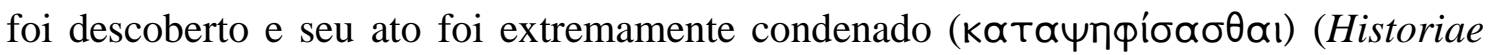
Romanae 39.58-59).

Enquanto os primeiros Ptolomeus são louvados por suas realizações em Alexandria, como se viu no capítulo anterior, o rei Aulete é o rei mais criticado pela tradição. O monarca é visto como o maior símbolo da "decadência" ptolomaica e da necessidade da presença romana cada vez mais constante no governo egípcio. Estrabão por exemplo, depois de enumerar toda a sucessão, declara que todos os reis, depois do terceiro, foram corrompidos pela vida luxuosa (трuфñs) e fizeram uma má 


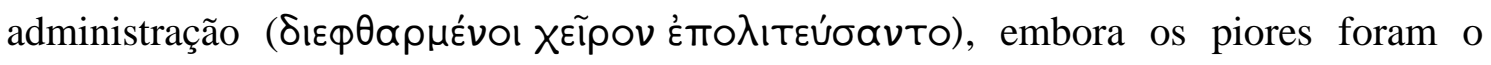
quarto, o sétimo e o último, Aulete, o tocador de flauta, que participava de competições no palácio (Geographica 17.1.11). No entanto, o autor nada comenta de sua expulsão do trono. Ateneu diz que toda a riqueza ( $\pi \lambda$ ○̃̃Tos) do rei Ptolomeu Filadelfo, depois de ser mantida por um período tão longo, foi perdida pelo último rei, que era um mero tocador de flautas e um jogador (Deipnosofistas. 5.206d). A ênfase aqui é no caráter descompromissado e fraco do rei, que gerou a reação dos alexandrinos, e exigiu um envolvimento ainda maior de Roma em questões dinásticas internas. O caso de Aulete foi apenas o mais forte exemplo de irresponsabilidade da realeza ptolomaica, entre vários outros, conforme já visto.

Apesar do comprometimento com Roma ter atingido o ápice no reinado de Aulete, tal época, como também o período posterior de Cleópatra, presenciou um renascimento cultural de Alexandria, pois as guerras com Mitrídates, rei do Ponto, promoveram um retorno da intelectualidade alexandrina de Atenas (CHAUVEAU, 2000, p. 61). Assim, se o cenário político deixava a cidade cada vez mais suscetível às transformações políticas da República, a crise foi culturalmente promissora para Alexandria. No entanto, não há nenhuma motivação das fontes em relatar esses ganhos culturais. Mas a censura promovida por Estrabão e Ateneu à dedicação do rei à música e jogos fornecem pistas de sua preocupação com o cenário cultural na cidade.

Se a fundação e a história inicial de Alexandria eram percebidas como um tempo de vitalidade, no qual foi plantado o potencial desenvolvido pela cidade posteriormente, a era iniciada depois dos primeiros três reis foi descrita como um contexto de decadência. Esses quase dois séculos se resumem na documentação à história dos conflitos da realeza. Os problemas dos reis geraram também conflitos sociais, que, no entanto, foram menos abordados. A história da Alexandria helenística foi condensada nesse cenário de instabilidade e incerteza, e os romanos foram descritos como salvadores de um mundo mergulhado no caos. Aumentar o foco sobre a fragilidade do reino ptolomaico era uma maneira de potencializar o talento romano na resolução dos problemas, legitimando as interferências promovidas no reino.

Roma tornou-se sinônimo de ordem e liberdade. Por isso, a literatura enfoca principalmente os problemas, com o intuito de tornar essa nova era ainda mais contrastante com o período helenístico anterior, e dessa forma, justificar e legitimar a ação da administração romana. A visão mais geral é que foram os próprios reis 
alexandrinos que clamaram pela presença romana de forma cada vez mais incisiva. Nesse sentido, Roma agira no território de forma reativa em resposta às atitudes "desmedidas" e "inconsequentes" da dinastia. Ou seja, foi pelo "bem geral" do Egito

que Roma começou a intervir progressivamente nas questões da realeza e "salvou" o reino em inúmeras ocasiões. Era conveniente representar Alexandria dessa forma frágil e mau governada, ao mesmo tempo em que chamar atenção para a sua prosperidade assinalaria a importância da execução de uma troca de poderes que soubesse estabelecer a autoridade e também organizar o fluxo de riquezas para Roma.

\subsection{Assassinato de Pompeu em Alexandria: abalo nas relações harmônicas}

Segundo Barbara Gold (1987, p. 54), o final do período republicano é caracterizado pela proeminência de indivíduos fortes, que ganharam grande reconhecimento público, e se tornaram "personalidades de mídia instantânea". Dessa forma, homens como César, Pompeu e Otávio naturalmente atraíam a atenção de escritores e se tornavam seus temas principais, pois estavam no centro de muitos assuntos em Roma. E como patronos ainda, tinham o poder de encomendar qualquer tipo de escrito, embora a disposição para colaborar e escrever o que demandavam dependia muito da posição social do autor, sua nacionalidade e talento literário (1987, p. 66). A autora menciona o exemplo de escritores que tiveram que alterar seu estilo ou assunto de escrita pra ganhar o interesse do patrono (principalmente os poetas sob Otávio) (1987, p. 59).

Nesse contexto, as narrativas sobre a vida de Pompeu, sua derrota e assassinato em Alexandria direcionaram grande parte do foco dos escritos para a cidade. $\mathrm{O}$ fato de a metrópole ter protagonizado um evento tão marcante, resultou em um aumento significativo de sua presença nos escritos da época e sua "participação" nesse evento tornou-se alvo de diversos julgamentos.

$\mathrm{Na}$ iminência de perder a guerra civil para César, Pompeu se refugiou em Alexandria, confiante na dívida da cidade com ele pelo apoio concedido ao Ptolomeu anterior (que ajudou a restaurar ao reino). No entanto, Pompeu foi assassinado a mando 
do rei, Ptolomeu XIII ${ }^{24}$, que estava consciente do perigo de tomar o seu partido, em uma guerra que já parecia vitoriosa para César. Assim, aparentemente a medida drástica teve a intenção de confirmar o apoio dos alexandrinos ao seu lado na guerra, embora tenha sido entendida por ele como uma afronta terrível. Resolveu então se vingar dos encarregados do assassinato por terem se intrometido em uma questão de Estado. Após o incidente, o romano decidiu ficar em Alexandria para resolver impasses dinásticos, o que acabou levando à guerra. A realização do assassinato seguindo o comando de Ptolomeu foi extensamente descrita pelas fontes, com a intenção de ressaltar o ultraje cometido pela realeza.

O relato de César aparentemente objetivava justificar aos romanos os motivos que levaram à guerra em Alexandria. Ele conta que Pompeu chegou ao Egito confiante de que conseguiria apoio, pela relação estabelecida com Aulete. Implorou ao rei para ser aceito como recompensa. Entre os que estavam a serviço de Ptolomeu, havia antigos soldados de Pompeu, que Gabínio tinha retirado do exército da Síria e levado com ele para Alexandria quando restabeleceu Aulete no trono, e por lá permaneceram (Bello Civili 3.103.3.2). Segundo o autor, os alexandrinos encarregados do reino (pela juventude do rei Ptolomeu XIII) justificaram o assassinato de Pompeu por estarem movidos por medo (timore), de que ele fosse cercar (occuparet) o Egito e Alexandria (Bello Civili 3.104.1). Assim, o autor interpreta a atitude dos alexandrinos mais como uma ação causada pelo temor do que como uma tentativa de aproximação de César (Bello Civili 3.106.4). Na sua versão, ele não menciona a indignação pela morte do opositor, talvez por se tratar de um relato pretensamente imparcial. Portanto, praticamente ignora o ocorrido para já tratar da guerra, sua prioridade na narrativa. Argumenta sobre a sua chegada ter causado tumulto (tumultu) na multidão que se aglomerou (concursu multitudinis concitationes), pois interpretava a chegada de uma autoridade romana como um possível cerco do reino. Por isso, César precisou usar suas tropas para conter o movimento, o que durou alguns dias. Em seguida, mandou chamar mais tropas ao descobrir que os irmãos Cleópatra VII e Ptolomeu XIII estavam em conflito (controversiis) (Bello Civili 3.107.1). Assim, o autor justifica a necessidade da guerra, pois considerava arriscada uma disputa pelo trono entre os irmãos. A contenda começou em 51 a.C. e o autor argumenta que essa discórdia poderia afetar todo o povo

\footnotetext{
${ }^{24} \mathrm{O}$ rei era adolescente na época, e seguia a decisão de seus tutores.
} 
romano, provavelmente pelo risco de interromper a chegada de provisões a Roma (Bello Civili 3.107.1). César menciona a seguir, o testamento do Ptolomeu anterior (já citado acima):

No testamento do pai deles, Ptolomeu, o mais velho dos dois filhos e a
mais velha das duas filhas, estavam registrados como herdeiros. No
mesmo testamento, Ptolomeu ordenou que o povo romano realizasse
essa cláusula, em nome de todos os deuses e de todos os tratados que
ele tinha feito em Roma. Uma cópia do testamento tinha sido enviada
a Roma pelos seus enviados para ser colocada no tesouro, mas tinha
ficado com Pompeu, pois não tinha sido possível depositar lá devido
aos problemas do estado; uma segunda cópia foi deixada fechada para
publicação (proferebantur) em Alexandria (Bello Civili 3.108.2).

Apesar de adotar uma postura de não condenar os alexandrinos pelo ocorrido, o relato de César tinha a intenção de justificar aos romanos sua decisão de guerrear com a cidade (pelo problema dinástico). O objetivo era também legitimar a dependência do Egito a Roma, com base no testamento de Ptolomeu, ou seja, em decisões dos próprios alexandrinos. César relata sobre o que desencadeou a guerra e descreve as primeiras batalhas, onde sublinha o pouco preparo das tropas alexandrinas (Bello Civili 3.112.2).

O relato da Guerra de Alexandria, atribuído a César, mas provavelmente escrito por Hírcio, um de seus oficiais, foi escrito pouco tempo depois dos eventos. A narrativa valoriza os detalhes das batalhas com a clara intenção de demonstrar a astúcia e força de César na condução da guerra. $\mathrm{O}$ autor ressalta que no decorrer de todo o conflito os alexandrinos foram muito habilidosos (homines ingeniosi atque acutissimi), pois conseguiram reunir um exército considerável e tinham conhecimento superior nas técnicas navais. Ressalta a esperteza do povo, pela facilidade e rapidez com que aprenderam algumas técnicas de batalha (sollertia efficiebant ut nostri illorum opera imitati viderentur). Descreve que os romanos tiveram dificuldades em dominar a cidade, pela força defensiva e natureza do litoral (nostras munitiones infestabant et suas defendebant). Mesmo assim, César demonstrou superioridade e conseguiu vencer. $\mathrm{O}$ autor enfatiza a riqueza de Alexandria e a abundância de todos os tipos de suprimentos, equipamentos e armamentos (Urbs fertilissima et copiosissima omnium rerum apparatus suggerebat) (Bellum Alexandrinum 3.1.1).

O registro sugere que os alexandrinos estavam conscientes do interesse de Roma em transformar o Egito logo em província, e o seguinte trecho mostra a vontade dos 
cidadãos em resistir à mudança. Denota também a relutância romana em resolver a questão de modo incisivo, pelas repercussões que podiam trazer:

\begin{abstract}
Nos seus conselhos e reuniões públicas os argumentos que seus líderes usavam eram os seguintes: "O povo romano está se habituando a cercar (occupandi) nosso reino; alguns anos antes Aulus Gabínio tinha ido ao Egito com um exército, Pompeu também tinha recorrido a isso na sua fuga; César agora veio com suas forças (copiis), e a morte de Pompeu não teve nenhum efeito de dissuadi-lo de ficar entre eles. Se eles falissem em mandá-lo embora, seu reino se tornaria uma província romana: e eles deveriam fazer isso logo; pois impedido como estava agora pela tempestade e pela estação do ano, ele não poderia receber reforços de fora (transmarina auxilia)" (Bellum Alexandrinum 3.1.1).
\end{abstract}

O autor enfatiza que os alexandrinos acabaram não se beneficiando de seus conhecimentos marítimos (numero navium praestantibus) e de suas habilidades (sollertia), e nem da grande multidão (tanta multitudine), pois a coragem (virtutem) dos romanos se provou superior a tudo isso (Bellum Alexandrinum 16.10.1).

Na sua perspectiva, o assassinato de Pompeu não teve a intenção de tomar o partido de César, mas de assustá-lo e evitar novos cercos do reino. O relato sugere que o fim da passividade dos alexandrinos (aqui personificado nos governantes, mas também na multidão) era uma forma de afronta que começava a preocupar os romanos.

Em vários momentos o autor descreve o rei como traiçoeiro, inseguro e despreparado e os alexandrinos como um povo propenso à rebelião e à traição. Quando a guerra já estava vencida, o autor enfatiza ainda mais o retrato da inclinação do povo à deslealdade, mostrando que o romano era responsável por devolver a racionalidade aos alexandrinos na busca de um consenso com o rei. $\mathrm{O}$ autor aponta que apesar da consciência de César da natureza enganosa dos alexandrinos, sempre fingindo algo diferente das suas reais intenções (fallacem gentem semperque alia cogitantem, alia simulantem bene cognitam habebat), decidiu satisfazer seu pedido por clemência. Avaliou que se de alguma forma o pedido do rei refletisse seus reais sentimentos, ele lhe seria leal quando liberado, mas acreditava que o mais provável de acordo com seu caráter (illorum naturae conveniebat) era o monarca querer vingança.

César aconselhou o rei a ter consideração pelo "reino de seus predecessores, de ter piedade pelo seu país mais ilustre, marcado vergonhosamente como estava pelo fogo e pela desolação" (consuleret regno paterno, parceret praeclarissimae patriae, quae turpibus incendiis et ruinis esset deformata). Além disso, ordenou ao rei que mandasse 
seus cidadãos recuperar a sanidade (sanitatem revocaret) para provar a lealdade ao povo romano. No entanto, o rei tentou enganar César em virtude de sua mente "educada em todas as lições de completa falsidade e engano, aprendidas com seu povo" (At regius animus disciplinis fallacissimis eruditus, ne a gentis suae moribus degeneraret). Fingiu se reconciliar com César, mas assim que foi solto, começou a guerrear contra ele de forma ainda mais enérgica (acriter bellum gerere) e todos ficaram surpresos com a sua falsidade (fallaciis) e com a mudança de rumo dos acontecimentos (Bellum Alexandrinum 24.1.1).

Pode-se inferir a ideia sublinhada pelo autor: a autoridade e força da multidão alexandrina e a fraqueza do rei em conter essa aglomeração. Ou seja, era um bando autogovernado, para o qual o rei não conseguia mais fazer frente. Portanto, a cidade clamava por comandantes mais poderosos. No final, apesar da rendição dos alexandrinos, o autor ressalta que César resolveu não tomar o Egito, embora não exponha suas razões, como se percebe no seguinte trecho:

Tendo se tornado mestre (potitus) do Egito e de Alexandria, César apontou como reis aqueles que Ptolomeu tinha deixado em seu testamento, com um apelo aos romanos que isso não devia ser alterado. Como o mais velho dos dois meninos - o último rei - agora estava fora de questão, César concedeu o reino ao mais novo e a Cleópatra, a filha mais velha das duas filhas, que tinha sido leal a ele; enquanto Arsinoé, a filha mais nova, em nome de quem, como demonstramos, Ganímedes estava exercendo um enorme controle, ele determinou que fosse removida do reino, para prevenir novas dissensões (nova dissensio), antes que o domínio do par fosse consolidado com o tempo. A sexta legião de veteranos ele levou embora; todas as outras ele deixou lá, para amparar o domínio (poterant) dos novos governantes, pois ainda não tinham a afeição (fideliter) da população, por terem se aproximado de César, e nem a autoridade (auctoritatem) de um reino bem estabelecido, por estarem a poucos dias apenas no trono. Ao mesmo tempo, ele julgou prudente para a dignidade do nosso império e que era adequado para o bem público, que se os governantes permanecessem leais (fide), eles seriam protegidos por nossas tropas; e se eles se provassem ingratos (ingrati), essas mesmas tropas poderiam repreendê-los. (Bellum Alexandrinum 33.1.1)

Foi então permitido o retorno dos reis, mas apenas na presença das tropas romanas. O trecho ressalta o interesse de César em controlar o Egito mesmo de forma indireta. Demonstra também a necessidade do seu comando em virtude da natureza 
inconsante do rei e da postura sempre inconsequente dos alexandrinos. Novamente apontar a fraqueza alexandrina era uma forma de apontar a força e o preparo romanos.

Exaltando a calma e o equilíbrio de César, Tito Lívio observa que depois da morte de Pompeu, quando Theódoto trouxe sua cabeça, ao invés de começar uma revolta (tumultuantem), o romano entrou em Alexandria tranquilamente e restaurou Cleópatra ao reino. Mas quando Ptolomeu o atacou (bellum), instigado pelo mesmo homem que matou seu inimigo, ele venceu depois de correr um grande risco pessoal (Periochae 112). Frontino diz que quando chegou ao Egito, César já estava ciente da morte de Pompeu. Por não confiar na lealdade dos egípcios (suspectam habebat Aegyptiorum fidem) tentou aparentar indiferença. Dessa forma, se envolveu em banquetes, enquanto inspecionava (inspectioni) Alexandria, fingindo se render ao charme do local (gratia locorum) e sucumbir aos costumes (mores) alexandrinos. Entretanto, apenas ganhou tempo para preparar suas reservas, pois em seguida ele disfarçou e cercou (occupavit) o Egito (Strategemata 1.1.5.3). Frontino demonstra uma maior predisposição de César para lutar, diferente dos autores anteriores, que reforçam que as circunstâncias tornaram as querelas inevitáveis.

O poeta Lucano é o autor que descreve a morte de Pompeu de forma mais exaltada, por ser nitidamente partidário dele. A morte de seu herói foi a ocasião oportuna para o autor expor todos os seus julgamentos de condenação aos egípcios. Considerava que o assassinato de um romano tão nobre só refletia o padrão traiçoeiro deste povo. O autor conta que assim que Pompeu chegou ao Egito, ocorreu um intenso debate entre os partidários do rei a respeito de como deveriam proceder diante de tal personalidade, já derrotada por César (Pharsalias 8.471-475). Houve pouco tempo para deliberar, e predominou a opinião de Acoreu, que considerava que Pompeu tinha chegado lá procurando um povo para compartilhar a sua queda. Observa que o destino desse homem estava condenado e que não podiam defendê-lo, além disso, deveriam ter consciência da fragilidade de seu comando diante de Roma (Pharsalias 8.475-535).

Lucano passa então a descrever em detalhes as circunstâncias da morte do eminente romano (Pharsalias 8.560). Além de ter sido um ato brutal, sangrento e mal executado, o que causava maior ira ao poeta era o desrespeito com que o seu corpo fora tratado (Pharsalias 8.715-800). Lucano destaca ainda a ironia da situação: a cabeça de Pompeu foi cortada por uma espada romana, pois Septímio, que executou a ordem, já tinha servido sob Pompeu e estava no Egito desde então (Pharsalias 8.595-615). 
Lucano complementa essa parte com uma reconstituição dos últimos pensamentos de Pompeu, em que ressalta a traição do Egito (Pharsalias 8.600-635).

Na sequência, Lucano aproveita o momento para expressar mais uma vez, e com maior clareza, o seu desprezo pelo Egito, o maior culpado pelos destinos da guerra civil (Noxia civili tellus Aegyptia fato). E remete ao oráculo da Sibila (da época de Aulete), que já havia alertado sobre o risco de qualquer romano visitar o Egito. Por fim, o autor amaldiçoa a terra egípcia com toda a sua ira (Pharsalias 8.825-870).

No livro 9, o autor continua expressando sua aversão ao Egito, através das palavras de Sexto Pompeu. Como demonstração de sua fúria, diz que deveria arrastar o corpo de Alexandre do seu túmulo e afundá-lo, junto à cidade macedônia (não menciona o nome de Alexandria), sobre as águas do lago Mareótis. Deveria também tirar Amásis e outros reis de suas tumbas nas pirâmides e pilhar o túmulo de Isis, adorada em todo o mundo romano, pois Pompeu também não tivera os ritos merecidos. E deveria punir a terra deixando seus campos inférteis (Pharsalias 9.150-165).

Lucano relata que, quando chegou ao litoral egípcio, César encontrou o local repleto de distúrbios (tumultu). Então, manteve seus navios longe da costa, temendo confiar em um reino traiçoeiro (dubiis veritus). Mas, oficiais do rei se aproximaram com a cabeça de Pompeu e disseram que tinham o ajudado a acabar com a guerra civil. Dessa forma, estariam lhe entregando o reino e o poder sobre o Egito sem derramamento de sangue. César, não escondeu sua emoção e indignação. E fez um discurso censurando os Ptolomeus por terem se intrometido em uma guerra de romanos sem a sua autorização (Pharsalias 9.1005-1105).

No livro 10, Lucano se volta para a temporada de César no Egito, e prossegue em sua crítica ao antigo reino faraônico. $\mathrm{O}$ autor inicia com uma reflexão condenando Alexandre e o império criado por ele (Pharsalias 10.5-50). Em seguida, trata da chegada de César em Alexandria e relata que assim que conheceu Cleópatra, ela fez um discurso pedindo ajuda; esclarecia não querer poder, mas apenas livrar o seu povo da culpa e da vergonha (Pharsalias 10.80-105).

Em seguida, Lucano descreve em detalhes o luxo e as riquezas do palácio, para os quais César se rendeu. Narra a magnificência do banquete, a riqueza das joias de Cleópatra, e dos adornos do palácio, provenientes do Mar Vermelho e da Índia. O autor observa que César nunca tinha visto tamanha ostentação, e condena toda essa exibição em um contexto de guerra civil. Diante de toda a magnificência, o poeta conta que 
César desejou encontrar um pretexto para entrar em guerra com os egípcios. O romano se espantou também com a multidão de serventes e auxiliares do palácio, de diferentes raças e idades (Pharsalias 10.105-170). Após as festividades, César pediu ao sacerdote Acoreu para revelar todos os segredos e hábitos do povo, suas origens, as características da terra, pois não era apenas a morte de seu oponente que tinha lhe atraído para a região, mas também a sua fama. O sacerdote então começou a contar os segredos, e disse que vários reinos anteriores tentaram descobrir seus mistérios (Pharsalias 10.175-270).

Na sequência, Lucano fala sobre a disposição de César em guerrear com os egípcios para vingar Pompeu. Não menciona nem uma vez Alexandria ou alexandrinos, fala sempre em egípcios e da "cidade de Alexandre". O livro 10, que está inacabado, deixa explícito o preconceito do autor contra o Egito e sua indisposição em relação a César. Maehler observa que entre os autores de poeta e prosa do séc. I d.C., a imagem negativa dos egípcios prevaleceu. Nesse sentido, Lucano se apropriou da visão de Virgilio sobre o Egito e o adaptou ao seu grande tema: a morte de Pompeu e o fim da República. Ele se utiliza dos lugares-comuns contra o Egito como uma terra traiçoeira, para reforçar o seu tema principal: a morte de seu herói realizada no local (2003, p. 211). Apesar da motivação de Lucano de condenar o Egito e os responsáveis pelo assassinato de Pompeu, ele alude ao poder do território de instigar e provocar em virtude de sua cultura "enigmática". Destaca também a mistura populacional da terra, assinalando a intensa convivência entre várias identidades desde o palácio real. $\mathrm{O}$ retrato elaborado de Alexandria é culturalmente plural, embora predomine os lugarescomuns a respeito do Egito antigo, como se o tempo não tivesse passado no local.

Semelhante ao relato de Frontino e Lucano, Apiano também demonstra uma maior disposição de César para lutar. Observa que a princípio, por estar sem seu exército, fingiu tranquilidade, recebeu visitas de um modo amigável e atravessou a cidade, admirando sua beleza (Toũ kód $\lambda \lambda$ ous) e ouvindo palestras de filósofos enquanto estava na multidão ( $\pi \lambda \hat{n}$ Oous). Assim, ganhou a estima dos alexandrinos como um aliado (Bellum Civile 2.89). Porém, quando sua guarda chegou, puniu os responsáveis pela morte de Pompeu. Os alexandrinos então se rebelaram ( $\theta \circ \rho u ß o u ́ v \tau \omega v)$ e a tropa de Ptolomeu marchou contra César, resultando em várias batalhas (đ̛̊ $\tilde{\omega} v \varepsilon \varsigma$ ), até que o romano teve uma vitória decisiva. Apiano diz que César ficou desolado quando viu a cabeça de Pompeu e ordenou que seu corpo fosse enterrado perto da cidade (Bellum 
Civile 2.90). Parece ser a intenção do autor realçar a sensibilidade de César em vingar Pompeu, mesmo sendo seu inimigo, apesar de demonstrar também sua motivação para a guerra, reduzindo assim a culpabilidade dos alexandrinos. É plausível que por ser alexandrino, Apiano aproveite a ocasião para chamar a atenção para a beleza e desenvolvimento cultural da cidade, que atraíra César.

Plutarco relata que assim que Pompeu chegou a Alexandria, um auxiliar de

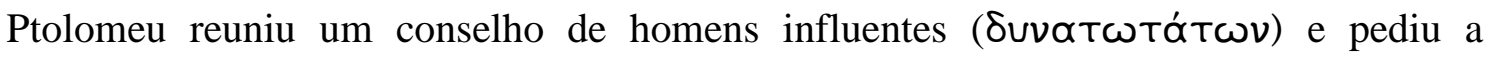
opinião de cada um a respeito da presença do romano (pelo rei ser muito jovem para tomar decisões). Theodotus de Chios, um professor de retórica, convenceu todos de que caso recebessem Pompeu se colocariam contra César, mas se o mandasse embora, ele poderia exigir vingança. Decidiram, então, que o melhor era matá-lo com o intuito de

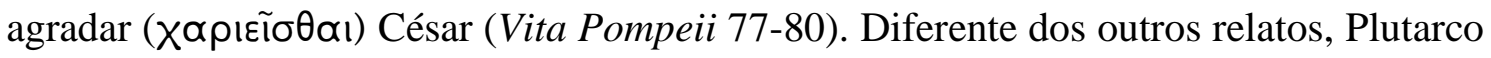
expõe também os motivos dos alexandrinos em temer o romano, não os tratando simplesmente como uma trupe de inconsequentes. Destaca também que houve ponderações por parte dos pensadores do local. Como Apiano, Plutarco denuncia de forma sutil o valor e preparo intelectual de Alexandria.

Dion Cássio observa que quando César soube da ida de Pompeu ao Egito, temeu que este, ao ocupar o país primeiro, se tornaria forte novamente. Foi então atrás dele com toda a velocidade. Quando chegou a Alexandria, os habitantes estavam

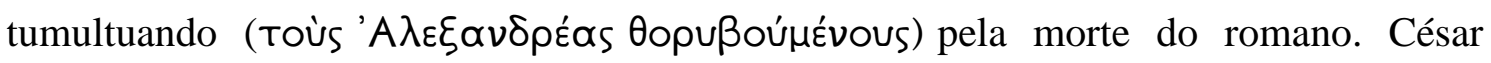
lamentou a morte de Pompeu e censurou os assassinos (Historiae Romanae 42.7.2).

Dion alude à ansiedade representada pela tomada do Egito, que se já era importante pela sua riqueza e produtividade, começou a representar também um foco de problemas e de desafio ao império. O autor relata que César:

Leu a eles o testamento do pai, que dizia que deveriam viver juntos,

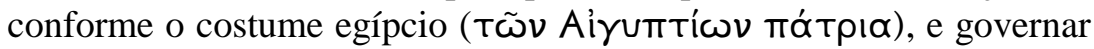

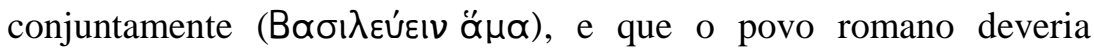
exercer a vigília sobre eles. Quando ele fez isso, e acrescentou que o

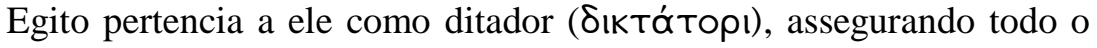

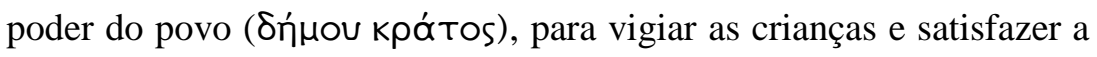
vontade de seu pai, ele concedeu o reino a eles dois, e assegurou Chipre a Arsinoé e ao Ptolomeu mais novo, a irmã e o irmão deles. Pois um medo tão grande se apoderou dele, que ele não apenas não se

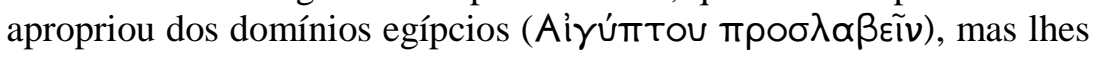
concedeu alguns de seus próprios. (Historiae Romanae 42.35) 


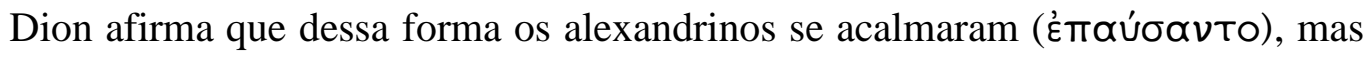

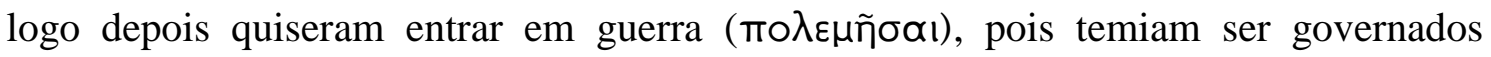

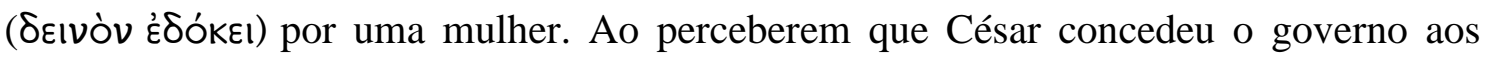

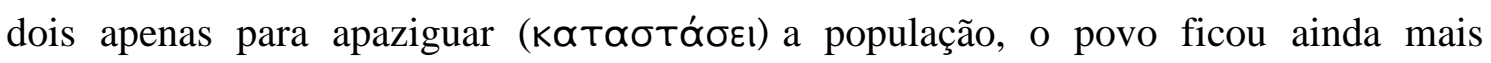
furioso, pois entendia que com o tempo o reino seria todo de Cleópatra. O autor ressalta que foi esse tumulto o desencadeador da guerra, descrita em pormenores na sequência (Historiae Romanae 42.36). Por fim, César dominou o Egito, no entanto, não o transformou em uma província, aparentemente por temer o caráter instável da população. Mas os pacificou, apesar de recear uma revolta ( $\phi \circ \beta \eta \theta \varepsilon i \varsigma)$, demonstrando a força romana em Alexandria (Historiae Romanae 42.44-46).

Floro relata que após a morte de Pompeu, desencadeou-se uma guerra contra César, que não tinha relação com a guerra entre as facções da cidade (Et in Aegypto quidem adversus Caesarem sine partibus bellum), pois Ptolomeu tinha tentado selar um trato de amizade com César através da morte de Pompeu, mas o destino clamou por vingança pelo assassinato de uma vítima tão ilustre. $\mathrm{O}$ autor sugere aqui a instabilidade da multidão por questões internas, que se intensificaram com a chegada do romano. Floro diz que César foi movido pela beleza de Cleópatra, ordenando que ela deveria ser restaurada ao reino, mas foi imediatamente cercado no palácio pelos assassinos de Pompeu. Embora tivesse apenas uma pequena tropa, César resistiu com grande coragem (Epitome Rerum Romanorum 2.13.55). Aqui o autor atribui o assassinato de Pompeu a uma tentativa de conquistar a amizade de César. O relato realça a sensibilidade e coragem do romano, em oposição a sua fraqueza diante de Cleópatra.

Suetônio relata que depois de vencer e terminar a guerra, César entregou o comando do Egito a Cleópatra e seu irmão, temendo que se o transformasse em província, poderia ser uma fonte de revolução (esset), sob a liderança de algum governante voluntarioso (violentiorem praesidem) (Divus Julius 35). Percebe-se que os autores notam a prudência e a sensibilidade de César nesse momento e não o criticam pela guerra, por entenderem que foi essa cautela que o fez poupar o Egito. Enquanto os outros autores ressaltam a sua decisão cuidadosa de não tomar o Egito nesse momento, o biógrafo reporta um rumor que chegou aos seus ouvidos: “(...) um relato espalhado em vários locais, que ele pretendia se mudar (quin etiam uaria fama percrebruit migraturum) para Ílion ou Alexandria, levando com ele os recursos do império, 
esvaziando a Itália de suas arrecadações, e deixando o comando da cidade aos seus amigos." Suetônio argumenta que esse foi mais um motivo para encorajar seus conspiradores a executarem o plano de matá-lo (Divus Julius 79). A citação de Suetônio é intrigante, pois é o único relato a mencionar essa intenção de César, e sugere que antes de Marco Antônio, Alexandria já era considerada como um potencial rival de Roma. Atribui a César certa carga de irracionalidade e fraqueza, talvez fruto do clima da propaganda de seus conspiradores. Suetônio poderia também transferir para César preocupações posteriores com relação à cidade. Como o intuito de suas biografias era justamente assinalar as fragilidades e os rumores a respeito de seus personagens ilustres, Suetônio demonstra menos receio de falar o que sabia sobre suas vidas do que outros autores mais envolvidos na vida política romana. No clima de incerteza do governo de César, em virtude das guerras civis recentes, seu caso com a rainha pode realmente ter suscitado esse tipo de desconfiança, segundo a qual o romano por vezes considerou Alexandria como uma alternativa para o governo do Oriente.

Suetônio declara que César teve casos amorosos com várias rainhas, dos quais o mais significativo foi com Cleópatra, com quem ele banqueteava (convivia) até o sol nascer. Depois convocou a rainha para a capital e a encheu das mais altas honras e presentes caros (maximis honoribus praemiisque), além de autorizá-la a dar seu nome ao filho gerado por ela. Suetônio diz que de acordo com autores gregos, a criança se parecia fisicamente com César. Marco Antônio declarou ao Senado que César e seus amigos realmente sabiam da criança. Contudo, o autor assinala sobre a publicação de um livro provando que a criança na realidade não era de César (Divus Julius 52).

Além de Suetônio, são poucas as fontes que detalham o envolvimento de César e Cleópatra, talvez por não terem o objetivo de ressaltar as fraquezas de uma personalidade romana tão ilustre (diferente de Marco Antônio posteriormente). Contudo, Plutarco argumenta de forma passageira que a guerra alexandrina não era

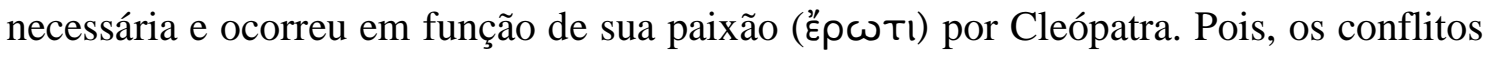
foram inglórios e cheios de perigos ( relato sobre Marco Antônio, Plutarco destaca a fragilidade de romanos tão fortes diante da rainha egípcia (De Vita Caesarum 48.2-3). César reconciliou a rainha com o irmão, ordenando a divisão do poder entre eles, porém quando notou que os oficiais do rei estavam tramando contra ele, mandou matá-los. Dessa forma, César foi forçado a entrar

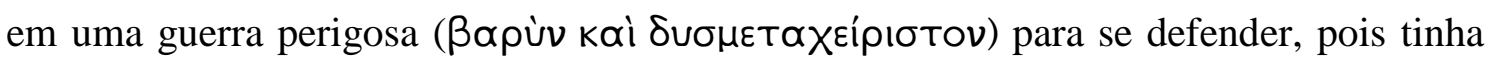




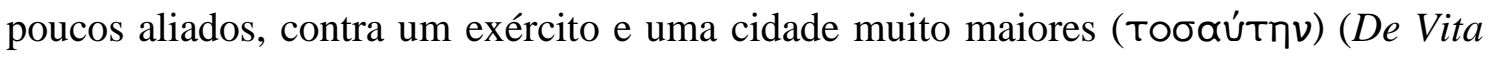
Caesarum 49.2). Após muitas batalhas, César venceu e deixou Cleópatra no trono e pouco tempo depois, ela teve um filho dele (De Vita Caesarum 49.4). Como veremos também no relato sobre Marco Antônio, Plutarco atribui grande peso aos sentimentos e a vida pessoal das personalidades e deixa os outros motivos parecerem banais em relação à importância das questões individuais. Dion ressalta o poder de persuasão da egípcia dizendo que assim que Cleópatra percebeu a sua influência sobre César, começou a lhe fazer pedidos (Historiae Romanae 42.34).

A relação estabelecida com Cleópatra não aparece com tanto peso nas fontes em comparação ao retrato de César como um homem prudente e cauteloso, um contraste com a multidão "inconsequente" de Alexandria. Ou seja, mais uma vez era um romano que salvava o Egito de seus governantes "fracos". É notável a mudança de ênfase dos autores ao tratar desse contexto, apesar de a riqueza agrícola egípcia ser ainda o principal motivador que adiava a incorporação do Egito. Para além do interesse romano na prosperidade egípcia, a guerra alexandrina demonstrou a César e aos romanos a força e grandeza da multidão da cidade e sua resistência a autoridades. Nesse sentido, dominar o território nesse momento poderia se tornar motivo de alvoroço e, portanto, não era uma atitude prudente. Assim, para manter a ordem a ocasião foi adiada, pois era arriscado entregar esse reino tão populoso a algum governante ousado, que poderia transformá-lo facilmente em foco de oposição a Roma.

O cenário pós-guerra alexandrina marcou um novo tipo de relação selada entre Egito e Roma, pois a aliança até então estabelecida entre os territórios sofreu abalos, fazendo os romanos tomarem consciência da necessidade de aumentar a vigília sobre Alexandria. Nesse contexto da presença de Pompeu e César em Alexandria, os aspectos mais marcados pelas fontes são a inconstância e falta de prudência dos alexandrinos em momentos cruciais, que contrastavam com a virtuosidade e racionalidade romanas, personificadas na figura de César. Não era mais a monarquia a desafiadora da ordem e causadora de problemas, mas o povo alexandrino e, provavelmente, alguns eminentes líderes (não nomeados).

A passagem de Pompeu e César por Alexandria resultou na maior presença da cidade nos relatos da época, pois ela deixou de ser secundária nos eventos da República e protagonizou momentos cruciais da história romana. Portanto, os autores latinos são os mais preocupados em narrar esse momento, em contraste com o período anterior, 
mais descrito por gregos. Ou seja, os eventos ocorridos na cidade (a morte de Pompeu e guerra com César) tornaram-se questão de Estado. Antes a realeza ptolomaica era o principal alvo de crítica na caracterização de Alexandria. Contudo, a partir desse momento, a população e os acontecimentos contemporâneos tornaram-se o foco, pois o maior espaço ocupado pelo Egito na política romana era notável.

\subsection{Cleópatra e Marco Antônio: hegemonia romana em risco}

O intuito desta parte do capítulo é discutir como as fontes tratam os desdobramentos do relacionamento entre Cleópatra e Marco Antônio, que resultaram na guerra civil com Otávio e por fim, na tomada do Egito. É possível perceber que as caracterizações feitas a respeito da relação privada do casal traduzem suas percepções sobre Alexandria. O objetivo é investigar como esse contexto foi interpretado na tradição de escritos da época e posteriormente, justamente por se tratar do momento que marcou a vitória de Roma sobre o Egito.

Os relatos sobre Cleópatra falam do ponto de vista romano e são extremamente condenáveis a rainha. Nesse sentido, um projeto político aparentemente ambicioso foi reduzido nas narrativas à fraqueza de um romano (Antônio) que começou a agir cegamente em virtude da paixão pela rainha egípcia (Cleópatra). Assim, o projeto político maior pretendido pelo casal não é abordado.

Se a morte de Pompeu representou para os romanos uma conscientização da necessidade de um cuidado especial com o Egito por parte de Roma, a relação entre Cleópatra e Marco Antônio, que ajudou a desencadear a guerra com Otávio (entre 39 e 31), forneceu a certeza que faltava. O peso dado à rainha e sua relação com um romano tão influente como Marco Antônio é visível no nosso objeto. A literatura sugere que nessa ocasião a supremacia romana esteve em vias de fragmentação, daí a preocupação em relatar extensivamente esse cenário único e em atribuir todo o peso do momento à ousadia de uma mulher, que "escravizou" um romano fraco e vulnerável.

A concepção de Estrabão é que Otávio, depois de destruir Cleópatra e Marco

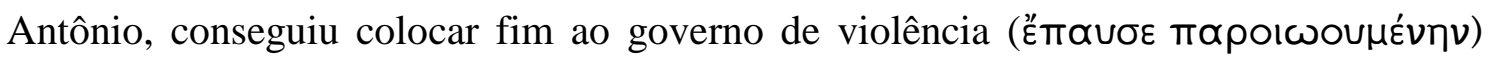
dos Ptolomeus (Geographica 17.11). O autor só faz referências passageiras à época, 
pois considerava que os últimos momentos da dinastia eram episódios insignificantes da história romana (YOYOTTE, 1997, p. 35).

A caracterização de Cleópatra por Josefo é extremamente condenável, pois além de todas as atitudes inescrupulosas contra os romanos, ela destinou aos judeus um tratamento desonroso (ingrata). E ao seduzir Antônio, o tornou um inimigo de sua própria pátria (corrumpens amatoriis rebus et patriae inimicum) (Contra Apionem 2.56.5). O interesse de Josefo em depreciar a rainha estava relacionado com a intenção de vitimizar os judeus, portanto, a referência é precisa.

Já foi visto acima a extrema condenação de Lucano ao Egito e à Cleópatra no contexto do encontro da rainha com César. O autor faz também uma observação remetendo ao período posterior. Relata que Cleópatra aterrorizou (terruit) o Capitólio, ameaçando governar (teneret) todo o mundo. Além disso, não se podia condenar Antônio por ceder aos seus encantos, pois até o virtuoso César foi sua vítima (Pharsalias 10.65-75).

A narrativa mais extensa, detalhada e emotiva sobre o casal está em Plutarco. Marco Antônio é retratado como um general exemplar, que sempre tinha se deixado levar por excessos e, quando conheceu Cleópatra, se perdeu definitivamente. Sua personalidade era tão fraca, que passou a agir como um mero fantoche e completo escravo da rainha. Essa é a idéia central da biografia de Marco Antônio, e a visão mais consolidada na tradição sobre o rumo da relação entre o casal.

Plutarco enfatiza a ambição de Marco Antônio e seu interesse no Egito desde cedo. No contexto da expulsão de Aulete, quando o rei tentou persuadir Gabínio a ajudá-lo a recuperar o Egito, a maior parte dos oficiais se opôs ao plano. No entanto,

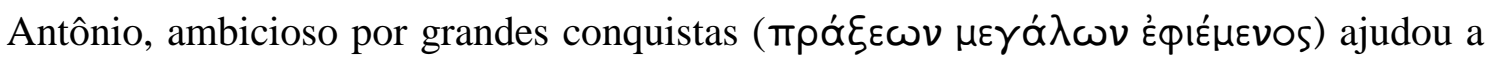
convencer Gabínio do projeto (Vita Antonii 3.2). E quando chegou com Ptolomeu e sua cavalaria em Pelusium, Ptolomeu, levado pela ira (ópyñs kaì híoous) (em decorrência

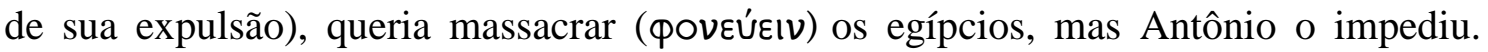
Além disso, provou a todos a sua capacidade de liderança em batalhas e competições. Por tudo isso, recebeu recompensas honrosas e conquistou uma grande reputação ( $\lambda o ́ \gamma o v)$ entre os alexandrinos e os romanos da expedição (Vita Antonii 3.4). Plutarco relata em detalhes todas as façanhas de Antônio nesse meio tempo até conhecer Cleópatra na Cilícia, quando toda a sua personalidade foi alterada, ao ser tomado por 


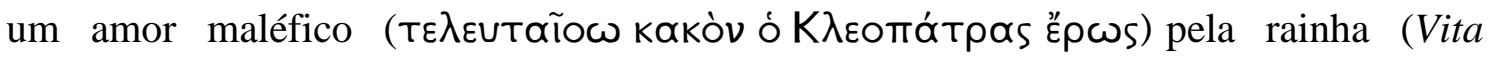
Antonii 25.1).

Apesar de ser alexandrino, Apiano reproduz a mesma visão de Plutarco a respeito da parceria formada por Antônio e Cleópatra. Relata que Antônio sucumbiu aos

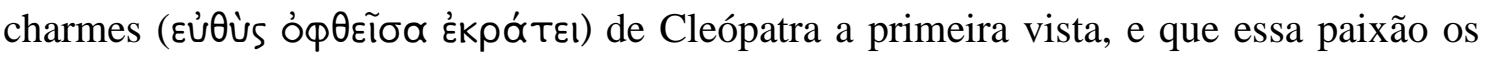
arruinou e destruiu (к๙коũ) o Egito (Bellum Civile 5.1.1). Apiano narra que na Cilícia, Antônio ficou admirado pela presença de espírito da rainha e se tornou seu escravo. $\mathrm{O}$ autor observa que o romano já tinha se apaixonado por ela quando ainda era uma menina, no momento em que estava servindo de cavaleiro sob Gabínio e afirma que desde o momento em que conheceu Cleópatra seu interesse em questões públicas começou a diminuir (Bellum Civile 5.1.8.21).

Plutarco relata que Délio, mensageiro de Antônio, quando viu a beleza e

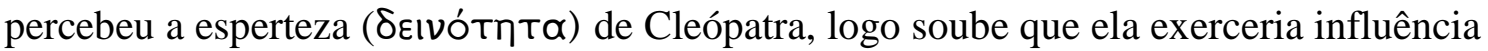
sobre ele. A rainha foi ao seu encontro, confiante no encanto que tinha exercido em César e no filho de Pompeu (Vita Antonii 25.4). Ofereceu um jantar a Antônio, que ficou impressionado com toda a preparação. No dia seguinte ele retribuiu, mas não conseguiu superar a sofisticação $(\lambda \propto \mu \pi \rho o ́ t \eta \tau \alpha)$ da festa oferecida por ela (Vita Antonii 27). Em seguida, passou uma temporada em Alexandria, se divertindo

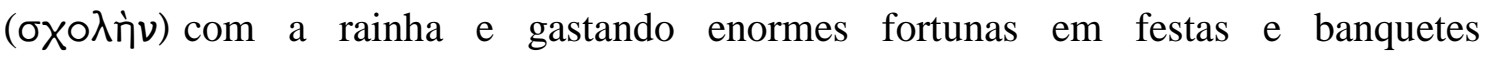

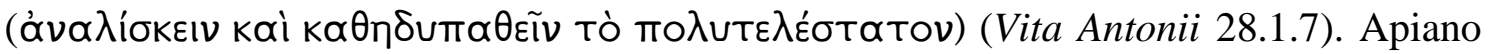
relata que ele passou o inverno na cidade sem as insígnias de seu posto, e com os hábitos e modos de vida de um cidadão comum. Até deixou de lado seus cuidados de general, e usou vestimentas gregas ao invés das romanas. Além disso, visitou templos, conversou com os eruditos do ginásio ( $\gamma \cup \mu \nu \alpha$ ó $\sigma$ ì $\phi ı \lambda \circ \lambda o ́ \gamma \omega \nu)$ e passou grande parte do seu tempo convivendo com gregos (Bellum Civile 5.1.11). Mais uma vez, como já visto na narrativa sobre a passagem de César por Alexandria, Apiano traz à tona o cenário erudito de Alexandria constituído no Ginásio e enfatiza a identidade grega da cidade, algo que por ser alexandrino lhe interessaria avivar. Dessa forma, chama a atenção para a tradição intelectual de cidade, algo enfraquecido nas representações externas sobre a metrópole.

Plutarco afirma que os alexandrinos adoravam Antônio pelo seu jeito cômico

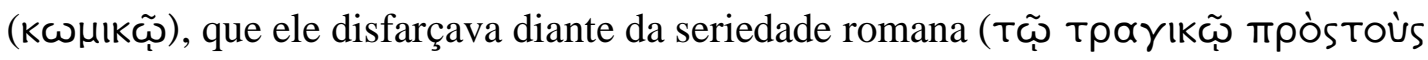


'Pouáíous) (Vita Antonii 29). No entanto, enquanto se divertia, recebeu notícias de Roma e soube que a Pártia estava tomando a Ásia e a Síria. Nesse momento, como se tivesse acordado de um sonho, partiu para lá, o que foi uma ocasião para restabelecer a paz com Otávio, e então combinaram a divisão do império: Otávio ficaria com o Ocidente, Antônio com o Oriente e Lépido com a África (Vita Antonii 30). Nesse contexto também, Antônio aceitou o acordo do casamento com Otávia, irmã de Otávio, pois ainda estava agindo racionalmente e sabia que não podia fazer de Cleópatra sua esposa (Vita Antonii 31).

Antônio foi apontado por Otávio como Pontífex Maximus e ambos estavam em acordo politicamente, embora o conselheiro de Antônio o alertasse que sua sorte estava sendo ofuscada por Otávio (Vita Antonii Antônio 33). O autor ressalta que nesse momento, a paixão de Antônio por Cleópatra, ressurgiu enquanto passava pela Síria. Nas palavras de Plutarco:

Quando ela veio ao seu encontro, ele adicionou aos seus domínios outros presentes nada sutis ou insignificantes, a saber: Fenícia, Coele Síria e Chipre, e grande parte da Cilícia; e mais adiante, uma parte da Judéia produtora de bálsamos, e toda a parte da Arábia Nabatea que desembocava no mar de fora. Esses presentes em particular perturbaram os romanos. Ele ainda deu presentes a muitos cidadãos comuns, e domínios de grandes povos ( $\dot{\theta} \theta \tilde{\omega} v \mu \varepsilon \gamma \alpha \dot{\alpha} \lambda \omega \nu$ ), e privou muitos monarcas de seus reinos, como por exemplo, Antígono o judeu, a quem ele chamou e decapitou, apesar de nenhum outro rei ter sido punido diante dele. Mas o mais vergonhoso foram as honras conferidas a Cleópatra. E ele aumentou o escândalo divulgando que tinha tido dois filhos com ela, e chamou um de Alexandre e a outra de Cleópatra, e os sobrenomes do primeiro era Sol e da outra Lua. Mas como ele era adepto de se orgulhar de feitos vergonhosos, ele dizia que a grandeza do império romano não se manifestava no que os romanos recebiam, mas no que concediam (Vita Antonii 36).

Plutarco menciona os rumores que Antônio estava tão ansioso para ver Cleópatra logo, que começou a guerra contra a Pártia antes do tempo e começou a agir de forma

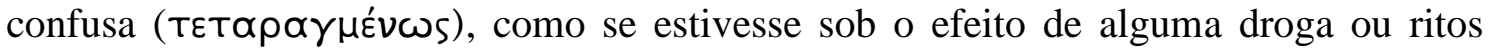
mágicos (Vita Antonii 37).

Sobre o mesmo contexto da distribuição de terras, a narrativa de Dion Cássio ressalta ainda mais a gravidade e audácia dos feitos de Antônio:

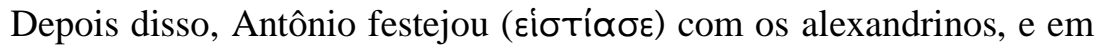
assembléia fez Cleópatra e seus filhos se sentarem ao seu lado; e 
também ao se dirigir para o povo comandou que ela deveria ser chamada de rainha dos reis, e Ptolomeu, que eles chamaram de

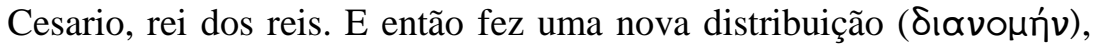
dando a eles o Egito e adicionando Chipre; pois ele declarava que na verdade uma era a esposa, e o outro o filho do antigo César, e proferia que estava tomando essas medidas em nome de César, apesar de que sua intenção era reprovar César Otaviano que era apenas um adotado (поптTòs) e não seu filho verdadeiro. Além de lhes conceder isso, ele prometeu que daria aos seus próprios filhos com Cleópatra os

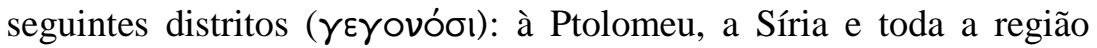
ocidental do Eufrates até o Helesponto; à Cleópatra a Cirenaica na Líbia; e ao seu irmão Alexandre, a Armênia e o resto das fronteiras

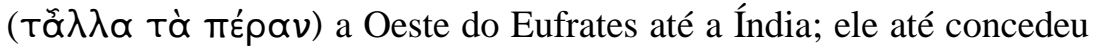

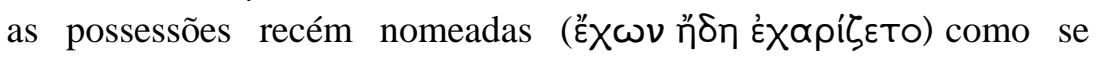
fossem suas. Não apenas ele disse isso em Alexandria, mas mandou um comunicado a Roma, para assegurar a ratificação (Kũpos $\lambda \alpha \dot{\beta} \beta n ̣)$ do povo de lá também. Nenhum desses comunicados, contudo, foram lidos em público

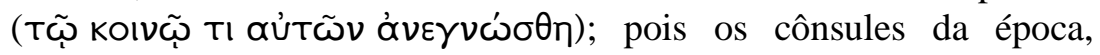
Domitio e Sósio, sendo extremamente devotos a ele, não quiserem

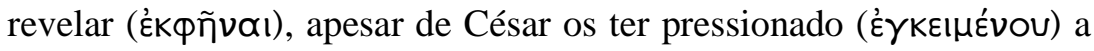
fazer isso (Historiae Romanae 49.41)

Dion Cássio afirma que nesse momento os romanos ficaram com medo de Antônio transferir a sede de poder para Alexandria, e acredita que Cleópatra tinha a

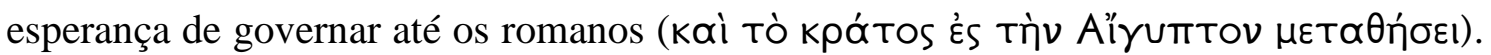
O autor salienta ainda, que Antônio começou a usar adereços orientais (ákıvóknv) (Historiae Romanae 50.4).

Plutarco relata que todos achavam que Antônio tinha destratado Otávia e, mesmo assim, Otávio tentou convencê-la a ficar do seu lado na disputa, mas ela não aceitou e continuou cuidando dos seus filhos, e apoiando a causa de Antônio, o que foi ainda mais ultrajante para a sua imagem, pois não se conformavam dele tratar de tal forma uma mulher tão devota como essa. Antônio também era odiado pela distribuição

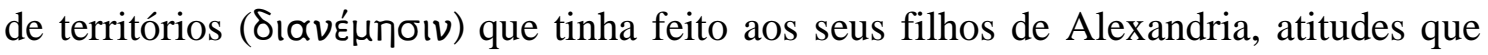
estimulavam ódio entre os romanos. Diziam ainda, que ele encheu o Ginásio com uma

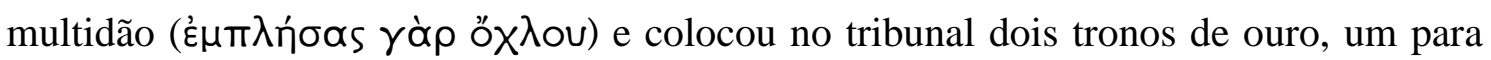
si e outro para Cleópatra, e outros menores para seus filhos. Novamente Plutarco enfatiza o absurdo da concessão de terras a Cleópatra, pela qual Antônio era odiado

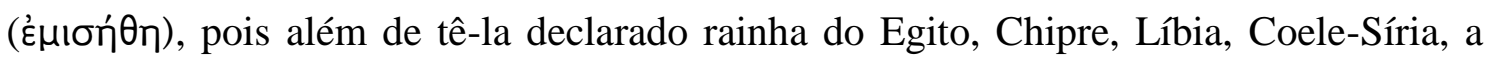
autorizou a compartilhar o trono com Cesário. O casal vestia os filhos como reis e Cleópatra se apresentava como a nova Ísis (Vita Antonii 54). 
Plutarco observa que ao reportar tudo isso ao Senado e diante do povo, Otávio tentou inflamar a multidão ( $\pi \propto \rho \omega ́ \xi \cup v \varepsilon$ тò $\pi \lambda \tilde{n} \theta 0 \varsigma$ ) contra Antônio (Vita Antonii 55). Os próprios amigos de Antônio da ordem consular passaram para o lado de Otávio e o informaram sobre o seu testamento, que foi lido no Senado. Antônio deu especial ênfase à cláusula com relação ao seu enterro, ordenando que seu corpo deveria ser enviado a Cleópatra e enterrado no Egito, mesmo se ele morresse em Roma (Vita Antonii 58). Suetônio relata que com a leitura do testamento nomeando suas crianças com Cleópatra entre seus herdeiros, Antônio foi declarado inimigo público do povo de Roma (Divus Augustus 17). Eleanor Huzar argumenta que foi a propaganda de Otávio que revelou (ou inventou) o testamento, pois sua realidade é muito suspeita (1985, p. 110).

Além da divulgação do testamento, o fato de Antônio ter celebrado os triunfos em Alexandria e não em Roma foi a oportunidade perfeita para a propaganda de Otávio começar a agir (SPENCER, 2002, p. 24). Depois de muita preparação, este decidiu proclamar guerra contra Cleópatra e tirar dela a autoridade conferida por Antônio. Diziam ainda que muitos sinais divinos contra Antônio apareceram antes da guerra (Vita Antonii 60).

Plutarco descreve detalhadamente as batalhas até a derrota final de Cleópatra e Antônio em Actium. Após o ocorrido, Antônio enviou uma embaixada a Otávio na Ásia,

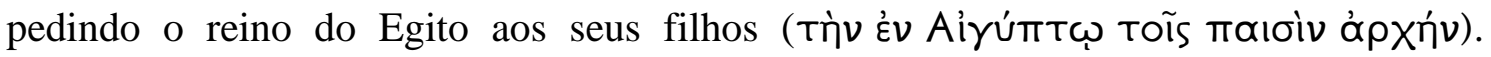
Solicitava também poder viver como um cidadão comum em Atenas. Otávio recusou as propostas de Antônio, mas respondeu a Cleópatra que ela receberia tratamento razoável dele, se condenasse Antônio à morte ou o expulsasse do Egito (Vita Antonii 72).

Imediatamente após a morte de Antônio, Otávio mandou buscar Cleópatra, pois queria que ela se submetesse com vida, considerando que sua exibição em uma procissão em Roma seria uma grande glória ao seu triunfo

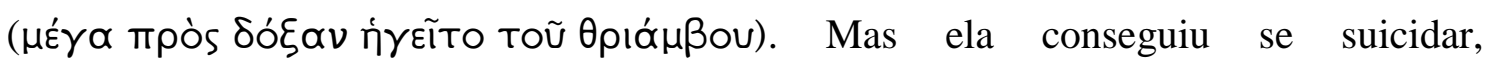
atrapalhando os planos do vencedor. Esses momentos finais de Cleópatra e Antônio são narrados detalhadamente por Plutarco de forma emotiva e dramática (Vita Antonii 7879). O relato do autor é nitidamente mais humano e simpático a Antônio e Cleópatra do que as outras fontes antigas.

Com relação aos filhos de Antônio, Plutarco afirma que seu filho com Fúlvia foi traído e morto pelo tutor Teodoro. Os filhos de Cleópatra foram mantidos sob custódia e depois criados por Otávia. Mas Cesário, que tinha sido mandado pela mãe para a Índia, 
foi convencido pelo seu tutor a voltar ao Egito, quando foi então morto a mando de Otávio. No entanto, este permitiu que o corpo de Antônio fosse enterrado com toda a pompa por Cleópatra (Vita Antonii 81-87). Cleópatra tinha 39 anos quando morreu, tinha sido rainha por 22 e dividido o poder com Antônio por 14 anos. No desfecho do relato, Plutarco observa que as estátuas de Antônio foram derrubadas, mas as dela foram mantidas, através de suborno a Otávio (Vita Antonii 86).

Por ter conquistado César e depois Antônio, Cleópatra esperava dos egípcios e dos romanos não apenas o perdão, mas a soberania de volta. Otávio estava ansioso para tomar posse de seus tesouros e carregá-la viva como triunfo

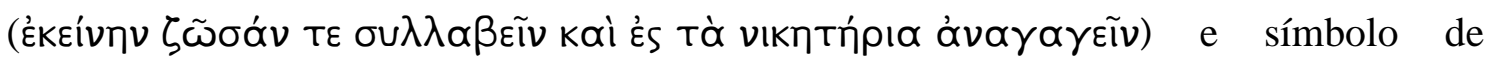

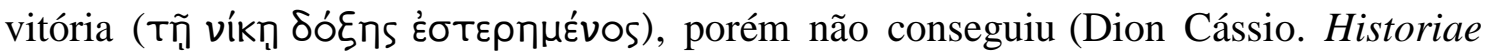
Romanae 51.9-14).

Veleio Patérculo avalia que à medida que o amor de Marco Antônio por Cleópatra aumentava, seus vícios também começaram a crescer (Crescente deinde et amoris in Cleopatram incendio et vitiorum), estimulados pela busca por poder (facultatibus licentiaque et adsentationibus aluntur), e por isso decidiu trair sua pátria (cum ante novum se Liberum Patrem appellari iussisset) (Historiae Romanae 2.82.4.8). Ou seja, aqui a união foi interpretada como uma decisão consciente de Antônio de proclamar guerra contra a sua própria terra e promover uma divisão de poderes. Dessa forma, ele não seria apenas o escravo de Cleópatra, mas tinha ambições de aumentar a sua autoridade através da parceria com a rainha. Na visão de Patérculo, o amor pela rainha apenas lhe deu coragem para executar suas ações.

Sêneca relata que no reino de Cleópatra o Nilo não encheu. O fato é interpretado pelo autor como sinal da perda de poder da rainha (potentibus defectionem), pois o império de "Cleópatra e Marco Antonio" tinha realmente caído (defecit) (Naturales Quaestiones 4a.2.16). Percebe-se toda a simbologia associada a essa união, buscando-se inclusive sinais sobrenaturais para promover Otávio e legitimar sua vitória. Mesmo que Sêneca acreditasse nesse sinal, ou o tivesse inventado, a motivação para mencioná-lo indica o grau de preocupação provocado por tal parceria e a necessidade de criar uma reação contrária nos romanos. O fato de o autor definir a relação do casal e o que foi alcançado através dela como o "império de Cleópatra e Marco Antônio" indica que na visão romana não se tratava de algo pequeno, mas sinaliza a existência de um plano grandioso e estruturado. 
Suetônio salienta que depois da vitória em Actium, Otávio seguiu para o Egito por uma rota indireta pela Ásia e Síria, armando um cerco a Alexandria (petit obsessaque Alexandrea), onde Antônio tinha se refugiado com Cleópatra, e rapidamente tomou a cidade (brevi potitus est). $\mathrm{O}$ autor observa que apesar de Antônio ter tentado fazer as pazes no último encontro, Otávio o forçou a cometer suicídio. Ele desejava deixar Cleópatra viva para o seu triunfo (servatam triumpho magno), o que não ocorreu. Otávio permitiu a ambos a honra de um enterro na mesma tumba, ordenando que o mausoléu começado a construir por eles fosse terminado. Condenou Cesário a morte, mas poupou o resto dos descendentes do casal e permitiu que Otávia os criasse como se fossem seus próprios parentes (Divus Augustus 17). Percebe-se a forma elogiosa e bondosa com que Suetônio retrata Otávio, principalmente quando enfatiza o fato do vencedor ter poupado os filhos de Antônio e Cleópatra. O autor infere que era esperado dele uma postura vingativa em relação aos descendentes do casal. Suetônio já fornece elementos também para analisar o peso que a propaganda de Otávio contra Antônio tivera nesses relatos. Ou seja, a caracterização de Antônio nas fontes não é sobretudo fruto dessa propaganda? E até que ponto o fato de Otávio ter realmente vencido Antônio não foi o que ditou o tom do que seria divulgado a respeito de Antônio e Cleópatra?

Como o período de conquista não é o foco da obra de Tito Lívio, ele apenas se refere ao contexto brevemente nos seus resumos. Lívio conta que ao ser derrotado em Actium, Antônio fugiu para Alexandria e quando estava cercado por Otávio e totalmente sem esperança, cometeu suicídio depois de ouvir a notícia falsa (falso rumore) a respeito da morte de Cleópatra. Depois de tomar Alexandria, e da rainha ter se matado, para evitar cair nas mãos do vitorioso, Otávio voltou a Roma para celebrar seus três triunfos (in urbem reuersus tres triumphos) (Periochae 133.1).

$\mathrm{Na}$ fase final da guerra, Dion Cássio relata que Otávio fez um discurso ao seu exército destacando que os romanos ultrapassavam todos os homens em valor e por isso, não podiam se dobrar justamente a egípcios. Através das palavras de Otávio, Dion Cássio aproveitou para realçar sua reprovação aos egípcios (aqui inclui alexandrinos

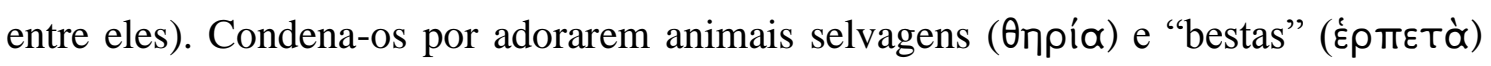
como deuses, por embalsamarem seus próprios corpos para alcançarem a eternidade, observa que eram descuidados nos enfrentamentos, mas fracos em coragem

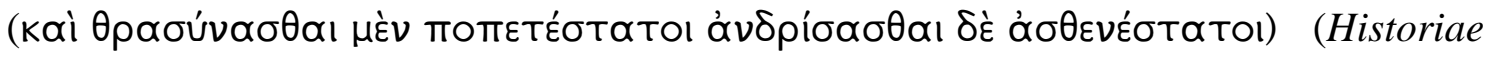
Romanae 50.24). Dion censura Antônio por abandonar seus hábitos ancestrais e adorar 
deuses egípcios. O mais grave dos feitos de Cleópatra foi tentar colocar a mão nas possessões romanas com a ajuda de um romano (Antônio). O autor diz que Antônio

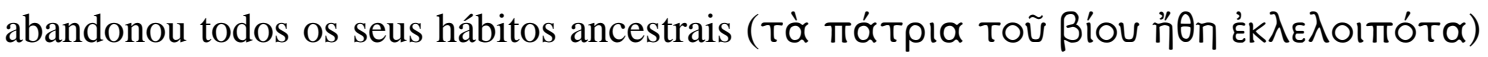
e adotou costumes bárbaros e estrangeiros

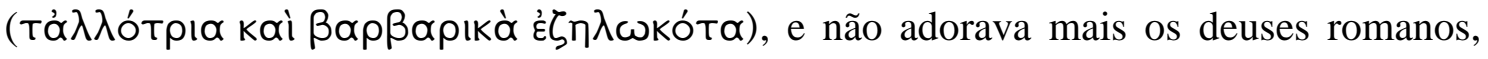
mas Ísis e Selene, e adotou para si mesmo o título de Osíris e Dionísio. Além disso, deu

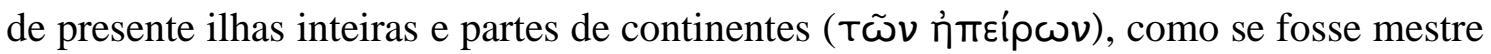
(KupıєúovTa) de toda a terra e mar (Historiae Romanae 50.25).

Dion continua o discurso de Otávio dizendo que ele mesmo era completamente devoto a Antônio, uma prova disso foi ter lhe concedido a sua irmã para casar. Mas ele a insultou e preferiu uma egípcia, e ainda deu para os filhos dessa mulher muitas possessões romanas. Como ele se tornou seu completo escravo e declarou guerra à

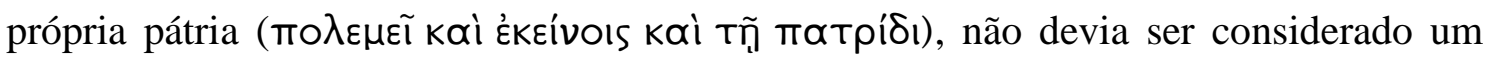
romano, mas um egípcio (Airútrtiov), pois recusou os títulos da sua terra

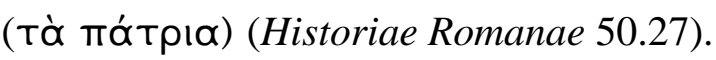

Dion Cássio coloca na boca de Otávio a posição convencional dos romanos diante de Alexandria há 250 anos (REINHOLD, 1980, p. 98). O autor junta vários elementos no trecho acima: o exotismo e aversão causados pela adoração de animais dos egípcios, a grandeza da multidão alexandrina e sua ousadia nos enfrentamentos. $\mathrm{O}$ relato de Dion Cássio enfatiza mais que o de Plutarco a orientalização de Antônio, e demonstra isso sendo usado por Otávio como um dos fatores para influenciar a opinião pública. A propaganda romana contra Antônio enfatizou sua adoção de um modo de vida extravagante, algo típico dos orientais e pouco apropriado para um romano. As festas organizadas por Cleópatra tinham um lado infantil, debochado e liberal, que era irritante para os romanos (GODDIO; BERNAND, 2004, p. 139). Até que ponto a orientalização de Antônio não diz mais da propaganda pró-Otávio do que das reais atitudes de Antônio? Walker (2003, p. 197) argumenta que a partir desse contexto de propaganda contra Cleópatra, a literatura imperial romana começou a disseminar com maior ênfase uma imagem a respeito do final do período ptolomaico como um tempo de excessos, imoralidade e promiscuidade.

Segundo Dion, Otávio usou todos esses argumentos e aproveitou o contexto já complicado para aumentar ainda mais a repulsa romana pelos egípcios. Fica claro que 
Dion esta aproveitando o momento para deixar claro sua própria aversão (que reforça em outros momentos) e atribui todo seu desprezo aos egípcios a esse cenário único em que justamente esse povo ameaçou Roma.

Duzentos anos depois da conquista, a vivacidade do relato de Dion demonstra o quanto essa conjuntura tumultuada ainda repercutia na mentalidade romana, ao relatar que a ambição de Cleópatra era a transferência da sede imperial para Alexandria. Os acontecimentos foram propagados dessa forma no imaginário romano no decorrer de todo esse tempo, o que demonstra o peso dos eventos no momento da divulgação e sugerem que uma ameaça à hegemonia romana foi realmente temida.

$\mathrm{Na}$ época dos acontecimentos os romanos precisavam de um “álibi” para controlar os planos ousados dos alexandrinos. Portanto, Cleópatra e Antônio foram o par perfeito. A eles foi direcionada toda a rejeição que estava se consolidando contra os alexandrinos, em virtude das ocorrências anteriores.

Segundo Dion Cássio, a adoção de Antônio de um modo de vida egípcio foi ultrajante para os romanos. Otávio aproveitou a propaganda contra ele para reforçar ainda mais o exotismo do modo de vida egípcio. Ou seja, não apenas a concessão de terras preocupava, mas a possível adoção dos romanos de hábitos estrangeiros era temida, já que o casal tinha exercido influência para além das questões políticas. $\mathrm{O}$ fato de Otávio ter ganhado a opinião pública foi crucial nesse contexto, como as fontes indicam. Huzar sugere abaixo:

A propaganda e a guerra contra Cleópatra despertaram uma xenfobia histérica na Itália, conforme os rumores que César, e depois Antônio planejavam mudar a capital imperial de Roma para Alexandria, um cidade considerada licenciosa, corrupta e perigosa. Poucos romanos haviam visitado o Egito, e ainda menos lá tinham se estabelecido, e o distanciamento se somava ao medo. Romanos cultos admiravam as tradições egípcias e suas antiguidades; e um número já considerável de peças de arte estava em Roma ou estava sendo copiada por artesãos romanos. Os cultos de Ísis e Serápis estavam firmemente ganhando adoradores na Itália. O comércio gerou o intercâmbio entre mercadores, marinheiros e viajantes, assim como entre artigos. (1988, p. 348$)^{25}$

\footnotetext{
25 "The propaganda and war against Cleopatra had roused an hysterical xenophobia in Italy, as had the rumors that Caesar, then Antony planned to move the imperial capital from Rome to Alexandria, a city judged licentious, corrupt and dangerous. Few Romans had visited Egypt, still fewer had settled there, and remoteness added to the fear. Nevertheless, more sympathetic feelings were also current. Educated Romans admired Egyptian traditions and antiquities; and already a number of Egyptian art pieces were in Rome or were being copied by Roman craftsmen. The Isis and Sarapis cults were steadily gaining
} 
Bingen entende a ação do casal como uma rivalidade ao poder supremo de Roma (2007, p. 49). Goddio e Bernand (2004, p. 107) consideram que o sonho de Cleópatra era restaurar o reino dos Ptolomeus e evitar que o Egito se submetesse a Roma, e, além disso, pretendiam governar todo o Império Romano a partir de Alexandria. Huzar acredita que Cleópatra lutava por um estado mediterrânico governado a partir de Alexandria, mas para isso precisava de Roma, daí sua relação com Antônio. Ou seja, a relação foi estratégica e vantajosa para ambos, que estavam disputando o controle pelo mundo romano (1985, p. 107). Percebe-se como a historiografia moderna já atribui às atitudes de Antônio um papel mais ativo e consciente e entende que ele não deve ser interpretado nesse processo como um mero "apêndice" de Cleópatra. Pelo contrário, acredita-se que ele tinha interesse nessa parceria com a rainha egípcia.

$\mathrm{O}$ fato de as fontes atribuírem tanto peso e responsabilidade a Antônio e Cleópatra demonstra que se Alexandria era temida como rival de Roma, alguém teria que ser responsabilizado por isso. Ou seja, os autores elegem o casal como o grande culpado por quase tornar real, uma preocupação central dos romanos. A ênfase na relação de duas figuras de grande peso naquele cenário foi impactante, porém mais ameaçadoras foram as repercussões desse envolvimento, que era uma possível divisão das terras romanas. Era necessário culpar alguém por essa remota possibilidade e a tradição de escritos da época elegeu os dois como responsáveis no contexto em questão.

Para Gurval (1995, p. 30), a propaganda pré-guerra de Otávio só alcançou tamanho impacto porque foi ao encontro do sentimento popular, que entendia a rainha egípcia como a causadora dos conflitos civis. Mesmo que existisse algum sentimento popular aflorando, o fato de Otávio ter explorado esses anseios e as atitudes do casal com as armas à disposição para eliminar todo o apoio que ainda restava a Antônio, demonstra uma estratégia de propaganda cuidadosa, com a intenção de massacrar os oponentes.

As fontes condenam a postura de Antônio (denotando a repercussão da propaganda), mas também evidenciam como Otávio se aproveitou dessas atitudes para lançar sua propaganda de oposição. Assim, por mais que atribuam certa culpa a Antônio e Cleópatra no decorrer dos acontecimentos, apontam como tal publicidade foi decisiva no rumo dos eventos. Nesse sentido, mesmo que os escritos ainda reforçassem o commodities." 
impacto da onda anti-Antônio e Cleópatra, estes têm um apelo diferente da poesia latina, propagada durante os eventos e logo após Actium, que sem maiores explicações apenas fazem referências pontuais ao medo romano de Cleópatra (Propércio. Elegiae 3.11.29-56); à Cleópatra como a rainha que ameaçou o Capitólio e a morte do Império (Horácio. Odes 1.37); Cleópatra como a esposa egípcia de Antônio, que trouxe deuses monstruosos com ela (Virgílio. Aeneid 8.696-697). A poesia estava inteiramente a serviço de Otávio. Assim, fazia uso de lugares-comuns e antigos preconceitos contra o Egito para suscitar uma oposição ao local, demonstrando um conhecimento superficial de suas tradições. A força da propagação fora tanta, que esses padrões de aversão se repetiam em trabalhos de poetas que apoiavam Otávio, e delinearam o retrato do Egito na poesia dos séculos seguintes (THOMPSON, 2000, p. 18). Dessa forma, uma reflexão sobre a imagem egípcia divulgada no império, principalmente no meio oficial latino, deve considerar o impacto da propaganda de Otávio, que enfocava justamente nos aspectos mais "bizarros" dos egípcios.

Em um artigo específico sobre as imagens do Egito divulgadas a partir da poesia romana no tempo de Otávio, Herwig Maehler argumenta que durante o séc. I a.C. quase não há referencias ao povo egípcio na literatura romana e que foi a batalha de Actium a responsável por realizar uma mudança completa na percepção do Egito entre os intelectuais romanos. Mesmo sob Otávio, quando os poetas abordam o local de forma a legitimar a sua vitória, nenhum deles se esforçou para entender a cultura egípcia. $\mathrm{O}$ conhecimento sobre suas tradições era superficial e baseado no senso comum, pois um entendimento mais completo sobre o Egito não era prioridade dos autores. Os poetas julgam o Egito de acordo com seus próprios contextos e preocupações específicas. Ou seja, reproduzem o estereótipo divulgado por Otávio para situações particulares. Essa imagem negativa predominou principalmente entre os intelectuais em Roma, não sendo perceptível nenhum interesse de se informar sobre a contemporaneidade egípcia para mudar esse quadro (2003, p. 213-215). Nesse sentido, a situação com relação à época de Heródoto tinha mudado, embora não radicalmente, pois os relatos do Egito ainda oscilavam entre a fascinação e a aversão (2003, p. 19).

Anteriormente à conquista era notável a formação de um contexto de Egitomania em Roma. Contudo, a onda de aversão ao Egito divulgada principalmente pela poesia do séc. I d.C., fruto da propaganda de Otávio, alterou substancialmente esse quadro. Segundo Caroline Vout (2003, p. 180), o resultado de Actium, e da política antiegípcia 
que o precedeu, foi tornar tudo o que era egípcio mais carregado e cobrado do que antes, e do que seria para sempre, na história de Roma. Porém, ainda havia certa ambiguidade na forma de apreender a cultura egípcia. Assim, durante todo o período romano se passou a ser um inimigo "maligno", era ao mesmo tempo, uma cultura a ser copiada em alguns aspectos (VOUT, 2003, p. 182).

A opinião de Maehler é que no final do séc. II d.C. Cleópatra e Actium não “assombravam" mais os romanos (2003, p. 205). É possível perceber que entre os latinos, o impacto maior da propaganda de Otávio é mais visível entre os autores do séc. I d.C. e mesmo assim o tratamento do assunto é mais pontual e já direcionado para as conclusões e ao julgamento negativo sobre Cleópatra. Contudo, os gregos Plutarco, Apiano e Dion Cássio que escreveram entre os séculos II e III remetem ao contexto de Actium de maneira mais detalhada que os latinos, sugerindo que as ressonâncias da história ainda ecoavam de alguma forma.

O fato do contexto não ser mais comentado na tradição latina sugere uma tentativa de silenciar para esquecer? É possível que o assunto não fosse mais abordado, pois não havia interesse na alteração da mentalidade predominante em relação a esse episódio. Ou seja, a imagem negativa, divulgada pela poesia de apoio a Otávio, tornouse a preponderante e era conveniente manter a mesma representação entre os latinos. É também plausível que os eventos ressoaram mais entre os autores gregos, pois foram mais impactantes e duradouros no ambiente de vivência menos romanizado. Ou seja, em meio ao mundo de tradições helenísticas, o temor e a repercussão causados por uma rainha egípcia produziram mais alarde.

Para além das consequências do relacionamento entre Cleópatra e Antônio e o que tal relação gerou, é essencial sublinhar que as ressonâncias da estória e o modo como foi perpetuado na documentação refletem mais a propaganda de Otávio contra o casal do que propriamente o alcance dos acontecimentos no Egito. Indicam também as maiores repercussões da história em um público restrito. Ou seja, percebe-se que nas esferas máximas de poder romano, e nas redes de elites interligadas ao poder, o fato criara algum alarde. No entanto, deve-se ter cautela em entender o episódio como algo que tenha sido excessivamente alarmante no local e uma notícia propagada em grande escala e por todo o Egito, já que os relatos refletem os anseios do extrato mais alto da sociedade. Entretanto, acredita-se que as decorrências do envolvimento entre Cleópatra e Antônio, resultante na concessão de terras ao Egito não foram desprezíveis nas elites 
alexandrinas, particularmente, naquelas mais diretamente envolvidas com Roma, como as fontes demonstram. Nas palavras de Bingen:

\begin{abstract}
Sentimento pró ou anti-romano era mais um problema alexandrino do que uma preocupação egípcia e não foi uma realidade urgente em 36 a.C.. O povo bom do Egito estava realmente chocado pelos casos de amor da rainha? A maioria dos egípcios morava longe da propaganda de Otávio direcionada para a opinião pública romana, e não poderia conhecer aquela grande invenção para o futuro, uma imprensa popular devotada para os casos sentimentais da realeza e de celebridades. $(2007 \text {, p. } 59)^{26}$
\end{abstract}

\title{
3.5. Vitória de Otávio sobre o Oriente: A conquista do Egito
}

A conquista de Otávio representou o fim oficial dos reinos helenísticos que dominaram o Oriente por trezentos anos, e o Ptolomaico era dentre eles o mais forte, estruturado e territorialmente estável. Otávio se tornou popular e venceu Marco Antônio pela desconfiança que este nutrira entre os romanos e por temerem que sua relação com Cleópatra e seu prestígio no Egito simbolizassem uma ameaça ao desenvolvimento romano. Otávio encerrou definitivamente um período já considerável de guerra civil entre os dirigentes do império e restabeleceu a paz, fazendo sua legitimidade e popularidade aumentarem ainda mais (ROSTOVTZEFF, 1937, p. 103).

A vitória de Otávio era vista como uma vitória sobre o Oriente. Ao menos foi isso que sua propaganda tentou divulgar. Ou seja, a derrota de Cleópatra e Antônio significava a rendição do Egito a Roma. Empereur (1998, p. 48) considera que era inevitável que um dia Alexandria e Roma se tornassem rivais, pela enormidade populacional da cidade comparável apenas à capital do Império. Na opinião do autor, durante a luta o destino do mundo ficou instável.

O que as fontes dizem sobre o momento de transição do Egito, que de monarquia independente se tornou uma província romana? O tom de celebração da documentação é

\footnotetext{
26 "Pro- or anti-Roman feeling was an Alexandria problem rather than an Egyptian concern and was not a pressing actuality in 36 B.C. Were the good people of Egypt really shocked by the queen's love affairs? Most of the Egyptians were living far from the propaganda of Octavian, meant for Roman public opinion, and could not know that great invention for the future, a popular press devoted to the sentimental affairs of royalty and celebrities."
} 
nítido, e também a ênfase no início de uma nova era, para a qual caberia a Otávio impor suas medidas. No contexto de tomada da cidade, Plutarco menciona em três momentos diferentes de sua obra, que quando Otávio entrou em Alexandria, os alexandrinos esperavam ser punidos e tratados de modo severo. Porém, ele decidiu não castigar a cidade por quatro motivos: pela sua grandeza e beleza, por respeitar o fundador Alexandre e pela sua amizade com o filósofo Areio. Na biografia de Antônio, Plutarco relata em mais detalhes sobre a entrada de Otávio em Alexandria:

E então César em pessoa, entrou na cidade, e estava conversando com Areio o filósofo, a quem ele tinha dado sua mão direita, para que Areio se sobressaísse entre os cidadãos, e fosse admirado pela honra demonstrada a ele por César. Depois de entrar no ginásio e ascender ao tribunal lá feito para ele, as pessoas estavam com medo ( $\delta$ Éous) e paralisaram diante dele, mas ele pediu a eles para se levantarem, e disse que os libertavam (ó qı́́vaı) de toda a culpa, primeiro por causa de Alexandre, seu fundador; segundo, pois ele admirava a beleza (Tò kó $\lambda \lambda \lambda_{\circ}$ ) e grandeza (тò $\mu \varepsilon ́ \gamma \varepsilon \theta \circ \varsigma$ ) da cidade; e terceiro, para gratificar seu companheiro Areio. Essa honra, César concedeu a Areio, e perdoou também muitas outras pessoas atendendo ao pedido dele (Vita Antonii 80).

Na obra Morália, o autor menciona novamente essas razões nos Máximas de reis e gerais (Regum et imperatorum apophthegmata 207.A.9), e mais uma vez nos Conselhos Políticos (Praecepta gerendae reipublicae 814.D.6): "E falou aos

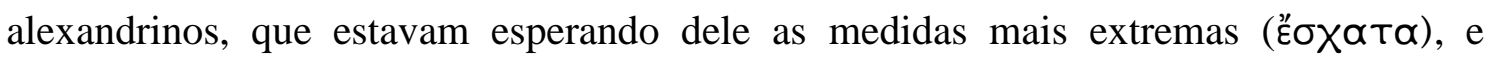
implorando por misericórdia, que ele perdoava ( $\left.\delta ı \alpha \lambda \lambda \alpha^{\prime} \tau \tau \varepsilon \sigma \theta \alpha \iota\right)$ a cidade (...)." Plutarco sugere que o fato de Otávio ter poupado os alexandrinos era considerado uma prova da sua grande bondade, denotando que os ultrajes cometidos pelos alexandrinos mereciam punição. A conquista da cidade é descrita como uma benfeitoria ao Egito e não restava aos alexandrinos senão agradecer ao vencedor. A amizade de Otávio com Areio é um exemplo de como intelectuais gregos ligados ao governo romano foram cruciais em momentos de crise. Assim, se estes eminentes gregos usavam sua amizade com comandantes romanos para conseguir avanços em suas comunidades, nesse caso Areio até salvou Alexandria da vingança de Otávio (CRAWFORD, 1978, p. 206). Ou seja, tratava-se de uma relação de reciprocidade e conveniência aos dois lados envolvidos. 
Dion Cássio ressalta outros motivos que levaram Otávio a perdoar e poupar egípcios e alexandrinos, indicando que a resistência promovida à Roma era interpretada como uma grande afronta. Como Plutarco, Dion enfatiza a grandeza da população alexandrina, dizendo que o vencedor preferiu não punir um povo tão numeroso, que podia se provar útil aos romanos de muitas formas. Então Otávio fez um discurso pedindo lhes perdão em grego e enumerando mais motivos que o levaram a tomar essa decisão: a grandeza da população ( $\pi \circ \lambda u ́ \alpha \nu \delta \rho o v)$, tanto da cidade, quanto do campo e

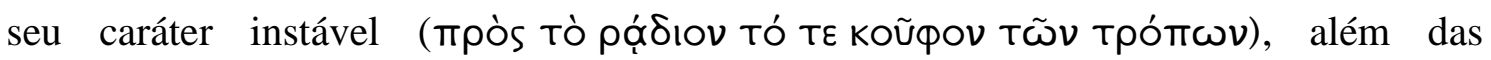
riquezas e da extensão do seu suprimento de trigo

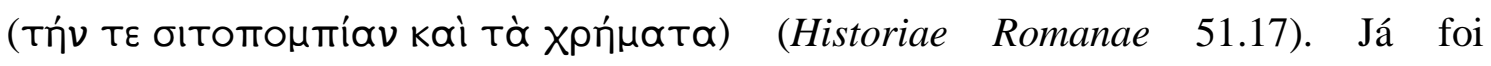
observado que o realce na instabilidade de Alexandria foi usado por Dion Cássio em inúmeros momentos ao tratar da cidade. Percebe-se aqui que Otávio não poupara os egípcios por bondade, mas pensando estrategicamente nos projetos subsequentes. $\mathrm{O}$ vencedor fala aos alexandrinos em grego, demonstra sua consideração por Alexandre, com a intenção de estabelecer uma ligação com o fundador da cidade, que como ele, havia chegado ao Egito para liberar a população de monarcas inconsequentes (antes os persas, e nesse momento, a decadente dinastia ptolomaica). A ênfase na grandeza da cidade também poderia ser uma associação com a fundação de Alexandre. Segundo Jacob Isager (1993, p. 78), a tentativa de Otávio de se associar à imagem de Alexandre tinha a finalidade de divulgar a sua representação como libertador do Oriente.

Suetônio também enfoca na ligação entre Otávio e Alexandre. Ele relata que logo após tomar Alexandria, Otávio ordenou que o corpo e o sarcófago de Alexandre, fossem retirados do santuário e trazidos para ele. Após visualizá-lo, lhe prestou homenagens, e depois de ter sido perguntado se desejava ver também a tumba dos Ptolomeus, Otávio respondeu que seu desejo era ver reis, não defuntos, deixando claro seu desprezo pelos reis seus antecessores (Divus Augustus 18). Dion Cássio conta essa mesma estória (Historiae Romanae 51.16). Aqui fica claro a intenção dos autores de marcar uma quebra com o passado e a realeza anterior, que era inferior a Alexandre em todos os aspectos, um contraste ao importante vínculo criado entre Otávio e o fundador.

Feeney (1998, p. 49) explica que por mais que a literatura romana evitasse o uso de mitos, pela ausência da mitologia na sua própria tradição, esse vácuo fez com que essa literatura fosse sempre influenciada por mitos gregos. Assim, os mitos tornaram-se uma parte vital da vida pública romana, principalmente para o período de Otávio, 
auxiliando na legitimação de seu regime (FEENEY, 1998, p. 56). Um exemplo era justamente sua tentativa de se associar a imagem de Alexandre, como libertador do Oriente. Vimos que até Dion Cássio, uma fonte duzentos anos posterior a Otávio, ainda estabelecia essa associação.

Em mais uma ocasião, Suetônio compara Otávio aos Ptolomeus, nesse momento com a intenção de marcar a simplicidade daquele comparado ao esbanjamento e sofisticação da dinastia. O autor afirma que Otávio condenava a extravagância (lautitiarum) dos antigos reis e uma prova disso foi sua recusa de tomar a mobiliária do palácio ao conquistar Alexandria. Otávio teria pegado apenas um cálice e derretido todos os vasos de ouro pensando na sua finalidade para uso diário (Divus Augustus 71).

Suetônio narra uma estória que se passara quando Otávio estava em Alexandria, novamente com o objetivo de marcar o novo tempo inaugurado na cidade e promover a paz entre ele e os alexandrinos. A ideia enfatizada é que o povo alexandrino estava aliviado com a conquista romana do Egito. $\mathrm{O}$ autor relata que Otávio navegava pelo golfo de Puteoli e encontrou um navio alexandrino que acabara de chegar lá. Os passageiros e a tripulação, vestidos de branco, com coroas de guirlanda, e queimando incensos, o encherem de bons desejos e dos maiores elogios, dizendo que graças a ele que o povo vivia e que a população aproveitava sua liberdade e sorte (libertate atque fortunis). Muito satisfeito com isso, Otávio deu quarenta pedaços de ouro a cada um de seus companheiros, exigindo deles um juramento de não gastarem aquele dinheiro de outra forma, a não ser investindo em mercadorias alexandrinas (emptionem Alexandrinam mercium absumpturos). Pelos dias restantes de sua estadia, ele distribuiu presentes de vários tipos, e também togas e vestimentas, estipulando que os romanos deveriam usar as roupas e a língua grega e os gregos as romanas (Divus Augustus 98). Esse trecho de Suetônio atribui a Otávio a criação de um novo tempo, em que todos deveriam ser um só povo, sem distinção entre gregos e romanos.

Marcando um contraste com a visão de Suetônio, Dion Cássio menciona a transferência de riquezas para Roma depois da conquista, através da tomada dos

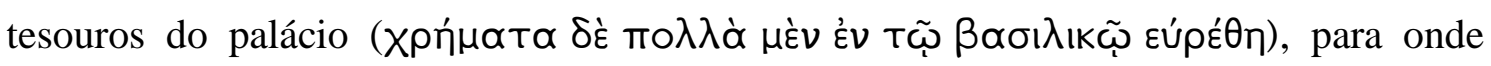
Cleópatra transferira as oferendas dos mais sagrados templos. Com essas riquezas e através do pagamento de homens punidos, os romanos conseguiram pagar tudo o que deviam para as tropas (Historiae Romanae 51.17.6). Assim, a transferência de riquezas não teria sido assim tão insignificante como afirma Suetônio. Além disso, as relíquias 
egípcias levadas a Roma para a exibição do triunfo são uma prova de que Otávio também valorizava a sofisticação, embora nesse caso, com a intenção de realçar a sua vitória, já que os símbolos foram exibidos como prêmios de guerra.

Na passagem citada acima sobre os reis, Suetônio e Dion Cássio sugerem a intenção de Otávio de se colocar como o continuador de Alexandre, porém, como um dirigente radicalmente diferente de seus predecessores Ptolomeus. Os trechos indicam também a vontade dos autores de marcar uma quebra com o tempo helenístico anterior e demonstrar a superioridade do novo comando no Egito, comparável apenas ao que Alexandre, o fundador da cidade, fizera por Alexandria. Nesse sentido, Otávio estava inaugurando um novo tempo e uma nova cidade. Na concepção helenística de monarquia, o rei não era vinculado ao território que governava, mas à terra natal da linhagem, a Macedônia. Os reis eram antes de tudo, reis macedônios que governavam o Egito. Assim, nunca deixaram de aparecer como estrangeiros aos nativos. Nesse sentido, o novo governo romano não era assim tão diferente do antecessor ptolomaico. Segundo Bingen, a autoridade do rei ptolomaico não emanava do território, não era essa a fonte de sua identidade real. Apesar de os Ptolomeus aparecerem como reis do Egito para os historiadores de fora do Egito, e de Cleópatra ser egípcia para os romanos que queriam estigmatizá-la, sua realeza era legitimada pela corte helenizada de Alexandria (2007, p. 60).

A vitória de Otávio foi a oficialização de um projeto intensificado no século I a.C.. Assim, apesar de a conquista ter aumentado a presença militar romana no Egito, antes disso, sua inserção já era significativa. Durante todo o século I, foi também notável a presença de intelectuais alexandrinos transferidos para Roma para ensinar. Portanto, um conhecimento recíproco entre os dois povos já estava em curso. Como já visto, muitos romanos proeminentes foram progressivamente se envolvendo em questões egípcias também antes da conquista, o que talvez fora um dos motivos que levou Otávio a posteriormente proibir a presença de senadores no Egito (CAPPONI, 1975, p. 9). O Egito também era objeto de informação e curiosidade pela tradição grecoromana há muito tempo. Nesse sentido, eram mundos que se conheciam. Porém, apesar desse conhecimento recíproco entre os territórios e de alguns acontecimentos terem feito os romanos ensaiarem medidas diferenciadas destinadas ao Egito, a oficialização das mudanças foi iniciada por Otávio. 
Mesmo que as riquezas do Egito fossem o maior foco de interesse de Otávio, o acesso a elas dependia do controle de outras instituições, daí o interesse do imperador em promover mudanças em inúmeras esferas. As fontes enfocam nas novidades administrativas instituídas pelo conquistador, mas a ênfase é também nas melhorias concedidas para a produtividade. Suetônio relata sobre os investimentos de Otávio para desenvolver o cultivo. Assim, não apenas reduziu o Egito a província, mas ajudou a torná-lo mais fértil e melhor adaptado para o suprimento de trigo para Roma (feraciorem habilioremque annonae urbicae redderet). Fez isso colocando seus soldados para trabalhar, limpando todos os canais em que o Nilo desembocava e que tinham enchido de lama (Divus Augustus 18). O autor indica aqui certa negligência dos reis em relação ao fluxo comercial e aos investimentos na colheita, que foi resolvido rapidamente após a conquista de Otávio.

Josefo também enfatiza a questão da produtividade. Observa que Alexandria enviava uma quantidade de trigo suficiente para alimentar Roma por quatro meses

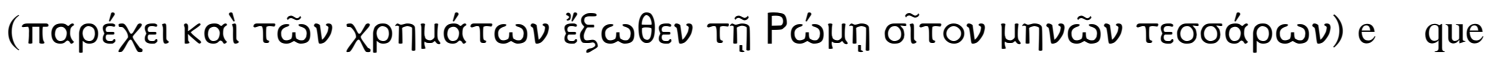
duas legiões estavam fixadas na cidade para garantir o suprimento (Bellum Judaicum 2.385.3). Em suma, interessava manter a provisão, e as fontes enfatizam que Otávio jamais descuidou desse setor, porém esse foi apenas um dos desdobramentos da conquista. Na perspectiva de Josefo, a presença do exército visava vigiar a manutenção da produtividade. Assim, a importância da preservação da paz tinha a finalidade, em última instância, de garantir o escoamento de trigo para a capital. Fica claro aqui, o interesse em tornar o Egito cada vez mais adequado para o abastecimento romano. Contudo, deve-se ressaltar que apesar das melhorias, a produção beneficiou Roma, e provavelmente os egípcios colheram poucos frutos dessas melhorias.

Além de apontar que o governo de Otávio era o início de um novo tempo, a literatura (principalmente Estrabão) enumera as novas medidas implementadas pelo governante na incorporação do Egito. Otávio precisou pensar em estratégias que facilitassem a convivência com o local, tão caro a Roma, mas que ao mesmo tempo já tinha causado problemas pelos acontecimentos anteriores. Daí nomear para a administração prefeitos da ordem equestre e proibir os senadores de entrarem na província sem a sua autorização. Tais medidas refletiam o seu medo de o Egito se tornar foco de oposição ao Império. Segundo Bowman (1992, p. 110), essas regras evitariam 
que membros importantes da aristocracia romana conseguissem comprar terras no Egito, o maior temor de Otávio.

Além do cargo de prefeito, todos os postos mais importantes foram concedidos à romanos da ordem equestre. Estrabão destaca que o prefeito era vigiado de perto e governava segundo as vontades do imperador, mas dispunha de uma autoridade quase real. Além disso, uma legião estava permanentemente na cidade, os impostos eram recolhidos com rigor, e foi negada a Alexandria o essencial de uma cidade grega, a Boule (Geographica 17.1.12). Com relação às modificações administrativas, o seguinte trecho de Estrabão resume as inovações na sua perspectiva:

O Egito é agora uma província; e não apenas paga tributos consideráveis (åkı 10 ó日ous), mas é também governado por homens prudentes ( $\sigma \omega \varphi \rho o ́ v \omega \nu)$ - os prefeitos, que são para lá enviados de tempos em tempos. Agora esse enviado tem o status de rei

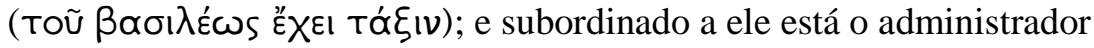

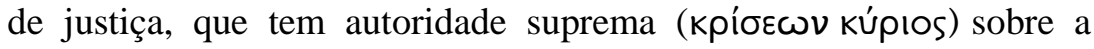
maior parte do conjunto de leis; e outro é o oficial chamado Idiologo

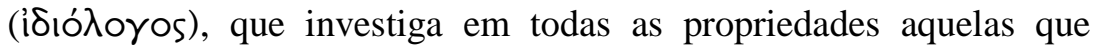
estão sem proprietário e que devem ser transferidas para César; e estas também são acompanhadas de libertos de César, e também por auxiliares, a quem são confiados assuntos de importância média. Há também três legiões de soldados, das quais uma está colocada na cidade e as outras no campo; e além dessas há nove tropas, três na cidade, três nas fronteiras da Etiópia em Syene, como guardas naquela

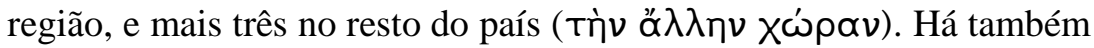
três corpos de cavalaria, que são designados para os pontos mais

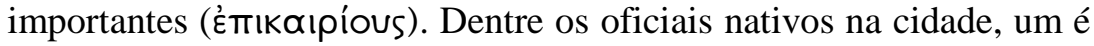
o intérprete, que se vestia de roxo, tem prerrogativas hereditárias, e

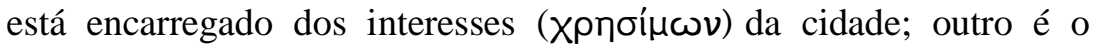
escriba; outro é o juiz chefe; e um quarto é o comandante noturno. Esses oficiais também existiam no tempo dos reis, mas como eles

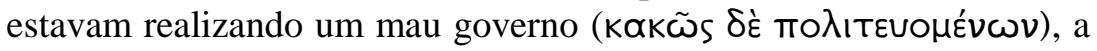
prosperidade (Eủkaı ía) da cidade estava desaparecendo

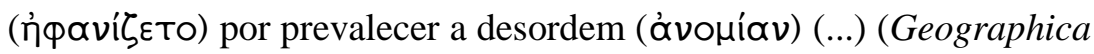
17.1.12)

Estrabão continua detalhando as inovações no Egito: os romanos nomearam oficiais por todo o país: epistrategos - દ̇mı тратńyous (que já existiam), nomarcas vouápxas (chefes dos nomos) e etnarcas - દ̇vvápxas (chefes das tribos). O Egito era dividido em mais ou menos cinquenta nomos, que era semelhante a um pequeno estado, divisão que foi mantida por Roma. O autor menciona também o aumento da tributação e sua organização, justificando sua necessidade diante de tantas benfeitorias concedidas 
(Geographica 17.1.13). Percebe-se que a sua intenção era ressaltar a ordem imposta por Otávio, explicitando que uma reorganização necessária e bem-vinda tinha sido promovida pelo novo governante. Estrabão concede especial destaque à presença das tropas, e na sua perspectiva, elas estavam ali para garantir a paz em regiões críticas, denotando a importância da vigília constante sobre o território. Ou seja, não estavam encarregadas apenas da prosperidade, mas dos problemas sociais e políticos que poderiam eclodir na região. As ressonâncias dos distúrbios sociais ocorridos sob os Ptolomeus podiam ainda preocupar, como também a força da multidão, e o predomínio de partidários de Antônio e Cleópatra que podiam ainda estar "rondando" o cenário.

Estrabão ressalta a nova era de paz e prosperidade iniciada por Otávio e o fim de um tempo em que prevaleceu o caos e a falta de governabilidade absoluta. Percebe-se como a questão da ordem é enfatizada por Estrabão e vista como uma das novidades da nova era. Deixa claro, no entanto, que Otávio trouxe paz para o Egito, embora a calma fosse garantida pelo exército fixado no local. Em seguida, o autor ressalta novamente que apesar da desordem predominante até então, os romanos tiveram a capacidade

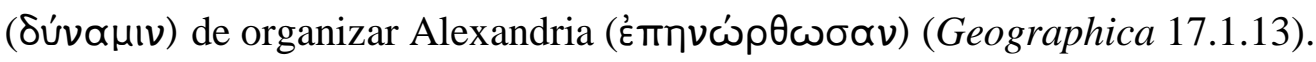

Mais adiante, o autor fala novamente que o Egito era suficientemente vigiado, pois os egípcios não eram guerreiros, apesar de serem numerosos, como deixa claro no importante trecho abaixo:

Então o Egito era desde suas origens inclinado para a paz, por causa da auto-suficiência ( $\propto$ UैT $\alpha \rho \kappa \varepsilon \varsigma$ ) do país e pela dificuldade de invasão por estrangeiros, sendo protegido ao norte por uma costa sem portos e pelo Mar Egípcio, e no Oeste e Leste pelas montanhas de deserto da Líbia e Arábia, como eu já disse; e as partes que restam, em direção ao sul, são habitadas por Trogloditas, Blemnyes, Núbios e Megabari, e daqueles Etíopes que vivem sobre o Syene. Estes são nômades, e não são numerosos, e nem adeptos da guerra, apesar de terem sido assim taxados pelos antigos, pois com frequência, como bandidos, eles atacariam pessoas indefesas. Com relação aos Etípoes, que se estendem com direção ao sul e ao Meroe, também não são numerosos, nem eles se reúnem em um povo só, pois habitam uma faixa de terra fluvial longa, estreita e de muitos ventos, como eu já descrevi anteriormente; nem são equipados para a guerra e nem para qualquer outro tipo de vida. E agora também, todo o país é igualmente disposto à paz. E o seguinte é um sinal de tal fato: o país é suficientemente vigiado (фроupєĩtaı) pelos romanos com apenas três tropas, e mesmo essas não estão completas; e quando os Etíopes ousaram fazer um ataque sobre elas, colocaram em perigo seu próprio país. As outras forças do Egito não são tão grandes como essas, e os romanos nunca $s$ 
usaram coletivamente; pois os egípcios não são eles mesmos

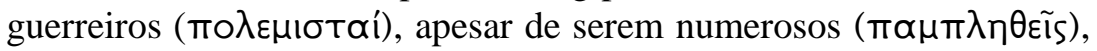
nem são as tribos ( $\left(\theta_{\eta \eta}\right)$ vizinhas. Cornélio Galo, o primeiro prefeito apontado do país por César, atacou Hernópolis, que tinha se revoltado

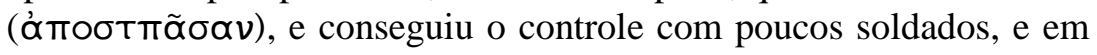
pouco tempo abafou uma rebelião (oTáoıv) que ocorreu na Tebaida por causa dos tributos. E em uma época posterior, Petrônio, quando

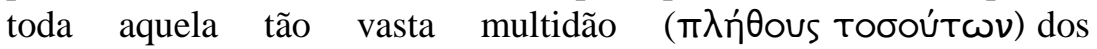
alexandrinos se apressou em atacá-lo jogando pedras, conseguiu freálos usando apenas sua própria tropa, e depois de matar alguns deles, conseguiu colocar um fim no resto. E eu já mencionei como Aélio Gallo, quando ele invadiu a Arábia com uma parte da guarda estacionada no Egito, descobriu que as pessoas não são propensas a guerra; na verdade se Syllaeus não o tivesse traído, ele teria submetido toda a Arábia Felix. (Geographica 17.1.53)

$\mathrm{Na}$ visão de Estrabão, o Egito era ainda no seu tempo pouco habitado por estrangeiros, pois suas fronteiras eram muito protegidas, garantindo sua auto-suficiência quase total. Em outro contexto mencionado acima, o autor havia citado Políbio para ilustrar a tendência do Egito a instabilidade, mas aqui sugere a ideia contrária, dizendo que historicamente o território era pacífico, justamente pela presença de poucos estrangeiros. Ainda sob Roma, Estrabão destaca as boas condições de convivência entre toda a população. Percebe-se, no entanto, que Alexandria é tratada como a exceção, pois usa o relato de Políbio para falar especificamente da organização na cidade e cita a multidão dos alexandrinos como os únicos que ainda trariam problemas. A realidade em Alexandria seria mais complexa justamente por ser a cidade mais misturada e habitada por estrangeiros? A passagem sugere que o Egito era pacífico e disciplinado em virtude de seu fechamento para estrangeiros, um claro contraste com o mundo grego fragmentado e guerreiro, que foi devastado pela briga de cidades (YOYOTTE, 1997, p. 31). No entanto, essa realidade foi alterada em Alexandria, ao se colocar em contato diferentes povos. Assim, a heterogeneidade populacional da cidade seria a raiz de seus problemas na visão de Estrabão.

Segundo Yoyotte (1997, p. 42), o relato histórico de Estrabão sobre o passado egípcio é muito mais resumido que o de Diodoro, e é sintetizado em três períodos: os primeiros ou antigos reis (faraós), os Ptolomeus (mais focado na história "moderna" dos reis) e o romano contemporâneo, sua prioridade. O autor considera que Estrabão não enquadra o Egito na categoria de bárbaros, pela sua civilidade e tranquilidade. A ênfase 
de Estrabão é na imobilidade e longa-duração da cultura egípcia, dando ao leitor a sensação de que nada mudara antes dos romanos (YOYOTTE, 1997, p. 46).

Fílon, referindo-se a uma conjuntura um pouco posterior, e condenando as homenagens dos alexandrinos prestadas a Calígula, também enfatiza o novo contexto pacífico promovido por Otávio em todo o Império. O autor argumenta que nem para Otávio foram dedicadas homenagens como as destinadas a Calígula, justamente para ele

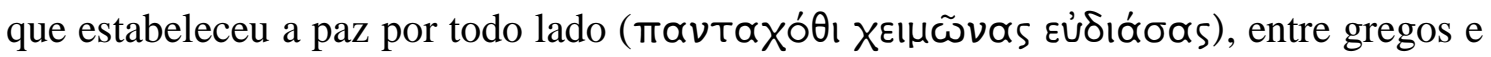
bárbaros, Ásia e Europa, entre ilhas e continentes. Ele que quebrou as correntes

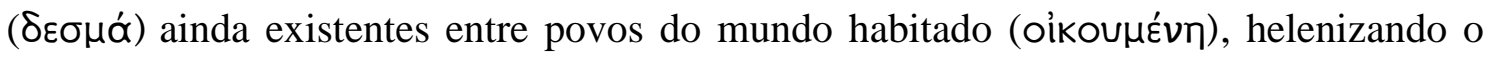

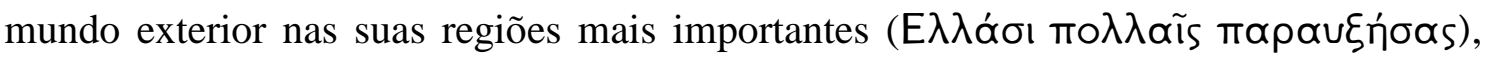

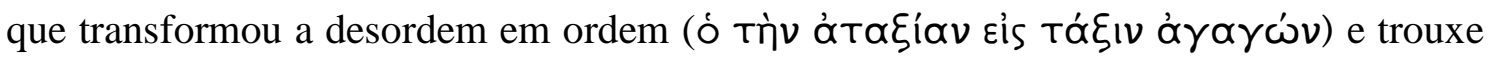
harmonia e boas maneiras para todos os povos mais "anti-sociais e brutalizados"

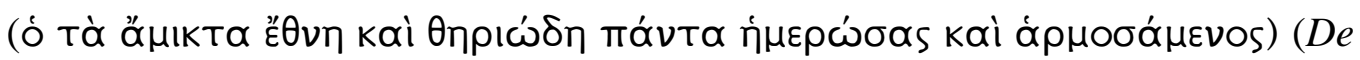

Legatione ad Gaium 21). Fílon destaca que mesmo diante de toda superioridade de Otávio em relação a Calígula, durante os 43 anos em que foi soberano, os alexandrinos nunca lhe dedicaram nenhum tipo de homenagem, justamente ele que era realmente merecedor (De Legatione ad Gaium 22). Como alexandrino, Fílon reproduz a mesma visão dos autores estrangeiros em relação à Otávio, e não demonstra nenhuma nostalgia referente ao tempo anterior. Mas não se deve esquecer de que a sua intenção nesse relato é condenar Calígula pela postura inconsequente destinada aos judeus, portanto, todos os elogios a Otávio tinham essa finalidade e devem ser vistos com cautela.

Arriano faz alguns apontamentos sobre as inovações estabelecidas no Egito por Alexandre, e parece aludir ao tempo de Otávio, pois como os autores aqui citados, sua ênfase é na ordem, na divisão de funções e na tributação. Observa que a ordem (દ̇Kó $\mu \eta \eta \sigma \varepsilon)$ fora instalada no Egito, e foram apontados dois governantes para o local.

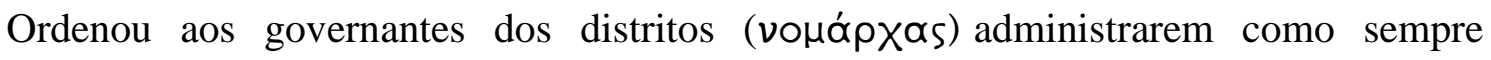

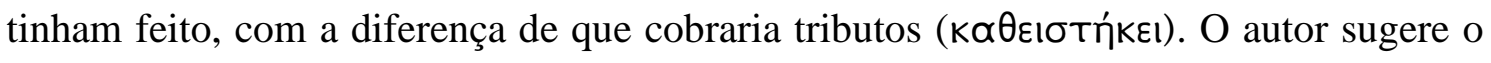
aumento da burocratização por Alexandre, fazendo uma clara alusão a Otávio. Afirma que Alexandre dividiu o governo do Egito entre muitos

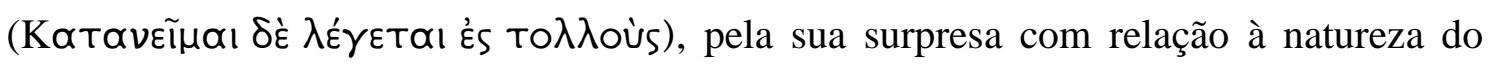

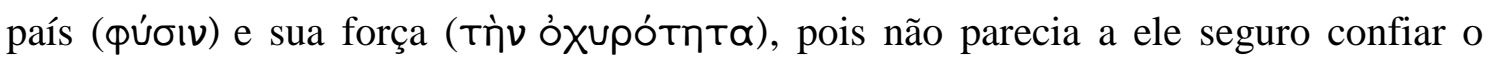
comando de todo o Egito (äpXeıv Aỉúntrou máons) a um só homem. E depois faz 
uma comparação com o seu tempo explicitamente, ressaltando que os romanos também tinham aprendido uma lição com Alexandre e mantinham o Egito sob vigília ( $\varphi \cup \lambda \propto \kappa \tilde{n})$. Também nunca mandavam ninguém do Senado como pró-consul, mas apenas os cavaleiros (Anabasis Alexandri 3.5). Percebe-se como além de destinar o cargo de administrador aos membros da ordem equestre, o aumento da burocratização foi pensado também para estabelecer a divisão de funções, e consequentemente, evitar o acúmulo de poderes pelos oficiais. Assim, o autor sugere que Otávio teria se inspirado em Alexandre com relação ao estatuto diferenciado do Egito.

Por todas as peculiaridades de Alexandria (grandeza, riqueza, produtividade e instabilidade), Dion Cássio afirma que Otávio não achou prudente deixar um conselho governar o Egito:

Depois ele tornou o Egito tributário (úmот $\varepsilon \lambda \tilde{\eta})$ e o confiou

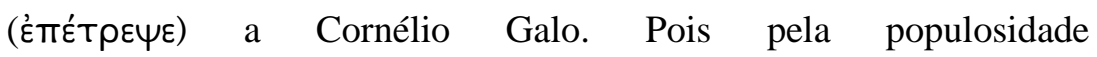
( $\pi \circ \lambda \cup u \alpha v \delta \rho \circ v)$ tanto das cidades quanto do campo, pelo caráter

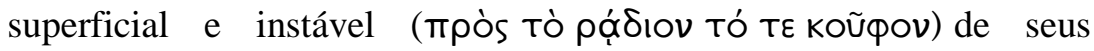
habitantes, e pela extensão do suprimento de trigos e de sua riqueza ( тท́ a nenhum senador, ele não concederia nem a permissão para senadores morarem lá, a não ser que ele pessoalmente fizesse a concessão nominalmente. Pelo outro lado, ele também não permitiu que os egípcios fossem senadores em Roma; mas como ele fez vários arranjos com relação às diversas cidades, ele comandou os

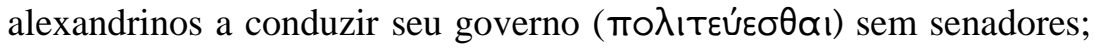
pela sua capacidade para a revolução ( $\nu \in \omega \tau \varepsilon \rho o \pi o l i ́ \alpha v)$, que eu suponho, ele lhes atribuiu. (Historiae Romanae 51.17)

Tácito condena o general Germânico, por no principado de Tibério entrar no Egito sem consentimento imperial, com a desculpa de que ia conhecer as suas antiguidades (antiquitatis). Porém, adotou hábitos da multidão (multaque), andando sem seus guardas e com vestimentas gregas. Além disso, abaixou o preço do trigo e abriu a produção ao povo (levavitque apertis horreis pretia frugum multaque in vulgus grata usurpavit). $\mathrm{O}$ autor diz que Germânico foi reprovado pelo imperador por desobedecer (inconsulto) a norma de Otávio e entrar no Egito sem a sua autorização. Tácito também atribui a motivação principal do imperador em vigiar o Egito à importância da produtividade. No caso de Germânico, demonstra como essa preocupação era legítima, pois sua atitude realmente colocara o suprimento de trigo para Roma em risco. Tácito deixa claro que a maior causa para a medida era o receio de a Itália passar fome caso alguém conspirasse e conseguisse ocupar a província por terra e mar (Annales 2.59.10). 
Pois Otávio, entre outros segredos do seu absolutismo (dominationis), através da proibição de todos os senadores ou cavaleiros romanos da mais alta distinção (inlustribus), de entrar no país sem permissão, assim manteve o Egito isolado (seposuit); para que a Itália não passasse fome caso alguém planejasse, com uma tropa pequena contra exércitos formidáveis, ocupar a província e a sua posição chave (claustraque) por terra e mar. (Annales 2.59.10)

Mais adiante no livro 12, Tácito explica que para manter o Egito vigiado, Otávio conferiu poderes judiciais (praesiderent lege agi decretaque) aos membros da ordem equestre, encarregados do governo do Egito. Ressalta que suas decisões tinham vigor como se tivessem sido formuladas pelos magistrados nacionais ou pelo próprio imperador (Annales 12.60). O autor pontua essa questão novamente nas Histórias, e mais uma vez realça o tema:

O Egito, com suas tropas para manter o controle (coerceretur), tem sido administrado, desde o tempo do digníssimo Otávio, por cavaleiros romanos no lugar de seus antigos reis. Pareceu sábio manter sob controle direto da casa imperial uma província de difícil acesso (aditu difficilem), produtiva de grandes colheitas (annonae fecundam), mas propensa a discórdia e instabilidade por causa da superstição e frivolidade de seus habitantes (superstitione ac lascívia discordem et mobilem), ignorantes (insciam) que são com relação às leis e com pouca familiaridade com as magistraturas civis. (Historiae 1.11.1)

Tanto nesse trecho como no anterior, Tácito deixa claro que entendia a medida da nomeação do prefeito como uma forma de controlar principalmente a colheita. Nesse sentido, o maior motivo de cuidado com o Egito era a sua riqueza agrária. Porém ressalta também, a propensão à turbulência da província.

Percebe-se que na perspectiva das elites governamentais romanas, as mudanças no Egito e a quebra com relação ao período anterior ficam nítidas, através da concepção de que uma nova era estava sendo iniciada. O contraste fica ainda mais evidente em relação ao período anterior, pela parcialidade das narrativas sobre o final do governo ptolomaico, que têm uma carga negativa, pois já falam na perspectiva de uma nova administração romana (WILLIAMS, 2004, p. 95).

Além das mudanças administrativas introduzidas no Egito, deve-se mencionar a simbologia de Actium, e como Otávio se aproveitou de sua vitória para firmar sua imagem e se legitimar como imperador. Sua vitória na batalha naval e a conquista do 
Egito foram os maiores triunfos comemorados por Otávio em Roma, dois anos depois do ocorrido. Suetônio faz referências às celebrações e observa que Otávio comemorou seus três triunfos na Dalmácia, Actium e Alexandria, em três dias sucessivos (Divus Augustus 22).

Segundo Gurval (1995, p. 19), os "fantasmas" da guerra civil ainda deviam preocupá-lo e influenciaram na preparação do triunfo celebrando a conquista do Egito, o maior já festejado em Roma. O último dia da celebração proclamava a incorporação do reino e a captura da rainha. A riqueza e o alto custo da celebração superavam os triunfos anteriores, e fez da última festa o clímax das comemorações. As riquezas trazidas do Egito foram expostas durante o festejo, e depois adornaram os templos de Roma (GURVAL, 1995, p. 29).

Wallace-Hadrill (2008, p. 356-357) analisa que conquistas e exibições de triunfos sempre traziam novidades e "modas" em Roma. Além de transformarem a cidade em virtude da chegada de grande quantidade de escravos, butins de guerra e influências nas construções. No entanto, nenhuma onda desse tipo é mais fácil de traçar arqueologicamente do que o impacto da conquista de Egito e a Egitomania que o seguiu. Portanto, apesar do esforço de Otávio para empreender uma campanha de propaganda antiegípcia, a conquista teve a contrapartida de criar certa curiosidade com relação ao território, reforçando a presença de elementos egípcios na capital.

No local em que venceu Antônio e Cleópatra, Otávio fundou uma cidade, chamada Nicópolis e fixou 20 mil soldados no local (GODDIO; CLAUSS, 2006, p. 58). Estrabão não menciona a sua fundação, apenas que era um lugar muito honrado por ele pela vitória (Geographica 17.1.10). Suetônio afirma que o conquistador fundou a cidade para estender a fama de sua vitória e perpetuar a sua memória (Quoque Actiacae victoriae memoria celebratior et in posterum esset), e instituiu lá a celebração de jogos a cada cinco anos. Além disso, aumentou o antigo templo a Apolo; e depois de adornar o sítio do campo ocupado com muitos troféus navais, o consagrou a Netuno e Marte (Divus Augustus 18).

Gurval (1995, p. 73) sugere que talvez o objetivo de Otávio fosse fundar a sua própria cidade da vitória em imitação a Alexandre, que tinha fundado Alexandria como uma celebração de sua conquista do Egito. O autor argumenta que nenhum general antes de Otávio tinha deixado tantos símbolos impactantes em Roma e pelo Império para celebrar vitórias e conquistas como os deixados por Otávio logo após Actium (1995, p. 
67). A grandeza do triunfo assinala o valor diferenciado do Egito para Roma em relação a outras conquistas. Nesse sentido:

No decorrer desses longos anos de estabilidade e de disputas civis esporádicas, a memória de Actium nunca foi esquecida. Transformada em um mito político, sempre potente, útil e atrativo, a vitória de Augusto constituiu o começo do governo imperial e concedeu glória e status louvável ao seu fundador e seus sucessores. (GURVAL, 1995, p. 85$)^{27}$

Actium era o início de um novo tempo, daí a importância de sua simbologia, por ser um dos instrumentos de legitimação de Otávio como imperador. Entretanto, apesar de seus esforços, as medidas de vigília impostas sobre o Egito demonstram resquícios dos projetos de Cleópatra. Por isso, os autores chamam atenção para a complexidade dos eventos passados, como forma de lembrar os problemas e justificar a necessidade de uma nova ordem.

Em um primeiro momento Alexandria era cara aos romanos como representante de um Egito antigo, de tradições milenares e principalmente, um território muito produtivo e rico. Após o conturbado século I a.C., começou a ser vista pelas elites imperiais também como uma potencial rival política de Roma. Não que representasse um enorme perigo, e muito menos a única ameaça enfrentada pelo Império, mas os autores trabalhados indicam que um cuidado especial com o local era necessário, principalmente no momento em que Otávio estudava a melhor forma de unificar o controle imperial.

Além da questão da produtividade e da ameaça política realçada pelos autores, Alexandria era a porta de entrada de um Egito que era alvo de curiosidade e especulação pelos gregos há séculos. Um local que provocava aversão pelo exotismo de sua religião, mas também encantava pela antiguidade. Por tudo isso, somado a sua importância cultural como aglutinadora de tradições literárias de muitos povos, na mentalidade das elites romanas pensava-se em Alexandria como a única capaz de abalar a hegemonia de Roma. Nesse sentido, mesmo que os romanos tivessem consciência da dificuldade de outra cidade substituir Roma na prática, percebe-se que mesmo uma remota

\footnotetext{
27 "Throughout these long years of stability and sporadic civil strife, the memory of Actium was never forgotten. Transformed into a political myth, ever potent, useful, and attractive, the victory of Augustus constituted the beginnings of imperial rule and bestowed the glory and exalted status of its founder on his successors."
} 
possibilidade causava algum tipo de apreensão. Tal preocupação rondou os romanos por algum tempo, como foi demonstrado através do objeto abordado. Daí a importância atribuída à conquista de Otávio e as medidas instituídas para manter o Egito controlado e próspero. Sublinhar que um novo tempo estava sendo inaugurado após o período de caos e instabilidade era primordial para que o novo líder conquistasse legitimidade não apenas no local, mas em todo o Império. Daí a ênfase na paz e prosperidade que só Otávio poderia promover. Além de justificar a importância do novo comando, era crucial saudá-lo como um governante bondoso, que poupou os alexandrinos sempre tão rebeldes. Além disso, dever-se-ia justificar as medidas adotadas, pois não restava outra saída diante do cenário instável criado pelos alexandrinos. Representar a turbulência constante em Alexandria era uma forma de valorizar e realçar a paz trazida por Roma.

O retrato da Alexandria ptolomaica é de uma cidade que foi progressivamente se afastando dos ideais de Alexandre e se arruinando em virtude de problemas sociais e políticos, fruto do despreparo e ambição de seus reis. A falta de autoridades legítimas no reino começou a gerar todo tipo de distúrbio social, levando o povo a se manifestar de formas autônomas. As autoridades romanas começaram a intervir também de forma crescente, até que ocorreram os primeiros choques entre os dois territórios. Esses momentos de embate conscientizaram o Império de que suas intervenções no Egito "custaram caro" e que seriam necessárias novas formas de interceder naquele rico território. Era importante, no entanto, alertar para as vicissitudes daquele contexto específico, que alterou as relações até então estabelecidas entre Roma e Egito. Portanto, a partir desse momento, uma nova forma de abordar e lidar com o local deveria ser buscada. Os textos aqui tratados sinalizam esse cuidado com a nova conjuntura. 


\section{Capítulo 4: A Alexandria conflituosa e rebelde}

\subsection{A intensificação de uma má fama: estabelecimento de um topos}

A historiografia contemporânea incorpora a noção da Alexandria turbulenta, a partir dos comentários dos antigos. Dessa forma, a tendência à instabilidade é o maior consenso na historiografia sobre a cidade, que se dedica a explicar as origens e os motivos para a eclosão de tantos problemas. A história de violência do Egito romano é um tópico de estudo há muito tempo. Para Alston (1994, p. 517), o problema é que a maior parte das abordagens faz generalizações a partir de episódios isolados, sem considerar que a questão da violência no Egito se tornou um topos na literatura. $\mathrm{O}$ ímpeto das fontes em se debruçar prioritariamente nos momentos de polêmica já não indica um posicionamento pré-concebido em relação à cidade? A intenção aqui é entender como os escritos colaboraram para a produção da imagem revoltosa de Alexandria. Dessa forma, um dos aspectos mais fortes na identidade alexandrina atribuída e reforçada por outsiders é a sua tendência à instabilidade.

Na perspectiva de Milne (1924, p. 171), consciente dessa propensão à rebelião, Augusto deixou três legiões permanentes do Egito. Ou seja, sua tradição à turbulência fez Augusto lhe destinar medidas diferenciadas. Bernand (1966, p. 75) acredita que a sua composição populacional heterogênea gerou tal caráter "revolucionário". Em um artigo de 1980, M. Reinhold conclui que as novas condições impostas à população alexandrina tornou a população volátil e rebelde, resultando em uma humilhação para a cidade, e fazendo do Egito um caso isolado do Império. A tendência já existia entre os Ptolomeus, porém foi ainda mais exacerbada sob Roma. Na sua visão, foi isso que levou os autores romanos a falarem tão mal de Alexandria (1980, p. 99). O autor reúne todas as fontes que expõem o preconceito romano contra os egípcios e as articula como prova de sua tendência rebelde. Em momento algum as concebe como topos ou exageros retóricos e questiona as motivações da documentação em sempre enfatizar os momentos de instabilidade. Segundo Bowman (1986, p. 212), os problemas ocorridos sob os Ptolomeus já deixaram os romanos cientes da tendência rebelde dos alexandrinos. Bagnall ressalta que Alexandria conquistou a fama de "volúvel e violenta" no período 
ptolomaico e tais traços foram apenas periodicamente manifestos no período romano (2004, p. 51).

Como visto no primeiro capítulo, a intenção de William Barry $(1988$, p.1) é desconstruir essa visão, pois considera que os historiadores se deixaram levar pela retórica dos antigos. Segundo ele tais descrições de problemas ilustram o interesse dos antigos em relatar esse tipo de evento mais do que explicar a realidade alexandrina (1988, p. 59). O autor faz um quadro comparativo entre Alexandria e Roma no mesmo período, e conclui que houve pouca violência política na cidade durante os primeiros dois séculos de Império, mesmo em comparação ao período ptolomaico (1993, p. 28). Autores exageram a sua propensão à violência não porque a cidade fosse mais revoltosa que as outras, mas por terem a consciência que a estabilidade de Alexandria era vital para a ordem no império (1993, p. 32). Assim, Barry vai para o outro extremo, de negar a possível realidade violenta da cidade, que entende como pura retórica das fontes.

$\mathrm{O}$ intuito aqui não é ignorar a dinâmica do momento que gerou problemas constantes em Alexandria, mas analisar o porquê de tanto interesse em sublinhar preponderantemente tal tendência, levando em consideração a proeminência da cidade em outros setores. Sly (1996, p. 51) entende que o seu tamanho e natureza cosmopolita acentuavam seus aspectos distintos e muitas de suas características. Nesse sentido, sua notoriedade fazia as questões da cidade chamar mais atenção do que problemas em outros locais. É provável também que os autores quisessem dessa forma desviar o foco da Alexandria cultural para a turbulenta. Watts (2006, p. 151) não nega que a mistura étnica possa ter sido um "combustível” para os conflitos, porém considera intrigante que apesar da cultura intelectual da cidade, a caracterização de Alexandria no período romano se volte exclusivamente para seu espírito rebelde. Já Trapp (2004, p. 125) entende que diante da importância adquirida pela cidade no período, muito pouco se falou sobre Alexandria, mesmo na literatura da segunda sofística, na qual o objetivo era resgatar o "orgulho nacional" dos gregos. Por ser uma cidade nova e de fundação helenística, Trapp argumenta que Alexandria era secundária em relação a outros lugares de tradição mais antiga.

No primeiro tópico desse capítulo, serão apresentadas passagens (algumas já abordadas parcialmente nos capítulos anteriores) que marcam o enfoque dos autores exclusivamente nas caracterizações negativas dos alexandrinos. O objetivo é percorrer as fontes cronologicamente e demonstrar como foi sendo estruturada uma má fama 
associada a Alexandria antes da conquista romana e que essa imagem se tornou ainda mais forte depois de ser reforçada pela propaganda de Augusto. Mas quem eram os desordeiros, alexandrinos ou egípcios? É possível dissociar a percepção negativa entre Alexandria e o Egito como um todo? O preconceito já arraigado sobre o Egito ajudou a consolidar uma imagem da turbulência em Alexandria, ou eram percepções diferenciadas, que não se relacionavam? Essas são algumas das indagações que nortearão essa parte.

Foi visto no terceiro capítulo o depoimento de Políbio transmitido por Estrabão, com relação a uma viagem que o primeiro realizara ao Egito. Políbio escreveu a

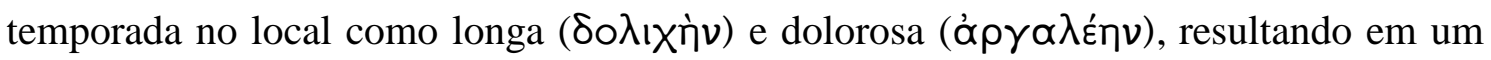
sentimento de profundo desgosto ( $\beta \delta \varepsilon \lambda u ́ t \tau \varepsilon \tau \propto \iota)$ diante dos problemas que predominavam no local (Geographica 17.1.12). O descontentamento de Políbio estava relacionado à manifestação de oposição das massas contra o rei Ptolomeu Euergetes Physcon, que havia usado seus soldados para puni-los. É possível que veiculação dessa imagem, nas palavras de um dos autores mais lidos da época, ajudara a consolidar a fama dos egípcios como um povo instável, colaborando para cristalizar o topos com relação à imprevisibilidade dos alexandrinos e sua tendência de enfrentamento diante dos reis. Dessa forma, essa imagem foi sendo fortalecida e reafirmada em cada nova geração de escritos. Contudo, ao receberem tais impressões de Políbio alguns autores o associam a egípcios, outros aos alexandrinos (por ser a sede da realeza). Outros ainda não parecem fazer uma diferenciação precisa e estabelecem generalizações, nas quais não fica claro se a referência é aos alexandrinos ou aos nativos de um modo geral. Apesar de Políbio escapar do recorte cronológico dessa pesquisa, ele é citado, pois se trata do primeiro relato a estabelecer apreciações sobre os egípcios em contexto ptolomaico. Suas impressões podem ter ajudado a propagar certo retrato sobre os alexandrinos/egípcios, que fontes posteriores reafirmariam.

Cícero faz um único julgamento cultural sobre o Egito, em que enfoca no seu aspecto mais repulsivo aos romanos: o culto aos animais:

Se alguém pudesse visitar muitos povos (gentis) e cidades (urbes) diversas e examiná-las, ver-se-ia facilmente que em primeiro lugar, os egípcios são sempre imutavelmente famosos, pois preservam registros de tempos muito antigos, que prova que consideram como deus um touro, chamado Ápis, e muitos outros monstros e animais de todo tipo são considerados divinos (deorum). (De Re Publica 3.9.14) 
Cícero associa a estranheza desse hábito à antiga fama egípcia, sugerindo que seus hábitos eram há muito refletidos, ao menos os mais contrastantes em relação aos gregos. Fica claro que nesse contexto em que Cícero pondera sobre a especificidade egípcia, Alexandria não está incluída. Ou seja, a cidade é entendida como uma entidade separada. Apesar de ressaltar a estranheza egípcia, o autor destaca a sua fama antiga, demonstrando um conhecimento (mesmo que superficial) consolidado dos gregos e romanos pela cultura egípcia.

Sobre os alexandrinos, Cícero se limita a fazer um julgamento em um contexto político, como visto no capítulo 3. No Discurso a favor de Rabírio Póstumo, o autor faz uma apreciação sobre o povo no momento em que narra a respeito de uma embaixada de alexandrinos em Roma. Cícero não se limita a descrever o comportamento dos enviados testemunhado por ele, mas aproveita a ocasião para fazer uma generalização sobre os alexandrinos, reforçando que há tempos ouvira falar de sua fama e que naquela situação eles a confirmaram. Ressalta que de lá vinha todo tipo de trapaça (praestigiae) e farsa (fallaciae). Assim, ele destaca o caráter traiçoeiro e imprevisível especificamente dos habitantes de Alexandria, sem fazer distinções referentes a status ou origem étnica (Pro Rabirio Postumo 12.34.2). Tal fama foi difundida pela leitura de Políbio e estava associada aos escândalos da história dinástica? No caso de Cícero o que causara maior incômodo foi aparentemente o modo debochado com que os alexandrinos se portaram na embaixada, talvez por não acatarem as ordens do momento e protestarem com o intuito de afirmar sua posição. Assim, a reclamação estaria associada ao ímpeto de lutarem por suas convicções.

Nas Guerras Civis, Julio César e principalmente o autor da Guerra de Alexandria confirmam tal tendência "traiçoeira", ao descrever o comportamento do rei, mas remetem também ao povo alexandrino em inúmeros momentos. Júlio César relata que por medo de Pompeu, os funcionários do rei se reuniram em segredo (clam consilio) e decidiram matá-lo (Bello Civili 3.104.1.4). Salienta que sua presença na cidade causou distúrbios na multidão e muitas arruaças aconteceram em dias sucessivos apenas pelo agrupamento da população (concursu multitudinis concitationes) (Bello Civili 3.106.4.1). O autor sugere a disposição para conflitos na cidade apenas pela possibilidade de reunir grandes aglomerações. César não aborda a composição social do agrupamento, mas é provável que fosse formado não apenas por alexandrinos cidadãos, mas egípcios nativos, judeus e outros estrangeiros, alguns residentes e outros que 
poderiam estar de passagem pela cidade, algo frequente em virtude de sua dinâmica comercial. Nesse sentido, os elementos de distúrbio seriam os habitantes de Alexandria como um todo.

O relato da Guerra de Alexandria expõe avaliações mais explícitas sobre o povo egípcio. Em um primeiro momento, o autor ressalta a esperteza e astúcia (ingeniosi atque acutissimi) dos alexandrinos, por aprenderem rapidamente as técnicas de guerra (Bellum Alexandrinum 3.1.1). Em seguida, faz uma apreciação com relação ao caráter do povo (natio, genus). Sublinha sua propensão à farsa, traição e rebelião (fallaces, temerarii, ad proditionem) (Bellum Alexandrinum, 7.2.5). Mais adiante, o autor aponta novamente o caráter traiçoeiro (fallaciis) do rei, algo talvez aprendido com seu povo (Bellum Alexandrinum 24.1.1) ${ }^{28}$. Ou seja, aqui o autor entende que a realeza seguia a tendência ao tumulto do povo alexandrino. No entanto, mais do que a propensão à rebelião, como Cícero a sua maior ênfase é na faceta traiçoeira e imprevisível (fallacis) do povo, o que podia estar relacionado com a falta de tato nas palavras e nos atos, além da propensão ao deboche, que normalmente não era compreendida por quem vinha de fora.

Levando em consideração o momento que os autores escreveram, acreditamos que um topos negativo associado aos alexandrinos estava em circulação já na segunda metade do século I a.C.. Ou seja, é possível que a resistência dos alexandrinos a autoridades ainda sob os Ptolomeus foi selando e propagando sua imagem, que depois foi reproduzida na tradição literária como um lugar-comum. Antes da instalação do Principado essas impressões sobre Alexandria começaram a se difundir e se consolidaram no decorrer desse século em virtude dos problemas enfrentados por Otávio no estabelecimento do Império, dos quais muitos foram protagonizados no Egito (como foi visto no capítulo anterior).

Apesar de reafirmar a visão de Políbio, Estrabão não tece apreciações explícitas sobre os alexandrinos em outros momentos, embora reflita sobre os egípcios como um povo tradicionalmente pacífico, conforme foi visto na longa passagem citada no capítulo 3. Estrabão afirma que as tropas romanas lá instaladas dificilmente eram usadas. Assim, apesar de ser uma população numerosa ( $\pi \propto \mu \pi \lambda \eta \theta \varepsilon \tilde{s})$, não era adepta

\footnotetext{
${ }^{28} \mathrm{O}$ historiador André Bernand defendia justamente o contrário, que foi a falta de exemplo dos seus reis que estimulou a instabilidade do povo, cf. BERNAND, 2001, p. 29.
} 


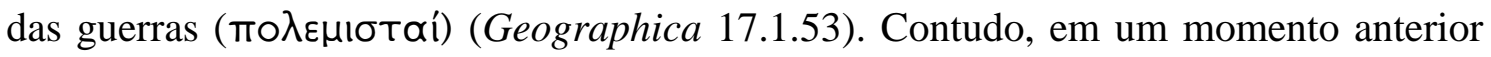
do mesmo livro, o autor destaca a prevalência da desordem (óvouíav) no governo dos reis, até a incorporação por Roma (Geographica 17.1.12). Fica claro que Estrabão faz uma diferenciação entre a antiga classe dirigente dos reis, que deixou o caos se disseminar pelo Egito, e a tendência antiga do povo egípcio pela paz. Quando cita Políbio para destacar o dito "mau estado das coisas", estaria se referindo às desavenças entre os reis, que resultaram na perda de controle da população. Assim, a visão do autor é que os romanos se instalaram transformando esse quadro, garantindo a autoridade e a ordem sobre a população alexandrina/egípcia. Tanto Estrabão, como os outros autores anteriores acima citados (Cícero e Júlio César) esclarecem que o motivo maior de preocupação em relação aos egípcios não era a natureza violenta e guerreira, mas um talento para a provocação, armadilhas e discórdia. Esse comportamento não necessariamente resultava em conflitos armados, embora fosse incômodo de outras formas, talvez por desestruturar a ordem e questionar práticas romanas.

Se antes de Augusto já era divulgada uma imagem do Egito e de Alexandria como um local instável e turbulento, sua propaganda agregou ainda mais um elemento para reforçar a oposição ao local: Alexandria vista como uma terra da devassidão e de excessos. A conquista colaborou para a propagação de um retrato do período ptolomaico, principalmente em sua fase final, como uma era de abusos e promiscuidade, pela propensão dos Ptolomeus (principalmente Cleópatra) a celebrarem festas e esbanjarem excessivamente. Assim, Alexandria foi retratada negativamente como uma "terra dos prazeres". Aos olhos romanos, juntamente a Cleópatra, Canopo, a cidade no Delta do Nilo, que era ligada a Alexandria por um canal, se tornou sinônimo de comportamento promíscuo e excessivo (WALKER, 2003, p. 197). Canopo era uma região que atraía pelos festivais musicais com dança, teatro (variando de dramas sofisticados até peças "vulgares"), além dos templos que abrigava, reunindo peregrinos de todo o mundo. Segundo o arqueólogo Frank Goddio (GODDIO; CLAUSS, 2006, p. 58-59), uma pessoa que não conhecesse Canopo podia ser acusada de não ter desfrutado a vida. O imperador Adriano conheceu o local e se entusiasmou tanto com a visita que construiu uma vila em Tivoli como uma alusão à Canopo (MCKENZIE, 2008, p. 185).

Mesmo Estrabão, que pretendia fornecer um relato mais formal e despido de juízos de valor, também explicita seu julgamento desfavorável a Canopo. Segundo o autor, lá foi instalado o templo dedicado a Serápis, o deus honrado com grande 
reverência e que realizava grandes curas. Seu poder era tanto que até os homens de maior reputação acreditavam nele. Em seguida, descreve a rotina do local:

\begin{abstract}
Mas para equilibrar tudo isso está à multidão de foliões

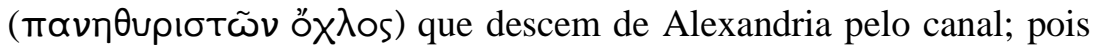
todo dia e toda noite fica abarrotado de gente $(\pi \lambda \eta \theta \dot{v} \varepsilon l)$ nos barcos

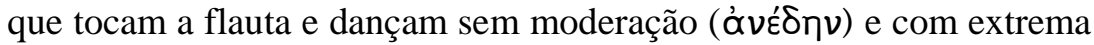

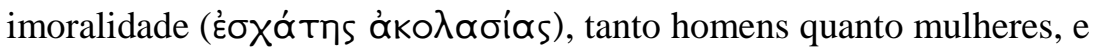
o próprio povo de Canopo, que tinha áreas de repouso

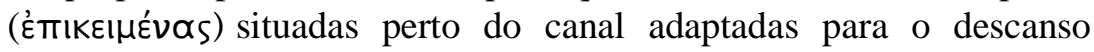

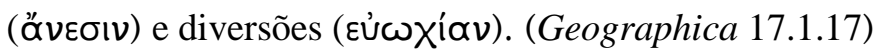

Horácio descreve Cleópatra como uma rainha louca, que estava tramando a ruína do Capitólio e pretendia destruir o Império propagando excessos (Odes 1.37). Propércio também menciona a devassidão de Cleópatra e de Canopo no seu poema escrito em comemoração ao primeiro aniversário dos jogos quinquenais, estabelecidos para comemorar Actium. A rainha não apenas agia promiscuamente, mas contagiava a todos com seus valores viciosos e excessivos (Elegiae 3.11.29-56).

Poetas do séc. I d.C. ainda divulgavam essa imagem negativa dos excessos de Alexandria e responsabilizam Cleópatra pela sua disseminação. Lucano é o autor latino que expressa de forma mais declarada sua aversão ao Egito, por ter sido palco da morte de seu herói Pompeu, como já visto no capítulo 3. A partir dessa ocorrência, o Egito foi definindo como uma terra impiedosa e traiçoeira (dubiis veritus), propensa a distúrbios (tumultu), barulho (murmure) e confusões (turbata) (Pharsalias 9.1005-1108). O autor culpava o Egito por causar a guerra civil (Noxia civili tellus Aegyptia fato) (entre Otávio e Antônio), e aproveita o cenário de crítica para censurar também seus cultos (Pharsalias 8.825-870). A exagerada ostentação de Cleópatra era mais um fator de condenação ao Egito: “... Cleópatra exibia a sua magnificência - magnificência esta que a sociedade romana ainda não tinha adotado" (Explicuitque suos magno Cleopatra tumultu nondum translatos Romana in saecula luxus) (10.110). O autor detalha o luxo e as riquezas do palácio, para os quais César se rendeu. Chama a atenção também para a opulência das jóias de Cleópatra e observa que César nunca vira tamanha ostentação (10.110-145). E expressa a sua repulsa: "Que cegueira! Que loucura de exibição! Revelar sua riqueza para o general em uma guerra civil, e incitar a avareza de um convidado armado!" (Pro caecus et amens ambitione furor, civilia bella gerenti divitias aperire suas, incendere mentem hospitis armati) (10.145). Além de toda a 
extravagância exibida no banquete, foram servidos ainda animais divinizados no Egito (Aegypti posuere deos). Diante de toda a exibição, o autor afirma que César ficou arrependido de ter guerreado com Pompeu e desejou um pretexto para entrar em combate com esse povo (gentibus) (Lucano 10.170).

O Egito a que Lucano se refere, é o Egito exótico, que adorava animais como deuses. Ou seja, sua concepção se baseava nos lugares-comuns da época, reforçadas pela propaganda de Augusto. Sua indignação era mais geral e aplicada não aos oficiais do rei ou especificamente a Alexandria (onde se localizava a corte real), mas a todo um povo e sua tradição antiga e arraigada. Portanto, tratava-se de um topos divulgado sem embasamento, já que suas críticas não se dirigiam a eventos específicos, mas a um povo como um todo e a respeito do que era superficialmente divulgado de sua cultura.

Juvenal também associa a má reputação de Alexandria a Canopo, mas depois diz que o comportamento vergonhoso do Egito não se limitava aos dois locais. Faz menção a Alexandria como "a cidade de fama vergonhosa" (famosaquemoenia) do Nilo, e que até Canopo condenava seus hábitos monstruosos (prodigia et mores urbis damnante Canopus) (Satura 6.82-84). E relata que o Egito era um "país grosseiro", mas em sua defesa, afirma que sua multidão "bárbara" não se limitava a Canopo de "reputação vergonhosa" (horrida sane Aegyptos, sed luxuria, quantum ipse notaui, barbara famoso non cedit turba Canopus) (Satura 15. 43-47). Ou seja, aqui o autor sugere que tal reputação se estendia para todo o Egito, não apenas para Canopo e ilustra que a realidade "vergonhosa" de Alexandria era até mais condenável que lá.

Ovídio sugere que alguns latinos ainda viam positivamente e se sentiam atraídos pelos entretenimentos da cidade, demonstrando que havia "tréguas" nas condenações romanas ao Egito apesar do consenso mais geral. No único trecho da sua obra em que menciona Alexandria o autor remete aos seus prazeres: "nem estou navegando para a famosa cidade de Alexandre para presenciar os seus prazeres, ó Nilo! (non ut Alexandri claram delatus ad urbem delicias videam, Nile iocose tuas)" (Tristia Ex Ponto 1.2.79).

Vitrúvio (De Architectura 7 Praefatio 4-8) e Sêneca (Epistulae Morales 9.5) não abordam o luxo dos Ptolomeus com relação às festas, mas julgam a Biblioteca como uma prova de esbanjamento excessivo dos reis, como foi visto no capítulo 2. Dessa forma, o comprometimento excessivo com o luxo fazia os reis perderem o controle da população, pois desviavam o foco do governo para questões supérfluas. 
Ao rememorar o momento em que Alexandre conquistou o Egito, Quinto Cúrcio Rufo se refere aos egípcios como um povo "falso e superficial" (vana gens), sempre inclinado a começar uma revolução (novandis). Em virtude desse comportamento se apressou em ajudar Alexandre a destruir as tropas persas (Historiae Alexandri Magni 4.1.28). Aparentemente, Cúrcio reforça o estereótipo egípcio da época de Augusto e o transfere ao tempo de Alexandre.

Tácito se refere aos habitantes do Egito como um povo propenso à discórdia e instabilidade ao justificar os motivos de Augusto para encarregar membros da ordem equestre para a administração. Menciona também a superstição de seus habitantes (superstitione ac lascívia discordem et mobilem) (Historiae 1.11.1), sugerindo que era a religião que os destituía da razão. Como Lucano, Tácito faz uso da percepção geral atribuída aos egípcios, e usa tal generalização para explicar questões contemporâneas.

Tácito faz uma observação sobre a escrita, da qual o Egito foi a civilização fundadora. Afirma que nas representações de animais, os egípcios foram o primeiro povo a simular pensamentos com desenhos. Assim, eram os primeiros documentos da historia humana (antiquissima monimenta memoriae humanae), e visíveis ainda no seu tempo. Consideravam-se os inventores do alfabeto. Acreditava-se também que de lá os fenícios, antigos líderes nos mares, introduziram (intulisse) o conhecimento na Grécia e ganharam o crédito por descobrirem o que na verdade tinham se apropriado (Annales 11.14). Tácito indica aqui a admiração pela antiguidade do povo, que estabeleceu as bases para algumas heranças posteriores dos gregos, embora considerasse que grande parte dessa fama era por direito dos helenos.

Nas Histórias, Tácito descreve em pormenores os costumes dos judeus, e observa que como os egípcios, eles enterravam seus mortos ao invés de queimarem-nos. Ressalta que os egípcios adoravam animais e imagens, enquanto os judeus adoravam um deus apenas (Historiae 5.2-5). Ou seja, por mais que considerasse a escrita como um aspecto da cultura egípcia que a tornava respeitável, em seguida destaca a mesma abominação que Cícero já havia mencionado, o que tornava a religião judaica, ainda assim, superior aos cultos egípcios.

Dion Cássio refere-se à tendência turbulenta dos egípcios em inúmeros momentos de sua obra. No contexto que resultou na expulsão do rei Ptolomeu Aulete,

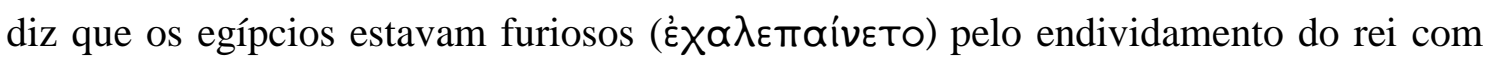

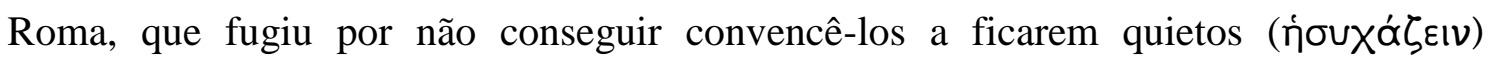


(Historiae Romanae 39.12.3). No ato em que Gabínio restituiu o rei ao trono, novamente Dion diz que os alexandrinos estavam sempre prontos a assumir uma postura corajosa ( (Historiae Romanae 39.58.1.5). No cenário das desavenças entre os egípcios depois da guerra contra César, Dion Cássio observa que eram o povo mais religioso do mundo em

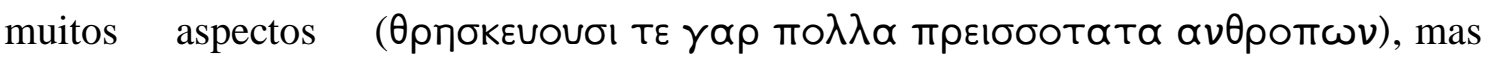

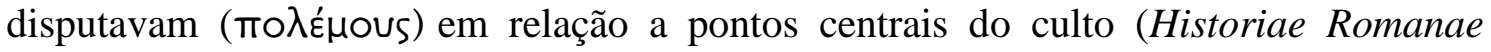
42.34). Ao final da guerra, observa que César dominou o Egito, mas ainda não o tornou uma província, pois tinha medo de os egípcios se rebelarem ( $\phi \circ \beta \eta \theta \varepsilon i \varsigma$ ) (Historiae Romanae 42.44.1).

Mesmo quando o autor profere um julgamento referente à religiosidade dos egípcios (aqui fala de alexandrinos e egípcios), ainda assim não deixa de enfatizar que eram descuidados nos enfrentamentos (тротєте́бтато।) e fracos em coragem

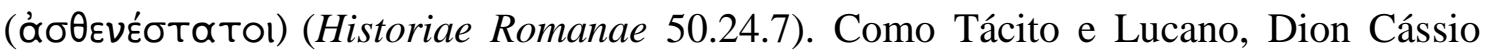
pontua a interferência da religião no comportamento do povo. Ou seja, se em momentos anteriores o autor fazia seus julgamentos a partir de situações concretas (expulsão de Aulete, sua restituição por Gabínio, vitória de César), nessa passagem em que trata da religiosidade egípcia, menciona novamente o topos. Dion Cássio entendia como turbulenta a postura dos alexandrinos de se manifestarem contra os abusos dos reis. Ou seja, sua oposição se refere ao comportamento de protesto constante da população, já que menciona eventos ocorridos na sede real. Assim, a realeza seria mera vítima da "massa em constante ebulição".

Todos os autores citados até aqui tratam de momentos turbulentos no Egito antes da instalação do Principado. Cícero, Júlio César e o autor da Guerra de Alexandria escreveram nesse mesmo contexto, enquanto os outros partem de uma conjuntura imperial pós-conquista, mas ainda focados em um período anterior. Estrabão escreveu em uma época das consolidações da conquista de Augusto, mas também retoma séculos anteriores, com o intuito de demonstrar a superioridade de sua época. E os poetas latinos remetem ao final do período ptolomaico.

A partir desse breve resumo é notável que entre os séculos I a.C. e I d.C. as valorações negativas atribuídas aos egípcio-alexandrinos predominavam entre os escritores latinos. Foram eles que verbalizaram abertamente a existência de uma aversão 
ao Egito, com predomínio para a época de Cleópatra. Contudo, não fazem distinções precisas entre o Egito antigo (faraônico) e o de sua contemporaneidade. A exceção é Dion Cássio, que mesmo grego e escrevendo ainda mais distante cronologicamente dos eventos do século I a.C., não economiza adjetivos para criticar os egípcios em praticamente todos os contextos em que os cita (veremos que ele continua usando os mesmos julgamentos para períodos mais próximos de sua escrita). Mais adiante será visto como a avaliação da literatura imperial em relação ao Egito pouco foi alterada ao narrar episódios ocorridos em Alexandria no decorrer dos séculos I e II d.C..

\subsection{Augusto e Tibério: retomada da ordem e predomínio da paz}

Para o período de Augusto ${ }^{29}$, as fontes se focam principalmente na tomada de Alexandria e na conquista do Egito, como visto no capítulo anterior. A ênfase é na era de paz e ordem introduzida pelo romano, marcando uma quebra radical com os governantes anteriores, um tempo em que predominou o caos. Assim, os autores se dedicaram a demonstrar os ganhos promovidos por Augusto no Egito, através de inovações no aparato administrativo e na presença do exército. Nessa etapa, a intenção é ilustrar que apesar da ênfase na harmonia e ordem, a literatura fornece indícios de que problemas ocorreram já nos principados de Augusto e Tibério. Portanto, houve algum tipo de reação às inovações, por mais que se perceba um objetivo nítido nas fontes de ignorar qualquer tipo de polêmica para o período. Ou seja, a documentação pretende difundir a representação do primeiro século de Império Romano na cidade como um tempo em que imperou um governo harmônico, ordenado e pacífico.

Estrabão detalha as novidades administrativas que estabeleceram a ordem no território, reforçadas pela presença do exército. Assim, a idéia mais sublinhada é que Augusto foi bem-sucedido em garantir a paz e a prosperidade, uma quebra brutal em relação ao tempo anterior (Geographica 17.1.12-13). Fílon elogia o tempo de Augusto e Tibério com a intenção específica de demonstrar o desvirtuamento do império com

\footnotetext{
${ }^{29}$ Se até agora, ao tratar do período anterior à conquista, usávamos a nomenclatura "Otávio" para se referir ao primeiro imperador, agora mudaremos para "Augusto", pois estamos nos referindo ao reinado como um todo e ao nome com que ficou conhecido na posteridade.
} 
Calígula, que se refletiu nos problemas enfrentados pelos judeus (De Legatione ad Gaium 21-22). Josefo realça que para garantir o suprimento de trigo para Roma, Augusto não descuidou da vigília constante do exército na cidade (Bellum Judaicum 2.385.3).

Estrabão é o único escrito a citar os problemas enfrentados pelo primeiro prefeito Cornélio Galo. Segundo o autor, ele atacou Heroópolis, que se revoltara

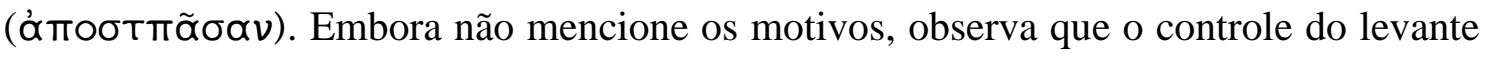
foi feito com poucos soldados. Estrabão nota também que em pouco tempo o prefeito abafou outra rebelião (oTóoıv) que ocorreu na Thebaid por causa dos tributos (Geographica 17.1.53). Percebe-se que o autor não traz o foco para a eclosão das rebeliões, mas no pouco tempo que o prefeito levou para freá-la. Ou seja, novamente a ênfase é na imposição da ordem, mas nesse contexto o autor deixa escapar a insatisfação que as novas medidas impostas por Roma estavam trazendo, deixando evidente que não pretendia abordá-las. O comentário de Estrabão indica a insatisfação dos egípcios com relação à mudança na taxação (LEWIS, 1970, p. 7). Sugere também que a laografia foi logo introduzidas por Augusto, talvez já em 26, sendo esta então a primeira reação a sua imposição no Império (RATHBONE, 1993, p. 88) ${ }^{30}$. Com relação à situação de Heroópolis, Milne (1924, p. 5) observa que o Baixo Egito já estava em "estado de rebelião" contra os Ptolomeus há algum tempo. Consequentemente, não aceitaria uma administração romana com facilidade. Então uma das primeiras tarefas do prefeito foi acalmar a situação no interior do Egito. Entretanto, o processo de pacificação foi relativamente simples, pois os egípcios logo entenderam que as forças militares romanas eram mais poderosas do que as anteriores. Assim, na visão de Milne, não se deve entender a revolta como uma reação a Roma, pois eram resquícios do governo anterior. E como evidência, o historiador se concentra apenas no comentário de Estrabão de que a revolta foi fácil de controlar. Porém, não era o intuito principal de Estrabão enfocar na superioridade militar romana e na ordem propiciada por sua

\footnotetext{
${ }^{30}$ No artigo de Dominic Rathbone "Egypt, Augustus and Roman Taxation" o autor faz um estudo detalhado sobre as taxações implantadas no Egito. Considera que as alterações no sistema fiscal em relação aos Ptolomeus foram brutais, além das diferenças do Egito de outras províncias nesse setor, o que reforçam ainda mais a sua excepcionalidade no império. A imposição da poll-tax anual (tributum capitis) era mais do que uma inovação fiscal, mas era um importante símbolo de submissão a Roma, pois não existia antes de 30. Foi testada inicialmente no Egito e depois se universalizou para quase todas as províncias. Para Rathbone, o Egito era como o "laboratório" de Augusto, onde testava algumas medidas que depois de tornaram padrão. Cf. RATHBONE, 1993.
} 
presença? Nesse sentido, é arriscado entender o comentário de Estrabão apenas como prova da capacidade de organização romana, sem levar em conta a hipótese que ele levanta sobre as possíveis reações a Roma logo no início do Império, que foram intencionalmente ignoradas por ele.

Suetônio enfoca nas melhorias da produtividade (Divus Augustus 18) e na conquista da paz (Divus Augustus 98). Tácito comenta a inovação de Augusto de apontar apenas membros da ordem equestre para o governo do Egito, para manter um controle mais rígido sobre a província, e garantir o suprimento para Roma (Historiae 1.11.1). Menciona também a proibição da entrada de senadores sem o consentimento imperial, medida que tinha a mesma preocupação (Annales 2.59.10).

Apesar dos relatos sublinharem a genialidade de Augusto de promover a organização da província e impor uma política de mais vigília frente ao Egito, com a nomeação de membros da ordem equestre para o seu governo, Suetônio relata que logo na primeira nomeação, Augusto enfrentou problemas. Segundo o autor, o prefeito Cornélio Galo foi condenado pelo decreto do Senado e banido das províncias imperiais pelo seu espírito ingrato e invejoso (ingratum et malivolum animum) (Divus Augustus 66.2). Dion Cássio detalha um pouco mais os motivos para a condenação de Galo, dizendo que ele foi insolente ( $\varepsilon \xi \cup \beta \rho i ́ \zeta \omega)$ diante da honra ( $\tau І \mu \tilde{n} \varsigma)$ conferida por

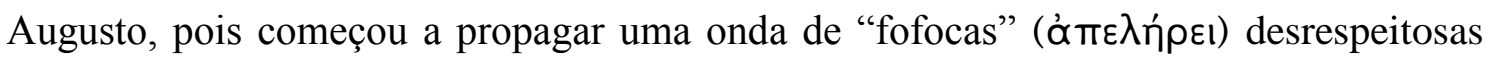

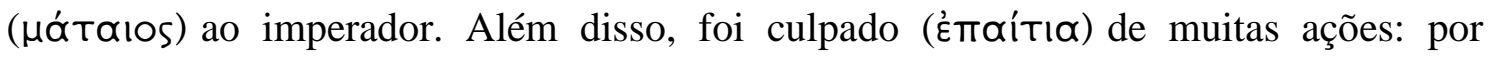

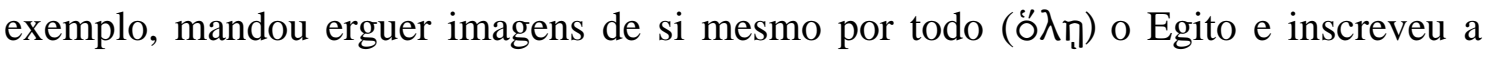
lista de suas realizações em pirâmides. Depois de ter sido atacado por muitos, foi condenado unanimemente pelo Senado e cometeu suicídio (Historiae Romanae 53.23.57). Segundo Lendon (2001, p. 158), Galo deveria ter demonstrado gratidão eterna ao imperador pela nomeação como primeiro prefeito do Egito, e o fato de promover elogios a si mesmo era entendido como o extremo da desonra, que chocou a todos. A situação do prefeito é um exemplo claro do peso da reciprocidade na concessão de favores nas relações dentro da elite imperial.

Como Estrabão, Dion Cássio trata das inovações administrativas promovidas por Augusto, como a introdução de novos impostos e a proibição de senadores de governarem o Egito, pela extensão do suprimento de trigo e de sua riqueza. Porém, o autor sublinha que as medidas especiais foram articuladas também em virtude da 


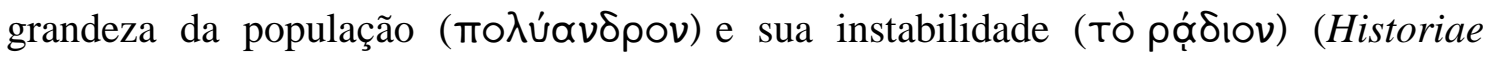

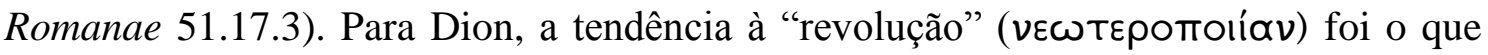
impediu à Alexandria a posse de uma Boule, concedida posteriormente por Severo (Historiae Romanae 51.17.1-2). Trata-se do único autor que menciona a ausência da instituição na cidade. No entanto, ele não cita a sua eliminação por Augusto, mas relata a negação de seu consentimento (demonstrando que os alexandrinos solicitavam a sua restauração ou concessão): "ele comandou os alexandrinos a conduzirem seu governo

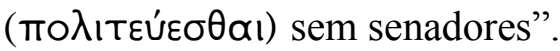

As fontes indicam que Tibério manteve o mesmo padrão de comportamento de Augusto em relação a Alexandria, no sentido de manter a vigília. Suetônio aponta a cautela e certa aversão de Tibério à entrada de novas religiões em Roma. Afirma que o imperador aboliu cultos estrangeiros (externas caerimonias), especialmente os ritos egípcios e judaicos, obrigando todos os que se dedicavam a essas superstições (superstitione) a queimar suas vestimentas religiosas e a "parafernália" toda (instrumento omni) (Tiberius 36). O autor sugere assim, certo conservadorismo cultural de Tibério, talvez ainda um resquício da política de Augusto.

Tibério adotou a mesma postura de Augusto com relação à entrada de senadores no Egito. Um indício disso, já citado no capitulo anterior, foi sua indignação quando em uma época de terrível fome (immensam et repentinam famem) em Alexandria, seu sobrinho Germânico foi a cidade sem a sua autorização. Tibério reclamou ao Senado por não ter sido consultado (inconsulto) antes da viagem (Suetônio. Tiberius 52.2). Tácito salienta que além de não pedir autorização, Germânico diminuiu o preço do trigo, disponibilizando a produção (frugum) para o povo e andou com trajes gregos. Mas o maior motivo de censura de Tibério foi o fato de ele ter desrespeitado as normas de Augusto (Annales 2.59.10). Josefo relata que Germânico distribuiu trigo à grande parte da população de Alexandria. $\mathrm{O}$ fato de a distribuição não ter se estendido à comunidade judaica era visto por Apião (escritor grego crítico aos judeus) como prova da falta de favorecimento dos romanos aos judeus. Josefo argumenta que ele não forneceu trigo a todos os habitantes de Alexandria, pois não havia o suficiente para todos, e não por ter algo específico contra os judeus (hoc indicum est sterilitatis ac necessitatis frumentorum, non accusatio Iudaeorum). Pelo contrário, o autor argumenta que a boa postura demonstrada por todos os imperadores diante dos judeus era notável (Contra Apionem 2.63.1). 
Germânico foi censurado, pois Tibério considerou a sua visita como uma provocação de um pretendente ao trono (CLARYSSE; WILLEMS, 2000, p. 34). O imperador sabia que um rival no Egito poderia derrubá-lo, caso se apoderasse de seus recursos (JONES, 1978, p. 38). Harker (2008, p. 60-61) comprova a visita de Germânico em outros documentos ${ }^{31}$, o que denota o impacto da sua presença, provavelmente por ele ter sido o primeiro herdeiro direto de Marco Antônio a visitar a cidade, o que justificaria a euforia dos alexandrinos. Percebe-se tanto no episódio de Cornélio Galo, quanto no de Germânico as consequências do desrespeito à medida de Augusto, e o temor que ainda havia de outros romanos de alto status (principalmente senadores) adquirir popularidade no Egito.

Por mais que as fontes demonstrem a aceitação do novo comando e pouco assinalem os momentos de vulnerabilidade, é perceptível nos comentários citados que ainda havia a preocupação de o Egito ser apoderado por algum romano ousado. Mantêlo controlado era vital para a continuidade do fornecimento de trigo, mas era também necessário chamar a atenção para a sua tendência ao distúrbio, pois a percepção era que uma população assim tão instável poderia ser facilmente mobilizada contra Roma. Tal percepção é consensual entre os gregos (Estrabão, Fílon, Josefo e Dion Cássio) e os latinos (Tácito e Suetônio) que tratam do primeiro século do Império Romano em Alexandria.

\subsection{De Calígula a Nero: tempo de conflitos sociais}

Apesar de tantas menções à instabilidade de Alexandria, a literatura descreve o principado de Augusto e Tibério como um tempo de tranquilidade e harmonia na cidade. As fontes voltam a se focar em sua tendência polêmica a partir de Calígula, um imperador que tinha uma simpatia especial pela cidade. No seu principado, Alexandria foi acometida por dissensões civis entre alexandrinos e judeus que passam a ser mais um motivo de alerta em relação ao Egito, somado aos anteriores (que ainda se

\footnotetext{
${ }^{31}$ O P.Oxy. XXV 2435 faz referência ao encanto de Germânico ao visitar Alexandria, mas justifica que não esperava menos de uma cidade fundada por Alexandre. Mas em outro documento (SB I 3924) ele comenta sobre o excesso de barulho da multidão alexandrina.
} 
mantinham no horizonte das fontes). Os problemas continuaram nos principados de Cláudio e Nero e voltaram a ocorrer no reino de Trajano.

O contexto a partir de Calígula é importante por demonstrar o início de posturas dúbias em relação ao Egito na elite imperial. Ou seja, se com Augusto e Tibério houve o predomínio de uma atitude semelhante de estimular a vigília ao território, nos impérios seguintes são perceptíveis algumas oscilações. Por mais que Augusto e sua literatura tentassem promover uma aversão ao Egito, sua inserção no Império como província facilitou o acesso a sua cultura, através do aumento de viagens imperiais e melhorias na comercialização, intensificando a rotina de chegadas e partidas da cidade. Segundo Mckenzie (2008, p. 185), as visitas imperiais a partir de Augusto resultaram em um interesse na arquitetura egípcia em Roma, com a introdução de obeliscos, pirâmides, pinturas de parede e templos a Ísis e Serápis. Assim, conforme aumentava a presença de elementos egípcios em Roma, mais se contrabalanceava a onda de propaganda avessa às suas tradições, resultando em uma curiosidade diante das tradições egípcias. Esse é exatamente o tema do livro dos historiadores franceses W. Clarysse e H. Willems Les Empereurs du Nil. (2000) ${ }^{32}$. Nesse sentido, uma das intenções desse capítulo é discutir como as fontes representam o comportamento de cada imperador diante do território milenar e de sua capital Alexandria.

No reino de Calígula irrompeu o primeiro conflito cívico entre a comunidade judaica de Alexandria e os alexandrinos. Pouco se sabe sobre as origens e os motivos das revoltas e de como se desenvolveram, devido à parcialidade dos relatos de Fílon e Josefo, pois por serem judeus, naturalmente atribuem toda a culpa do conflito aos alexandrinos. Após o primeiro conflito em 38, embaixadas dos dois grupos se direcionaram a Calígula para expor os problemas, e Fílon era membro do lado judeu. A partir do seu relato, Josefo também aborda a conjuntura, e fala de outros embates no tempo de Cláudio e Nero.

A comunidade judaica de Alexandria era a maior da Diáspora, e representava por volta de um terço da população total da cidade. É provável que estivessem presentes desde a fundação, mas o aumento da comunidade ocorreu no séc. III a.C. após a revolta dos Macabeus na Judéia. Os Ptolomeus e os primeiros imperadores garantiram aos

\footnotetext{
${ }^{32}$ Citemos alguns exemplos da visão dos autores: Calígula utiliza os elementos egípcios para criar sua teoria sobre a personalidade divina do imperador; Vespasiano foi escolhido imperador graças à ajuda do prefeito do Egito, assim, passa a sua primeira noite em Roma no templo de Ísis e Severo e Caracala eram adoradores de Serápis (2000, p. 30).
} 
judeus o direito de praticarem sua religiosidade de acordo com as tradições antigas, reforçando seu pertencimento étnico, algo que diminuiu após a revolta da Judéia (entre 66 e 73 d.C.), tempo de escrita de Josefo (BOWMAN, 1986, p. 123). Para Davis (1951, p. 118), o crescimento da hostilidade mútua entre judeus e alexandrinos foi evidente no séc. I d.C., mas só se manifestou em conflitos no tempo de Calígula, o que ele entende como uma evidência de enfraquecimento no controle central do Império.

O primeiro embate entre os grupos ocorrido em 38 foi extensivamente narrado por Fílon, judeu influente na comunidade alexandrina e escolhido para representar o seu lado na embaixada a Calígula. Seu papel de destaque em Alexandria lhe fez deixar de lado as preocupações filosóficas, para se referir a questões contemporâneas e cívicas nos livros Contra Flaco e Embaixada a Calígula. Nesses escritos, as distinções entre judeus e não-judeus são mais visíveis e a hostilidade e o desprezo pelos seus opositores é claro, embora Fílon fale de egípcios e alexandrinos sem fazer muitas distinções (BIRNBAUM, 2004, p. 156). Assim, a obra é importante por ilustrar o antagonismo entre os povos e demonstrar o cosmopolitismo alexandrino (BERNAND, 1966, p. 257). O envolvimento de Fílon com política era relutante e mesmo em textos políticos, a sua intenção prioritária era explicar a religião judaica para um público não-judeu (LEWIS, 1983, p. 29). A Embaixada a Calígula narra eventos ocorridos até 41, provavelmente retaliações dos judeus aos ataques anteriores, mas ambos mostram como as políticas de Calígula afetaram os judeus por todo o império (SLY, 1996, p. 169).

A prioridade do Contra Flaco é descrever o desvirtuamento do prefeito de Alexandria Flaco, que foi cooptado por alexandrinos a preparar um ataque contra o povo judeu. Apesar de descrever a injustiça Fílon não explica as razões para o desenvolvimento do antijudaismo na cidade. Segundo o autor, os problemas se iniciaram quando Flaco foi obrigado a se aliar a facção antijudaica dos alexandrinos e executar uma política de "ataque" ('̇mıßou $\lambda \hat{\nu} v)$ à comunidade, iniciada pelo predecessor Sejano. Flaco foi nomeado prefeito sob o principado de Tibério. Segundo Fílon, nos primeiros cinco anos de governo Flaco fez uma excelente administração e um

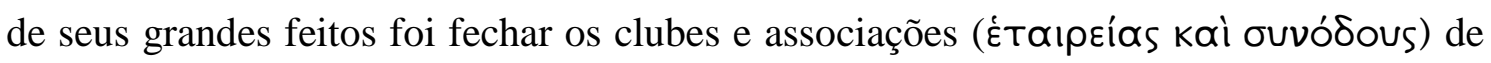
Alexandria, por terem se tornado o cenário de bebedeiras e intrigas políticas

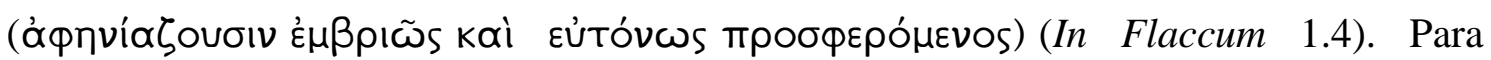
Modrezejewski (1995, p. 166), Fílon profere inúmeros elogios a Flaco nessa parte com 
a pretensão que seu relato servisse de manual moral para seu sucessor, demonstrando como um homem com enorme zelo e grandes talentos poderia cair em desgraça se houvesse abuso do poder.

Em seguida, Fílon começa a circunscrever o círculo alexandrino a quem dirige o seu ataque, fazendo a primeira generalização sobre o Egito:

E quando os governantes desistem de manter o controle, os sujeitos imediatamente se tornam inquietos (úmnkóous), principalmente

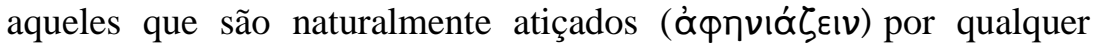
ocorrência normal e pequena. Entre eles o povo do Egito (Tò Aìvurtıakòv) fica em primeiro lugar, acostumado como está a transformar as menores faíscas ( $\left.\sigma \pi ı v \theta \tilde{n} \rho \circ)^{2}\right)$ em sedições graves

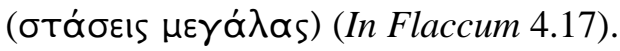

Com a autoridade enfraquecida por não ter proximidade com o novo imperador Calígula, Flaco foi obrigado a se aliar aos seus antigos inimigos

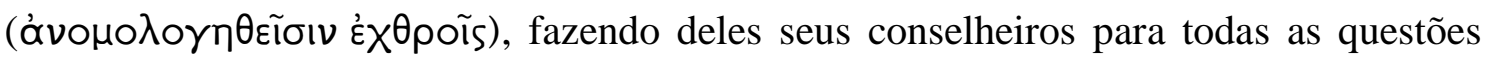

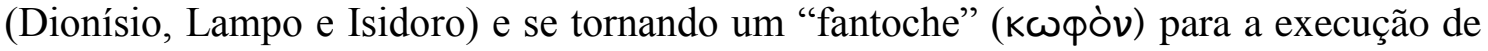
seus planos. Esses homens tinham preparado uma "armadilha"

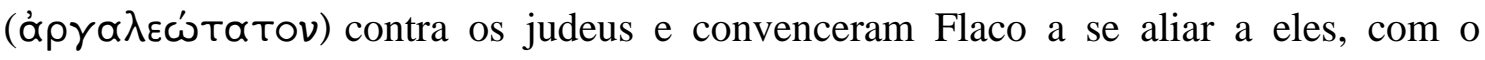
argumento de que se opondo aos judeus ele agradaria Calígula, diziam também que por

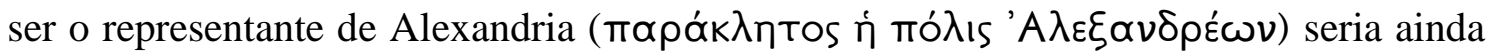
mais fácil a aproximação de Calígula, pois a cidade tinha sido honrada por toda a casa de Augusto (ämas ó $\sum \varepsilon \beta$ aotòs oî́kos) (In Flaccum 18-24). O autor demonstra a predileção de Calígula pela cidade, e retrata o tempo de Augusto e Tibério como um momento de tranquilidade e vantagens para o local. Assim, Fílon demonstra grande admiração por Augusto, e expressa essa aprovação em inúmeros momentos, com o intuito de esclarecer que sua oposição era restrita a poucos romanos.

A situação se agravou ainda mais com a visita de Agripa, rei da Judéia. O rei passou por Alexandria na rota de retorno para a Síria, mas seu objetivo era passar por lá rapidamente e não visitar a cidade (In Flaccum 5.25-28):

Mas como a inveja ( $\varphi \theta$ óvou) é parte da natureza egípcia ( ( aventurança (Eủtuxías) a outros como azar (kakompayías) a eles

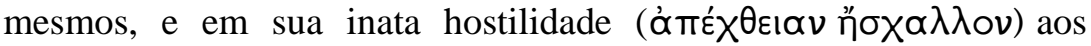


judeus, eles ressentiam um judeu ter sido feito rei como se cada um deles tivesse sido privado de seu trono ancestral

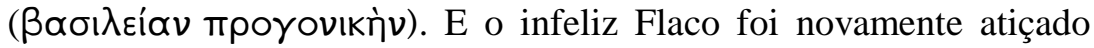
por seus companheiros, com provocações e apelos

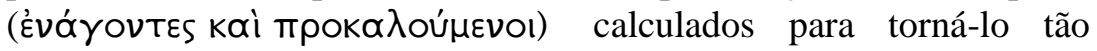
invejosos ( $\phi \theta$ óvov) como eles. 'A estadia dele aqui', eles diziam, 'é a sua deposição'. A dignidade da honra e do prestigio

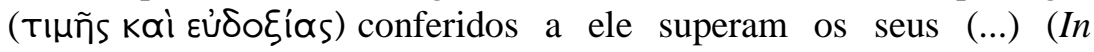
Flaccum 5.29-30).

Os alexandrinos então convenceram o prefeito de que a presença de um rei em terras fora de seu domínio o inferiorizaria (In Flaccum 5.30-32). Assim, a honra concedida a outro rei era um insulto a Flaco, pensamento que se adequava às regras políticas da época (LENDON, 2001, p. 208). Na sequência, Fílon expressa com mais clareza sua visão sobre a multidão alexandrina, que era facilmente coagida para executar qualquer projeto sem valor:

Pois o bando preguiçoso e desocupado da cidade

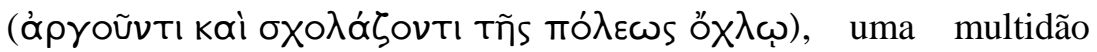
$(\pi \lambda \tilde{\eta} \theta$ os) especialista em conversas sem fundamento ( $\gamma \lambda \omega \sigma \sigma \alpha \lambda \gamma(\dot{\alpha} \alpha)$, que devotava o seu lazer a difamação e falas

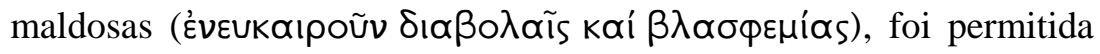

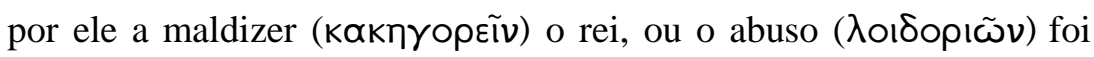
começado realmente por ele mesmo ou causado pelo seu incitamento e provocação endereçada a eles que eram seus ministros regulares nessas questões. Começaram então o processo passando seus dias no

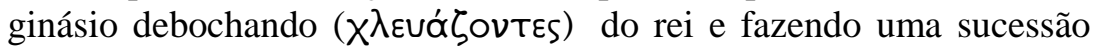

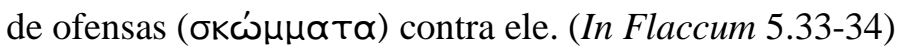

Percebe-se que mesmo sendo alexandrino, Fílon confirma a fama do Egito como um local turbulento. Assim, apresenta a mesma visão estereotipada sobre o povo: perigoso, imprevisível, e movido por paixões (SLY, 1996, p. 46). É provável que o autor fizesse uso do topos para reforçar a posição de vítima dos judeus nesse contexto, pois os leitores rapidamente associariam a "multidão instável" aos alexandrinos que se rebelaram contra os judeus, incitados pelo povo do Ginásio. Dessa forma, seria mais fácil divulgar uma imagem da comunidade judaica como o grupo perseguido da cidade.

A chegada de Agripa foi o estopim para o conflito (MILNE, 1924, p. 17). Fílon condena Flaco por não ter feito nada para impedir a oposição que se formava, e opina

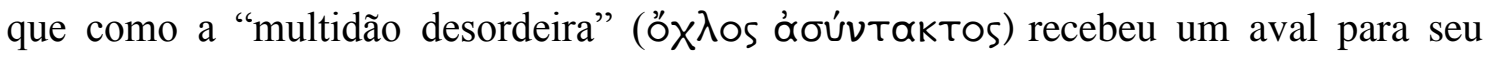


mau comportamento, continuaram propagando a violência

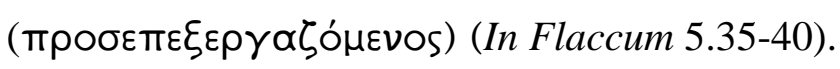

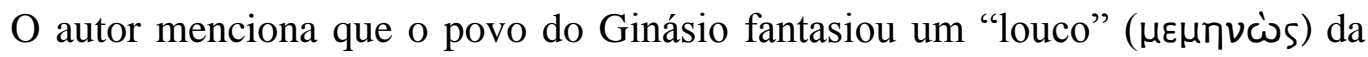
cidade de rei, e fez um teatro para agredir Agripa (In Flaccum 6.36-39). Condena Flaco por estimular a situação, além de não frear os alexandrinos, fazendo com que "a multidão sempre apta a criar confusão"

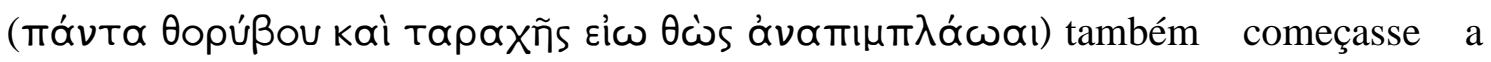
ridicularizar o rei e o judaísmo, instalando imagens nos seus locais de reunião (In Flaccum 6.40-42). Fílon interpreta essa atitude da multidão como uma manifestação

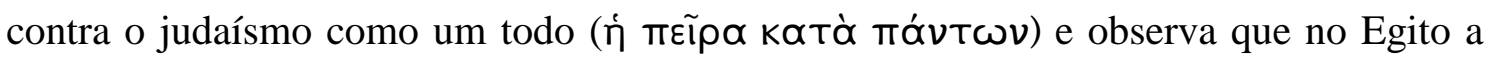
população judaica deveria ser respeitada por sua grandeza (In Flaccum 6.43).

Flaco era, então, um dos responsáveis pelo "conflito racial de todo o mundo

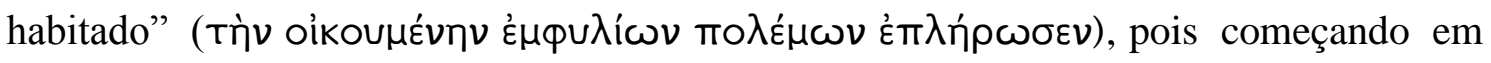

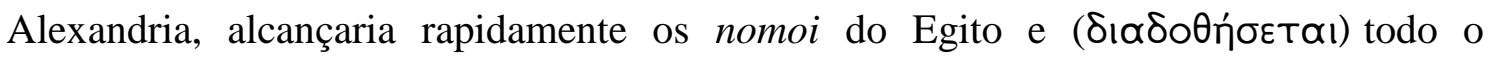
Oriente, pois os judeus eram tão populosos (

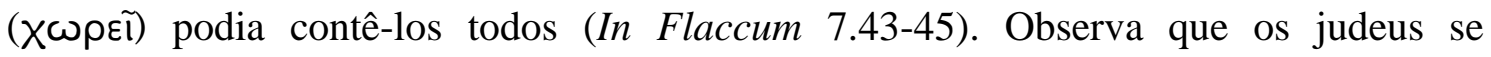

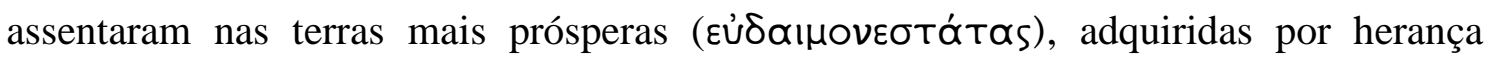
( $\left({ }^{\prime} \lambda \propto \chi \bigcirc \vee\right.$ ) e para outras tinham ido no momento de fundação (In Flaccum 7.46). Fílon temia que seguindo o exemplo de Alexandria, pessoas de todos os lugares

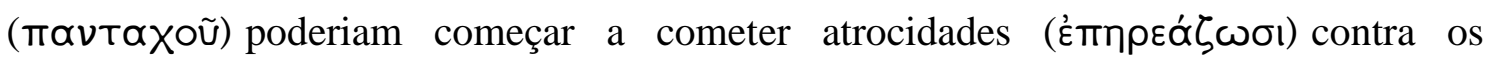
judeus, atacando suas sinagogas e seus costumes ancestrais. Pois apesar de serem um

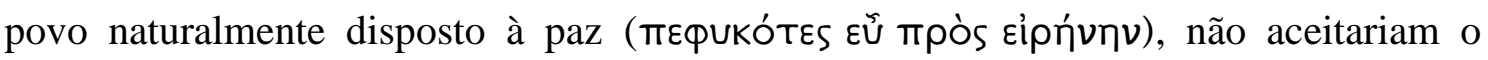
desrespeito às suas tradições (In Flaccum 7.47-49). Per Bilde (2009, p. 112) argumenta que através da ênfase na grandeza do judaísmo, Fílon tinha a intenção de avisar a elite romana de que se a política destinada aos judeus não fosse alterada, haveria problemas, podendo até provocar reações armadas dos judeus. Se na parte anterior o objetivo foi descrever a facilidade com que a multidão alexandrina era colocada em movimento, seguindo a liderança de membros das associações que o autor tanto desprezava, a partir dessa etapa a intenção de Fílon é demonstrar como os judeus se sobressaiam nessa cidade pelos seus valores. Nesse sentido, se tornaram vítimas e o "outro" em meio a essa enormidade que tinha como "princípio" apenas a arruaça. 
Em seguida, Fílon afirma que Augusto tinha confirmado ( $\beta \varepsilon \beta \propto ı$ ऽ̃v) os direitos e a fé antiga dos judeus e que a hostilidade alexandrina foi gratuita (In Flaccum 7.5052). El-Abbadi (1993, p. 52) sugere que os alexandrinos se voltaram contra os judeus pela confirmação dos mesmos privilégios que tinham tido sob os Ptolomeus, pois era mais seguro atacá-los do que se revoltar abertamente contra os romanos.

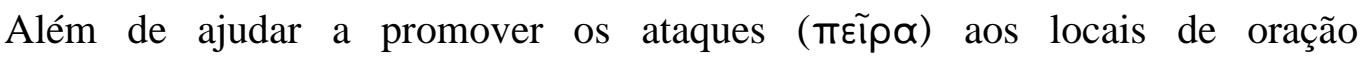
(

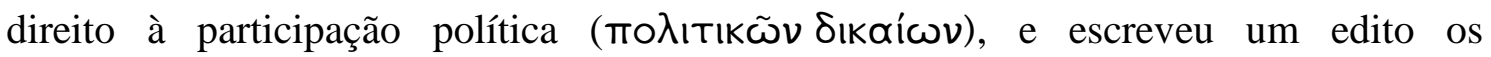

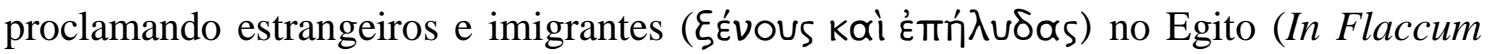
8.53-54). O comentário de Fílon demonstra que a insatisfação em relação aos judeus se referia também à questão da participação política, e o fato de os gregos protestarem contra isso sugere que estaria havendo uma maior abertura para a sua aquisição, o que pode ter desagradado os gregos.

Fílon explica que os judeus foram transferidos a força ( $\sigma u v \eta ́ \lambda \propto \sigma \propto \nu)$ para um único bairro da cidade, tiveram as casas saqueadas e as oficinas de trabalho destruídas (In Flaccum 8.55-57). $\mathrm{O}$ autor descreve em detalhes todas as violências

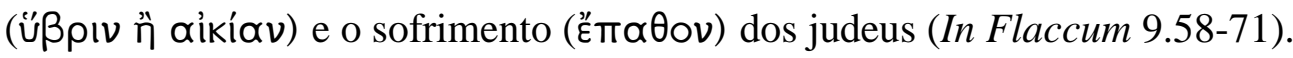

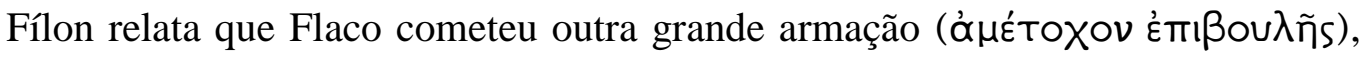

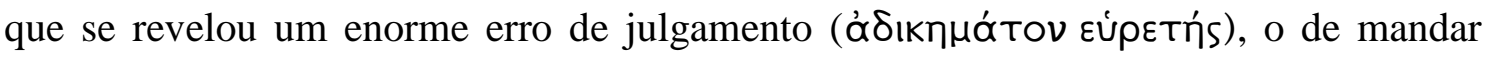
prender e matar 38 senadores judeus. Seguindo uma ordem de Augusto, o antigo prefeito Magius Maximus havia criado um senado para tratar de questões específicas da comunidade. Relata novamente em pormenores toda a crueldade da situação (In Flaccum 10.73-77).

Na sequência, Fílon enfatiza o baixo status dos egípcios, explicando que havia diferentes tipos de flagelo ( $\mu \alpha \sigma \tau i ́ \gamma \omega \nu)$ na cidade, reguladas pela posição social ( $\propto \xi \xi \iota \dot{\mu} \mu \alpha \tau \alpha)$ das pessoas punidas, e os senadores foram tratados como egípcios culpados das maiores iniquidades (In Flaccum 10.78-81). O autor relata que depois das

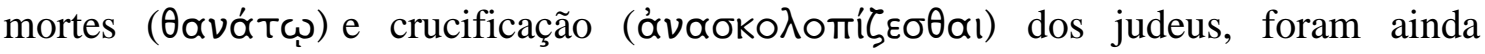
exibidas orquestras, danças, mímicas e competições teatrais (In Flaccum 10.85). Sly (1996 p. 172) observa que é nítido o esforço de Fílon em identificar os egípcios como inimigos dos judeus. Era mais seguro atribuir a culpa aos egípcios, em virtude do desprezo com que eram universalmente tratados (COLLINS, 2005, p. 27). Fílon realça o 
baixo status dos egípcios em inúmeros momentos, mas também condena os que frequentavam clubes (gregos) e a multidão alexandrina de forma geral. A única categoria que Fílon não teme nomear são os egípcios, pois era mais aceita a oposição a eles. Além disso, Fílon tinha muitos comprometimentos com a elite grega da cidade. Associá-los a egípcios era também uma forma de rebaixar a posição dos líderes do Ginásio. Porém, a maior fronteira estabelecida por Fílon é entre judeus e não-judeus. Aparentemente não era a sua intenção nomear categorias entre os não-judeus, mas realçar a situação minoritária dos judeus em uma cidade que conspirava contra eles.

$\mathrm{O}$ autor denuncia que antes de toda essa situação, os judeus tinham enviado um decreto a Flaco solicitando uma embaixada a Calígula, mas o prefeito não o passou adiante. Quando o rei Agripa visitou Alexandria, os judeus pediram a sua intervenção e este garantiu que transmitiria o decreto ao imperador com urgência (In Flaccum 12.97104). Foi então que o caso do prefeito começou a ser esclarecido em Roma (In Flaccum 12. 105-108).

Dessa parte em diante, Fílon se dedica a descrever em detalhes a prisão de Flaco e toda a humilhação sofrida por ele (In Flaccum 13.109-115) e menciona uma circunstância que considerou prova da providência divina ( $\theta$ Eíạ mpovoíạ). Quando chegou à Itália, os membros do Ginásio Isidoro e Lampo, seus piores inimigos

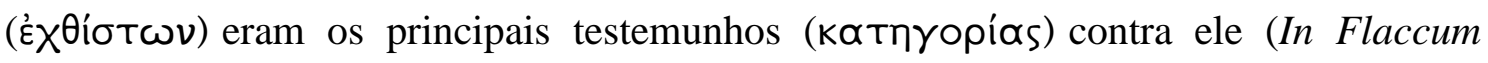
16.125). Os alexandrinos estavam em Roma à espera de seus respectivos julgamentos (In Flaccum 16.128). Fílon então estabelece sua crítica a Isidoro: "vilão, sedutor de multidões, demagogo, experiente em produzir distúrbios e confusões, inimigo da paz e da tranquilidade, adepto de criar discórdia e tumulto onde eles não existiam"

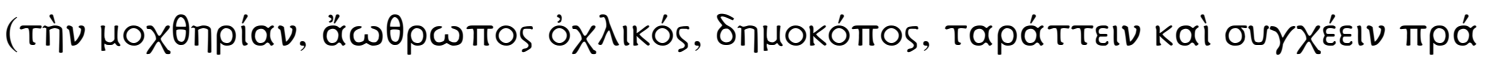

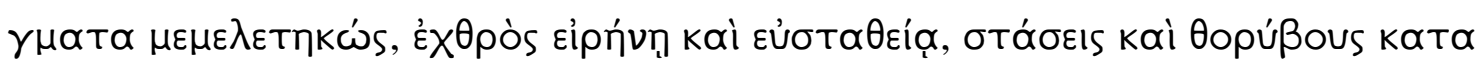

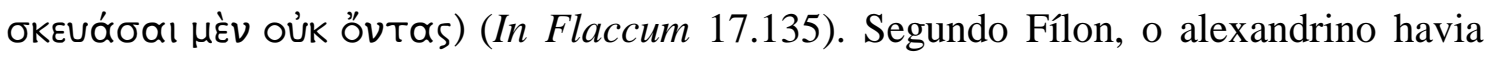
contratado "multidão desgovernada e instável"

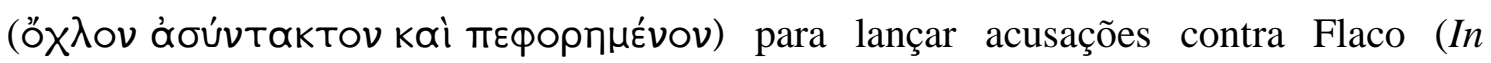
Flaccum 17.139). Mesmo que gregos do Ginásio tenham estimulado os conflitos, para Fílon a propagação foi obra da multidão egípcia (GRUEN, 2002, p. 65). Fica claro que os principais culpados eram membros do Ginásio, pois a multidão é retratada como um bando sem princípios e que servia como "massa de manobra" para líderes gregos 
ousados. Dessa forma, Fílon explicaria a grandeza do conflito sem acentuar a oposição generalizada e consciente aos gregos, pois essa multidão não sabia o que estava fazendo. Era, portanto, mais conveniente culpá-la do que estender a responsabilidade aos gregos da elite.

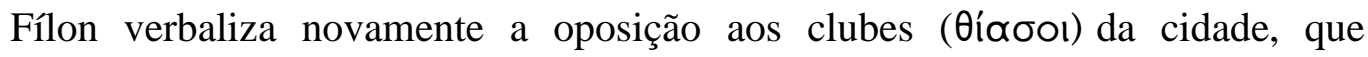

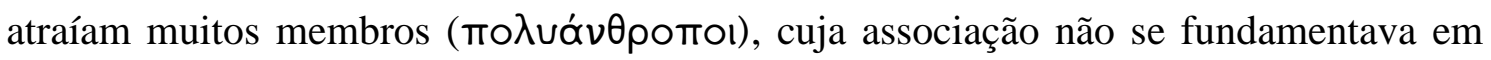
nenhum princípio saudável (Ư Ylés), mas apenas em violentas bebedeiras

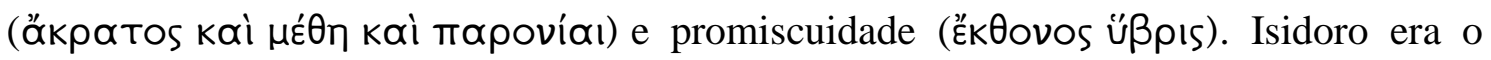

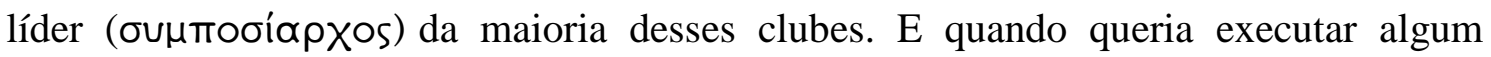

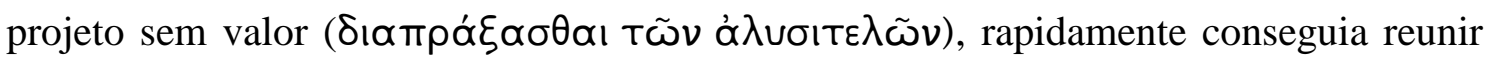
uma multidão (In Flaccum 17.135-140).

Modrezejewski (1995, p. 170) realça os exageros de Fílon, tanto com relação à violência sofrida pelos judeus, quanto do retrato que faz de Isidoro e das associações, pois apesar de ser alexandrino e querer reforçar o seu ponto de vista, também tinha acesso às visões estereotipadas de outros escritores antigos. Em toda a crítica direcionada a Isidoro chama a atenção a sua capacidade de liderança em Alexandria (confirmada por outras fontes ${ }^{33}$ ). Percebe-se a preocupação de Fílon em relação a esse "poder paralelo" formado em Alexandria através da crítica elaborada aos clubes e associações, pois estavam conquistando autoridade perante o povo e incitando a rebelião contra os judeus. A conquista da legitimidade das associações e seus líderes em meio a grande parte da população (que Fílon nomeia sempre de "multidões") abalaria os direitos e privilégios da comunidade judaica diante dos romanos e poderia ameaçar a própria consolidação do poder romano na cidade. Tal situação não interessaria a Fílon e à elite judaica, que estava mais bem posicionada com os romanos do que com a elite alexandrina.

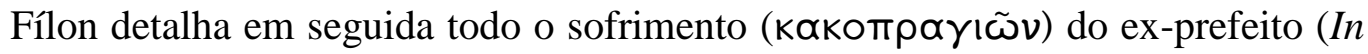
Flaccum 18.148). Após perder tudo, ele foi expulso do continente (ท̉ாєıрou), “o maior

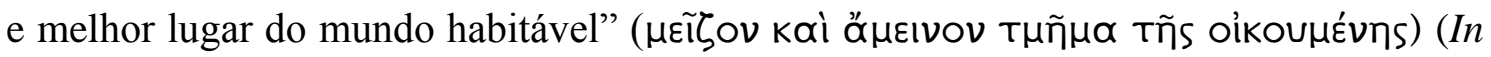
Flaccum 18.151). Encerra com um discurso de Flaco lamentando o seu destino, dizendo que a conquista do governo do Egito foi a maior de suas realizações

${ }^{33}$ Os textos dos Acta Isidori, dos Acta Alexandrinorum, defendem Isidoro na perspectiva dos alexandrinos. Cf. MUSURILLO, 1954. 


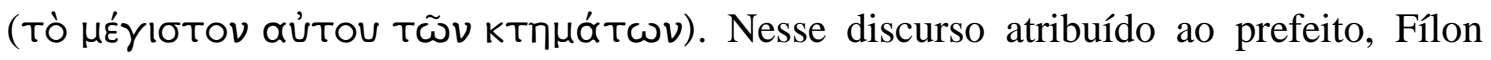
profere os maiores elogios ao Egito e Alexandria. Ressalta a enormidade da cidade, a chamando de megalópole ( $\mu \varepsilon \gamma \alpha \lambda$ 入

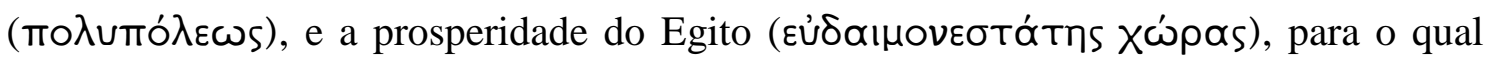
tantos mil habitantes prestam reverências

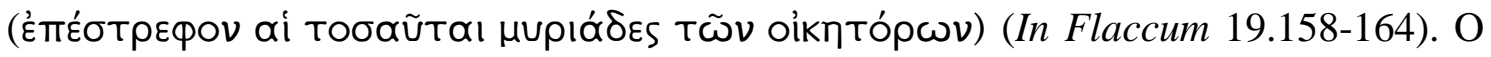
discurso final de Flaco é repleto de arrependimento. Afirmava ter sofrido todas as penas que ele mesmo impôs aos judeus (In Flaccum 20.167-191). A intenção do autor em fazer uma descrição tão minuciosa da decadência de Flaco é demonstrar a força da punição divina que interferiu a favor dos judeus. Segundo Collins (2005, p. 11), Fílon trata da vida de Flaco como uma fábula moral, pois ele mesmo reconhecia sua decadência como punição divina.

O objetivo maior de Fílon nesse livro é retratar os judeus como vítimas de uma conspiração cuidadosa que estava sendo semeada em Alexandria e encontra em Flaco a oportunidade para se alastrar. O prefeito é retratado como o culpado, mas ao mesmo tempo vítima de uma armadilha, de que acabou sendo o protagonista. Os outros vilões são os alexandrinos do Ginásio. Apesar de Fílon só nomear três deles, ele descreve sempre os "clubes e associações" como o cenário das maiores conspirações. De lá partiam as ideias "malignas", que encontravam eco na multidão; um bando "inconsequente", pouco informado e disposto a colaborar com qualquer insurreição apenas pelo prazer do caos. Essa multidão amorfa, que Fílon não define e não caracteriza, era culpada de grande parte dos problemas da cidade, e a ela o autor direciona algumas de suas críticas. O objetivo era também enaltecer o judaísmo, sua amplitude geográfica, e sua legitimidade em inúmeros territórios, pela antiguidade de sua história e força.

Chama atenção a passividade com a qual os judeus são retratados, algo suspeito nesse cenário (COLLINS, 2005, p. 13). A destituição de Flaco não amenizou as disputas, e alexandrinos e judeus direcionaram suas reclamações ao imperador, tema do outro livro de Fílon, a Embaixada a Calígula, no qual Fílon retrata a oposição do imperador aos judeus. Seu conteúdo é mais filosófico que o Contra Flaco, pois explica em maiores detalhes os preceitos do judaísmo. Expressa também com mais nitidez a sua visão sobre o império e Alexandria. Assim, é mais reflexivo a respeito de sua postura 
diante de Roma e dos imperadores anteriores, para os quais não economiza elogios. Sua intenção, em realçar as benesses promovidas pelo império, era esclarecer que sua oposição era destinada estritamente a Calígula.

No início do livro, Fílon observa que após a morte de Tibério, a Itália já tinha o

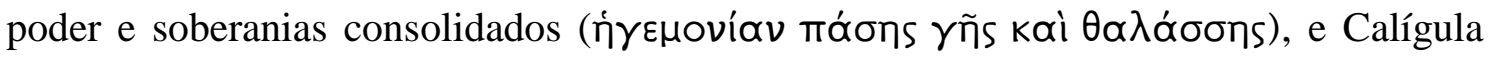

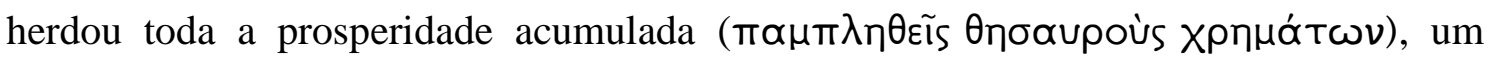

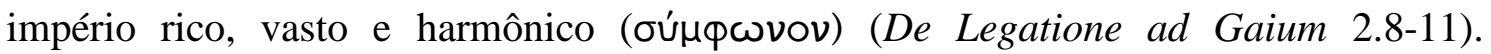
Rostovtzeff (1937, p. 193) argumenta que no relato de Fílon fica evidenciada a sua compreensão que o tempo de Cláudio e Calígula não foi proveitoso para o Egito como o de Augusto e Tibério. Denota assim, certa nostalgia pelos principados anteriores. Apesar de toda a prosperidade, Calígula conseguiu desvirtuar o rumo do reinado, tendo

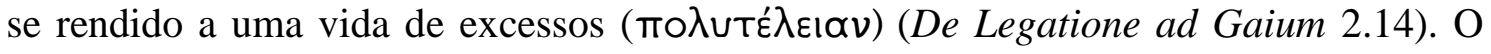
autor relata os pormenores das conspirações de Calígula para conquistar o poder. Então novamente elogia os romanos, que trouxeram coisas benéficas e lucrativas

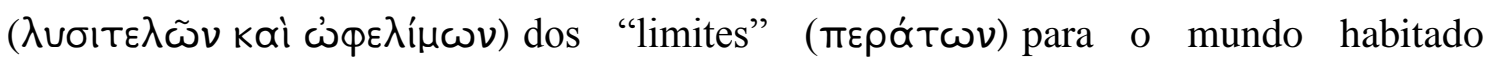

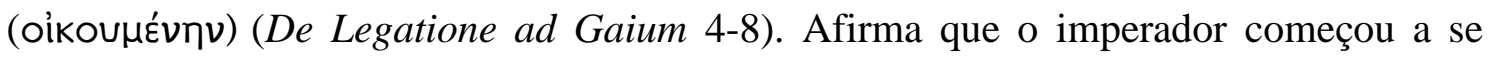
comparar a vários deuses (Dionísio, Heracles, Hermes, Dioscuri) e pretender um status de adoração divina. Seu exibicionismo era ofensivo, aparecendo no teatro sempre com roupas, fantasias e adereços de diferentes deuses (De Legatione ad Gaium 11-13). Com essa postura, todos os povos se curvaram diante de suas aspirações divinas, menos os judeus, cujas leis só permitiam a adoração de um único deus. Então Calígula preparou

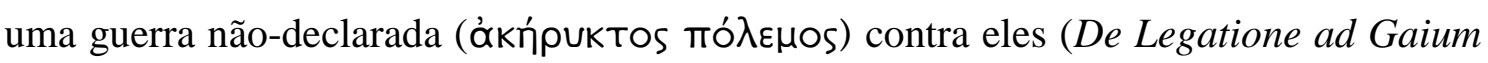
16-17).

Fílon cita o apoio dos alexandrinos à divinização de Calígula como uma forma de se opor aos judeus:

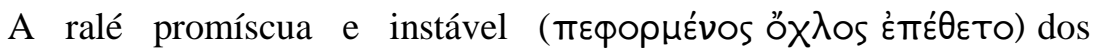
alexandrinos percebeu isso, e pensando que uma oportunidade

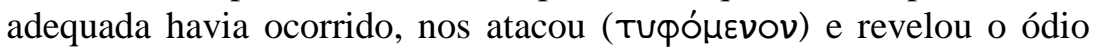
que há tempos inflamava ( $\mu$ ĩoos ávéqve), reduzindo tudo a caos e

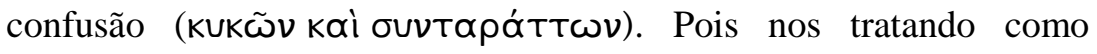
pessoas abandonadas e destinadas pelo imperador a sofrer

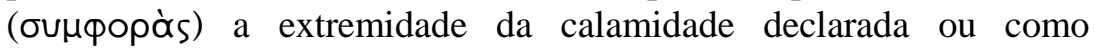

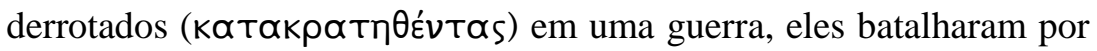

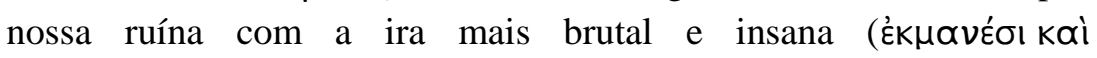




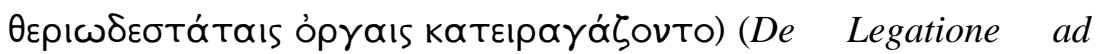
Gaium 18.120-122).

Novamente Fílon, enfatiza a tendência de Alexandria ao caos, mas aqui se referindo especificamente aos alexandrinos não-judeus, apesar de não precisar se gregos ou egípcios. Haas observa que os alexandrinos são comumente representados como uma massa não diferenciada nas fontes (sem distinção entre grupos). Assim, mesmo que as categorias internas fossem importantes dentro da cidade, quem relatava os eventos não fazia grandes diferenciações (1997, p. 84). Fílon faz as mesmas generalizações de um estrangeiro, então mesmo que estivesse ciente das diferentes categorias sociais de Alexandria, talvez não interessasse nomear seus opositores, o que poderia causar comprometimentos futuros. Destinar as críticas à multidão dos alexandrinos era mais seguro, já que seu interesse era manter as boas relações com as elites (COLLINS, 2005, p. 230). Como no Contra Flaco sua intenção é principalmente delimitar as barreiras entre judeus e não-judeus e retratar a sua comunidade como vítimas de uma conspiração, por isso não importaria tanto definir os grupos.

Na sequência Fílon descreve outro massacre, ocorrido provavelmente em 41 d.C. e que fora semelhante ao anterior, narrado no Contra Flaco (De Legatione ad Gaium 18-19). Mais uma vez, detalha o sofrimento dos judeus, os ilustrando como vítimas inocentes da situação. Ressalta que a passividade de Flaco, deixou os alexandrinos

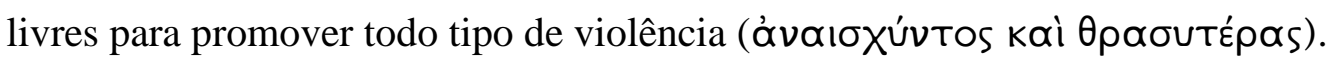

$\mathrm{O}$ autor argumenta que os alexandrinos ergueram imagens a Calígula nos locais

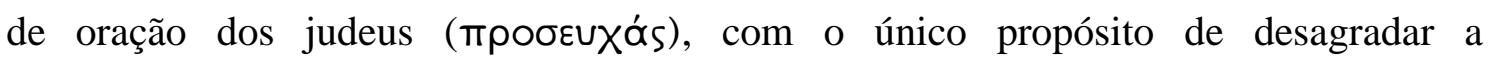
comunidade. Durante trezentos anos nunca dedicaram imagens aos antigos reis nos templos judaicos, mesmo eles sendo do mesmo grau de parentesco

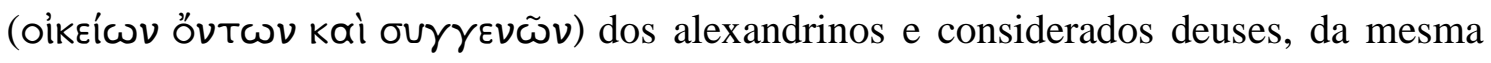
forma que divinizavam todo tipo de animal (De Legatione ad Gaium 20.132-139). Talvez os alexandrinos se justificassem dizendo que os imperadores eram superiores aos

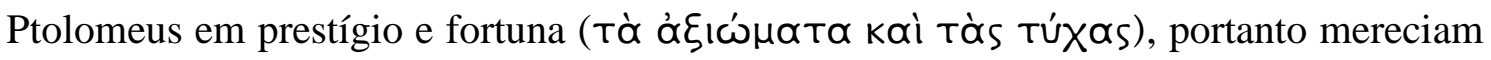
maiores honras. No entanto, nunca promoveram homenagens a Tibério e nem Augusto,

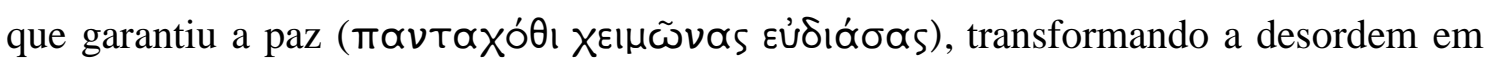

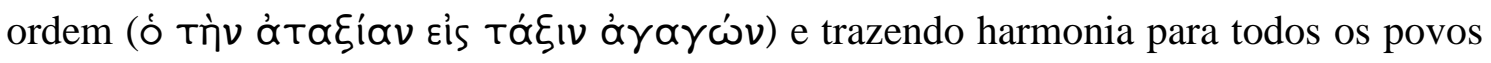
mais anti-sociais e brutalizados, que estavam sendo destruídos em virtude de tanta 


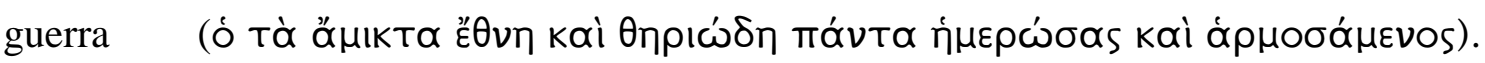

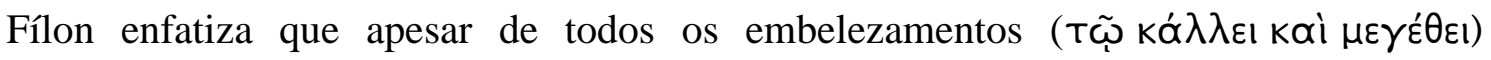
promovidos em Alexandria em honra de Augusto, nunca fizeram esse tipo de homenagem a ele no seu longo governo (De Legatione ad Gaium 21-22).

$\mathrm{O}$ autor justifica que os alexandrinos sabiam do cuidado de Augusto, com a manutenção dos costumes de cada povo ( $\pi \alpha \tau p i ́ \omega v)$, e sempre respeitou as diferenças do judaísmo (De Legatione ad Gaium 23.153-157). Assim, Fílon acredita que toda a motivação de honrar Calígula tinha a intenção única de ofender os judeus. Apesar dos relatos sobre os conflitos serem muito semelhantes nos dois livros, na Embaixada Calígula era inteiramente culpado pelos ataques, tendo encontrado apoio nos alexandrinos:

Então, ele não encontrou entre todos os povos nenhum mais adequado

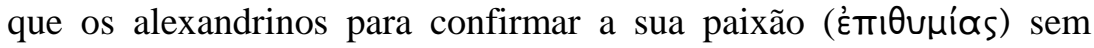
medida, pois necessitava de mais do que era natural a humanidade.

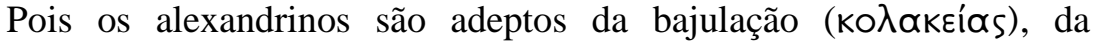

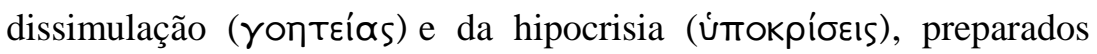

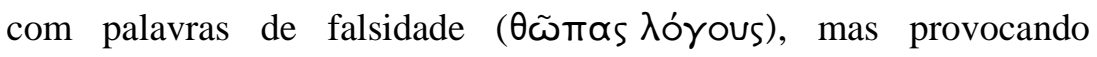

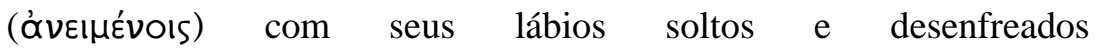

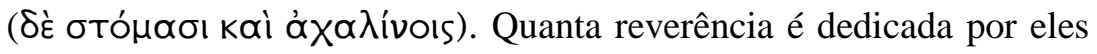
ao título de deus fica demonstrada por eles permitirem que o título seja compartilhado por íbis e cobras venenosas e muitos outros animais selvagens. Era natural que por esse uso de nomes irrestrito para se referir a deus, enquanto enganavam os espertos que não apreendiam a impiedade (á日eótnтos) egípcia, eles fossem condenados por aqueles que entendem suas grandes loucuras

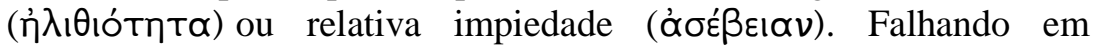
entender isso Gaius supôs que ele era realmente considerado pelos alexandrinos como um deus, pois eles usavam plenamente e sem nenhum propósito termos que outros povos normalmente empregavam quando falavam de deus. Ele então novamente pensou que os procedimentos violentos contra os locais de reunião tinham se espalhado de uma consciência clara e um desejo sincero de lhe prestar honras. (De Legatione ad Gaium 25-26)

Nessa passagem, o autor aproveita para explicitar sua oposição ao culto de animais dos egípcios. $\mathrm{O}$ fato dos antigos reis serem considerados deuses, da mesma forma que animais selvagens, foi visto como uma prova que os alexandrinos não tinham critério para quem merecia ou não ser considerado divino. Pelos mesmos motivos, o autor indica que a adoração a Calígula não era legítima. No entanto, acreditando que era considerado deus pelos alexandrinos, Calígula julgou que a violência destinada aos 
locais de culto dos judeus tinha fundamento. Na sequência, Fílon esclarece que a maioria dos adoradores de Calígula era egípcia (De Legatione ad Gaium 26.166). Então se antes o autor não deixava claro a que grupo de alexandrinos estava dirigindo sua acusação, aqui nomeia seus opositores de egípcios, talvez até com a intenção de ofender os gregos e depreciar seu status.

Em seguida, conta que um egípcio chamado Helicon assumiu a liderança da

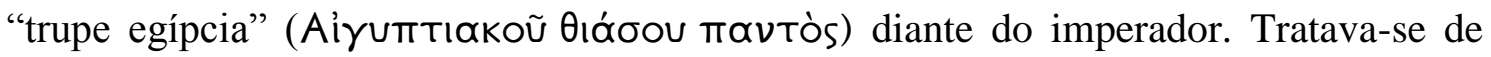
um escravo que tinha entrado na casa imperial ainda no tempo de Tibério (De Legatione ad Gaium 26-27). Assim, tendo todo acesso ao imperador, Helicon foi lentamente

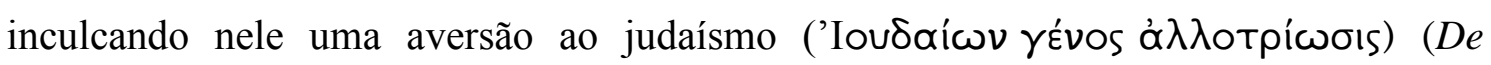
Legatione ad Gaium 28. 171-177). Atribuir toda a culpa a Helicon era uma estratégia conveniente para Fílon, pois os egípcios eram universalmente desprezados e seu interesse era se associar aos gregos e se diferenciar dos egípcios (COLLINS, 2005, p. 13). Apesar de Fílon ter morado toda a vida em Alexandria, percebe-se que quando falava da cidade ele adotava o estilo de um estrangeiro, realçando os exotismos do Egito. Segundo Sly (1996, p. 19-21), no decorrer de toda a sua obra, Fílon fala dos egípcios, como se fossem os mesmos da estória do Êxodo. Seu desdém por eles não distingue entre gerações, e da mesma forma que gregos e romanos, o que ele mais condenava era as práticas religiosas e o culto a animais.

Os judeus mandaram ao imperador um documento apresentando de maneira

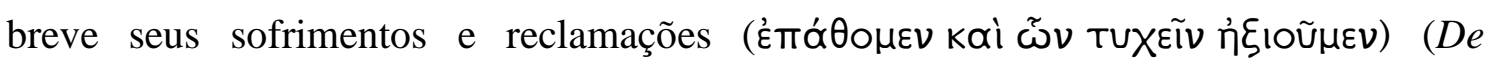
Legatione ad Gaium 28.178-183). Então Fílon e um grupo de enviados judeus se dirigiram a Roma para esperar a audiência, e durante a espera tiveram a notícia de que Calígula tinha colocado uma estátua colossal de Zeus e outra dedicada a si mesmo no templo de Jerusalém, o que chocou a comunidade judaica, que ficou "paralisada de

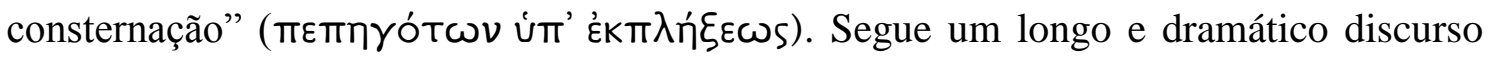
de Fílon em defesa do judaísmo, indicando que menos importante do que os problemas políticos em Alexandria era a ameaça à continuidade da religiosidade conforme suas leis antigas. Relata sobre o dilema do prefeito Petrônio da Judéia que escreveu uma carta para tentar adiar os planos de Calígula, justificando o seu temor de que uma revolta dos judeus poderia interferir nas colheitas. Mesmo a viagem que Calígula estava planejando 
para Alexandria poderia ser afetada. Mas Calígula não se convenceu ao ler a carta, e ficou enfurecido com o prefeito (De Legatione ad Gaium 29-34).

Agripa se deparou com a indignação ( $\xi \xi \varepsilon \tau \rho \propto \chi \cup ́ v \theta \eta)$ do imperador e lhe escreveu uma carta em um tom de tentativa de conciliação, ressaltando a quantidade de locais onde havia judeus residentes, e que agradando os de Jerusalém ele alegraria toda a Diáspora. Ou seja, um povo muito numeroso e espalhado por todo o mundo habitado. Através das palavras de Agripa, Fílon faz outra defesa do judaísmo e novamente profere elogios a Tibério e Augusto (De Legatione ad Gaium 35-41).

Ao ler a carta, Calígula decidiu adiar seus planos de instalar a estátua e ameaçou punir qualquer um que colocasse, mas segundo Fílon, tratava-se de um plano para

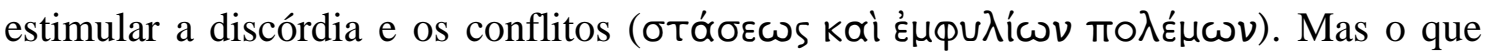
imaginou não ocorreu, assim, começou a repensar seu plano que executaria durante a viagem ao Egito (De Legatione ad Gaium 42):

Pois tinha uma extraordinária ( ${ }^{\prime} \lambda \varepsilon \kappa T$ $\lambda$ ) paixão ( Alexandria. Seu coração estava totalmente voltado para a sua visita e em ficar lá por um tempo considerável. Pois considerava aquela cidade única, pois lá foi onde nasceu e se fortaleceu a ideia de divinização que ocupava seus sonhos, e seu vasto tamanho e sua beleza no mundo habitado

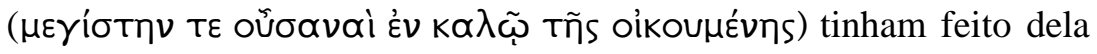

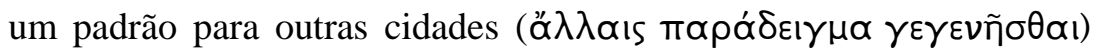
na adoração a ele, pois é verdade que tanto para indivíduos como populações inteiras que os inferiores tentam imitar as qualidades de grandes homens e grandes cidades

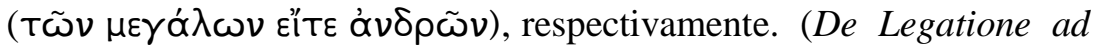
Gaium 43)

O autor relata que quando os judeus foram convocados ( $\mu \varepsilon \tau \propto \pi \varepsilon \mu \phi \theta \varepsilon ́ v \tau \varepsilon \varsigma)$ para conversar com o imperador, já o encontraram totalmente hostil ('̇xӨpóv). Os alexandrinos comemoraram acreditando que tal recepção representava uma vitória e intensificaram ainda mais as invocações a Calígula como deus (De Legatione ad Gaium 44). $\mathrm{O}$ alexandrino Isidoro se aproveitou para acirrar a hostilidade dizendo que enquanto toda a humanidade prestava homenagens a Calígula, os judeus eram os únicos a se negarem (De Legatione ad Gaium 45). Para concluir, realça que a situação não se tratou

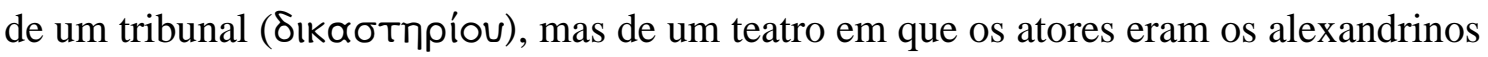
e o próprio Calígula, pois em nenhum momento o imperador pareceu estar motivado a 
resolver a questão dos judeus (De Legatione ad Gaium 46). Aqui o autor sugere certa identificação "artística" entre Calígula e os alexandrinos, com a intenção de ofender ambos.

Fílon ilustra Flaco e Calígula como inimigos não só dos judeus, mas do próprio deus, o prefeito pela arrogância e o imperador pela pretensão divina (BORGEN, 1984, p. 251). Os reais motivos das confusões entre os grupos permanecem um enigma em virtude da parcialidade de Fílon. Sabe-se, no entanto, que nenhum preconceito étnico tinha levado a ações tão violentas até então, apesar de certa dose de animosidade étnica ser normal no local (COLLINS, 2005, p. 28). Para Gruen (2002, p. 67), a situação não se tratou de um caso de anti-semitismo, como a historiografia tradicionalmente compreende, já que o imperador também não favoreceu os gregos. Nos dois livros a intenção maior de Fílon é retratar e denunciar uma realidade de oposição ao judaísmo que estava se fortalecendo em Alexandria e denunciar os abusos dos gregos do Ginásio, depreciando sua origem étnica os associando a egípcios.

Com base no relato de Fílon, Josefo trata brevemente das embaixadas direcionadas a Calígula. Os judeus são também ilustrados como vítimas de toda a situação, mas diferentemente de Fílon, sua ênfase maior é na atuação de Apião, um dos líderes da embaixada alexandrina e atuante contra os judeus. Josefo conta que uma

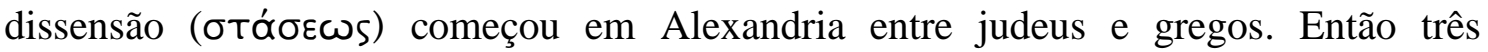

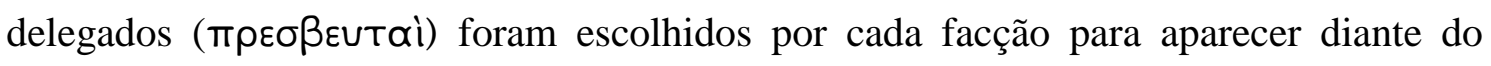
imperador. Apião alegava que os judeus se recusavam a honrar Calígula ( enquanto todos os povos tinham lhe dedicado altares e templos e proferiu então muitas palavras raivosas $(\chi \alpha \lambda \varepsilon \pi \grave{\alpha})$ esperando comover ( $\alpha \rho \theta \tilde{n} v \propto \iota)$ o imperador. Fílon, descrito

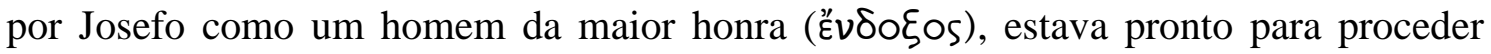

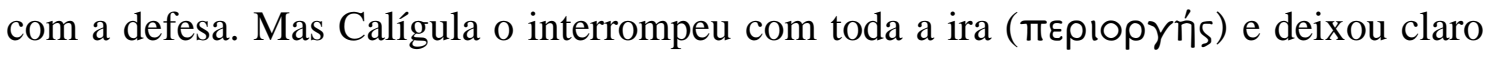
que iria lançar atrocidades ( $\delta \varepsilon ı$ òv) contra os judeus. Tendo sido tratado dessa forma, Fílon saiu da sala, dizendo para seus companheiros terem coragem ( $\theta \propto \rho \rho \tilde{\imath} v)$, pois a

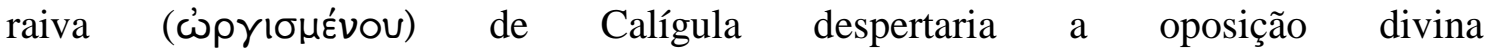

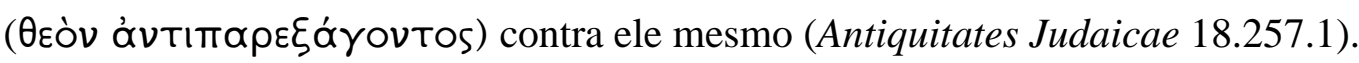

A indignação de Josefo diante das colocações de Apião era tão grave, que o Contra Apião é um livro inteiro dedicado a promover a defesa do judaísmo e derrubar os argumentos de Apião. O livro foi escrito depois das Antiguidades e sua intenção era 
esclarecer definitivamente as dúvidas que ainda restavam com relação ao pertencimento dos judeus no Egito (BARCLAY, 1998, p. 196). Trata-se do trabalho mais retórico e de conteúdo apologético de Josefo, pois estabelece a defesa do judaísmo refutando a argumentação de autores que desde tempos antigos se opunham a eles de alguma forma, principalmente Apião (BARCLAY, 1998, p. 194). O livro é extenso, assim, a prioridade aqui é tratar do contexto alexandrino, quando Josefo responde ao decreto de Apião tratando da recusa da comunidade judaica em adorar Calígula. $\mathrm{O}$ autor afirma que o grande contraste entre a religião egípcia e judaica foi a raiz da animosidade entre os dois grupos e condena o culto a animais (Contra Apionem 1.25). Josefo responde a uma reclamação do grego Apião pelos judeus serem chamados de alexandrinos. Argumenta que todas as pessoas chamadas para fundar uma colônia ( $\alpha$ moıkı $\alpha \nu)$, mesmo de origens ( $\gamma \varepsilon v \varepsilon \sigma ı)$ diferentes, levavam o nome de seus fundadores (Contra Apionem 2.38). Aqui Josefo infere que a religião não era a fonte de todas as disputas, mas que os judeus estavam brigando por maior espaço político em Alexandria.

Nas Antiguidades, Josefo se refere à eclosão de um conflito entre gregos e judeus. Enquanto no Contra Apião eram os egípcios os grandes responsáveis pela eclosão de problemas contra os judeus, deixando claro que não pretendia se indispor com a comunidade greco-macedônia de Alexandria:

Ele ainda nos acusa de fomentar sedições (seditiones). Mas, se for garantido que ele tem razão de trazer essas acusações (accusat) contra os judeus de Alexandria, por que então ele faz uma queixa (culpat) contra os judeus de forma geral com relação a nossa notória concórdia? Além disso, os reais promotores da sedição (seditionis), como qualquer um poderia descobrir, foram os cidadãos de Alexandria (Alexandrinorum fuisse ciues) do tipo de Apião. Os gregos e macedônios, desde que a cidadania foi conferida a eles, nunca se levantaram contra nós (seditionem aduersus), mas nos deixaram livres para aproveitar nossas antigas formas de adoração (sollemnitatibus). Mas quando, pelas desordens prevalecentes (confusiones temporum), o seu número aumentou por uma horda de egípcios (multitudo Aegyptiorum), os conflitos se tornaram crônicos. Nossa raça (genus), pelo contrario, permaneceu inalterada. Foram eles então que começaram esses distúrbios (molestiae), pois a população (populo), não possuindo nem a força de caráter (constantiam) dos macedônios, nem a prudência (prudentiam) dos gregos, universalmente (utentibus) adotou os hábitos maus dos egípcios (malis moribus Aegyptiorum) e estimularam seu ódio antigo (antiquas inimicitias aduersum) a nós.

A reprovação (improperare) com a qual eles ousam nos tratar é aplicável, pelo outro lado, a eles mesmos. A maioria deles assegura sua posição como cidadãos sem título regular; ainda chamam aqueles que conquistaram o privilégio (priuilegium) das autoridades 
apropriadas de estrangeiros (peregrinos). Nenhum rei, aparentemente, e nenhum imperador dos nossos tempos conferiu direitos de cidadania aos egípcios. Nós, pelo contrario, devemos nossa posição na cidade a Alexandre, e nossos privilégios foram estendidos pelos reis, e esses privilégios os romanos tem a satisfação de assegurar (custodire) sempre.

Apião consequentemente tentou nos denunciar (derogare) por não erigir estátuas aos imperadores. Como se fossem ignorantes do fato e precisassem de Apião para defendê-los! Ele devia ao invés disso ter admirado a magnanimidade e moderação (magnanimitatem mediocritatemque) dos romanos em não exigir que os seus sujeitos violem os seus preceitos étnicos (cogunt patria), e se contentarem a aceitar as honras como obrigações religiosas e legais das doações permitidas a eles de pagar. Eles não são gratos por honras conferidas sob compulsão e força (necessitate et uiolentia). Os gregos, como outros povos (et aliis), acham certo fazer estátuas: eles deliram com a representação em retratos de pais, esposas e filhos; alguns até obtém a aprovação de pessoas totalmente sem vínculos com eles, outros fazem o mesmo por escravos favoritos. Qual a surpresa então, de encontrálos dedicando essa honra aos seus imperadores e mestres em geral também? Pelo outro lado, nosso legislador, não para colocar, como pareceu, um veto profético sob honras dedicadas a autoridade romana, mas não contente com uma prática sem utilidade (utilem) nem para deus nem para homens, proibiu a confecção de imagens, de qualquer criatura viva, e mais ainda de Deus, que, como será visto mais adiante, não é uma criatura. Contudo, ele não proibiu a dedicação de homenagens de outros tipos, secundárias àquelas pagas a Deus, a homens de valor; tais honras nós conferimos a imperadores e ao povo de Roma. A eles nós oferecemos sacrifícios perpétuos (continua); e não apenas fazemos essas cerimônias diariamente, aos custos de toda a comunidade judaica, mas enquanto nós não oferecemos outras vítimas na nossa capacidade corporativa, até para a família [imperial], nós conjuntamente dedicamos apenas ao imperador esse sinal de honra (honorem) que não dedicamos a nenhum outro individuo. Acho que agora eu dei, uma resposta compreensiva e suficiente às observações de Apião com relação a Alexandria (Contra Apionem 2. 68-78)

Josefo e Fílon concordavam que os responsáveis pelo agravamento dos conflitos eram os egípcios, que por disporem de uma condição social pior que a dos judeus eram facilmente inflamáveis contra eles, talvez por não terem nada a perder (GRUEN, 2002, p. 63 e 64). Josefo faz uso de estereótipos étnicos contra os egípcios para fortalecer a sua argumentação (BARCLAY, 2004, p. 112). Mesmo que eles não fossem os reais culpados, percebe-se a intenção de Josefo de direcionar a propagação dos conflitos a eles. O autor tenta aproximar Apião dos egípcios, rebaixando o seu nascimento como forma de enfraquecer as suas colocações, mas Barclay considera inconcebível que Apiano fosse egípcio por nascimento, por ter se tornado líder da delegação dos 
alexandrinos e pela educação a que teve acesso. Chamá-lo assim foi a arma mais poderosa encontrada por Josefo para responder a ele e invalidar seus argumentos. Dessa forma, ele transforma a sua defesa em ataque (BARCLAY, 2004, p. 119).

Collins (2005, p. 47) sugere que talvez Apião não estivesse tão centrado em criticar o judaísmo e que a ênfase nas críticas foi colocada por Josefo. Com relação à aquisição da cidadania, Apião pode ter se posicionado contra a sua obtenção por imigrantes de modo geral. Assim, o relato foi trabalhado retoricamente por Josefo para tornar-se um relato antijudaico. Josefo estaria respondendo à propaganda antijudaica do tempo dos flavianos e nesse sentido, sua narrativa não deve refletir uma guerra antiga entre gregos e judeus, pois atende às preocupações de sua época (COLLINS, 2005, p. 48-50).

No trecho citado anteriormente da Guerra dos Judeus, em que Josefo define a grandeza egípcia, as dimensões de Alexandria e a quantidade de impostos enviados à Roma toda ano, o autor esclarece a sua percepção de que o Egito aceitava bem o

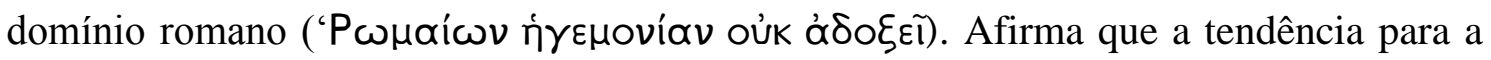

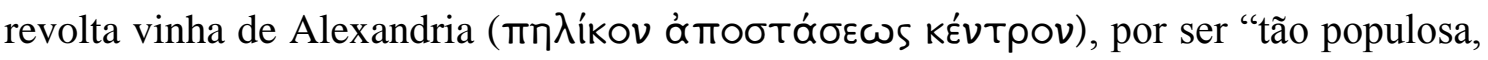

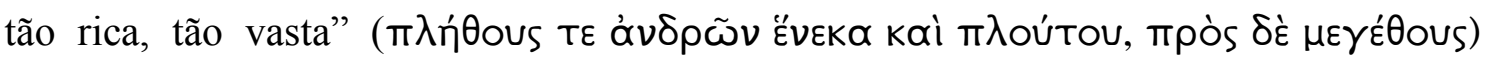
(Bellum Judaicum 2.385-389). Na mesma passagem, Josefo fala da existência de duas legiões do exército na cidade assegurando a provisão. Ou seja, denunciar a presença das tropas tinha a intenção de provar a precaução e organização romana, mas ao mesmo tempo, de advertir para a vigília constante do comando imperial, através da imposição de força. $\mathrm{O}$ autor delimita o seu foco, para depois narrar as revoltas entre judeus e alexandrinos. Talvez, por isso, interessasse explicar que os problemas sociais eram provenientes de Alexandria, apesar de ter outras ressalvas com relação aos egípcios, como ele deixa evidente no Contra Apião.

Os problemas em Alexandria não se encerraram após a morte de Calígula, e Josefo continua tratando dos distúrbios sob Cláudio e Nero. O autor conta que logo após

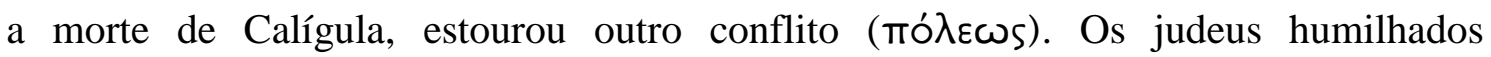

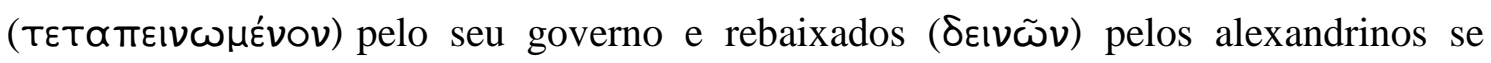

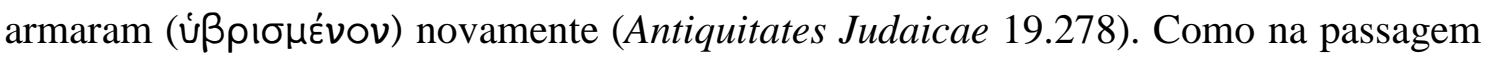
citada acima das Antiguidades (Antiquitates Judaicae 18.257.1), e em contraste ao Contra Apião, aqui Josefo fala que os opositores dos judeus eram os gregos. Cláudio 
comandou o prefeito do Egito (C. Vitrasius Pollio) a acabar com a guerra de facções (бтáoıv), e escreveu um edito para Alexandria, respondendo a petição dos reis Agripa e Herodes. A carta relata o seguinte ${ }^{34}$ :

Ao ficar sabendo que os judeus de Alexandria, chamados de alexandrinos eram colonizadores dos tempos mais remotos

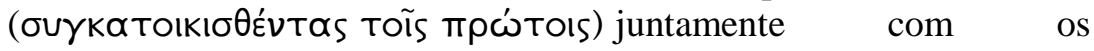

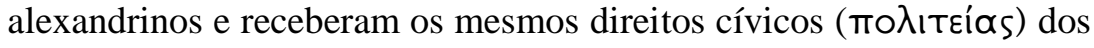
reis, como está manifesto nos documentos em sua posse e nos editos; e depois de Alexandria se tornar sujeita ao nosso império

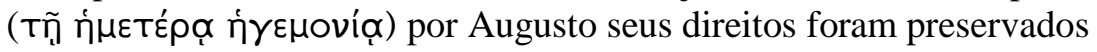
( $\left.\pi \varepsilon \varphi \cup \lambda \alpha^{\prime} X \theta \alpha \iota\right)$ pelos prefeitos enviados de tempos em tempos, e esses direitos nunca foram discutidos; além disso, no tempo que Aquila estava em Alexandria, na ocasião da morte do etnarca dos judeus, Augusto não impediu a continuidade das reuniões dos etnarcas, desejando que cada povo submetido (ن́motetá $X \theta \propto \iota)$ deveria continuar seguindo seus próprios costumes (íंíoıs है $\theta \varepsilon \sigma ı$ ) e não ser

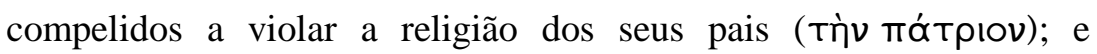
entendendo que os alexandrinos se levantaram ( $\dot{m} \pi \alpha \rho \theta \tilde{\eta} \nu \propto \iota)$ contra os judeus no tempo de Gauis César, que humilhou ( $\pi \alpha \rho \alpha \beta \tilde{n} v \alpha ı)$ os

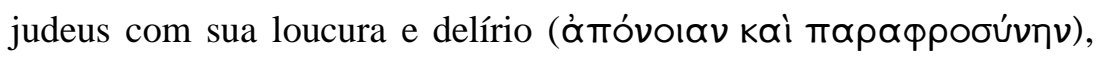
pois eles se recusaram a desrespeitar a religião dos seus pais

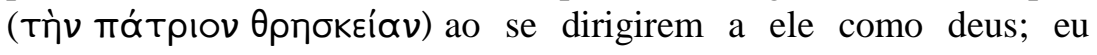
desejo que nenhum dos seus direitos seja perdido aos judeus pela

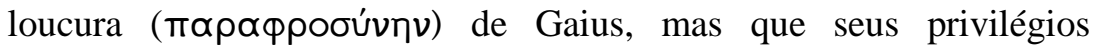
anteriores ( $\delta ı \alpha \propto i \omega v)$ sejam mantidos; enquanto eles continuam com seus próprios costumes (Toîs íóols है $\theta \varepsilon \sigma ı$ ); e eu ordeno aos dois partidos a tomarem as maiores precauções para prevenir qualquer

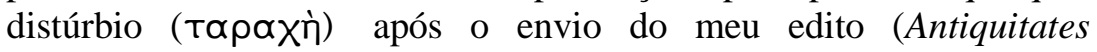
Judaicae 19.278-285).

Josefo ressalta que os mesmo direitos garantidos aos judeus de Alexandria

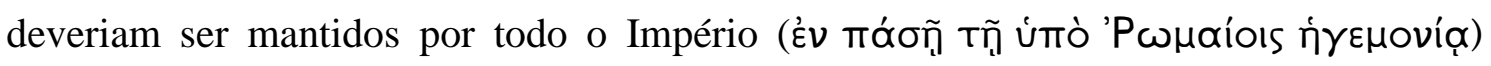
(Antiquitates Judaicae 19.288.4). Em relação à Fílon, o relato de Josefo denota uma postura mais atuante dos judeus pela luta de seus direitos em Alexandria, mesmo que ainda os retrate como vítimas de uma conspiração por parte dos gregos.

Com a eclosão da revolta da Judéia, o aumento de hostilidades entre judeus e gregos repercutiu também em Alexandria. Na Guerra dos Judeus, Josefo aborda os conflitos do momento, mas retoma o cenário de instabilidade formado antes disso.

\footnotetext{
${ }^{34}$ Essa é a versão de Josefo de outra carta de Cláudio, com algumas leves alterações que a torna mais simpática aos judeus (P. London 1912).
} 


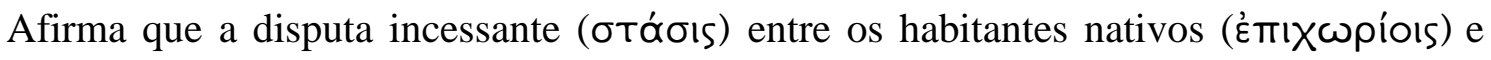
judeus de Alexandria ocorria desde o tempo de Alexandre, que lhes haviam concedido a permissão de morar na cidade em situação de igualdade (ioouoıpías) com os gregos.

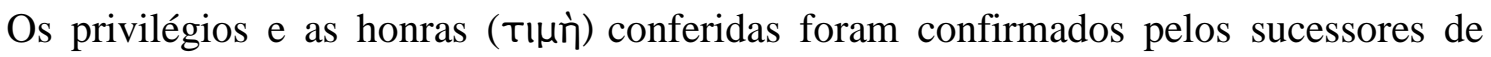
Alexandre e pelos primeiros imperadores. Os reis concederam aos judeus um bairro separado na cidade, para que através de "menos mistura" ( $\kappa \propto \theta \propto \rho \omega \tau \varepsilon ́ \rho \propto \nu)$ eles pudessem observar suas leis com mais rigor. No entanto, estavam em constante colisão

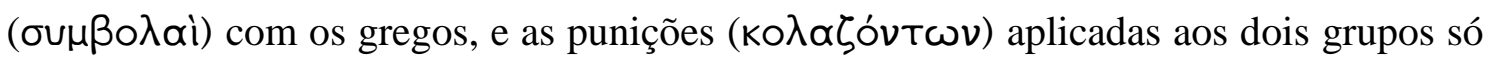

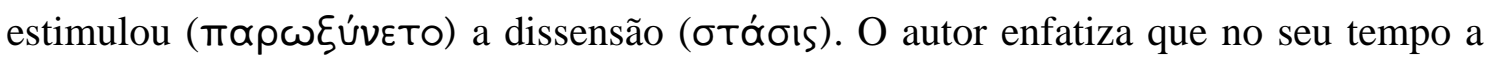
desordem (દ́тєтópณкто) tinha se disseminado e os conflitos se agravaram (દ̇тєта́ракто) (Bellum Judaicum 2.487-490). Josefo legitima o pertencimento dos judeus no território argumentando que foi o próprio fundador da cidade que lhes concedeu residência fixa em Alexandria desde as origens e ilustra a vivência separada praticada pelos judeus desde então, como algo necessário para a prática das suas tradições. Se nas outras passagens Josefo destaca a antiga boa convivência com os vizinhos desde Alexandre, nesse momento sugere que a eclosão de violência entre os grupos não foi repentina como Fílon enfatizava.

Na Guerra dos Judeus, Josefo narra mais um conflito ocorrido no reinado de Nero. Em uma ocasião que os alexandrinos estavam reunidos no anfiteatro para planejar o envio de uma embaixada ao imperador, um grupo de judeus entrou no local infiltrado no meio dos gregos. No momento que a presença deles foi percebida, começou a briga

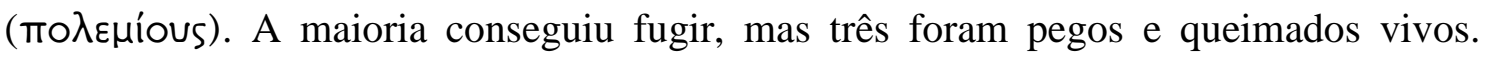
Nesse momento, toda a colônia judaica se voltou contra os gregos para se defender

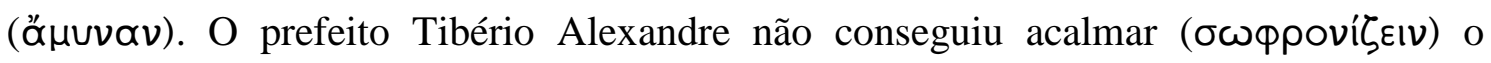
conflito sem o auxílio do exército e percebendo que nada aquietaria os revoltosos

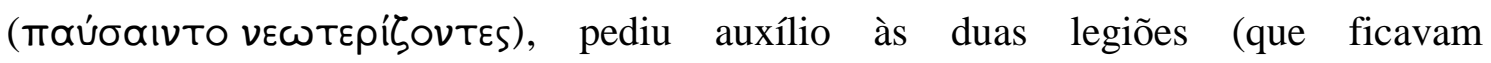
permanentemente na cidade) para punir os judeus, além de dois mil soldados da Líbia. As tropas então se dirigiram ao Delta (bairro judeu) e massacraram (фoveúEıı) os judeus, com grande resistência do povo e muitas baixas do exército romano. Josefo ressalta a crueldade do massacre e fala em 50 mil mortos. Mesmo depois da retirada dos romanos por ordem do prefeito, a população alexandrina não desistiu, pois estava

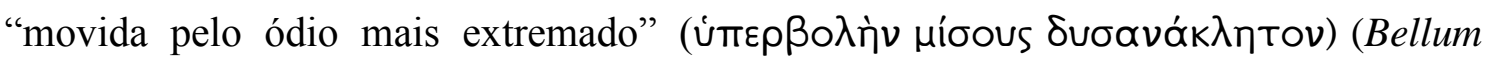


Judaicum 2.491-498). Em relação à descrição dos conflitos anteriores, nota-se uma propensão maior dos judeus para lutar e a responsabilidade parcial pela revolta. Talvez estivessem motivados pelos acontecimentos na Judéia.

Nesse contexto, Josefo menciona inicialmente alexandrinos do anfiteatro, depois responsabiliza os gregos como os opositores dos judeus, indicando que os grupos que protagonizavam os conflitos tinham se alterado. Não era mais a multidão dos egípcios os responsáveis por todos os males. Segundo Collins (2005, p. 18), Fílon e Josefo exploram as ambiguidades dos termos "cidadãos" e "alexandrinos" propositalmente para indicar que a oposição aos judeus era generalizada. Percebe-se, no entanto, que o autor evita associar os alexandrinos culpados aos gregos, embora nem sempre consiga, inferindo que a oposição partia da parcela helenizada da população.

Fílon em primeiro lugar, mas também Josefo tinham como objetivo vitimizar a vivência da comunidade judaica de Alexandria, principalmente no tempo de Calígula. Por isso os outros grupos são sempre retratados como "inconsequentes" e extremados, colaborando para a representação dos alexandrinos, de maneira geral, como um povo facilmente movido por distúrbios e paixões desmedidas. No entanto, os autores fornecem pistas de que havia questões políticas e cívicas mais complexas em jogo, para além das motivações religiosas. A intenção de retratar os judeus como o grupo perseguido da cidade acaba por silenciar outras possíveis polêmicas e crises, e dessa forma, ajuda a manter a imagem dos alexandrinos como meros baderneiros e adeptos dos tumultos. Apesar de a ênfase principal dos relatos ser na questão judaica, eles enriquecem a representação imperial de Alexandria no sentido de atentar para a diversidade cultural da cidade, a complexidade identitária das multidões e as tensões que eclodiam em virtude das diferenças.

Apenas Fílon e Josefo abordam a eclosão de hostilidades entre alexandrinos e judeus em Alexandria no tempo de Calígula, Cláudio e Nero, enquanto outros autores enfocam no posicionamento dos imperadores frente à cidade. Como Fílon, Josefo

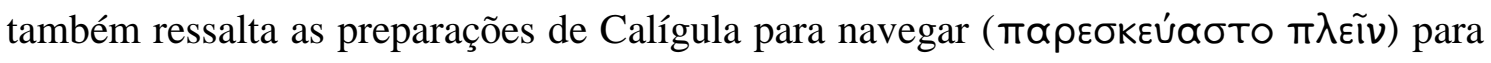

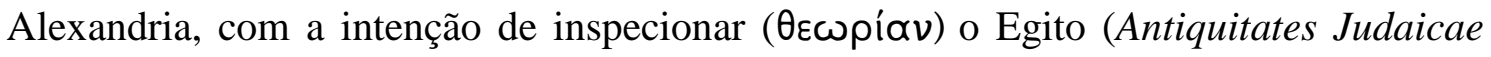
19.81.1). Sua adoção de hábitos orientais e egípcios era visto como uma ameaça às instituições latinas.

Suetônio observa que Calígula proibiu a celebração das vitórias de Augusto em Actium e na Sicília, justificando que eram desastrosas e ruins para o povo de Roma 
(funestas p. R. calamitosas) (C. Caligula 23). Talvez o autor quisesse ressaltar a admiração de Calígula pela cultura egípcia. Assim, relembrar Actium era uma forma de reforçar certa oposição ao Egito em Roma, o que ele era contra. Suetônio também menciona a sua decisão não realizada de se mudar (commigrare) para Alexandria $(C$. Caligula 49). Consideravam que sua admiração pela cidade talvez estivesse relacionada à fixação por Alexandre (C. Caligula 52).

Como Calígula, Nero planejava uma viagem para Alexandria e tinha um "temperamento" que o identificava com a vida na cidade. Tácito relata que a sua imaginação (secretis imaginationibus) estava ocupada com as províncias orientais, principalmente o Egito. Então, depois de escrever um edito justificando que sua ausência seria breve, foi ao Capitólio para tratar de sua ida. Realizou suas devoções, mas, quando entrou no templo de Vesta, começou a tremer compulsivamente. Então, ficou aterrorizado com a divindade (numine exterrente), e abandonou seu projeto provavelmente por entender o sinal como mau presságio (Annales 15.36). Suetônio ressalta o mesmo presságio ameaçador (religione simul ac periculo) como motivo de sua desistência (Nero 19), embora todos os preparativos estivessem feitos para a sua visita. Suetônio e Dion Cássio contam que um banho foi construído especialmente para a ocasião, e que o prefeito do Egito, Caecina Tuscus, foi banido pelo imperador por ter se banhado lá antes dele (Suetônio. Nero 35 e Dion Cássio. Historiae Romanae 62.18.1). Segundo o autor, alguns astrólogos tinham previsto que ele seria o rei do Oriente, talvez outra motivação para conhecer Alexandria. Ainda de acordo com Suetônio, sua atração por Alexandria era tanta, que quando estava sendo perseguido e pedindo perdão pelos seus pecados, solicitou a prefeitura (praefecturam) do Egito como último refúgio. Depois um discurso com esse propósito foi encontrado em sua mesa, porém não teve coragem (deterritum) de proferi-lo por medo de ser massacrado (discerperetur) antes de chegar ao fórum (Nero 47).

Dion Cássio e Dion Crisóstomo sugerem que a identificação entre Nero e os entretenimentos de Alexandria foi o que motivou a sua ida em virtude de certa afinidade artística com a cidade. Crisóstomo realça que os alexandrinos estavam sofrendo da mesma doença de Nero, a devoção exagerada ao divertimento e à música. Argumenta que o imperador foi prejudicado com a sua paixão por música e representação

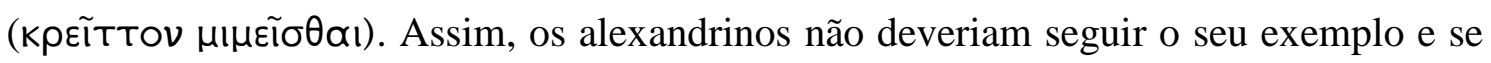
inspirar no imperador do presente, mais devotado à cultura e a razão 


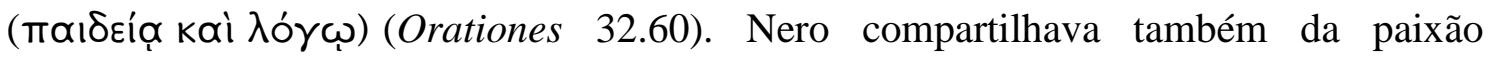
alexandrina por corridas de cavalos, outro motivo que o fez ansiar por passar seus últimos dias na cidade (JONES, 1978, p. 39).

Dion Cássio conta que depois de ter sido abandonado por todos, Nero começou a elaborar seus planos de matar todos os senadores, mandar queimar a cidade e ir para Alexandria. Segundo o autor, ele tinha a ideia "tola" de que lá ele poderia viver como

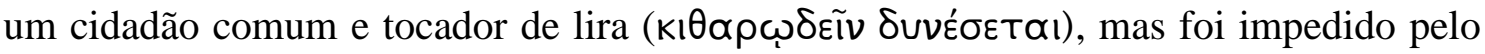
Senado (Historiae Romanae 63.27.2.7).

Tratar-se-ia de uma coincidência o fato de os imperadores mais criticados do século (Calígula e Nero) serem também os descritos como os mais apaixonados por Alexandria e pelo Oriente? Acreditamos que ressaltar o apreço de Calígula pelas divindades egípcias e pelo modo de vida oriental, e a sedução de Nero pelos prazeres e divertimentos de Alexandria era um modo de criticar os imperadores, porém era também uma forma de promover uma rejeição ainda maior a Alexandria. Ou seja, a metrópole atraía homens como Marco Antônio, Calígula e Nero. Nesse sentido, representava uma afronta a Roma, pois eram exemplos de romanos que valorizaram tudo aquilo condenado pela nobreza romana. Rostovtzeff $(1937$, p. 163) argumenta que Nero e Calígula foram também os imperadores que tentaram se associar a figuras divinas e instituir o culto a eles mesmos, já Tibério e Cláudio, homens mais ilustrados, consideravam absurda essa pretensão. Assim, o "temperamento" de Alexandria combinava com o espírito dos imperadores que se dedicaram apenas aos excessos e aos prazeres orientais. Portanto, era conveniente ressaltar esse vínculo (entre maus imperadores e Alexandria) para mostrar como Roma era a negação e a superação dessa forma de viver. Dessa forma, a literatura ilustra quão absurda era essa identificação de imperadores com a cidade e desvia o foco sobre o real problema que estava em jogo: Alexandria foi considerada, mesmo que de forma passageira, como uma moradia alternativa para governantes romanos. Enfatizar a "loucura" desses líderes também reduziria a atratividade exercida pela cidade nas esferas culturais.

Para o contexto de Calígula, sua paixão pela cidade se somaria a sua oposição à comunidade judaica. Portanto, o imperador é criticado por Fílon e Josefo em um contexto de censura conjunta aos alexandrinos. Apenas Suetônio assinala a sua predileção por Alexandria de forma independente dos problemas cívicos. Enquanto que para o contexto de Nero, Tácito, Suetônio, Dion Crisóstomo e Dion Cássio enfocam 
exclusivamente na paixão do imperador pelas atividades lúdicas de Alexandria, que o aproximavam da cidade.

\subsection{Vespasiano, Tito e o Oriente: um novo rumo para o Império?}

A ascensão de Vespasiano marcou um novo momento do principado, pois além de ter encerrado a sucessão da casa Júlio-Cláudia, caracterizou-se pela primeira coroação promovida pelo exército e só depois sancionada pelo Senado. Representou também uma virada na política desde a República, pois o general vitorioso era um homo novus, sem prestígio familiar e nascimento ilustre e, mesmo assim, alcançou o comando imperial. Assim, a casa dos flávios precisaria ser legitimada para ser aceita pelos tradicionalistas do Império. Vespasiano foi surpreendentemente muito elogiado pela literatura do período. No entanto, seu reino precisava ser promovido e validado por razões divinas. Portanto, autores como Tácito e Suetônio, fazem uso de presságios e explicações divinas para explicar a sua ascensão e o consideram como um novo Augusto.

Outra novidade na promoção de Vespasiano é que pela primeira vez um imperador foi escolhido e aclamado no Oriente e só depois passou pela aprovação romana, demonstrando a importância crescente dessa parte do Império. Pouco antes do fim do reino de Nero, Vespasiano foi enviado como legionário para acabar com uma rebelião na Judéia e sua competência no comando o popularizou junto às legiões. Um ano depois da morte de Nero, Vespasiano começou sua própria "campanha" pelo poder, quando o prefeito do Egito Tibério Alexandre, liderou suas tropas e os alexandrinos juraram apoio. Segundo Jones (1978, p. 39), os vários meses que passou em Alexandria foram suficientes para coroarem-no imperador. Devido à influência decisiva da cidade e do prefeito do Egito na elevação de Vespasiano, a metrópole ganhou um espaço notável nas fontes referentes ao seu principado.

Antes da nomeação de Vespasiano, Josefo menciona a visita do rei da Judéia Agripa II à Alexandria para parabenizar o judeu Tibério Alexandre pela conquista do governo do Egito, confiado a ele por Nero (Bellum Judaicum 2.309.2). Tratava-se do primeiro judeu-alexandrino a se tornar prefeito do Egito. $\mathrm{O}$ fato de um alexandrino ter sido nomeado prefeito por Nero indicava a sua predileção e confiança na cidade, 
situação que tinha sido consideravelmente alterada em relação a Augusto. Além disso, Tibério Alexandre era judeu (sobrinho de Fílon), o que demonstra a influência política conquistada por judeus de alto status em Alexandria. A postura do prefeito no rumo dos acontecimentos foi um exemplo de conquista de poder pelos judeus (BOWMAN, 1998, p. 41). Além de judeu, Tibério Alexandre se destacou pelo tempo em que ficou no cargo, mantendo o seu título sob cinco principados sucessivos (nomeado por Nero em 66 e ficou até 69/70 no início do reinado de Vespasiano) (MODREZEJEWSKI, 1995, p. 186).

Tibério Alexandre é uma personalidade intrigante e contraditória, que demonstra as mudanças ocorridas nas províncias após mais de meio século de Império. Sua figura ilustra também as transformações políticas em Alexandria, que décadas antes presenciava brigas pela conquista de espaço dos judeus nas decisões da cidade. Tibério é um exemplo de que parte das queixas da comunidade tinha sido resolvida. Mesmo judeu, o prefeito apoiou a ascensão do general que tinha massacrado os judeus de Jerusalém, o que indica que sua identidade romana e alexandrina predominaram nesse contexto em relação ao seu judaísmo, pois sendo prefeito do Egito não podia negar o apoio de suas tropas para auxiliar o general romano.

Antes de se tornar imperador, Vespasiano já requisitara o apoio das tropas de Alexandria quando estava na Judéia. Josefo conta que assim que Vespasiano foi nomeado general para comandar o exército na Síria, seu filho Tito visitou Alexandria a mando do pai, para pedir o auxílio de uma das legiões da cidade (15 legião), (Josefo. Bellum Judaicum 3.8.2). Josefo menciona a passagem rápida de Tito pela cidade, quando se tornou o comandante dessa legião (Bellum Judaicum 3.64.1).

Antes da formalização de seu comando, Josefo observa que os generais de Vespasiano cobravam que ele agisse como imperador, mas seu objetivo primeiro era estabelecer uma guarda (El’X€To) em Alexandria, pois reconhecia a importância do Egito

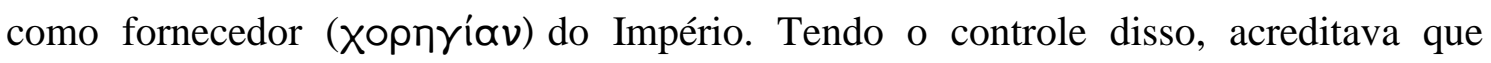
Vitélio se renderia, pois a população romana não passaria fome. Queria também anexar as duas legiões de Alexandria, em caso de incertezas na sorte (Tñs TúXns å $\delta \hat{\lambda} \lambda \omega \nu$ ) (Bellum Judaicum 4.605-615):

Com boas razões então Vespasiano estava ansioso para obter controle aqui, para garantir a estabilidade de todo o império. Consequentemente, logo escreveu para o prefeito Tibério Alexandre, o 
governante do Egito e de Alexandria, lhe informando do zelo de seu exército, e como tinha sido forçado a carregar o peso (Tò ßópos) do império sozinho, desejava conseguir a sua cooperação e assistência. Ao ler a carta em público, o prefeito prontamente exigiu que o exército e a população prestassem um juramento de lealdade

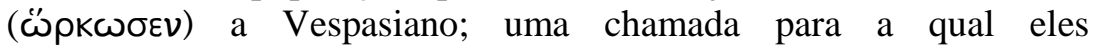
responderam alegremente ( $\alpha$ ó $\varepsilon^{\prime} \nu \omega \varsigma$ ), sabendo da maior qualidade do homem pelo seu comando na região vizinha (Tñs Ėy Yùs). Tibério,

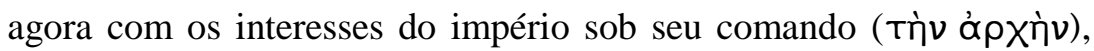
fez todos os preparativos para a chegada de Vespasiano; e mais rápido que o pensamento, os rumores ( $\phi \tilde{n} \mu \alpha \mathrm{l})$ se espalharam com a notícia do novo imperador do Oriente (Bellum Judaicum 4.616-619).

As forças flavianas derrotaram o exército de Vitélio na Itália, e Vespasiano foi nomeado imperador em Roma sem estar na cidade. Josefo narra que após o seu comando ser confirmado e quando chegou a Alexandria após a derrota de Vitélio, Vespasiano recebeu as boas notícias de Roma e embaixadas de todo o mundo, agora sob seu comando. E Alexandria, apesar de ser a segunda cidade após Roma em magnitude, provou ser "pequena demais para tamanha multidão"

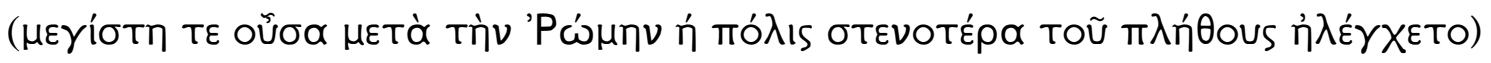
(Bellum Judaicum 4.656-658).

Josefo demonstra um sentimento de orgulho da importância de Alexandria (cidade mais importante do Oriente), e do papel determinante de Tibério Alexandre (um judeu) no rumo das decisões, dizendo que nesse momento o comando imperial ficou em suas mãos. Sua satisfação é visível quando chama Vespasiano de "imperador do Oriente", além de ressaltar a grandeza de Alexandria e seu posicionamento logo após Roma. O autor indica que o novo governante tinha consciência da importância ascendente dessa parte do Império e da relativa sujeição de Roma a Alexandria, devido ao controle que a cidade exercia sobre o fornecimento de trigo para a capital.

Esperando as coisas se acalmarem em Roma, Vespasiano passou os primeiros meses do seu governo em Alexandria com seu filho Tito, para quem transferira o comando das tropas da Judéia. Josefo conta que enquanto estava em Alexandria, auxiliando seu pai no estabelecimento do império "concedido por obra divina"

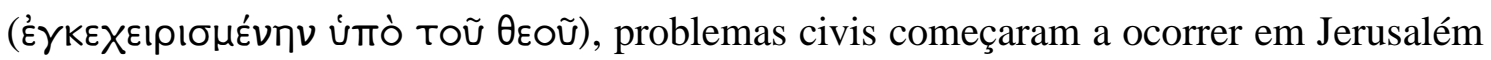
e Tito foi para lá (Bellum Judaicum 5.2.2). Dois mil homens do exército de Alexandria foram levados à Judéia por Tito e com o apoio de Tibério Alexandre (Bellum Judaicum 5.44-46). No término da guerra da Judéia, Tito e Vespasiano passaram por Alexandria 
(e por várias outras cidades) (Bellum Judaicum 7.22.1). De Antioquia, Tito passou por Jerusalém e lamentou a destruição da cidade e foi direto para Alexandria, onde devolveu as legiões da cidade que o tinham acompanhado (Bellum Judaicum 7.117.1). Percebe-se a importância dada pelo autor às tropas de Alexandria que prestaram assistência a Vespasiano, inicialmente para vencer a guerra da Judéia e depois para coroarem-no imperador.

No mesmo livro, Josefo fala do aumento da perseguição generalizada aos judeus após a última resistência em Massada, que colocou fim à guerra da Judéia. Cita Alexandria como um exemplo de local onde os problemas se intensificaram através da migração de muitos judeus sicários, encontrando a destruição (ámoӨ $\alpha v \varepsilon \tilde{v}$ ). Eles tinham a intenção de continuar a revolução por lá

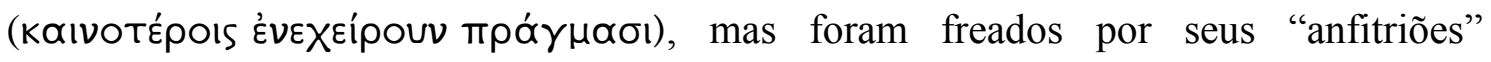

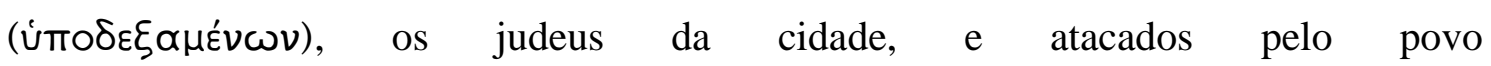

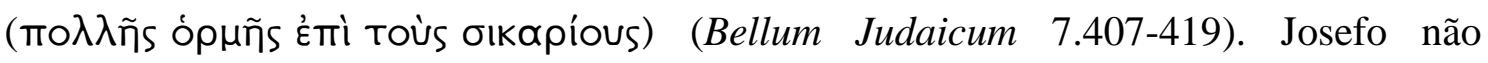
esclarece precisamente quem foram os responsáveis pelo ataque, mas aparentemente era uma coalizão entre romanos e os judeus mais influentes da cidade. O prefeito Lupus estava em controle de Alexandria e reportou o ocorrido ao imperador, que temendo pela tendência revolucionária dos judeus

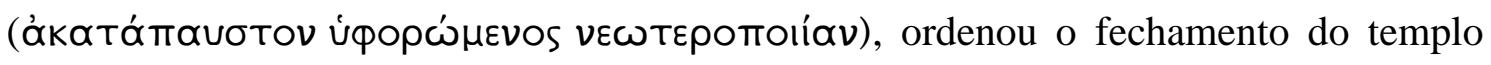
judaico em Onias (Bellum Judaicum 7.420-422). Seu sucessor Paulínio, saqueou os tesouros do lugar, ameaçou os sacerdotes e barrou todo tipo de acesso ao local. Josefo menciona que o local funcionava como local de culto há 340 anos (Bellum Judaicum 7.433-436). Os sicários iniciaram outra revolta nas cidades em volta de Cirene, e os judeus abastados da cidade pediram ajuda a Catulo, o governador romano da Líbia, que massacrou os revoltosos. A intenção era punir também os mais respeitados judeus de Alexandria e Roma (entre os quais estava Josefo), os acusando de sedição (

Josefo sugere novamente uma maior proximidade dos romanos de sua própria comunidade, dizendo que quando Vespasiano e seu filho Tito se tornaram mestres do mundo habitado, os alexandrinos e antioquinos pediram a eles que tirasse dos judeus o direito a cidadania, o que não foi concedido. Eles passaram por cima de seus ressentimentos de guerra e dos pedidos de comunidades poderosas 


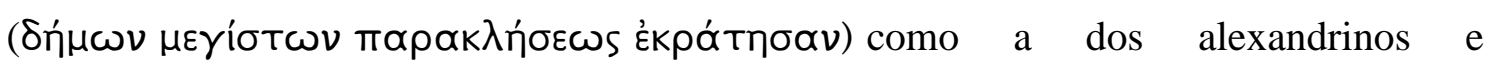
antioquinos, atitude que Josefo entendeu como uma prova da bondade dos romanos (Antiquitates Judaicae 12.121-124). Aqui o autor deixa claro que foi a força de Roma e de Alexandria o que falou mais alto nessa circunstância, obrigando os judeus a exercerem o autocontrole. Percebe-se que em relação a Fílon e apesar de estar também preocupado em narrar as desventuras dos judeus de Alexandria, Josefo é menos comprometido com o lado judeu da cidade, pois priorizava a sua aliança com Roma.

Suetônio e Tácito também ressaltam a posição central de Alexandria na aclamação do novo imperador. Suetônio narra que após o exército considerar o nome de todos os governos consulares para o comando, Vespasiano foi recomendado vivamente antes da morte de Nero. Quando a ação se tornou conhecida, o prefeito do Egito foi o primeiro a mandar suas legiões a fazerem um juramento para Vespasiano (Suetônio. Divus Vespasianus 6). Tácito conta que Tibério Alexandre se colocou ao seu lado assim que Vespasiano começou a refletir sobre as possibilidades de guerra (Historiae 2.74). Igualmente, o autor sublinha que a transferência do poder imperial começou em Alexandria, pela ação rápida (festinante) do prefeito do Egito e todo o ato foi organizado pelos seus soldados entusiasmados sem nenhum discurso formal (Cuncta impetu militum acta non parata contione) (Historiae 2.79.1).

Os dois autores relatam ainda mais que Josefo a motivação de Tibério Alexandre em tornar Vespasiano imperador, sugerindo que o impulso inicial foi do prefeito. Ambos demonstram o entusiasmo de Tibério, talvez com a intenção de indicar que Alexandria poderia ter uma posição diferenciada a partir de uma nova casa imperial.

Tácito relata que depois de Vespasiano conquistar o apoio de todo o Oriente, ficou decidido que Tito deveria seguir no comando da guerra na Judéia, enquanto Vespasiano asseguraria as "chaves do Egito" (obtinere claustra Aegypti placuit) (Historiae 2.82). Ele tinha instruído suas forças a não continuar suas operações na guerra com Vitélio, realçando que como tinham o controle do Egito e do suprimento de trigo pra Roma (claustra annonae), tinham também o lucro das províncias mais ricas (vectigalia opulentissimarum provinciarum obtientur) (Egito, Síria e Ásia). Consequentemente, o exercito de Vitélio seria forçado a se render pela falta de pagamento e comida (Historiae 3.8). Após as notícias da batalha de Cremona, ele foi para Alexandria às pressas, onde podia impor o fardo da fome (opis indigam fame 
urgeret) aos exércitos falidos de Vitélio e a Roma, que sempre precisou de apoio de fora (Historiae 3.48.13). Suetônio também relata sobre o desencadear da guerra:

Então ao começar a guerra civil ele mandou na frente os generais com suas tropas para a Itália, ele atravessou para Alexandria, para tomar posse da "chave" do Egito (claustra Aegypti optineret). Lá ele dispensou todos os seus ajudantes e entrou no templo de Serápis sozinho, para consultar os presságios (auspicium) com relação à duração de seu poder. E depois de muitas oferendas ao deus como forma de reconciliação (propitiato), por um tempo considerável ele se virou, e lhe pareceu que seu liberto Basilides ofereceu a ele ramalhetes sacros, guirlandas e pães, como era o costume lá; e ele sabia bem que ninguém o tinha deixado entrar, e por algum tempo ele era incapaz de andar por causa de um reumatismo, e, além disso, estava distante. E imediatamente cartas vieram com notícias que o imperador Vitélio tinha sido cercado em Cremona e o imperador tinha se matado. (Divus Vespasianus 7.1)

Para Tácito e Suetônio, a motivação de Tibério Alexandre foi suficiente para conquistar o apoio dos alexandrinos, porém toda essa espontaneidade é um pouco suspeita (ANDO, 2000, p. 193). Segundo Haynes (2003, p. 116), Tácito atribui o triunfo de Vespasiano mais a uma feliz coincidência das circunstâncias, do que ao seu caráter superior. Nesse sentido, em virtude do contexto de guerra civil e dos problemas de sucessão, o consenso daquele tempo era que a dinastia dos flavianos tinha se sobressaído por forças divinas e por circunstância propícias, o que explicaria o seu talento de trazer o Império de volta para o rumo certo.

As passagens citadas sugerem que toda a transferência de poder foi rápida, espontânea e de certa forma inesperada, até por Vespasiano. No entanto, um estudo mais atento do conjunto das evidências indica que sua proclamação começou meses antes e se realizou no dia anteriormente combinado e com grande planejamento (LEVICK, 1999, p. 43). Os autores sublinham a sagacidade de Vespasiano de perceber a possibilidade de ganhar a guerra através do controle do trigo egípcio. Nesse sentido, ele deve ter tido algum trabalho de convencimento para trazer os alexandrinos para o seu lado e ter acesso a toda essa riqueza. Foi visto no capítulo 3 o quanto a questão da riqueza egípcia era motivo de alvoroço nos antecedentes da conquista romana por Otávio. Os comentários de Josefo, Tácito e Suetônio demonstram que pouco tinha se alterado na mentalidade da elite imperial nesse quesito, pois sublinhavam a força da riqueza e seu poder de decisão também nas questões políticas. 
Na sequência, Suetônio descreve os milagres realizados por Vespasiano. Diz que um homem cego e outro paralítico vieram a ele quando se sentou no tribunal, afirmando que Serápis tinha prometido em sonho que Vespasiano consertaria seus olhos, e fortaleceria as pernas com seu simples toque. E apesar do imperador não acreditar no que foi dito, foi bem sucedido (Divus Vespasianus 7.2-3).

Suetônio se interessa menos em narrar o desencadear da guerra e dos eventos políticos, e se concentra mais na presença de Vespasiano em Alexandria e nos sinais divinos promovidos por Serápis confirmando a sua vitória. No entanto, Tácito detalha ainda mais os milagres realizados legitimando o seu comando. Relata que durante os meses que ficou em Alexandria, muitas maravilhas (statos aestivis flatibus dies) continuaram marcando o favor dos céus (quis caelestis favor) e certa parcialidade dos deuses diante dele. $\mathrm{O}$ autor descreve os alexandrinos que lhe solicitaram a cura a mando do deus Serápis, o deus mais adorado pelo "mais supersticioso dos povos" (superstitionibus gens). Em um primeiro momento, Vespasiano ridicularizou e desprezou esses apelos, mas temeu o que poderia acontecer se os ignorasse, e pensou nos elogios que receberia se fosse bem sucedido. Então, com a ajuda dos médicos, conseguiu curá-los. Tácito expõe que os dois fatos eram contados por testemunhas oculares ainda nos seus dias (Historiae 4.81.1-4). O autor observa que esses eventos deixaram Vespasiano com desejo de visitar o santuário dessa divindade para consultá-la com relação à sorte do Império. Então, ordenou que o templo fosse esvaziado e depois de entrar no recinto e contemplar ao deus, viu um dos principais homens de Alexandria, chamado de Basilides, que fora retido pela doença em um local distante. Perguntou aos sacerdotes se o homem tinha entrado no templo naquele dia e se havia sido visto na cidade, finalmente descobriu que ele estava 80 milhas distantes, e concluiu que se tratava de uma visão sobrenatural (divinam speciem) (Historiae 4.82.5). Tácito detalha então sobre as origens do culto a Serápis sob os Ptolomeus, já citadas no capítulo 2. Tácito e Suetônio atribuem a conquista da glória e fama de Vespasiano em Alexandria aos milagres realizados (LENDON, 2001, p. 110).

Na visão de Tácito, a confirmação da vitória de Vespasiano por Serápis, o deus mais poderoso de Alexandria, indica que ele restava recebendo o mesmo aviso para a consolidação de seu poder que Ptolomeu recebera no seu tempo. Talvez seja por isso que o autor descreveu com tantos detalhes o estabelecimento do culto pelo rei (Historiae 4.83-84). Assim, são relatos semelhantes, pois ambas são narrativas de 
fundação nas quais o poder divino sanciona o comando terreno (HAYNES, 2003, p. 134). A associação com Serápis também vincula a dinastia flaviana a influências externas, misturando as funções sacras e seculares do princeps (HAYNES, 2003, p. 140). Assim, Tácito pretendia demonstrar a maior presença do Oriente nesse novo principado e sua legitimação pela divindade suprema de Alexandria indicavam a importância da cidade na ascensão do imperador.

Com as menções aos milagres realizados em meio à multidão, depois a confirmação de seu poder por Serápis, a divindade mais adorada pela elite alexandrina, os autores pretendem enfatizar que todas as "classes" de uma cidade complexa, tinham confirmado sua adesão e fidelidade a Vespasiano. Os autores indicam também que o fato de Alexandria conferir carisma ao futuro imperador ajudaria a promover o status da própria cidade (LEVICK, 1999, p. 69).

Filostrato também relata sobre a chegada de Vespasiano em Alexandria, quando teve um encontro com o sábio Apolônio de Tiana, com quem queria se aconselhar. A conversa teria se realizado na ocasião de sua visita à cidade logo após o cerco de Jerusalém. O autor afirma que Vespasiano ambicionava o poder absoluto e quando se aproximava da cidade, os sacerdotes foram ao seu encontro nos portões, juntamente aos magistrados do Egito, e os representantes dos diferentes nomos. Os filósofos e suas escolas também estavam presentes, mas Apolônio não foi e continuou conversando no templo. O imperador perguntou por ele, enfatizando que fora até o Egito para se aconselhar com ele. Depois de oferecer sacrifícios, e presenciar audiências oficiais nas cidades, se dirigiu a Apolônio e perguntou se seria rei, este respondeu que ele já era, deixando Vespasiano em completo estado de satisfação. Filostrato afirma que o resultado da sua visita foi que os egípcios recuperaram sua prosperidade, depois de um período de exaustão pela opressão sofrida

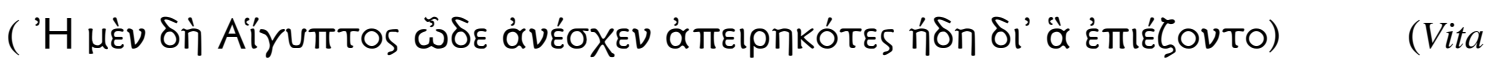

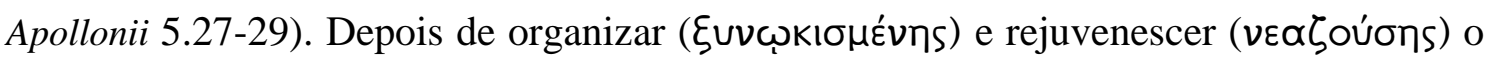
Egito, Vespasiano convidou Apolônio para sua viagem, mas ele recusou, pois ainda não tinha visto o Egito em toda extensão (Vita Apollonii 5.37).

Filostrato elabora mais um retrato de Vespasiano como alguém aprovado e legitimado por todos os sinais divinos e por todos os povos, quando enumera a quantidade de pessoas que o receberam na chegada a cidade. No entanto, está claro que 
seu encontro com Apolônio é fictício, e o único fato comprovado desse diálogo é a visita de Vespasiano a Alexandria (JONES, 1978, p. 14).

Filostrato faz uma breve observação condenando o culto a animais dos egípcios. Diz que quando Apolônio entrou no templo, ele ficou impressionado com sua organização, mas desaprovava o sacrifício de animas (Vita Apollonii 5.25). O autor sugere aqui, um misto de curiosidade, admiração e aversão pelas tradições egípcias, no contexto de exaltação à cultura grega da segunda sofística.

As curas promovidas pelo imperador são uma metáfora usada pelos autores para demonstrar o estado do império herdado por Vespasiano e o talento que ele teve em livrá-lo de todos os males (HAYNES, 2003, p. 130). Os milagres também eram sanções divinas da escolha imperial, pois não tendo os pré-requisitos dos imperadores anteriores e sendo um homo novus, Vespasiano dependia de aprovações dos céus para o sucesso de seu governo. Assim, forças divinas estariam confirmando o poder do novo imperador e sua legitimação em Alexandria, a segunda cidade em tamanho e importância do império. Ressaltar a sua ascensão e aceitação divina em Alexandria seria uma forma de promover a sua aceitação em Roma. Tácito e Suetônio demonstram que além do controle do fornecimento alexandrino ser vital para o império (e Vespasiano se utilizou dessa ferramenta), a conquista de sua legitimidade política em Alexandria também deveria ser considerada.

Desde Augusto que um imperador romano não visitava Alexandria, apesar das tentativas de Calígula e Nero, o que foi entendido pelos seus habitantes como um crescimento da sua importância no Império, o que logo se provou falso pelo aumento de impostos e introdução de novos tributos promovidos por Vespasiano (MILNE, 1924, p. 29). O aumento da taxação foi aparentemente ressentido em Alexandria, embora seja menos comentado pela documentação. Suetônio faz uma referência breve à ganância (pecuniae cupiditas) de Vespasiano, que o levou a subir todos os impostos das províncias (Divus Vespasianus 16.1). E apesar das benfeitorias concedidas por todo Império, não conseguia se livrar da fama de avarento, os alexandrinos inclusive o chamavam do sobrenome de um antigo rei conhecido por sua avareza (cupiditatis infamia) (Divus Vespasianus 19.2).

O enfoque de Dion Cássio referente ao reino de Vespasiano é na oposição que os alexandrinos fizeram ao imperador em virtude do aumento dos impostos, após ressaltar rapidamente as benfeitorias que sua visita trouxe ao Egito. Ele relata que depois da 
entrada de Vespasiano em Alexandria, o Nilo teve uma cheia maior do que o normal, algo que só ocorrera uma vez e, alem disso, Vespasiano curou duas pessoas, mas:

Apesar de os céus estarem então agradecendo e o magnificando

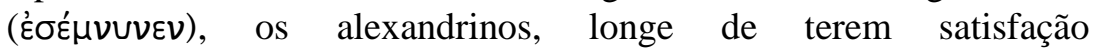

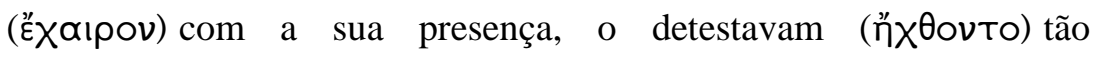

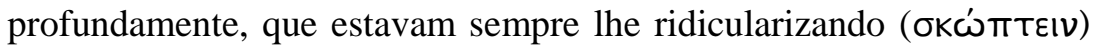

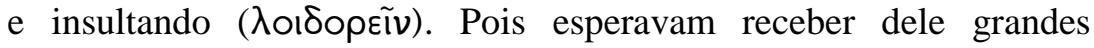
recompensas por terem sido os primeiros a fazerem dele imperador, mas ao invés de assegurar qualquer coisa, tiveram impostos extras

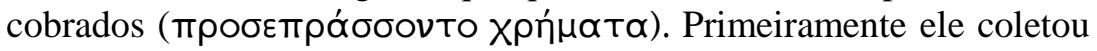
grandes somas de várias formas, sem ignorar nenhuma fonte, por mais trivial ou repreensível que fosse, mas explorando todas, tanto sagradas, quanto profanas, de onde dinheiro pudesse ser assegurado. Ele também renovou várias taxações que já tinha caído em desuso, aumentou outras já em vigor, e ainda introduziu outras novas. E adotou o mesmo procedimento no resto do território submetido, na Itália e mesmo em Roma (Historiae Romanae 65.8.1-5).

Os alexandrinos entendiam que ao invés de serem recompensados com o favorecimento da cidade, eles foram punidos por Vespasiano. Consequentemente,

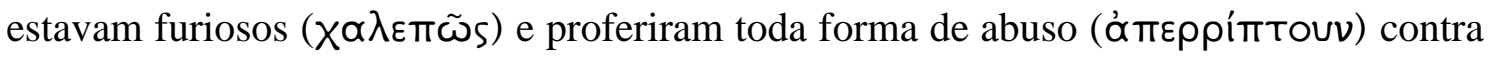
o imperador em multidão. Vespasiano pensou seriamente em castigá-los ( $\tau$ $\mu \omega \rho i ́ \alpha v)$,

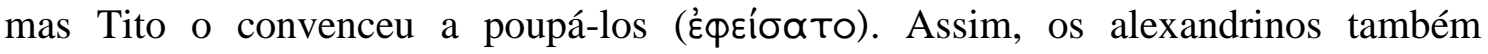

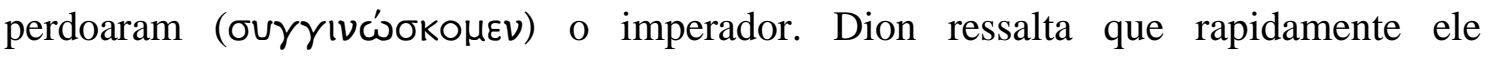

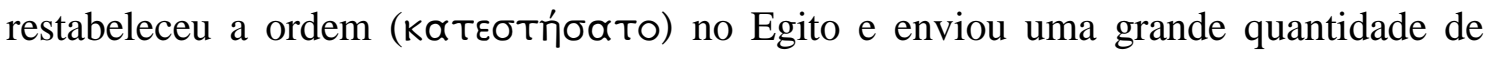
trigo a Roma (Historiae Romanae 66.9.1-2).

Suetônio conta que no contexto do final da conquista da Judéia, antes de se tornar imperador, Tito esteve em Alexandria. Ele chegou à cidade usando um diadema da consagração do touro Ápis de Mênfis, um ato tradicional da antiga religião (rituque priscae religionis) e desfavoravelmente interpretado por alguns, que viram no ato uma tentativa de competir com o poder de seu pai (Divus Titus 5). Suetônio sugere a "modernidade" da cultura egípcia ainda sob Roma, pela permanência desses cultos milenares, também na Alexandria de sua época. Assim, o autor aproxima um pouco mais a capital grega do reino antigo. Milne (1924, p. 191) observa que o único culto a animais permitido em Alexandria era o culto ao boi Ápis e Mnevis, devido à importância e ao fanatismo exercido por essas divindades. Sem dúvida Tito já estava realizando atividades diplomáticas e alimentando suas próprias ambições, pois em 
virtude da idade do pai ele tinha todo o interesse em ajudar a promover a si mesmo (LEVICK, 1999, p. 45). Sua atitude indica uma forma de apreço pela cultura egípcia antiga, ou ainda, foi um sinal de agradecimento ao apoio do Egito ao principado de seu pai, graças ao qual ele também se tornaria imperador.

Ainda segundo Suetônio, Domitiano teria se dedicado com grandes custos (impensissime) a renovar as bibliotecas que foram tomadas pelo fogo (provavelmente se referindo à Biblioteca de Alexandria, que foi queimada no tempo de César). Domitiano procurava por cópias de trabalhos perdidos, e mandava escribas para Alexandria para fazer a transcrição e correção (describerent emendarentque). Indica assim a admiração pela riqueza cultural da cidade, que interessava a Roma manter (Domitiano 20). A observação de Suetônio, mesmo que não seja fidedigna, marca a continuidade da cidade como um centro de aprendizado ainda no seu tempo (KNOX, 1985, p.184). Suetônio é a única fonte que indica algum tipo de consideração de Tito e Domitiano pelo Egito e Alexandria. Nesse sentido, mesmo que se trate de episódios fictícios, as referências apontam a permanência e a vivacidade da cultura egípcia e a contínua importância cultural de Alexandria, além de uma predileção da dinastia dos flávios pela metrópole oriental.

O tempo de Vespasiano assinala importantes transformações no Império. E Alexandria não passaria imune a essas mudanças, em virtude de sua centralidade e vitalidade para o Mediterrâneo. Os relatos sobre o seu reinado e o papel decisivo de Alexandria na ascensão do novo imperador sinalizam que a cidade representava para o Império algo mais do que um pólo comercial e um centro de distúrbios. A grandeza populacional e vitalidade cívica a tornaram influente nas decisões políticas de Roma. No entanto, era necessário justificar essa promoção do local de forma divina e como fruto do acaso e de circunstâncias específicas.

\subsection{De Trajano a Severo}

Nos impérios de Trajano e Adriano, novas menções de Alexandria são feitas, em virtude de mais problemas na cidade, que demandaram a atenção dos príncipes. Posteriormente, as fontes se tornam mais escassas para o Império de forma geral. 
Consequentemente, os testemunhos sobre Alexandria são mais raros. Os breves comentários para o período de Trajano a Severo estão em Plínio (o jovem), Dion Crisóstomo, Apiano, Dion Cássio e Aquiles Tacio.

Uma troca de cartas entre Trajano e Plínio lança luz sobre a restrição na concessão das cidadanias, alexandrina e romana. Ilustra também as delimitações das categorias identitárias dentro de Alexandria, na qual os egípcios ainda estavam em um patamar inferior aos alexandrinos. Plínio escreve a Trajano relatando que queria conceder a cidadania ao médico egípcio Arpocras como recompensa por um tratamento. Mas foi lembrado por aqueles mais informados nesses quesitos, que como o homem era um egípcio, ele não poderia ter pedido a cidadania romana antes de se tornar cidadão alexandrino (Alexandrinam civitatem). Plínio esclarece não saber a respeito da distinção entre egípcios e outros estrangeiros (peregrinos) e solicitava ao imperador torná-lo cidadão de Alexandria. Para isso, estava lhe mandando as informações pessoais do médico (C. Plinius Traiano Imperatori 10.6). Trajano responde que seguindo as regras de seu predecessor, ele não tinha a intenção de conceder a cidadania alexandrina a não ser em casos especiais, mas como Plínio já tinha obtido a cidadania romana para o médico, ele não podia recusar o pedido. E pergunta sobre o nomos do homem para que pudesse mandar uma carta a Pompeius Planta, o prefeito do Egito (Traianus Plinio 10.7). Plínio responde agradecendo ao imperador por abrir uma exceção, sabendo de sua intenção de seguir rigorosamente a regra dos seus predecessores e garantir a cidadania alexandrina apenas em casos especiais. E responde que o nomos do médico era Mênfis (C. Plinius Traiano Imperatori 10.10). Percebe-se no relato de Plínio a importância da cidadania alexandrina como ponte para a conquista da cidadania romana e o poder de decisão de Roma sobre questões próprias dos alexandrinos, certamente um motivo de insatisfação para o povo.

O discurso de Dion Crisóstomo, que será tratado mais detidamente no capítulo seguinte oferece poucos elementos para uma datação mais precisa. No entanto, algumas passagens se referem a situações mais específicas, que sugerem que a escrita se refiria ao reinado de Trajano. Contudo, sua fala aos alexandrinos pretende transmitir uma mensagem "atemporal" ao povo, pois faz grandes generalizações indicando que na sua percepção, o comportamento dos alexandrinos reproduzia um padrão que pouco se alterara desde seus reis. Ao enfatizar a grandeza da multidão alexandrina e ressaltar o poder do povo, o autor faz uma diferenciação entre o que considerava um bom rei e um 
tirano, provavelmente se referindo a Trajano e Domiciano, respectivamente. Reflete que

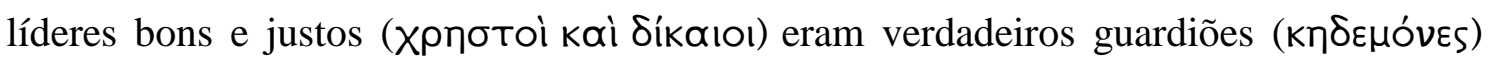

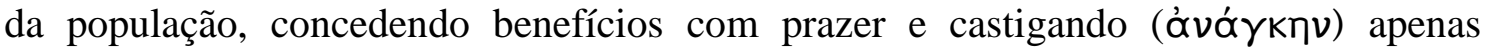
quando necessário. Outros pelo contrário, eram severos, tiranos

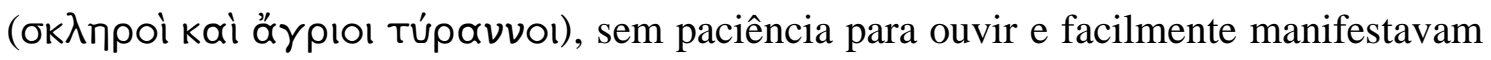

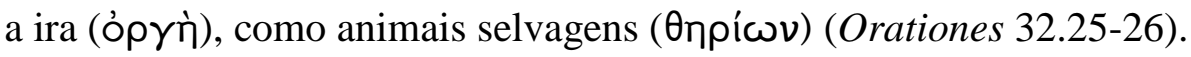

Na sequência, Dion elogia o governo romano pela manutenção da paz em Alexandria:

Contudo, deus é indulgente, eu suponho, pois é deus, e trata com leveza as loucuras das massas ( $\pi \circ \lambda \lambda \tilde{\omega} \nu$ ơvoı $\alpha v$ ). Consequentemente, ele deu a vós, seus filhos, os guardiões e guias

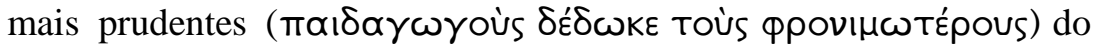
que vós alexandrinos, e através de sua companhia, não apenas no teatro, mas em todos os lugares, sua conduta irá melhorar

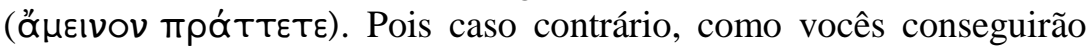

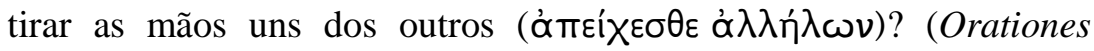
$32.51)$

Em seguida, Dion ressalta novamente a vigília contínua dos romanos, fazendo referência a algum conflito ocorrido em Alexandria. Afirma que, o seu mau comportamento fez os romanos desenvolverem um sentimento suspeito em relação a eles, apesar de terem governantes tão razoáveis, resultando no aumento da vigília em relação a períodos anteriores:

(...) vocês não sabem nem como ser bons sujeitos

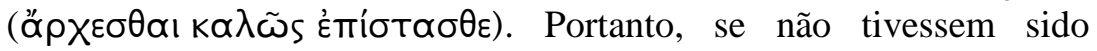
afortunados (દ่TÚXદTE) com seus presentes líderes, dificilmente sua existência poderia ser assegurada. Como evidência eu cito os seus mais recentes eventos ( $\sigma u \mu \beta \alpha ́ v \tau \alpha)$. Por exemplo, quando você ainda era independente, o seu rei se ocupava em tocar a flauta e só se concentrava nisso; e estavam em termos hostis com ele e divididos em

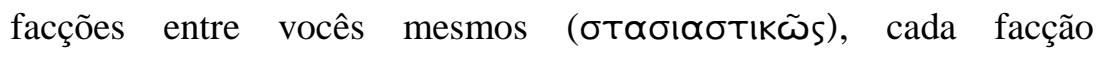
separadamente trabalhando pela ruína do estado

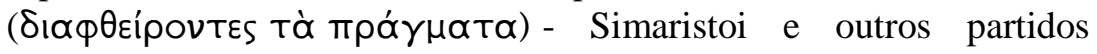

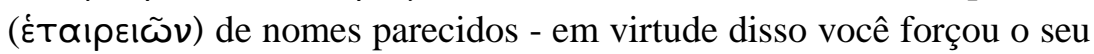
rei a fugir, e depois a proceder com o seu retorno através da guerra (то入е́ $\mu \omega)$, e com a ajuda dos romanos também? E finalmente ele

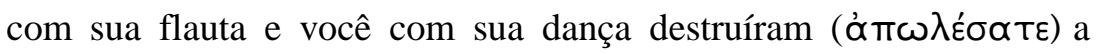
cidade. E apesar de agora terem homens tão razoáveis como

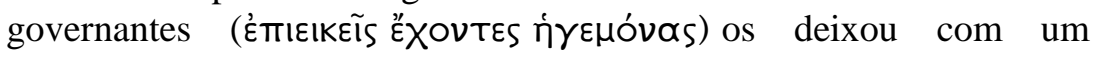
sentimento suspeito (úTrơíav) em relação a vocês, a tal ponto que os fez crer que era necessária mais vigília atenta 
(

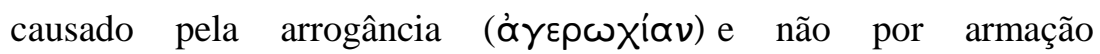

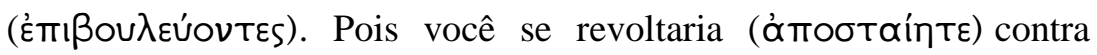

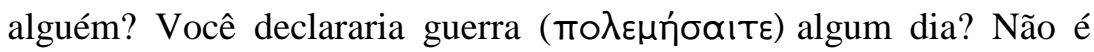
verdade que no distúrbio ( $\propto \alpha \rho \propto \times \tilde{n}$ ) ocorrido a maioria só chegou ao

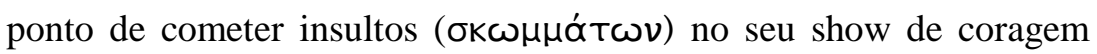

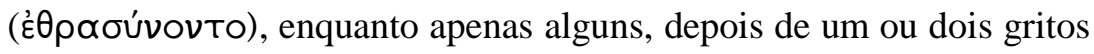
com alguma coisa momentânea, como pessoas que encharcam com lamas os transeuntes, rapidamente se debruçam e começam a cantar, e alguns foram pegar grinaldas, como se estivessem a caminho de uma

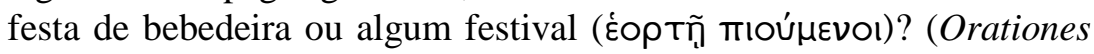
32.69-71)

$\mathrm{O}$ autor nota que o tratamento desafiador dos alexandrinos diante das autoridades era antigo, pois antes de ser conquistada por Roma, já tratavam seus reis com hostilidade e se dividiam em facções. Para ilustrar seu argumento, usa o exemplo de Ptolomeu Aulete, que foi exilado e retornou com a ajuda romana. Esse comportamento provocador levou os imperadores a estabelecerem mais vigília sobre a cidade. E a falta de moderação fez o exército romano intervir, devido a alguma situação que resultou em conflito armado. No entanto, Dion esclarece que a propensão dos alexandrinos a provocação e a enfrentar autoridades não fazia deles um povo corajoso e guerreiro. Pelo contrário, o autor ressalta que quando era esperado deles uma postura mais ativa, eles se acovardavam.

Dion reflete ainda, que a desordem (átakías) que governava a vidas dos alexandrinos só poderia resultar em mais caos, mesmo em momentos que exigiam

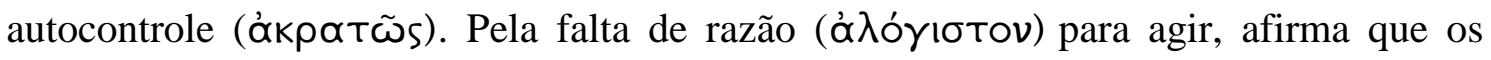
alexandrinos não sabiam as fronteiras entre as grandes questões que exigiam seriedade

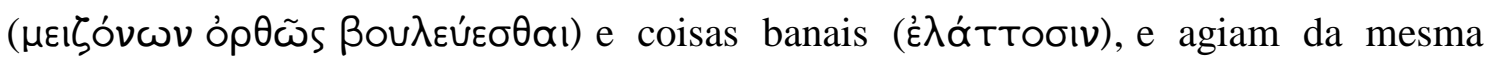

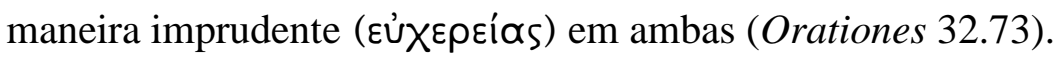

Jones argumenta que a posição de Dion diante de Roma é um elo comum entre todos os seus trabalhos. Porém, em nenhum discurso os romanos são tão mencionados como nesse, denotando que Dion estava realmente preocupado em melhorar o comportamento dos alexandrinos diante do Império. $\mathrm{O}$ autor era um simpatizante dos romanos, principalmente por prezar a ordem. Assim, seu "patriotismo grego" era completamente conciliável com uma boa atitude diante de Roma. Ou seja, Dion 
valorizava a cultura grega, mas não questionava a validade do comando romano (JONES, 1978, p. 124-129).

Com frequência, Dion usa exemplos gregos para ensinar os alexandrinos, ou seja, inclui a metrópole entre os gregos, com o intuito de envaidecer a população. No entanto, as referências sugerem que Dion entendia que a cidade deveria preservar seu passado e ter orgulho de sua cultura, mas, ao mesmo tempo, aceitar o poder romano, que só estava beneficiando aquele mundo.

Dessa forma, o autor realça as benfeitorias realizadas pelo imperador, portanto, os alexandrinos deveriam se comportar bem como recompensa. E argumenta que, nesse caso, o imperador poderia até fazer novas concessões à cidade e querer visitá-los (Orationes 32.95). É possível que Dion estivesse se referindo às reformas iniciadas por Trajano depois da revolta dos judeus. No entanto, como o autor não se refere aos judeus em momento nenhum e não ressalta a gravidade do conflito abordado, o mais provável é que estivesse se referindo a algum distúrbio de menores proporções ocorrido antes do grande conflito de 115-117. Porém, na sua percepção, a natureza turbulenta dos alexandrinos poderia resultar na sua ruína:

Em nome dos céus, você não percebe a consideração (દ่mı que o seu imperador demonstrou diante de sua cidade? Então você

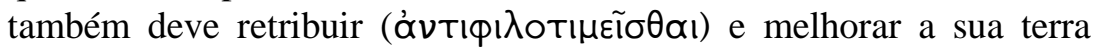
( $\pi \alpha \tau p i ́ \delta \alpha)$, não, por Zeus, através da construção de fontes ou portais - pois você não tem a força $(\delta u ́ v \propto \sigma \theta \varepsilon)$ para desperdiçar em coisas desse tipo, nem você poderia superar a magnificência $(\mu \varepsilon \gamma \propto \lambda \circ \psi \cup \cup(\alpha \boldsymbol{})$ ) do imperador - mas através do bom comportamento

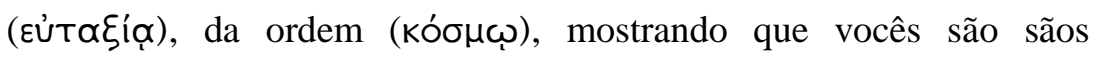
( $\left.\sigma \dot{\phi} p \circ v_{\alpha \varsigma}\right)$ e estáveis ( $\left.\beta \varepsilon \beta a i ́ o u \varsigma\right)$. Pois nesse caso não apenas ele não vai se arrepender de sua generosidade diante do que aconteceu

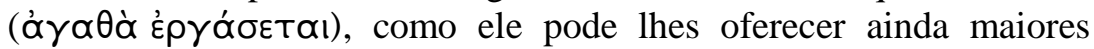

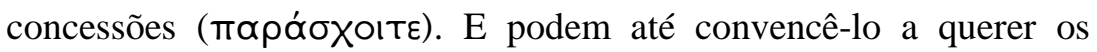

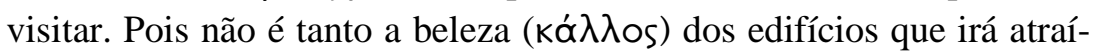
lo, pois ele tem edifícios de todo tipo, mais bonitos e custosos que em qualquer lugar; mas ele pode ficar atraído quando ouvir que as pessoas que o receberiam valem o seu favor (eưvoías) e a sua confiança

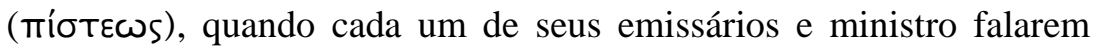

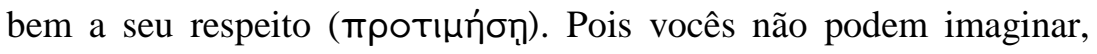
que, apesar de vocês mesmos questionarem a respeito daqueles que entram no seu porto, sobre que tipo de pessoas elas podem ser, e seu julgamento a respeito deles vai se basear em sua reputação ( $\left.\phi n_{\mu \eta}\right)$, então os agentes do imperador ainda não tem curiosidade de aprender que tipo de pessoas os alexandrinos são. Portanto, se ele ouvir que

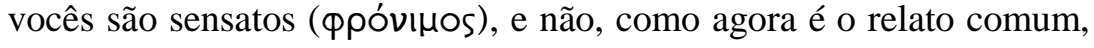




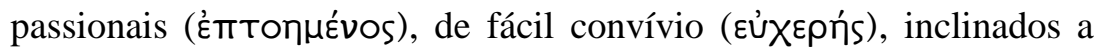

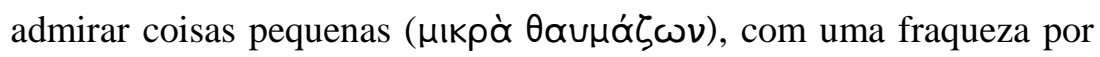

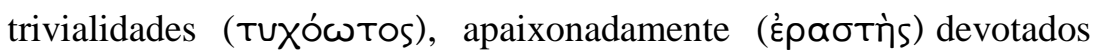
aos jóqueis e harpistas, não há dúvida de como se sentem. (Orationes 32.95-96)

Jones (1978, p. 103) ressalta que auxiliada por imperadores, as cidades tinham muitas formas de se tornar poderosas e construir mais. Assim, benfeitorias continuaram sendo um fator vital para a ascensão de cidades, do mesmo modo que eram nos reinos helenísticos e na República. A promessa por recompensas é mais um argumento usado por Dion para ser ouvido. Ou seja, segundo sua concepção, "prêmios" eram um bom artifício para ajudar os alexandrinos a melhorar o comportamento diante dos romanos.

Percebe-se no decorrer de todo o discurso de Dion, uma preocupação política associada a um ideal moralizante e ambos garantiriam a ordem e o bom funcionamento da "máquina imperial". Dessa forma, as cidades continuariam tendo privilégios, contanto que demonstrassem merecimento. Na sua visão, os romanos eram os únicos capazes de garantir a ordem em uma região tão ampla. Dion sublinha o seu papel como bons governantes, que assegurariam a paz, contanto que as regiões submetidas permanecessem quietas. Dessa maneira, lucrariam com novas construções, melhorias e todo tipo de benfeitorias. Ou seja, era um governo que as cidades deveriam prezar para que a prosperidade fosse garantida. Assim, mais do que um mundo ordenado, o que Dion prezava era um mundo organizado e governado pelos únicos capazes de manter essa estrutura: os romanos. Principalmente uma cidade da magnitude de Alexandria, ao mesmo tempo, com uma herança grega para zelar, tinha a obrigação de servir de exemplo para toda a região, pois ajudaria a disseminar a ordem e o bom comportamento diante das autoridades. Dion Crisóstomo escreveu em um momento relativamente pacífico do império. Portanto, episódios ou povos vistos como "ameaçadores" à ordem deveriam ser advertidos, por ameaçarem abalar uma estrutura que estava funcionando perfeitamente.

O reinado de Trajano foi palco do pior conflito da história de Alexandria, que praticamente aniquilou o judaísmo da cidade. O problema provavelmente surgiu pela hostilidade geral dos judeus em relação aos líderes romanos e aos vizinhos gregos (BOWMAN, 1998, p. 43). Mas diferente das dissensões anteriores, a rebelião dos judeus contra gregos e romanos emergiu de fora, e só depois atingiu Alexandria. A 
rebelião durou mais de dois anos (115-117) e se espalhou pela Cirenaica, Egito, Chipre, Mesopotâmia e Palestina.

Modrezejewski (1995, p. 198-199) comenta que por não haver nenhum historiador judeu como para os períodos anteriores (Josefo e Fílon), sabe-se pouco do conflito, que recebeu pouca atenção da literatura da época. Mas textos em papiro de autoria desconhecida e evidências arqueológicas ajudaram a reconstruir a sequência dos eventos e a gravidade da situação, e a interpretar os raros textos literários. Apesar de vários vestígios apontarem para a amplitude da destruição em Alexandria e diversas regiões do Egito, documentos de datas seguidas aos eventos demonstraram o comprometimento romano para a reconstrução do Egito (KASHER, 1976, p. 147-149).

Apiano e Dion Cássio descrevem brevemente o conflito dos judeus, e posteriormente Eusébio (História Eclesiástica 4. 2) fornece um relato mais detalhado, sugerindo que teria se baseado em alguma fonte anterior. Apiano menciona o conflito de forma passageira, enquanto descreve o contexto da morte de Pompeu e da guerra alexandrina. Relata que César estabeleceu um local para o enterramento de Pompeu, que "foi destruído no seu tempo enquanto o imperador Trajano exterminava o povo judeu no

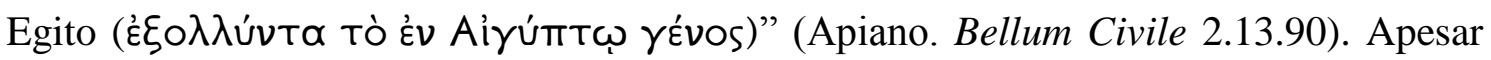
da brevidade de seu comentário, Apiano sugere a força romana para a contensão do conflito, indicando que Trajano foi rígido contra os judeus. O relato de Dion Cássio sobre a guerra está nos seus resumos. Mesmo que passageiro, o trecho ilustra a gravidade da guerra e a "selvageria" dos judeus:

\footnotetext{
Enquanto isso na região de Cirene os judeus tinham colocado certo Andreas como líder, e estavam destruindo ( $\sigma \phi \omega \nu)$ tanto romanos quanto gregos. Eles comiam a carne de suas vítimas, faziam cintos para eles mesmos de suas entranhas, se ungiam com seu sangue e usavam suas peles como vestimenta; muitos eles serraram em dois, a partir da cabeça até embaixo; outros eles entregavam a animais selvagens, e outros ainda eles forçavam a lutar como gladiadores. No total duzentos e vinte mil pessoas morreram. No Egito, também eles, realizaram atos semelhantes, e em Chipre, sob a liderança de um certo Artemion (Dion Cássio. Historiae Romanae 68.32.1-2).
}

Quando Adriano foi nomeado imperador, a revolta judaica estava praticamente terminada, mas a ele coube recuperar muito do que havia sido destruído (MILNE, 1924, p. 42). Nos seus resumos, Dion Cássio menciona outro conflito em Alexandria sob o principado de Adriano. Relata que os alexandrinos estavam em rebelião e nada os faria 


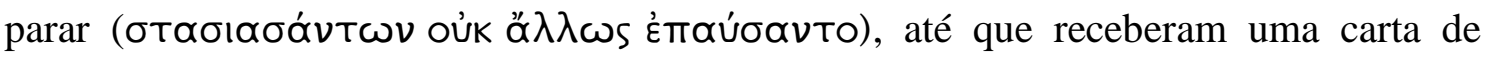

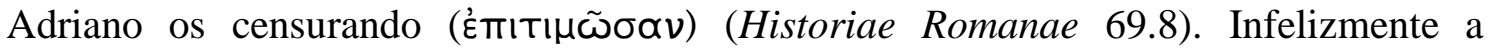
literatura se cala com relação a essa rebelião e não dispomos de mais fontes para entender se essa revolta ainda teria alguma relação com a guerra anterior sob Trajano.

Dion Cássio menciona de forma passageira a visita de Adriano para o Egito, dizendo que o imperador ofereceu sacrifícios para Pompeu e lamentou o estado de seu túmulo, decidindo restaurá-lo. Fundou também a cidade dedicada a Antinoos (Antinopolis), que tinha sido um favorito do Imperador e morreu no Egito. Adriano afirmava que ele caiu no Nilo, mas Dion argumenta que na verdade ele foi oferecido para sacrifício. O autor, ainda, explica que o imperador honrou Antinoo (por seu amor a ele ou pela sua decisão de se suicidar) com a construção de uma cidade no local onde ele tinha morrido, e ainda mandou construir estátuas dedicadas a ele por todo o mundo romano (Historiae Romanae 69.11.1-4). Adriano tinha uma afeição especial pelo Egito, que fez com que construísse a vila de Tivoli fora de Roma fortemente inspirada emCanopo. No entanto, os testemunhos contemporâneos são silenciosos com relação a sua simpatia pelo local.

Entre 171 e 172, no tempo de Marco Aurélio eclodiu outra grande rebelião no Egito. O conflito partiu da região do Delta, mas adquiriu uma grande amplitude e foi iniciada por um povo chamado Boukoloi, nome dado à população de um distrito perto de Alexandria. A revolta foi confirmada por vários tipos de fontes e ajudam a entender melhor a região do Delta (ALSTON, 1998, p. 129). Trata-se do único embate de algum relevo dos camponeses egípcios de que se tem notícia, e teve aparentemente motivações religiosas e nacionalistas (SARTRE, 1994, p. 493).

Na literatura, o relato de Dion Cássio é a fonte principal e mais detalhada dos distúrbios, embora pouco explique as suas origens:

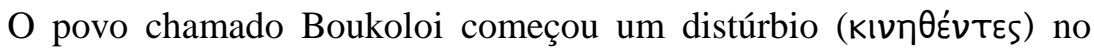
Egito sob a liderança de tal Isidoro, um sacerdote, que incitou o resto

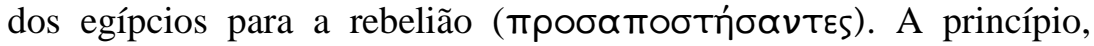

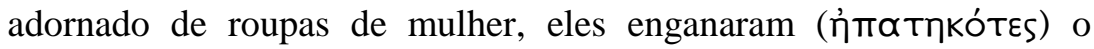
centurião romano, o fazendo acreditar que eram as mulheres dos Boukoloi e que lhe dariam ouro pelo resgate de seus maridos, o mataram quando se aproximou. Também sacrificaram o seu companheiro, e depois de fazer um juramento sobre suas entranhas, as devoraram. Isidoro superou todos os seus companheiros em coragem

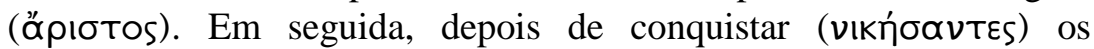
romanos no Egito em uma batalha disputada, eles chegaram perto de 
capturar ( $\varepsilon i \mathfrak{\lambda} o v)$ Alexandria também, e teriam sucedido caso Cássio não tivesse sido enviado contra eles da Síria. Ele conseguiu destruir ( $\lambda$ ũ $\sigma$ ) seu acordo mútuo e separá-los uns dos outros (pois por causa do seu desespero e também pelo seu número ele não arriscou atacá-los enquanto estavam unidos), e então, quando terminaram as disputas

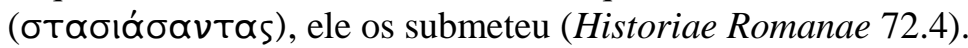

Sendo o líder um sacerdote egípcio, Dion sugere motivações religiosas para a revolta e, em poucas linhas, atribui a eles canibalismo, rebelião e travestismo (ALSTON, 1998, p.131). A intervenção de Avidius Cassius, talvez o mais importante governante da Síria e do Oriente aponta que as forças romanas do Egito não foram suficientes para suprimir a insurreição, indicando o grau de sua violência (ALSTON, 1998, p. 134). Alston defende um contexto mais amplo para a revolta, e mesmo que tenha sido iniciada pelos Boukoloi, não ficou restrita a eles, embora o mito que associa a rebelião a eles tenha predominado (1998, p. 145). Para Alston, a semelhança do relato de Dion com seu testemunho anterior, sobre a revolta judaica em Cirene, sugere que o historiador estaria se baseando em uma fonte única que retratava os judeus e egípcios de forma extremada (ALSTON, 1998, p. 132).

Aquiles Tacio também detalha alguns aspectos, principalmente sobre a região que eles habitavam, em meio a pântanos. Mas seu registro não se assemelha em nada com o de Dion Cássio, descrevendo apenas a ocorrência de uma batalha com tropas romanas na região (Leucippe et Clitophon 4.13-14). Tatius demonstra que eles venceram os romanos através da traição e de armadilhas.

Como foi visto anteriormente no tratamento de Dion Cássio a questões egípcias, a ênfase de sua escrita continua voltada para os comportamentos "bizarros" e "imorais" do povo egípcio, além da tendência para a instabilidade. A carência de literatura do período é contrabalanceada pela existência de evidências de outras naturezas (arqueológica e papirológica), que ajuda a fornecer um quadro mais completo dos séculos II e III d.C.. No entanto, o foco aqui é na literatura e em suas representações sobre Alexandria. Assim, por mais tentador que seja, não há condições de explorar esses outros vestígios na atual pesquisa.

Young (2001, p. 85) explica que depois de 160 o Egito sofreu distúrbios demográficos sérios. O banditismo, que fora sido sempre um problema, foi intensificado entre o final do século II e início do III, à medida que muitos habitantes do campo saíam de suas casas para fugir dos pesados pagamentos de impostos. Assim, a revolta dos 
Boukoloi podia ter alguma relação com esse contexto de insatisfação generalizada pelo Egito, em virtude das condições precárias de vida da população. Percebe-se, no entanto, uma mudança de cenário, pois os problemas nesse momento emergem de fora e só depois atingiam Alexandria, demonstrando que as condições de vida na cidade eram melhores que no meio rural. Ou seja, de forma indireta Dion elucida que a multidão facilmente "explosiva" da metrópole não era mais incitada com a mesma facilidade por qualquer problema vindo de outros lugares, e no caso dos Boukoloi manteve-se fora das dissensões, mesmo se tratando de uma região próxima. Mesmo o comentário do autor para o tempo de Adriano é breve e pouco sublinha a eclosão de problemas, apesar de ressaltar a sua existência.

Trata-se de um momento difícil de analisar em virtude da escassez de literatura para o Império de forma geral, e ainda mais de relatos sobre Alexandria. Fica claro, no entanto, que depois do massacre da comunidade judaica sob Trajano, as dissensões em Alexandria se aquietaram ou, ao menos, deixaram de ser o foco, em virtude da eclosão de problemas em outros lugares. O silêncio das fontes a partir de Adriano pode ser um indício de que a cidade estava em plena decadência, e, por isso, não atraia mais olhares, pois suas forças estavam minadas? Fora os comentários sobre problemas isolados no Egito, Alexandria ainda tem algum destaque na literatura da segunda sofística. Embora o seu período mais vibrante fora no século II (Dion Crisóstomo, Apiano, Arriano e Achilles Tatio), Ateneu e Filostrato são mais tardios. Como visto no capítulo 2, tais autores se direcionam prioritariamente ao período de maior glória de Alexandria. A contemporaneidade alexandrina, no entanto, foi pouco abordada, sinalizando uma espécie de nostalgia com o que anteriormente fora conquistado.

Severo e Caracala visitaram o Egito, o que novamente suscita comentários para a região. De acordo com o relato de Dion Cássio, Severo apresentou uma postura dúbia diante do Egito: demonstrou um misto de curiosidade, no sentido de entender a força de sua cultura, mas, ao mesmo tempo, parecia ter a intenção de escondê-la, talvez para que não se perpetuasse na posteridade. No livro 76, Dion conta que o imperador subiu o

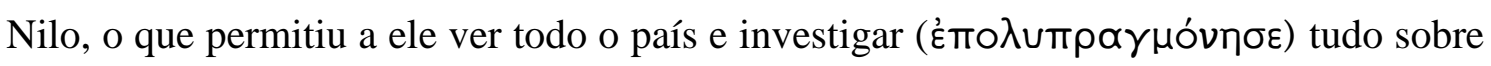
os egípcios. Tirou todos os livros que encontrou e trancou o túmulo de Alexandre para que no futuro ninguém visse o seu corpo ou lesse o que estava nos livros (Dion Cássio. Historiae Romanae 76.13). De acordo com Fergus Millar (1964, p. 144), a visita de Severo ao Egito marcou a etapa mais importante na história da província desde a 
incorporação ao Império, pois Alexandria finalmente conquistou a sua Boule e foram feitas também mudanças na administração do país como um todo. Porém, só a concessão da Boule foi mencionada por Dion, e apenas no relato sobre Augusto. Contudo, sobre a sua visita, que teria resultado em tantas modificações na província, Dion só profere essas palavras, demonstrando que não era seu interesse entrar em grandes detalhes a respeito de questões periféricas. Sobre a concessão da Boule, Dion relata:

E do sistema então imposto a eles, muitos detalhes são rigorosamente preservados no tempo presente, mas eles têm seus senadores

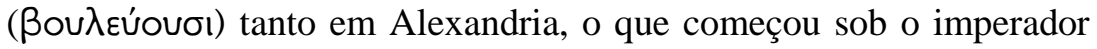
Severo, quanto em Roma, que foram inscritos no Senado pela primeira vez no reino do filho de Severo, Antonino (Historiae Romanae 51.17.2-3).

Alan Bowman (1986, p. 212) destaca que no período em que a Boule foi concedida, já não tinha tanto valor político, pois até o final do séc. III havia muitos representantes imperiais na cidade controlando a autonomia cívica. Assim, por mais que se tratasse de algo que há tempos os alexandrinos almejassem, já teria pouca valia depois de duzentos anos de império. Pode então ter gerado nos alexandrinos um sentimento duplo: por um lado estavam satisfeitos, pois sua posse deveria ter grande simbologia para a cidade no que se refere ao retorno de sua autonomia. Por outro lado, a sua conquista fora generalizada a todas as capitais dos nomos, o que podia ser entendido pelos alexandrinos como perda de destaque da cidade (BOWMAN; RATHBONE, 1992, p. 127).

\subsection{Massacre dos alexandrinos por Caracala}

Após um tempo de calmaria, em que a literatura praticamente não abordou questões em Alexandria (desde Adriano), apesar de tratar de outros problemas no Delta, que de alguma forma podiam repercutir na cidade, a visita de Caracala a Alexandria foi contada detalhadamente por Dion Cássio e Herodiano. Os dois autores descrevem o contexto de massacre dos alexandrinos promovido pelo imperador em 215 d.C. e que trouxe novamente à tona problemas cívicos na cidade. 
Dion Cássio elabora uma descrição extremamente condenável a Caracala, ressaltando a sua obsessão por Alexandre, e admiração pelos macedônios de forma geral (Historiae Romanae 78.7). O autor aponta que apesar da afeição pelo herói, o imperador

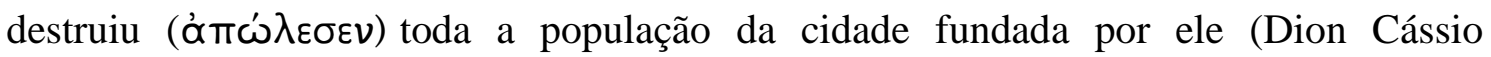
(História Romana 78.22.1). Segundo Schwartz (1948, p. 33), o relato de Dion Cássio sobre o massacre pode exagerar a loucura de Caracala, em virtude do ódio que tinha pelo imperador, assim as fontes tinham a intenção de esconder os fatos e colocar toda a culpa em Caracala. No entanto, como visto anteriormente, em diversos momentos da sua obra, Dion Cássio era um dos maiores críticos ao temperamento turbulento dos alexandrinos. Nesse sentido, é improvável que tivesse qualquer interesse de defender a cidade, até mesmo em contexto de extrema condenação a Caracala.

Segundo Dion, a fúria de Caracala começou depois de ouvir rumores que estava

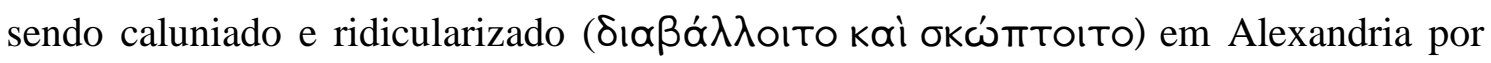
vários motivos, entre eles por ter matado o seu irmão. Seguiu então para a cidade,

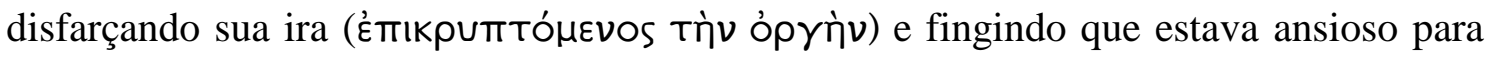
vê-los. Ao chegar, ofereceu um banquete para os cidadãos de mais prestígio

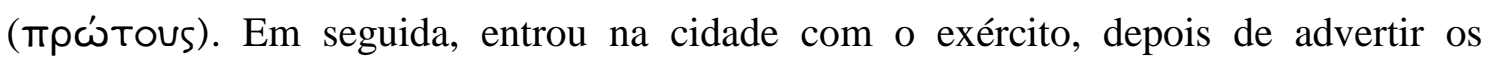

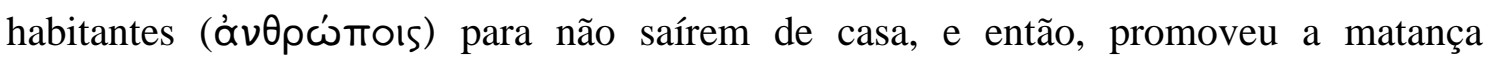
(Historiae Romanae 78.22.2-3).

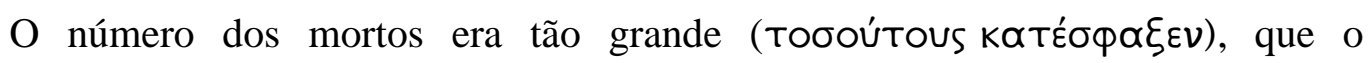
imperador nem noticiou, apenas escreveu ao Senado justificando o merecimento dos

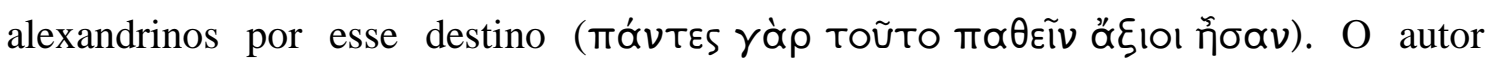
revela que junto aos habitantes, morreram também muitos estrangeiros

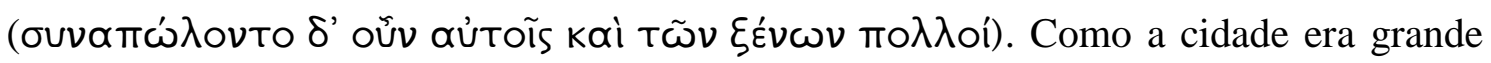
( $\mu \varepsilon \gamma \alpha \dot{\alpha} \lambda \eta \varsigma)$ e a matança estava acontecendo em todas as partes simultaneamente durante a noite e o dia, era impossível distinguir a identidade dos defuntos. Depois de mortos, os corpos eram jogados em covas profundas para que não fossem vistos por outros que

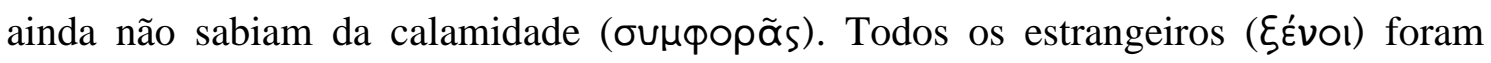
expulsos, exceto os mercadores ( $\left.\dot{\mu} \mu \pi o^{\prime} \rho \omega \nu\right)$ e suas propriedades foram confiscadas. As riquezas da cidade foram pilhadas e destruídas, e muitos templos foram saqueados. $\mathrm{O}$ autor destaca que Caracala estava presente na maior parte da matança e mandava ordens a partir do templo de Serápis, enquanto fingia lhe prestar cultos. Dizia ao Senado que 
estava realizando ritos de purificação, enquanto estava na verdade fazendo sacrifícios humanos a ele mesmo.

Depois da matança, Caracala aboliu os espetáculos e festas públicas dos

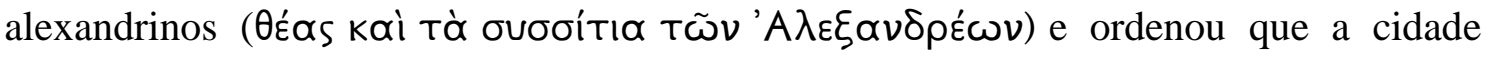
fosse dividida em muros e ocupada por guardas para garantir que seus habitantes não se visitassem com frequência (Historiae Romanae 78.22-23). A proibição das visitas talvez estivesse relacionada ao fato das aglomerações serem vistas como ameaçadoras da ordem, portanto, deveriam ser evitadas. Nesse sentido, é um indício de que ainda havia a percepção de que os alexandrinos poderiam se tornar inconvenientes e "perigosos" se reunidos em grandes grupos, pois espalhariam rumores com facilidade, que poderiam ter um impacto negativo, como os que divulgaram em relação à morte do irmão de Caracala. Além disso, a primeira medida do imperador foi reunir os cidadãos de maior prestígio, sugerindo que eram os líderes dos movimentos que fortaleciam a publicação dos boatos. Depois de tudo, o imperador deixou tropas permanentes de vigília na cidade, demonstrando que as circunstâncias ainda eram complicadas (MILNE, 1924, p. 64). O autor conta ainda, que antes da morte de Caracala, um incêndio tomou conta do interior do templo de Serápis, mas não destruiu nada a não ser a espada que matou seu irmão e depois que o fogo acabou muitas estrelas apareceram (Historiae Romanae 79.7.4).

Herodiano também descreve o massacre, provavelmente se baseando na narrativa de Dion Cássio, pela semelhança geral dos relatos, apesar de alguns pontos de discórdia. No entanto, sua descrição é mais viva e detalhada, ou seja, o autor também poderia ter tido acesso a outras fontes ao elaborá-la. Antes de descrever a matança, Herodiano relata que quando Caracala estava na região da Macedônia, começou a se associar a Alexandre. Viajou por várias províncias e de lá seguiu para Alexandria (Herodiano 4.8.1-5).

O imperador entrou em Alexandria com o pretexto de honrar Alexandre,

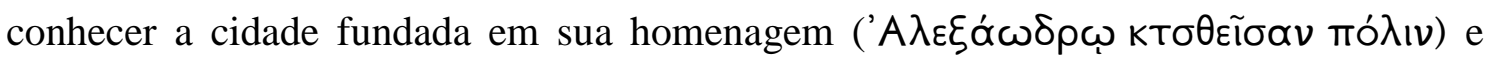
cultuar Serápis. Ao chegar, ordenou que fossem feitos grandes sacrifícios públicos. Antes de descrever o massacre, Herodiano já apresenta o topos referente aos alexandrinos: "O povo de Alexandria é por natureza extremamente frívolo e facilmente irritável por qualquer motivo trivial"

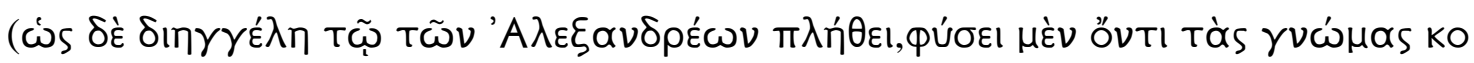




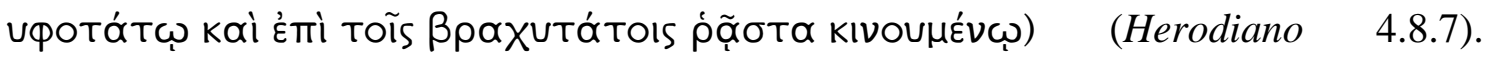

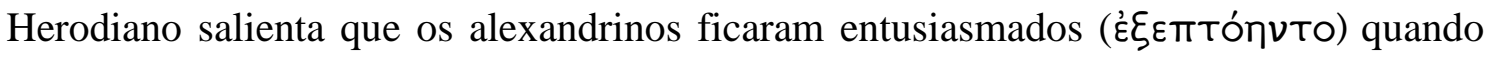
souberam da boa disposição ( $\varepsilon u ̛ v o ı \propto v)$ do imperador em relação a eles e prepararam uma grande recepção em sua homenagem. Caracala entrou na cidade com todo o seu exército e foi direto para o templo oferecer sacrifícios e depois para a tumba de Alexandre, onde deixou várias homenagens ao seu herói (Herodiano 4.8.8-9).

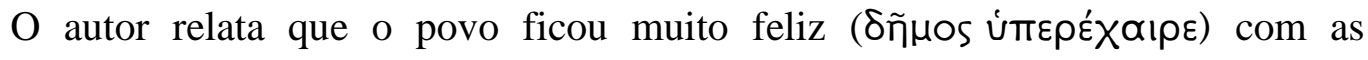
homenagens ao fundador da cidade, mas era tudo parte de um plano para realizar o

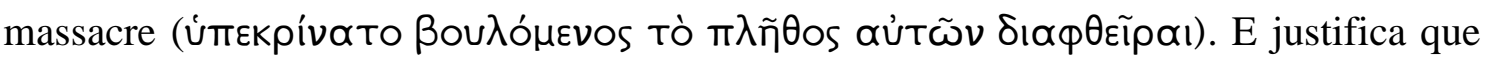
a razão do ódio ( $\mu$ íoous) do imperador era por terem chegado a Roma rumores

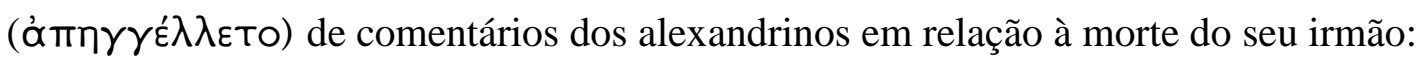

Até certo ponto era uma característica natural ( $\pi \varepsilon \varphi u ́ k \alpha \sigma ı)$ do povo permitir sátiras e a repetição de muitas caricaturas amargas e piadas depreciando as autoridades (

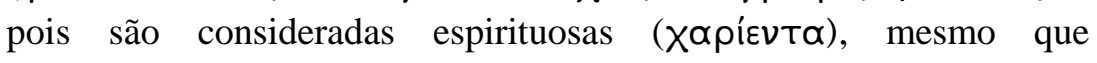
difamatórias ( $\lambda \cup \pi n \rho \alpha \dot{)})$ para as vítimas. As provocações ( $k v i \zeta \varepsilon ı)$ que

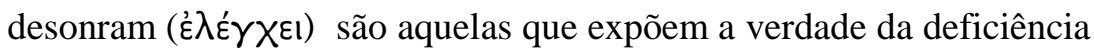
de alguém. Muitas de suas sátiras sobre Antonino se referiam à morte (ávaípeoıı) de seu irmão e de sua idosa mãe, que chamavam de Jocasta, e o ridicularizavam $(\chi \lambda \varepsilon \varepsilon \propto \alpha \zeta o ́ v \tau \omega \nu)$ por imitar Alexandre e Aquiles, que eram homens muito fortes e altos, enquanto ele era só um homem pequeno. Apesar de eles considerarem esse tipo de insulto

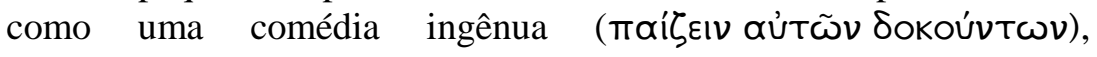
Antonino tinha uma personalidade irritável e assassina

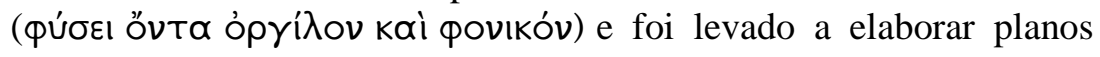

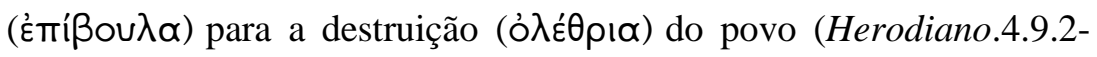
$3)$.

Dion Cássio e Herodiano concordam quanto aos insultos e piadas produzidas como o principal motivo para o massacre, pois Caracala não tolerava esse tipo de brincadeira que o diminuísse (GODDIO; BERNAND, 2004 p. 92). Deboches populares podiam colocar em perigo a honra imperial, tornando natural a reação violenta dos imperadores (LENDON, 2002, p. 122). Nesse sentido, se a opinião pública tivesse mesmo desonrado Caracala, a punição aos alexandrinos estaria justificada (LENDON, 2002, p. 173). Ou seja, a naturalidade com que os dois autores descrevem a ira do imperador diante do cenário de deboche a sua figura e sua motivação para a vingança, 
indica que era esperado que ele agisse com violência diante dos insultos recebidos. Ainda mais um dirigente com uma personalidade forte como a de Caracala.

Em seguida, Herodiano relata que o imperador aproveitou a ocasião e participou

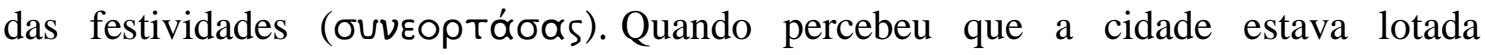

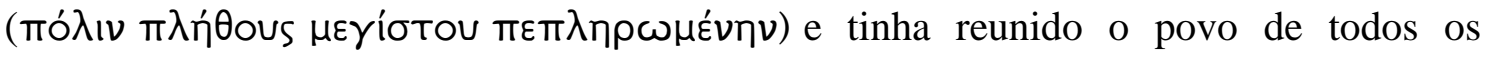

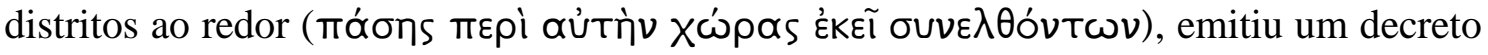
ordenando aos homens jovens ( $v \varepsilon \circ \lambda \alpha i ́ \alpha v)$ para se reunirem em um lugar aberto a fim de homenagear (

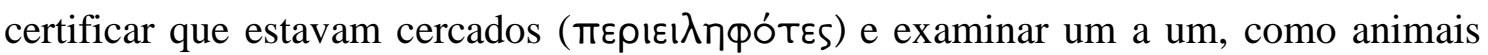
presos em uma armadilha (SUKTúols), sutilmente saiu de lá com seu exército pessoal. Enquanto isso sua tropa cercou e matou todos que ali estavam. Alguns de seus soldados promoviam a matança ('̇фóvevov), enquanto outros escavavam covas para empilhar os mortos e enterrá-los e, nesse processo muitos foram enterrados vivos. Segundo o autor, a matança (申óvos) foi tão grande que o vale do Nilo e grande parte do litoral ficaram vermelhos de sangue (Herodiano 9.4-8).

É perceptível a maior vivacidade e detalhamento na narrativa de Herodiano em relação à de Dion Cássio. Herodiano explica em pormenores os motivos que levaram Caracala a se indignar contra os alexandrinos, mas ao mesmo tempo justifica que fazer piadas e produzir sátiras contra autoridades já era um hábito dos alexandrinos, algo que faziam como forma de divertimento. Percebe-se também algumas contradições entre as duas narrativas: na de Dion Cássio, o autor diz que Caracala ofereceu um banquete para os homens mais importantes, já Herodiano observa que foi a cidade que preparou uma grande recepção para ele. Dion ressalta que a matança foi generalizada pela cidade e direcionada, principalmente, para os homens de prestígios (cidadãos) e estrangeiros (egípcios). Enquanto Herodiano salienta que Caracala tentou poupar os estrangeiros e matar apenas os "homens jovens", provavelmente os responsáveis pela produção das sátiras. Porém, no final também realça que a matança acabou sendo generalizada. A real causa dos eventos que levaram ao massacre permanece um mistério, e infelizmente temos pouquíssimos elementos para investigar as circunstâncias de sua ocorrência (MILLAR, 1964, p. 156-158).

A historiografia contemporânea concorda que o alvo principal de Caracala eram os egípcios estrangeiros. Segundo Barry (1988, p. 142), a expulsão de egípcios sugere a 
surpresa e a indignação de Caracala com relação à sua presença na cidade, acreditando que se trataria de uma cidade grega ${ }^{35}$. No entanto, o alvo principal eram os homens de prestígio da cidade, e aparentemente algo aconteceu que generalizou a matança para os egípcios.

Dion Cássio e Herodiano assinalam o planejamento de Caracala em destruir Alexandria, mas a historiografia desconfia de toda essa preparação, entendendo que como os autores tinham a intenção de retratar a loucura do imperador, não interessava descrever os antecedentes dos conflitos. Barry acredita que Caracala respondeu a algum conflito já existente na cidade e assim o problema foi iniciado (1988, p. 137). Já Harker (2008, p. 135) não descarta a hipótese de que o ocorrido pudesse ter sido a supressão de alguma rebelião durante a sua visita. $\mathrm{O}$ massacre podia ter se iniciado como um episódio de oposição a Roma, suscitado pelos notáveis alexandrinos e Caracala teria apenas reagido (SCHWARTZ, 1948, p. 32). Harker (2008, p. 139) sugere ainda que tradições alexandrinas "sensacionalistas" podiam ter colocado a culpa do massacre em Caracala para não culpar os próprios alexandrinos. Assim, Dion e Herodiano, grandes opositores de Caracala, tiveram acesso a essa documentação que era conveniente para o processo de crítica ao imperador, e então foi Caracala que levou toda a culpa. É de fato intrigante que em meio a uma literatura de tantas críticas e censuras aos alexandrinos, eles sejam retratados nesse momento como meras vítimas.

A explicação para o menor detalhamento da narrativa de Dion, na visão de Aalders (1986, p. 299) é por esse autor realmente não se interessar em descrever especificidades e distúrbios locais. Assim, pode-se observar em todo o seu relato que as menções a Alexandria e ao Egito são normalmente breves e que a cidade só é mencionada em episódios envolvendo imperadores. Ou seja, em momentos que de alguma forma repercutiam em questões imperiais maiores, seus reais objetos de interesse. Quando se dispõe a mencionar alguma situação local, dificilmente se alonga ou reflete sobre as circunstâncias que levaram aos acontecimentos, como no caso do massacre de Caracala. Embora em outros momentos pudesse tecer apreciações sobre os fatos e demonstrar seu ponto de vista, Millar (1964, p. 118) justifica que o tempo dedicado por Dion a escrever toda a história romana não o permitiu formular grandes

\footnotetext{
${ }^{35} \mathrm{O}$ édito de Caracala exigiu a saída de egípcios de Alexandria, principalmente aqueles provenientes do meio rural. Assim, os autores usam esse documento como confirmação de que quando Dion Cássio se refere a estrangeiros, ele estava se referindo a egípcios, seu maior objeto de aversão. Cf. (ABD-ELGHANI, 2004, p. 168)
} 
teorias. Seu enorme esforço de compor uma obra monumental não deixou tempo para grandes análises e interpretação dos fatos. Ou seja, o que produziu foi uma história que se justifica principalmente pelo enorme período coberto.

Herodiano apresenta uma narrativa mais detalhada sobre questões mais rotineiras, o que expressa um maior envolvimento na narrativa. É importante destacar que a riqueza de detalhes e a subjetividade dos relatos eram menores conforme o maior comprometimento dos autores com os romanos. Tanto Dion quanto Herodiano tiveram acesso à corte imperial e se envolveram em questões do império. A diferença principal é que Herodiano era um funcionário imperial de status inferior. Assim, podia demonstrar seu ponto de vista com menos receio (GONÇALVES, 2007, p. 148).

Mesmo que o episódio de Caracala fora descrito por Dion Cássio e Herodiano para corroborar com a visão crítica que ambos tinham do imperador, não se nota na narrativa nenhuma surpresa ou condenação grave da atitude diante dos alexandrinos. O contrário também não é argumentado, ou seja, os autores também não aprovam a atitude de Caracala. No entanto, a naturalidade com que descrevem o ocorrido, sem recorrer a muitas explicações, ou aos antecedentes do episódio e às suas repercussões, são elementos indicativos de que não se tratava mesmo de nenhuma surpresa para eles, diante das atitudes tumultuosas e instáveis dos alexandrinos. Herodiano se alonga mais sobre a questão, mas Dion Cássio é breve, mesmo com tamanha aversão que tinha a Caracala e a Alexandria.

O problema com Caracala é o único embate direto entre alexandrinos e um imperador romano narrado pelas fontes. Por se tratar de um imperador extremamente impopular em Roma, a literatura trata do episódio abertamente, embora o desencadear dos acontecimentos não fique totalmente esclarecido. Nos outros cenários de conflito na cidade, os romanos são retratados como mediadores, como promotores da ordem necessários para conter os distúrbios entre alexandrinos e judeus, principalmente. Mesmo na crítica de Fílon proferida a Flaco e Calígula, o propósito principal do autor é retratar os dois romanos como vítimas de uma conspiração dos alexandrinos. Ainda que seu julgamento fosse conduzido também aos dirigentes, o autor deixa claro que se tratava de uma censura específica, pois no geral os romanos eram adeptos da ordem e tinham feito o seu trabalho com extremo zelo até o principado anterior. Aqui toda a culpa é atribuída ao imperador, e os alexandrinos são retratados como vítimas de sua loucura. Assim, mesmo que o foco esteja em Alexandria, é notável uma mudança de 
ênfase, denotando um novo momento do Império e um principado nitidamente impopular entre os romanos.

A intenção deste capítulo foi demonstrar que para os dois primeiros séculos de Império Romano a literatura focou prioritariamente os problemas cívicos dos próprios alexandrinos e destes com alguns imperadores, enquanto que para a era anterior (helenística), as narrativas se concentravam principalmente nos problemas internos da dinastia. Nesse sentido, ocorreu um deslocamento de foco do governo (no período ptolomaico) para questões cívicas (na era romana), embora as fontes demonstrem que o povo era atuante tanto no período anterior, quanto na época romana. O ideal de realçar a era de paz introduzida por Roma resultou no silenciamento em relação a questões administrativas e do novo poder instalado.

Para a Alexandria romana o enfoque principal das fontes é nos problemas e polêmicas envolvendo a cidade, ou entre seus próprios habitantes, ou ainda de embates de alexandrinos com alguns imperadores. O topos da cidade turbulenta, instável e rebelde continua em uso pela documentação do período romano, embora pouco explique a respeito de como essa turbulência se expressava no cotidiano da população. Pois se a cidade era tão polêmica, deveria haver um cenário de oposição frequente também aos governantes romanos. Apenas Crisóstomo se volta mais para o cotidiano. No entanto, o seu foco é principalmente no comportamento dos alexandrinos em espetáculos públicos (que veremos no capítulo seguinte), e quando trata de problemas com seus dirigentes, é breve e nebuloso, como foi visto nas passagens citadas aqui. A impressão é que Dion não queria se comprometer, além disso, sua ênfase é na crítica aos alexandrinos. Portanto, não interessava a ele dirigir suas acusações a nenhum romano (e nem nomear qual imperador teve problema com os alexandrinos no contexto tratado).

Em suma: percebe-se que dos problemas sociais em Alexandria, só são narrados aqueles causados pelos próprios cidadãos, sendo evitados os embates diretos com Roma. Não são tratados também qualquer outro tipo de destaque da cidade e questões cotidianas, pois mesmo os eventos culturais eram vistos como ameaçadores da ordem, e descritos apenas nesse contexto (como será visto no próximo capítulo).

A segunda sofística se volta principalmente para a proeminência e exuberância da cidade no tempo dos Ptolomeus e está menos preocupada de tratar da contemporaneidade alexandrina, denotando que houve uma decadência cultural da metrópole em sua época. No entanto, a sua riqueza agrícola é ainda constantemente 
assinalada, normalmente em tom de alerta, além da dinâmica comercial, assinalando que a cidade ainda era importante nesse setor. A Alexandria romana seria então, apenas um pólo agrário e de tendência para a rebelião? Enquanto toda a exuberância da cidade, sua importância cultural e intelectual teriam se perdido?

Mesmo os entretenimentos só são descritos com reprovação. As diversões não traziam nenhum retorno positivo para a cidade, apenas mais caos e desordem? O silêncio das fontes em relação à vivência cultural de Alexandria parece estratégico, sendo uma espécie de "aviso" de que a prioridade do período era manter a cidade quieta e produtiva. Uma das formas disso ser feito, era divulgando a sua imagem de instabilidade e reforçando o seu papel como celeiro de Roma. Ao mesmo tempo, silenciando a respeito dos outros setores que por ventura poderiam tornar a cidade notória. Os lugares-comuns da Alexandria grandiosa, rica e exuberante ainda eram usados, mas normalmente em um contexto atemporal e para remeter apenas à sua constituição física. Assim, tais elementos faziam parte da representação alexandrina no Império, mas, são mais usados pela literatura para alertar sobre o seu potencial do que informar sobre a sua história recente e descrever seu cotidiano sob Roma. 


\section{Capítulo 5: Centro comercial e festivo}

\subsection{Centralidade comercial e prosperidade agrícola}

A prosperidade agrícola do Egito e a centralidade comercial de Alexandria são elementos que perpassam vários contextos no tratamento da cidade pela documentação. A representação do local como um centro dinâmico e de acesso à produção egípcia é contínua desde os Ptolomeus, mas essa imagem foi intensificada a partir da conquista de Augusto. A intenção do presente capítulo é discutir como a documentação enfatiza o desenvolvimento comercial alexandrino a partir da transformação do Egito em província, mas ao mesmo tempo fornece pistas de que as melhorias foram plantadas na era helenística. Veremos também como as festividades da cidade se relacionavam com essa vivacidade comercial, tornando-a ainda mais ativa, pulsante e ao mesmo tempo aglomerada.

Foi visto no capítulo II o realce das fontes na decisão de Alexandre em fundar Alexandria em um local estratégico. A ideia central é que o macedônio estaria buscando um ponto que intensificasse a comercialização com o mundo grego, e ao mesmo tempo tornasse a prosperidade do Egito acessível a essa região. Assim, quando viu o sítio de Alexandria não teve dúvidas da sua adequação. A literatura faz uma leitura da cidade a posteriori, já que trata da Alexandria do seu tempo; um pólo comercial por excelência. Consequentemente, quando falam em "posição estratégica" se referem, principalmente, à melhoria da comercialização do mundo greco-romano possibilitada pela fundação da metrópole e de seus portos. Por mais que os comentários se concentrem na época de construção da cidade, a prosperidade do Egito e a centralidade comercial de Alexandria estão presentes em vários contextos de sua descrição.

Antes da conquista do Egito por Roma, autores latinos já assinalavam a sua importância comercial. No relato de Cícero fica claro que as relações entre a classe política romana e o reino deveriam ser cuidadosas, devido à prosperidade do território, algo assinalado para os seus conterrâneos em vários momentos. Nas Leis Agrárias observa o seguinte: “(...) nossos cidadãos estão propensos a deixar Roma e emigrar para aquele país, atraídos pela fertilidade da terra e pela abundância de todos os tipos de 
suprimentos" (agrorum bonitatem et omnium rerum copiam) (De Lege Agraria Contra Rullum 2.16.41). Em seguida faz elogios ao Egito como o reino mais bonito e próspero e Alexandria como a cidade mais rica e bela (urbis copiosissimae pulcherrimorumque agrorum iudex, arbiter, dominus, rex denique opulentissimi regni reperietur) (De Lege Agraria. 2.16.43). Em outro livro, que trata de dilemas morais, cita Alexandria em um exemplo retórico, sobre um tempo de fome e escassez em Rodes, em que se comprava uma grande quantidade de trigo (frumento) de Alexandria (De Officis 3.12.50). Cícero estaria sugerindo a abundância de Alexandria em tempos de escassez em outros lugares?

Nas Cartas a Ático, Cícero comenta que estava há muito tempo ansioso para fazer uma visita a Alexandria e ao resto do Egito (Alexandream reliquamque Aegyptum), o que não chegou a realizar (Epistulae ad Atticum 2.5.1.1). O autor menciona ainda em outro contexto, sua preocupação com uma guerra desastrosa e eminente, em que a frota de Alexandria, Colchis, Tyre, Sidon, Aradus, Chipre, Pamphylia, Lycia, Rodes, Chius, Byzantium, Lesbos, Smyrna, Mileto, Cós poderiam cortar os suprimentos para a Itália e ocupar as províncias produtoras de trigo (occupandas frumentárias provincias comparatur) (Epistulae ad Atticum 9.9.2.13).

Nessas passagens, o autor ilustra a dependência e suscetibilidade romana do trigo egípcio. Devido ao contexto de sua escrita, podemos inferir que Cícero menciona a produtividade egípcia como uma espécie de advertência, ou como um lembrete da importância de Roma dominar o Egito logo. Em um primeiro momento, o Egito torna-se um foco de atenção para Cícero, pela prosperidade. Seus comentários denotam também que o Egito já era um importante fornecedor romano durante o período helenístico ao lado da Sicília (CASSON, 1984, p. 82).

No contexto do embate de César com os alexandrinos, o relato da guerra alexandrina realça a abundância (fertilissima et copiosissima) da cidade em todos os tipos de suprimentos (apparatus) (Bellum Alexandrinum 3.1.1). Assinala também a supremacia alexandrina nos mares e em suas técnicas, pois os egípcios tinham comando irrestrito do mar (mare libere tenerant) Mediterrâneo. O conhecimento sobre os ventos, mares e navios os deixavam em uma melhor condição de mobilidade. Além disso, seus edifícios estavam bem preparados para a defesa (velocitatem locorumque et aedificionrum notitiam) (Bellum Alexandrinum 8.5.4). No entanto, com as derrotas, começaram a confiar menos na habilidade defensiva de suas edificações, e se reanimaram a reconstruir suas frotas, acreditando na superioridade e no domínio do 
conhecimento nesse setor e conseguiram se reequipar (Bellum Alexandrinum 12.1.1). Depois do extenso e detalhado relato das batalhas, o autor conclui que os alexandrinos acabaram não se beneficiando de suas habilidades marítimas (maritimis nauticisque sollertia atque ars praesidium ferret), e nem da sua vasta multidão (neque electi ad virtutem e tanta multitudine). Pois a coragem romana acabou se provando superior, apesar de todas as vantagens alexandrinas (Bellum Alexandrinum 16.10.1). O autor parece elogiar os alexandrinos unicamente com a intenção de demonstrar como os romanos surpreenderam vencendo mesmo em condições inferiores na disputa. De qualquer forma, o relato atenta para o conhecimento dos mares e o desenvolvimento naval dos alexandrinos, promovidos pela fundação dos portos em um contexto anterior à incorporação ao Império.

A literatura menciona as boas condições comerciais da região no contexto ptolomaico, porém ressalta ainda mais o avanço após a conquista por Roma. A tradição indica que houve uma demanda imediata por produtos logo após 31, pois a situação de paz ajudou a retomar a rota comercial com o Oriente (YOUNG, 2001, p. 25). Para além das melhorias, deve-se considerar que os escritos do período tendem a enfatizar a importância de Augusto nesse processo. Assim, dão pouca atenção às rotas comerciais estabelecidas antes do impacto da paz romana. Ao se concentrar mais no valor de Alexandria para o mundo de fora, a literatura dos outsiders ilumina pouco a respeito das questões internas da cidade. Em contrapartida ilustra suas ligações com a chora, ajudando a entender também as conexões entre o Egito e o Mediterrâneo (ROWLANDSON; HARKER, 2004, p. 80).

No período helenístico houve um estímulo ao consumo generalizado, causado pelo aumento populacional na região, incitando as trocas entre os reinos (REDEN, 2011, p. 425). A aproximação romana com o Egito ocorreu em um momento de crescimento de Roma, que precisava de mais trigo para alimentar a sua população ascendente, e o Egito, que até então se mantivera neutro nas Guerras Púnicas, apareceu como o seu aliado ideal. O inchaço de Roma e o contato com o Oriente resultaram também na maior entrada de produtos de luxo na capital. Segundo Wallace-Hadrill (2008, p. 346), “ondas de luxo" arrastaram Roma desde o início do séc. II a.C., principalmente a partir da destruição e do saque de Cartago. A invasão de artigos de luxo do Oriente representou um enorme estímulo econômico para mercadores e comerciantes, incitando a mobilidade social e promovendo alterações na dinâmica da 
sociedade. Novos grupos começaram a enriquecer e buscar a ascensão social e a proeminência, daí o surgimento de leis que tentavam regular o avanço do luxo. O debate sobre a ostentação se insere nessa sociedade em transformação que caracterizou o fim da República (WALLACE-HADRILL, 2008, p. 354). Daí ser mau visto pelos conservadores que prezavam pela manutenção da hierarquia social. Dessa forma, no final do período republicano iniciou-se uma condenação ao luxo, pela crescente demanda por produtos. Foi visto nos capítulos II e III a censura ao esplendor e riqueza dos Ptolomeus, que se enquadra nesse contexto em que os moralistas de Roma depreciavam tudo referente à opulência oriental.

A disponibilidade desses artefatos aumentou consideravelmente sob Augusto, pois a paz proporcionou maior liberdade de acesso aos mercados (YOUNG, 2001, p. 15). Ou seja, se no período republicano havia certa resistência à entrada desses produtos, sob o Império, mesmo que ainda houvesse preconceito de alguns setores da sociedade, os artigos orientais inundavam o comércio de Roma. Assim, essa estrutura comercial encontrou em Alexandria o local propício para se disseminar, pela sua localização e rotina dinâmica, que estimulava a ascensão social. Como a cidade era uma significativa fonte para produtos de luxo, e também a mais importante fornecedora de trigo, esses itens eram mais um incentivo para os navegantes fazerem a viagem. Assim, os mesmos navios de carga que levavam as riquezas orientais também embarcavam o trigo (WALLACE-HADRILL, 2008, p. 332).

Estrabão é o autor que delineia de forma mais clara essas redes comerciais com o Oriente e Alexandria como um ponto de acesso a essas riquezas. Ele ilustra que tais redes se formaram no período anterior, mas prosperaram e se dinamizaram principalmente após Augusto, pois o intuito principal era ressaltar o desenvolvimento comercial do seu tempo. Observa que em sua época, a maior parte dos aromáticos vindos da Arábia e Índia era transportada através do Nilo para Alexandria. O autor explica que os artigos eram levados de camelo até Copto no Tebaida, alcançavam um canal do Nilo, e de lá seguiam em direção à metrópole (Geographica 16.4.24.20). Dessa forma, Estrabão realça a posição de Alexandria como via de acesso às riquezas do Oriente e às benesses levadas pelo Nilo em todas as regiões irrigadas pelo rio.

Estrabão explica essa intensificação comercial como uma inovação característica de seu tempo e nem menciona o investimento dos Ptolomeus nesse processo. Contudo, Young (2001, p.19) ressalta que há evidências consideráveis assinalando que antes dos 
romanos, os reis já exploravam o comércio com a Índia e Arábia, através da construção de portos ao longo da costa do Mar Vermelho. Bowman (2010, p. 103) também chama a atenção para as grandes mudanças na comercialização do Delta após a construção dos portos de Alexandria, fruto de um projeto real. Apesar da permanência de outros importantes portos, as evidências do aumento em atividades de produtos essenciais e de luxo são impressionantes como resultado dessas construções. Os artigos que chegavam do Mar Vermelho eram depositados, estocados em Copto, onde os comerciantes pagavam impostos pela sua liberação e, então, seguiam para Alexandria. Assim, Copto foi se tornando um centro extremamente fundamental no comércio com o Oriente. Quando alcançavam Alexandria, os comerciantes pagavam outro imposto, mas para o governo. Depois disso os mercadores tinham liberdade para comercializar. Contudo, a maioria realizava suas transações em Alexandria mesmo, enquanto outros seguiam para Roma (BOWMAN, 2010, p. 48-52). Dessa forma, houve um incremento nas rotas comerciais procedentes e destinadas a Alexandria, enriquecidas também com o que chegava dos portos do Mar Vermelho e de Copto (BOWMAN, 2010, p. 107).

Apesar de não mencionar investimentos na comercialização promovida pelos reis, Estrabão ressalta o fechamento do território egípcio antes dos Ptolomeus, citando Eratóstenes. Segundo este, a expulsão de estrangeiros era um costume comum entre todos os bárbaros, e entre os egípcios era ainda mais acentuado. Antes de Alexandria, o acesso aos portos era difícil e muito vigiado, pela presença de pastores que eram também piratas e atacavam barcos ao chegarem lá (Geographica 17.1.19). Fica claro que o autor está assinalando a maior abertura comercial do Egito possibilitada pela construção de Alexandria e o desenvolvimento promovido pela instalação de novos portos.

Estrabão remete também à antiguidade da administração do Egito e às benfeitorias concedidas pelos faraós, que na sua avaliação fora algo favorável para a região. Estrabão compara os egípcios aos etíopes, que levavam uma vida nômade pela falta de recursos e pelo clima instável, enquanto no Egito ocorria o contrário, pois tinham uma vida culta e cívica desde o princípio, por terem se estabelecido em várias regiões conhecidas, portanto sua organização era objeto de comentário para muitos

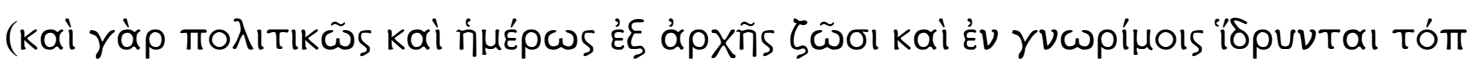

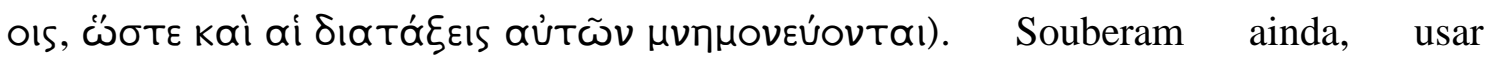

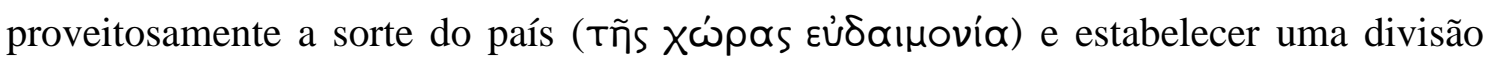


do terreno adequada, quando tiveram um rei nomeado e dividiram a população em três

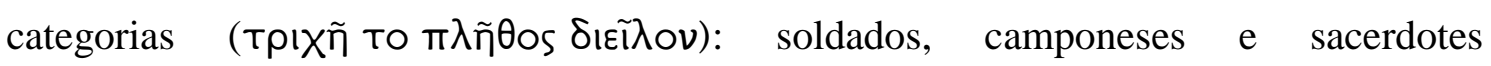
(Geographica 17.1.3).

Estrabão demonstra o controle espacial dos egípcios desde cedo, e indica sua admiração pela antiguidade e civilidade do território, concedida pela realeza desde o princípio. Ele enfatiza que essa divisão precisa foi necessária por causa das confusões nas fronteiras causadas na época das cheias do Nilo, que sempre alterava a disposição das terras. Ressalta ainda, o quanto as atividades da população estavam associadas ao rio e explica em detalhes o funcionamento das cheias. Se antes Estrabão destacava as benfeitorias da administração anterior (referindo-se aos faraós), em seguida, realça novamente as vantagens da terra, afirmando que por natureza o território produzia mais

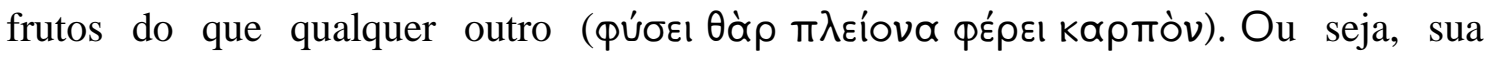
produtividade e fartura natural o tornavam mais admirável (Geographica 17.1.3). Assim, o autor tende a naturalizar as vantagens do Egito e seu desenvolvimento, atribuindo suas conquistas mais aos presentes ofertados pela disposição dos recursos naturais, do que à eficiência administrativa dos primeiros reis.

Estrabão descreve em detalhes todas as regiões do Delta no seu tempo, uma terra com muitos afluentes do Nilo e inteiramente navegável por canais (Geographica 17.1.4). Manning (2011, p. 307-308) destaca que a excepcionalidade do Egito era por ser a exceção para a regra na dificuldade de comunicação. Poucos lugares do Mediterrâneo dispunham de um canal de integração como o Nilo, que era central para o transporte de grãos para Alexandria, promovendo também um rápido acesso entre a capital e o interior.

Na sequência, Estrabão assinala novamente a posição conveniente de Alexandria

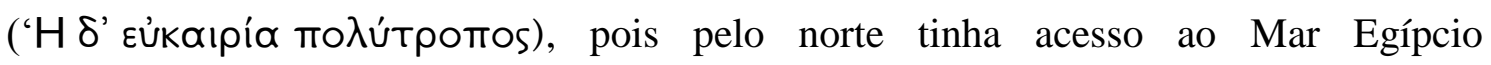
(Mediterrâneo) e pelo sul ao lago Mareótis, onde vários canais do Nilo desembocavam. Muitos produtos chegavam pelo rio e tornavam esse porto ainda mais rico do que o marítimo. Dessa forma, saíam mais produtos desse porto do que chegavam

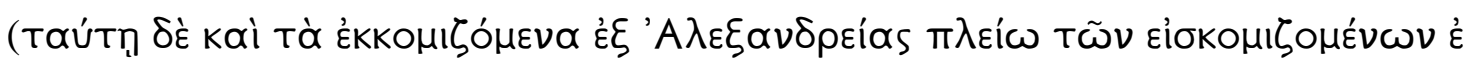
oтí) (Geographica 17.1.7).

Estrabão volta a ressaltar a localização de Alexandria como a maior vantagem da

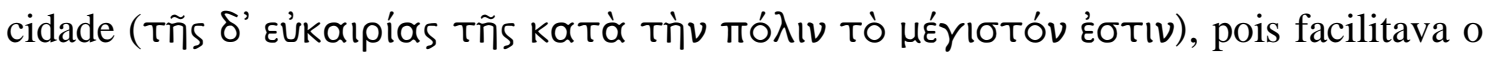


comércio por terra e mar, o único lugar do Egito com essas facilidades

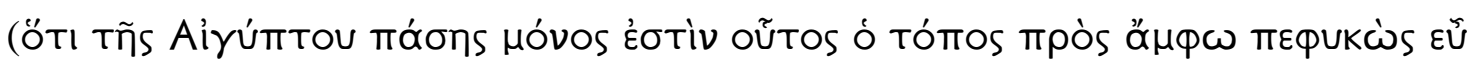

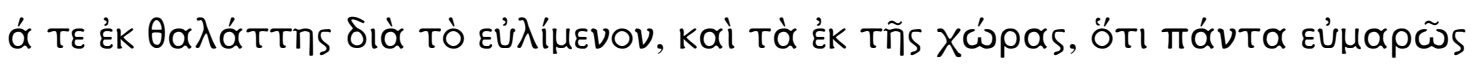

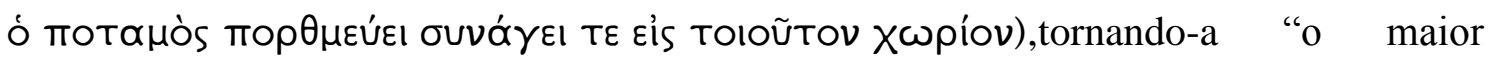

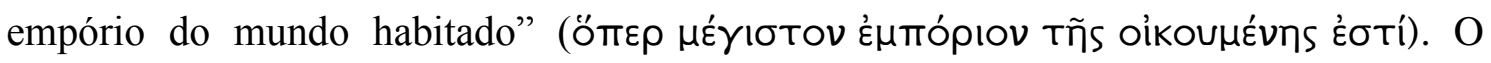
autor justifica o fato de os romanos terem instituído maiores impostos para administrar corretamente, pois os Ptolomeus tinham falhado nesse setor, apesar de também cobrarem. Para Estrabão, os impostos estimulavam o comércio do reino com a Índia e os Trogloditas, que aumentara consideravelmente. Observa que anteriormente poucos barcos ousavam atravessar o golfo da Arábia, enquanto no seu tempo grandes frotas eram despachadas para a Índia e extremidades da Etiópia. A partir daí cargas mais valiosas eram mandadas ao Egito e depois para outras regiões, cobrando "impostos duplos", quando chegavam e saíam de Alexandria

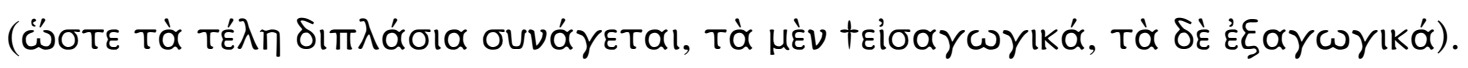

Estrabão atribui o aumento da comercialização ao aumento dos impostos com a clara intenção de justificar as novas cobranças estabelecidas por Roma.

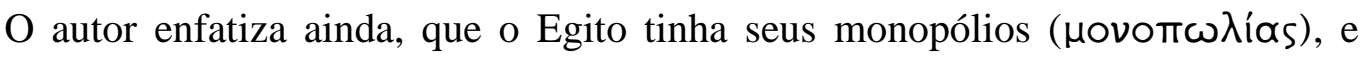

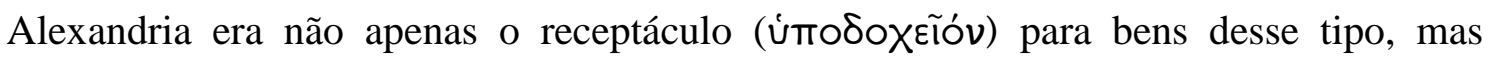
também uma importante fonte de suprimentos para $\mathrm{o}$ mundo de fora

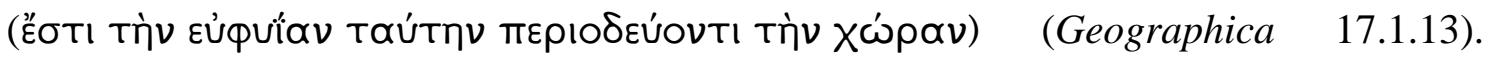
Gabrielsen esclarece que quando se fala de monopólios em Alexandria (e para o mundo antigo de modo geral) o conceito aplica-se ao fato de que a cidade se especializara em servir de ponto de distribuição para produtos de longa distância, e que se tornaram comodidades raras. Nesse sentido, Alexandria era o único ponto de armazenamento e distribuição para esse tipo de produto, o que a caracterizava também como empório (2011, p. 226).

Estrabão atribui a intensificação das redes comerciais da região do Mediterrâneo com o Mar Vermelho à capacidade de Augusto de reordenar os trajetos com novas cobranças. $\mathrm{O}$ autor sugere também o aumento na segurança dos mares como outro fator decisivo que estimulou as trocas. É notória a sua ênfase nas boas condições comerciais na região promovidas pelos romanos. Assinala também o aumento da comercialização destinada a Roma e proporcionada pelo Império, fatores que intensificaram a 
importância econômica de Alexandria naquele cenário. Estrabão indica as melhorias nesse setor como um desenvolvimento do seu tempo. Ou seja, graças aos investimentos imperiais a comercialização da região foi beneficiada. Seu relato evidencia a abertura da região facilitada pela fundação de Alexandria e a intensificação dos contatos entre povos diversos, controlado e direcionado pela cidade. Nesse sentido, Estrabão demonstrava ter consciência do domínio e centralidade de Alexandria nesse processo, e sua vitalidade para Roma, principalmente à medida que ela passou a consumir cada vez mais os produtos do Oriente. O geógrafo pretendia assim, informar a respeito da posição central de Alexandria nesse contexto e ressaltar a importância da continuidade dos investimentos para a circulação de produtos no império. Dessa forma, o autor infere que Roma estimulou esse circuito comercial e passou a depender dele.

Estrabão explica ainda o funcionamento dos portos e do que chegava a cada um. Diz que Schedia era o "bairro" de Alexandria que continha a "estação" para barcos, onde se pagavam impostos sobre os produtos em circulação (Geographica 17.1.16). O autor se refere ainda à agitação e festividades da boca de Canopo, onde se situava o

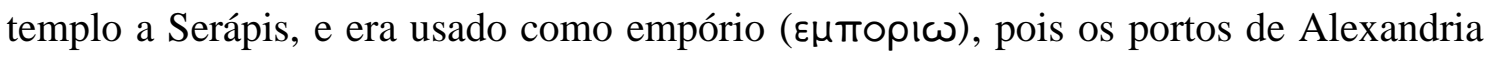
ficavam fechados para produtos de fora (Geographica 17.1.17-18). Segundo Plínio, o lago Mareótis concentrava um tráfego comercial do interior para o Mediterrâneo (ex mediterraneo commercia) através de um canal da boca de Canopo do Nilo, onde havia também um número considerável de ilhas (Naturalis Historiae 5.11.62).

Ao mencionar os monopólios, Estrabão aborda a produção do papiro, que não crescia em muitos lugares, mas florescia em grandes quantidades nas partes baixas do Delta. Diz que em virtude de sua escassez os romanos tiveram que aumentar seu preço (Geographica 17.1.15). Novamente o autor justifica que as maiores cobranças impostas por Roma visavam apenas melhorar as condições comerciais do Império.

Plínio é a fonte mais detalhada para entender sobre o emprego do papiro e sua comercialização. Justifica a necessidade de explicar a natureza da planta, pois os registros de "sua civilização" dependiam largamente do emprego do papel. Segundo Marco Varrão, os romanos deviam o descobrimento do papel à vitória de Alexandre, ao fundar Alexandria no Egito (in Aegypto Alexandria), pois antes o papel não era usado amplamente. Enumera os materiais antes usados para escrever, e cita novamente Varrão para dizer que foi devido à rivalidade entre o rei Ptolomeu e o rei Eumenes a respeito de suas bibliotecas, que Ptolomeu suprimiu a exportação de papel (supprimente chartas 
Ptolemaeo). E então, o pergaminho foi inventado em Pérgamo, "e depois o emprego do material sobre o qual depende a imortalidade dos seres humanos se espalhou indiscriminadamente" (postea promiscue patuit usus rei qua constat immortalitas hominum) (Naturalis Historiae 13.21.68-70).

Plínio direciona novamente o foco para Alexandria como centro, pois era responsável por fornecer material do qual o conhecimento universal dependia. Esse era um dos motivos de anseio dos romanos em relação à cidade? Ou seja, a sua centralidade em muitos setores era notória e escapava mesmo ao controle de Roma, que também era beneficiada e dependente de sua produção e das inovações realizadas na metrópole egípcia.

Plínio observa que o papiro cresce nos pântanos do Egito e nas águas lamacentas do Nilo em épocas de cheias abundantes (Naturalis Historiae 13.22.71-73). Na sequência, o autor fornece detalhes de como o papel era cultivado e produzido. Explica que inicialmente o papiro era empregado para a religião, mas que em sua época seu uso se disseminou e passou a atender outras funções. Enumera as várias qualidades de papiro disponíveis, os locais onde eram produzidos em abundância e a história de seu uso (Naturalis Historiae 13.23-27).

Estrabão e Plínio destacam também, mesmo que de forma não intencional, a centralidade de Alexandria, e a dinâmica promovida pela sua comercialização, ao enfatizar os ganhos comerciais na região possibilitados por Roma. Como os dois autores, Josefo enfatiza não só a importância comercial de Alexandria, mas principalmente sua centralidade como a distribuidora de produtos para outras regiões. $\mathrm{O}$ autor ressalta as vantagens da posição geográfica do Egito e fornece um importante relato sobre suas fronteiras:

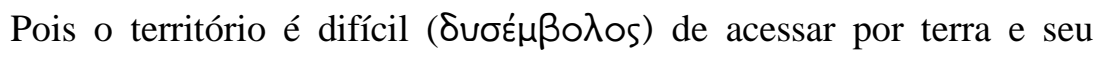
litoral é destituído de portos. Ele é protegido no leste pelos desertos áridos da Líbia, no sul pela fronteira que o separa da Etiópia - Syene e pelas cataratas não-navegáveis do Nilo - no Oriente pelo Mar Vermelho, que penetra no Norte até Copto; enquanto suas fronteiras são as terras em direção a Síria e o então chamado Mar Egípcio, totalmente destituído de portos. Portanto, o Egito é fortificado

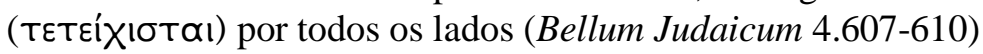

O porto de Alexandria é de difícil acesso (סvompóoıtos) para os navios se aproximarem até em épocas de paz, pois a entrada é estreita e obstruída por rochas submersas que impedem a passagem direta. Do lado esquerdo o canal é protegido por montes artificiais e do lado direito fica a ilha chamada Faros, que comporta uma enorme torre, 
emitindo uma luz visível a trezentos estádios de distância a marinheiros a caminho do porto, para alertá-los para ancorar a noite a alguma distância por causa da dificuldade da navegação. Ao redor dessa ilha, enormes muros artificiais

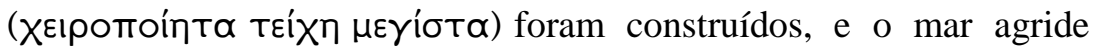
contra estas e quebra em volta dos piers do lado oposto, tornando difícil e perigosa ( $\sigma \phi \alpha \lambda \varepsilon \rho \alpha \dot{v})$ a entrada pelo estreito. Contudo, o

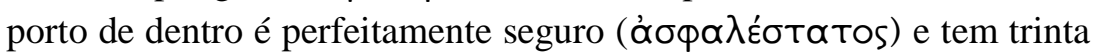
estádios de extensão. A esse porto é levado o que faltava na terra

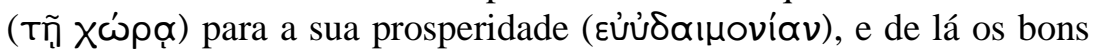

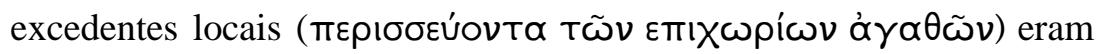
distribuídos para todas as partes distintas do mundo habitado

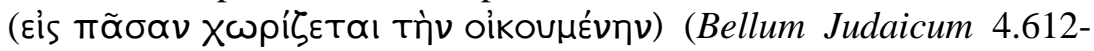
$615)$.

Josefo ressalta a riqueza do Egito e suas vantagens geográficas quando remete ao contexto de Vespasiano. $\mathrm{O}$ autor afirma que Vespasiano estabeleceu uma guarda em

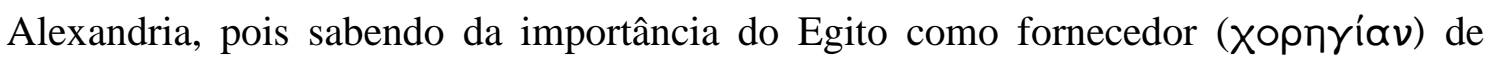
Roma, acreditou que Vitélio se renderia, para não arriscar o abastecimento romano (Bellum Judaicum 4.605). Josefo ressalta a grandeza do Egito, que segundo sua estimativa tinha uma população de sete milhões e quinhentos mil habitantes, de acordo

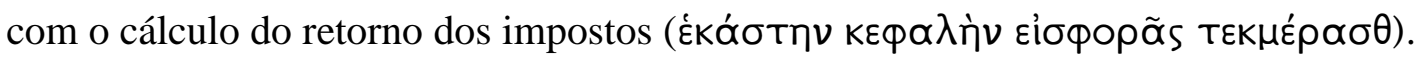

$\mathrm{O}$ autor especifica as dimensões de Alexandria, o fato de ser cercada pelo deserto, por portos, rios e lagoas por todos os lados. E então, reafirmando o peso do suprimento de trigo para Roma observa que um terço do que Roma consumia vinha do Egito (Bellum Judaicum 2.385-389).

Dion Crisóstomo também aponta a posição central de Alexandria na comercialização do Império. Dirige o seu alerta aos alexandrinos com a intenção de que melhorassem seu comportamento diante de Roma, pois pela centralidade comercial da cidade, deveriam servir de exemplo para todo o mundo. $\mathrm{O}$ autor define a cidade como um ponto de convergência mundial, tanto de produtos, quanto de pessoas. Assim, valorizava Alexandria não apenas pela posição comercial estratégica, mas também pelas repercussões humanas causadas por essa dinâmica. Segundo Dion, a cidade tinha o monopólio da navegação de todo o mar pela beleza ( $\left(\alpha \alpha{ }_{\alpha} \lambda \lambda \varepsilon ı\right)$ de seus portos e magnitude

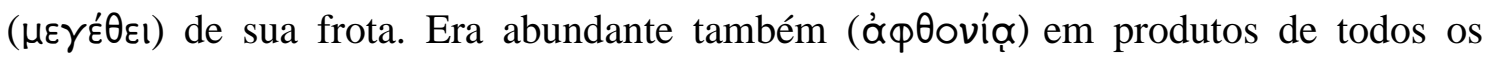

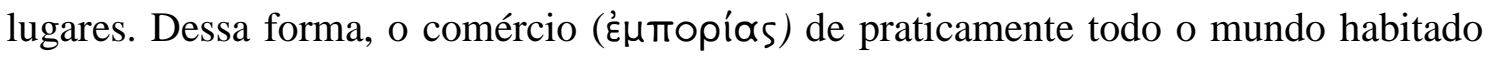

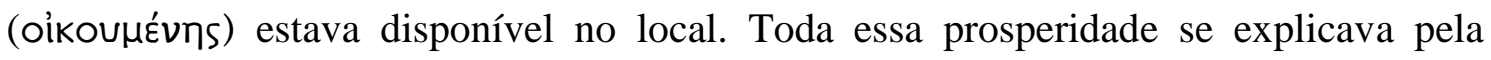


cidade se situar na reunião de toda a terra, como se fosse um mercado servindo a uma única cidade (Orationes 32. 35-36).

Tácito se refere à importância do fornecimento egípcio para Roma em vários momentos. No mesmo contexto de guerra entre Vitélio e Vespasiano abordado por Josefo, Tácito fala que este sabia da importância de controlar o Egito, pois direcionaria o rumo do suprimento de grãos para a capital do império (claustra annonae) e o exército de Vitélio seria obrigado a se render, pela falta de pagamento e comida (Historiae 3.8). Em outra ocasião, Tácito justifica que Roma não dependia tanto de outras regiões de cultivo. Tratando de um período de escassez e crise em Roma, ressalta que no passado a Itália exportara suprimentos para suas legiões em províncias remotas; que a esterilidade não era um problema mesmo naquela época, e que cultivavam na África e no Egito apenas por preferência. No entanto, a vida do povo romano foi colocada em risco por navios de carga, acidentes e infortúnios (Annales 12.43). O fato de ele tentar justificar que Roma não precisava do Egito, quando em outros momentos chama a atenção justamente para a necessidade de se controlar o trigo, sugere que não agradava tal nível de dependência do Egito. Portanto, dever-se-ia ter o cuidado de tomar medidas para manter o suprimento. Talvez não fosse confortável para o autor assumir tal grau de suscetibilidade em relação a Roma.

Diferente dos outros autores acima citados (Estrabão, Plínio, Josefo e Dion Crisóstomo), Tácito menciona apenas o papel do Egito como fornecedor de Roma, ou seja, a ênfase é principalmente na sua riqueza agrária. Ele não aborda a importância comercial e estratégica de Alexandria. Dominic Rathbone (1993, p. 86) entende que o papel do Egito como fornecedor de Roma é exagerado nas fontes, e o perigo de Roma passar fome caso o Egito não fosse controlado tornara-se um "mito" na documentação, divulgado como resultado da propaganda de Augusto. O autor afirma que a África e a Sicília ainda eram as principais fornecedoras. O argumento de Rathbone é frágil, pois como visto, Cícero chamava atenção para a riqueza agrária egípcia antes de Augusto. Além disso, há evidências que a Sicília perdera seu papel como a principal fornecedora (CASSON, 1984; ERDKAMP, 2005).

A documentação não deixa dúvidas de que o contexto pacífico do Império promoveu melhorias comerciais em relação ao cenário de instabilidade anterior. A historiografia contemporânea adota os comentários dos escritos da época como evidência do desenvolvimento comercial e da importância crescente de Alexandria sob 
Roma. No entanto, não nos esqueçamos de que são escritos que dificilmente elogiariam as evoluções do contexto anterior, pois a ênfase é justamente nos avanços gerados pela romanização. Assim, apesar de serem evidências dos desenvolvimentos comerciais possibilitados por Roma, são também sinais do enaltecimento ao Império e engrandecimento de uma época, que, no entanto, desenvolveu-se muito a partir do que foi plantado na era anterior.

Plínio, o jovem, descreve um tempo de escassez no Egito nos Panegíricos, em um contexto posterior referente ao reinado de Trajano. A carência foi provocada por uma colheita mal sucedida, ocasionada por mudanças no ritmo das cheias do Nilo. Então, os egípcios tiveram que recorrer ao imperador em busca de um auxílio para o seu abastecimento interno (Panegyricus 30). Segundo Plínio, a "sorte" (fortunam) escolheu o Egito para testar os recursos (vires) e a vigília (vigilantiam) de Roma. E argumenta:

Há muito tempo havia uma crença geral que Roma só podia ser alimentada e mantida pela ajuda egípcia (opibus Aegypti ali sustentarique non posse), a ponto que essa nação vaidosa e presunçosa (ventosa et insolens natio) costumava se vangloriar (superbiebat) que ainda tinha que alimentar seus conquistadores (victorem), que seu rio e seus navios asseguravam nossa abundância ou nossa carência. Agora nós retornamos ao Nilo suas riquezas (copias), mandamos de volta seus cereais que recebemos; eles tiveram que levar para casa as colheitas que costumavam despachar para o outro lado do mar. Deixe ser esta uma lição para o Egito; deixe-o aprender pela experiência que sua função não é nos conceder comida, mas pagar um tributo adequado; deixe-o perceber que ele não é indispensável (necessariam) ao povo de Roma apesar de ser seu servo (Panegyricus 31).

Plínio ressalta que apesar de parecer milagre que o suprimento de Roma não fora atingido pela escassez do Egito, o fato era uma prova que a capital não precisava mais do Egito, embora o contrário fosse verdade (Panegyricus 31). O autor conclui o seu argumento demonstrando como as províncias submetidas a Roma eram "abençoadas" por um imperador tão preparado para ajudar quando houvesse necessidade (Panegyricus $32)$.

Segundo Erdkamp (2005, p. 228), a passagem de Plínio indica a dependência romana do trigo egípcio (em forma de impostos) e infere que tais excedentes mandados por Roma para alimentar o Egito eram provavelmente originários do próprio Egito, o que Plínio entende como uma espécie de "vingança" romana e uma mudança no antigo quadro de submissão em relação ao território. Embora Plínio negue a dependência e use 
seus argumentos como provas do contrário, sua postura defensiva ilustra um lamento em relação à posição do Egito como fornecedor vital de Roma e indica que a província até mesmo se gabava de seu posto. Ou seja, a vulnerabilidade romana em relação ao trigo egípcio não agradava a potência, e essa situação foi usada como prova de que esse quadro estava sendo alterado. Como Tácito no século anterior, Plínio elucida sobre a importância do fornecimento egípcio e denuncia o descontentamento romano diante da situação.

A questão da prosperidade perpassa praticamente todos os estágios e contextos em que a tradição se refere a Alexandria, era algo visível no seu contexto de fundação, ajudando o local a desenvolver, e tornou-se ainda mais comentado no contexto pré e pós conquista romana. Os autores gregos se referem abertamente à importância do local, deixando claro que se tratava de um assunto para o qual deveria haver conscientização. A observação de Tácito e Plínio negando a dependência romana, após realçar a importância de se ter o controle da produção egípcia em repetidos momentos, indica uma espécie de desconforto e lamento com a situação, para a qual deveria haver algum tipo de reação e preparo. Ou seja, os gregos reforçam a posição de destaque comercial de Alexandria, enquanto os latinos estão mais focados na questão específica do fornecimento de trigo.

A preocupação em remeter com frequência ao cenário de fundação de Alexandria (como visto no capítulo 2), séculos depois do ocorrido, tinha a intenção de justificar ainda mais a sua prosperidade ao longo dos tempos? Na percepção das fontes, foi Alexandre que concedeu à nova cidade o potencial que ela desenvolveria futuramente, como se atrelada ao mito fundador à enorme fertilidade do território tornar-se-ia mais aceitável a Roma, mesmo que a superasse nesse quesito. No entanto, uma região rica e com grande valor comercial deveria ser incorporada ao Império Romano, que passaria a ser responsável por gerir e controlar toda essa riqueza. A imagem de Alexandria como uma potência comercial no mundo romano é contínua nas narrativas desde Cícero até Dion Cássio, sugerindo que era um elemento forte e constante na sua representação entre os antigos. Algo que deveria ser reforçado e divulgado, pois havia todo o interesse na sua manutenção por parte de Roma. 


\subsection{Centro de entretenimentos}

Os entretenimentos em Alexandria eram mais um aspecto do cotidiano na cidade que a tornavam notória em seu meio. Infelizmente temos poucas descrições pormenorizadas das formas de diversões realizadas, já que normalmente são abordadas pela literatura em tom de censura, por serem entendidas como ocasiões que desvirtuavam a população. A intenção é destacar o tipo de apreciação estabelecida em relação aos momentos de descontração e investigar como os eventos se relacionavam com a dinâmica da cidade, tornando-a ainda mais atrativa nos arredores, porém ao mesmo tempo, permanentemente criticada por aqueles que eram avessos às atividades lúdicas.

Alexandria não se popularizou apenas pela frequência de festas e celebrações, mas também por um tipo de humor que parece ter sido muito mal compreendido pelos expectadores de fora. Segundo Goddio, o riso no Egito, e principalmente em Alexandria era um componente integral da vida social e para entendê-la, deve-se levar em conta esse modo de ver a vida diferenciada. Tratava-se de uma forma de espantar a tristeza e a tragédia muito própria dos alexandrinos, que fazia reinar na cidade uma atmosfera constante de bom humor (GODDIO; BERNAND, 2004, p. 139). Se para os alexandrinos a alegria era um aspecto característico de seu cotidiano, para os visitantes de fora era um comportamento visto como excessivo e malicioso.

Além da frequência de festivais e atrações no teatro, foi visto no capítulo IV o quanto os autores criticam a tendência dos alexandrinos ao descomedimento, deboche e falta de moderação nas palavras. Esse comportamento de falar sem critérios e ironizar personalidades públicas era uma espécie de tradição no local, que os alexandrinos praticavam no seu cotidiano, mas também no trato com estrangeiros, provavelmente dentro e fora da cidade. Ou seja, era uma atitude vista como teatral e imprópria, que os tornou famosos. Portanto, quando as fontes falam na tendência rebelde dos alexandrinos, não estão necessariamente se referindo à iniciativa para conflitos armados, mas a esse talento em semear a discórdia e o alvoroço a partir de palavras. Tal conduta era ainda mais intensificada no cenário dos entretenimentos, por ter maior visibilidade e amplitude em meio a grandes aglomerações, e nessas situações podia repercutir em dissensões concretas. Assim, a dedicação dos alexandrinos para esses eventos lúdicos, 
além do modo como se portavam nas ocasiões, tornaram-se mais uma via para criticar seus habitantes; por serem considerados abusivos, mas principalmente, por serem realizados em bando. Ou seja, se cometidos por poucos já eram vistos como inconvenientes, em meio à multidão cosmopolita e turbulenta, ficavam ainda mais ameaçadores e perigosos.

Foi pontuado no capítulo IV que Cícero (Pro Rabirio Postumo 12.34.2) e o autor da Guerra de Alexandria (Bellum Alexandrinum, 7.2.5) já haviam ressaltado a natureza alexandrina de falar sem moderação e propagar calúnias. O quadro de condenação aos lazeres alexandrinos se fortaleceu ainda mais entre o século I a.C. e I d.C. para além da promiscuidade e diversões (através da propaganda de Augusto), e se voltaram também para a tendência dos alexandrinos a promover deboches e ofender autoridades. Quintiliano faz uma referencia à "língua solta" dos alexandrinos, ressaltando sua falta de prudência para falar coisas não toleradas, fazendo alusão a alguém que "falava palavras não toleradas nem de uma página alexandrina" (verba ne Alexandrinis quidem permittenda"), dizendo talvez coisas ousadas, impróprias e engraçadas (Institutiones 1.2.7.4).

No capítulo III, já foram vistos os comentários de Veléio Patérculo (Historiae Romanae 2.82.4.8) e Plutarco (Vita Antonii 28.1.7) do quanto os luxos e vícios de Cleópatra e sua paixão por festas e banquetes contaminaram Marco Antônio. Plutarco ressalta ainda que Antônio logo se identificou com os alexandrinos, pelo seu jeito

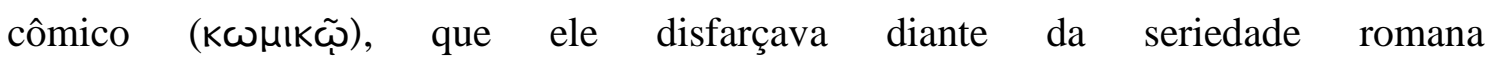

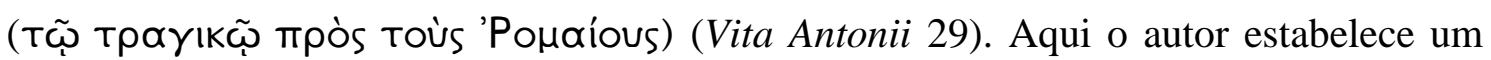
paralelo claro entre a tradição dos alexandrinos para o riso, que se contrastava com a seriedade romana, e Antônio se perdeu por se deixar levar por essa leviandade. Assim, a atratividade da Alexandria imprudente poderia se tornar uma ameaça à integridade romana e sua moralidade (TRAPP, 2004, p. 122).

Fílon também condena o tipo de lazer popularizado em Alexandria na sua crítica a Flaco, o prefeito romano que apoiou a onda anti-judaica na cidade. Segundo o autor, todas as idéias "malévolas" dos alexandrinos encontraram eco na multidão desocupada

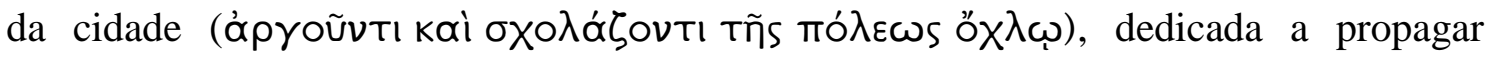

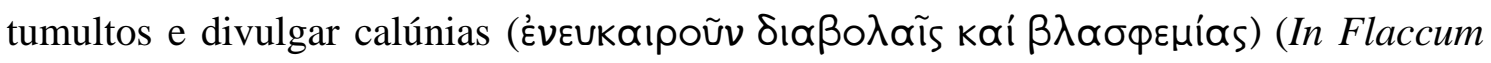
33). Assim, seu principal alvo de ataque é direcionado para essas multidões, reunidas 
principalmente nos eventos e espetáculos públicos. Além da multidão, Fílon condena os

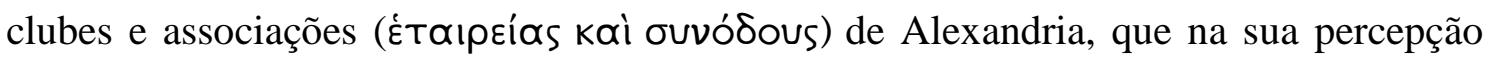
eram o principal cenário de bebedeiras e badernas e facilmente davam vazão a intrigas

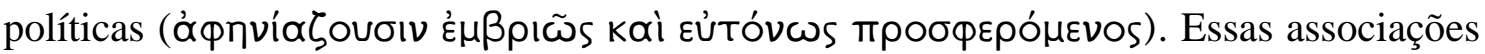
eram os locais onde os alexandrinos promoviam suas críticas a autoridades e divulgavam suas sátiras de maneira cômica para eles mesmos, mas ofensiva para muitos. Eram aparentemente esses núcleos que "atiçavam" as multidões. O autor relata que para agredir o rei Judeu Agripa, que estava presente em Alexandria, os alexandrinos fantasiaram um louco da cidade como rei e promoveram um teatro para ridicularizá-lo (In Flaccum, 36-39).

O caso do rei demonstra o tipo de postura e humor promovidos pelos alexandrinos que era mal compreendido por quem era de fora. Como um filósofo judeu adepto da moralidade e aliado dos romanos, Fílon critica seus próprios conterrâneos e pode até mesmo usar do exagero no retrato elaborado dos alexandrinos para agradar romanos. Faz isso através de um discurso que correspondia às críticas que os próprios romanos faziam do povo da cidade. Além disso, essas associações (principalmente o Ginásio) promoviam eventos e entretenimentos para sua própria comunidade, e Fílon não sendo um membro do grupo, compartilhava a visão de alguém de fora. Ou seja, para quem não era parte do contexto, a postura crítica dos alexandrinos podia ser entendida como mais ofensiva e imprópria do que realmente era.

Em suas obras filosóficas, Fílon faz alguns comentários aludindo com censura aos entretenimentos em Alexandria. Ressalta os diferentes efeitos provocados na audiência do teatro, desde o excitamento mais profundo ao ponto de não se controlarem nos aplausos, enquanto outros sentiam repulsa pelos efeitos da música e o ignoravam (De Ebrietate 177). Embora o autor não se refira explicitamente ao teatro de Alexandria, é plausível que estivesse falando de um exemplo que vivenciava em sua própria cidade. Assim, Fílon entendia o teatro como um local de entretenimento e sofrimento (SLY, 1996, p. 85). Em outro livro, o judeu fala sobre a violência das corridas de cavalo e da imprudência e estupidez dos que montavam o animal ( $D e$ Agricultura 312.76). Fala também da dificuldade de controlar as carruagens, pois os animais podiam ficar desgovernados (Legum Allegoriae 3.223). Nos Sacrifícios de Abel e Cain, o autor elabora uma detalhada condenação ao prazer, seus efeitos e tudo que ele causava nos homens, e organiza uma lista em que enumera todos os seus efeitos 
maléficos (De Sacrificis Abelis et Caini 221-32). Ainda com relação aos prazeres, Fílon condena a falta de moderação nos banquetes, citando os prejuízos causados por comida e vinho em excesso (De Fuga et Inventione 31-32). O autor ilustra também a movimentação e vivacidade da ágora como um ponto de encontro e de negociações, com carruagens e animais circulando. O cenário tumultuado com frequência resultava em violência, provavelmente pela multidão aglomerada (De Somniis 2.91, De Specialibus Legibus 3.105).

Fílon expressa nesses breves comentários sua familiaridade com os espetáculos da cidade (BARRY, 1988, p. 64). Faz uma referência clara à Alexandria quando condena os festivais realizados no seu país por gerarem o caos absoluto. $\mathrm{O}$ autor reflete que diferentes povos, gregos e bárbaros tinham seus próprios festivais, e que seu único propósito em todo lugar era a exibição. Na sequência, detalha sobre os festivais e aglomerações de sua terra, que só resultavam em excessos, bebedeira, discórdias, prazeres, insolência, ultrajes e depravação, etc. $\mathrm{O}$ autor faz uma lista de todos os efeitos maléficos do caos gerado pelos festivais e afirma que nessas ocasiões tudo virava de cabeça para baixo, pois as boas ações eram desacreditadas, enquanto os erros eram honrados. Além disso, tudo era considerado divino, como música; enquanto filosofia e cultura eram negligenciadas e esquecidas nesses momentos (De Cherubim 91).

Dion Crisóstomo predomina nessa parte da nossa análise, pela extensão do seu relato, que se concentra justamente em aconselhar os alexandrinos sobre os seus excessos. $\mathrm{O}$ autor elabora uma série de elogios à beleza e grandeza da cidade, traços que eram diminuídos pelo caráter da população, a quem não poupa críticas (Orationes 32). E apesar de, como Fílon, também ser um avesso às multidões de forma geral, sua crítica aos alexandrinos era específica, pois considerava que este povo tinha um modo próprio de se portar em grupo que se tornara incompreensível para outros. É importante destacar que por se tratar de oratória, a riqueza retórica é priorizada em relação à sucessão dos eventos. Assim, sua visão relativamente mais "subjetiva" expõe com maior clareza a percepção dos fatos. Não que em outros gêneros como a historiografia predomine a neutralidade, mas a pretensão de não tomar partido acaba omitindo alguns detalhes que um ideal explícito de convencimento como o de Dion Crisóstomo deixa mais evidente. O discurso 32 era destinado ao povo de Alexandria, provavelmente para a Assembléia popular, por estar em grego. Segundo Jones (1978, p. 36), não há dúvidas de que Dion tinha mesmo visitado a cidade. Trata-se de um discurso atípico pelo tamanho (o 
segundo maior do autor) e pela elaboração. Durante toda a fala, todos os detalhes de argumentação são voltados para convencer o leitor a respeito de sua posição, explicitando uma opinião sobre Alexandria. A data do discurso é controversa; a maioria dos autores o atribui ao reinado de Trajano, visão a que Jones se opõe por defender uma datação no tempo de Vespasiano (1973) ${ }^{36}$.

Dion profere um discurso advertindo os alexandrinos a serem mais comedidos nos espaços públicos e controlarem o entusiasmo dedicado aos espetáculos. A euforia era tanta que os fazia dedicar excessiva energia a esses eventos, e quando precisavam de seriedade em ocasiões críticas, não tinham foco. Esta é a mensagem central do discurso. Mas para firmar sua opinião, Dion elabora uma detalhada narrativa sobre Alexandria e sua população; reflete sobre as consequências desse comportamento para a cidade, e o que ocorreria caso não alterassem esse padrão e se conscientizassem do problema.

No primeiro parágrafo, Dion já expõe o tema que será detalhado no decorrer de todo o discurso:

Meus amigos, vocês poderiam por gentileza ficar sérios ( $\sigma \pi 0 \cup \delta a ́ \sigma \alpha ı)$ por um período breve e prestar atenção nas minhas palavras? Pois sendo sempre infantis ( $\pi \alpha i \zeta \zeta o v T \varepsilon \varsigma$ ) e continuamente

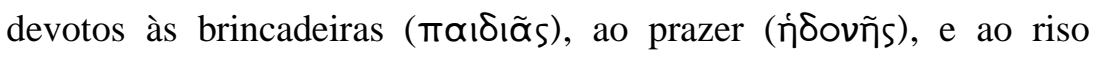
( $\gamma \varepsilon \dot{\varepsilon} \lambda \omega T O S$ ), e nunca perdem (ámopeĩte) com isso - na verdade vocês são realmente adeptos da diversão e provocação ( $\gamma \in \lambda$ oĩoí), e têm

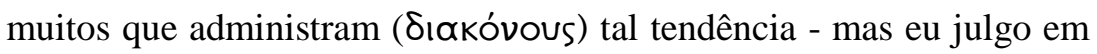

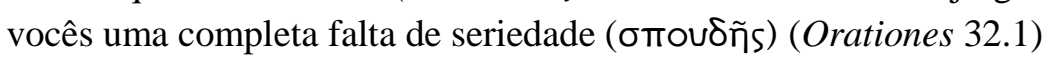

Dion começa sua denúncia, ressaltando que no teatro, o local onde os alexandrinos deveriam utilizar para ouvir conselhos dos sábios, só estava havendo

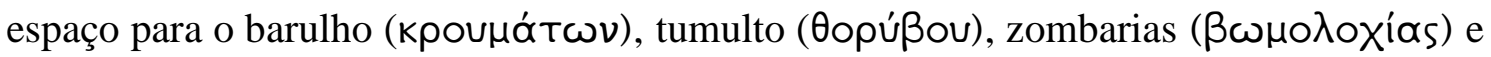

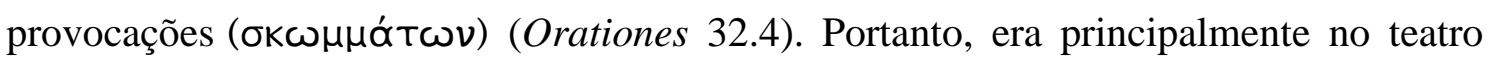
onde acontecia todo tipo de abuso das multidões. Dion esclarece que não estava os aconselhando a largar os entretenimentos e as diversões ( $\psi \cup \times \propto \gamma \omega \gamma$ ías), mas a se

\footnotetext{
${ }^{36}$ A argumentação de Jones se baseia na critica de Dion aos cínicos e Vespasiano era justamente o imperador mais avesso aos filósofos, chegando a provocar sua expulsão de Roma. Como resposta a Jones, Harry Sidebottom escreveu um artigo com a intenção de novamente fazer predominar a datação no reinado de Trajano, principalmente pelo amadurecimento demonstrado na elaboração do discurso, habilidades desenvolvidas por Dion especialmente após o seu exílio. Além disso, o orador menciona uma possível visita do imperador a Alexandria, algo que não faria sentido se já conhecesse a cidade, como era o caso de Vespasiano, o único imperador do tempo de vida de Dion a visitá-la logo no início do seu reinado (SIDEBOTTOM, 1992, p. 417). Sua oposição entre tirano e bom imperador também se situaria melhor se estivesse fazendo referência respectivamente a Domiciano e Trajano, um topos nos escritos da época.
} 


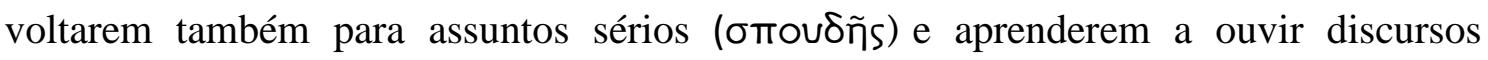
honestos, como o que estava pronunciando. Usa o exemplo dos atenienses, que mesmo em seus momentos críticos, estavam aptos a ouvir no caso de agirem com abuso. Porém os alexandrinos não tinham ninguém para reprová-los (ỏveıઠıı̃̃) e revelar as fraquezas

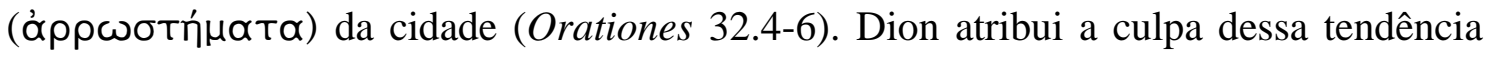
parcialmente aos filósofos, pois preferiam não aparecer em público por desprezarem as "massas" (Toùs mo $\lambda \lambda$ oús), ficando resguardados em "salões de conferências" (ákpootnpíoıs) e falando apenas para homens de seu grupo. Ou então, faziam como os cínicos, seita numerosa na cidade, na qual os adeptos ficavam pelos cantos escondidos,

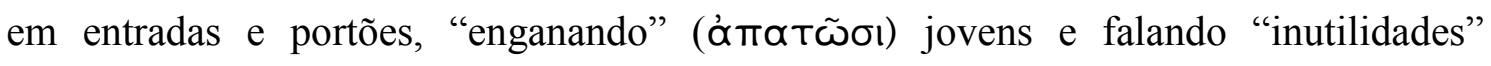

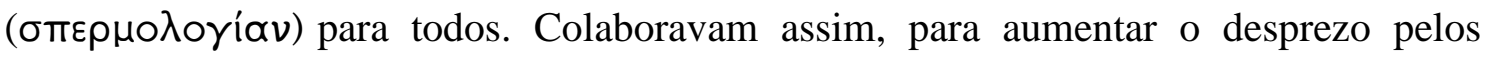
filósofos de modo geral (Orationes 32.8-9).

Dion considerava seu discurso como um presente divino à Alexandria, pois

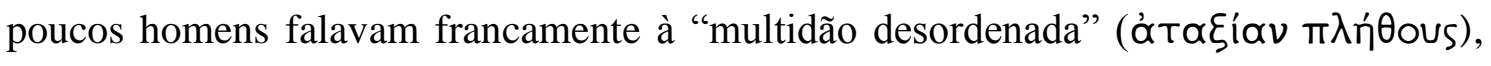
sem pretensões à reputação e fama (Orationes 32.11-12). O autor adverte que o estado precisava de homens que curassem os "vícios" (movnpíav) do povo, através da

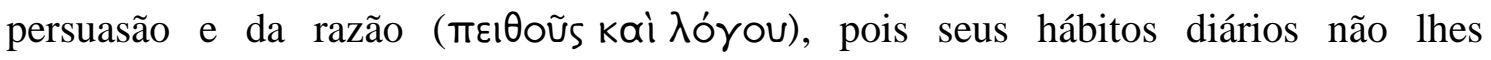

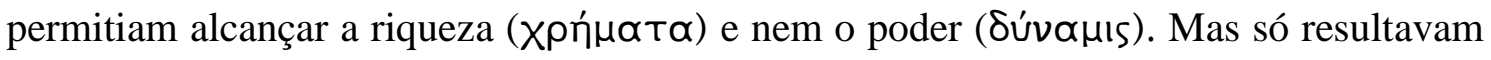

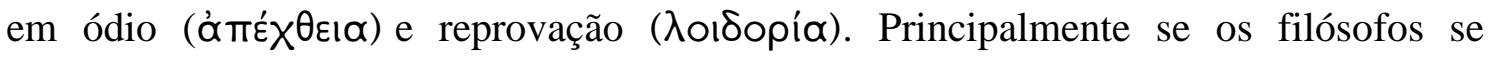

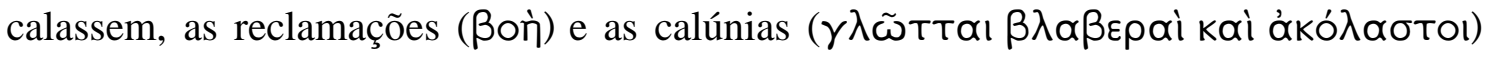
certamente apareceriam na multidão ( $\pi \lambda \tilde{n} \theta 0 \varsigma$ ) (Orationes 32.18-19).

Dion então detalha um pouco mais sobre uma das práticas que fazia os alexandrinos perderem a cabeça dessa forma, a paixão por música, especificamente pela

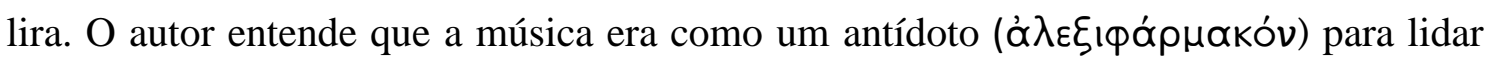
com a população dessa cidade (Orationes 32.20).

Na sequência, ele realça novamente a má fama de Alexandria naquele universo, pedindo para ser ouvido para provar àqueles que o condenaram de ir para lá que estavam errados. Dessa forma, o autor deixa ainda mais explícita a ampla disseminação de uma fama associada ao padrão de comportamento dos alexandrinos, que fazia parte do senso comum: 
Então talvez vocês também me esmaguem com o seu barulho ( $\theta \circ \rho u ́ \beta \omega)$ e desordem ( $\alpha \propto \rho \propto \chi \tilde{n})$, apesar de meu desejo de servi-los. Mas se esperarem e me ouvirem até o fim, todos os homens

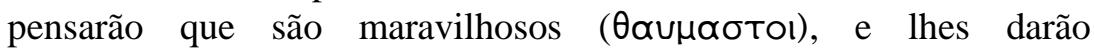
credibilidade, não apenas com liras zunindo e pés dançantes, mas com palavras prudentes ( $\lambda$ ó yov $\phi p o v i ́ \mu \omega \nu$ ) também, a tal ponto que eu possa ter uma defesa justa para oferecer àqueles que me censuraram

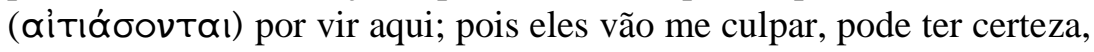
e irão dizer que eu estou em busca de popularidade (ठоรоко́тоv) e

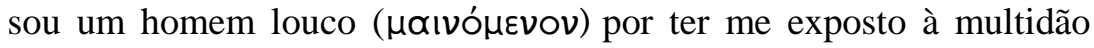
(o’ $\chi \lambda \omega)$ e seu tumulto ( $\theta$ oú́ $\beta \omega)$. Deixe então, eu lhes certificar que

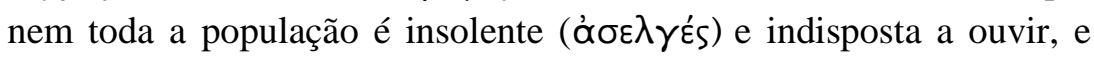
que nem toda reunião do povo deve ser evitada por homens

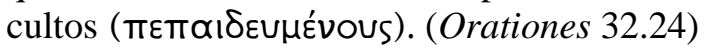

Dion afirma que já tinha ouvido relatos dizendo que bastava jogar pão e ingressos para o hipódromo que os alexandrinos se satisfariam, pois não tinham interesse em nada mais (Orationes 32.31). Estariam assim, "possuídos" nesses dias específicos. Segundo Jones (1978, p. 40) a discrição de Dion desses eventos os aproxima mais de romanos do que de gregos. Apenas as maiores cidades do império tinham corridas (Roma, Alexandria, Antioquia, Cartago e Thessalonica).

Nesse momento, Dion chega ao ápice do discurso, por fazer uma importante caracterização de Alexandria e de seus cidadãos, criticando a população, mas ao mesmo tempo, elogiando sua beleza e grandeza. Em seu propósito de crítica, o autor faz um comentário definindo Alexandria como uma "cidade-mundo" por aproximar todos os povos, denotando que principalmente por dispor de todo esse potencial mundial é que seu povo precisava alterar o padrão de comportamento:

Como você come no ambiente privado, como dorme, como cuida de sua casa, essas são todas questões que como indivíduos vocês não são notáveis ( $\delta \tilde{n} \lambda o ́ s)$ de forma alguma; mas pelo outro lado, como se comportam como espectadores ( $\theta \varepsilon \omega \rho \varepsilon \tilde{T} \varepsilon)$ e como são no teatro são questões de sabedoria comum entre gregos e bárbaros.

Pois sua cidade é a maior em magnitude e posição e é reconhecidamente classificada em segundo lugar entre todas as cidades sob 0 sol

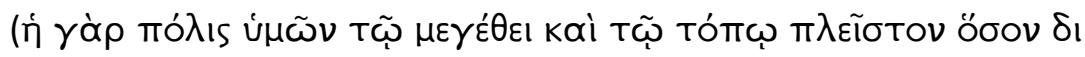

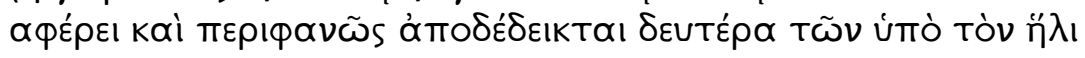

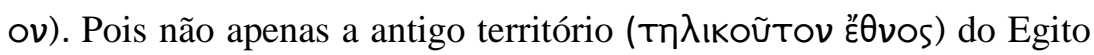

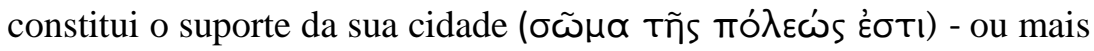
precisamente o seu sustento - mas a natureza peculiar do rio, quando comparado com todos os outros, desafia descrições com relação tanto 
aos seus hábitos maravilhosos e sua serventia

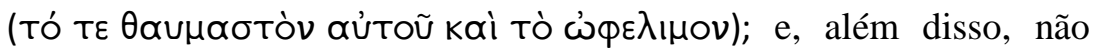
apenas você tem o monopólio da navegação de todo o mar pela beleza ( $\left(\alpha \dot{\alpha} \lambda \lambda \varepsilon ı\right.$ ) de seus portos, a magnitude $\left(\mu \varepsilon \gamma^{\prime} \theta \varepsilon \varepsilon\right)$ de sua frota, a

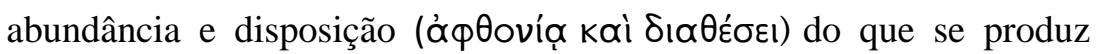
em todo lugar, mas também as águas de fora estão ao seu alcance, tanto do Mar Vermelho como do Oceano Índico, cujo nome era raramente ouvido dias atrás. $\mathrm{O}$ resultado é que o comércio

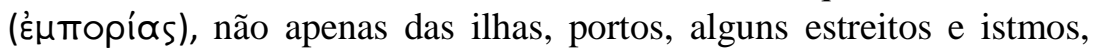
mas de praticamente todo o mundo habitado (oikoupévns) é seu. Pois está situada, na reunião de toda a terra, até dos povos ( $\varepsilon v \omega \tilde{\omega} v)$ mais remotos, como se fosse um mercado servindo a uma única cidade, um mercado que reúne todos em um só lugar, os expondo um diante do outro, fazendo deles semelhantes

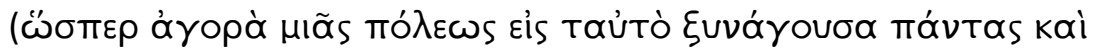

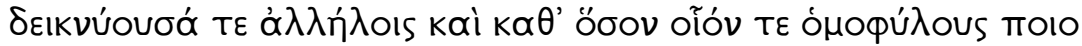

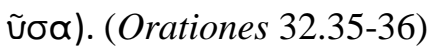

Dion enfatiza novamente os excessos do povo na multidão, traindo a boa reputação da cidade com esse comportamento. O autor menciona o domínio comercial

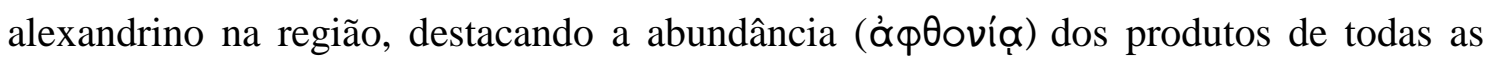
terras em circulação no local. Esclarece que não pretendia orgulhá-los com essas palavras, pois estava tratando da constituição física da cidade e que os elogios (દ่ாற̣́ $v \in \sigma \alpha)$ não podiam ser estendidos para a população. Seu objetivo em louvar a cidade tinha apenas a intenção de lhes mostrar que qualquer inconveniência realizada, era cometida não na presença de poucos, mas de "toda a humanidade"

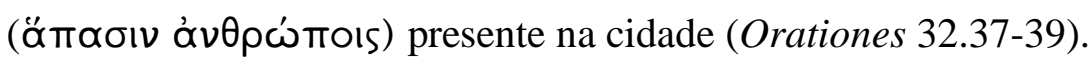

Jones realça que nos elogios de Dion às cidades era comum citar a situação do momento, o tamanho, seus rios, territórios, estradas, fertilidade, beleza, como também sua fundação e herança, aspectos que serviam de argumento para honrá-las (1978, p. 64). Dion garantia ter consciência da importância de Alexandria provavelmente com a intenção de estimular a vaidade dos alexandrinos. As disputas por títulos entre cidades eram muito comuns no Império e o sistema administrativo dos romanos acabava encorajando essas competições. Imperadores "brincavam" com a sua vaidade e as estimulavam, concedendo ou retirando títulos de privilégios como sinal de favorecimento ou castigo (JONES, 1978, p. 84-86).

O autor continua então a delinear o seu retrato cosmopolita da cidade: 
[...] Pois eu vejo entre vocês não apenas gregos e italianos e pessoas das vizinhanças $(\pi \lambda \eta \sigma i ́ o v)$ da Síria, Líbia, Cilícia, e ainda Etíopes e Árabes de regiões mais distantes, mas até mesmo Báctrios, Scítios e Persas e alguns indianos, e todos esses formam a audiência ( $\sigma \nu \nu \theta \varepsilon \tilde{\omega} \nu \tau \alpha \iota)$ do seu teatro e se sentam ao seu lado em todas as ocasiões; portanto, quando você por acaso estiver ouvindo um único harpista, e este for também um homem que você conhece bem, está

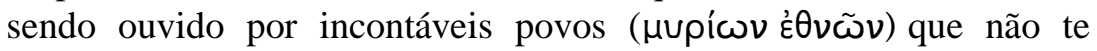
conhecem; e enquanto você está assistindo três ou quatro condutores de charretes (ívióxous), você está sendo assistido por incontáveis gregos e bárbaros também.

O que então você espera que essas pessoas digam ao retornarem para as suas casas nos confins do mundo ( $\gamma \tilde{n} \varsigma$ $\pi \varepsilon ́ p \alpha \tau \alpha)$ ? Eles não irão dizer: 'nós vimos uma cidade que em quase tudo é admirável

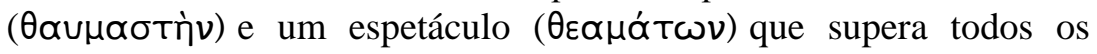

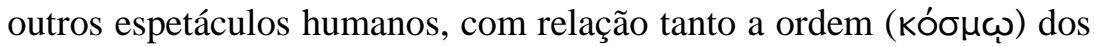
seus santuários e a multidão de seus habitantes ( $\pi \lambda \eta \dot{\theta} \theta \varepsilon ı$ по $\left.\lambda_{\imath} \tau \tilde{\omega} \nu\right)$ e

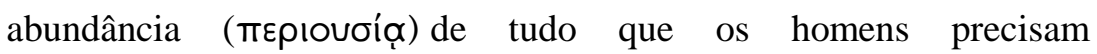

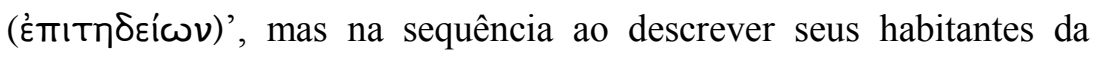
forma mais fiel, todas as coisas que eu mencionei a pouco- tudo sobre o Nilo, a terra, o mar, e em particular a epifania ('́mıфóvveı $v$ ) do deus; 'e ainda', eles dirão, 'é uma cidade que é louca

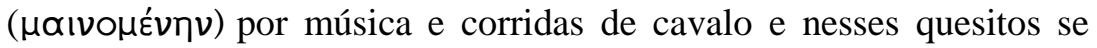
comporta de forma indigna ( $\mu \eta \delta \dot{\varepsilon} \nu$ oै $\xi ı v)$ de si mesma. Pois são homens moderados ( $\mu \varepsilon ́$ tpıoı) o suficiente ao oferecer sacrifícios ou quando passeiam sozinhos ou se comprometem com outros propósitos; mas quando entram no teatro ou no estádio, como se

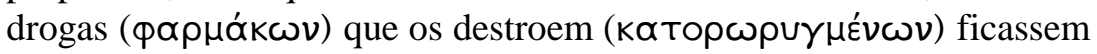
lá depositadas, eles perdem a consciência com relação a todo o estado anterior e não tem vergonha de dizer ou fazer qualquer coisa que os ocorre. E o mais aflitivo ( $\chi \alpha \lambda \varepsilon \pi \omega$ tatov) é que, apesar do interesse no show, eles não vêem realmente, e apesar de desejarem ouvir, eles não ouvem, estando evidentemente fora de seus sentidos e da sanidade- não só homens, mas também mulheres e crianças. E quando

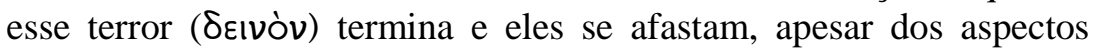

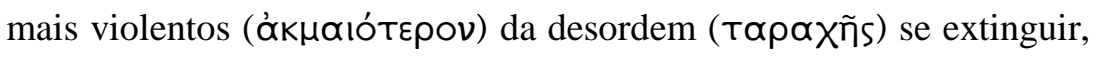
nas esquinas das ruas e nos corredores das vielas a doença ( $\mu \varepsilon ́ v \varepsilon ı)$ continua pela cidade inteira por vários dias seguidos; da mesma forma que quando um poderoso incêndio se apaga, você ainda pode ver por um tempo não apenas a fumaça, mas ainda alguns pedaços do edifício em chamas. (Orationes 32.40-42)

Depois de enfatizar que "o mundo inteiro" estava presente em Alexandria, Dion ressalta que todas essas pessoas, retornando para suas terras de origem, iriam elogiar a cidade, mas criticar seus habitantes. Sua percepção é que como uma "cidade-mundo", que aproximava todos os povos, Alexandria devia servir de exemplo, pois todos os 
olhares estavam voltados para a localidade. Percebe-se que Dion enfatiza principalmente a composição multicultural da cidade em relação à herança grega.

Em seguida, o autor esclarece novamente que não os estava aconselhando a acabar com as performances e espetáculos. Era o comportamento do povo que deveria

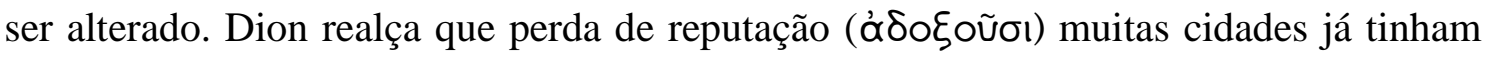
sofrido, mas Alexandria, no "centro do mundo civilizado", não podia (Orationes 32.4547). E novamente ressalta a centralidade de Alexandria naquele mundo:

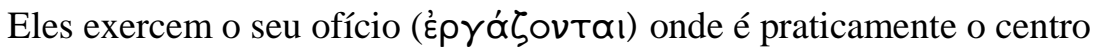

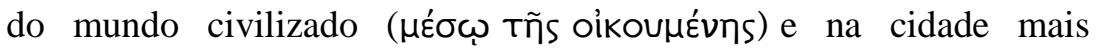

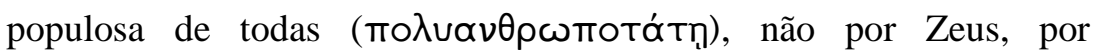
qualquer charme ou poder próprio, mas pela sua própria estupidez. Pois por que é que fora de Alexandria eles produzem uma impressão muito parecida com àquela dos líderes das performances comuns, nem são considerados desagraveis? É possível que o ouvido do povo tenha parado nesses lugares. (Orationes 32.47)

Então, o autor descreve em mais detalhes o comportamento nos espetáculos que tanto condenava, ressaltando o predomínio da euforia:

E agora não vamos falar mais sobre esses pobres afortunados

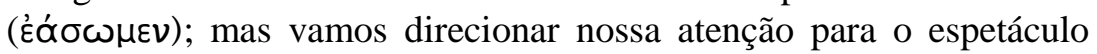

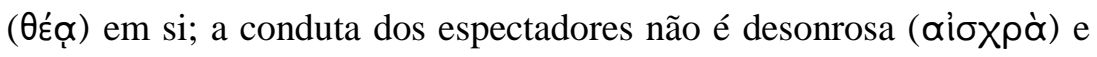
repleta de toda a variedade de imoralidade (ú $\beta p \varepsilon \omega \varsigma)$ ?- Eu quero dizer que a intensidade dos olhares, suas almas penduradas em seus lábioscomo se pensassem, que era pelos ouvidos que homens recebem felicitações - e aplicando o termo 'salvador' e 'deus' para um ser humano infeliz ( $\left.\alpha \theta^{\theta} \lambda_{\iota} \circ v\right)$ ! Com que gargalhadas sem limites ( $\gamma \varepsilon ́ \lambda \omega \tau \alpha)$, você imagina, devem os deuses rir ( $\kappa \alpha \tau \alpha \gamma \varepsilon \lambda \tilde{\alpha} \nu)$ de você com desdém, quando na próxima adoração a eles sua conduta será a mesma e são compelidos a usar os mesmos termos usados para honrar a divindade? (Orationes 32.50)

$\mathrm{Na}$ sequência, Dion esclarece que em outras cidades havia os mesmos entretenimentos de Alexandria, mas em nenhum lugar se tratava de uma paixão tão

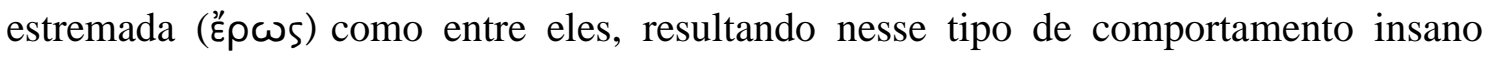
(oĩotpos) (Orationes 32.51-52). E volta a tratar dos efeitos que a música provocava no povo, dizendo que os alexandrinos não se controlavam e se tencionavam com o

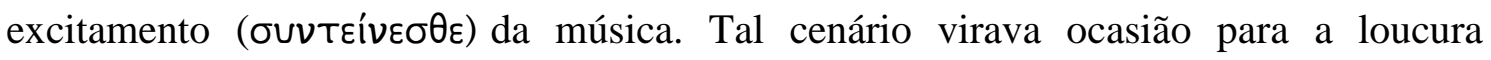

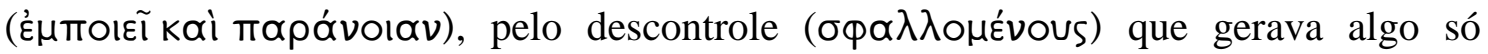


perceptível nos alexandrinos (e talvez entre bárbaros), porém não entre outros gregos. Aqui Dion deixa claro o seu entendimento de Alexandria como uma cidade grega, que por isso, tinha uma herança a zelar. Portanto, seus habitantes não podiam se comportar como "bárbaros".

O autor reflete que: se a música foi inventada com a intenção de curar as

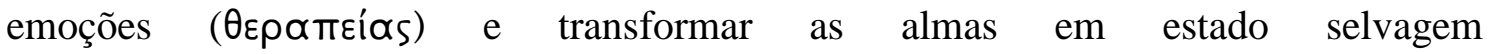

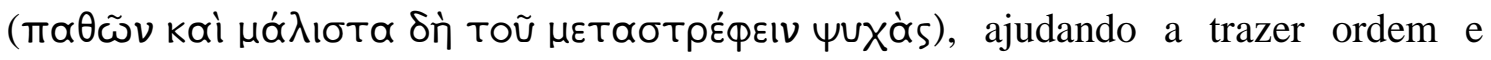

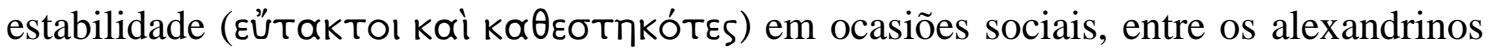
tinha exatamente o efeito contrário (Orationes 32.55-59).

Apesar de todo esse entusiasmo, Dion explana que nem ao menos se tratava de um povo talentoso para a música:

\begin{abstract}
Algum de vocês consegue produzir uma música terminada ou um ritmo nobre? Nada, é um pot-pourri de toadas efeminadas e dedilhadas da lira com música de salão e do excesso de bebedeiras de monstros

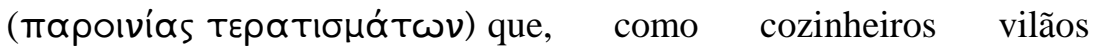
(KaKoì) com um comichão por novidades, misturam tudo para formar a melodia e então excitam uma audiência ignorante e ávida.

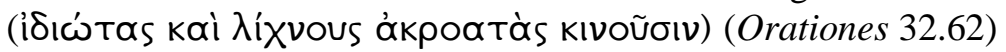

Dion ressalta a procedência "selvagem" (áypiótnta) dos macedônios, que depois de misturada com a tribo de Alexandre, se instalou em Alexandria. Por tal

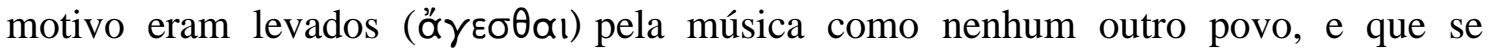
ouviam a melodia da lira, mesmo que ruim, perdiam os sentidos e a razão (Orationes 32.64-65). Dessa forma Dion diminui a herança grega dos alexandrinos, os aproximando a "bárbaros-selvagens". Para adquirirem novamente o status de gregos, teriam que apresentar uma postura mais "civilizada" nos espetáculos. O autor segue em sua reflexão:

E influenciada por isso, parece que a doença já está afetando, não apenas oradores públicos, mas alguns filósofos também- apesar de ser mais correto dizer que os oradores públicos não são mais fáceis de reconhecer. Pois como eles observam o seu interesse em cantar e sua

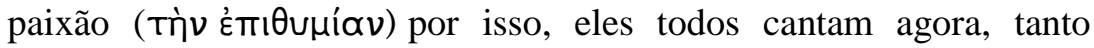
oradores públicos como sofistas, e tudo é feito pela música; se você

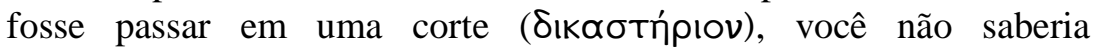
reconhecer se o que estava em progresso era uma festa de bebedeira ( Tívovoıv); e se há na sua vizinhança uma conferência de um sofista, você jamais conseguiria reconhecer a conferência. E em minha opinião as pessoas chegariam ao ponto de usar a música para acompanhar seus exercícios no ginásio, e até mesmo para curar os 
doentes. Pois mesmo agora, quando médicos discursam a respeito de seu oficio, eles entoam. (Orationes 32.68)

Dion novamente realça a má fama atribuída aos alexandrinos: todos que falavam

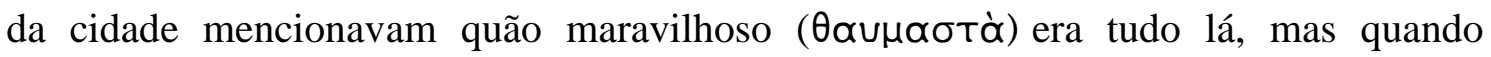
tratavam de seus habitantes, nada diziam que pudessem ter orgulho. Pois os alexandrinos eram sempre descritos como homens sem valor

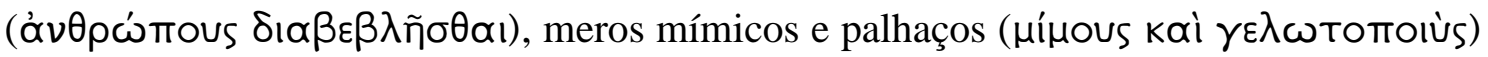

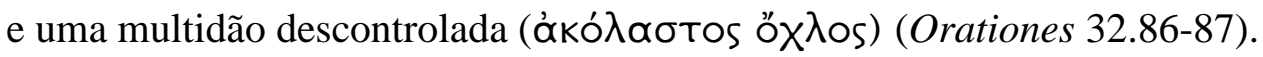

Apesar da ênfase de Dion na tendência alexandrina à turbulência, percebe-se que ele se refere às confusões mais associadas aos divertimentos do que aos conflitos (BARRY, 1988, p. 10). O povo é julgado principalmente em virtude da obsessão pelas corridas de cavalos e pela música. O problema principal não era a dedicação aos espetáculos, mas os efeitos que as competições despertavam nas audiências, levando a distúrbios e a atitudes desmedidas, repletas de irracionalidade. Diferentemente dos outros autores (como visto no capítulo 4), sua oposição está voltada especificamente para as multidões gregas de Alexandria, egípcios não são nem citados. Ou seja, aqui quando Dion se refere a alexandrinos estaria provavelmente tratando da população helenizada da cidade (mesmo que entre esses houvesse egípcios helenizados).

A intenção principal do autor é explicar a origem de sua indignação aos alexandrinos e as consequências de tais atitudes para a cidade. A ênfase de Dion é que as atenções dos alexandrinos voltadas exclusivamente para as diversões e os entretenimentos estariam provocando grandes tumultos na cidade. Ou seja, a raiz de todos os males era os divertimentos. Trata-se de uma alteração considerável na imagem divulgada sobre a cidade, pois embora ainda associe à turbulência, a relação com as diversões era algo novo e próprio do período romano. Entretanto, não eram os entretenimentos que preocupavam o orador, mas as consequências dos eventos, após a aglomeração do povo. Mesmo que entenda os divertimentos como problemas, percebese que sua grande preocupação estava voltada para o que esse comportamento poderia gerar na dinâmica da cidade.

Mais do que propensos à rebelião, os alexandrinos se dedicavam a diversões e espetáculos, e tal disposição tinha que ser controlada. Apesar de esse ser o eixo do discurso de Dion, aparentemente não eram tanto os divertimentos que o preocupavam, 
mas justamente a quantidade de pessoas reunidas para presenciar os espetáculos, além da atratividade exercida pela aglomeração sobre os que lá chegavam. Ou seja, nenhum local além de Roma tinha a capacidade de agrupar uma multidão tão imensa e variada como Alexandria. Ao colocar tantos universos em contato, dali poderiam eclodir tumultos e rebeliões em grande escala. Mais do que isso, a partir de Alexandria, rumores e ideias de desafio à ordem poderiam facilmente se propagar e alcançar regiões amplas. Ao reforçar a sua grandeza e quantidade de povos que lá circulavam, Dion infere que uma cidade tão povoada e com "talento" tal para o caos podia facilmente ameaçar a ordem romana. Justamente por se tratar de um local em que tantos povos entravam em contato, o que tornava sua rotina notavelmente dinâmica e instável, deveria ser controlado para servir de exemplo aos demais grupos. Pois sendo Alexandria uma "cidade-mundo", se o caos fosse ali instalado, prontamente se propagaria por todo aquele universo conquistado por Roma. Ou seja, ao sublinhar a sua posição central e todos os rumores que corriam sobre a cidade, Dion assinala seus motivos pelos quais a vigilância sobre o local não podia ser descuidada.

Dion recorre constantemente a exemplos gregos, como foi citado ao comparar Alexandria a Esparta, Atenas e Tróia. Por ser de origem grega (helenística), tais exemplos estavam sempre em mente e Dion os usava ainda mais para reforçar a sua visão de mundo. Como as grandes cidades gregas citadas, ele visualizava em Alexandria um potencial que o permitia fazer essas comparações. Mas os exemplos parecem ser usados prioritariamente para envaidecer os alexandrinos e fazê-los valorizarem sua história e herança. Além disso, seu discurso seria destinado principalmente aos líderes dessa multidão. Ou seja, voltava-se para a elite helenizada e orgulhosa do passado ligado a Alexandre. No entanto, a herança grega de Alexandria não era o mais significativo para Dion em comparação à ênfase em sua posição geográfica como uma "cidade-mundo". O que importava para ele era principalmente o potencial da cidade de unir tantas identidades e de promover uma movimentação sem igual em toda a região. Ao menos a Alexandria de Dion Crisóstomo que nos salta aos olhos era a Alexandria voltada para o Mediterrâneo, a "Alexandria-mundo", uma cidade que ameaçava justamente o que o autor mais valorizava: a ordem.

Suetônio alude ao excitamento dos alexandrinos no teatro no seu livro sobre Nero. $\mathrm{O}$ autor faz referência ao aplauso entusiasmado do povo (modulatis Alexandrinorum laudationibus), após Nero cantar em um teatro em Nápoles. Segundo o 
autor, eles estavam em multidão na cidade em virtude de uma frota atrasada. Nero tinha ficado tão contagiado pelos aplausos, que selecionou homens da ordem dos cavaleiros e mais de alguns homens comuns, para se dividirem em grupos e aprender o "estilo alexandrino" de aplaudir (plausuum genera condiscerent). Posteriormente esses homens eram contratados para o aplaudirem vivamente sempre que cantasse (Nero 20). Suetônio não estabelece nenhum julgamento negativo desse hábito alexandrino, embora ridicularize a postura de Nero de adotar algo assim em Roma para as suas apresentações.

Filostrato faz Apolônio de Tiana condenar o comportamento dos alexandrinos em espetáculos públicos e sua devoção a cavalos, provavelmente a partir do relato de Dion Crisóstomo, argumentando que estavam se destruindo pela falta de seriedade:

Pois como os alexandrinos são devotados ( $\pi \rho \circ \sigma k \varepsilon 1 \mu \varepsilon ́ v \eta \varsigma)$ a cavalos, eles vão ao hipódromo para ver o espetáculo ( $\theta \varepsilon \dot{c} \alpha)$ e matam uns aos

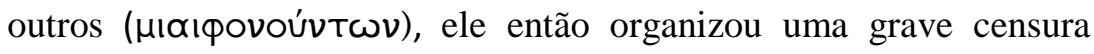

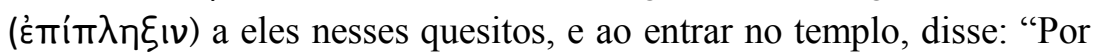
quanto tempo vocês persistirão em encontrar as suas mortes

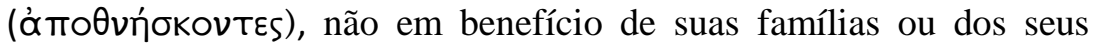
altares, mas por estarem determinados a poluir os recintos sagrados entrando neles exalando sangue e matando ( $\phi \theta \varepsilon i ́ p o ı \sigma \theta \varepsilon)$ uns aos outros dentro dos muros. E Tróia foi destruída e vingada por um único cavalo, que os Aqueus daqueles dias tinham projetado; mas as suas carroças e seus cavalos são subjugados para o seu próprio desdém e não lhe dão nenhuma chance de viver em submissão ao reino das leis (Eủnuíws). Portanto, vocês não estão sendo destruídos ('́̊mó $\lambda \lambda \cup \sigma \theta \varepsilon$ ) pelos filhos de Atreu nem pelos filhos de Ajax, mas por vocês mesmos, algo que os troianos não teriam feito nem se estivessem bêbados. Em Olímpia, contudo, onde há prêmios para a luta livre, o boxe e para as competições atléticas mistas, ninguém é

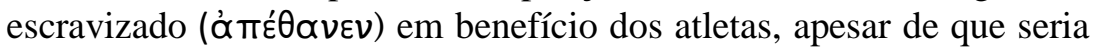
justificável se alguém demonstrasse perdoar os ataques

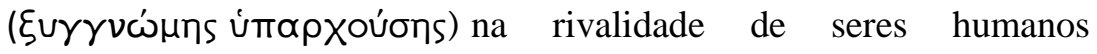
semelhantes a si mesmo. Mas aqui eu os vejo atacando

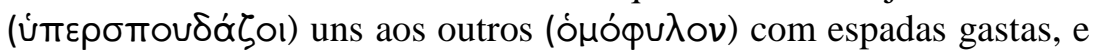
prontos para lançar pedras, tudo por uma corrida de cavalo. Eu gostaria de incendiar uma cidade como essa, onde no meio das

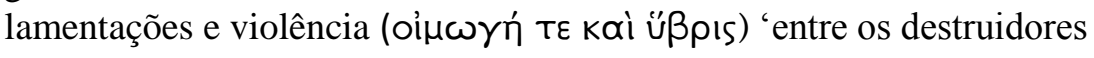
e os destruídos escorre sangue pela terra'

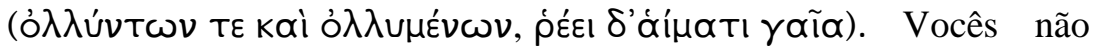

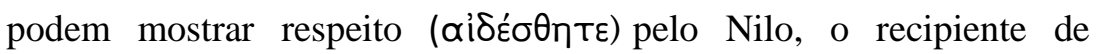
mistura ( para homens cujo padrão de medida é uma maré de sangue crescente 


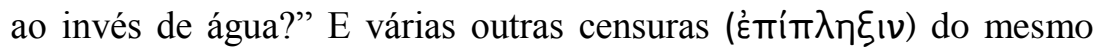
tipo ele dirigiu a eles, como Damis nos informa. (Vita Apollonii 5.26)

Como Dion Crisóstomo, Filostrato insere Alexandria em uma dinâmica de cidades gregas. Entretanto, entende que o comportamento no hipódromo os estava afastando do padrão de conduta dos gregos e os levando à "merecida" destruição. O autor demonstra, contudo, certo respeito pelo Egito e o Nilo, a fonte de suas riquezas.

Certamente o teatro, o hipódromo e a ágora eram os principais focos das multidões e lócus das aglomerações urbanas, pois eram espaços que permitiam a convivência entre diversos grupos e etnias. Além de cenário para as diversões, os estabelecimentos eram também pontos de interação entre a população urbana e autoridades cívicas e romanas. Foram, portanto, além de palco para eventos, o cenário de expressões de vontades mais violentas da população, por permitir a aglomeração e organização das multidões (HAAS, 1997, p. 64-65). Procissões e eventos públicos de homenagem ou demonstração de hostilidade a indivíduos eram comuns em Alexandria, além da tradição de suntuosos festivais para alexandrinos importantes (HAAS, 1997, p. 85-86). As multidões reunidas para espetáculos eram as maiores, e pelo envolvimento com as performances, eram provavelmente as que causavam mais tumultos. Assim, não era as aglomerações rotineiras o maior problema, mas os agrupamentos reunidos para alguma ocasião especial (BARRY, 1988, p. 54-56).

Apesar da condenação aos espetáculos e aos locais onde eram realizados (teatro e hipódromo) por sua propensão a turbulência, percebe-se pelo relato de Dion que se sob o Império Alexandria não era mais o mesmo centro cultural que tinha sido sob os Ptolomeus, sua população continuava sofisticada e amava os "prazeres da vida" (JONES, 1978, p. 37). Tornou-se então, conhecida pela sua devoção ao teatro e espetáculos públicos dessa natureza. Mas por só atentarem para o lado negativo dos entretenimentos, pouco se sabe do potencial da cidade como um centro de divertimentos. Enfocar apenas nas consequências dos espetáculos e nos problemas da aglomeração era um modo de desviar o foco da Alexandria prazerosa e cultural, que estaria atraindo multidões e se destacando no setor. A elite romana não estimularia o desenvolvimento dessa tendência, pois por um lado, poderia aglomerar multidões e repercutir em caos e pelo outro, a capital do Império nos setores de entretenimento era Roma e não deveria haver outras. Ainda mais uma cidade helenística e capital da 
província do Egito, que já provocava encanto por si só não deveria desenvolver esse potencial.

Foi visto acima que um traço do humor alexandrino incômodo aos outsiders era um talento especial para ironizar autoridades. Outro episódio de deboche de uma figura pública que fez os alexandrinos serem castigados ocorreu quase duzentos anos depois da situação narrada por Fílon (zombaria de Agripa) e refere-se ao massacre dos alexandrinos por Caracala. O contexto foi visto em maiores detalhes no capítulo IV, interessa aqui apenas ressaltar que os relatos de Dion Cássio (Historiae Romanae 7879) e Herodiano (Herodiano 4.8-9) justificam as calúnias divulgadas pelos alexandrinos com relação à morte de seu irmão como motivo maior da indignação de Caracala. Esse tipo de comportamento, de depreciar autoridades através do humor foi ressaltado principalmente por Herodiano, que dizia ser "natural" dos alexandrinos produzirem sátiras e fazerem piadas rebaixando as autoridades ( eram consideradas espirituosas ( $\chi \propto \rho i ́ \varepsilon \nu \tau \alpha)$ pelos alexandrinos, mas difamatórias para

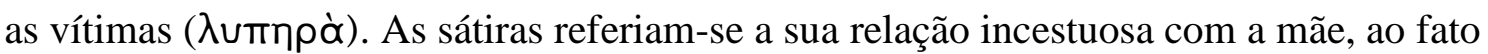
de ter matado seu irmão e de estar constantemente se comparando a Alexandre e Aquiles (Herodiano 4.9.2-3).

A mímica era uma forma de entretenimento antiga e bem conhecida em Alexandria, que remete à tradição dos Ptolomeus (MUSURILLO, 1954, p. 248). Tal modalidade de arte não era usada apenas como diversão, mas também como fator de crítica (HARKER, 2008, p. 119). Eram manifestações mais elevadas no tom que outros eventos públicos da cidade e constantemente faziam referência a questões contemporâneas (BOWMAN, 1986, p. 216). Assim, a produção de sátiras e zombarias a autoridades através da mímica era uma tradição de longa duração na história alexandrina. Porém só é citada em forma de censura, como foi visto no episódio contra Agripa, a censura de Caracala e o comentário de Dion Crisóstomo, onde chama os alexandrinos de "meros mímicos" como forma de desprestigiá-los. Além de todas as críticas destinadas aos alexandrinos, de serem pouco comedidos para a fala e adeptos da provocação e calúnia, as evidências em Fílon, Dion Cássio e Herodiano sugerem que era através da mímica que rumores e reclamações se disseminavam. Em suma, a mímica era mais uma forma de entretenimento que escaparia ao controle imperial, pois não visava à diversão em seu estágio "puro". Contudo, difundia a crítica e o questionamento 
a questões contemporâneas e cívicas através da descontração. Nesse sentido, tornam-se mais um motivo para repreender os alexandrinos, pois seus ensinamentos não estimulavam o silêncio e a reflexão, porém induziam o povo a se tornar mais atuante em questões da cidade.

Em outras palavras: tudo seria feito em busca de uma Alexandria quieta, ordenada e pouco reflexiva. Por isso, toda a ênfase no espírito descomedido dos seus habitantes. Pois divulgando uma imagem da população com tal tendência à instabilidade e comportamento excessivo era mais fácil criar uma aversão ao que lá se praticava e difundia, desviando o foco de uma Alexandria atrativa pelos seus entretenimentos.

Chama a atenção aqui o fato da identidade alexandrina voltada para os entretenimentos ser divulgada apenas por autores gregos, a partir do final do século I d.C.. Apenas o breve comentário de Suetônio indica a natureza festiva dos alexandrinos na perspectiva de um latino, embora com o intuito principal de criticar Nero. Dion Crisóstomo e Filostrato, ambos representantes da segunda sofística, são os escritos mais enfáticos na crítica aos espetáculos. Ou seja, a situação turbulenta e festiva de Alexandria não era algo que como gregos, interessasse a eles reforçar. A cidade herdeira de Alexandre deveria zelar por sua herança e tradição de outra forma, e não promovendo o caos através dos entretenimentos. Em contrapartida Ateneu, também membro da segunda sofística, escreveu depois dos autores citados e não aborda as festividades da Alexandria romana. No entanto, sua ênfase é na grandiosidade e exuberância dos espetáculos anteriores dos Ptolomeus. Seus comentários sobre o passado alexandrino seriam uma forma de justificar e legitimar os espetáculos de sua própria época (que eram desacreditados)? Ou seja, através do destaque na tendência festiva da cidade desde o período helenístico, o autor ressaltaria a dedicação aos entretenimentos como parte da história alexandrina. É também possível que Ateneu fizesse uso do relato de Callixenius para ilustrar o esplendor das festas de outrora, sugerindo que na Alexandria helenística havia espaço para esse tipo de vivência, promovida e estimulada pelos próprios governantes. Nesse sentido, seria uma forma de "saudosismo" e uma reação sutil ao domínio romano.

Dion Cássio e Herodiano censuravam a produção de sátiras e mímica na cidade por resultarem em ofensas a autoridades. Ou seja, nesses autores, a crítica às diversões estava mais restrita e direcionada para esse tipo específico de manifestação artística realizada no local. Nesse sentido, não era toda a tradição festiva que estava sendo 
censurada, mas uma postura "inconsequente" de promover julgamentos a autoridades romanas, o que poderia abalar a ordem e incomodar o comando imperial. Os autores latinos fazem menção apenas à porção dos entretenimentos da identidade alexandrina no cenário de crítica a Cleópatra. No entanto, usam a figura da rainha para promover uma oposição generalizada à "devassidão" e aos comportamentos excessivos praticados em Alexandria eCanopo. Dessa forma, como os latinos não mencionam mais o contexto de entretenimentos pós-Cleópatra fica implícito que não interessava à tradição veicular as mudanças nas formas de divertimentos praticados. Ou seja, era conveniente manter o retrato anterior, de Alexandria como a terra da "promiscuidade" e dos prazeres excessivos.

\section{3. "Cidade-mundo" e centro aglutinador}

Foi visto durante todas as etapas dessa pesquisa como a grandeza, riqueza e a exuberância de Alexandria são elementos destacados nas suas descrições. Tais traços estão presentes na construção da identidade imperial de Alexandria, como também a sua classificação em uma espécie de "ranking" de cidades. No capítulo I foi discutida a enunciação da grandeza para o contexto de fundação, mas o uso de adjetivos associados ao tamanho perpassa muitos cenários de caracterização da cidade. A velocidade de seu crescimento teria sido impressionante para os padrões da época e perceptivelmente inquietava os antigos, pois adjetivos associados à grandeza são os mais empregados pela literatura para se referir ao centro urbano (BERNAND, 1995, p. 12). Mckenzie (2008, p. 68) observa como o desenvolvimento da cidade foi acelerado, pois já no século II a.C. o autor da Carta de Aristeas a mencionava como a primeira, superando todas as outras em tamanho e riqueza.

Estrabão estabelece uma "classificação" de cidades citando que Antioquia, a metrópole da Síria, onde foi instalada a residência real para os governantes do país não ficava muito atrás, em tamanho e poder, da Selêucia, no Tigre, e de Alexandria no Egito

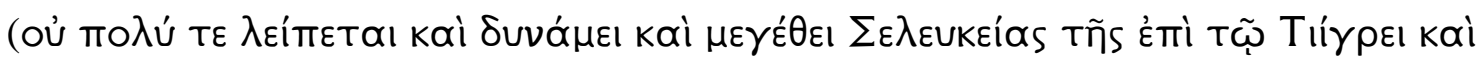

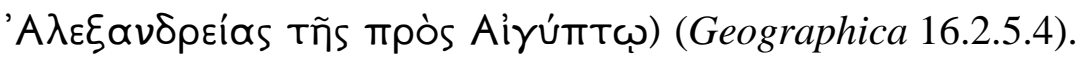


No relato de Dion Crisóstomo, foi visto que além da colocação de Alexandria como segunda cidade do Império, era a sua posição como centro aglutinador de muitas culturas o que a tornava notória, imponente e também ameaçadora. A centralidade era reforçada ainda mais pela popularidade dos entretenimentos e sua força comercial. Consequentemente, o "magnetismo" de Alexandria a transformava em um local cada vez mais populoso e aglomerado, daí a propensão maior a discórdias, tumultos e conflitos. Assim, não é fortuita a ênfase de Dion Crisóstomo principalmente nos dois aspectos: grandeza e turbulência, pois eram elementos inter-relacionados que se complementavam e intensificavam um ao outro.

Já foi citada acima a passagem em que o autor menciona o estatuto de Alexandria. Segundo Dion, a cidade era superior em tamanho e situação a muitas

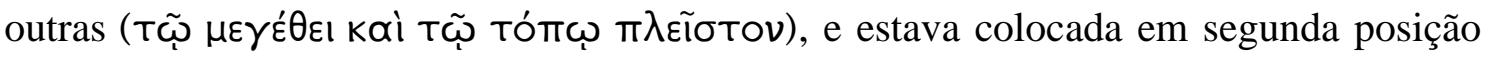
entre as mais importantes cidades

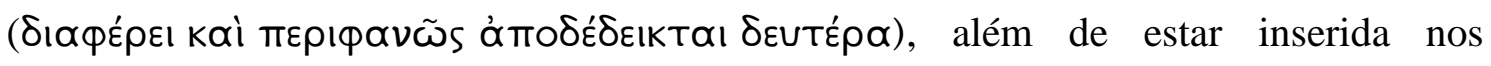

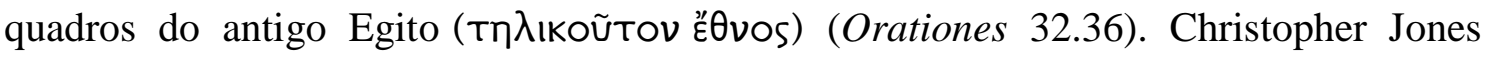
(1978, p. 90) observa que o tamanho era um aspecto comumente enfatizado por Dion no elogio a cidades, como a fundação e herança também eram argumentos usados pelo autor para honrá-las. Assim, Alexandria não era a única cidade elogiada pelo autor, o que importa aqui é principalmente o posicionamento na qual ele a coloca diante de Roma.

No Contra Flaco, Fílon também destaca a enormidade de sua própria cidade. Ao citar o discurso de lamento do prefeito, Fílon atribui ao prefeito as seguintes palavras: "Eu era governador de Alexandria, aquela megalópole ou agrupamento de cidades, governante da terra afortunada do Egito"

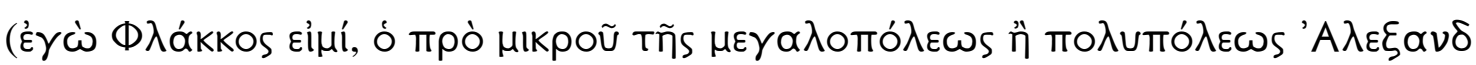

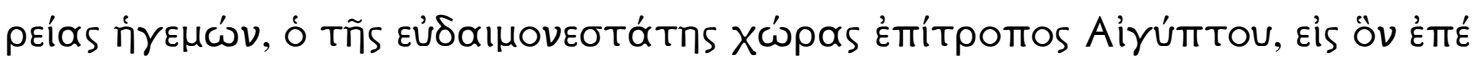

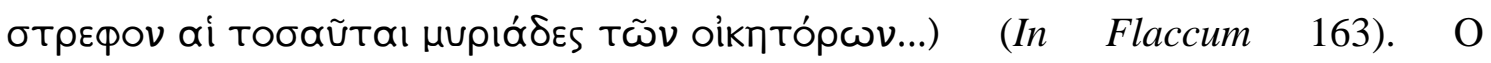
comentário de Fílon destaca não apenas a grandeza populacional e territorial de Alexandria, mas o fato de o local ser um aglutinador de comunidades diversas. Assim, fica expressa além da enormidade territorial, sua centralidade como ponto de encontro entre vários povos e seu cosmopolitismo. Como em outros momentos o intuito principal do autor era defender os interesses da comunidade judaica, portanto sua opinião em 
relação a sua própria cidade não fica tão evidenciada. Para conquistar apoio para os judeus, o autor "disfarçava" sua identidade alexandrina, e denuncia os problemas como um estrangeiro, já que o intuito principal era conquistar o apoio romano. Contudo, nessa passagem o autor evidencia sua admiração pelo desenvolvimento da própria cidade.

Aquiles Tacio, outro autor alexandrino, fornece um quadro da variedade populacional de Alexandria, além de ressaltar sua enormidade, beleza e vivacidade. Em uma passagem do livro IV, o autor faz um breve, porém sugestivo comentário de alguém que teria mencionado que Alexandria era a única vila onde tudo era feito em público, e onde muitos viam tudo o que acontecia (Leucippe et Clitophon 4.7). Esse trecho reforça o retrato já sugerido por Dion Crisóstomo de Alexandria como um ponto de divulgação e disseminação de "modas", pois com tamanha multidão e eventos públicos, as notícias se espalhavam com rapidez e facilidade.

No livro V Aquiles Tacio enfatiza de forma poética e com ainda mais realce a mistura populacional e dinâmica da cidade. Diz que assim que seu personagem entrou pelo portão do sol, ficou instantaneamente impressionado com a "beleza iluminada" da

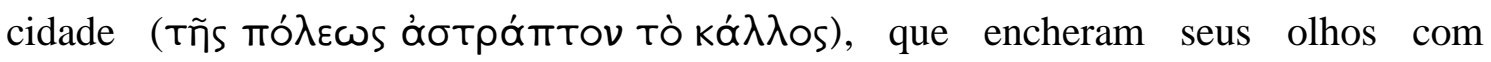
encanto. E sublinha com exagero retórico a enormidade e variedade populacional de Alexandria. Elabora uma metáfora da cidade como sendo maior que um continente

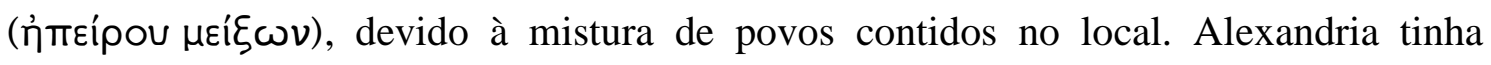
tantas ruas que andando por elas tinha-se a impressão de estar no exterior mesmo estando em casa e que era impossível apreender toda a beleza das ruas de uma vez só. E reforça que duas coisas o impressionaram muito, e era impossível decidir o que era maior: a grandeza do lugar ou sua beleza, a própria cidade ou seus habitantes, pois a primeira era maior que um continente, e a segunda era maior que uma "nação inteira". Observando tal grandeza ele duvidava se algum povo poderia algum dia enchê-la, e com tantos habitantes, imaginava se alguma cidade seria grande o suficiente para abrigá-los

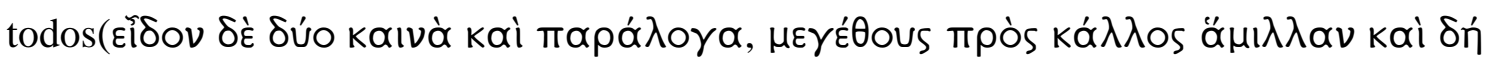

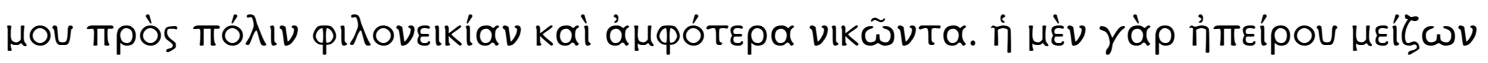

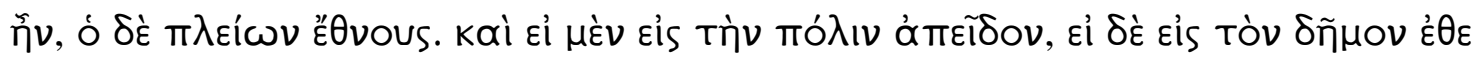

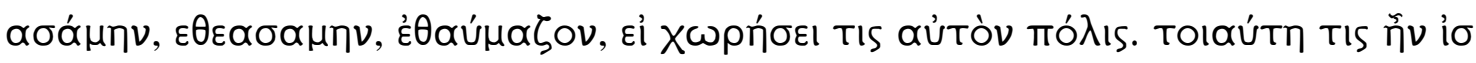

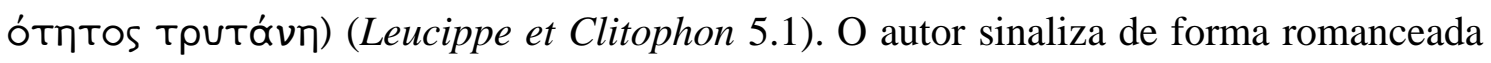
um grande encantamento pela cidade, embora demonstre um envolvimento pessoal e 
afetivo, por ser alexandrino, algo menos notável em Fílon e Apiano, os outros dois alexandrinos que foram aqui trabalhados.

Na sequência, descreve o festival a Serápis que presenciara, onde havia uma procissão de tochas. Diz que foi o maior espetáculo já vivenciado por ele, "Eu pensei que naquela ocasião a cidade estava competindo com o céu por beleza" (Leucippe et Clitophon 5.2). Mais adiante, elogia a estrutura e imponência do farol de Faros (Leucippe et Clitophon 5). Por mais poética que seja sua narrativa, o relato de Aquiles Tacio explicita a vivacidade da cidade na segunda metade do séc. II d.C (MCKENZIE, 2008, p. 188).

Ateneu refere-se a Roma como uma comunidade internacional, pois era a

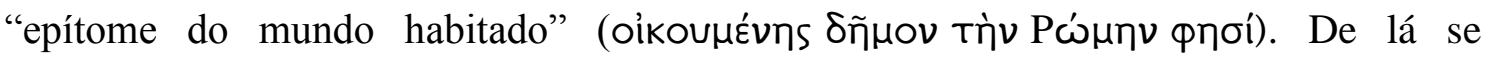
vislumbrava todas as cidades do mundo, por exemplo, a "dourada Alexandria"

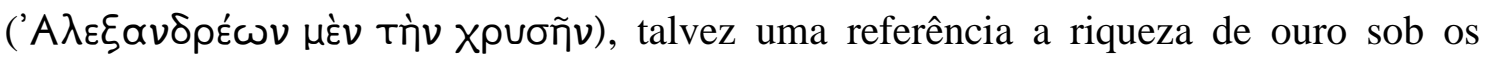
Ptolomeus, a "agradável Antioquia" e a "linda Nicomédia", embora Atenas fosse a mais radiante. Diz que um dia não era o suficiente para listar as importantes cidades incluídas em Roma, pois todas as comunidades estavam lá representadas. Nesse comentário, Ateneu enumera as cidades mais importantes do momento (Roma, Alexandria, Antioquia e Nicomédia) e fala que Roma continha a "população do mundo", pois de lá se poderia ter acesso a todas as cidades, com suas características próprias (Deipnosophistae 1.20b). O autor faz aqui uma evidente referência a Roma como o Império. Ou seja, Roma não apenas dominara, mas representava o Império Romano em sua própria cidade, por ser um microcosmo de tantos povos.

Para Ateneu, Roma era a cidade a partir da qual se poderia vislumbrar todo o mundo, já Alexandria era um agrupamento de cidades na perspectiva de Fílon, e uma cidade maior que um continente segundo Aquiles Tacio. Chama atenção aqui a semelhança nas caracterizações de Roma e Alexandria. Apesar dessa aproximação, no momento de classificar a metrópole em uma colocação, as posições ainda oscilam entre primeiro e segundo lugar (como visto em Diodoro no capítulo 2), com predominância absoluta da segunda colocação. O fato de os autores destacarem tanto a status de Alexandria depois de Roma indica mais do que a percepção de sua grandeza, mas principalmente seu papel central, como núcleo aglutinador de muitos povos. Ilustra também o ritmo acelerado de suas transformações, promovido pela dinâmica comercial e pela atratividade estimulada pelos divertimentos. A ênfase no "segundo lugar" sugere 
o interesse de marcar essa posição após Roma, inferindo que em virtude de sua magnificência, Alexandria às vezes a superava, podendo ser posicionada a frente da capital do Império.

Como na questão referente aos entretenimentos, são os autores gregos que destacam a enormidade e variedade populacional de Alexandria e sua posição como uma "caixa de ressonância", pela propensão à divulgação. Em suma, a percepção das fontes (principalmente gregas) era a seguinte: a posição central de Alexandria como centro comercial a transformava em um local muito visado. Mas além de pólo comercial, os mercadores que ali circulavam para comercializar eram atraídos por suas festividades. Tais ocasiões festivas resultavam em grandes aglomerações, que poderiam gerar turbulência, caos e conflitos. Para além do caos, as multidões reunidas podiam também disseminar rumores e "modas". A partir de Alexandria, era possível atingir grande amplitude, pois de lá alcançariam as terras de origem de todos os que passavam pelo local. Ou seja, nenhum local do Império Romano tinha todo esse talento para a divulgação e propagação como Alexandria, e esse potencial era notado pelos antigos.

Com a hegemonia romana, muitas cidades eram tentadas a imitar a magnificência de Roma e quanto maior o prestígio de uma cidade, mais de perto e com mais “inveja” ela era vigiada (LENDON, 2001, p. 77). Ou seja, não é mera coincidência ser Alexandria a cidade mais (mal e bem) falada e também a mais controlada por Roma. Daí tantos relatos enquadrando a cidade ao seu lado e estabelecendo uma espécie de classificação para deixar claro que Roma estava à sua frente. Segundo Lendon (2001, p. 111), a posição de honra de Alexandria era ameaçadora, pois a lógica romana para cidades era a mesma que a de indivíduos: da mesma forma que homens de renome eram perigosos ao imperador, cidades renomadas podiam ser ameaçadoras para o Império.

Claude Nicolet (1999, p. 112) escreveu um artigo com o objetivo de discutir as aproximações entre Alexandria e Roma promovida pelos antigos. O autor argumenta que a comparação entre o tamanho de cidades não é um fenômeno novo, e já era muito usado pelos antigos, principalmente entre Roma e Alexandria. Mas esses dados devem ser vistos com cautela, pois se utilizavam de categoriais diferentes para estabelecer suas medidas. Com a introdução de instrumentos modernos para as medições (principalmente mapas), e através de sua sobreposição, o autor conclui que Alexandria era comparável, mas claramente inferior a Roma em termos de extensão (1999, p. 120). A análise de Nicolet é importante, mas o autor leva a questão do tamanho da cidade ao 
extremo. Os autores ilustram que não se trata apenas da comparação de uma grandeza geográfica e populacional, mas ao fato de a cidade se sobressair em uma série de aspectos, que no geral a assemelharia a Roma e em alguns casos Alexandria até ultrapassava a capital do Império. Assim, tantos adjetivos de elogio a sua enormidade serviriam para compará-la a Roma, demonstrando com isso suas semelhanças e diferenças. Daí a origem da preocupação dos autores em traçar uma categorização de cidades, talvez como uma espécie de alerta. Através de Alexandria a excelência romana ficaria refletida como em um espelho e também as suas ausências e falhas ficariam mais proeminentes. 


\section{Considerações Finais}

A recorrência de caracterizações sobre Alexandria produzidas no contexto imperial traduz mais do que um mero desejo de determinados autores de fornecer informações sobre a cidade. A repetição de certas temáticas e julgamentos com relação a sua trajetória e vivência específicas demonstram um tipo de posicionamento da administração imperial frente à cidade. Tal postura foi sendo configurada ao longo dos séculos e se intensificando conforme Alexandria adquiriu crescente importância para Roma e conquistou proeminência em diversos setores.

Alexandria foi o centro urbano mais descrito pela literatura antiga em virtude de sua semelhança com Roma, tornando-a um incômodo constante para o Império. A tradição clássica reproduz essa inquietação no modo de representar Alexandria naquele mundo. Diferentes "Alexandrias" são retratadas conforme o contexto específico de quem estava escrevendo, mas é perceptível uma espécie de padrão, que nem sempre era divulgado de maneira intencional. Acreditamos que esse "padrão" indica certo modo da elite imperial se portar diante da cidade e ajudou a estabelecer diversas identidades alexandrinas produzidas pelo outro, ou seja, o não-alexandrino. Dessa forma, as representações da cidade foram estruturadas e divulgadas com base principalmente no modo como ela era entendida por outsiders, já que houve pouco espaço para a voz dos próprios alexandrinos.

As identidades criadas sobre Alexandria a partir de perspectivas externas são múltiplas e, mesmo existindo preocupações comuns com relação ao seu destino, diferentes "nuances" foram usadas para explicar a sua tradição, história e realizações. Os elementos gregos, egípcios, mistos, helenísticos, orientais, monárquicos, eram trazidos a tona e reforçados segundo autorias diferentes. Às vezes elementos discrepantes foram utilizados por um mesmo autor para explicar diferentes contextos. Além de tudo isso, essa cidade de enorme complexidade cultural foi incorporada por Roma. Dessa forma, para alguns autores a tomada do Egito se tornou preponderante na caracterização de Alexandria em detrimento de outros traços de sua história. A partir da conquista, a herança helenística perdeu espaço em relação ao papel de Alexandria como segunda cidade do Império Romano. Entre os autores latinos preocupados em entender o crescimento e a manutenção do império, Alexandria naturalmente foi abordada a 
partir de suas relações com Roma, daí representarem-na conforme o esperado dessa dinâmica.

Observamos nas fontes que algumas características da cidade refletiam a própria Roma e por isso, deveriam ser freadas e contidas. As maiores censuras e os aspectos mais realçados de sua estruturação eram justamente os elementos que mais a aproximavam de Roma: a cidade revoltosa, grandiosa, opulenta, festiva, aglomerada e culturalmente ativa. Por ser uma espécie de reflexo da capital do império, tais facetas eram as mais criticadas, pois representavam uma espécie de ameaça à sua hegemonia e preponderância. As críticas eram talvez feitas com o intuito de atenuar os aspectos que a tornavam semelhantes a Roma e criar uma rejeição ao cenário erudito, festivo e dinâmico configurado na cidade. Nesse sentido, a documentação demonstra que o mais almejado era uma Alexandria controlada política e culturalmente, pouco reflexiva e sem grandes aglomerações.

Em compensação, as imagens de uma Alexandria "conveniente" para o império eram reforçadas. Dessa forma, sua prosperidade deveria ser mantida e estimulada, pois a produtividade era oportuna e necessária para o Império. Daí a contínua ênfase da literatura nas formas de Roma ter acesso a essa riqueza e dominá-la. Assim, prezava-se pela manutenção do que faltava a Roma (fertilidade). Contudo, dever-se-ia controlar a multidão e as turbulências, pois tais aspectos não trariam nada de positivo ao Império. Pelo contrário, a predisposição da cidade para reunir enormes multidões intimidava os detentores da ordem, pois poderia gerar um cenário de reflexão crítica e "caos". Em suma: uma Alexandria "conveniente" para o Império Romano era tudo aquilo que Roma não alcançara: prosperidade, tranquilidade e ausência de grandes agrupamentos.

Para os autores greco-helenísticos como Estrabão, e mesmo em meio aos representantes da segunda sofística (Plutarco, Arriano, Dion Crisóstomo, Apiano, Pausânias, Ateneu) o Império Romano era algo benéfico por levar paz e ordem a um mundo onde predominava o caos. No entanto, culturalmente as referências dos autores eram gregas e o universo que lhes interessava abarcar era mais amplo e diversificado em relação ao dos latinos, mais concentrados no centro administrativo do Império. Dessa forma, Alexandria ainda era entendida como uma cidade helenística, que, no entanto, tornara-se capital da província romana do Egito. Porém, apesar de sua nova faceta imperial, sua herança helênica ainda era valorizada e relembrada. Daí o maior interesse 
no vínculo com Alexandre, no passado ptolomaico e nas realizações da cidade antes da anexação ao Império.

Entre os latinos há visivelmente um menor interesse no passado grego. Apenas Tito Lívio tratou de questões ptolomaicas e, mesmo assim, as abordava em situações de contatos diplomáticos com Roma. Em contrapartida, nota-se o realce na prosperidade agrícola do Egito e na necessidade do Império ter acesso ao seu controle (Cícero, Vitrúvio, Quinto Cúrcio, Tácito, Plínio o velho, Plínio o jovem). É perceptível também o maior uso de lugares-comuns ao se referir ao Egito como um todo, através da ênfase nos aspectos mais superficiais da antiga cultura faraônica para explicar suas tradições. Mesmo para Alexandria, percebe-se uma maior ênfase no topos da cidade instável e revoltosa, com julgamentos e juízos de valor mais constantes, mesmo sem acessarem sua história com profundidade (Vitrúvio, Sêneca, Quinto Cúrcio, Lucano, Tácito). Como Alexandria era tratada como uma questão de Estado, os embates com Roma foram também narrados com maior detalhamento, da mesma forma que a presença de eminentes romanos na cidade (Pompeu e César) e as mudanças estabelecidas por Otávio após a conquista do Egito.

Em suma: a abundância e a riqueza das descrições sobre Alexandria pela tradição clássica são estarrecedoras. Alguns episódios e temáticas foram narrados repetidamente, enquanto outros assuntos foram aparentemente, descartados e ignorados. Percebe-se também a manutenção proposital de determinadas lacunas. Nesse sentido, a escolha dos conteúdos para tratar da cidade já fornece consideráveis pistas da Alexandria que os antigos queriam representar. Portanto, uma leitura atenta dessa diversidade de narrativas permite, a contrapelo, uma compreensão mais apurada das tensões entre Alexandria e Roma e da importância alcançada pela metrópole no mundo greco-romano. 


\title{
Referências bibliográficas
}

\author{
1. Fontes
}

ACHILlES TATIUS. Leucippe and Clitophon. Cambridge, Mass.: Harvard University Press, 1969. (The Loeb Classical Library)

APPIAN. Roman History. 4 vols. London: Harvard University Press, 1912-1913. (The Loeb Classical Library)

ARRIAN. Anabasis of Alexander. 2 vols. Cambridge: Harvard University Press, 19761983. (The Loeb Classical Library)

ATHENAEUS. The Learned Banqueters. Cambridge, Mass.: Harvard University Press, 2007-2012. (The Loeb Classical Library)

CAESAR. Civil Wars. Cambridge, Mass.: Harvard University Press, 1914. (The Loeb Classical Library)

Alexandrian War. Cambridge, Mass.: Harvard University Press, 1955. (The Loeb Classical Library)

CICERO. On the Republic. Cambridge, Mass.: Harvard University Press, 1928. (The Loeb Classical Library)

On the Agrarian Law. Cambridge, Mass.: Harvard University Press, 1984. (The Loeb Classical Library)

Letters to Quintus and Brutus. Harvard University Press, Cambridge, Mass.: Harvard University Press, 2002. (The Loeb Classical Library) 
- Letters to Friends. 3 vols. Harvard University Press, Cambridge, Mass.: Harvard University Press, 2001. (The Loeb Classical Library)

. Letters to Atticus. 4 vols. Cambridge, Mass.: Harvard University Press, 1999. (The Loeb Classical Library)

Pro Caelio. Cambridge: Harvard University Press, 1970. (The Loeb Classical Library)

- Pro Rabirio Postumo. Cambridge, Mass.: Harvard University Press, 1953. (The Loeb Classical Library)

De Domo Sua. De Haruspicum Responsis. Cambridge, Mass.: Harvard University Press, 1979. (The Loeb Classical Library)

DIO CASSIUS. Roman History. 9 vols. Cambridge, Mass.: Harvard University Press, 1954-1961. (The Loeb Classical Library)

DIO CHRYSOSTOM. Discourses. 5 vols. Cambridge, Mass.: Harvard University Press, 1932-1951. (The Loeb Classical Library)

DIODORUS SICULUS. Library of History. 12 vols. Cambridge, Mass.: Harvard University Press, 1933-1967. (The Loeb Classical Library)

FLORUS. Epitome of Roman History. Cambridge, Mass.: Harvard University Press, 1984. (The Loeb Classical Library)

FRONTINUS. Stratagems. Aqueducts of Rome. London: Harvard University Press, 1925. (The Loeb Classical Library)

GELLIUS. Attic Nights. 3 vols. Cambridge, Mass.: Harvard University Press, 1927. (The Loeb Classical Library)

HERODIAN. History of the Empire. 2 vols. Cambridge, Mass.: Harvard University Press, 1969-1970. (The Loeb Classical Library) 
HORACE. Odes and Epodes. Cambridge, Mass.: Harvard University Press, 2004. (The Loeb Classical Library)

JOSEPHUS. Jewish Antiquities. 5 vols. Cambridge, Mass.: Harvard University Press, 1930-1965. (The Loeb Classical Library)

. The Jewish War. 3 vols. Cambridge, Mass.: Harvard University Press, 19271928. (The Loeb Classical Library)

Against Apion. Cambridge, Mass.: Harvard University Press, 1926. (The Loeb Classical Library)

JUVENAL. Juvenal. Cambridge, Mass.: Harvard University Press, 2004. (The Loeb Classical Library)

LIVY. History of Rome. 14 vols. Cambridge, Mass.: Harvard University Press, 1970. (The Loeb Classical Library)

LUCAN. The Civil War (Pharsalia). Cambridge, Mass.: Harvard University Press, 1928. (The Loeb Classical Library)

OVID. Tristia. Ex Ponto. Cambridge, Mass.: Harvard University Press, 1924. (The Loeb Classical Library)

PAUSANIAS. Description of Greece. 5 vols. Cambridge.: Harvard University Press, 1918-1935. (The Loeb Classical Library)

PHILO. On the Embassy to Gaius. London: Harvard University Press, 1962. (The Loeb Classical Library)

Against Flaccus. Cambridge, Mass.: Harvard University Press, 1941. (The Loeb Classical Library)

On Special Laws. 2 vols. Cambridge, Mass.: Harvard University Press, 19371939. (The Loeb Classical Library) 
. On Flight and Finding and On Dreams. Cambridge, Mass.: Harvard University Press, 1934. (The Loeb Classical Library)

On Drunkenness. On Husbandry. Cambridge, Mass.: Harvard University Press, 1930. (The Loeb Classical Library)

. On the Cherubim. The Sacrifices of Abel and Cain. London: Harvard University Press, 1929. (The Loeb Classical Library)

On the Creation. Allegorical Interpretation. Cambridge, Mass.: Harvard University Press, 1929. (The Loeb Classical Library)

PHILOSTRATUS. Life of Apollonius of Tyana. 3 vols. Cambridge, Mass.: Harvard University Press, 2005-2006. (The Loeb Classical Library)

PLINY. Letters and Panegyricus. 2 vols. Cambridge, Mass.: Harvard University Press, 1972-1975. (The Loeb Classical Library)

PLINY. Natural History. 10 vols. Cambridge, Mass.: Harvard University Press, 19381963. (The Loeb Classical Library)

PLUTARCH. Moralia. 16 vols. Cambridge, Mass.: Harvard University Press, 19272004. (The Loeb Classical Library)

Lives. 11 vols. Cambridge, Mass.: Harvard University Press, 1914-1926. (The Loeb Classical Library)

POLYBIUS. The Histories. 6 vols. Cambridge, Mass.: Harvard University Press, 20102012. (The Loeb Classical Library)

PROPERTIUS. Elegies. Cambridge, Mass.: Harvard University Press, 1990. (The Loeb Classical Library)

QUINTUS CURTIUS. History of Alexander. 2 vols. London: Harvard University Press, 1946. (The Loeb Classical Library) 
TACITUS. Histories and Annals. 4 vols. London: W. Heinemann, 1980. (The Loeb Classical Library)

THEOCRITUS. Greek Bucolic Poets. Cambridge, Mass.: Harvard University Press, 1977. (The Loeb Classical Library)

SENECA. Natural Questions. 2 vols. London: Harvard University Press, 1971-1972. (The Loeb Classical Library)

Moral Essays. 3 vols. Cambridge, Mass.: Harvard University Press, 19281935. (The Loeb Classical Library)

STRABO. Geography. 8 vols. London: Harvard University Press, 1960. (The Loeb Classical Library)

SUETONIUS. Lives of the Caesars. 2 vols. Cambridge, Mass.: Harvard University Press, 1997-2001. (The Loeb Classical Library)

VELLEIUS PATERCULUS. Compendium of Roman History. Cambridge, Mass.: Harvard University Press, 1924. (The Loeb Classical Library)

VITRUVIUS. On Architecture. 2 vols. Cambridge, Mass.: Harvard University Press, 1924. (The Loeb Classical Library)

VIRGIL. Aeneid. Cambridge, Mass.: Harvard University Press, 1918. (The Loeb Classical Library)

\section{Bibliografia}

AALDERS, G.J.D. Cassius Dio and the Greek World. Mnemosyne. Fourth Series, v. 39, fasc. 3/4, p. 282-304, 1986. 
ABD-EL-GHANI, Mohammed. Alexandria and Middle Egypt: Some Aspects of Social and Economic Contacts under Roman Rule. In: HARRIS, W.V.; RUFFINI, G. (Eds.). Ancient Alexandria between Egypt and Greece. Columbia Studies in the Classical Tradition. Leiden: Brill, 2004, p. 161-178.

ALSTON, Richard. Violence and social control in Roman Egypt. Proceedings of the $20^{\text {th }}$ International Congress of Papyrologists. Copenhague, p. 165-176, 1994.

The Revolt of the Boukoloi: Geography, History and Myth. In: HOPWOOD, Keith. Organised Crime in Antiquity. London: Duckworth, 1998, p. 129-153.

ANDO, Clifford. Imperial Ideology and Provincial Loyalty in the Roman Empire. Berkley, Los Angeles and California: University of California Press, 2000.

ARAÚJO, Sônia Regina Rebel de; ROSA, Claudia Beltrão da; JOLY, Fabio Duarte (orgs.). Intelectuais, poder e política na Roma antiga. Rio de Janeiro: Nau Editora, 2010 .

ASHTON, Sally-Ann. Ptolemaic Alexandria and the Egyptian tradition. In: HIRST, Anthony; SILK, Michael (Eds.). Alexandria, Real and Imagined. Aldershot: Ashgate Publishing Ltd., 2004, p. 15-40.

BAGNALL, Roger. Egypt in Late Antiquity. New Jersey: Princeton University Press, 1993.

BAGNALL, Roger S.; FRIER, Bruce W. The Demography of Roman Egypt. Cambridge: Cambridge University Press, 1994.

Alexandria: Library of Dreams. Proceedings of the American Philosophical Society, v. 146, n. 4, p. $348-362,2002$.

BAGNALL, Roger S.; RATHBONE, Dominic. Egypt from Alexander to the Early Christians: An Archaeological and Historical Guide. Los Angeles: Getty Publications, 2004.

BALLET, Pascal. La vie quotidienne à Alexandrie. Paris: Hachette Littérature, 1999. 
BARCLAY, John. Jews in the Mediterranean Diaspora: From Alexander to Trajan (323 BCE - 117 CE). Berkeley / Los Angeles/ London: University of California Press, 1996.

Josephus V. Apion: Analysis of an Argument. In: MASON, Steve. Understanding Josephus. Seven Perspectives. Journal for the Study of the Pseudepigrapha. Supplement Series 32. Sheffield: Sheffield Academic Press, 1998, p. 194-221.

The Politics of Contempt: Judaeans and Egyptians in Josephus's Against Apion. In: BARCLAY, John M.G. Negotiating Diaspora: Jewish Strategies in the Roman Empire. London: T \& T Clark International, 2004, p. 109-126.

BARNES, Robert. Cloistered Bookworms in the Chicken-Coop of the Muses: The Ancient Library of Alexandria. In: MACLEOD, Roy (Ed.). The Library of Alexandria: Centre of Learning in the Ancient World. New York: I.B. Tauris \& Co Ltd., 2010, p. 61-74.

BARRACLOUGH, Ray. Philos' politics, Roman rule and Hellenistic Judaism. In: TEMPORINI, Hildegard e HAASE, Wolfgang. Aufstieg und Niedergang der Römischen Welt, II.21.1, p. 417-553, 1984.

BARRY, William D. Faces of the Crowd: Popular Society and Politics of Roman Alexandria., 30 B.C. - A.D. 215. Tese de Doutorado - University of Michigan, 1988.

Popular Violence and the Stability of Roman Alexandria, 30 BC.- AC 215. Bulletin de la Société archéologique d’ Alexandrie, v. 45, p. 19-34, 1993.

BELL, Harold I. The Problem of the Alexandrian Senate. Aegyptus, v. 12, p. 173-184, 1932.

Anti-semitism in Alexandria. Journal of Roman Studies, v. 31, p. 1-19, 1941.

Egypt from Alexander the Great to the Arab Conquest. Oxford: Claredon Press, 1948. 
BERNAND, André. Alexandrie la Grande. Paris: Haccette Littérature, 1966.

BERNAND, André. Alexandrie des Ptoloémées. Paris: CNRS Éditions, 1995, 2001.

BIEZUNSKA-MALOWIST, Iza. Formes de résistance dans l'Égypte grecque et romaine et l'attitude de gouvernement. In YUGE, Toru; DOI, Masaiki (Eds.). Forms of Control and Subordination in Antiquity. Tokyo: The Society for Studies on Resistance Movements in Antiquity, 1988, p. 239-245.

BILDE, Per. Philo as a Polemist and a Political Apologist. An Investigation of his Two Historical Treatises Against Flaccus and The Embassy to Gaius. In: HINGE, George; KRASILNIKOFF, Jens A. (Eds.). Alexandria. A Cultural and Religious Melting Pot. Aarhus: Aarhus University Press, 2009, p. 97-114.

BINGEN, Jean. Hellenistic Egypt: Monarchy, Society, Economy, Culture. Berkeley/ Los Angeles/ California: University of California Press, 2007.

BIRNBAUM, Ellen. Portrayals of the Wise and Virtuous in Alexandrian Jewish Works: Jews' Perceptions of Themselves and Others. In: HARRIS, W.V.; RUFFINI, G. (Eds.). Ancient Alexandria between Egypt and Greece. Leiden/ Boston: Brill, 2004, p. 125160.

BLOUIN, K. L'Égypte, grenier de Rome? Cahier des études anciennes. Société des Etudes Anciennes du Québec, v. 41, p. 28-51, 2004.

BORGEN, Peder. Philo of Alexandria. In: STONE, M (Ed.). Jewish Writings of the Second Temple Period. CRINT (Compendia Rerum Judaicorum ad Nowum Testamentum), v. 2, p. 233-282, 1984.

BOWMAN, Alan. Egypt after the Pharaos 332 B.C. -A.D.642. California: University of California Press, 1986.

BOWMAN, Alan K.; RATHBONE, Dominic. Cities and Administration in Roman Egypt. The Journal of Roman Studies, v. 82, p. 107-127, 1992. 
In: BOWMAN, Alan K.; CHAMPLIN, Edward, LINTOTT, Andrew (Eds.). The Cambridge Ancient History. Vol. 10, 2nd Edition. Cambridge: Cambridge University Press, 1996, p. 676-702.

Egypt in the Graeco-Roman World: from Ptolemaic Kingdom to Roman Province. In: CRAWFORD, Harriet (Ed.). Regime change in the ancient Near East and Egypt: from Sargon of Agade to Saddam Hussein. Proceedings of the British Academy 136. Oxford: Oxford University Press, 2007, p. 165-181.

. Trade and the Flag - Alexandria, Egypt and the Imperial House. In: ROBINSON, Damian; WILSON, Andrew. (Eds.). Alexandria and the North-Western Delta: Joint Conference Proceedings of Alexandria, City and Harbour (Oxford 2004) and The Trade and Topography of Egypt's North-West Delta, 8th century BC to 8th century AD (Berlin 2006). Oxford: Oxford Centre for Maritime Archaeology, 2010, p. 103-110.

Ptolemaic and Roman Egypt: Population and Settlement. In: BOWMAN, Alan; WILSON, Andrew (Eds.). Settlement, Urbanization and Population. Oxford studies on the Roman economy. Oxford/ New York: Oxford University Press, 2011, p. 317358.

BRUNT, Peter A. The administrators of Roman Egypt. Journal of Roman Studies, v. 65 , p. $124-147,1975$.

BURTON, Anne. Diodorus Siculus. Book I: A Commentary. Leiden: Brill Academic Publishers, 1972.

CAPPONI, Livia. Augustan Egypt: The Creation of a Roman Province. New York and London: Routledge, 1975.

CARDOSO, C.F. A cidade-estado antiga. São Paulo, Ática, 1985.

CASSON, Lionel. Ancient Trade and Society. Detroit: Wayne State University Press, 1984. 
CHAUVEAU, Michel. Egypt in the Age of Cleopatra. Ithaca and London: Cornell University Press, 2000.

CLARYSSE, W.; WILLEMS, H. Les Empereurs du Nil. Leuven: Ed. Louvain, 2000.

CLÍMACO, Joana Campos. Cultura e Poder na Alexandria Romana. Dissertação de Mestrado. São Paulo, FFLCH/USP, 2007.

COLLINS, John. Between Athens and Jerusalem: Jewish Identity in the Hellenistic Diaspora. Michigan: Eerdmans, 2000.

Anti-semitism in Antiquity? The Case of Alexandria. In: BAKHOS, Carol (Ed.). Ancient Judaism in its Hellenistic Context. Leiden, Boston: Brill, 2005, p. 929.

CORASSIN, M.L. Sociedade e política na Roma Antiga. São Paulo: Atual, 2002.

CRAWFORD, M.H. Greek intellectuals and the Roman Aristocracy in the First Century B.C. In: GARNSEY, P. D. A.; WHITTAKER, C. R (Eds.). Imperialism in the Ancient World. Cambridge: Cambridge University Press, 1979, p. 193-206.

CRIBIORE, Raffaella. Gymnastics of the mind: Greek Education in Hellenistic and Roman Egypt. New Jersey: Princeton University Press, 2001.

CUCHE, Denys. A noção de cultura nas ciências sociais. Bauru: Edusc, 1999.

DALBY, Andrew. Empire of Pleasures: Luxury and Indulgence in the Roman World. London and New York: Routledge, 2000.

DAVIS, Stuart. Race-relations in Ancient Egypt: Greek, Egyptian, Hebrew, Roman. London: Methuen \& Co. Ltd., 1951.

DELIA, Diana. The population of Roman Alexandria. Transactions of the American Philological Association, v. 118, p. 273-292, 1988.

Alexandria Citizenship during the Roman Principate. Atlanta: Scholars Press, 1991. 
DUNAND, Françoise. Fête et propagande à Alexandrie sous les lagides. La Fête, pratique et discours. (Centre de recherches d'histoire ancienne 42 - Annales littéraires de l'Université de Besançon 262), Paris, p. 13-40, 1981.

EL-ABBADI, Mostafa. Alexandria: Thousand-Year Capital of Egypt. In: STEEN, Gareth L. (Ed.) Alexandria: The Site and the History. New York/ London: New York University Press, 1993, p. 35-81.

EMPEREUR, Jean-Yves. Alexandria Rediscovered. London: Harcover, 1998.

Alexandria: Past, Present and Future. London: Thames \& Hudson Ltd., 2002.

ERDKAMP, Paul. The Grain Market in the Roman Empire: A Social, Political and Economic Study. Cambridge: Cambridge University Press, 2005.

ERSKINE, Andrew. Culture and Power in Ptolemaic Egypt: The Museum and Library of Alexandria. Greece and Rome, v. 42, p. 42-48, 1995.

Life after Death: Alexandria and the Body of Alexander. Greece and Rome, 2nd Ser., v. 49, n. 2, p. 163-179, 2002.

FAVERSANI, Fábio. A sociedade em Sêneca. Tese de Doutorado. São Paulo, FFLCH/USP, 2001.

FEENEY, Denis. Literature and religion at Rome: Culture, Contexts, and Beliefs. Cambridge: Cambridge University Press. 1998.

FINNERAN, Nial. Alexandria: A City and Myth. Stroud, UK: Tempus Publishing, 2005.

FRASER, Peter M. Ptolomaic Alexandria. Oxford: Clarendon Press, 1972. 3 v.

FUNARI, Pedro Paulo. Uma Antiguidade sem conflitos. Boletim do CPA. IFCHUnicamp, ano VI, vol. 11, p. 13-24, janeiro/junho 2001. 
FUNARI, Pedro Paulo (org.). Repensando o mundo antigo. Fronteiras do Mito (JeanPierre Vernant) e Concepções de Roma: uma perspectiva inglesa (Richard Hingley). Campinas: IFCH-UNICAMP, Coleção Textos Didáticos n.47, 2002.

GABRIELSEN, V. Profitable partnerships: Kings, cities, and trade. In: ARCHIBALD, Zosia; DAVIES, John K.; GABRIELSEN, Vincent (eds.). The Economies of Hellenistic Societies. Third to First Centuries BC. Oxford: Oxford University Press, 2011, p. 216-250.

GARNSEY, Peter; SALLER, Richard. The Roman Empire: Economy, Society and Culture. London: Duckworth, 1987.

GEARY, Patrick J. O Mito das Nações: a invenção do nacionalismo. São Paulo: Conrad Editora, 2005.

GODDIO, Frank; BERNAND, André. Sunken Egypt: Alexandria. London: Periplus Publishing, 2004.

GODDIO, Frank; CLAUSS, Manfred; GERIGK, Christoph. Egypt's Sunken Treasures. München and New York: Prestel Pub., 2006.

GOLD, Barbara K. Literary Patronage in Greece and Rome. North Chapel Hill: University of North Carolina Press, 1987.

GOODMAN, Martin. The Roman World: 44BC - AD180. London/ New York: Routledge, 1997.

GONÇALVES, Ana Teresa Marques. Imagem, poder e amizade: Dião Cássio e o debate Agripa-Mecenas. In: JOLY, Fábio Duarte (Ed.). História e retórica: Ensaios sobre historiografia antiga. São Paulo: Alameda, 2007, p. 147-164.

GOUKOWSKY, Paul. The Pomp of the Ptolemies. In: JACOB, Christian; POLIGNAC, François de. (Eds.). Alexandria, third century BC. The Knowledge of the World in a Single City. Alexandria: Hapocrates Publishing, 2000, p. 135-147. 
GREENBERG, Mark; HAMMA, Kenneth; GILMAN, Benedicte e MOORE, Nancy (Eds.). Alexandria and Alexandrinism: Papers Delivered at a Symposium Organized by the J. Paul Getty Museum and The Getty Center for the History of Art and Humanities and Held at the Museum April 22-25, 1993. Malibu, California: The J. Paul Getty Museum, 1996.

GRUEN, Erich. Diaspora: Jews amidst Greeks and Romans. Cambridge/ Massachusetts/ London: Harvard University Press, 2002.

GUARINELLO, N.L. Imperialismo Greco-Romano. São Paulo, Ática, 1987.

Cidades-estado na Antigüidade Clássica. In: PINSKY, J. \& PINSKY, C. B. (Org.) História da cidadania. São Paulo: Contexto, 2003, pp. 29-47.

História Antiga. São Paulo: Editora Contexto, 2013.

GURVAL, Robert Alan. Actium and Augustus. The Politics and Emotions of Civil War. Michigan: The University of Michigan Press, 1998.

HAAS, Christopher. Alexandria in Late Antiquity: Topography and Social Conflict (Ancient Society and History). Baltimore/ London: The Johns Hopkins University Press, 1997.

HARKER, Andrew A. Loyalty and Dissidence in Roman Egypt: the case of the Acta Alexandrinorum. Cambridge: Cambridge University Press, 2008.

HAYNES, Holly. The History of Make-Believe: Tacitus on Imperial Rome. Berkeley/ Los Angeles/ London: University of California Press, 2003.

HEKSTER, Olivier. Kings and regime change in the Roman Republic. In: SMITH, Christopher; YARROW, Liv Mariah (Eds.). Imperialism, cultural politics and Polybius. Oxford: Oxford University Press, 2012, p. 184-202.

HINGE, George. Language and Race: Theocritus and the Koine Identity of Ptolemaic Egypt. In: HINGE, George; KRASILNIKOFF, Jens A. (Eds.). Alexandria: a cultural and religious melting pot. Aarhus: Aarhus University Press, 2009, p. 66-79. 
HUZAR, E. Mark Antony: Marriages vs. Careers. The Classical Journal, v. 81, n. 2 p. 97-111, December 1985 - January, 1986.

Alexandria ad Aegyptum in the Julio-Claudian Age. In: HAASE, Wolfgang; TEMPORINI, Hildegard. (Eds.) Aufstieg und Niedergang der Römischen Welt, II.10.1, p. 619-668, 1988.

Augustus, Heir of the Ptolemies. In: HAASE, Wolfgang e TEMPORINI, Hildegard. (Eds.) Aufstieg und Niedergang der Römischen Welt, II.10.1, p. 343-382, 1988.

ISAGER, Jacob. Alexander the Great in Roman Literature from Pompey to Vespasian. In: CARLSEN, Jesper.; DUE, Bodil (eds.). Alexander the Great: Reality and Myth. Rome: Analecta Romana Instituti Danici, 1993, p. 75-84.

JOLY, Fábio Duarte (org.). História e retórica. Ensaios sobre a historiografia antiga. São Paulo: Alameda, 2007.

JONES, A.H.M. Cities of the Eastern Roman Province. Oxford: The Claredon Press, 1937.

JONES, Stuart. Claudius and the Jewish question at Alexandria. Journal of Roman Studies, v. 16, p. 17-35, 1926.

JONES, C. P. The Roman World of Dio Chrysostom. Cambridge/ Massachussets/ London: Harvard University Press, 1978.

JONES, C.P. The Date of Dio of Prusa's Alexandrian Oration. Historia: Zeitschrift fur Alte Geschichte, v. 22, n. 2, p. 302-309, 1973.

KAHIL, Lilly. Cults in Hellenistic Alexandria. In: Alexandrina and Alexandrinism: Papers Delivered at a Symposium Organized by the J. Paul Getty Museum and The Getty Center for the History of Art and Humanities and Held at the Musuem April 2225, 1993, p. 75-84. 
KASHER, Aryek. Some Comments no the Jewish Uprising in Egypt in the Time of Trajan. Journal of Jewish Studies, v. 27.2, p. 147-158, 1976.

KNOX, B.M.W. Books and reader in the Greek world: from the beginnings to Alexandria. In: The Cambridge History of classical literature. Vol. I: Greek Literature, Cambridge: Cambridge University Press, 1985, p. 1-41.

KRAUS, Christina Shuttleworth. Historiography and Biography. In: HARRISON, Stephen (Ed.). A Companion to Latin Literature. Oxford: Blackwell Publishing, 2005, p. 241-256.

KRASILNIKOFF, Jens A. Alexandria as Place: Tempo-Spatial Traits of Royal Ideology in Early Ptolemaic Egypt. In: HINGE, George; KRASILNIKOFF, Jens A. (Eds.). Alexandria. A Cultural and Religious Melting Pot. Aarhus: Aarhus University Press, 2009, p. 21-41.

LEGRAS, Bernard. L’Égypte grecque et romaine. Paris: A. Colin, 2004.

LENDON, J. The Empire of Honour: the Art of Government in the Roman world. Oxford: Oxford University Press, 2001.

LEWIS, Naphtali. Greco-Roman Egypt: Fact or Fiction. Proceedings of the XII International Congress of Papyrology. Toronto, p. 3-14, 1970.

Life in Egypt under Roman Rule. Oxford/ New York: Oxford University Press, 1983.

Greeks in Ptolemaic Egypt: Case studies in the Social History of the Hellenistic World. Oakville, Connecticut: American Society of Papyrologists, 2001.

LEVICK, Barbara. Vespasian. London/ New York: Routledge, 1999.

LOBIANCO, Luis Eduardo. A Romanização no Egito: Direito e Religião (séculos I a.C. - III d.C.). Tese de Doutorado. Rio de Janeiro, UFF, 2006. 
MACHADO, Carlos Augusto Ribeiro. Imperadores Imaginários: Política e Biografia na História Augusta. Dissertação de Mestrado. São Paulo, FFLCH/USP, 1998.

MAEHLER, Herwig. Roman Poets of Egypt. In: MATTHEWS, Roger; ROEMER, Cornelia (eds.). Ancient Perspectives on Egypt: Encounters with Ancient Egypt. London: University College London Press- Institute of Archaeology, 2003, p. 203-215.

MAEHLER, Herwig. Alexandria, the Mouseion and Cultural Identity. In: HIRST, Anthony; SILK, Michael (eds). Alexandria, Real and Imagined. Aldershot: Ashgate Publishing Ltd., 2004, p. 1-14.

MANNING, J. G. Networks, hierarchies and markets in the Ptolemaic economy. In: ARCHIBALD, Zosia; DAVIES, John K. \& GABRIELSEN, Vincent. (eds.). The Economies of Hellenistic Societies, Third to First Centuries BC. Oxford: Oxford University Press, 2011, p. 296-323.

MARLOWE, John. The Golden Age of Alexandria. London: Victor Gollancz, 1971.

MARINCOLA, John. Authority and Tradition in Ancient Historiography. Cambridge: Cambridge University Press, 1997.

MARQUES, Juliana Bastos. Tradições e renovações da identidade romana em Tito Lívio e Tácito. Tese de Doutorado. São Paulo, FFLCH/USP, 2007.

MCKENZIE, Judith. The Architecture of Alexandria and Egypt: 300 B.C. to A.D. 700. London: Prestel, 2008.

MELEZE-MODRZEJEWSKI, J. The Jews of Egypt: from Rameses II to Emperor Hadrian. Princeton and New Jersey: Princeton University Press, 1995.

Droit Imperial Et Traditions Locales Dans L'Egypte Romaine. Collected Studies Series, 321. Variorum, Hardcover, 1990.

Statut Personnel Et Liens De Famille Dans Les Droits De L'Antiquite. Variorum Collected Studies, Cs411. French Edition. Hardcover, 1993. 
MENDES, Norma Musco. Romanização e as questões de identidade e alteridade. Boletim do CPA. IFCH- Unicamp, ano VI, vol. 11, p. 25-42, janeiro/junho 2001.

MILLAR, Fergus. The Emperor in the Roman World: 31 BC - AD 337. London: Duckworth, 1977.

MILLAR, Fergus. A Study of Cassius Dio. Oxford: Claredon Press, 1964.

MILNE, Grafton. A History of Egypt under Roman Rule. London: Methuen \& Co., 1924.

MOMIGLIANO, Arnaldo. Os limites da Helenização: A interação cultural das civilizações grega, romana, céltica, judaica e persa. Rio de Janeiro: Jorge Zahar, 1991.

MUSURILLO, Herbert. Acts of the Pagan Martyrs. New York: Oxford University Press, 1954.

NICOLET, Claude. Alexandrie et Rome: Peut-on Comparer? In: LECLANT, Jean (ed.). Alexandrie: une mégapole cosmopolite. Actes du 9ème colloque de la Villa Kérylos à Beaulieu-sur-Mer, les $2 \& 3$ octobre 1998. Paris: Académie des Inscriptions et Belles Lettres, 1999, p. 113-127.

PINSKY, Jaime. Os judeus no Egito helenístico. Assis: Faculdade de Filosofia, Ciencias e Letras de Assis, 1971.

RATHBOnE, Dominic. Egypt, Augustus and Roman Taxation. Cahiers du Centre Gustav Glotz, 4. S., p. 81-112, 1993.

REDEN, S. Von. Demand creation, consumption and power in Ptolemaic Egypt. In: ARCHIBALD, Zosia; DAVIES, John K.; GABRIELSEN, Vincent (eds.). The Economies of Hellenistic Societies. Third to First Centuries BC. Oxford: Oxford University Press, 2011, p. 421-440.

REINHOLD, M. Roman attitudes towards Egyptians. Ancient World, v. 3, p. 97-103, 1980. 
RODRIGUEZ, Chris. Acta Alexandrinorum. Paris, Mémoire de l'Ecole Pratique des Hautes Etudes sous la direction de Joseph Mélèze-Modrzejewski, 2010, (forthcoming in the Supplements for the Journal of Juristic Papyrology.)

ROSTOVTZEFF, Michael I. Historia Social y Econômica del Império Romano. Madrid: Espasa-Calpe, S.A., 1937. 2 v.

. Social \& Economic History of the Hellenistic World. Oxford: Clarendon Press, 1941. 3 v.

ROWLANDSON, Jane; HARKER, Andrew. Roman Alexandria from the perspective of the papyri. In: HIRST, Anthony; SILK, Michael (eds.). Alexandria, Real and Imagined. Aldershot: Ashgate Publishing Ltd., 2004, p. 79-111.

RUNIA, David T. Polis and Megalopolis: Philo and the Founding of Alexandria. Mnemosyne, Fourth Series, v. 42, fasc. 3/4, p. 398-412, 1989.

The Idea and the Reality of the City in the Thought of Philo of Alexandria.

Journal of the History of Ideas, v. 61, n. 3, p. 361-379, July 2000.

SAMUEL, Alan. From Athens to Alexandria: Hellenism and social goals in Ptolemaic Egypt. Louvain: Studia Hellenistica 26, 1983.

SCHULLARD, H.H. From the Gracchi to Nero: A History of Rome 133 B.C. to A.D. 68. London and New York: Routledge, 1982.

SCHWARTZ, Jacques. Caracalla et les troubles d'Alexandrie. Études de papyrologie, v. 7, p. 17-33, 1948.

SARTRE, Maurice. El Oriente Romano: Provincias y sociedades provinciales del Mediterráneo Oriental. De Augusto a los Severos (31a.C. - 235 d.C.). Madrid: Akal Ediciones, 1994.

SILVA, Gilvan Ventura da; MENDES, Norma Musco (orgs.). Repensando o Império Romano: perspectiva socioeconômica, política e cultural. Rio de Janeiro, Mauad/Vitória, Edufes, 2006. 
SILVA, Tomaz Tadeu da. A produção social da identidade e da diferença. In: SILVA, Tomaz Tadeu da. (ed.). Identidade e Diferença: A perspectiva dos estudos culturais. Petrópolis: Editora Vozes, 2000, p. 73-102.

SLY, D. Philo's Alexandria. Routledge: London, 1996.

SIDEBOTTOM, Harry. The date of Dio of Prussa's Rhodian and Alexandrian Orations. Historia: Zeitschrift fur Alte Geschichte, v. 41, n. 4, p. 407-419, 1992.

SMITH, Robert W. The Art of Rhetoric in Alexandria: Its Theory and Practice in the Ancient World. The Hague: Martinus Nijhoff, 1974.

SPENCER, Diana. The Roman Alexander: Reading a Cultural Myth. Exeter: University of Exeter Press, 2002.

STEPHENS, Susan. Seeing Double: Intercultural Poetics in Ptolemaic Alexandria. Berkeley/ Los Angeles/ London: University of California Press, 2003.

SWAIN, Simon. Hellenism and Empire: Language, Classicism, and Power in the Greek World AD 50-250. Oxford: Claredon Press, 1996.

TAKACS, Sarolta. A. Alexandria in Rome. In: Harvard Studies in Classical Philology, v. 97, 1995, p. 263-276.

THIERS, Cristophe. Fêtes et propagande sous lês Lagides. Les sorties processionnelles des statues du pharaon-basileus. Égypte, Afrique et Orient, n. 32, p. 23-30, Décembre 2003.

THOMPSON, Dorothy. Athenaeus in his Egyptian Context. In: BRAUND, D. ; PRICE, M.J. (eds.). Athenaeus and his World: Reading Greek Culture in the Roman Empire. Exeter, 2000, p. 77-84.

TRABULSI, José A. Dabdab. Ensaio sobre a mobilização política na Grécia antiga. Belo Horizonte: Editora UFMG, 2001. 
TRAPP, M. B. Images of Alexandria in the writings of the Second Sophistic. In: HIRST, Anthony; SILK, Michael (eds). Alexandria, Real and Imagined. Aldershot: Ashgate Publishing Ltd., 2004, p. 113-132.

VASQUES, Márcia Severina. Crenças funerárias e identidade cultural no Egito Romano: máscaras de múmia. Tese de Doutorado. São Paulo, MAE/ USP, 2006.

VASUNIA, Phiroze. The Gift of the Nile. Hellenizing Egypt from Aescchylus to Alexander. Berkeley/ Los Angeles/ Londres: University of California Press, 2001.

VOUT, Caroline. Embracing Egypt. In: Woolf, G. \& Edwards, Catharine. In: EDWARDS, Catharine \& WOOLF, Greg. Rome the Cosmopolis. Cambridge: Cambridge University Press, 2003, p. 177-202.

WALlACE-HADRILL, Andrew. Rome's Cultural Revolution. Cambridge: Cambridge University Press, 2008.

WALKER, Susan. Carry-on at Canopus: The Nilotic Mosaic from Palestrina and Roman Attitudes. In: Ancient Perspectives on Egypt: Encounters with Ancient Egypt. London: University College London Press- Institute of Archaeology, 2003, p. 191-202.

WATTS, Edward. City and School in Late Antique Athens and Alexandria. Berkeley and London: University of California Press, 2006.

WILLIAMS, Kimberly M.A. Alexandria and the Sea: Maritime Origins and Underwater Explorations. 2004.

WOODWARD, Kathryn. Identidade e diferença: uma introdução teórica e conceitual. In: SILVA, Tomaz Tadeu da. Identidade e Diferença: A perspectiva dos estudos culturais. Petrópolis: Editora Vozes, 2000, p. 7-72.

YOUNG, Gary. Rome's Eastern Trade. International Commerce and Imperial Policy, 31 BC-AD 305. London: Routledge, 2001.

YOYOTTE, Jean. Strabon: Le Voyage en Egypte. Un regard romain. Paris: Nil Editions, 1997. 